


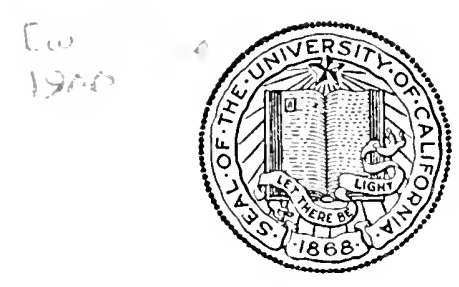

THE LIBRARY OF

THE UNIVERSITY OF CALIFORNIA LOS ANGELES

SCHOOL OF LAW 


\title{
AN Exposition
}

\author{
OF TIIE
}

\section{PRINCIPLES OF ESTOPPEL}

\section{BY MISREPRESENTATION}

BY

JOHN S. EWART 
Copyright, 1900,

BY

JOHN SKIRVING EWART.

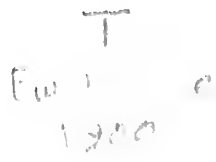

STATE JOURNAL PRINTING COMPANY.

Printers and Stereotypers,

MADISON, WIS. 


\section{PREFACE.}

We are sally in need of some short phrases wherewith to distinguish the actors in cases of estoppel. There is "the party to whom the representation is made." More shortly we might say "the party asserting the estoppel," - in other words, the "estoppel-asserter," as we shall style him. And there is "the person by whom the representation is made." IIim we shall eall, in sharp contrast, "the estoppel-(lenier." Such phrases are preferable to the arbitrary designation of the parties as A. and B. - a plan resorted to in sheer desperation by some writers; ${ }^{1}$ for there is nothing in the letters to help one to remember which is which. Even head-notes are often too long for easy identitication of $\mathrm{A}$. and $\mathrm{B}$.

Remembering that special glossaries for single rohmes may be necessary, but, at the hazard of rejection, must be capable of comfortable assimilation and effortless recollection, the present writer hesitates to do more at present than submit for approval a word which may, in discussing estoppel, be substituted for the ever-recurring phrase: "One who changes his position prejulicially upon the faith of some misrepresentation."

Fulsûert ${ }^{2}$ has the advantage of having for its first syllable a word familiar enough to all lawyers, and for its second that

1 Cababé on Estoppel, 53.

2 Kindly sugrested by the Rev. Prof. Joln Campbell, Presbyterian College, Montreal. The Rev. Father Drummond, S. J., St. Boniface College, St. Boniface, offers "I'ithallactos," as indicating sufticiently the main idea. It is a combination of
"Pilh," the rallical of a Greek verb siguifying to persuade; and "allactos:" a verbal adjective (from the Greek verb allaso, to change) signifying something that has been clianged - some one, therefore, who hass heen persulded to change lis positiun. 
which is readily recognized (with the same meaning) in eonrert and perrert. Fulsi is proferable to falso, the last letter of which would firequently be taken as belonging to the vert, instead of to the first factor in the combination; and it is used as an adjective in the ablative having the word re understood the whole word thus indieating one who has ehanged his position by reason of a falsity.

The writer believes that the chicf characteristies of the present work are (1) a completer and more seientific analysis and classifieation of estoppel; (2) a elearer apprehension and appreciation therefore of the bases and methods of estoppel; and (3) a successful substitution in various departments of the law of the principles of estoppel for others now in vogue.

(1) Analysis and Classification.-Estoppel by misrepresentation has not hitherto been divided into its two most obvious elasses, namely, (1) estoppel by personal misrepresentation; and (2) estoppl by assisted misrepresentation; and much perplexity has arisen from the absence of the distinction.

It is often affirmed, for example, that a misrepresentation must be mula fide in order to work estoppel; whereas the fact is that there may be estoppel although tho estoppol-denier has made no misrepresentation at all, nor indeed been awaro of the existence of misrepresentation by any other person. Estoppel sometimes arises because the estoppel-denier (perhaps (fuite innocently) has assisted the misrepresentation of a third person - he has furnished the means or oceasion for the misrepresentation, done that which has made it eredible, and for that reason alone is estopped. The moral quality of the misrepresentation in such eases cannot be material.

That the classification just suggested has been overlooked is all the more extraordinary when it is remembered that as early as 1757 Mr. Justice Ashhurst enunciated a rule which has 
obtained very general aceeptance, and is to-day very widely quoted:

"We may lay it down as a hroarl general principle that whenever one of two innocent persons must sufier by the acts of a third, he who enabjes such third person to occasion the loss must sustain it."1

Although stated too broadly, and lackingr therefore in scientific value, this rule embodies the principle of estoppel by assisted misrepresentation. ${ }^{2}$ It does not so profess; but this causes no surprise when it is remembered that we are accustomed to dat common-law recornition of estoppel, even in its more simple form, from Pickard v. Sears, ${ }^{3}$ which was not decided until 1837. That the relation of the dictum to estoppel should still be frequently denied is due entirely to the lack of recognition of the distinction between personal and assisted misrepresentation."

Another classification (by no means new, sare in uses subserved) is the division of personal misrepresentation into (1) active, and (2) passive misrepresentation. By it the conflict between those who affirm and those who deny that fraud is necessary to estoppel is terminited.

Active misrepresentation will estop irrespective of its moral quality:

"If persons take upon themselres to male assertions as to which they are ignorint whether they are true or untrue, they must in a civil point of riew be held as responsible as if they had asserted that which they knew to be true." 5

Passive misrepresentation is impossible without mala fides (innosent passivity eannot be misrepresentation), and therefore fraud is in such case necessiry - necessary however not to the estoppel, but to the existence of the misrepresentation, ${ }^{6}$ upon which the estoppel is founded.

1 Lickbarrow v. Mason, 2 T. R. 63.

"See cil. XIV.

${ }^{3} 6$ A. \& E. 469.

4 See cl. XIV.
5 l'er Lord Cairns in Reese $\mathrm{r}$. Smith (1869), L. R. 4 HI. L. 79 ; 39 L. J. Ch. 849.

6 Seg ch. VIIl. 
A third classification, or rather distinction, will be much insisted upon in the present work, namely, that between ostensible ownership and ostensible agency. It is indeed obvious enough when pointed to, but its disregard has led to the strangest confusion and misconception. ${ }^{1}$

(2) Buses and Methods of Estoppel.--The first of the above distinctions (that between personal and assisted misrepresentaltion) aids in very material (legree the fuller apprehension of the bases and methols of estoppel; brings into clearer relief the concept of duty as underlying all its principles; and compels a closer examination of social obligations in the affairs of business and commerce.

The existence of a duty, not purposely and by palpable untruth to mislead another into a prejudicial change of position, is easily recognized; and the common law action of deceit has provided a remedy in damages for breach of it. The prescription of a legal duty, in the physical domain also, "to observe in varying eircumstances an appropriate measure of prudence to aroid causing harm to one another," "appears to be a natural and ineritable consequence of the establishment of social relations of even the most imperfect character. But the application of this latter conception to the realm of affairs is plainly of hater growth. It must (such is human limitation), through a long course of struggle between it and its denial, become patently necessary and obviously right, before it can take its place as a principle of decision.

That the imposition of a duty of "an appropriate measure of prudence" in commerce is as essential for the effective conduct of business as it is for physical safety seems to the present writer to be a conviction now within measurable distance of complete acceptance. The strong tendency is in that direction, notwithstanding that the Irouse of Kords has recently inti- 
mated its adhesion to the view that every one must take care of himself - the criminal law being there to give him such satisfaction, or rather gratification, as he ean get out of it.' The case before their lordships, however, related to a bill of exchange, with regard to which we have been taught to think in a groove male specially for "nerotiable instruments," and been trained to believe that sueh documents and their vagaries are quite outside of all possibility of explanation according to the ordinary principles of law. Estoppel will help us to reduce their distracting fractiousness to order and principle. ${ }^{2}$

(3) Substitution of Estoppel for Other Principles.-(A) For it is the belief of the present writer that the hollowness of the word "negotiable," as a distinguishing characteristic of certain instruments, has in later years become very apparent. A "negotiable" instrument was said to have two peeuliarities: (1) a transferee could sue upon it in his own name, and (2) a purchaser might take a better title than that of his vendor. Recent legislation, by sanctioning the legal assignment of other choses in action, has abolished the first of these distinctions. And as to the second, there are scores of cases (other than those relating to bills and notes) in which a purchaser takes a better title than that of his vendor. Is there anything more "nonnegrotiable" than land? and yet is there no such thing as purchaser for value without notice of a prior elaim? An owner of goods stands by while an ostensible owner sells them; and is not the purchaser in a better position than the vendor? Estoppel will supply the reason for the decision of all such cases, and afford a harmonizing principle.

(B) 'The law relating to bills of lading, warehouse receipts, doek warrants and other "clocuments of title," with its antag-

1 Schofield r. Londesborough (1894). 1 Q. B. 536; 64 L. J. Q. B. 893 ; (1596) 2 Q. B. 660; 63 L. J. Q. B. 649; (1895) A. C. $514: 65$ L. J. Q. B. 593. 
onistic principles of (1) "negotiability" of the documents, and (2) caveat emptor as to the goods they represent, can be rationalized and rendered consistent only by the steady application to it of the law of estoppel by assisted misrepresentation.

(C) Rules groverning priorities to real estate - those relating to the legral estate, to possession of the deeds, to Qur prior est tempore potior est jure - must be superseded by the principles of estoppel.

(D) The distinction between roid and voidable instruments (with reference to their obligatory character upon the signers of them when obtained by fraud) is unscientific, and must give place to estoppcl.

(E) Distinction between general and spceial agency, so far as estoppel is concerned, will be denied. The same principles apply to agencies of all kinds.

(F) Perplexing points in the law of partnership will be found to yield easily when treated upon the lines of estoppel.

(G) "Estoppel by negligence," for which elaborate rules have been framed, but of which it is said there is no example in the law, will, it is hoped, with the help of "assisted misrepresentation," be relluced to intelligibility. Various classes of such cases will be discovered, but the rules provided for their decision will be found to be unsupportable.

(H) The relation of estoppel to deceit is in need of explanation. Its elucidation will bo attempted.

The method of the present work is to investigate and establish (in succedingr chapters) the essential requisites of estoppel by misrepresentation, and to formulate them in such terms as will permit of their being carried into and effectively applied in all the departments of the law in which estoppel operates. 
This accomplished, the fourteenth chapter is deroted principally to the widely, and above quoted rule laid down in Lickbarrow v. Mason: ${ }^{1}$

"We may lay it down as a broal general principle that whenever one of two innocent persons must suifer by the act of a third, ho who enables such third person to occasion the loss must sustain it."

And the assertion is ventured that that rule is "luat a short and pregnant statement of the essential principles of estoppel by assisted misrepresentation." Chapter XV is an endeavor to declare with precision the nature and effect of estoppel. And chapter XVI discusses the relation of estoppel to deceit.

The way having been thus cleared - the principles of estoppel having been defined, and their effect and forcign relations (as it were) determined - the remaining twelve chapters are devoted to the application of those prineiples to difierent forms of property and various departments of the law - to lands, goods, choses in action, documents of title, execution of documents, principal and agent, and partnership; with the result, as is hoped, that the principles of the earlier half of the book will be found not only workable in each of these departments, but of much service in the elucidation of problems which at present (for lack of them) are either relegated to the unsitisfactory catalogue of anomalies, or are recommended to our understandings by fictions of more or less impossibility.

The writer cannot fail to be impressed with the gravest ap. prehensions as he hands over to the profession the result of his labors upon a programme such as this. Nevertheless he has a strong conviction that although many defects in his work may be found, the main positions which he has assumed are riglit, or very nearly so, and that into harmony with them must be 
brought serelal departments of the law. He has, at all events, contributed something towards a scientific synthesis of a very dillicult subject.

To prevent frequent repetition, it may be said here, once for all, that liberty has been taken with many of the quotations appearing in the book, to the extent of italicizing some of the words, in order that the mind of the reader may be the more easily carried to the point to which attention is at the moment desired.

J. S. E.

Whinipeg, MaNitoba, $1 \subseteq 00$. 


\section{TABLE OF CON'TENTS.}

PREFACE • • • • • • . . . . .

TABLE OF CASES CITED. • • • • • • . TABLE OF ABBREVIATIONS USED IN TIIS WORK • xlii-xlvii

\section{CIIAPTER I.}

INTRODCTION • • • • • • • $1-9$

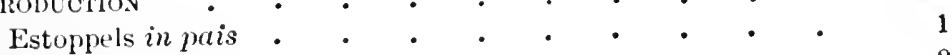

Subdivisions • • • • • • •

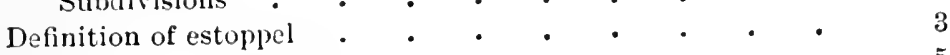

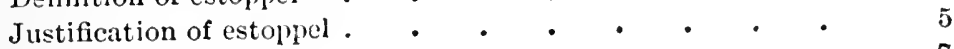

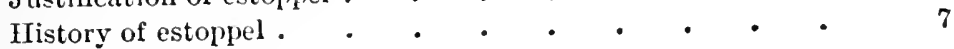

CIIAPTER II.

CONDITIONS OF ESTOPLEL

CHAPTER III.

There MUST BE a MisRepresextation

$\cdot+2 \cdot 12$

Necessity for misrepresentation . • . . . . . 12

Classification of misrepresentation $\quad . \quad$. $\quad . \quad . \quad 13$

Personil and assisted . . . . . . 13

Direct and indirect . . . . . . . . . 13

Active and passive $. \quad . \quad 14$

Expressed and implied . . . . . . . . 11

Distinction where fraud $. \quad . \quad . \quad . \quad . \quad . \quad 17$

\section{CIIAPTER IV.}

THE Misrepresentation MUST Be MADE EITHER (I) BY THF ESTOPPEL-DENIER (PERSONAL MISREPRESENTATION); OR (2) BY SONE PERSON WHOSE MISREPRESENTATION THE ESTOPIILDENIER HAS MADE CREDIBLE (ASEISTED MISLEPRESEXTTATION)

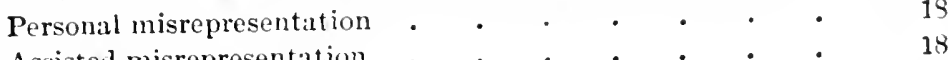

Assisted misrepresentation $\quad \cdot \quad \cdot \quad \cdot \quad \cdot \quad \cdot \quad \cdot \quad 21$

Principal and agent . $\quad \cdot \quad \cdot \quad \cdot \quad \cdot \quad \cdot \quad \cdot \quad \cdot \quad 23$

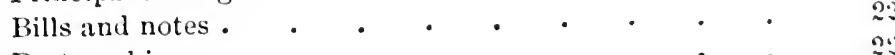

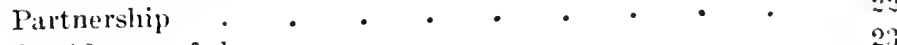

Certificates of shares $\quad \cdot \quad \cdot \quad \cdot \quad \cdot \quad \cdot \quad \cdot \quad \cdot 0$

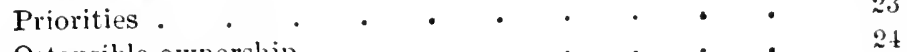

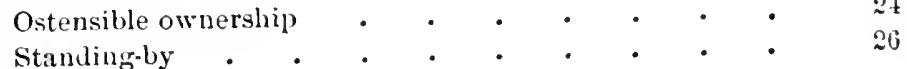




\section{CIIAPTER V.}

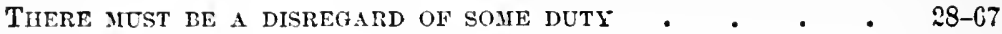

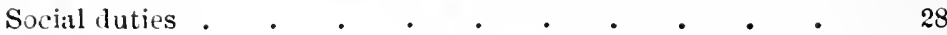

An appropriate measure of prudence . . . . . . 30

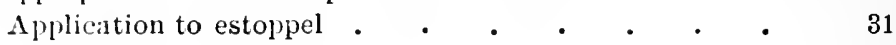

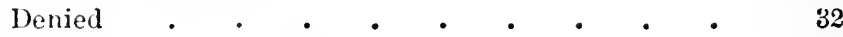

Principle already in operation . $\quad$. $\quad$. . . $\quad 34$

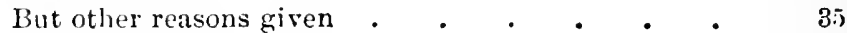

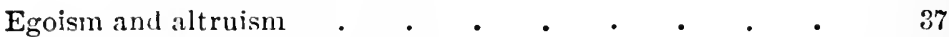

The altruistic view adrocated . . . . . . 48

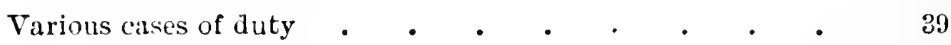

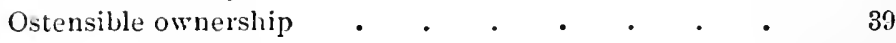

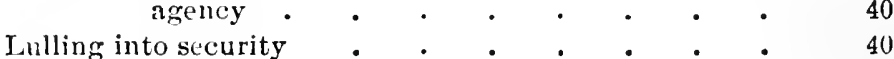

Partnership . . . . . . . . . . . . 41

Spaces carelessly left in documents . . . . . . . 4 . 4 ?

Young v. Grote . . . . . . . • 42,44

Schofield v. Londesborough . • • . • • • 43,45

Distinction between checks and bilis . . . . $\quad$. 46

Acceptor not responsible for form of bill $\quad$. $\quad$. 47

No duty to guard against crime . . . . . . 48

Crime and any other fraul . $\quad . \quad$. $\quad . \quad 50$

Suggested views supported . . . . .

Impossibility of a rule not to facilitate fraud . $\quad . \quad 5 \%$

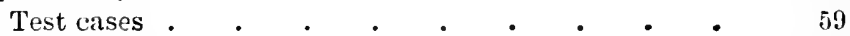

Custody of negotiable instruments $\quad$ - $\quad$. $\quad . \quad . \quad 61$

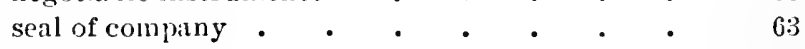

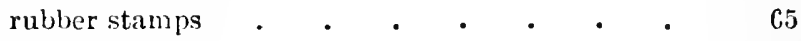

Miscellaneous cases of no duty $\quad$ - $\quad$ - $\quad$. $\quad . \quad$. 65

\section{CHAPTER VI.}

THE MISREPRESENTATION MUUT BE AS TO FACT OR LAW; NOT AS TO INTENTION OR OPINION

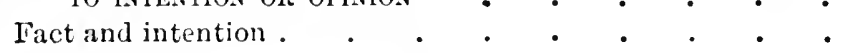

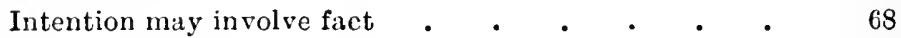

Fact and opiniou.$\quad \cdot \quad \cdot \quad \cdot \quad \cdot \quad \cdot \quad \cdot \quad \cdot \quad \cdot$ as ground of estoppel $\quad$ - $\quad . \quad . \quad . \quad 69$

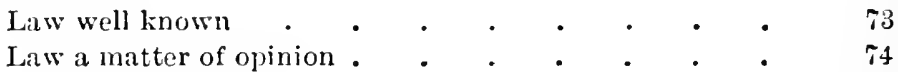

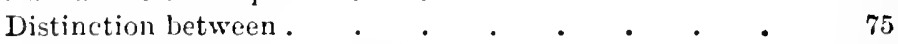

Advantige taken of ignorance of law $\quad . \quad$. 49

Innocent misrepresentation $\quad$ - $\quad . \quad$ - $\quad . \quad 79$

\section{CHAPTER VII.}

The misrepresentation Must fe of somethixg material - SO-S2

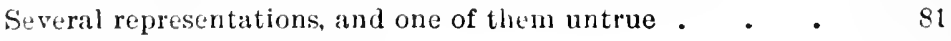

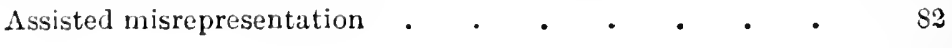




\section{CIIAPTER VIII.}

Fraud or bad faitu is not essextal

$82-97$

Miscepresentation and deceit . • • • • • . 83

rescission $\quad \cdot \quad \cdot \quad \cdot \quad \cdot \quad \cdot \quad \cdot \quad$ s.

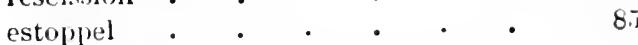

by passive assistance - Fraud a part of the misrepresenta-

tion . . . . . . .

1. I must be aware of my own right. . $\cdot$.

2. The other party must be unaware of my right .

3. I must have reasonable ground for assuming the other party"s ignorance $\cdot \quad \cdot \quad \cdot \quad \cdot \quad \cdot \quad 00$

Mortgage cases . $\quad . \quad+\quad \cdot \quad \cdot \quad \cdot \quad \cdot \quad \cdot \quad \cdot$

Certificates of shares $\quad . \quad+\quad \cdot \quad \cdot \quad \cdot \quad \cdot \quad \cdot \quad 95$

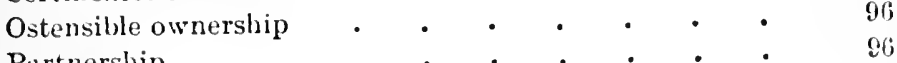

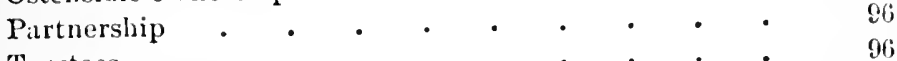

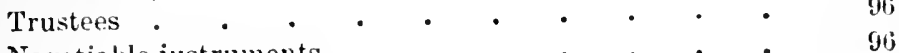

Negotiable instruments $• \quad \cdot \quad \cdot \quad \cdot \quad \cdot \quad \cdot \quad \cdot \quad \cdot 90$

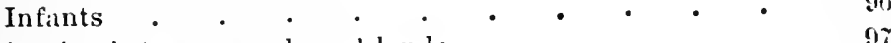

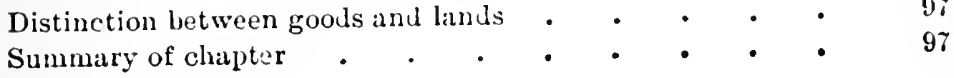

\section{CHAPTER IX.}

Negligerice (CARelessiess) Is sonetmies essextial •

Meaning of negligence and carelessness $\quad$ • $\quad$ • $\quad$ • 98

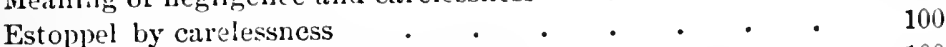

Misrepresentation an essential elcment . $\quad$. . . . 100

Personal misrepresentation - No instances in this class . 101

Assisted misrepresentation - General rule . . . . 102

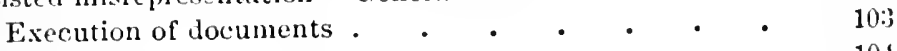

Priorities . . • • • • • • • • 104

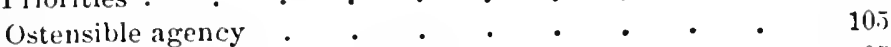

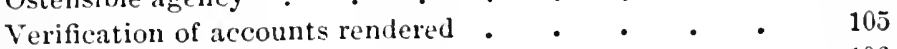

Stimding-by . • • • • • • • • • 106

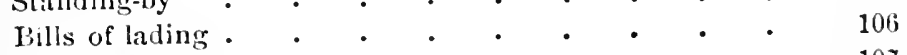

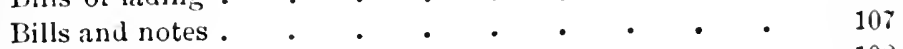

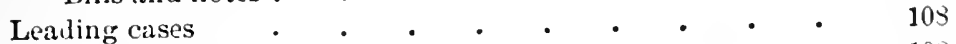

Bank of Ireland v. Evans . . . . • • • 108

Ex pirte Swan: Swan v. N. B. A. . . • • • 10s

Rules deducible from them . • . • . • 109

Mr. Bigelow's criticism . . . . . . . 103

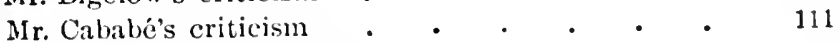

Rule I. There must be the neglect of some duty . . . $\quad 112$

II. The neglect must be in the transaction itself . . 112

This impossible . . . . . . . 113

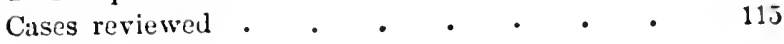


Negligexce (Carelessiess) is sometmes essextial-Continued. Result and its explanation . . . . . "In the transaction itself" . . . .

Analogy from torts . . . . .

III. The neglect must be the proximate cause of the lead-

\section{CHAPTER X.}

THE ESTOPPEL-ASSERTER MUST BE A PERSON TO WHOM IMMEDI-

ATELY OR MEDIATELY THE MISREPRESENTATION WAS MADE

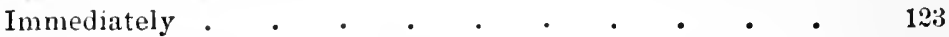

Mediately: Intended to be passed on . . . . . 124

Ambulatory and non-ambulatory representations . • 124

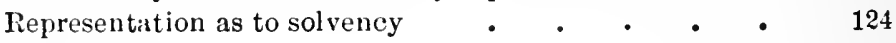

Partnership . . . . . . • . . 124

Commercial instruments . . . . . . . 125

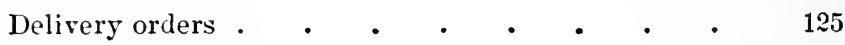

Warehouse receipts . • • • • • • 126

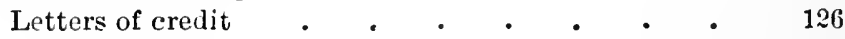

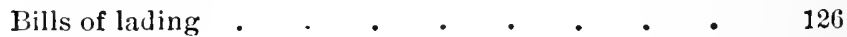

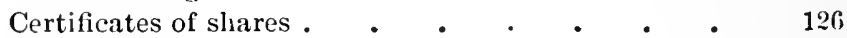

Prospectuses . . . . . . . . . . 127

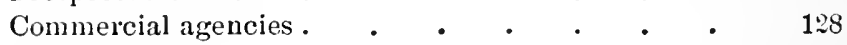

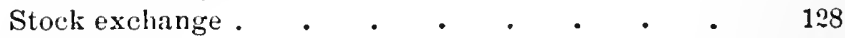

Title-deeds . $\quad . \quad$. $\quad . \quad$. . . . . 128

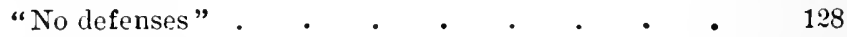

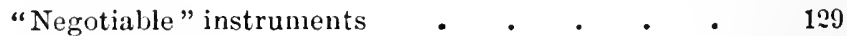

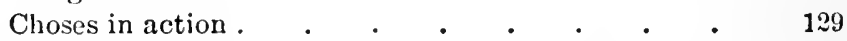

Misrepresentation to person who will probably be ap-

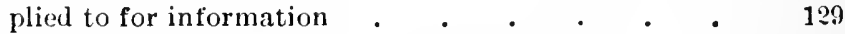

Misrepresentation by appearing to subscribe for shares $\quad$. $\quad 130$

\section{CHAP'TER XI.}

THE ESTOPPEL-ASSERTER MUST, ON THE FAITH OF THE MISREPRESENTATION, have ChaNGEd his position PREJUdicially .

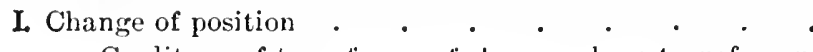

Creditors of transterrer of shares, where transfur un-

By appearance of having received money . . 133

Not advising of forgery . . . . . 135

Not objecting to accounts . . . . 136

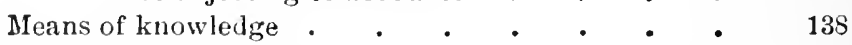

Registered instruments . . . . . 133

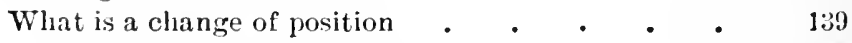

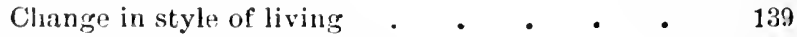

Change by bringing ar action . $\quad$ - $\quad$ - 139

A possible change $\quad$. $\quad . \quad$. 140 
The estoppelasserter.... nust ilave cinasged, etc.-Continucd.

IL. On the faitli, etc.

Misrepresentation not believed . . . . . 140

Withdrawn • • • • • • • • • 140

Investigated. $\quad \cdot \quad \cdot \quad \cdot \quad \cdot \quad \cdot \quad \cdot \quad \cdot 110$

Eximples . • • • • • • • • • 140

Principal and agent . . . . . , 141

Certificates of shares .

Seeming exceptions to rule $\quad . \quad$. $\quad . \quad$. $\quad$. 141

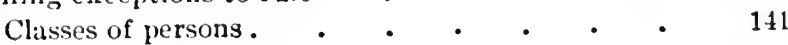

Shareholders • $\quad \cdot \quad \cdot \quad \cdot \quad \cdot \quad \cdot \quad \cdot 142$

Creditors . . . . . . . . 142, 143

Reputed ownership . . • • • • • 142

The actuating motive. . . . . . . 144

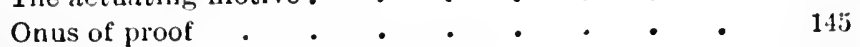

Several reasons for changing position . . . 146

III. Prejudicially.$\quad$ •

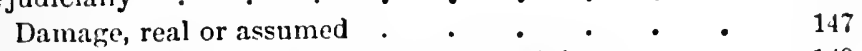

IV. Purchaser for value without notice, and falsâvert . . $\quad 149$

Auxiliary jurisdiction • • • • • • 150

Concurrent jurisdiction . . • . . . 150

Estoppel • • • • • • • • • • 151

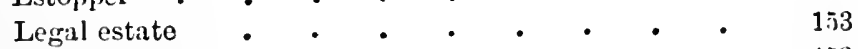

Summary • • • • • • • • •

CHAPTER XII.

ThE ESTOPPEL-DENIER MUST HaVE REASONABLE GROUND FOR ANticipating SOME ChaNge of POSITION UPON the FatTh OF the REPRESENTATION • • • • • • • . 155-16?

Distinction • • •

Personal misrepresentation .

Deceptive answer to impertinent question . . . 156

Mr. Narkby's view • • • • • • • • • • 159

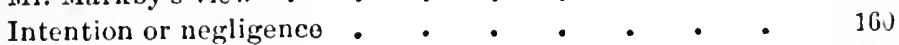

Assisted misrepresentation . • • • • • • 160

Active . . • • • . . • • • • 161

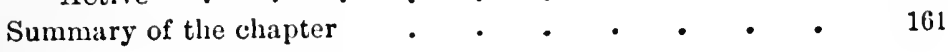

CIIAPTER XIII.

The ciange nust be reasonably CONSEqLeNt Uton the misREPRESLATATION OR ASSISTANCE • • • • • 163-1iG

The Barry v. Croskey rules . . • • • • • • 163

C:arr v. London rules $\quad$ •

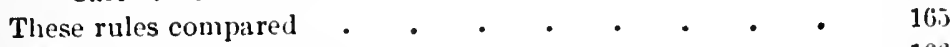

Classification necessiry .

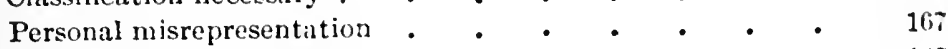

The two cases applied .

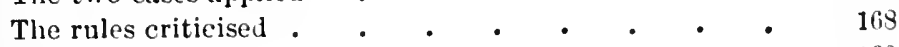

Rule suggested . $\quad$ • $\quad$ • 
THe Change must be reasonably consequent, etc-Continued

Assisted misrepresentation (passive)

Rule suggested

Assisted misrepresentation (active)

Rule suggested

Application of suggested rule to the cases

Proximate cause

Summary of the chapter

\section{CHAPTER XIV.}

The Lickbarrow v. Mason and Halifax v. WheelwrigitT

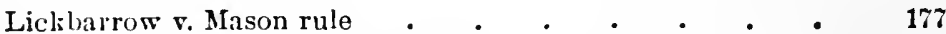

Equivalent to estoppel by assisted misrepresentation $\quad$ • 177

Dispilrate from estoppel? . • • • • • • • 178

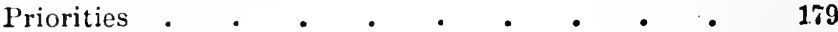

Bill of exchange $\quad . \quad+\quad . \quad+\quad . \quad \cdot \quad 179$

Principal and agent . $. \quad . \quad . \quad . \quad . \quad . \quad 180$

Sale of goods . $\quad . \quad$ • . . . . . . 181

Mr. Pomeroy's concurrence $\quad$ - . $\quad$ - . $\quad$ • 182

Rule cannot be supported? . . . . . . 183

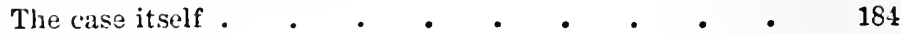

Halifax v. Wheelwright rule . . . . . . 185

CHAPTER XV.

\section{Nature and LFFeCt of estoppel}

Estoppel as a cause of action .

Estoppel as a rule of evidence

Questions do not so arise

Evidence must go to jury

Not affect weight of evidence . . . . . . 190

Testimony must be admitted . . . . . . 190

Nature of relief affected by it . . . . . 100

Amount of damages affected by it . . . . 191

Parties and privies .

1. Does estoppel bind purchasers from the estoppel-denier $\quad 196$

Rule as to parties and privies . . . . 196

Mr. Bigelow's qualification . . . . 197

Rule not intended for estoppel by nisrepresen-

tation . . . . . . • • • 198

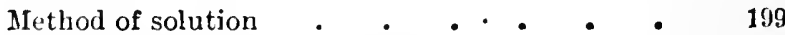

Estoppel as an "equitable right" . . . $\quad 200$

Applications of proposed method - . - 203

Does estoppel pass an estate • • • • 206

2. Does estoppel bind creditors of the estoppel-denier - 208

Privity and no privity . $\quad$ • . . . $\quad$ • 203

The cases . . . . . . . . . 210

Ground of error . . . . . . . 212

True position $\quad$ - $\quad$ - $\quad$ - $\quad$ - $\quad$ - $\quad 212$ 
NatUre AND EFFECT OF FSTOPPEL - Continued.

Joint and separate crelitors of partnership - $\quad 213$

Bona fide and fraudulent debentures . . . 217

Shares paid by estoppel only $\quad$. $\quad$ • $\quad$ • $\quad 219$

3. Does estoppel bind in faror of an assignee of the es. toppel-asserter

\section{CII.APTER XVI.}

DECEIT AND ESTOPPEL .

1. Deceit .

2. Restitution .

3. Estoppel

Conditions for relief direrse . . $\quad . \quad \cdot$

1. Deceit - Fraud necessary $\quad$ • $\quad$ • . . . 224

2. Restitution - Is fraud necessary . . . . . . 225

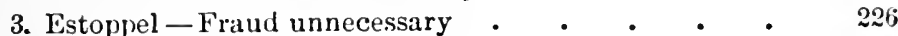

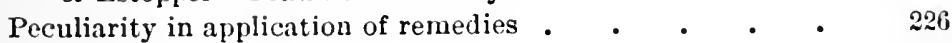

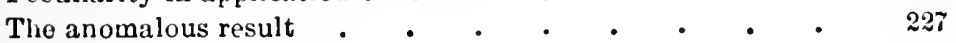

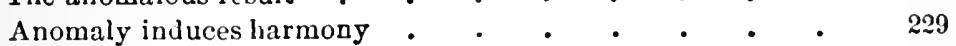

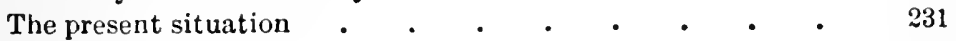

A suggestion . . . . . . . . . . 232

Unsatisfactory . . . . . . . . . . 231

Principal and agent $\quad . \quad$. $\quad . \quad . \quad . \quad . \quad . \quad 236$

1. Tort • • • • • • • • • 237

2. Deceit . • • • . • • . • • 237

3. Estoppel • • • • • • • • • 237

CHAPTER XVII.

OsteNSIBLE OWNERSHIP AND AGENCX

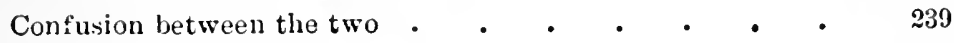

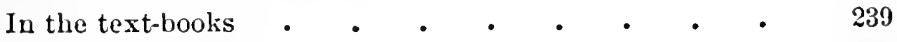

Factors Acts . • • • • • . • 240

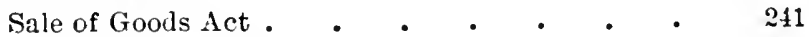

Current phraseology • • • • • • • 241

Where ostensible owner is really an agent $\quad$ - $\quad$. 242

Benefit of distinction . • • • • • • • 242

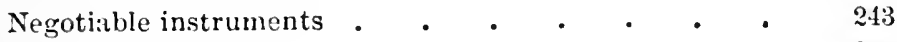

Priorities . . . . . . . • • . 243

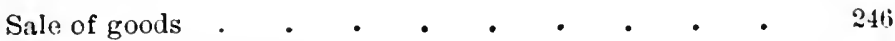

Ostensible ownership explained . . . . . . . 248

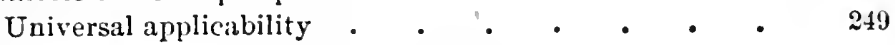

CHAPTER TVIIL

LAND - The LEgal ESTATE .

Where the equities are equal the law will prevail . $\quad . \quad 251$

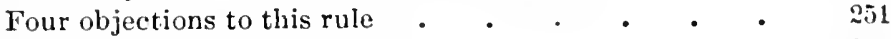

The scramble for the legal estate . . • • • • 252

$\Lambda$ general riew of it . . . . . . . . 254

Origin of the doctrine . . . . . . . . . $\quad$. 25

Cessat ratione legis, cessat ipsa lex . . . . . . 255 b 
LAXD - TII IEGAL ESTATE-Continued.

"Nothing but fraud or evidence of fraud will oust the prior.

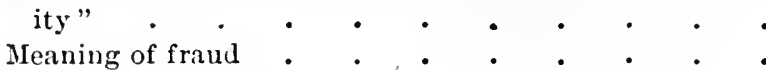

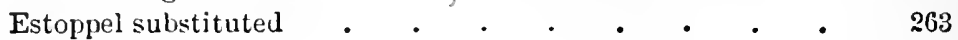

Application . . . . . . . . . . 264

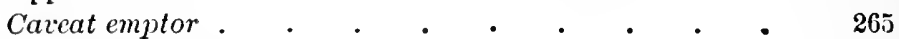

Standard of conduct $\quad . \quad$. $\quad . \quad . \quad . \quad . \quad 26 \%$

Apologies for the old rule . . . . . . . . . 268

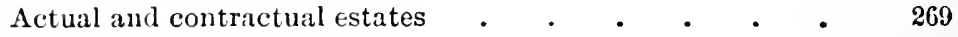

Support for new methods $\quad . \quad$. $\quad . \quad$. $\quad . \quad 271$

Factors Acts . . . . . . . . . . . . . 274

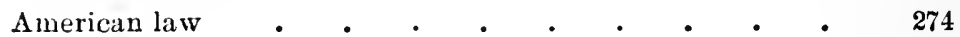

\section{CHAPTER XIX.}

LAND - POSSESSION OF THE DEEDS

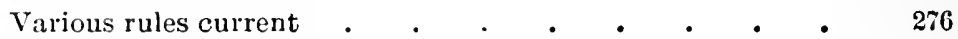

Possession of deeds only a circumstance $\quad$ • $\quad . \quad$ • $\quad$ • 278

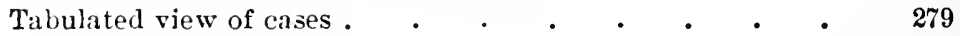

Examination of them . . . . . . . . . 283

Possession of deeds no effect upon priority . $\quad$. $\quad$. 283

Conduct with reference to them may estop . . . . 284

"Fraud" as explained by the cases . . . . . . . 285

Estoppel the applicable doctrine . . . • • • • 287

\section{CHAPTER XX.}

LAND - QUI PRIOR EST TEMPORE, POTIOR EST JURE

Subsidiary to two other rules .

Conventional meaning and application. ${ }^{\circ} \cdot$

Contrast between the rule and estoppel . $\quad . \quad . \quad$.

Opposing conclusions . . . . . . . .

An involuntary trustee . $\quad . \quad$. $\quad . \quad$. $\quad . \quad$. 295

\section{CHAPTER XXI.}

GOODS - Possession

Lands and goods, divergent rules usually applied .

Iere possession not evidence of ownership .

1. Character of the goods. . . . . .

2. Character of the place where they are . . .

3. Usual employment of the person who has them . Reputed-ownership clatuse compared with estoppel

4. Possession accompanied by other circumstinces . .

\section{CHAPTER XXII.}

Goods - Documexts of TITLE

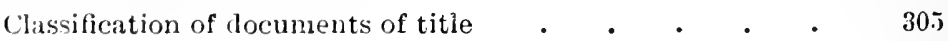

Division of the subject . . . . . . . . . . . . 30 ?

1. Documents usually spolien of as conveyances . . . 30 ? 
Goods-Documests of tithe - Comtinued.

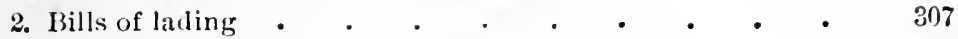

Intended as a representition by its signer . $\quad . \quad$. 308

And also ly its transferrer . . . . . 309

3. Dock warrants. etc. . . . . . . . . 309

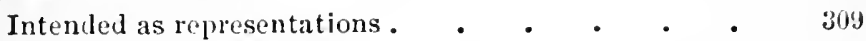

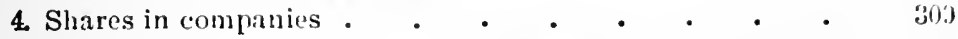

Certificates iutenled as representations by company $\quad 809$

Transfers intended as representations by transferrers 310

Resemblances between the four classes . . . . . . 310

Exposition of estoppel as applied to these documents . . 311

Purchase of merchanilise from a nisrchant . . . 312

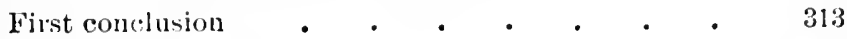

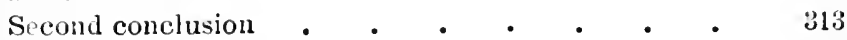

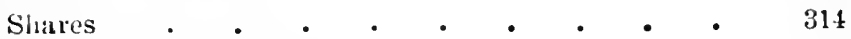

Estoppel of the signer of the documents $\quad$. $\quad$ • $\quad . \quad$. 316

When carelessmess essential . . . . • . 316

Upon what points are signers estopped . • • • $\quad 319$

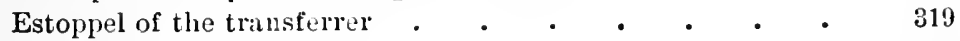

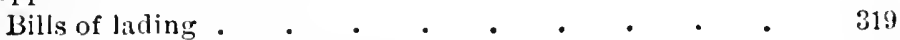

Do transfers pass the property . . . . . . 390

Negotiability $. \quad . \quad . \quad . \quad . \quad . \quad . \quad . \quad 3 ? 2$

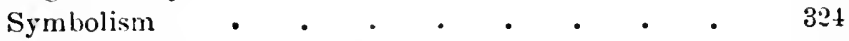

Negotiability, symbolism and estoppel . . . 32 \%

The true view . . . . . . . . . 327

American law . . . . . . . . . . . 328

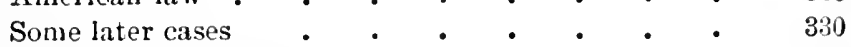

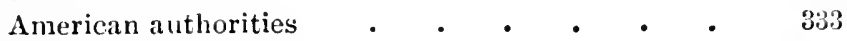

Dock warrants, etc. . . . . . . • •

A commencement upon principle $\quad$. . . . 335

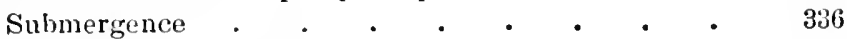

Courts rersus Parliament . • . • • • 336

Resemblance to bills of lading . $\quad . \quad$. $\quad . \quad$. 383

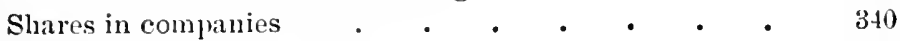

Estoppel usually applied . . . . . . . 341

McNeil v. Tenth Nit. Bank • • . • • $\quad 342$

Estoppel sometimes repudiated . . . . . . 343

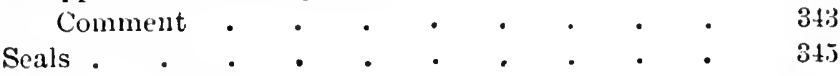

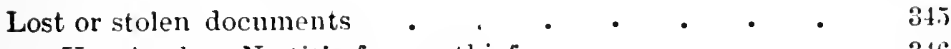

Usual rule - No title from a thief . • . • • 346

Modifications in some cases . . . . . . . 340

CIIAPTER XXIII.

Goods - Legislation

Estoppel principles wide enough for factors .

1. Cise of a fictor in possession . . . . . . 3iil

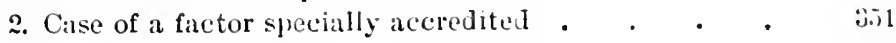

3. Case of a merchant . . . . . . . . . . 32

4. Case of a merchint who is a!so a factor $\quad$. 352 
GOODS - LEGISLATION - Continued.

- Reriew of Fictors Acts and Sale of Goods Act - • • 353

"Factors cannot pledge"-Why? . . . . . 853

1. Mercintile agent in possession . . • . . 356

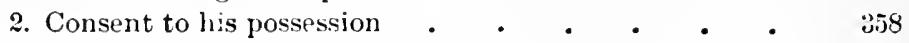

3. Possession given for consignment or sale . . . $\quad 200$

4. Vendor retaining possession . . • • • • $26 \mathrm{l}$

5. Vendee prematurely obtaining possession . $\quad . \quad$ $\quad ₫ 64$

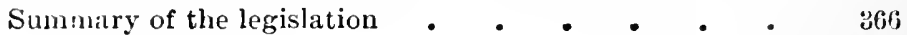

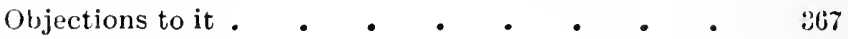

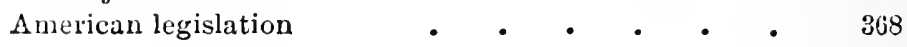

\section{CHAPTER XXIV.}

Choses in aCtion - Ambelatory and nON-AMbULATORY •

The law merchant • • • • • • • • •

Its alleged antagonism to the general law $\quad . \quad . \quad 3 \pi 2$

What is it . . . . . . . . . 373

Negotiability - Two characteristics . . . . . 375

1. Transferee sue in his own name • $\quad$ • $\quad$ • $\quad$ • 376

No distinction there . $. \quad . \quad . \quad . \quad . \quad 3 r 6$

2. Honest acquisition confers title • . . - . . 378

No distinction there $\quad$. $\quad . \quad$. $\quad . \quad$. $37 \mathrm{~s}$

Negotiability and transferability . . . . . . 380

What is negotiability? - Two meanings . . . . . 383

1. Transferability . . . . . . . . 354

2. Effects of transferability . . . . . . $\quad$ • 384

Ambulatory and non-ambulatory . • • • • • • 386

The cycle through which we have come $\quad$. . . 486

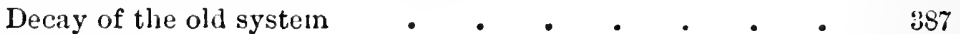

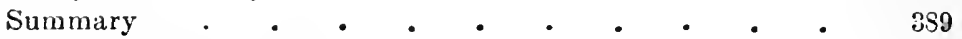

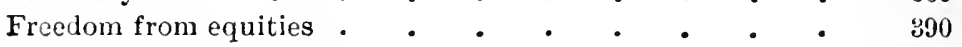

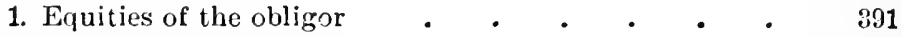

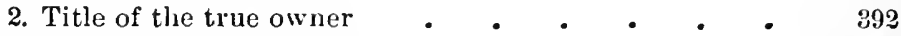

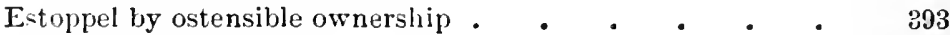

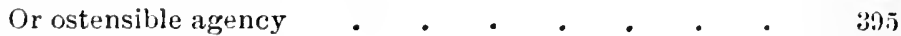

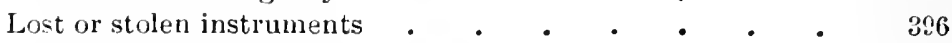

Appropriate measure of prudence . . . . . 896

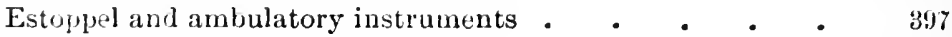

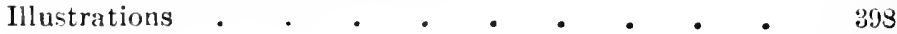

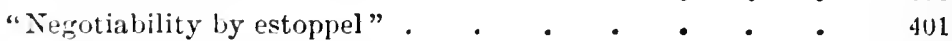

Consilerations in support of new methods . . . . 404

Market overt . . . . . . • • • • 404

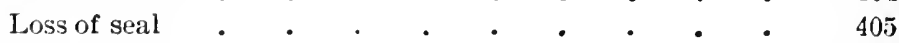

New methods contrasted witl old . . . . . 406

Summary . . . . . . . . . • . 409

Ambulatory instruments $\quad . \quad$. $\quad . \quad$. 409

Bunds . . • . . . . . . . 409

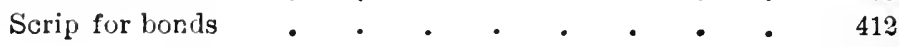

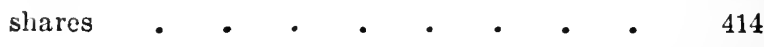


Choses in action - Ambelatory aNd xon-ambulatory - Continued.

Mortgage debentures . . . . . • • 411

Mortgages • • • • • . . • • • 415

Vouchers . . . . . . . . . . . . .

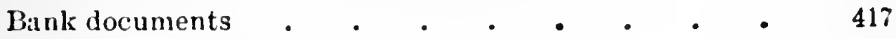

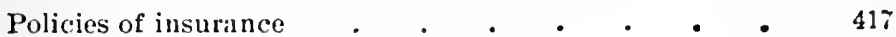

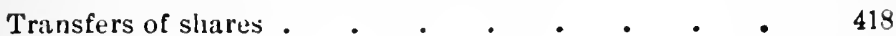

Charter-parties . . . . . . . . . . 418

Generally • . • • . . . . . 419

Bills and notes with extra clauses . . . . . . 420

"Intended to be assigned" . . . . . . . 421

Conclusion . . . . . . . . . . . . . 422

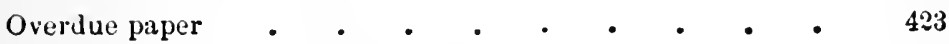

CHAPTER XXV.

ExECUtion OF DOCCMENTS - Where signer DEFrauded • . 426-4i2

Estoppel the ground of decision .

I. Execution fraudulently obtiined • • • • • 427

Review of atuthorities . $\quad . \quad \cdot \quad \cdot \quad \cdot \quad \cdot \quad \cdot 428$

Void and roidable - Unsatisfactory . . . . . 431

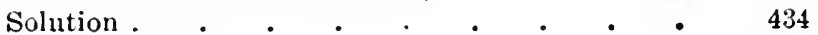

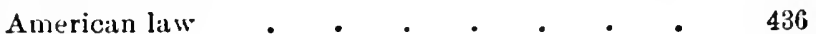

Analogy . . . . . . . . . . . 443

II. Execution fraudulently completed • • • • • 438

1. Documents confided to another person . . $\quad 439$

A. Negotiable instruments . . . . . 4049

(1) Completed documents . . . 439

(2) Blank documents . . . . 440

(a) Known to transferee $\quad . \quad 442$

Customary effect . . 443

Estoppel the ground of decesion . . . . 444

(b) Unknown to transferee . $\quad 447$

(3) Spaces as distinguished from blanks . $44 i$

(4) Signed but otherwise blank slips 448

(a) Imperfection known . • 418

(b) Imperfection unknown . . 448

Summary . . . • • • • 4449

B. Non-negotiable instruments . . . $\quad$. 449

Deeds included with other instruments $\quad . \quad 449$

(1) Completed instruments . • . 452

(2) Blank instruments . • . . 453

(a) Known to transferee . . 453

(b) Unknown to transferee . . $\quad 455$

1. Documents stolen or found _ . . . . . . 456

A. Negotiable instruments . . . . 456

Present uncertainty in the law . . $\quad 456$

Complete and incomplete instruments . $\quad 458$

Criticism of present rules $\quad . \quad . \quad . \quad 459$ 
Exection of Docluexts - Where signer derradded - Continued.

Egoism and altruism . . . . . 460

Ostensible ownership . . . . . . $\quad$. 461

Incomplete instruments . . . . $\quad 46 \mathrm{~L}$

Signed slips . . . . . . . . 463

Appropriate measure of prudencs . . $\quad 46 t$

Current practice $\quad . \quad$. $\quad . \quad$. 46.5

The codes $. \quad . \quad . \quad . \quad . \quad . \quad 466$

B. Non-negotiable instruments . . . . 467

An approprlate measure of prudence $\quad . \quad 467$

"Negotiable" - Meaning of word . . 469

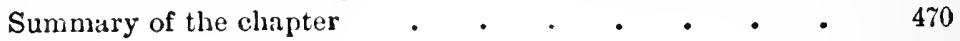

\section{CHAPTER XXVI.}

Prixcipal axd aGeNT.

Four difficulties . . . . . . . . . 4 . 473

Some tentative propositions . $\quad$. $\quad$. $\quad$. . 473

I. General and special igency . . . . . . . 474

The customary distinction valueless . $\quad . \quad$. 474

Review of the text-writers . . . . . 474

Suinmary . . . . . . . . . $48 \%$

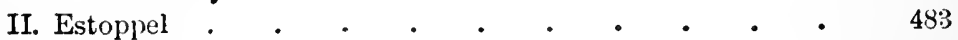

As to existence of agency . . . . . . . 483

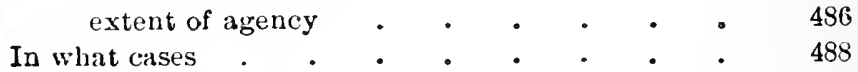

General proposition . $\quad . \quad$. $\quad$ • 488

Medium powers . . . . . . . . . 488

Rules, authorities and illustrations . . 488

Estoppel where powers withlueld . . . 490

Application of principles .

Unauthorized warranty upon sale of a liorse by an agent . . . . . . . . 492

1. Sale at a fair . . . . . . . 492

2. The owner is a horse-dealer . . . 493

3. The agent is a horse-deater . . . 493

4. No special circumstances . . . . 493

Opinions of the text-writers $\quad$. $\quad . \quad$. $\quad .493$

III. "For the master's benefit" . . • • • • • • 496

Two opposing cases and rules . . . . . . 496

Tort compared with estoppel . . . . . 497

Deceit classed with estoppel $\quad$ • $\quad$ • $\quad$ • $\quad$ • 499

Reconciliation by this method . $\quad$ - $\quad$ - 500

IV. "Within the scope of his a uthority" • . • . 501

Appearance as to the authority . . . . 502

"Class of acts"- Extrinsic facts . . . . 503

Bills of lading $-\Lambda$ present exception $\quad \cdot \quad \cdot 508$

Appearance of authority . $\quad$. $\quad$ • $\quad$ • 511 


\section{CIIAPER MXVII.}

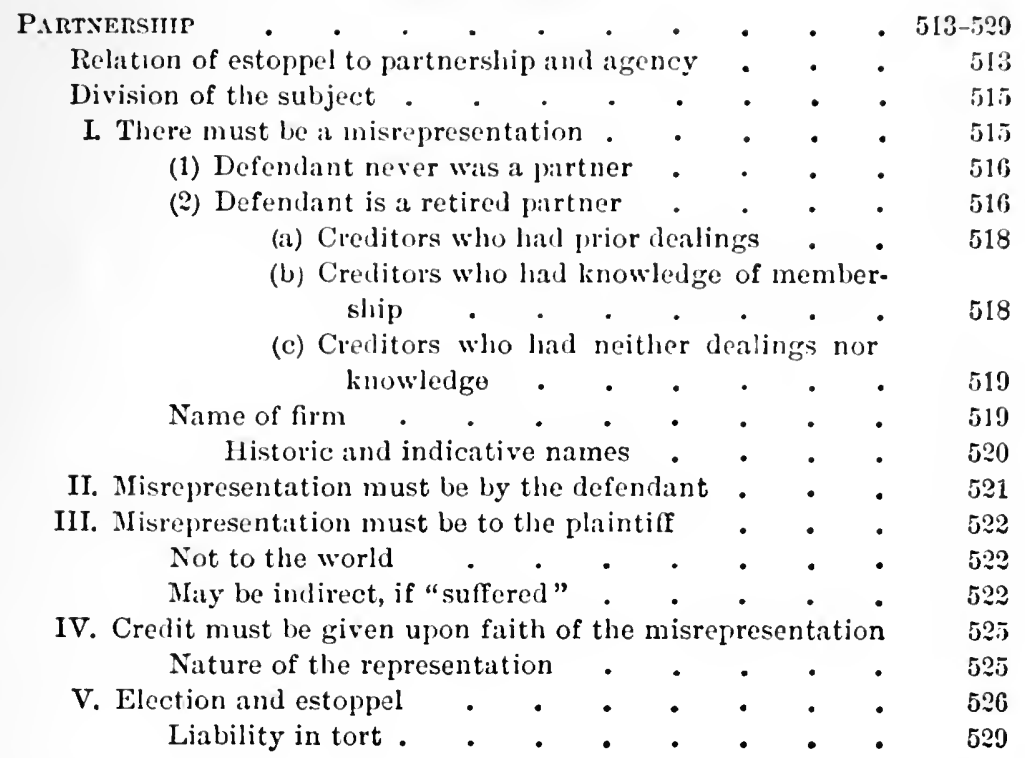

INDEX . 



\section{TABLE OF CASES CITED.}

Abbott $\mathrm{v}$. Rose, 419.

Ackerman v. Humphery, 320 .

Adams v. Folly, 3:1.

Adamson, Ex parte, 12, 131, 147.

Attna v. Franks, 436.

African Gold Co., Re, 140.

Agra \& Masterman, Re, 126, 129, 377, $379,417$.

Agra Bank v. Barry, 260, 261, 279.

Agricultural v. Federal, 112, 130.

Akins v. Kellogg. 72.

Alderson v. Miallison, $70,71$.

Alderson v. Pope, 525.

Alexander v. Campbell, 493.

Alexander v. Gibson, 490, 492, 493.

Alexander v. Harkins, 519.

Alexanuler v. McKenzie, 504.

Allan v. Knight, 281.

Allan v. Mc'Tavish, 212.

Alleroft v. Bishop of London, 84.

Allen v. Ayer, 449.

Allen r. Knight, 253, 283.

Allen v, Louis, 354.

Allen v. Shaw, 39.

Allen v. South Boston, 496 .

Allis r. Billings, 433.

Allum v. Perry, 156.

American, etc. v. American, 412.

American, etc. r. Crowes, $41 i$.

American, etc. v. Hammond, 7 .

American, etc. $v$ Henlerson, 321.

American, etc. v. Malllock, 511.

American, etc. r. Vemmer, 47.

Anderson v. Hubble. :6. 94.

Andrews s. Lyous, $5,15 \%, 187$.

Andrews v. Mockford, 12\%, 164.

Angle v. N. W. Mutual, 453.

Angus v. Clifford, 84, 224.

Antem $\therefore$ Crahan, $41 \%$.

Argentini, Thr, 396, 331.

Arlington v, Yiates, 235.
Armour v. Michigan, 40, 126, 273, 417.

Arunstrong $v$ Potter, 139, 533.

Arnold v. Cheque Bank, 44, j1, 1\%8, $183,396$.

Arnold v. Hart, 518.

Arthur v. Barton. 482.

Ashurst v. Ashurst, :26.

Ashwix v. Stanwix, :30.

Atchison v. Brassfield, 49, 437.

Atkins v. Payne, 123, 226.

Atliyns v. Kimnier, 53.

Atlanta r. Hunt, 297, 299, 302, 335, $35 \pi, 489$.

Attorney-General v. Great Eastern, 490.

Audenried v. Betteley, 216.

Austin r. Balın. 69.

Austin v. Dye, 298.

Austin v. Great Western Ry. Co., 6 ?.

Awde v. Dixon, 439, 443.

\section{B.}

Babcock v. Lawson, 96, 181, 183.

Bacon v. Harris, 25.

Backhouse v. Cluarlton, 20\%, 256.

Binleley v. Consolidiated, 25.

Ballia, Re, 23, 40, 102, 126, 141, 18\%, 230, 235, 309. 315, 317, 340.

Bitiley v. Batrues, 251, 252, 255.

Bailey v. Bensley, 489.

Bailey v. Semour, 81, 145.

Bilille v, McKewin, 253, 260.

Baines r. Ewing, 490 .

Baines v. Swainson, 96, 346, 355.

Inaird r. Planque, 525.

lialier r. Bamett. 503.

Baler $r$. Nottingham, 512.

Bilker v. Searey, 25.

Bilker v. Tilylor, 297. 
Balkis r. Tomkinson, 40, 126, 1s7, 230, 315.

Baldry v. Bates, 493.

Baldwin v. Kingstone, 75.

B.ltimore v. Willins, 511.

bingor v. Robinson, 177, 377, 397, 461, 468.

Bank v. Duffington, 136 .

Bank v. Flathers, 20 .

Bank r. Keene, 149.

Bank v. Norgan, 136.

Bank v. Wentzell, 148.

Bank v. Whitney. 300 .

Bank of Bistavia v. New York Ry. Co., 305, :373, 50:3, 511.

Bank of England v. Vagliano,102,1r8, 183.

Bank of Green Bay v. Dearborn, 322.

Bank of Hamilton v. Gillies, 420.

Bank of Hamilton v. Harvey, 411.

Bank of Hamilton v. Inperial Bank, 43.

Bank of India v. Henderson, 320, 323, $331,334$.

Bank of Ireland v. Evans, 43. 44, 45, 63, 108, 109, 115, 116, 117, 118.

Bank of Nlonongahela $\mathbf{v}$. Weston, 519.

Bank of Montreal r. Baker, 450.

Bink of Montreal v. Thomas, 417.

Bank of New York v. American Co., 503.

Bank of Pittsbursh v. Neal, 449.

Bank of Toronto v. Cobourg, 411, 412, 450.

Bank of U. S. v. Bank of Georgia, $193,148$.

Banks v. Everst, 477.

Banner, Ex parte, 349.

Banber v. Clark. 75.

Barber v. Myerstein, 321.

I3arluer v. Van Horn, 513.

Barnard v. Camplell, 132, 302, 325, $339,381$.

Barrington, Re, 38:.

Barry v. Croskey, 169, 164, 165, 166, $167,169,169,171.175$.

Barry v. Kirlikind, 131.

Sarry v. Wachosky, 383,

liarllett v. Board, 451.

liartlett v. Raymond, 520.

Barton v. London, etc. Co., 140.
Barwick v. English, 237, 496, 498, 501, 506.

Batchelder v. Sanborn, 39.

Bates v. Swiger, 26.

Baxendale v. Bennett, 6, 12, 43, 48, 180, 379, 380, 440, 445, 457, 463.

Bixter v. Bradluary, 207.

Baxter s. Sherman, 512.

Bayley v. Manchester, 237, 498.

Bayliffe v. Butterworth, 489.

Beckerer v. Asher, 247.

Bechuanaland v. London, 65, 371, 380, $397,409,412$.

Bedford v. Bagrslaw, 128, 169.

Bealuchampr. Winn, 75, 78.

Beem v. Lockhart, 480.

Bell v. Macklin, 85.

Bell v. Moss. 381.

Bellamy, Re, 138.

Belmont v. Talbot. 494.

Benedict v. Cowden, 60.

Bennett v. Mattingly, 433 .

Benterick v. London, 452 .

Berisford v. Milward, 284.

Berkling v. Watling, 381.

Berry v. W. D. Allan \& Co., 495.

Bickerton v. Walker, 19, 95, 129, 233, 416.

Biddle Boggs v. Merced, 86.

Biggerstaff v. Rowatts, 496.

Biggs v. Evans, 246, 434.

Bilbee v. Lumley, 73 .

Bill v. Richards, 284, 289.

Birch v. Steppler, 160.

Bishop v. Balkis, 17, 340.

Bissell's Ex'rs v. Warde, 139.

Black v. Christ Church, 30, 59.

Blizck wood v. London, 253.

Blain v. Wait, 94.

Blake v. Belfast, 320 .

Blakely, Re, 126, 377, 410, 422 .

Blaky v. Johnson, 60.

Blaisdell v. Leach, 436.

Bloomenthal v. Ford, 17, 74, 137, 209, 219.

Blyth v. Birmingham, 30, 100.

Boggs v. Hargrave, 78.

Bonzi v. Stewart, 3ij4, 356, 360.

Booth v. Mofratt, :38, 63.

Boultbee v. Growski, 342.

Boulton v. Ifamilton, 206, 207. 
Boulton v. Jones, 528.

Bourne v. Freetl, 516.

Bowen v. Evalns, 150.

Bower v. Peate, 58.

Boyce v. Elwards, $41 \%$.

Boyson v. Coles, 21, 238, 254, 296. 311, $335,353$.

Brace v. Duchess of Marlborough, 255.

Bracewell v. Williams, $7 \mathrm{I}$.

Bradley v. Iuce, 26 .

Bralley v. Riches, 265.

Brady v. Todd, 493.

Braithwaite v. Power, 524.

Braley v. Powers, 225.

Brandt v. Bowlby, 392.

Brant v. Virginia, $86,96,160$.

Brayton v. Harding, 25.

Breckenridge v. Lewis, 362, 448.

Breeze v. Brooks, 25, 144.

Brigham Young v. Wagner, 86.

Bridge v. Connecticut, 417.

Briggs v. Jones, 272.

British Mutual v. Charnwood, 496, $499,500,506$.

Brocklesby $v$ Temperance, 214, 2\%3, 379, 39:3. 399, 446.

Brooke v. New York. 511.

Brooks v. Hassal, 49?.

Broughton v. Hutt, $\boldsymbol{\tau} 6$.

Brown v. Equitable, 342. 417.

Brown v. Foster, 518, 525.

Brown v. Holland, 78.

Brown r. Leonard, 514.

Brown v. Pierce, 36?.

Brown s. Powell, 508, 509.

Brown v. Probate, 452.

Brown v. Reed, 50, 60, 107.

Brown v. Sims, 124.

Brown v. Wilmerding. 362.

Bryant v. La Banque, 496, 505.

Bryant v. Moore, 4\%8, 482, 494.

Bryant v. Whitcher, 25.

Buchanan v. Young, 38.

Bucld v. MeLilughlin. S5.

Building, etc., Re. 496.

Bullard v. Bell, $3 \% 6$.

Bullitt $:$ Farrar, 22.5.

Burbrilge v. Manuers. 466 .

Burchfield ₹. Moore, $3 \pi 9$.

Burgess r. Seligman, 132.
Burk v. Clark, 529.

Burkenshaw v. Nicolls, 6, 15.

Burrowes v. Lock, 96, 102, 223, 224, 225, 228.

Burrows v. Grover, 125, 522.

Burrows v. Klemk, 60.

Burson v. IIuntingilon, 439.

Burton v. Curyea, :j:4, 337.

Bush v. Brown, 433.

Bush v. Fry, 302.

Butler r. Mitples, $4 \pi 4$.

C.

Cady r. Owen, 26.

Cahn v. Pocketts, 339, 36.j.

Cairncross v. I.orimer, 114, 136.

Caldwell v. Accident, 139.

Calvert v. Baker, $3 \pi 9$.

Cameron r. Cameron, 527.

Camp v. St. Lonis, 26 .

Campell v. Edwards, 73.

Camplell v. Gemmell, 25.

Canadian P. Ry. v. Burnett, 201.

Carnegie v. Morrison, $41 \%$.

Carpenter, Re, :01.

Carpenter r. Longan, 20.

Carr v. La Fevre, 412. 420.

Carr v. London, 109, 158, 164, 10.5. 166, 168, 169, 171, 172, 173, 175. 318.

Carritt v. Real, 26j, 266.

Carter v. Carter, 2 $\$ 2 \%$

Carter v. Palmer, $3 \pi \%$.

Carter v. Whalley. 519.

Cartwright $\because$. Wilmerding, $35 \tilde{,}, 40 \tilde{}$

Case v. Bartlett, 25.

Cason v. Grant, 444.

Cisstell, Re, Roper v. Castell, 276, 2s1, 284. 288.

Castle v. Castle, 19.

Caswell r. Worth, 62.

Catholic Bishop v. Troup, 477.

Cator v. Burke, 409.

Callitins v. Whisler, 464.

Cave v. Cave, 151, 153, 254, 265, 28?, 29:3, :94.

Cave v. Mills, 1 s9.

Cawthorn v. Linsk. 490.

Central Bank, Re, 40i, 417.

Chadwick v. Manning, 6s, 201. 
Cliamplain s. Layton. 78. Chaplin v. Vermont, 412. Chapman r. Pingree. 26.

Chase Nat. Bank v. Faurot, 439.

Chatham v. Motfatt, 224.

Chew r. Balruet, 268, 27j.

Chicago v. Troup, 482.

Clicago v. Werner, 72.

Chipman r. Tucker. 449.

Citizens v. Booze, 420.

Citizens v. First National, 68, 201.

Citizens v. Tepitre, 38, 62.

City Bank v. Barrlow, 398, 512.

City Bank v. Rome, 322.

Cliırk, Re, 143, 144, 216.

Clarli v. Dillman, 94, 137.

Clark r. Eckroyd, 66, 148.

Clark v. Kirby, 203.

Clark s. National Bank, 137.

Clark r. Roberts, 264, 407.

Clarke v. Palmer, 10., 280, 287, 318.

Claxton v. Shibley, 27.

Cleveland v. Cleveland, 207, 275.

Cleveland v. Shoeman, 368.

Close r. Holmes, 360.

Coates $r$. London, 51.

Cochrane v. Nelueker, 107.

Cockrill v. Cockrill, 433.

Cocks v. Masterman, 148.

Coffey v. Coffey. 312 .

Colren r. Mitchell, 14 .

Cole v. Northwestern, 308, 337, 357, 486, 491, 49.j, 511.

Cole v. Pope, 73.

Coles v. Jones, 409.

Coles v. Pilkington, 71.

College v. Tuttle, 70.

Cullier v. Miller, 48.

Colling, Re, 201.

Collingwool v. Berkeley, 96, 102.

Collins v. Archer, 151.

Collins v. Martin, 394, 461.

Collins v. Rosenbaum, 309.

Colonial Bank r. Cady (and sub nom.

Williams v. Colonial Bank), 116, 238, 272, 342, 343, 344, 345, 373, $404,408,412,418,420.440,454$.

Colonial Bank v. IHepworth, 253, 271, $342,454$.

Colonial Bank v. Whinney, 310 .
Columbia s. Cornell, 60, 217, 379, 458, 466.

Colyer v. Finch, 150, 151, 205, 252, $262,280$.

Coner v. Cunningham, 298.

Commercial Bank, Re, 417.

Commercial Bank v. Colt. 346.

Comnissioners v. Clirk, 394.

Conard v. Atlantic, 333.

Concessions, Re, 17, 317, 340, 496.

Confederation r. Merchants, 66.

Conrad r. Fisher, 131.

Consort v. Deep Level Gold Mines Co., Re, 485, 486.

Continental Bank v. National, 9s, 133, 1:36, 144.

Cooke v. Eshelby, 140. 141, 512.

Cooke v. United States, 458.

Coolidge v. Payson, 417.

Coombs v. Chandler, 302, 407, 408.

Cooper v. Great Falls, 140.

Cooper v. Phibbs, 75, 76, 78.

Corbett v. Brown, 15, 25.

Cornish v. Abington, 15, 96, 102.

Corser v. Paul, 148.

Cory v. Eyre, 265.

Cottrell v. Carter, 298.

Couchman v. Maupin, 211.

Court v. Berlin. 525.

Coventry v. Great E. Ry. Co.. 35. 40, $95,114.125,172,173,316,317,509$.

Covil v. Hill, 297 .

Coward v. Hughes, 78.

Cowdry v. Vandenburgh, 396, 407, 416.

Cowgill v. Pettifish, 436.

Cox v. Bruce, 508.

Coxe v. Hardin, 322.

Craig v. Vicksburg, 394.

Crane v. London, 404.

Crocker v. Crocker, $3 \$ 1$.

Cromwell v. Sac, 424,425 .

Cross v. Currie, 439.

Crotty r. Horlges, 379 .

Crouch v. Credit Foncier, 376, 410, $411,412,413$.

Crowley v. Crowther, 406.

Crystal Lake v. Hill, 452.

Cudahy Co. v. Sioux, 417.

Cuming, Re, $20 \mathrm{l}$. 
Cummings v. Gilman, 30 ?.

Cummings v. Powell, 432, 435.

Cumily v. Lindsily, $: 302$.

Curtis v. Wilcox, 25 .

\section{D.}

Dane r. Bark. 137.

Diniel v. Sinclair, 139.

Daugherty v. Yates, 159.

Darenport v. Homeyer, $3 S 1$.

Diavey's Appeal, 34 .

David v. Park, 74, 137, 139.

Dilvid Sterenson v. Iba, 42.5.

Davis v. Allen, 524.

Davis s. Bank of England, 140, 19;.

Daris v. Beckstein, 407.

Davis v. Best, 4ir.

Davis v. Bigler, $\ddot{362}$.

Davis v. Bradley, 348.

Davis v. Snyder, 26.

Dean v. Crall, 131.

Dean v. Driggs, 317, 319.

Dean v. King, 511.

Dean v. MrcCarty, 38, 63. 349.

De Berkom v. Smith, 125.

De Berry v. Wheeler, 86 .

De Bussche v. Alt, 89.

De Lay v. Carney Bros., 84.

Degg v. Midland R. Co., 28, 100.

Delitield $\because$. Illinois, $\$ 1$ ?

Denishorne v. Hock, 125.

Denton v. Great Northern, 3ri.

Derry v. Peeli, 84, 8.5, 187, 224. 226, $228,230,231,233,235,236$.

Desbrow v. Wetherly, 3:9.

Devaynes v. Noble, 35, 106, 136.

Dezell v. Odell, 87.

Diamond r. Lawrence, 412.

Dickenson v. Vilpy, 125, 515, 524.

Dickerson $v$. Colgrove, 20i.

Dickson v. Reuters, 34. 427.

Dickson v. Swansea, 421.

Dillaye v. Commercial Bank, 264, 407.

Dingle v. Hare, 489.

Directors of Central Ry. Co. s. Kiseh, $13 \pi$.

Dixon, Ex parte, 17t, 242, 299, 490.

Dixon v. Bell, 30, 396.

Dixon v. Bovill, 3i7.
Dixon r. Mrucklestone, 20j, 252, 25j, 282.

Dolell v. Stevens. 137.

Dorluls v. Hills, 25i3.

Dorlge v. Jope, 138.

Dolbeer v. livingston, 452 .

Dolmatn v. Orehatrd, 521.

Dommion Bank v. Blair, 431.

Jorwin v. Thompson, 43.

Dowle v. Saunders, 259, 262, 282.

Dows v. Greene, 177.

Dreher v. Conmolly, 519.

Dunlap v. Lambert, 174.

D)unlop v. Silver, 374, 387 .

Dunston v. Paterson, 195.

Durrant v. Ecclesiastical, 66.

Dyer $v$ Hargrace, 1:37.

Dyer v. l'earson, 3̈̈6.

\section{E.}

Eaglesfield r. Londonderry, 76,87 , 102.

East India v. Fiensley, 477.

East India r. Vincent, 89.

Easton $r$. London (and sub nom. Sheffield v. London), 15, 377, 401, $403,411,512$.

Elgington v. Fitzmaurice, 68, 69, 146.

Edmouson v. Thompson, 5:0, 522 .

Elmunds s. Bushell, 247.

Edwards v. Brown, 428, 431.

Ererton v. Earl Brownlow, 260.

Elurler v. Braun, 132, 157.

Eldridge v. Railroad Co., 436.

Ellis v. Schmoeck, 96, 102.

Ellis v. Wait, $422,454$.

Eimendorf v. Tejarla, 436.

Eluira v. II Irris, 525.

Emmerson r. Ind, 258.

Engstad v. Syverson, 436.

Ensley v. Lewis, 295.

Erb v. Great Western Ry. Co., 1S1, 309. 509.

Espin v. Pemberton, 261, $2 \% 9$.

luropean Bank, Re, 494.

Evans r. Bank of Ireland. 95.

Erans v. Bicknell, $7,33.98,105,160$, 201, 2:2, 223, 225, 234, 252, 278, $2 s 1$. 
Evans v. Farstall, 138.

Evins v. Grer, 451.

Erans v. Hadfield. 521.

Erans v. Roinoke, 268.

Everett v. Hyilialic, 62.

Everts v. Agnes, 449.

Ewell v. Dalgers, $4: 33$.

Exchange Bank r. People's Bank, 60, 504.

Eyre v. Burmester, 200.

F.

Fairweather v. Archball, 75.

Fall River v. Buffinton, 193.

Faris v. Briscoe, ?0.

Farmeloe v. Bain, 339.

Falmers v. Butchers, 501.

Farmers s. Norrich, 444.

Farmers v. Orr, 133, 136.

Farrand r. Yorkshire Banking Co., 101, 289, 286, 289.

Farrant v. Barnes, 119.

Farrar v. Deflinne, 525.

Farrow v. Rees, 252.

Favill v. Roberts, 201, 206.

Fearing v. Clark, 439.

Featherstone v. McDonnell, 207.

Fenn v. Harrison, 477, 493.

Fenner v. Mears, 385 .

Fifth A venue Bank v. Forty-Second. 496.

Fine Art Society v. Union Bank, 51.

Finks v. Buch, 16.

Finlay v. Liverpool, 314.

First Nat. Bank v. Allen, 137.

First Nat. Banls v. Brener, 461.

First Nat. Banis v. Cody, 18, 522.

First Nat. Panle v. Compo, 439, 441. $442,44 \%$.

First Nat: Bank v. Dean, 219.

First Nat. Bank v. First Nat. Bank, $19,20$.

First Nat. Bank v. Marslaall, 1:5, 156.

First Nat. Bank v. Security. 417.

First Nat. Bank v. Zeims, 458.

First State Sav. Bank v. Webster, 444.

Fish v. Clelland, 74.

Fislee v. Mellen, 2:5.

Fisher r. Mossman, 138.
Fitzherbert r. Mather, $17 \%$.

Flanagan v. Elliot, 26 .

Fletcher v. Iteath, 495.

Floricla v. Hope, 156.

Ford, Ex parte, 14:3, 216.

Ford v. Auger, 464.

Ford v. Fellows, 158.

Forlyce r. Kosminski, 60.

Forse v. Sovereign, 153.

Forsyth v. Day, 114, 130.

Foster v. Green, 406.

Foster v. II ISinnon, 103, 371, 378, 429, $43 . \overline{5}, 44$.

Fountain v. Whelpley, 156.

Fourth Nat. Bink v. American, 495.

Fourth Nat. Bank v. Compress, 94.

Fourtl Nit. Bituk v. St. Louis, 334.

Fox v. Ciifton. 18. 5\%2.

Frank v. Chemical, etc. Bank, $13 \%$.

Frankel v. Watlien, 518.

Franklin v. Lyneh, 417.

Frinklin v. Meriula, 5.

Fraser, Re, 125, 515, 521.

Frazer v. Jones, 151.

Freeman v. Buckingham, 511.

Freeman v. Cooke, 34, 93, 94, 140,158, $170,183,223$.

Freeny v. Hall, $15 \%$.

Frere v, Moore, 281.

Friedlander v. Texas, 177, 325, 348, 405.

Frigg v. Read, 77.

Frith v. Cartland, 282.

Fuentes v. Montis, 359, 359, 495, 511.

Furlong v. Carroll, 3.).

Furnace Co. v. Molriatt, 225.

\section{G.}

Gabarron v. Kreeft, 297, 461.

Gage v. Rogers, 518, 519.

Galvin v. Syfers, 439.

Gammill v. Johnson, 138.

Gardner v. IValsh, 3\%9.

Garland v. Thompson, 224.

Garland v. Towne, 62 .

Garland v. Wells, 452.

Garnham v. Skipper, 253, 251, 279.

Garrard v. Lewis, 44 ?

Gaston r. Brandenlury, 88.

General Estittes Co., Re, 391, 422. 
General Finance Co. v. Liberator, 6. General Holticultumal, Re, 25.

General Provident, Re, 14:.

George v. Cutting, 39.

Gerhard v. Bates, 69, 127.

Gerner v. Mosher, 294.

Gettysburg Bank v. Chisholm, 411.

Giannoune v. Fleetwool, 295.

Gibbons v. Wilson, 496.

Gibson v. Bank, 321.

Gibson v. Sterens, 322.

Gilbert v. Erie, 34?.

Gilbert v. Richin!rison. 70.

Gillson v. Nortlı Grey, 38.

Girault v. A. P. Hotaling, 25.

Glassur v. Rolls, 224.

Glenn v. Gill, 21.j.

Glyu v. Baker, 410.

Glynn : East \& West India, 308.

Goetz. Jonis \& Co., Re, $300,363$.

Goffey v. O'Reilly, 138.

Gold Medal v. Lumbers, 224.

Goodall v. Middaugh, 225.

Goodenow v. Ewer, 78 .

Goodman v. Eastman, 48, 60.

Goodmin v. Simonds, 442.

Goodtitle v. Morgan, 36, 105, 257, 276, 250.

Goodwin v. Robarts, 15, 75, 374. 358, $402,407,411,412,413,422,4.40,45 \%$.

Gordon v. James, 133, 177.

Gordon v. Street. 81.

Gorgier v. Mieville, 335, 407, 410.

Gorham r. Gross, 62.

Gorman v. Davis, 525.

Gould v. Close, 409.

Gould v. Legee, $45 \%$.

Gould v. Wise, 452.

Grabill v. Bearden, 149.

Grabenheimer v. Rindskoff, 215.

Graff v. Logne, 439.

Gralıam v. Furber, 142, 301.

Graliam v. Thompson, 25, 137, 135.

Grant v. Mekee, Fis.

Grant v. Norway, 308, 317, 508.

Grant v. Vaughan, 347, 37\%, 355, 396.

Graves v. Horton, 470.

Graves $v$ Key, 8.

Gray ×. Agnew. 352, 354.

Gray v. Bank, 128.

Gray r. Harris, 6:?
Gray v. MeLennan, 89.

Great Northern Ry. Co. v. IIarrison, 62.

Green v. Wilkie, 436.

Greene v. Smith, 106, 160 .

Greenfield, Re. $4 \% 6$.

Greenfield v. Elwads, 45:?

Greenfield v. Stowedl, 43, 60.

Gregg v. Wells. 21, 93, 1:0.

Gritlin v. Nielsols, 20.

Grillith v. Brown, 160 .

Grilith v. Wright. 160.

Grissler v. Powers, 192.

Gunn r. Bistes, $15 \%$.

Gunn v. Bolckow. :309, 339.

Gurney จ. Behrend, 324, 316, 381, 468.

\section{II.}

Hadenck v. Osmer, 224, 225.

Hager v. Buffalo, $4 ! 7$.

Hahn v. Kenefich, 519.

Hale v. Milwaulee, 319.

Halifax v. Wheelwright, $43,41,185$.

Hall v. West End, 2s?.

Hall v. Wilson, 45\%.

Himbleton v. Central, 146.

Hamlin v. Abell, 512.

Hamnala v. Taylor, 125.

Hanover s. American, 192.

Harding, Ex parte, 1:38.

Hardy r. Chesapealie, 106, 156, 13\%, 160.

Harkraeder v. Clayton, 449.

Harlem v. Mercantile. 149.

Harpham v. Shacklock, 153, 253.

Harris v. Brooks, $\boldsymbol{0} 0$.

Harris v. Truman, :09.

ffarrison v. Cotgreave, 379.

Harrison v. Kansas, 489.

Ifurt v, Frontino, 191, 317.

Hart v. Mearl, 4is.

Hart v. Swaine. 78.

Harrey r. Smith, 10\%.

Ifatch $v$ Searls, 443.

Ilatchett v. Gibson, 39r.

Hatfield v. Phillips, 308, $856,360$.

Hareland v. Willets. $\pi$.

Hawlien $v$. Bourne, 490.

Hayman, Ex parte, $214,216,5 \approx 0$. 
Harner v. Churchill, 490.

Heild r. Henely, 105, 484.

Heane v. Roger's, 4, 8, 140, 211, 218.

Heath v. Crealock, 151.

Heatle v. Sansom, 519.

Heatlı r. Stoddard, 299, 357, 489.

Hearen v. Pender, 40.

Hedderly v. Backus, 297.

Hefner v. Palmer, 524.

Helly v. Matthews, 365.

Henderson v. Case, 425.

Henderson v. Comptoir, 308, 331.

Henderson $\mathrm{r}$. Lacon, 127.

Henderson v. Williams, 95, 96, 177, 303, 304, 327, 33:2, 337, 438.

Henry v. Carson, 449.

Henty v. Miller, 408.

Herchmer v. Elliott, 103, 133, 431.

Hern v. Nichols, 510.

Herring v. Skaggs, 499.

Helting \& Nerton, Re, 133.

Hewitt v. Loosemore, 25:, 261, 279.

Heyman v. Flewker, 355.

Hibblewhite v. McMorin, 434, 451.

Higgins v. Burton, 239.

Higgs v. Northern, 201, 422.

Hill v. Cumberland, 201.

Hill v. Epley, 86, 8\%, 89.

IIill s. Jewett, 497 .

Hill v. Lewis, $37 \%$.

Hill v. Van Sandt, 2.J.

Hill r. Tarbrough. 436.

Hinckley v. Bank, 461.

Hiorns v. Holton, 4?8.

Hirsch v. Norton, 132.

Hirsch field v. London, 78.

Hirschtield v. Smith, 379.

Jirscliman v. Budd, $3 \% 9$.

Jforkley v. Bantock, 207, 250.

IIorglinson, Ex parte, 528.

IIogarth v. Latham, 443.

IIoig v. Gordon, 170.

Hoffman v. Tuolunne, 62.

Holcomb v. Boynton, 86.

Holland v. Anderson. 138.

Holland v. Swain, 303.

Hollins v. Fowler, 302.

Hollis v. Harris, 452.

Holman v. Herscher, 522.

IIolmes v. German, 322.

Holines v. Mather, 58.
Holmes v. Trumper. 60.

Holt v. Schneider, 105, 491.

Holton v. Sanson, 40, 120̈, 229, 303. 316.

Hone v. Boyle, 342.

Hooper v. Gumm, 284 .

Hopkins v. Hemsworth, 415.

Horn v. Baker, 354.

Horn v. Cole, 6, 94, 158.

Horne v. Boyle, 408.

Hosegood v. Bull, 123.

Hosler v. Beard, 379.

Hostetter v. Alexander, 19.

Howard v. Baillie, 489.

Howard v. Hudson, 5, 86, 93, 132, 187.

Howard v. Saller, 265.

Howard v. Slieward. 493.

Howard 5 . 'lucker, 508.

Howland v. Woodruff, 174.

Hubbard s. Tenbrook, 247.

Hubbersty v. Ward, 308, 508.

Huber v. Guggenheimer, 76, 81.

Hughes v. Percival, 59.

Huglies v. Twisden, 17, 145.

Humbleton v. Central, 141.

Hume v. Bolland, 139, 194.

Hunt v. Elmes, 205, $2 S 0$.

Hunt v. Mississippi, 511.

Hunt v. States, 452.

Hunter v. Walters, 36, 102, 103, 104.

150. 179, 275, 276, 430, 432, 436.

Hutchinson v. Calder, 81.

Hutchinson r. Gill, 129.

Hyde v. Casey Grimshawe, 528.

I.

Ibbotsen $\nabla$. Rliodes, 284.

Ida, The, 316.

Imperial Land Co., Re, 421, 422.

Ind v. Emerson, 151.

Indiana v. First Nat. Bank, 147.

Ingals $\mathrm{v}$. Ferguson, 25.

Ingham, Re, 205, 281.

Ingluam v. Primrose, 22, 107, 372, 379

$406,4.57,459,462$.

Inglis v. Robertson, 213 .

Insurance Co. v. Eggleston, 72.

Insurance Co. v. Mawry, 72.

International v. Bowen, 26, 188, 203, 200. 
Ireland $\mathrm{v}$. Livingstone, 489. Irish Bank v. Gudlum, 125. Irving Bank v. Wetlerald, 149. Iseminger 5 . Criswell, 25 Isnard v. Torres, 60.

\section{J.}

Jackson $\nabla$. Allen, 68, 19. .

Jacobs v. Shorey. 515.

James v. James, 207, 256.

Jamison v. Miller, 131.

Janberry v. Britten, 35\%.

Jamie r. London, 136.

Jarmain v. Hopper, 505.

Jarvis $\nabla$. Davis, 362.

Jenkyns v. Usborne, 320, 321, 323, $339,365,366,373,406$.

Jessel v. Bath, 509.

Jewel v. Rock River, 453.

John Shillito Co. v. McClung, 221.

Johannessen v. Munroe, $41 \%$.

Johnson v. Credit, 49, 231, 337, 356, $361,495,511$.

Johnson v. Gulick, 225.

Johnson r. Hurley, 482.

Johnson v. Investmeut Co., 491.

Jones $v$. Clifford, $\%$.

Jones v. Derlick, 20, 415.

Jordan v. Money, 68, 96, 123, 15\%, 200, 226.

Jordan v. Picket, 225.

Jordan v. Provincial, 85.

Jordan v. Stevens, 78.

\section{K.}

Kagel v. Totten, 440, 457.

Kalamazoo r. Clark, 436.

Keane r. Boycott, 432.

Keate v. Plitlips, 8, 201, 203, 204.

Keating r. Orme, 14, 68, 189.

Kemp r. Falk, 184, 328.

Kennedy v. Green, 103, 432.

liepp v. Wiggett, 14.

Kern v. Day, 25, 211.

Kettlewell v. Watson, 1\%3, 273, 294.

Keyes v. Merrill, 73.

Keys v. Williams, 207, 256 .

Kiefer v. Rogars, 138.

Kiersky v. Nichols, 158 .
Kinder v. Shaw, 35t.

King v. Box, 382.

King v. Doolittle, ij.

Kingman v. Graham, 25, 86, 138, 158.

Kingstord v. Mlerry, 96, $30: 3$.

Kingston Sav. Bank v. Bossernan, $3 \% 9$.

Kinnear r. Markey, 221.

Kinney v. Whiton, 123.

Kirk s. Hamilton, 207.

Kirkwood v. First Nat. Bank, 417.

Kirkwood r. Smitl, 420.

Knights v. Wilfen, 147.

Knouff $\mathrm{v}$. Thompson, 138.

Knoxville Bank v. Clark, 60 .

Krause r. Busacker, 225.

Krause v. Lutly, 525.

Krothowhl v. Dawson, 69, 221.

Kuriger v. Joest, 26, 136, 149.

\section{I.}

Laing 5 . Taylor, $73,78$.

Lake v. Argyll, 514, 516.

Lamb r. Attenborough, 355 .

Lanfear v. Summer, 362.

Lang $v$. Smyth, 412.

Langdon v. Doud, 68, 187, 188.

Lange, Ex parte, 433.

Lanslown $\approx$. Lansdown. $7 \%$.

Litrt Wilkinson v. Blades, 198.

Lausatt v. Lippincott, 299, 354, 35\%, 459.

Layard v. Maud, 36, 105, 179, 276, 281.

Lay thoarp r. Bryant, 69.

Le Lievre v. Gould. 123, 224, 226.

Leas v. Walls, 60, 107.

Leather v. Morgan, 35, 136, 137, 461.

Leduc r. Ward, 308.

Ledwick v. IIcKim, 440, 457, 461.

Lee 5. Bank, 417.

Lee v. Butler, 365.

Lee v. Taylor, 223.

Lee v. Zagury, 424 .

Lees v. Fisher, 207, 256.

Leete v. State Bank, $2 \overline{0}$.

Legge r. Croker, 78 .

Leggo $\mathrm{r}$. Newbold, 62.

Leonard 8 . Merritt, 450.

Lester v. Snyder, 105, 484.

Lewenberg r. Hayes, 299, 35\%, 459. 
Lewer, Re, 16.

Lew is v. Carstairs, 189.

Lewis $\mathrm{r}$. Jones, 73.

Libel v. Craddock, 525.

Lickbarrow v. Mason, 7, 21, 177. 183, 184, 319, 320, 322. 325, 327, 328, 330, $347,381,384,396$.

Lightner's Appeal, 132.

Limpus v. London, 237, 498.

Lines v. Grange, 27 .

Lingonner v. Ambler. 131.

Lloyd v. Attwood, 279.

Lloyds v. Bullock, 4i2.

Lloyds v. Jones, $36,105,179,261,276$, 280.

Lofius v. Maw, 71 .

London Celluloid Co., Re, 6, 219.

London v. Bank of Liverpool, 148.

London v. Goddard, 253.

London v. Simmons, 403, 495.

London v. Suffield, 24, 133, 136.

London $v$. Wentworth, 178, 180, 3r1, 445.

Long Island v. Columbus, 439.

Losee v. Buchanan, 62.

Louisiana $\mathrm{v}$, Laveille, 511.

Louisville v. Gray, 4:0.

Low v. Bouverie, $14,15,17,89,94,111$, 131, 187, 225, 227, 228.

Lowden $\nabla$. National, 64.

Lowe v. Raleigh, 346, 468.

Lucas v. Dorrien, 309.

Lynch v. Nurdin, 33, 62.

Lyon v. Morgan, 210.

Lyon v. Reed, 1.

Lyon v. Travellers, 72.

Lysaght v. Edwards, 201.

Lythe v. Bank, 476.

Lyttle v. Cozard, 452.

\section{M.}

NacAleer $\nabla$. Horsey, 80, 146.

MacKreth v. Symmons, 203.

McAdow v. Hassard, 144.

McArthur v. MacDowell, 424.

Mcßjetlı v. Craddock, 84 .

McClain v. Abshire, 25.

McCord v. Levi, 225.

ItcCornick v. Bay City, 452.

McCravey v. Kemson, 203.
McDiarmid v. Hughes, 26.

McDonald v. Museatine, 448.

MeDonald v. Weeks, 298.

MeEwan v. Smith, 339.

McFarlane v. McHugh, 525.

McGee s. Kane, 86, 96.

McKay v. Commercial Bank, 496, 506.

McKenzie v. British Linen, 22, 41, $114,136$.

McKenzie v. Montreal, 392, 412, 422, 424.

McKowan v. Ferguson, 225.

Mclunis v. Milton, 441, 459.

McLean v. Buffalo, 229, 316, 317.

McLean v. Clark, 125, 137, 138, 515, $520,522,525$.

McLean v. Fleming, 508.

McLenmore v. Rankin, 518.

Mclathon v. Sloan. 393 .

Mcilinus v. Watkins, 132

McMullen v. Williams, 490, 493, 495.

McNeil v. Tentlı Nat. Bank, 297, 342, $40 \%, 408,45 t, 46$ s.

McNeilan's Estate, 523.

Mack v. Prang, 20.

Maddick v. Marshall, 96, 102, 514 .

Maddison v. Alderson, 68.

Maguire v. Selden, 123.

Makins v. Pigrott, 38, 62.

Man v. State, 374.

Mander v. Royal, 417.

Mangan v. Atterton, 62 .

Mangles v. Dixon, $66,90,94,136,157$, 249,418 .

Manitobal v. Bank, 136.

Manley v. London, 19.

Manufacturers v. Hazard, 101, 157.

Market v. Sargent, 441, 442.

Markhan v. O'Connor, 138.

Marschall v. Aikin, 23, 522.

Marsh v. Falker, 225.

Marsh v. French, 475, 476.

Marshall v. Furgason, 225.

Marshall г. National Bank, 116, 341.

Marshall v. Nelwood, 62.

Marshall v. Pierce, 39 .

Mirston v. Allen, 3i1, 445.

Martin v. Bearman, 415.

Martin v. Hanning, 450.

Murtin v. Martin, 394.

Martinez v. Cooper, 252. 
Martini v. Coles, 351, 352, 353, 354.

Martyn v. Gray, 17, 125, 5:2, 5:3.

Mason v. Bickle, 16, ?95.

Mason v. Bralley, 370.

Mason v. Frick, 412 .

Master v. Hill, 379.

Masters v. Miller, 3r8. 398.

Masury v. Arkansats, 1:32, 342.

Mather v. Maidstone, 1.18.

Maxfield v. Burton, 2:33.

Mayor v. Bank of England, 43, 49, 64 , $65,95,108,116$.

Meggy v. Imperial, 298, 489.

Mercer v. Hackett, $41^{\prime}, 414$.

Merchants v. Bank of England. See Mayor v. Bank.

Merchants' Bank v. Good, 371, 439, $441,446$.

Merchants' Bank v. Lucas, 69, 114, $136,147,148$.

Merchants' Bank v. McKay. 436.

Merchants' Bank v. Monteith, 219.

Merchants' Bank v. Morrison, :.j3.

Merchants' Bank v. Phonix, 309, 316, $317,318,339,342,345$.

Merchants' Bank v. State Bank, 504.

Meridian Nat. Bank v. MIConica, 210 .

Merrimac v. Illinois, 503.

Merritt v. Williams, 518.

Metcalf v. Metcalf, 436 .

Michigan v. Phillips, 309, 321. 325.

Midaugh v. Elliott, $3 i 9$.

Midland Ry. Co. v. Johuson, $73,75,70$.

Miles v. Furber, 514, 518.

Miles v. MeIlwraith, 132.

Miller v. Mnor, 433.

Miller v. Parker, 1\%7, 298.

Miller v. Race, 385, 406.

Miller v. Ross, 26 .

Milmo Nat. Bank v. Carter. 525.

Mississippi v. Ottumwa, 157.

Mitchell v. Warner, 376.

Moakes v. Nicholson, 322.

Mollett v. Robinson, 489.

Molson`s Bank v. Brockville, 493.

Monk v. Whittenbury, 35.5.

Montagu, Ex parte, 142, 301.

Montagu v. Forwood, 242 .

Montagu v. Perkins, 36, 243, 446.

Montaignac v. Shitta, 503.

Montgomery v. Hardaway, 476, «D.
Montgomery v. Keppel, 160.

Moore v. Albro, 13:. 143.

IIoore v. Bank, 407.

Moore v. Brownfield. 86.

Muore v. Harper, 515 .

Moore v. Kiane, 265, 2\%?.

Moore v. Metropolitiln, 238, 2.3, 409, 416.424.

Moore v. Moore, 96.

Moore v. Northwestern. 25t.

Inore v. Spiegel, 158, 163.

lloore v. Trimmer, 70.

Moores s. Citizens, 340, 497.

Morian v. Pitt. 49:.

Moreland v. II. C. Frick, 26.

Morsan, Re, 2i4. 28:.

Morgan v. Knight. 144.

Uorgan v. Railioad Co., 6, 26.

Morgan v. United States, 412, 424, 495.

Morris v. Preston, 439.

Moss v. Hall, 69.

Moss r. Hancock, 406.

Mott v. Clark, 238, 425.

Nount Morris $v$. Lawson, 370.

Nowatt v. Carstle, 21\%.

Moyce v. Newington, 181.

Mumford v. Stolnwasser, 253.

Munroe v. Philadelphia, 333, 331.

Numroe v. Pritchett, 225.

Murphy v. Barnard, 132.

Murray v. Eagle Bank, 50t.

Nurray r. Laldner, 394.

Murray v. Lylburn, 425.

\section{$\mathrm{N}$.}

Nish v. Frigate. 452.

Nital Inrestment Co., Re, 404, 421.

Nitional v. Chicago, 511.

National v. Gray, 396.

National v. Jaclison, 104, :S6, 2SS, 4:0, 431.

National v. Texas. 425.

National v. Thomas, 525.

National r. Wilson, 491.

Nerial $v$ Robinson, 27.

Neal v. Williams, 30 ?.

New Albany r. Meyers, 4 s?.

New Brunswich r. Conybeare, 127, 150. 
New England v. Brown, 453.

New York v. Bailey, 62.

New York r. National, 504.

New York $\mathrm{r}$. Rothery, 33.

Newall r. C. P. R. Co., 298.

Newbold r. Wrimht, $29 \pi, 854$.

Sewell v. Williston, 132.

Newman v. King, 3 \%9.

Newman s. Newman, 10j, 25\%, 261, 283.

Newsome r. Coles, 520. 521.

Newson v. Thornton, 321.

Newton v. Newton, 151.

Nichols v. Peck, 156.

Niclıolson v. Sedgwick, 417.

Niren v. Belknap. 138.

Nixon v. Brown, 348.

Nodle v. Hawthorne, 26.

Nofsinger v. Goldman, 125, 522.

Norquist v. Dalton, 518, 524.

Norris v. Morrison, 39

North River Bank v. Aymar, 504.

Northern Counties v. Whipp, 21, 98. 10.), 160, 1ร9, 252, 281, 288, 465, 496.

O.

Oak Creek v. Helmer, 131.

Oberfelder v. Kavanagh, 210.

O'Connor v. Clark, $30 \pm$.

Odlin r. Gove, 189.

Orilvie v. Jeaffreson, 103, 104, 429.

Orilvie r. West Australia, 26.

Dgle v. Atkinson, $31 \%$.

Old Colony v. Dubuque, 68.

Olver v. G. W. R. Co., 509.

Oliver v. Hinton, 260.

Olson r. Royern, 4:36.

Ontario Bank v. Gibson, 439.

Ontario Bink v. McTaggart, 23S.

Onward v. Smithson, 14, 188, 224, 376, 431, $432,434$.

Oregon v. Forrest. 433.

Ormond v. Holland, 30.

Orr v. Orr, 68.

Otis v. Gardner, 272, 342.

Ottos, Re, $187,315,316,317,340,317$.

Orerend, Re, 424, 496.

Owens v. Burgess, 38, 63.
P.

Paisley v. Bannatyne, 476 .

Palacios r. Brasher, 452.

Parbury's Case, 146.

Parker v. Carolina, 261.

Parlier v. Clarke, 19.

Parker v. Crittenden, 209, 211.

Parsons v. Kruger, 528.

Pasley v. Freeman, 64, 222.

Partridge . Bank of England, 417.

Patterson v. Hitchcock, 160.

Patterson v. Lytle, 87.

Patterson v. Tash, 354, 495.

Peacock v. Rhodes, 377, 385, 394.

Pearson v. Brown, 31, 225.

Pearsoll v. Chapin. 43.j.

Pease v. Gloahec, 96, 253, 303, 320, 326, $331,346$.

Peavy v. Seigler, 199.

Peck v. Gurney, 15, 127, 128, 164, 223.

Peerless v. Gates, 297.

Pence $\nabla$. Arbuclile, 456.

Pennsylvania Ry. Co.'s Appeal, 116, $128,1 \% \pi, 342$.

People v. Bank, 136, 362.

People's Bank v. Gridley, 132.

Perry v. Lawless, 69.

Perry-Herrick v. Attwood, 243, 245, $273,379,393,399$.

Pertuit v. Damare, 20 .

Peter v. Russell, 284.

Petrie v. Guelph, 85.

Plrelps v. Illinois Ry., 15 .

Phillips v. Hunt, 336.

Phillips v. Huth, 3500, 360 .

Plillips v. Plillips, 151, 153.

Plocenix v. Gray, 47\%.

Pickard v. Sears, $8,44,89,93,1 \% 8,220$, $238,284,: 289,402$.

Picker $\nabla$. London, 412.

Pickering v. Busk, 8, 9, 246. 299, 335, $353,351,357,443,473,478,486,489$, $491,511$.

Pickert $\nabla$. Marston, 489

Pieratt $\nabla$. Young. 225.

Pierce v. Andrews, 156.

Pierce v. Horner, 132, 144.

Pierson v. Dunlop, 417.

1 Piggott v. Stratton, 68. 
Pilcher v. Rawlins, 253.

Pillans v. Mierop, $41 \%$.

Pitcher v. Dove, 86.

Pitkin v. Benfer, 525.

Plumb v. Fluitt, 25:, 261, 269, 270.

Plumer v. Lord, 157.

Poillon v. Secor, 514.

Polak v. Everett, 39, 60.

Pole v. Leask, $45 \%$.

Pollard v. Reardon, 321, 325, 329, 830, $334,369$.

Pollirrd v. Vinton, 308, 511.

Pooley v. Driver, 513.

Polson v. Degeer, 298.

Pott v. Eyton, 5.5.

Potter v. Faulkner, 28, 396.

Potts v. Temperance, 66, 91 .

Powell v. Fall, es.

Powell v. London, 153, 179, 250, 254, $271,286,288$.

Powell v. Rogers, 86.

Powell v. Snith, $73,7 \delta$.

Powers v. large, 25.

Pratt v. Drake, 136.

Prentice v. Page, 303.

Preston v. Mann, 69, 138, 1\%.

Proctor v. Bennis, 16, 26, 91, 140.

Prole v. Soady. 68.

Proserpino, The, 316.

Provident r. Mercer, 412, 439.

Pryce v. Bury, 2;6.

Pullen v. Ready, 73.

Pulsford v. Richards, $80,222$.

Putuam v. Sullivan, 49.

Pyne v. Wilson, 365.

\section{Q.}

Quebec Bank v. Taggart, 126, 417.

Quinn v. Davis, 299.

Quirk v. Thomas, 303, 523.

\section{R.}

Railroad Co. v. Howard, 381.

Raleigh v. Lowe, 325, 318.

Ramozotti v. Bowring, 174, 242, 299.

Ramboll v. Soojumnull, 260 .

Ramsden v. Dyson, 22, 33, :39, 47, 89, 138, 249, 516.

Iásiadall v. Ford, 73, 76.
Rastrup v. Prendergast, 2.

Ratcliffe v. Barnard, :26:, 279.

Rathburn v. Snow, 490.

Jaynell s. Sprye, 81.

Rector v. Joard of Improvement, 520.

Relfern v. Ferrier, 4.5.).

Redgrave v. Ifurd, 13\%, 114

Reed v. Ingham, ;i $;$.

Reese v. Bates, 489.

Reese v. Smith, 8j, 87, 10\%

Reid, Ex parte, 282.

Reid v. Coleman, 519.

Reg. v. Blenkensop, 139.

Reg. v. Charnwool, 191, 9:0, 23\%, $23 \%$.

Reg. v. Chesley. 45? 4.i5.

Reg. v. Shropshire, 2j3, 20i3, 207, 271, $296,311$.

Reg. v. Wilson, 52.

Reynell v. Lewis, 516.

Rice v. Rice, 251, 270, 281 .

Richards, Re, 2fij, 2\$2.

Richards v. Bauk of Nova Scotia, 496.

Richards s. Jenkins, 196, 210.

Richards r. Johnston, 4, 196, 209, 210, $212,220,221$.

Richardson v. Richardson, 382

Richardson v. Silvester, 12t.

licher v, Voyer, 417.

Riclietts v. Scothorn, 70

Rigrgs s. Pursell, 129.

Rimel v. Hayes, 5:33.

Rives $\nabla$. Miclraels, 595.

Rizey v. James, 521

Roach v. Karr, 436.

Robarts v. Tueler, 441.

Robb v. Pennsyluania, 65, 10\%, 139, $275,172$.

Robinson v. Cook. 26.

Robinson v. Flocd, 518.

Robinson r. Jenkins, 310 .

Robinson v. Montgomeryshire, 218, $245,342,418,47 s, 496,50 \%$.

Rotinson r. Nail, 111.

Roberts $\mathrm{v}$. Croft, 205, 28\%

Roberts v. Trammel, 25.

Robertson r. Hay, 12s.

Rockford v. Young M. C. Ass'n, 420.

Rodger v. Comptoir, 321, 323.

Rodriguez v. Hetrerman, $3 \bar{z}$.

Rogers $v$ Bacliman, 298.

Rogers v. Rotinson, 1iz. 
Romford, Re. 15, 75, 194, 201, 421.

Rooper v. Harrison, 252, 256.

Root 5. French, 25, 96, 182.

Roots v. Williamson, 153, 2.53.

Rose v. Douglas, 452 .

liose r. Watson, 201.

Royal Ins. Co. v. Byers, 80, 140.

Royal v. Turquand, 218.

Rowland \& Crankshaw, Re, 213, 214.

Rumball v. Metropolitan, 414.

Rumensnyder v. Gans, 70 .

Russell v.|Langstaffe, $240,371,441,447$.

Russell v. Wiggins, 417.

Rutz v. Kehr, $20: 3$.

Ryan v. Bank of Montreal, 148.

Ryekman v. Canada Life, 19.

Rylands v. Fletcher, 6 .

S.

Saderquist $\nabla$. Federal Bank, 118.

Saderquist v, Ontario, 95.

Sage v. Shepherd, $29 \%$.

Salem v. Gloucester, 148.

Saltus v. Everett, 297, 333, 346, 394, 399.

Sanders v. McLean, 321.

Sandys v. Hodgson, 13.

Sanitary v. Cook, 140.

Sauce v. Exchange, 417.

Saunders v. Delsew, 253.

Scarf ₹. Jardine, 41, 517, 518, 526, 528.

Schmidt v. Ittman, 52\%.

Seholfield v. Londesborough. 42, 43, $44,46,47,48,55,57,58,107,109$, $117,140,185,378,441$.

Schooner Freeman v. Buckingham, 308.

Schuchardt $r$. Allens, 494.

Schultz v. Astley, 441, 447.

Schuster v. AcKellar, 334.

Schuyllill v. Copley, 440, $45 \%$.

Schway v. Bank, 136.

Sclauch v. O'Hare, 420.

Scollans v, Rollins, 109, 396.

Scotland v. O'Connell, 60.

Scott v. Bank, 114, 136.

Scott v. Dixon, 127.

Scott v. Pllkington, 377.

Searles v. Seipp, 60.

Second Nat. Bank v. Hewitt, 378.
Second Nat. Bank v. Wallbridge, 95. Sessions v. Rice, 158.

Seton $\mathrm{v}$. Laf fone, 120, 171, 172, 187, 193, $309,31 \%$.

Sewell v. Burdick, 308, 321.

Seylar v. Carson, 43j.

Sharp v. Foy, 205.

Sharples v. Adams, 253.

Shaw v. Levy, 36\%.

Shaw v. Picton, 139.

Shatr v. Port Philip, 50, 52, 64, 95, 108, 28\%, 496, 499.

Shaw v. Railroad Co., 325, 346, 348, $376,378,383,468$.

Shefiveld v. London (and sub nom. Easton v. London), 15, 377, 401, 403, 411, 512 .

Sheffield v. Woodstock, 434 .

Sheldon v. Hurtley, 3\%\%.

Sheldon v. Parker, 382.

Sheppard v. Union Bank, 96, 346.

Sherrod v. Langdon. 516 .

Shields v. McClure, 131, 156.

Shorthard v. Sutton, 203.

Shott v. Streatfield, 522, 523.

Shrewsbury v. Smith, 62.

Shroeder v. Young, 50.

Sibley v. Quinsigamon, 132.

Sioux v. First Nat. Bank, 511.

Sioux v. Trust Co., 218.

Simm v. Anglo-American, 4, 6, 147, 187, 191, 22 i, 235, 236, 317.

Simmons v. Atkinson, 60.

Simmons v. London, 239, 329, 372, 376, $377,383,411,512$.

Simpson v. Accidental, 66.

Showkegan v. Cutter, 132.

Skyring v. Greenwood, 139.

Slim v. Croucher, 223, 228.

Sliney v. Davis, 143.

Small v. Attwood, 140.

Smith v. Chadwick, $13 \pi, 144$.

Smith v. Grouette, 174, 242, 299.

Smith v. Hughes, 66, 91.

Smith v. Hull, 490.

Smith v. Kay, 69, 81, 145.

Smith v. Kendall, 382.

Smith v. Land \& House, 144.

Smith v. London, 100.

Smith v. Mercer, 148.

Smith v. McGuire, 239. 
Smith v. Missouri, 511.

Sinith v. Slavin, 191.

Smith v. Sinith, 71.

Smith v. Wallerville, 317, 493.

Sinith v, Wegnellin, 41:.

Smith v. Proria, 451, 4iso.

Smith v. Loach, 15\%.

Smith v. loggers, 312. 409.

Snell v. Insurance Co. $78,79$.

Société v. Metropolitan, 43, 48, 49, 58, $60,46 \pi$.

Société v. Walker, 345.

Soltau v. Gerdau, 302, :30 \&. 49J.

Somers v. Brewer, 311, 43.

Sornborger v. Sanford, 4i33.

South Essex. Re, 209, 218.

Southall v. Riggr, 78 .

Southard v. Sutton, 70 .

Southern v. Silva, 10.

Spear v. Travers, $336,353,365$.

Spencer's Case, 370.

Spencer v. Clarke, 36, 105, 179, $2 \pi 6$.

Spooner v. Browning, 4\%.

Spooner v. Cummings, 299, 475.

Squire v. Whitton, 451.

St. Cesaire v. McFarlane, 412.

St. Louis v. Larned, 316.

Stables v. Eley, 529.

Stackhouse v. Jersey, 151.

Stanhope v. Verney, 203, 204.

Stansfeld v. Cubitt, 138.

Stanton v. Estey, 131.

Starr v. Bennett, 74.76.

Starr r. Newman, 123.

State v. Flathers, 416.

State v. Dean. 451.

State v. Hastings, $39 \bar{\jmath}$.

State v. Peck, 451.

State v. Pepper, 451.

State v. Potter, $45 \%$.

State v. Matthews, $49,437$.

Staton v. Bryant, 86.

Stephens r. Baird, 8.

Stephens v. Barfoot. 298.

Steplens v. Dennett, 89, \$6.

Stephens v. Head, : 26.

Stevens v. Dermett, $\tau, 39,86$.

Sterens v. Irwin, 362 .

Stevens v. Ludlum. 128.

Stevens v. Wilson, 368.

Stewart v. Brown, 53J.
Stewart v. Kennedy, 78.

Stewart v. Rounds, 132, 475.

Stewart v. Stewart, 78 .

Stiff v. Ashton, 86.

Stinson v. Whitney, 517.

Stoddard r. Clambers, 207.

Stoessing v. Southeastern, 441.

Stollenwercli v. Thatcher, 333.

Stone v. Denny, 22.5.

Stone v. Engstran, 27.

Stone v. Georgia, 199.

Storer v. Keitlr, 452.

Strand v, Griffith, $13 \%$.

Strauss v. United Tel. Co., 412.

Strecker v. Conn, 517, 525.

Stronge v. II is kes, 284.

Studulard v. Lemmond, 26.

Sullivan v. Colly, 86, 160.

Summers v. Heard, 528.

Sunderlin v. Struthers, 211.

Sutton v. Tatham, 443, 478, 489.

Swamell v. Watson, 436.

Swan, Ex parte, 41, 105, 109, 341, 347, $397,44 \pi, 450,468$.

Swan v. N. B. A., 18, 33, 36. 43, 44, 47, $49,104,108,109,110.11 \%, 120,129$, 178, 183, 184, 341, 347, 370, 37:, 897, $433,445,44 \tau, 449,450,452,459,468$.

Swaisland v. Davidson, 60, 107.

Swigert v. Aspden, 519.

Swinbanks, Re, 13:3.

Swinney v. Edwards, $3 \% 9$.

Swire v. Francis, 503.

Swift v. Winterbotham, 124, 125, $156,506$.

Sylvester v. Henrich, 25.

\section{$\mathrm{T}$.}

Tailby v. Official Receirer, : 01.

Tithlum v. Curtis, 62 .

Tilpl v. Lee, 15, 25.

Tapscott $v$. Williams, 370 .

'auskel v. Small. 201.

Talunton s. Royal, 490.

Tayler v. Great Eastern, 177.

Taylor v. Ely, 39.

Tilylor s. Garliner, 493.

Taylor v. Great Indian, 4jt.

Tilylor v. Kymer, 336.

Talylur v. Medham, 96. 
Taylor v. Pope, 299. 302, 357. 4\$9.

Taylor v. Russell, 253, 26:2,263, 285.

Taylor v. Stray, 489.

Taylor v. Truman, 356.

Telegrapls Co. v. Davenport, 141.

Texira r, Evans, 451.

Third Nit. Bank v. Merchants, 149.

Third Nat. Bank v. Spring, 4:0.

Thistle v. Buford, 197.

Thomas v. Brown, 15.

Thomas r. Grise, 146.

Thompson v. Dominy, 320.

Thompson v. First Nat. Bank, 524.

Thompson $v$. Perrine, $3 \% 6$.

Thompson v. Shelton, 105, 491.

Thomson $v$. Clydesdale, 406.

Thorman v. Burt, 509.

Thorne v. Heard, 496.

Thornton v. McDonald, 522.

Thorougligood's Catse, 104. 428.

Thorpe v. Houldsworth. 105, 276, 286.

Tillotson v. Mitchell, 156.

Timpson v. Allen, 177, 486 .

Tinson v. Francis, 423.

Tobin v. Allen, 133.

Tobin v. Manhattan, 461.

Told v. Coshell, 62.

Tomkinson v. Balkis, C, 17, 224, 317, 340.

Torrance v. Bolton, 260.

Tower v. Hoslam, 131.

Towle v. Leavitt, 299, 478, 489, 512.

Tracy v. Lincoln, 158.

Traill v. Baring, $81,145$.

Trenton v. Duncan, 25, 26.

Trevivian v. Law rence, 207.

Trimble v. Bank, 141, 340.

Tripp s. Martin, 512.

Trougton v. Gitley, 143, 299.

Tryon v. Whitmarsh, 225.

Trust \& Loan Co. v. Hamilton, 397.

Trust \& Loan Co. v. Ruttan, 206.

Trustees v. Smith, 86, 96 .

Trustees $\nabla$. Wheeler, 17\%.

Turner v. Francis, 84 .

Two Rivers Co. v. Day, 138, 158.

\section{U.}

Udell v. Atherton, 493.

Union v. Kent, 48, 28\%.
Union v. Laird, 132.

Union v. Mersey, 45, 48, 53. 55, 110.

Union v. Southern California, 496.

Union v. Wilmot, 196.

Upton v. Tribilcock, 74, 75.

Utica v. Mersereau, $20 \%$.

Utterson v. Rennie, 153.

\section{V.}

Vagliano v. Bank of England, 43, 96.

Vallett v. Parker, 439.

Van Dusen v. Jungleblut, 299, $4 \$ 9$.

Van Duzen v. Howe, 53, 57, 441, 448.

Van Hasselt v. Sack, 139.

Van West v. First Nat. Bank, 141, 149.

Vance v. Lowther, 379.

Vaughan v. Menlove, $30,38$.

Vaughan v. Taff Vale Ry. Co., 38, 99.

Venables v. Baring, 380, $897,410,412$, $422,468$.

Vermilyea v. Cannif, 76.

Vernon, Re, 282.

Vice v. Anson, 125.

Vickers v. Hertz, 303, 337.

Viele v. Judson, 33, 39, 136.

Vilmont v. Bently, 181.

Vimeberg v. Anderson, 174, 299.

Vorley v. Cooke, 103, 429, 432.

Vulcan v. Rapid City, 298.

Vulliamy v. Noble, 522.

TV.

Wachsman r. Columbia Bank, 136.

Wachussett v. Sioux City, 25, 143, 209.

Waldron v. Sloper, 101, 105, 173, 282.

Walker v. Hyman, 140, 30 t.

Waller v. Missouri, 121.

Wallerick v. Suith, 158.

Walls v. Ritter, 131.

Walsh v. Ilunt, 60, $10 \%$.

Walters s. Tielkmeyer, 461.

Warden r. Greer, 319.

Warlow v. IJarrison, $37 \%$.

Warner v. Martin, 49j.

Warner v. Watson, 25.

Warrington v. Eirly, 379.

Waterhouse v. Bank of Ireland, 342, 408. 
Watlins, Ex parte, 300, 36 :

Watson v. Jones, 54, 22.4.

Watson v. Russell, 459.

Watson v. Threlkeld, 27.

Watteau v. Fenwick, 246, 247.

Waugh v. Carver, 12j.

Weaver v. Barden. 341.

Webb v. Corbin, 436.

Webu v. Herne Bay, 19, 414, 422.

Webster v. Peck, :36:2.

Webster v. Wehster, 5:2.

Weeks v. Palmer Bank. 139.

Wegner v. Second Ward, 461.

Weilman v. Symes, 60 .

Weinstein v. National Bank, 137.

Weir v. Bell, 237, 49 S.

Welland v. Hathaway, 8, 196.

Werrich v. Mahoning Co. Bank, 407.

West v. Jones, $19,24,94,10^{2}, 157,231$.

West v. MacInnes, 424.

West Chicago v. Morrison, 272.

IVestbrooke v. Gurdereau, 158.

Western v. Addic, $12 \%$.

Western v. Page, 489.

Western v. Wagner, 324, 337.

Wheal Unity Co., Re, ?09.

Wheeler v. Benton, $4 i 6$.

Wheeler v. Guild, 466.

Wheeler v. McGuire, 4 S3.

Wheeler v. Smith, is.

White v. Ashton, 68.

White v. Continental Nat. Bank, 149.

White v. Grunish, 195.

White v. Sage, 84.

White v. Southend Hotel Co., 201.

White v. Vermont, 41 ?.

White v. Walker, 69,70 .

Whitehead v. Tuckett, 474.

Whitemore v. Nickerson, 442.

Whiteside v. First Nat. Bank, 380 , $39 \pi, 412$.

Whitney v. Snyder, 4t0.

Whyte v. Heyman, 38:.

Wichita v. Atchison, 31\%, 511 .

Wiechers v. Centril Trust Co., 136.

Wigle r. Williams, 519.

Wilding v. Sanderson, 78.

Wilkinson r. Johnson, 148.

Willinson v. King, 511.

Willoughby v. Willoughby, 253.

Williams v. Barton, ¿ủo.
Williams v. Carrardine, 3\%氵.

Williams r. Colonial bank (and sub) nom. Culonial l'ank v. (ady). 116,

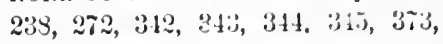
$404,412,418,420,410,45$.

Williams v. Donnelly, 42.;.

Willians v. Given, $311,431$.

Williams v. Keats, 5:1.

Williams r. Lambe, $15 l$.

Williams v. Stern, 71 .

Williams s. Wilmington, i11.

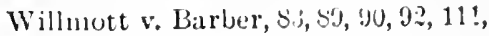
137.

Win v. Bell, 261.

Winch v. Keeley, 389.

Winslow v. Leonard, 30 ?

Winter v. Belmont, $31 \%, 469$.

Witzler v. Collins, 511.

Wool v. Argyll, 514, 516.

Wood v. Seely, 2:1.

Wood $\nabla$. Rowcliffe, 3i.s.

Woodhull v. Rosenthall, 26.

Woodworth v. Bank, 374.

Wookey v. Pole, 347, is.;, 396.

Worrall v. Gheen, 43,48 .

Wortham s. Curley, 2:21.

Worthington v. Morgill, :201, 2:0.

Wortley v. Birkhead, 258 .

Waters' Appeal, 14:.205, 211 .

Wright's Appeal, 146.

Wright 5 . Campbell, 35.

Wright v. Fonda, 525.

Wright v. Hazen, 198.

Wrighit v. Solomon, 369 .

Wright s. Snow, 9\%.

Wynne v. Mason, 138.

\section{Y.}

Yocum $\vee$. Smith. 60.

Young v. Brewster. 347, 461, 408.

Young v. Grote, 34, 4:, 43, 44, 45, 10i, $117,11 \leq, 45 \pi, 468$.

Young v. Hope, 142, 301.

Foung v. MineNider, 241, 398, 407, 424 .

Young r. Ward, 212.

\section{Z.}

Zimmerman s. Rote, 50, 60, 10\%, 460 .

Zuchitminn $\vee$ Rolserts, 4, 86, 159, 298. 



\section{ABBREVIATIONS USED IN THIS VOLUME.}

A. C. (1891, A. C.)... Law Reports, Appeal Cases of 1591.

A. \& E.......... Arlolphus \& Ellis - Reports.

Ala............ Alabama - Reports.

Amb. .......... Ambler - Reports.

Anst............. Anstruther - Reports.

App. Cas.......... Law Reports, Appeal Cases.

Ark............ Arkansas-Reports.

Atk........... Atkyns - Reports.

Atl. R............ Atlantic Reporter.

B. \& Ald......... Barnewall \& Alderson - Reports.

B. \& Ad......... Barnewall \& Adolphus - Reports.

B. \& C.......... Birnewall \& Cresswell - Reports.

B. \& S........... Best \& Sinith - Reports

Bac. Abr......... Bacon's Abridgment.

Bill \& B........ Ball \& Beatty - Reports.

Barb.......... Biarbour (New York) - Reports.

Bear............ Beavan - Reports.

Bing........... Bingluam - Reports.

Binæ. N. C........ Bingham's New Cases - Reports.

B1. H... ........ Blackstone (Henry) - Reports.

Bli............ Bligh - Reports.

Bli., N. S......... Bligh, New Series - Reports.

Bos. \& Pul........ Bosanquet \& Pullen - Reports.

Bro. Ch.......... Brown's Chancery - Reports.

Brod. \& B........ Broderip \& Bingham - Reports.

C. B............ Common Bench - Reports.

C. B., N. S........ Common Bench, New Series - Reports.

C. C. A. ........ Circuit Court Appeals - Reports.

C. \& J........... Crompton \& Jervis - Reports.

C. P. D........... Law Reports, Common Pleas Division.

C. \& M......... Crompton \& Meeson - Reports.

C., M. \& R..... .... Crompton, Meeson \& Roscoe - Reports.

Cab. \& E......... Cababe \& Ellis - Reports.

Cal............. California - Reports.

Cent. Dig.......... Century Digest.

Ch. (1891, Ch.)..... Law Reports. Chancery Dirision of 1891.

Cl. D. ............ Law Reports, Chancery Division - Ieports.

Cl. \& F........... Chark \& Finnelly - Repurts.

Co. Lit........... Coke on Littleton. 
Co. Rep........... Coke - Reports.

Cold............ Coldwell (Tennessee) - Reports.

Colo.............. Colorado - Reports.

Colo. App......... Colorado Appeal - Reports.

Com. Dig.......... Comyn's Digest.

Conn............ Connecticut - Reports.

Cr. \& St.......... Craigie \& Stewart - Reports.

D. \& Ry.......... Dowling \& Ryland - Reports.

Dall............ Dallas (Pennsylvania) - Reports.

De G., F. \& J ...... De Gex, Fisher \& Jones - Reports.

De G. \& J........ De Gex \& Jones - Reports.

De G., J. \& S...... De Gex, Jones \& Smith - Reports.

De G., M. \& G...... De Gex, Macnaghten \& Gordon - Reports.

De G. \& Sm....... De Gex \& Smale - Reports.

Dra............ Draper (Upper Canala) - Reports.

Dr. \& War........ Drury \& Warren-Reports. .

Drew............ Drewry - Reports.

E. \& E.......... Ellis \& Ellis - Reports.

El., B. \& S........ Ellis, Best \& Smith - Reports.

El. \& Bl......... Ellis \& Blackburn - Reports.

E., B. \& E........ Ellis, Blackburn \& Ellis - Reports.

Esp............ Espinasse - Reports.

Ex........... Exchequer - Welshy, Hurlstone \& Gordon - Reports.

Ex. Div.......... Law Reports - Exchequer Division.

Fed. R............ Federal Reporter.

Ga............ Georgia - Reports.

Gr............. Grant (Ontario) - Reports.

Grat ............ Grattan (Virginial) - Reports.

H. \& C.......... Hurlstone \& Coltman - Reports.

H. \& N. ......... Hurlstone \& Nornan - Reports.

H. L. C. .......... House of Lords Cases.

Head........... Head (Tennessee) - Reports.

Hem. \& M......... Hemming \& Miller - Reports.

Hill............ Hill (New York) - Reports.

How............ Howard (United States) - Reports.

Humph .......... Humphrey (Tennessee) - Reports.

Hun ........... Hun (New York) - Reports.

Ill. ............ Illinois - Reports.

Ill. App.......... Illinois Appeal - Reports.

Iun, St.......... Imperial Statute.

Ind............ Indiana - Reports.

Ind. App........ Indiana Appeal - Reports.

J. \& H......... Johnson \& Hemming - Reports.

J. \& W.......... Jacob \& Walker - Reports.

Jac............ Jacob - Reports.

Jolnn............ Johnson - Reports.

Johns............ Johnson (New York) - Reports.

Johns. Ch......... Johnson Chancery (New York) - Reports.

Kan.. .......... Kansas - Reports. 
Kay \& J......... Kay \& Johnson - Reports.

Ky............. Kentucky - Reports.

L. C. J........... Lower Canada Journal.

I. J............. L Lilw Journal.

L. J. Bk......... Law Journal, Bankruptey - Reports.

L. J. C. P......... L.iw Journal, Common Pleas - Reports.

L. J. M. C......... I Law Joumal, Magistriates' Cases - Reports.

L. J. N. S......... Liw Journal, New Series.

L. J. O. S.......... Law Journal, Old Series.

L. J. P. C...... ... Law Joumil, Privy Council - Reports.

L. J. Q. B......... Law Journal, Queen's Bench - Reports.

L. R............ Law Reports.

L. R. Ir.......... Law litports, Ireland.

L. T............ Liw Times.

L. T. N. S......... Law Times, New Series.

La. Ann.......... Lotrisiana Annual-Reports.

Ld. Ray.......... Loid Raymond - Reports.

M. \& S.......... Haule \& Selwyn - Reports.

M. \& W.......... Meeson \& Welsby - Reports.

Mac. \& G... ....... Misenaghten \& Gordon - Reports.

Macq. H. L......... Macqueen's Appeal Cases

Madd........... Maddock - Reports.

Miın............ Manitoba - Reports.

Man. \& G......... Manning \& Grauger - Reports.

Man. \& R......... Manning \& Ryland - Reports.

Mass........... Massachusetts - Reports.

MI............. Marylaud - Reports.

Me............ Maine - Reports.

Mer............ Merivale - Reports.

Met . ......... Metcalf (Massichusetts) - Reports,

Mich........... Michigan - Reports.

Minn........... Minnesota - Reports.

Misc. R........... Miscellaneous (New York) - Reports.

Miss............ Mississippi - Reports.

Mo............. Missouri - Reports.

Mo. App........... Missouri Appeal - Reports

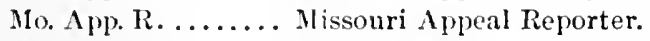

Moo. \& M......... Moody \& Malkin - Reports.

Moo. P. C.......... Moore's Privy Council Cases - Reports.

Moo. Ind. App...... Moore's India Appeals - Reports.

Noo. \& R......... Moody \& Robinson - Reports.

Moo., J. B.......... Moore, J. B.-Reports.

Moo. \& P........... Moore \& Payne-Reports

Moo. \& S.......... Moore \& Scott-Reports

Mos............. Moseley - Reports.

My. \& C. .......... Mylne \& Craig - Reports.

My. \& K........... Mylne \& Kene-Reports.

N. \& P.......... Neville \& Perry - Reports.

N. C. .......... North Carolinib-Reports 
N. D. .......... North Dakota - Reports.

N. E. R......... North Eastern Reporter.

N. H............ New Hampshire - Reports.

N. Y ........... New York - Reports.

N. Y. St......... New York State - Reports.

N. Y. Sup. Ct...... New York Supreme Court - Reports.

N. Y. Supp........ New York Supplement-Reports.

N. W. R ........ North Western Reporter.

Neb. ........... Nebraska - Reports.

Ohio C. C. . ....... Ohio Circuit Court - Reports.

Ohio C. D......... Ohio Condensed Cases - Reports.

Ont. ........... Ontario-Reports.

Ont. App.......... Ontario Appeal - Reports.

Oreg. ........... Oregon - Reports.

P. C. ........... Privy Council.

P. D............ Law Reports, Probate Division.

P. Wms. ......... Peere Williams - Reports.

Pa. ............ Pennsylvania - Reports.

Pac. R........... Pacific Reporter.

Paige.......... Paige (New York) - Reports.

Q. B............ Adolphus \& Ellis, New Series - Reports.

Q. B. (1891,.Q. B.)... Law Reports, Queen's Bench Division, 1891.

Q. B. D........... Law Reports, Queen's Bench Division.

Que. L. R......... Quebec Law Reports.

R. I. ........... Rhode Island - Reports.

Raym........... Lord Raymond - Reports.

Russ. ........... Russell - Reports.

Russ. \& M. ........ Russell \& Mýlne-Reports.

Ry. \& M.......... Ryan \& Moody - Reports.

S. C. ............. Supreme Court.

S. C. Can........... Supreme Court, Canada - Reports.

S. C. R. .......... Supreme Court Reporter.

S. D............ South Dakota - Reports.

S. E. R. .......... South Eastern Reporter.

S. R............ Southern Reporter.

S. W. R. ......... South Western Reporter.

Saund........... Saunders - Reports.

S............... Scott - Reports.

Sc. N. R. ......... Scott's New Reports.

Sch. \& L. ........ Scholes \& Lefroy - Reports.

Serg. \& R. ........ Serceant \& Rawle (Pennsylvania) - Reports.

Show. ........... Shower - Reports.

Sim. ........... Simmons - Reports.

Sim. \& St. ........ Simons \& Stuart - Reports.

Sm. L. C.......... Smith's Leading Cases.

Sw. \& Tr. ......... Swabey \& Tristram -- Reports.

Sw............. Swanston - Reports.

T. R........... Term Reports (Duruford \& East) - Reports.

Taml........... Tamlyn - Reports. 
Taunt.......... Taunton - Reports.

Tex........... Texas-Reports.

Tex. Civ. Ap]...... Texas Civil Appeals - Reports.

Tied. R. P........ Tiedeman's Real Property.

T. \& R.......... Turner \& Russell - Reports.

Tyrw .......... Tyrwhitt - Reports.

U. C. C. P........ Upper Cauala, Common Pleas - Reports.

U. C. Q. B........ Upper Canada, Queen's Bench - Reports.

U. S............ United States - Reports.

V. \& B......... Vesey \& Beames - Reports.

Va............ Virginia - Reports.

Vent. ........... Ventris - Reports.

Vern........... Vernon - Reports.

Ves............. Vesey - Reports.

Vin. Ab.......... Viner's Abridgment.

Vt............. Vermont - Reports.

W. N........... Weekly Notes.

W. R........... Weekly Reporter.

W. Va........... West Virginia - Reports.

Wall. ........... Wallace (United States) - Reports.

Wash. R. P........ Washburn`s Real Property.

Wend. ............ Wendell (New York) - Reports.

Wheat........... Wheaton (United Stites) - Reports.

Wis. ........... Wisconsin - Reports.

Y. \& C.......... Younge \& Collyer - Reports.

Y. \& C. C......... Younge \& Collyer's Chancery Cases.

Y. \& J........... Younge \& Jervis - Reports.

You............. Younge - Reports. 



\section{THE LAW OF ESTOPPEL}

BY

\section{MISREPRESENTATION.}

\section{CIIAPTER I.}

INTRODUCTION.

Iord Coke divides estoppel into (1) Estoppel by record; (2) Estoppel by writing (or deed); and (3) Estoppel in pais (Estoppel by matter in the country). We hare the same subdivisions to-day, but the third class has rery largely ehanged its character and ought to ehange its name. ${ }^{1}$ Of it Loril Coke said : ${ }^{2}$

"By matter in pais, as by liverie, by entry, by acceptance of rent. and by acieptance of an estate, as here in the case that Litleton putteth; wherent Littleton maketh a speciall observation, that a mall shall be estopped by matter in the countrey without any writing."

Such estoppels are now saill to be obsolete, ${ }^{3}$ but that is not 'puite the fact. It may be that livery of scizin is out of date; that estop!el will now but seldom arise "by entry;" and that "acceptance of an estate" will more frequently operate as an election or a wairer than as an estoppel. Nerertheless it may not only be said that "acceptanee of rent" as an estoppel is still fimilial to us, but that the principle of estoppel which underlies all of Lord Coke's instances is of ever-growing importance.

For they may all be included under Mr. Bigelow's title "Estoppel by Contract," which embraces

"All cases in which there is an iletulal, or virtusl, undertaking to treat a fact as settled, so that it must stidld spectitically as agreed."

1 The phrase "estoppel in pris" has yet the value of marking ofl estoppel by record and estoppel by deed, from all the heterogeneous cases which are not these. It was never intencled to cover cases of estoppel ly misrepresentations; and such cases have only been assigned to it because they were less allied to either of the other two categories.

2 Upon Litt. 35: (a). And see Lyon v. Reed (18t4), 13 II. \& W. 309 ; 13 L. J. Ex. $3 \pi \%$.

3 Ciabalé on Estoppel, p. 4.

4 Higelow on Estoplel (jth ed.), 45i. 
At the present day a vendor, if by his deed be have assumed to convey an estate in fee, is estopped from asserting otberwise. In Lord Coke's time the deed would have had the same effect; and, if the conveyance had been by parol, accompanied by livery of seizin, there would have been the same estoppel. Estoppel "by liverie," therefore, is clearly within the class estoppel by contract, as described by Mr. Bigelow. The other three instances mentioned by Lord Coke proceed upon identical principles.

Estoppel in pais, then, or rather the principle connoted by that expression, is far from obsolete. The estoppel of a baileo to deny the bailor's title; the estoppel of an acceptor of a bill to deny the signature of the drawer; the estoppel of a tenant to deny the estate of the landlord; and scores of other cases depend upon it.

There has been a still more remarkable inclusion under the title estoppel in pais; one wholly unknown in Loid Coke's time, namely, estoppel by misrepresentation. Estoppel of this sort does not in any way depend upon contract, and cannot claim sufieient kinship with Lord Coke's four instances to. merit inclusion with them in his class "Estoppel in Pais." Nevertheless, fuute de mieux, there it has gone.

\section{Subdivisions of Estopyer in Pais.}

Mr. Bigelow, the principal text writer upon the subject of estoppel, retaining the phrase "estoppel in pais," sublivides it into (1) estoppel by contract; and (2) estoppel by conduct. Est ppel by conduct he subdivides into: (1) estoppel by mislepresentation $;^{2}(2)$ estoppol by negligence; ${ }^{3}$ and $(3)$ estoppel by wiver. ${ }^{4}$

The present work does not treat of estoppel by record; nor of estoppel by deed; nor yet of estoppel by contract. Of estoppel by negligence, apart from misrepresentation and as an instance of it, it donies the existence. ${ }^{5}$ Ancl estoppels by waiver are dismissed with $\mathrm{Mr}$. Bigelow's remark that

"It appears to be little, if anything, nore thin giving a new name to call them estoppels." 6

1 Iigelow on Estoppel (5th ed.), 20, $453,459,5.56$.

IId., p. 5.j0.

3 I1., p. 6.j3.

4 Id., p. 630.

5 See ch. IX.

6 Higelow on Estoppel (5th ed.), p. 660. 
The volume, then, is limited to estoppel by misrepresentation. Mr. Bigelow's classilication makes estoppel of this sort a subaivision of estoppel by conduet. But in such a division of the subject, the class (estoppel by conduct) is narrower than the sub-class (estoppel by misrepresentation) $;^{1}$ and necessitates the re-subdivision of the sub-class (estoppel by misrepresentittion) into misrepresentation by language, and misrepresentation by conduct; thus reproducing estoppel by conduct in the second analysis of itself. It would be better to divide estoppel in pais into estoppel by contract, and estoppel by misrepresentation. Both of these, then, may be respectively subdivided (if thought advisable) into contract and misrepresentation (1) by language, and (2) by conduet.

The classification of estoppels in pais suggested in Smitl's I.eading Cases ${ }^{2}$ - estoppels by statement, by eonduct, and by negligence - is defective (1) because it fails to recognize this main division into contract and misrepresentation, in both of which "statement" is but the expression of that which "by conduct" is implied; and (2) because, concurring with IIr. Bigelow, the author regards estoppel by negligence as something which may exist apart from misrepresentation. IIe is, however, as nnable as Mr. Bigelow to give an instance of it -incleed does not try to do so.

Another sublivision (not heretofore distinctly made) is arrived at by distinguishing between cases in which the misrepresentation is made by the estoppel-clenier himself (personal misrepresentation); and those in which the misrepresentation has been made by some third person, the estoppel-denier hasing but furnished the occasion, or opportunity, for it - having done that which was necessiry to make it eredible. 'Tlis latter class may be termed assisted misrepresentation. The present writer believes that the phrase will be found to be of much service.

\section{Defintiton.}

Lord Coke tells us thiat

.. Estoppel' cometl: of the French rord estoupe, from whence the English word stopled; and it is called an estoppel, or conclusion. becalnse it man's own act. or acceptince, stoppeth or closeth up his mouth to allerge or plead the truth."

1 For misrepresentation may be 2 10th ed. 834. hy conduct, or by direct assertion. 
Estoppel in pais has been well defined to be: ${ }^{1}$

"An impeliment or bar, by which a man is prectulel from alleging, or denying, a fact, in consequence of his own previous act, ablegation or denial to the contriary."

Mrr. Bigelow deseribes estoppel as follows: ${ }^{2}$

"Estoppel in pais arises (1) from contract; (2) independently of cont ract, from act or conluct, which has induced a change of position. in accordance with the real or apparent intention of the party arainst whom the estoppel is allered: and it designates some present or past fact. fixed by or in virtue of the contract, or of the act or conduct in question."

Of this it may, respeetfully, be said that it hovers between a definition and a statement of conditions: that as the latter it is inadequate; and that for a delinition the one above quoted is sulticient.

\section{Mr. Cababé's definition is as follows: ${ }^{3}$}

"An aulmission of a state of facts, or of fact irrespective of its truth, which, for the purpose of determining their rights and oblugitions arising out of a given transaction, the parties thereto are entitled to exact from one another, or one of them is entitled to exact as against the others, or other."

\section{And in Smith's Leading Cases ${ }^{4}$ estoppel is said to be}

"An admission. or something which the law treats as an admission of an extremely high and conclusive nature."

The present writer sees no good reason for deseribing an estoppel as an "admission." An impediment (which prevents denial of an alleged fact) may be equivalent in effect to an admission; but it is not an admission. Inability for any reason to prove a fact may be equivalent, for practical purposes, to an admission that it is not a fact; but it would be altogether misleading so to describe it. The word, moreover, will not fit. A. misrepresented a fact and is estopped cannot well be translated into $\mathrm{A}$. admitted a fact in a highly conclusive fashion. Mr. Cababé met with much embarrassment in his endeavo: to effect the change; and M[r. Bigelow, who introdnced it, has abandoned it. ${ }^{5}$

1 Jacob. And see Bouvier; also Stephen on Pleading (Tth ed.), 181.

2 On Estoppel (jth ed.), 463.

3 On Estoppel, 10s. And see Everest \& Strode on Estoppel (p. 2) to the stime effect.

4 10th ed., vol. 2, 726 .

5 Mr. Bigelow in the third edition of his work defined estoppel "as an express or implied admission," etc., and this was adopted by some of the American judges. See Zuchtmann v. Roberts (1871), 109 Mass. 53, and cases referred to in Bigelow on Estoppel (5th ed.), 453, note 1 . See also the language of Bramwell, L. J., in Simm v. Anglo-American Co. (1879), 5 Q. B. D. 202, otherwise and probably more accurately reported in $49 \mathrm{~L}$. J. Q. B. 396, and of Bayley, J., in Heane v. Rogers (18:9), 9 B. \& C. $57 \%$, quoted in Richards v. Johnston (1859), $4 \mathrm{H}$. \& N. 663; 28 L. J. Ex. 322. In his later editions Mr. Bigelow has discarded the language. 


\section{Justification of Estopret.}

Adopting then the definition of estoppel as "an imperliment or bar," which has the effect of precluding a man from "alleging or denying a fact," the question naturally arises: Why should any one ever be so precluded? Surely the facts ought to be known, and should govern the rights of the parties.

Suppose, howerer, that goods are delivered to a warehouseman for storage; and when the bailor requires delivery tive warehouseman refuses, upon the ground that the bailor cannot prove a clear title to the groods. One sees at a ulance that the warehonseman shonla not be permitted to take sucir a position; and the reason really is that, for the purposes of the bailment, the title of the bailor has been assumed, and impliedly agreed to. This is estoppel by contract; and it is based upon the soundest equity, which say s that not only, or indeed mainly are the facts as they exist those which govern the relations of the parties, but those chiefly which the parties have assumed and agreed upon.

Again, suppose that the owner of property stands by and allows it to be sold by another person to one unaware of the real state of the title; the owner is and ought to be estopped from asserting his position. He has misrepresented, or rather contributed to the misrepresentation of the facts, and is estopped, therefore, from asserting them. This is estoppel by mispepresentation. It is the solt of estoplel treated of in the present volume.

In the carlier years of the development of the law of estoppel by misrepresentation (not so long ago), all this was little understool, and the phrase "estoppels are odious" represented the disinclination of the courts to prevent the assertion of the real facts. The language persists in even some of the more recent cases. In $1553 \mathrm{Lom}$ Camplell, speaking of estoppel by misrepresentation, saicl: ${ }^{1}$

"Like the ancient estoppel, this comclusion shuts out the truth, and is odions. and must be strictly made out."

1 Howard v. Hudson (1553). 2 E. \& B. 10; 2: L. J. Q. B. 34, quoted by Colt, J., in Anulrows s: Lyous (186;.), 9:3 Mass. 3\%0. In Franklin ve Merilal (1S154), 3.5 Cill, 5.58, it was sail that "the doctrine is a harsh one, and is never to be applied except when to allow the truth to be toll would consumuate a wong to the one party or enalile the other to secure an unfair advantage." 
In the same case Crompton, J., more cautiously said:

"I do not think that an estoppel of this kind is alwalys odious; in many cases I think it extrmely equitable to act upon that cloctrine."

In 1sis Bramwell, L. J., siill: ${ }^{1}$

"Estoppels are odious, and the doctrine should never be applied without a necessity for it."

But in the following year he said: ${ }^{2}$

"I do not wish to spe:lk against estoppels: for I do not know how the business of life conld go on unless the la w recognized their existence."

The true justification for estoppel by personal misrepresentation is clearly put in a note in the eleventh edition of Colie upon Littleton:

"No man ought to allege anything but the truth for his defense: and what he bas alleyed once is to be presumed to be true, and therefore lie ought not to contridict it; for as it is said in the 2 Inst. 272, Allegans contraria non est audiendus."'3

Blackburn, J., well states the matter: ${ }^{4}$

"Now sometimes there is a degree of olium thrown upon the doctrine of estoppel, because the same word is used occasionally in a very teclnical sense; and the doctrine of estoppel in pais has been thought to desarve some of the odium of the more technical classes of homologation. But the moment the doctrine is looked at in its true light it will be found to be a most equitable one, and one without which in fuct the law of the country could not be satisfactorily administered. When a person makes to another a representation, 'I take it upon myself to say such and such things do exist,' and the other man does really act upon that basis, it seems to me that it is of the very essence of justice that, between these two parties, their rights should be regulated, not by the real state of the facts. but by that conventional state of facts which the two parties agree to make the basis of their action; and that is what I apprehend is meant by estoppel in pais or homologation."

The rationale of estoppel by misrepresentation is put in epigrammatic form by Mr. Justice Swayne of the Supreme Court of the United States, as follows: ${ }^{5}$

"It proceeds upon the grround that he who has been silent as to his alleged rights when he ought in good fith to have spoken, shall not be heard to speali when he ought to be silent."

And little can be added in justification of estoppel to what was said by Perley, C. J., in distinguishing the "legal" estoppels in pais of Lord Coke's time from the more modern "equitable estoppel:" 6

'Baxendale $\nabla$. Bennett (1878), 3 Q. B. D. $529 ; 47$ L. J. Q. B. 624.

2 Simin v. Anglo-American (1879), 5 Q. B. D. $202 ; 49$ L. J. Q. B. 39 ?.

3 Colse, Lit., L. 3, c. 12, 5667 , note 1.

4 Burkinshaw v. Nicolls (1878), 3 App. Cas. $1026 ; 49$ L. J. Ch. 179, approved in Re London Celluloid Co. (1888), 39 Ch. D. 202; 57 L. J. Ch. 84:; Tomkinson v. Balkis (1891), 2 Q. B. $623 ; 60$ L. J. Q. B. 558. And see

Blackburn on Sales, 162. Distinction shoula be made between estoppel by deed and estoppel by misrepresentation, the latter of "which is founded upon reason:" Per Jesse], M. R., in General Finance Co. v. Liberator (1878), 10 Ch. D. 20. And see Everest \& Strode on Estoppel, 11-15. 5 Morgan v. Railroad (1877), 96 U. S. 720.

${ }^{6}$ Horn v. Cole (186S), 51 N. H. 290 , 
"The legal estoppel sluts out tho truth and also the equity and justirs of

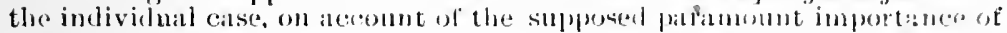
rigorously enloreing a certall and unvayiug maxim of the law. For reatsons of general policy a record is held to import incontrovertible verity; and for the same reason a flirty is not permited to contradict his sulenin admission by teed. And the simue is equally toue of leral estolypls liy matter in pais. . . For this reason beranse legal estrupels, whether ly recoril, reed, or natter iu juis, slut out proof of the truth and justive of individual cases, they have ben called orlous and hatve been construlal with much strictness atgaimst pilrtics that set them up). . . Eijuitible estopyels are almitted on the exactly opposite gromal of promotine the equity and justice of the individual case, hy preventing the party findu

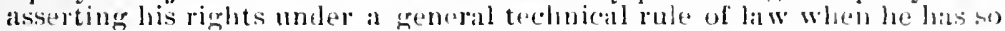
conducted himself that it womld be contrary to equity anel good consedence for him to alloge and prove the truth."

The learned atuthor of Smith's Leading Cases, not perceiring the distinction of Perley, C. J., limits the application of the word odlious in this way: ${ }^{1}$

"The truth is. that the courts have been for some time favorable to the

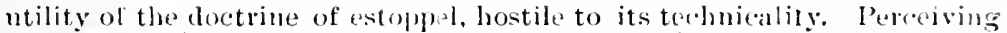
how essential it is to the quirk an leasy transartion of husiness that one man should be able to put faith in the conduct and representations of his fellow, they have inclined to hold such conduct and such representations binding in cases where a miseluief or injustice would be cansed by treating them rffect as revocable. At the same time they lave been unwilling to allow men to be entrappen by formal statements and admissions, which were perhins looked upon as nomportant when made, and by which no one ever was aleceived or induced to alter his position; such estoppels are still as formerly consilered odious."

But this is equivalent to saying that estoppels are odions only in eases in which there is no estoppel; for if "no one ever" wals deceived or inlueed to alter his position," one of the essential conditions of the existence of estoppel is absent. ${ }^{2}$

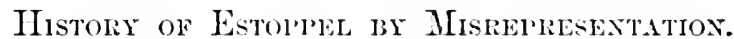

In equity it could be said as early as the year 1801 that it Was

"it very old luead . . that if a representation is male to another pre son goiner to teal in a matter of intelest upon the faith of that representation, the former shall make that representition good if he linows at to be filse." 3

Still earlier (in 1TST) Mrr. Justice Ashhurst, in a ease at law, sicil:

" We may lay jt lown as a hroid general prineiple that whenerer one of two innocent persons must sulle hy the act of a third, he who enables sucl person to oecasion the luss mast sustatin it."

291, 292. See also Stevens r. Mommett (1872), j1 N. II. 8333; Am. \& Eng. : iney. (2l ed.), vol. II, 385, n. 3 .

1 loth ed.r vol. II, 810. See also $\mathrm{Am}$. \& Eng. Ency. (:d el. ), vol, Il, 3ss, n. :.
2 See prost, ch. II.

3 Par Lord Elklon, Evaus v. Bick: nell (1s01), (i Ves. 1si3.

+ Iiclibarrow v, Mison (17Si), \& $\mathrm{T}$. R. 70 . 
Although not then so recognized, these doctrines were based upon prineiples which in scientific elassification must be referred to estuppel. The equity doetrine of restitution has inseed quite faded away, leaving estoppel in almost undisputed possession of the field. Mr. Justice Ashhurst's dictum is still much groted, and perusal of a subsequent chapter ${ }^{1}$ will denonstrate that it was a very notable effort to formulate the principles of the law of estoppel by assisted misrepresentation.

It is very remarkable that although these principles were blockel out in 1757 , yet it was not until lifty years afterwards (until Chief Justice Denman's famous sentence in Pickard $v$. Sears $\left.{ }^{2}\right)$ that courts of law first became thorougbly aware that there wis a principle of decision, consonant with their system, which enabled them to apply that equity which was essential to the proper administration of justice. It is not asserted that Pichard v. Sears was the first case of its kind, ${ }^{3}$ but it is indubitable that that decision marks an epoch in the history of the development of the law, and gave to the idea of estoppel by misrepresentation marked vitility and impetus. It formulitterl a principle which has spreid into almost every department of the law. The principle was this:

"The rule is clear that where one by his words or conduct wilfully" rauss another to beliere the existence of a certain state of things, and induces him to act on that belief so as to alter his own previous position, the former is concluded fron averring a rainst the latter a different state of things as existing at the same time." 5

Of this common-law rule Vice-Chancellor Bacon, in 18s1, said : ${ }^{6}$

"The common-law doctrine of estoppel was, as I ha ve said, a device which the common-law courts resorted to at a very early period to strencrthen and lengthen their arm; and not venturing to exercise an equitable juris. diction over the subject before them, they did convert their own special pleading tactics into an instrument by which they could obtain an end, which the cont of chancery without any foreign assistance did at all times, and I hope will at all times put into force in order to do justice."

1 See cl. XIV.

$2(1836) 6$ A. \& E. 469.

3 On the contrary. that case arowedly proceeds upon the earlier calses of Heane v. Rogers (18:9), 9 B. \& C. jsi;, and Graves v. Key (1S32), 3 13. \& Ad. 318, note (a). The present writer would also joint to Pickerings" v. Busk, in 1812 (15 East), as a case in some respects more importint and deserving of distinction tiatu
Pickard v. Sears. See also the American cases prior to Pickird v. Sears, of Stephens v. Baird (18:8), 9 Cowen, 2it (N. Y.): Weliand v. Hathaways (1832), 8 Wend. 480 (N. Y.).

4 This word "wilfully" will be discussed hereafter.

5 Pickard v. Siars (1837), 6 A. \& E. 47.

6 Keate v. Dinillips (ISS1), 18 Cl. D. $57 \%$; 50 L. J. Ch. 664. 
To the present-day student it would appear that both courts were slowly evolving and disengrang the principles of estroppel. The court of equity no doubt was less trammeled than its sister courts by traditions and "cilkes of custom;" but it may fairly be said that the dicta of MLr. Justice Ashlutrst and? Chief Justice Denman and Lord Ellenborough ${ }^{1}$ are the most notable contributions to the law of estopprel that are to be found in any of the Engrish courts.

1 In Pickering v. Busk (1812), 15 East, 4.j. 


\section{CHAPTER II.}

\section{CONDITIONS OF ESTOPPEL BY MISREPRESENTATION.}

The essentials of estoppel by misrepresentation will be considered under the following healings:

1. There must be a misrepresentation.

2. Either (1) by the estoppel-denier (personal misrepresentation); or (2) by some person whose representation he bas made credible (assisted misrepresentation).

3. There must be a disregard of some duty.

4. The misrepresentation must be as to fact or law - not merely of intention or opinion.

5. The misrepresentation must be of something material.

6. Frand or bad faith in the estoppel-denier is not essential - an innocent misrepresentation will estop.

7. Negligence (carelessness) is sometimes essential.

8. The estoppel-asserter must be a person to whom immediately or mediately the misrepresentation was made.

9. The estoppel-asserter must, on the faith of the misrepresentation, change his position prejudicially.

11. The estoppel-denier must have reasonable grounds for anticipating some change of position upon the faith of the misrepresentation.

11. The change of position must be reasonably consequent upon the misrepresentation or the assistance.

$A$ discussion of each of these will supply a comprehensive view of the subject. Afterwards will follow some applications of them to rarious branches of the law.

The Supreme Court of the United States has lately summed up the points which a plaintiff in an action for the rescission of a contract must establish: ${ }^{1}$

1. That the defendant bas made a representation in regard to a material fact.

2. That such representation is false.

ISouthern Development Co. v. Silva (1888), 125 U. S. 247, 250. See Pollock on Contracts (6th ed.), 542. 
3. That such representation was not actually believed by the defendant on reasomable grounds to be true.

4. That it was made with intent that it shomid be acter upon.

5. That it was acted on by complainant to his damage.

6. That in so acting on it the complainant wits ignorant of its falsity and reasonably belicred it to be true.

Comparing these with the foregoing conditions we find the following:

$1,2,4$ and 5 in estoppel equal 1 and 2 in rescission.

3,8 and 11 in estoppel are probably implied in rescission.

9 in estoppel equals 5 and 4 in rescission.

10 in estoppel equals $t$ in rescission.

7 in estoppel is inipplicable in rescission.

This leares 6 in estoppel to compare, or rather to contrast, with 3 in rescission. In England, Canadi, and many of the American states there is more of harmony than contrast, ${ }^{1}$ for 3 in rescission is found to be unteriable.

1 See post, ch. VIII. 


\section{CHAPTER III.}

\section{CONDITION NO. 1.}

\section{There Must be a Misrepresentation.}

The subject of this work being "Estoppel by Misrepresentation," we are clearly open to criticism in positing misrepresentation as an element in that kind of estoppel. Justification might be obtained by changing the title of the book, but that, for other reasons, is inadvisabie.

It may, however, be urged in extenuation that we are dealing with several very large classes of eases; that these cases are not within any of Lord Coke's eategories (Estoppel by Reeord, Estoppel by Deed, or Estoppel in Pais); that they are of modern reeognition, and of reeent and portentous growth; that they all present a common feature, namely, misrepresentation; and that for a place in this new eategory we may say that "there must be a mispepresentation."

\section{Definition of Misrepiesentation.}

Mr. Bigelow's definition of misrepresentation is sufficient:'

"By misrepresentation is meant a false impression of some fact, or set of facts, created upon the mind of one person by another, by language, or by language and ronluct together, or by conduct alone equivalent to languace, where there appears to be no intention to warrant the same."

\section{Nechest'ty for Mismepresentation.}

There can be no reason to doubt the correctness of Lord Justice Bram well's statement ${ }^{2}$ that this modern doetrine of estoppel " never can be applied except in cases where the person against whom it is used has so condncted hinself, either in what he has sail or done, or failed to say or do, that he woukl, voless estopped, be saying something contrary, to his former conduct, in what he had sabd or done, or failed to say or do."

In other words, no one is to be estopped from asserting a fact unless there has been some prior misrepresentation of that

I On Estoppel (5th ell.), 5is.

2 Baxendale v. Bennett (18\%8), $3 \mathrm{Q}$.

B. D. $525 ; 47$ L. J. Q. B. 624. And sce Ex parte Adamson (1878), $8 \mathrm{Ch}$.

D. $81 \% ; 47$ L. J. Bk. 103. 
fact, upon the faith of which some person has changed his position.

$\Lambda$ single case ${ }^{1}$ will suliice to illustrate the point. $\Lambda$ plaintiff got a verdict for 250 , to be reclucel to one shilling if the dog in question was returner to him by the defendant within a certain timo. The defendant not haring the dog borrowed him from the owner, and handed him over to the plaintiff, at the same time telling the plaintiff that the dog had been borrowed, and that the owner would demand him on a certain day. The plaintiff accepted the dog. In a new contest over him it was held that the owner was not estopped as against the former plaintiff by what had happened from asserting his title. There had been no misrepresentation as to the owner's title, and there was no estoppel, therefore, argainst its assertion.

\section{Ctasemifation of Misreptesextation.}

It is absolutely essential to the clear understanding of the law of estoppel - at all events to an appreciation of the exposition of that law as attempted in this rolume - that the following elassification should constantly be borne in mind.

Misrepresentation mily be

1. Personal, or

2. Assistel.

And may be

1. Direct, or

2. Indireet.

And may be

1. Active, or

2. Passive.

And may be

1. Explessed, or

2. Implied.

Personal axi Assisten Misrepiesentation.

This very important distinction will be dealt with in the next succeeding chapter.

\section{Direct and Indinect Misiemeresentation.}

And this one in chapters $\mathrm{X}$ and XIII.

1 Sandys v. Hodgson (1839), 10 A. \& E. 4i2; 8 L. J. Q. B. 34. 


\section{Active and Passive Misrepiegentation.}

Passivity can be penalized only where a duty to be active ean be preciicated. Chapter $\mathrm{V}$ discusses that subject.

Chapter VIIf makes use of the distinction in hand in order to harmonize the cases relating to the necessity for bad faith as an element in misrepresentations which estop.

And chapter IX will indicate that passivity, as the result of carelessness rather than design, may work an estoppel.

\section{Expressed and Implied Misrepresentation.}

This classification is by no means the same as that just dealt with (although frequently confounded with it), as will at once be seen when it is observed that an active misrepresentation may be either expressed or implied in the words or conduct in which it is embodied. In fact, an implied as distinguished from a passive misrepresentation may be said to be an inference properly drawn from some activity. $\Lambda$ nd the question arises whether such inferences may freely be drawn, or whether we are to say with Coke upon Littleton: ${ }^{1}$

"Every estoppel, because it conclulpth a man to alleadge the truth, must be certaine to every intent, and not to be taken by argument or inference;"

and with Kay, L. J.: ${ }^{2}$

"In order to create an estoppel. the statement by which the defendant is held bound must he clear and unimbirzuous;"

and with Mrr. Bigelow: ${ }^{3}$

"The representation. further, to justify a prudent man in acting upon it must be platin, not donbtinl or mitter of questionable inference. Certainty is essential to all estoppels. The courts will not readily suffer a man to be deprived of his property where he had no intention to part witl it."

Some palliacion of the rigor of the "legal" estoppel, fittingly denominated "odlious," ${ }^{4}$ is obtained by the prescription of periect identity between the misstatement alleged to have been made and the fact as the estoppel-denier desires to show it; but the justice of the requirement is less obvious when applied to those "equitable estoppels" which promote " the equity

1 L. 3, c. 12,567 . And see Am. C. P. 49; Onward v. Smithson (1893), \& Eng. Ency. (21 ed.), vol. 11, p. 338, 1 Ch. 14, 15; 62 L. J. Ch. 138.

n. 5 .

3 On Estoppel (5th ed.), 578. And

2 Low v. Bouverie (1891), 3 Cl. 113; see cases there cited, and Keating $\mathbf{v}$.

60 L. J. Cl. 594. And see Kepp v. Orme (1874), 77 Pa. 89.

Wiggett (1850), 10 C. B. 5:; 20 L. J. $\quad 4$ Ante, cl. I. 
and justice of the individual case." 1 In the interpretation of statutes we are familiar with the distinction between penalizing and enabling statutes; and for the modern estoppel by misrepresentation we need have little hesitation in making application of the language of Pollock, C. B.:

"If any person by a course of conduct, or by actual expressions, so conducts himself that another ma!l reasomably infer the existence of an arrobmeint or license, whether the purt!l interds that he shonth to so or mot it

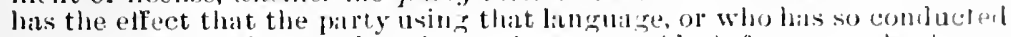
limself. cannot afterwillels gainsay the reasonable inference to be drawn trom his words or conduct."'

$\Lambda$ few eximples will be useful:

A representation by a company that its debentures are legally transferable may be implied from the fact that their form so indiciates. $^{3}$

If a company represents that its shares are paid up, it must be taken as a representation "that they are paid up in the way in which they are to be paid up" - for example, in cash."

A merchant being about to furnish defendant's sons with goods on credit inquired of defendant whether his son had, as he asserted, $\$ 300$ of his own property; defendant answered that he had; the fact was that the defendant had lent his son the $\$ 300$; held that a loan was inconsistent with the representation. ${ }^{5}$

A railway company may agree to carry goods, and yet not be estopped from asserting that it was, as to those goods, a common carrier. By agreeing to carry the groods there is not an implien representation that it is bound to carry them. ${ }^{6}$

$\Lambda$ trustee of a fund who receives notice of a charge upon it is under no obligation to volunteer information as to prior charges; and there is therefore no implied representition as to the state of the fund.

1 Ante, ch. I.

"Cornish v. Abington (1859), $4 \mathrm{H}$. \& N. 556; 28 L. J. Ex. $26:$. Approved in Thomats v. Brown (1876). 1 Q. 13. D. T2:; 45 L. J. Q. B3. 811 . And sie per Lord Calirns in Peek r. Gurny (15i3), L. R. 6 H. L. 3\%; 43 1. J. Ch. 19; Bigelow on Estoplel (jth ed.). 634; aid post, ch. XII.

${ }^{3}$ Goodwin v. Roberts (1876), 1 App. Cas. 476 ; 4 i L. J. Q. 13. 748; Re Romford (1S8:3), 24 Ch. D. 93; 52 L. J. Ch.
729; Eiston v. London (1S\&6), $34 \mathrm{Ch}$.

D. 95; 56 L. J. Cl. 569.

+ Burkinshaw v. Yicolls (1SiS), 3 App. Cis. 1021; 48 L. J. Ch. 179.

scorbett v. Brown (1531), \& Bing. 3\%. And see Tapp r. Lee (1SU:3), 3 Bos. \& P. 367.

'Phelps v. Illinois Ry. (18s0), 94 III. 545 .

† Low ‘. Bouverie (1591), $3 \mathrm{Cl}$. S2; 60 L. J. Cl. 50 t. 
A trustee replied to certain interpogations as to incum. brances upon the trust property. Afterwards it was sought to make the trustee liable in respect of certain incumbrances of which he had made no mention. Lindley, J., said:

"But the difficulty of affording the plaintiff relief on this ground arises from the ambirnity of the defenclant's letters. They are quite consistent with the view that the incumbrances mentioned by the defendant were all he knew of or remembered. A statement, however, to that effect would not estop him from stating that there were others which he did not know of or remember. . . . Knowledge, and means of knowledge, are very dif. ferent things; and if a person truly says he only knows or remembers so and so, is it right to treat him as saying that he knows more, even if it is his duty to inform himself accurately before he speaks." 1

Where the holder of a chattel mortgage, on payment of a portion of the note secured by it, surrenders the note to the maker after allowing it to be marked "paid," he is estopped as against a bona fide purchaser of the mortgaged property, who purchases in reliance on the evidence of payment shown by the note in the mortgagor's hands, to claim that there is a balance due on the mortgage."

But the result would be different if the note was not marked pail, but merely given up in exchange for a renewal of it.

"I would not think that any reasonable man would take possession of the note by Robinson to be equivalent to a representation by the plaintiffs that the price of the piano was paid. The practice of renewing notes is so common that the defendants, as business men, can scarcely have excluded it from their contemplation." 3

A patentee, in urging a customer to give his machine the preference over another that was offered in sale, said in substance: "Now, co give mine a trial; you will find it a very much better machine." But this was not a representation that the other machine might safely be purchased - that it was not an infringement upon the patent. The statement was not equivalent to "now, just try, and see which is the best machine, and then you may take whichever you think to be the best." It was putting forward "one strong commercial reason why be desired the defendants to purchase his machine;" but it was not a suggestion that he intended to abandon any legal rights; nor was it a representation that the other machines were no infringement upon his patent.

1 Re Lewer (18\%6), 4 Ch. D. 101; 5 Ch. D. $61 ; 46$ L. J. Bk. $r 0$.

2 Finlis v. Buck (1891), 27 S. W. R. 1031 (Tex.).
3 Mason v. Bickle (1878), 2 Ont. App. $291,299$.

4 Proctor v. Bennis (1887), $36 \mathrm{Ch}$. D. 740; 57 L. J. Ch. 11. 
Where it is alleged that some person has been helil out as a partner (although not really such) it is not necessaly that the person said to be a partner should, in the holding ont, have been identitied by his christian and surname. It is enough that there shoula be such a description as will be tantamount to maming him. Thus, the estompel-asserter may have known merely that there was "a gentleman down from London, a man of capital;" and if he retied upon this indiridual the "capital" would have to be fortheoming.

As to the proper implication from a certificate by a company of a transfer of shares; and as to the difference between it aud a certilicate of ownership of shares, see cases in the note. 2

Distinction where Fr(und.- Lord Justice Kay has suggested an important distinction which is not elsewhere to be met with. He silid: ${ }^{3}$

"If there "res fruml, and the statement was intended to mislead, its amhiguity would not be a defense; but where no fraud is alleged it is essential to show that the statement was of such a nature that it could have misled any rcasunable man, and that the plaintiff was in fact misled by it."

The distinction appears to be well founded. In the first case a fraud is intended and is successful; the defrauder then urges that if his dupe had acted as a reasonable man he would not have been misled by the arts which proved to have been well adapted to his deceiving. It is a poor argument. In the second case no frand was intended; an ambiguous phrase was honestly made use of; a different meaning from that intended was tikien out of it; a reasonable man would not have taken that meaning and would not have been misled. Such a case is easily distingruishable from the other.

I Martyon v. Gray, 14 C. B. (N. S.) 8.3:).

2 Bishop v. Ballis (1S90), 2i Q. B. D. 77, 512; 59 L. J. Cl. 5(5.5: Tompkinson v. Balkis (1891), 2 Q. B. D. $614 ; 60$ L. J. Q. B. 558 ; $(1893)$ A. C. $396 ; 63$ L. J. Q. B. 134; Re Concession's Trust (1s96), 2 Ch. 757; 6j L. J. Ch. 909.
3 Low v. Bourerie (1S91), $3 \mathrm{Ch}$. 113; 60 L. J. Ch. 594. See analogy supplied by Bloomenthal v. Ford (15!\%), A. C. 156 ; 66 I. J. Ch. 25:3; Hurhles v. Twisden (1886), 55 L. J. Ch. 481. 


\section{CHAPTER IV.}

CONDITION NO. 2.

The misrepresenta'ion must be made either (1) by the estoppeldenier (personal misrepresentation); or (2) by some person uhose misrepresentation the cstophel-denier has made credille (assistel misrepresentaiton).

\section{Personal Misrepresentatron.}

"In all cases of the kind of estoppel we are called upon now to consider, the party has, I conceive, either himself male. or authorized to be made, a statement of fact untrue, ol he has conducted himself so as to give rise to the belief of a fact untrue." 1

The first of these alternatives needs little enforcement. It means merely that a man is not to be damaged by a misrepresentation which he las neither made nor anthorized," unless indeed he comes within the second class of cases. For example, if a man be held out as a member of a firm, he cannot be liable if he was ignorant and innocent of all that was done.

"The hollung one's self out to the world as a partner . . . im. ports at least the voluntary nct of the party so holding himself out. . . and is altogether incompitible with the want of knowledge that his name has been so used." "3

And so where the estoppel-denier's name appeared in a list of shareholders, which without his knowledge had been shown to the estoppel-asserter by the secretary of the company, and the secretary had no authority to disclose the list, it was held that there was no estoppel. ${ }^{4}$

\section{Assisted Misrepresentation.}

The second alternative of the condition confronts us with problems altogether freculiar to the law of estoppel. It will be observed that it implies, notwithstanding what has already

1 Per Channell, B., in Swan v. N. sentation ly the estoppel-denier himB. A. (1862), 7 H. \& N. 6.5; 31 L. J. self and by his agent. Qui facit per Ex. 425; First Nat. Bank v. Cody alium, facit per se.

(1894), 93 Ga. 127 ; 19 S. E. R. 8:31.

2 No distinction is necessary for 261 . present purposes between misicpre- $\quad \mathrm{Id}$. 
heen said, that a man may under eertain circumstances be estopperl, not merely by his own misrepresentations, but by the misrepresentation of another person. It implies further, as we shall see, that he may be estopped by such a misrepresentation if he has assisted it, althourh he has been perfectly innocent of any intention to do so, and although unaware of the misrepresentation until after the mischief has been accomplished. This class of cases the writer ventures to denominate " $\Lambda$ ssisted Misrepresentation;" for the estoppel arises from the assistanee rendered by the estoppel-denier to the misrepresentation. An example will be the best introduction to the problems inrolved: Suppose that I execute a mortgage for $£ 2: 50$; afterwards I pay $£ 200$ upon it; and afterwards the mortgagee, by representing that $£ 250$ is still owing, sells the mortgage lol that amount. I am not estopped from asserting that there is only $\$ 50$ due. I have not in any way contributed to the misrepresentation of the mortgagee. Viarying the case: Suppose that the mortgage purports to secure 2250 (and acknowledges the receipt of that amount); that only $£ 100$ was in reality advanced; and that, concealing this fact, the mortgagee sells the mortgage for $£ 250$. I am now estopped becanse of the assistance which I have given to the misrepresentation; my acknowlelgment has made credible the misrepresentation of the mortgiagee.

1 Bickerton $\nabla$. Walker (1855). 31 Ch. D. 151; 55 L. J. Ch. 227; and see West v. Jones (1851), 1 Sim. (N. S.) 205; Parker v, Clarke (1861), 30 Beav. 51; Webb v. Herne Bay (15\%0), L. R. 5 Q. B. 642 ; 39 L. J. Q. B. 221; Manly v. Lonilon (1896), 23 Ont. Apl. 139; 26 S. C. Can, 443 . But see Ryckman v. Canada Life (18\%0), 1\% Gr. 550. In the United State's distinction must be made between three clisses of mortgages: (1) Where the mort girge secures payment of a promissory note the law is as stited in the text. except in Illinois (Hostetter r. Alexander (18\%6), : N Mim. 5.59), New J r. sey (by stiltute: R. S. 1sir, [. 76s, $\$ 31$ ), Ohio, Oregon (Jones on Mortgirges (ith el.), \$834 1r.), and Kin- sas. (2) Where the mortgage secures payment of a bond the law is saicl to be otherwise (IU.). But if the bond be of ambulatory sort there should be no distinction. for the principles of estopmel apply equally to both cases: First Nat. Bank r. First Nat. Bank (1880), 2:2 Hun, 339. (3) Where the mortgage secures paymunt of money only, it is sail in Jones, 841 (a), that an assignee takes subject to the mortrageces equities; but the only case cited is Cistle v. Castle, is Mich. 295: 14 20 W. R. 3TE, where the question wats not whether the assignee took subject to original equities (contritdeted by the instrument). bnt whether he was bound by subsequent 
Ender IThat Circumsiances.-The question, then, for solution is this: Under what cireumstances shall one person be estopped by reason of assistance given to the misrepresentation of another?

The present writer, aware of its dangers, is unwilling to advance any well-defined rule; but perhaps he may be permitted to sugrest a phrase which may prove to be of some service. $A$ perusal of the eases leaves upon the mind this impression: that one man may be estopped by a misrepresentation made by another, when the former, in breach of some duty to the deceived person, has supplied the defrauder with thut witich was necessary to malie the representation credible. If the fraud was accomplished witbout assistance, there can, of coirse, be no estoppel (of any one but the defrauder). If, although there accountings. The reasoning in First Nat. Bank v. First Nat. Bank (1880), :2 Hun, 339 (N. Y.), strongly supports the contrary view.

Ir. Pomerov,criticising the United States Supreme Court case of Carpenter v. Longan (18\%2), 16 Wall. 2 in, in which it was held that the assignee of a mortgage securing a promissory note takes free from equities, says that the argument which supports it is "that the debt is the principal thing and the mortgage is the mere adjunct of the iebt;" that the answer to the arguinent is that " the note and the mortgage do not together constitute a promissory note; "that the rule as to notes "was first adopted by the courts and hasever since been maintained solely with a view to promote the interests of merchants, and to secure the success and freedom of mercantile and commercial dealingrs. $\Lambda$ promissory note accompanied by a mortgage is not in any sense a mercantile or commercial security." There are two answers to this:

(1) The underlying argument of the court is inadequately stated. It is as follows: "To let in such a defense against such a holder would be clear departure from the agreement of the mortgagor and mortgagee, to which the assignee subsequently in good faith became a party. . . If one of two innocent persons must suffer by a deceit, it is more consonant to reason that he who 'puts trust and confidence in the deceiver should be a loser rather than a stranger:'" This principle is that of estoppel (see post, ch. XIV) as applied to ambulatory choses in action. See ch. XXIV. It covers the case of a mortgage to secure payment of money as well as one to secure payment of a note.

(2) It is not correct to say that the rule as to the assignee of notes tak. ing free from equities has been confined to "mercantile and commercial dealings." It has been much more widely extended, and now covers all ambulatory transactions. See ch. XXIV.

Some recent cases are State Bank v. Flathers (1892), 45 Lil. Ann. 78; 12 S. R. 244; Pertuit v. Damare (1898), 50 La. Ann. 893 ; 24 S. R. 681 ; Ferris v. Briscoe (1898), is Ill. App. 242; Jones v. Dulick (1898), 55 Pac. R. 522 (Kiln.); Marck v. Prang (1899), 79 N. W. R. $7 \% 0$ (Wis.). 
was assistance, yet the assistance was an immaterial factor in the accomplishment of the frand, there ought, likewise, to be no estoppel - the assistance did not furnish the occasion or the opportunity for the fraud. But if the assistance was in some way essential to the suceess of the fraud - furnished the occasion or opportunity for it; male credible a representation which, without it, could not have been successfully made,- then, if there has been a breach of some duty in reudering that assistance, estoppel will ensue.

It is not intencled at this place to deal at length with the cases illustrative of the subject. It will be sufficient for the general view which the first part of the work is intended to present that a few representative examples, taken from different branches of the law, should be shortly noted. At the same time, as the doctrine of estoppel by assisted misrepresentation has a somewhat novel appeal'auce, it must justify its existence and be made familiar.

Principal and Agent.- I employ an agent to sell my horse and tell him not to warrant. By representing that he has sufficient authority, he sells the horse, giving a warranty. In this case there is no reason why I should be estopped from denying my agent's authority to warrant. My agent has made a misrepresentation, but he had no anthority from me to do so: and

IHappily not much originality can be claimed for the phraseology. The term "assisted misrepresentation," and the other language employed, were sugrested by happy conjunction, during stuls. of siv. eral judicial utterances. Lord benman, in one of the early leadingr cases (Gregg v. Wells (18:39, 10 A. d E. $97 ; 17$ L. J. Q. B. 193), silil: “ $A$ party who negligently or culpably stands by and allows another to contract. on the faith and unlerstinding of a fact which he can contradict, cannot afterwarls dispute that fact in an action agrinst the pren whom he himself has assisted in deceiving." Fry, J., in Northern Counties v. Whipp (188.1), :8 Cl. D. 494; 53 I. J. Ch. 6:9, said: "That the court will postpone the prior legal estate to a subsequent equitable estate, where the owner has assisted in, or comnired at, the fraud which has led," etc. Bayley, J., in another cise (Boyson v, Coles (1817), 6 M. \& S. 21). said: "But this rule will certiainly not apply where the owner of goods has lent himself to accredit the title to another person." And Grose, J., in still another case (Lickbarrow r. Mason (1757), 2 T. R. 63), in which the owner of gools, by indorsing over a bill of lading, was held to be precluded from the right to stop in transitu, said: "A bill of lading carries credit with it; the consignor, by his indorsement, gives credit to the bill of lading; and on the faith of that, money is ad. vanced." 
I have in no way made his representation credible. Supposing, however, that in selecting the agent I had ehosen a horse cealer - that is, one whose usual powers are understood to inciucle a power to warant. In this case I ought to be estopped, jeeanse I have by the selection of my agent male the misrepresentation as to authority credible. ${ }^{\mathbf{I}}$

Again varying the case: Suppose that I sent my agent with the horse to a fair (where it is usual to give a warranty), with instructions to seli but not to warrant, and he sold and warranted. I am in tiis case also precluded from denying my agent's authority to warrant, because, by allowing my agent to operate at a fair where warranties are usually given, I have male credible his misrepresentation of his authority. ${ }^{2}$

Bills and Notes.-I draw a note and leave it in my desk unsigned. It is stolen. My name is forged, and the note passed to an innocent holder. I am not estopped. I have not made credible the representation that the note was my real obligation. ${ }^{3}$ Varying the case: I give a friend an accommodation acceptanee which he afterwards returns unused. I tear it in two (but so neatly that the severance might well be taken to bave been for safer transmission through the mails) and throw it on the ground. He picks up the pieces, pastes them together, and passes the bill. I am liable; for I have by insufficient cancellation made credible the representation that the acceptance was genuine. ${ }^{4}$

Varying the case again: Suppose that the forged note is presented to me for payment, and that I forbear denouncing the forgery until after the holder's position has been damaged by the flight or change of circumstances of the forger; I am estopped by the assistance which $I$ have rendered to the success of the fraud. ${ }^{5}$ Seeing "the mistake into which he had fallen, it was my duty to be active." 6

Partnerslip. - Members of a firm, for the purpose of obtaining credit, falsely represent that I also an a member of it. I

1 See ch. XXV.

2 See ch. XXV.

3 See ch. XXV.

4 Ingham v. Primrose (1859), $28 \mathrm{~L}$. J. C. P. 294. The case has been much suspected. See ch. XXV.
${ }^{5}$ McKenzie v. British Linen Co. (1881), 6 App. Cas. 82. And see cases cited with this one in ch. XI.

${ }^{6}$ Ramsden v. Dyson (1866), L. R. 1

H. L. 140 . 
am not bound.' I have not assisted the mispepresentition. Varying the case: I was at one time a member of the firm, but nave ceased to be so; no notice of my withdrawal was given to persons with whom the firm used to deal; these persons continued to give eredit to the firm upon the representation of the remaining parties that I was still a nember; and I am liable, because my previous connection with the firm and the absence of the usual notice of dissolution have made the misrepresentation credible."

Certificutes of Sherres. - Falsely elaiming to be the owner of shares in a certain company I execute a transfer of them to one who believes my representation to be true. No reason is here apparent why the eompany should be in any way affected by my action. Varying the case: Suppose that the company had, through inalvertence, issued to me a certificate of ownership of the sbares, and that my purchaser relied upon it as evi. dence of my ownership; the company would now be estopped, because by its certilicate it had assisted my misrepresentation and made it credible. ${ }^{3}$

Priorities. - The owner of an equity of redemption, representing that he is an uninemmbered owner, mortgages the estate to another person who has no notice of the first incumbrance; no ground exists for holding the first mort gatree responsible for this misrepresentation, and he is not estopped from asserting his true position. The mischief arose from the folly of the second mortgrigee in taking the unsupported assertion of the mortgagor. Tary the ease: Suppose that prior to the mispepresentation the mortgagor hat, upon some pretext, obtained from the first mortgagee possession of the title deeds, and that he harl, in support of his representation of unincumbered ownership, produced the deals to the seeond mortgitgee. The first mortgagee may now be estopped (it depends upon eiremmstances), for he has assisted the misrepresentation by handing orer the title deels."

Trustees. - Two trustees arreed to make a loan upon mortgage, and one of them (call him No. 2) was intrusted by the

1 Marshall v. Aiken (1997), 170 Mass. 37 L. J. Q. 13.176. And ace reference 3: 48 N. E. R. 84 i.

2 See ch. XXVII. to this calse in els. XXII.

${ }^{3}$ Re Bahil (1868), I. R. 3 Q. B. 581; t See past, cl. XIX. 
other with the money; No. 2 procured the mortirage to bo executed by the mortgagor, who signed the usual receipt for the money; the mortgage was sent to the other trustee (No. 1), and executed by him; some of the money was kept by trustee No. 2, and was therefore nerer received by the mortgagor; No. 2 afterwards died; and the question arose between the surviving trustee (No. 1) and the mortgitgor as to whether the latter owed the sum retained by No. 2. It was held that the mortgagor was estoppel by the acknowledgment upon the mortgage. IIe had enabled No. 2 to represent to No. 1 that he (the mortgagor') had received the whole amount, and had thus prevented discovery of the fraud.'

Ostensible Ownership.- There are very many cases in which estoppel is due to assisted misrepresentation by ostensible ownership. That is to say, the true owner of property may be estoplped from asserting his title by enabling some other person to successfully represent himself as the owner, and thus to deceive an innocent purchaser.

it here the true owner has really transferred the title, and it has fraudulently been passed on to an innocent transferee, the true owner may also be said to be estopped. But that case can be viewed as one in which the purchaser, having actually got the estate in the property, is entitled to hold it without refer. ence to estoppel, as against a merely equitable claimant. Whicherer ground maty be thought to be the true one, the result, at all events, is uncjuestioned. ${ }^{2}$

Estoppel must clearly be involied, however, where not the title itself, but the appearance of it only, has been conferred upon the fraudulent grantor - for example, by transferring to lim for particular purpose a bill of lading. In such case it is impossible for the innocent purchaser to say that he has any title at all; and his position must be maintained by estoppel, grounded upon the misrepresentation of the custodian of the bill and the assistance rendered by its real owner. Many such cases will be found in subsequent chapters. ${ }^{3}$

And estoppel must be appealed to where, although the title

1 West v. Jones (18,51), 1 Sim. (N. S.) of solution when the purchaser talkes 20\%. And see London v. Suffield \{189\%), 2 Ch. 608: 66 L. J. Ch. 790. (that which is still called) an equita. ble estate. See ch. XVIII.

2 'The case becones more difficult

3 l'ust, chis. XVII to XXVI. 
itsolf has been rested in a trustee, the person misled by the appearinee of beneficial ownership is not a sub-purchaser, but a creditor of the trustee. Usually a ereditor can seize such estates only as his debtor in reality owns; and if the debtor be a trustee, his ereditors are not commonly entitled to levy upon the trust estate.' It has been held, however, in a great many cases that if the property has been transferred to the debtor in order that by his appearance of finaneial strength he may obtain eredit, the true owner may be estopped from setting up his beneficial title agrinst ereditors. ${ }^{2}$ For estoppel in sich cases it is not sulficient that the title to the property hits been vested in the name of the debtor ${ }^{3}$ so to hold wouli be to add a new terror to trusteeship.4 Intent to mislead ereditors must more or less clearly appear. ${ }^{5}$

Concealment of an incumbranee ${ }^{6}$ "1pon the debtor's own property, or eoneealment of a debt dne by him, may, upon similar grounds, have the effect of estopping the incumbrancer or ereditor from asserting his claim. The reputed ownership clanso of the English bankiputey act has given statutory approbation to this principle. ${ }^{8}$

${ }^{1}$ Re General Horticultural Co. (1886), 32 CH. D. $512 ; 55$ L. J. Ch. 608 ; Badeley v. Consolidated (1888), 38 Ch. D. 238; $5 \pi$ L. J. Ch. 468: Campbell v. Gemmell (1890), 6 Man. 353; Carse v. Bartlett (IS9S), 12 Man. 2১0; Root v. French (18:35), 13 Wend. 5\%0 (N. Y.): Bryant r. Whitcher (15\%2), 52 N. H. 15s. See as to creditors of a shareholder in a company, after he has executed a trinsfer, but before it is registered, ch. II.

2Talp v. Lee (1si):3), 3 Bos. \& P. 36i; Corbett v. Brown (1831), 8 Bing. 33; Graham v. Thompson (159:), 5.j Ark. 996; 18 S. W. R. 5s.

${ }^{3}$ Breeze v. Brooks (1886). 71 Cal. 169; 9 Pis. R. 6i0; 11 id. Shis; Roberts $\mathrm{s}$. Trammel (1596), 15 Ind. App. $44.5 ; 4+$ N. E. R. 321.

+Korn v. Day (1893), 4,j Ia. Ann. 71: 12 S. R. 6; Girault v. A. P. IIotalingr Co. (1593). r Wasll, 90; 34 Pate. $R$. 4i1; Hill v. Vau Sandt (1S95), 1 Kan. Aplu. نं6i; 40 P:te. R. 6ió.
5 Trenton $v$. Duncan (1SS1), S6 N. Y. 221; Kingman v. Gralam (1851). 51 Wis. 23: Leete v. State Imank (1893), 11; Mo. 184; 21 S. W. R. 788, 793; Ingals v. Ferguson (1894), 59 Mo. 2. pp. 299; Wamer $v$ Watson (1s95), 3.j Fla. 40:2; 17 S. R. 654: HeClain v. Abshire (1s95), 1 Io. App. R. .51; 0j3 Mo. App. 33:3; Iseminger v. Criswell (1896), 98 Iowil, 38:; 6i N. W. R. :249.

${ }^{6} \mathrm{Trenton}$ Bank v. I)uncan (18i1), 86 N. Y. 2.21; Curtis v. Wilcox (189?), 91 Mich. 22!); 51 N. W. R. 922; Brayton v. Iatriling (1s91), j6 lll, Aplp. 3(t): Wachusett v. Sioux City (1x!1), 6:3 Fed. R. 366; Bacon r. IIarris (1:94), 6: Fell. R. 99; Baker v. Sulvey (1597), 16:3 Mats. 52?: 40 N. E. R. 863; s.y. vester v. Henrich (1595), 93 Iowa, 189 ; 61 N. W. R. 94:.

¿Powers v. Large (1S89), 75 Wis. 494: 43 N. W. R. 1112.

$8 \mathrm{~S}$ re relerence to this statute in ch. NL 
Standing 6y-- Perbaps the most familiar form of assisted misrepresentation is that in which an owner of property stands by while it is sold by another person to an innocent purchaser. Since Pickard $v$. Sears ${ }^{1}$ it might well be thought to he elear that an owner of property would be estopped, as against an innocent purchaser of it, were he to stand by and allow it to be sold without disclosing his title. Ritchie, C. J., of the Canadian Supreme Court, however, in a case involving the validity of a tax sale, saill: ${ }^{2}$

"As to the estoppel claimed. I do not think that the mere fact of . . i knowing of the sale and not forbidling it or protesting against it would estop them from contesting its validity: nor the mere fact of . . . requasting D. to attend the sile and bid the property in. . . All the admission amounts to is that the plaintiffs knew of the sale. and dut not forbul or profest ugainst it. This in my oprinion they were not bound to do; there was no duty to spcak:"

'ihe learned judge was of opinion that there was no estoppel because the defendant (the purchaser) did not know that the plaintiffs (the owners) were represented at the sale, and that, therefore,

"the defendant was (not) at all influenced by what the . . plaintiffs did or omittud. So far as the defendint is concerned there is no representation made to her at all, and certanly none male with the intent that it should be acted upon by her. . . In other words, the defendants were never deceived, or induced to alter their position. by any statement or act of the plaintiffs. . . Therefore in this case the two great ingredients . . . are winting, namely, lhat the plaint iff intended that the defendant should act on the faith of his act or representation, nor that the defendant did so act."

l(183\%) 6 A. \& E. 469. See the following cases: Proctor v. Bennis (188\%), 36 Ch. D. $740 ; 5 \%$ L. J. Ch. 11; Ogilvie v. West A ustralia (1896), A. C. 257: Dalvis v. Suyler (18501, $1 \mathrm{Gr}$. 1:34; Rolinson v. Cools (1881), 6 Ont. 590; II:Diarmid v. Hughes (1888), 16 Ont. jio: Cady v. Owen (1861), $34 \mathrm{Vt}$. igs: Woodhull v. Rosenthal (187i), 61 N. Y. 38: International v. Bowen (18i5), so Ill, 541; Studilard v. Lemmond (18\%3), 4s Ga. 100; Chapman v. Pingree (18ri), 6r Me. 198: Morgan v. Ratilroarl Co. (1850), 98 U. S. 716, 720: Wagner's Aphral (1881), $98 \mathrm{~Pa}$. St. $\pi$; Trenton Banking Co. v. Duncan (1S81), 86 N. Y. 221; Bradley v. Luce (1881), 99 Ill. 284; Griffin v. Nichols (1883), 51 Mich, 575; $17 \mathrm{~N}$. W. R. 6:3; Miller v. Foss (1895), 107 Mich. 538; 65 N. W. R. 562; Moreland v.
H. C. Fricke \& Co. (1895), 170 Pa. St. 33; 32 Atl. R. 634; Bates v. Swiger (1895), 40 W. Va. 420; 21 S. E. R. 874; Camp) v. St. Louis (1895), 62 Mo. App. 83: Stephens v. Head (Ala., 1898), 24 S. R. 738; Ashurst v. Ashurst (Ala., 189S), 24 S. R. 760; Nodle v. Hawthorne (1899), 107 fowa, 380: $77 \mathrm{~N}$. W. R. 109:; Lastrup v. Prendergast (1899). 179 III. 55:; 53 N. E. R. 995.

"The term 'stamling-by' . . . does not mean actual presence or actual participation in the transaction, but it means a silence where there is knowledge and a duty to malke a disclosure." Antlerson v. IIuble (1883), $93 \operatorname{lnd}$.56); :1proved in Kuriger v. Joest (1899), 5* N. E. R. \%(i8.

2Flanagan v. Elliott (1886), $12 \mathrm{~S}$. C. Can. 443. 
With deference it is sulmitted that eases of personal and assisted misrepresentation are here confommled together, and the conditions of the former applied to a case of the latter. When I stand by and allow another to sell my property as his, the purchaser may truly say that he did not act upon my misrep)resentation, for he aeted upon the misrepresentation of his vendor. But that is only to say that the ease is not one of personal misrepresentation. That there maly be estrppel by the misrepresentation of another, in which the estuplel-nenior has assisted, is beyond dispute; and the only question can be, does an owner assist in such a mispepresentation by standing by, and giving no hint of his title? The decision, it is respectfully submitted, must be supported, if at all, by the alroment that the sale was one for taxes; one in which its valiclity depended upon its regularity; and that there was no representation of regularity (as to which the owner might be, and indeed was, quite as uninformel as the purehaser) by not objecting at the time of the sille. ${ }^{1}$

Mloig v. Gordon" is a sugrgestive ease upon the line under consideration. It would have been otherwise decided were the judgment just eited to be taken as the law.

"Where for ten years a wife concealed from the public her relation to her hustand, anl allowed him to live with another woman as his wife tinter an assmmed name - the real wile livine in the neighborhoot. and rereivin from them he: support. - it was held that she was precluded from cliamme dower out of land morchased during this period in the husband's asium vi name, and afterwards sold by him and his supposed wife to a purchaser who bought in good faith and without any notice of the real relalionship of the parties."

i As to irregularities see Claxton $\mathrm{v}$. Shibley, 9 Ont. 4i) 1 ; Stone v. Fngstran (R. J.), 32 Atl. R. 916; Neal r. Robinson (Ky.), :S S. W. R. 33.5. Bielding at a sale will not mislead if your position and objection be first clearly stated. Lines r. Grange (185-1), 1: U. C. Q. B. 209.

2 (18r0) 1\% Gr. 599. And see Watson v. Threlkeld (1798), 2 Esp. $63 \%$. 


\section{CHAPTER V.}

CONDITION NO. 3.

\section{There Must be a Disregard of Some Duty.}

\section{INTRODUCTORY.}

Everyone is familiar with the maxim Sic utere tuo ut alienum non ladas, in its application to property of physical character. It is not dissimilar from Mr. Herbert Spencer's definition of the compromise which the social state imposes between "that positive element implied by each man's recognition of his claims to unimpeded activities and the benefits they bring," on the one hand, and "that negative element implied by the consequences of limits which the presence of other men, having like claims, necessitates," on the other.' His formula is this: "Every man is free to do that which he wills, provided he infringes not the equal freedom of any other man." 2 What is the relation of such rules and maxims to the realm of business and commerce?

Man in the whirl and complexity of modern conditions and engragements is fur less an individual than a member of a society owing duties to bis fellow members. He is a unit, no doubt, but one baving relations and associations productive of responsibilities. As in the physical domain he owes a duty of carefulness and circumspection and behavior, regulated by the peculiarities of his personal environment; and as in the region of morals he is debtor (although sometimes without legal enforcement) to his fellowmen; so also in the affairs of commerce and business he is obliged to observe and have some degree of regard for the interests of others. He cannot always safely " "io with his own as be pleases."

That the duties thus imposed are not absolute but relative to the eonditions which may obtain from time to time ${ }^{3}$ is but to

1 Justice, 37.

2 Id. 46. ${ }^{3}$ See Degg v. Midland (185\%), 1 H. $800 ; 31$ L. J. Q. D. 30.
\& N. 781: 26 L. J. Ex. 171, approved in Potter v. Faulkner (1861), 1 B. \& S. 
say that social rules are not yet finally codified; that adrancement and progress and improvement have not yet ceased. Indeed, as we observe the rapid derelopment of the law of estoppel, and the increasing list of duties which is ever being lengthened by the necessities of later activities, we see that not only are the relations of life still willening out into greater complexities, but that the laws of altruism and mutual aid aro making rapid head as against those of mere individualism. ${ }^{1}$

I In the same sense, Mr. Herbert Spencer, in his Data of Ethies (pp. 238, 239), says: "Social evolution has been bringing about a state in which the claims of the individual to the proceeds of his activities and to such satisfactions as they bring are more and more positively asserted; at the sime time that insistanee on other's' claims, and habitual resuect for them, have been increasing. . . . Regard for the wellbeing is increasing pari passu with the taking of means to secure personal well-being." Again (p. 207): "And here as before each is personally interested in securing good treatment of his fellows by one another. For in countless ways evils are entailed on cach one by the prev. alence of framblent transuctions."

In his "Ecclesiatstieal Institutions" (p. 825) in speaking of the future of the priest (hatd he been thinking of estoppel he would have said "judg(e") he says: "At the siture time insistance on duty, which has formed an increasing element in religious ministration, may be expected to assume a marked predominance and a wider range. . . All natters concerning individual and social welfare will come to be lealt with, and a chief function of one who stands in the place of a minister (judge) will be not so much that of emphasizing precepts already accepted, as that of developing men's judgments and sentiments in relation to those more difficalt questions of conduct, arising from the ever-increasing complexity of social life."

In "Justice" the same writer says: "For let us remember that there is now recognized, by law and by jublic conscience, the truth that not only actual physical mischief to others, but also potential physical mischief to others, are flagitious" (p. 70). "With the progress of civilization the administration of justice continues to extend and to become more efficient" (p. 208) "Thus while in uncivilized societies, and in eariy stages of civilized societies, the individual is left to defend his own life, liberty and property as best he may, in later stages the community through its government more and more undertakgs to defend them for him " (p. 153).

And the process has been recently well described by Alexander Sutherland (The Origin and Growth of the Moral Instinct, vol. II, p. 2:2): "We know, as a matter of fact, that in the development of hmman society it is not lizw which gives rise to duty, nor duty which is the foundiztion of morality; but that morality originates in sympathy; crystallizes viguely into duty; and duty, thus formed, finds a voice and a definite scope in law. Then law by reactive force gires new strength to luty, and duty adds continuity to sym. pithy." 


\section{"An Appropriate Meascre of Predexce."}

\section{Sir Frellerick Pollock in his work on Torts says: ${ }^{1}$}

"The whole modern law of negligence, with its many developments, enferces the duty of fellow-citizens to observe, in varying circumstances, (in appropriate measure of prudence to avoid causing harm to one a nother. The situations in which wa are under no such duty appear at this day not as normal but as exceptional. A man cannot keep shop, or walk into the street. without being entitled to expect, and bound to practice observance of this kind, as we shall more fully see hereafter. If there exists then a positive duty to avoid harm, much more nust there exist, whether it be so expressed in the books or not, the negative duty of not doing wilful harm, subject. as all general duties must be subject, to the necessary exceptions. The three main heads of duty with which the law of torts is concerned, namely, to alstain from wilful injury; to respect the property of others; and to use due diligence to avoid causing harm to others, are all alike of a comprehensive nature. As our law of contract has been gen. eralized by the doctrine of consideration and the action of assumpsit, so has our law of civil wrongs, by the wide and various applications of actions on the case."

Videly comprehensive rules of such character find multitudinous illustration: You may construct reservoirs or fish-ponds, but - Inu may burn rubbish-heaps or enjoy bonfires, but You may build a factory or play a piano, but - ${ }^{2}$

What is "an appropriate measure of prulence," the same

1 Pollock on Torts (jth ed.), 22.

2 To remind readers of the general law, the following quotitions are given from Underbill on Torts (4th ed.. 160 and 66 ):

"Negligence consists in the omis. sion to do something which a reasonable man would do, or in doing something which a reasonable man would not do. Blyth v. Birmingham Water Co. (1856), 25 L. J. Ex. 212.

"It is a public duty incumbent upon every one to exercise lue care in his daily life; and any damage re. sulting from his negligence is a tort.

"Thus where the plaintiff was in the occupation of certain farm buildings, and of corn standing in a field adjoining the field of defendant, and the defendant stacked his hay on the latter, knowing that it was in a highly dangerous state and likely to catch fire, and it subsequently did ignite, and set fire to the plaintiff's property, it was held that the defend- ant was liable. Vaughan $\nabla$. Menlore (18:3i), 3 Bing. N. C. 46 s.

"So where the defendant intrusted a loided gun to an inexperienced servint girl witl directions to take the priming out, and she pointed and fired at the plaintiff's son, wounding and injuring him, the defendant was behl liable. Dixon v. Bell, 5 M. \& S. 198.

"A master is bound to take reason. able precantions to insure his servant's safety; and if, through the absence of such reasonable precautions, or through the breach of some duty incumbent on the master, or through the personal negligence of the mister, the servant is injured, the master will be responsible. Ormond v. Holland (1858), E. B. \& E. 102; Asluwix v. Stanwix (1861), $30 \mathrm{~L}$. J. Q. B. 183." See also Black v. Christchurch, etc. (1894), A. C. 48, 63 L. J. P. C. 32. 
learned author discusses in a passigge to which the present writer desires to subscribe: ${ }^{1}$

"The loctrine of 'uatural and probable cousequence' is most clearly illustrated, however, in the law of segligence. For these the substatuee of the wrong itself is failure to act with due foresiglit; it has been defiucl as - the omission to do something whieh a reasonable man, guided by those consilerations which ordinatily regulate the conduct of lumban affirs, would do: or doiner somethiner whic|lu a judent and reasonable man would not do.' Now a reasomable miln ('an be gruided only by a reasonible esti. mate of probabilities. If man went about to gllarl themselves aginint every risk to themselves or others which might, by ingenious conjucture. le conceived as possible, lumman atfairs could-not be carried on at all. The reaconable man then to whose behavior we are to look as the stamiarl of cluty will neither neglect what he ean forecast as probable, nor waste his andiety on events that are barely possible. He will order his pracaution by the measure of what appears likely in the known course of things. This being the standard it follows that if in a particular case (not heing within certain special and more stringent rules) lle ham complatined of is not such as a reasomable man in the defendant's place woulil hitve foreseen as likely to haplen, there is no wong and no liability. Anl the

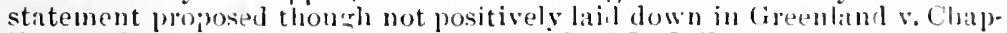
lin. per Pullock, C. B. (15,70), 5 Ex. at p. 248, 19 L. J. Ex. 293, nammy, that a person is expereml to anticipate and guard arainst all reatsonable consefaunces, but that he is not by the law of Enchand expected to anticipate and guard against that which no reasomable man would expect to occur. appears to contain the only rule tenable on principle where the liability is founded solely on nerlicence. "Mischief which could by no possibjity have been fojeseren, and which no reasonable person would have anticipated,' may be the ground of legal compusation under some rule of exceptional severity, anil such rules for virious reasons exist; but under an intelligible rule of due care and caution it caunot be taken into account."

$\mathrm{Mr}$. Cooley defines negligence as

"the failure to observe for tise protection of the interests of another that degree of care, preciution and vigilance which the circumstances justly demand." "2

\section{Applichtion of the Principle to Estoppel.}

The present writer believes that this principle - "Observe an appropriate measure of prudence to aroid causing harm to others" - is the chief corner-stone not only of the law of torts but of the law of estoppel by assisted misrepresentation; and that the confusion we are to meet with in the present chapter is largely due to lack of recognition of that fact.

'Two main stumbling blocks are enconntered. First, although in various departments of the law to which estoppel is applicable the principle in hand is in reality the ellicient and dominating factor, yet other reasons for the decisions than the true one are put forward and accepted as satisfictory. Secondly, there are many cases in which all possible application of the princi-

1 Pollock on Torts (5tls ed.), 3 r.

2 On Torts, 630 . This definition

has met with rery general approha- tion in the United States. Jaggar.1 on To:ts, s10, v. 
ple is completely denied. An efiort will be made to show that the principle hats been in some branches of the law of estoppel in reality accepted; to uphold the principle as one necessary to the condition of commercial nations; and to urge its adoption in eertain lines of cases from which it is at present excluder.

But first observe the relation and application of the principle in band to estoppel by assisted misrepresentation. In other words: How can the duty of observing "an appropriate measure of prudence to avoid causing harm to others" have any bearing upon the law of estoppel?

Suppose that a mortgagee hands over the title deeds to the mortgagor, and that the mortgagor fraudulently deposits them with a banker as security for a loan. The mortgagee may now be estopped from setting up his title against the banker; and the reason is that he has assisted the misrepresentation of unincumbered ownership made by the mortgagor-be has marle that representation credible. ${ }^{1}$ But we cannot arrive at this result without bringing our principle into operation as a major premise. We must say tbat there is a duty to "observe an appropriate measure of prudence to avoid causing harm to others;" that the mortgagee in handing orer the deeds committed a breach of that duty (for he knew that he was equipping the mortgagor with a simple metbod of clefrauling other people); and that for such breach of duty he is estopped - for

"The common-law duty to exercise care to avoid doing harm to others may be derivel from the ownership, custody. control or use of instrumentalities which may of necessity, or in reasonable probability, inflict damage." 2

The rule applies that

"When any person under a legal duty to any other person to conduct himsclf with leasonahle caution in the transaction of any business, neglects that duty; and when the person to whom the duty is owing alters his position for the worse because he is misled as to the conduct of the negligent person by a fraud of which such neglect is, in the natural course of things, the proximate cause, the negligent person is not permitted to deny that he acted in the manner in which the other person was led by such fraud to believe him to act." 3

\section{Appuication of time Prixciple to Estoppel Denied.}

It is of the greatest importance that this relationship between duty and estoppel should be clearly appreciated. From

1 See many similar cases referred to in chapter IV.

2 Jagrarard on Torts, 865.
3 Stephen's Dig. Law of Evidence (2d ed.), 124. 
it all else is derived. Nevertholess its existence is not merely often ignored, but is sometimes expressly denied. In a very important case' Wille, B., sitid:

"It is I think always difficult and sometimes illusory to compare two principles whicis emanate from different sources, and proceed in.tifferent

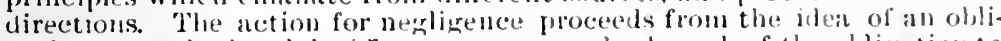
gation towarls the plaintifs to use calce, and a beach of the ohligntion to the plantiff's injury. The ductrine of estoppel as applied to these cases of

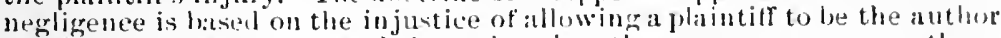
of lus own mistoltune, and then flatging the conseguences on othres. . - It woull be very fillacions to test any set of circunstances as riasing an estoples or not, by asking whether, reversing the parties, an action for negligence would lit."

A crucial question is here raised: Does estoppel by misrepresentation depend upon breach of duty? The learned baron (just quoted) would answer in the negative; and would emphasize it by saying that estoppel has nothing whatever to do with duty - with "obligation."

Take the simplest case of estoppel, namely, standing by while some one sells your property to an innocent purchaser. You are estopped. But why? The learned baron would say that you were the author of your own misfortune, and must not charge the consequence of it upon others. But this is not correct, for you were not the author of your own misfortune, but of that of the purchaser. Apart from estoppel you still have your property; and the purchaser, although he has paid his money, has receired nothing for it. We must then say that the bystander is estopped (if at all), not because he was the author of his own misfortune, but because he was the author or part author of damage to inother. But if damage be caused to another there is no legal responsibility for it in the absence of the breach of some duty owed to that other; there must therefore have been some duty; and thus we arrive at the neeessity for the existence of duty as a requisite of estoppel. In accordance with this view it was said in the Ilouse of Lords:?

"When I saw the mistake into which he had fallen it was my duty to be active and to state my adverse title."

I Swan r. N. B. A. (1862), 7 IH. \& N. 63.i; 31 L. J. Ex. 43\%. Much can be said in favor of the alternative test here suggested. It would be very anomalous if certian negligenee could be penalized by estoppel; but that the negligent person would go flee were the circumstances not such that estoppel would hurt him.
See the discussion in chapter XVI: and Evans v. Bicknell (1801), 6 Ves. 173: Lynch s. Murlin (1S 41$), 1$ Q. B. $29.3 \%$.

2Ramsden r. Dyson (1S6?), L. R. 1 H. L. 140. And see Viele v. Judson (1840), 82 N. Y. 32; New Tork r. Rothery (18si), $10 \pi$ N. Y. $310 ; 14$ N. E. R. 269. 
Try the alternative: that there is not, in a case of estoppel by standing by, the element of duty. We must then say that the bystander did perfectly right in silently permitting the fraud to be committed (for there was no duty incumbent upon him to reveal his title), and for doing that which was perfectly right he must lose his property - must be estopped. That is not very satisfactory.

"Before any person can complain of negligence he must make out a duty to take care: and that duty can only arise in one of two ways, naniely, eitlier by contract, or by the law imposing it." 1

$" A$ person camnot be said to be culpable in not doing a particular thing. unless it is his duty to do it." 2

It is equally clear that in all other cases of estoppel there must be the element of breach of duty. In all of them it is not that the estoppel-denier has been the author of his own misfortunes, but that he bas got some other person into trouble. In all of them he, upon the facts, is unhurt; and what we have to do is to find some reason for saying to him: "You must not assert these facts." The only reason we can give is that upon the faith of his misrepresentation or assisted misrepresentation of the facts some other person has changed his position. But if he was perfectly right in misrepresenting - that is, if the law did not impose upon him any duty not to misrepresent, or to aid in misrepresentation, there is no reason (known to the law at least) why he should not assert the facts. If he has done something (legally) wrong, then penalize him. If he has been silent when he ought to have spoken, then, and not otherwise, compel silence when he wishes to speak.

\section{The Principle Already in Operation.}

It has been said that the duty of "an appropriate measure of prudence" has been allowed (althongh frequently unconsciously) to govern the decision of cases in various departments of the law (besides that of tort). For example, it is your duty in drawing a check not to leave tempting spaces in it; for thereby your banker may be defrauded. ${ }^{3}$ It is your duty not to allow your mortgagor (except under special circumstances) to have the custody of the title deeds; for thereby some money lender

1 Per Bramwell, J., in Dickson v. Cooke (1848), 2 Ex. 654; 18 L. J. Ex. Renters (18;7), 3 C. P. D. 5; 46 L. J. 114.

C. P. 197.

3 Young v. Grote (1827), 4 Bing. 253;

2 Per Alderson, B., in Freeman s. 12 Moo. 484 ; 5 L. J. C. P. 165. 
may be defrauded.' It is your duty not to permit others to have possession of your "negotiable" securities; for thereby purchasers of them may be deceived." It is your duty not to furnish your trustee with evidence that he is the bencicial owner; for therewith he may cheat some innocent purchaser. ${ }^{3}$ It is your duty not to permit your agent to have an apparent authority larger than his real authority; for thereby others may be tricked." It is your duty, when retiring from partnership, to give notice of that fact; for otherwise credit may be given upon the faith of your continued membership. ${ }^{5}$ It is your duty in executing a document to see that it is that which you believe it to be; for otherwise some third person may be led to believe that you have agreed to that which in reality you have not even considered. ${ }^{6}$ It is sometimes by usage your duty to examine an account delivered to you, and to give timely notice of your objections thereto; otherwise the other party may fail to take steps for his protection which he could and would have taken. ${ }^{7}$ It is your duty to exereise care with reference to documents which "have a certain mercantile meaning attached to them;" for otherwise "persons likely to deal with the documents" may suffer damage. ${ }^{8}$

The law of estoppel is the legal sanction for all such duties; and provides for their disregard the penalty of silence in respect to all rights and claims which, at the proper time, ought to have been put forward.

\section{But Other Reasons Given.}

The application of the law of estoppel to many of these cases has not, howerer, been sufficiently observed; and in its absence, or even sometimes in declared opposition to it, other reasons have been offered for the results arrived at. If, for example, blank spaces have been left in your check, it has been said that you thereby authorized the payee to fill them

1 See ch. XIX.

2See ch. XXIV. "Ambulatory" ought to be substituted for "negotiable."

3 See ch. XVII to XXVI.

4 See ch. XXVI.

5 See cli. XXviI.
6 See ch. XXV.

‘Deraynes r. Noble (1815), 1 Mer. 530; Leather v. Morgan (1886), 11; U. S. 96. See references to these cases in ch. XI.

${ }^{8}$ Corentry v. Great Eastern (1\$83), 11 Q. B. D. 766 ; 52 L. J. Q. B. $690^{\circ}$ 
up ${ }^{1}$ - a plea that would not save the payee from a charge of forgery, for it is not true. If you allow your mortgagor to have the cleeds and thus to pose as nnincumbered owner, the reason given for your postponement is that "a second mortgagee who has the title deeds without notice of any prior incumbrance shall be preferred;" ${ }^{2}$ a proposition which, as we shall see, ${ }^{3}$ holds good only where, according to the principies of estoppel, it ought to do so, and in other cases is falsitied. If you intrust your negotiable securities to a broker who transfers them in defiance of your instructions, it is said that yon lose because "the law merchant validates in the interest of commerce a transaction which the common law wonld declare void;" " and that "the ordinary rules of the common law are made to bend;" 5 whereas the ordinary rules of estoppel are quite sufficient for the case. ${ }^{6}$ If you permit your agent to have an apparent authority larger thin the real, it is saicl that you are responsible for the agent's acts because "the authority of the agent to perform all things usual in the line of business in which he is employed cannot be limited by any private order or direction not known to the party dealing with him;" ? whereas the truth is that you can limit bim as much as you like, but that if, notwithstanding such limitation, you allow him to act as though there were none, you are estopped from setting it up. And if you execute a document which does not reflect your true agreement, it is said that one sort of fraud upon you will render the document void, whereas another will render it voidable only - a bit of lochomachy that will not stand investigation. ${ }^{8}$

\section{Comiron Characteristics - Estoppel.}

Gathering all such cases together, we find that they have this strong common characteristic, that there has always been

1 Montagu v. Perkins (1853), 22 L. J. C. P. $18 \%$.

2 Goodtitle v. Morgan (1787), 1 T. R r62; Layard $\mathrm{v}$ Maud (186テ), L. R. 4 Eq. 397, 406; 36 L. J. Ch. 669; Hunter v. Walters (1871), L. R. 11 Eq. 316; 41 L. J. Ch. 175; Spencer r. Clark (1878), 9 Ch. D. 142; 47 L. J. Ch. 692; Lloyd v. Jones (1885), $29 \mathrm{Ch}$. D. $229 ; 5 \pm$ L. J. Ch. 931.
${ }^{3}$ See post, ch. XIX.

${ }_{4}^{4}$ Swan v. N. B. A. (1862), 7 H. \& N. 634: 31 L. J. Ex. 436.

5 Per Byles, J., in Swan $\nabla$. N. B. A. (1863), 2 H. \& C. 185; 32 L. J. Ex. 273. ${ }^{6}$ See post, ch. XXIV.

7 Smith's Mer. Law (8th ed.), p. 575; and see post, ch. XXVI.

${ }^{8}$ See ch. XXV. 
some fraud perpetrated by which one of two innocent persons has to suffer (the property of one innocent person has been fraudulently transferred to another; the obligation of one innocent person has been fraudulently passed on to, or created in favor of, another), and the question is, Who is to suffer? To this, in all such cases, the law of estoppel replies: There is a duty to observe "an appropriate measure of prudence to avoid causing harm to others;" and if, in breach of this duty, one person has assisted the misrepresentation of anothersupplied that which has made it credible-he ought to be estopped as against the person to whom the harm has been caused.

\section{Egoism axd Althetsis.}

Coming now to the departments of the law in which the application of the principle in hand has been denied, let it be observed that there are two views which may be taken with reference to the conduct of affairs: the egoistic and the altruistic. According to the former I may do as I please with my own, and others may look after themselves. Acting upon this view I shall draw my checks as I please; leare my title deeds and negotiable instruments with whom I choose; allow my agent to misrepresent his authority as he thinks fit; stand by as an indifferent spectator while other people assume to sell my property; and if any one is injured I shall tell him to pursue the one who def rauded him with such eivil or criminal process as is appropriate.

Following the other view - the altruistic - I shall have a care that I am not made an accomplice, or even an unwitting instrument, in frauds upon others; I shall refuse to give opportunity or occasion for misrepresentation; and, profiting by experience of recurring rascalities, I shall so use my own liberties as not unnecesarily to expose others to the machinations of the defrauder.

This altruistic view as cognizable by law is necessarily the outcome of a highly developed state of society. In earlier stages the idea would not only be unfamiliar, but would be opposed to all the analogies of the time.' It bas emerged (as have

I It is hard to realize the total absence, in earlier periods, of ideas which now seem to be obvious. To

the question, Why did not Augustus introlnce the representative system when the Roman state became too 
other ideas) from observation of the injuries worlied by its disregard. But the induction is not yet complete, and although in the future some finished and detailed code of conduct as applied to the transactions and affairs of business and commerce may be formulated, the authorities as yet provide none such. For the present we must be content when (as is not always the case) the broad law of reasonable care for the interests of others is beld to be incumbent upon us.

\section{The Altruistic View Advocated.}

Speaking generally, the view advocated in this work is the altruistic. The principles which obtain with reference to physical relations ought, it is believed, to regulate business intercourse; and the language of Sir Frederick Pollock above quoted ${ }^{1}$ should be imported in to the law of estoppel:

"The whole modern law of negligence, with its many developments, enforces the duty of fellow-citizens to observe, in varying circumstinces, an, appropriate measure of prudence to avoid causing harm to one another."

In the realm of torts it is plainly seen that if the owner of hay (in a highly combustible condition) will unnecessarily stack it against a neighbor's barn (although on his own land), be ought to be liable if it cause the barn to burn. ${ }^{2}$ But it is by no means so clearly recognized that if the maker of a blank note (a bighly "negotiable" document) will so carelessly deal with it that it is fraululently made use of to filch money from a third person's pocket, the maker ought to stand the loss. It is an accepted principle in torts that

"One who enters on the doing of anything attended with risk to the persons or property of others is lield answerable for the use of a certain measure of caution to guard against the risk." 3

large for direct participation in government? Prof. Seeley makes answer: "You might as well ask, Why did not Augustus discover Amerjca?" "Introduction to Political Science," p. 164.

1 Ante, p. 30.

2 Vaughan v. Menlove (1837), 3 Bing. N. C. 468 . And see the principles laid down by Cockburn, C. J., iu Vaughan v. Taff Vale Ry. Co. (1860), 5 H. \& N. 685; 29 L. J. Ex. 247; and by Bramwell, L. J., in Powell v. Fall (1880), 5 Q. B. D. 600 ; 49 L. J. Q. B. 428 .

3 Dean v. McCarty (1846), 2 U. C. Q. B. 448; Buchanan v. Young (1873), 23 U. C. C. P. 101; Gilson v. North Grey Ry. Co. (18\%2), 33 U. C. Q. B. 128; Furlong v. Carroll (1882), 7 Ont. App. 145; Booth v. Moffatt (1896), 11 Man. 25; Owen v. Burgess (1896), id. 75; Citizens v. Lepitre (1898), 29 S. C. Can. 1; Makins v. Piggott (1898), 29 S. C. Can. 188. 
But, it is alleged that a company owes no duty to anyborly to take care of its seal, so as to prevent the fratululent execution of documents which may ruin other people.

\section{Variots Casis of Duty.}

A complete list of cases in which it has been held that there is a duty of carefulness not to offer obvious opportunities for the commission of fratud will not be attempted here. Representatives of the various clisses may be met with in their appropriate places thronghout the work. A somewhat comprehensive summary, however, will be instructire, and will much assist the almoment in faror of the altruistic view of business conduct:

1. Ostensible Ounerslip. - Such view has been widely accepted in cases which the present writer classes under the title "Ostensible Ownership."

(a) An owner of property may not stand by and permit an innocent person to be deluded into purchasing property to which the venclor hats no title.

"When I saw the mistake into which he had fallen, it was my duty to be active and to state my anlverse title."

"Tocreate an estoppel hy silence there must be not only the opportunity but the apparent duty to sjeak. The party keeping silent must lnow thit someone is relying thereon, and is either acting or about to act, as he would not if the truth were known to him." 3

"In Pickald v. Sears it was hell that he who stands by and sees another alter bis position, on the fith of a fict which he can contradict, cannot afterwards talie adrantage of that alteration; but the rule was corrected in Freeman $\vee$. Cooke, when it wils salul that if a maln stands by and allows

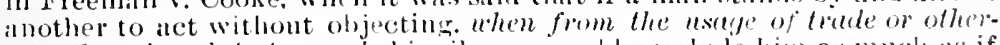
urise there is a duty to spechlis his silence woud preclude him as much as if he proposed the act himself." 4

(b) A railway company issued, by mistalie, two delivery orders for the same groods, and then refused delivery to an innocent transferee of the second of them. It was a mistalie, and they owed no duty of infillibility to the purchaser, they said, but Brett, M. R., told them,

"It is true that there can be no nergligence unless there be a duty but here the documeuts have a certain medeantile meaning attached to tiasu,

I See infra.

2 Rimusilen v. Dyson (1S66), L. R. 1 H. L. 141 .

3 Allen v. Shaw (18s1), 61 N. H. 97, citing Vicle 2. Julson, 8: N. Y. 32; Taylor $\times$ Ely, 25 Conu. 250 : Marshall r. Pierce, 12 N. H. 12i; bialchelder
․ Siuborn, 24 X. II. 499; Georme v. Cutting, 46 N. H. 46.5 : Norris s. Mur. rison, 4.) N. H. 4!9: Stevens $v$ D. 1) mett, 51 X. 11. :3:4: Bigr. Estop. 4!i$50 \%$

t Polak r. Everett (1SiG), 1 Q. B. D. $673 ; 45$ L. J. Q. B. 369. 
and therefore tise defondants owed a duty to merchants and persons likely to deal with the document.." 1

(c) For the same reason, a company owes a duty of carefulness in issuing certificates as to the ownership of shares, and will be estopped if they are made use of to support misrepresentation." They are intended "to be acted upon by purchasers of stares in the market." s

(d) So also with reference to bills of lading; representations in them are to be taken as having been

"malle to any one who, in the course of business, might think fit to make advances on the faith of them." 4

And thers is therefore a cluty of carefulness with regard to the assertions which they contain towards persons to whom they may be offered in support of representations of ownership of goods. ${ }^{5}$

(e) So also with reference to warehouse receipts, ${ }^{6}$ and other such documents. ${ }^{7}$

2. Ostensible Agency.-The remarks just made with reference to indicia of ownership are equally applieable to indicia of ageney. Every one must observe such reasonable precautions as will prevent his complicity in misrepresentation as to the authority of his ostensible agents. ${ }^{8} \quad$ It is upon this ground that the reasonableness of the Factors Acts can be upheld; and that the appearance of larger powars than those really conferred will often work estoppel. ${ }^{9}$

3. Lulling into Security.- It will be observed that of the instances above referred to, some are eases in which actice misrepresentation is forbidden, but some also are cases in which activity is imposed as a requisite of reasonable social conduct. It is in such instances, of course, that the altruistic theory finds its highest development; calling as it does, upon every one to throw off his cynicism and indifference, and to exercise (actively if need be) "an appropriate measure of prudence to a roid caus-

${ }^{3}$ Coventry v. Great Eastern Ry. Co. (1883), 11 Q. B. У. 766 ; 52 L. J. Q. B. $(69)$.

${ }^{2}$ Re Bahia (1868), L. R. 3Q. B. 584; 37 L. J. Q. B. 166; and see cases cited with this one in ch. XXII.

${ }^{2}$ Per Lord Herschell in Balkis v. Tomkinson (189:3), A. C. 403; 63 L. J. Q. B. 134.
${ }^{4}$ Armour v. Michigan (187,j), 6j

N. Y. 111, 122.

5 see ch. XXII.

${ }^{6}$ Holton v. Sanson (1862), 11 U. C. C. P. 606. And soe ch. XXII.

7 Prospectuses and company reports, for example. See ch. $X$.

8 see ch. XXVI.

9 Sue ch. XXIIL. 
ingr harm" to others. A grood example of this duty is to bo found in eases in which a man, finding that his name has been forged, neglects to notify the victim until after his position (by the death, escape or bankruptey of the forger) has been changed. Why, it may be asked, should the good man trouble himself; he has done nothing wrong, nor has he connived at it? But fortunately the law has declared otherwise; ${ }^{1}$ although, inconsistently as the writer thinks, it holds that a man may accept a bill in which the drawer has left spaces which offer the most obrions temptation to fraudulent increase of the amount, and may tell the victim that

"it is not consistent with the general spirit of the law to hold innocent persons responsible for not taking measures to prevent the commission of a irime which they may have no reason to anticipate."

In a later part of the present chapter some reasons will be offered as against this holling; for (with deference) it is itself out of harmony with the principles of the law of estoppel, and that altruism which is an essential and indispensable feature of modern affairs.

4. Another class of cases in which there is a duty to be active is to be found in the law of partnership. When a member of a firm retires from it, he is under "a cluty" 2 to give notice of that fact to those accustomed to deal with the firm. But. why? May he not say, "Let the dealers take care of themselves; I have retired; I an not liable for the goods, for I did not buy them." And the courts might say (as in other departments of the law they sometimes do), "The dealer's knew that a partner might have retired since the last transaction; they shonld have inquired." No doubt this conld very properly be said if the egoistic view were the correct one. That it is not said is to be attributed to the mulerlying, but usually mespressed, feeling that "an appropriate measure of prulence to aroid causing barn to others" must be exercised - actively if need be.

Mckenzie v. British Linen Cn. (18811,6 Apl. Cas. 8:. And see carses cited with this one in (ll. XI.

2S(“arf r. Jariline (188:2). 7 Apy). Cirs. 3.); 65 L. J. Cl. 915.

3 Where a master signs a hill of liwling for grools not put on board, it is held that the owaters of the ship are not liable to an innocent transferee of the bill. It is sabil that the transferee linew that the master haul anthority to give bills for grools shipped only, and that he should have inqured. See the subject discussed in ch. XXVL 
5. The following general statements of the law are not too comprehensive:

"Whenever one person is by circumstances placed in such a position with regard to another that every one of ordinary sense who did think would at once recognize that if he did not use ordinary care and skill in his own conduct with regard to those circumstances he would cause danger of injury to the person or property of the other, a duty arises to use ordinary care and skill to a void such danger.": 1

"When a person perceives that. in a matter of interest to himself. another person is acting, or about to act, or likely to act, in a mode in which as a reasonabléman he would not act or be likely to act if he knew the real facts, a duty arises on the part of the former to inform the latter of such real facts, if he is aware of them, and if the relative position in which the two parties stand towards one another is such that the latter might reasonably expert the former to tell him the real facts if the former were aware of them." 2

\section{Spaces Carelessly Lefet in Documents.}

These opposing views (egoism and altruism) have come into very notable conflict with regard to the question whether a party to a negotiable instrument may safely leave in it spaces which may easily be made available for increasing its amount. The subject has been elaborately discussel in the very recent case of Scholfield $v$. Londesborough, ${ }^{3}$ and in it the old case of Young v. Grote was once more dissected, explained, supported and condemned. Let us consider these cases somewhit closely, and more especially the later of the two, for by it the principle of egoism has received a predominance which is not only opposed to the decisions in many other analogous cases, but which the present writer believes to be highly injurious to commercial intercourse.

(1S27) Young v. Grote - "that fount of bad argument." ${ }_{5}$ A depositor in a bank signed a blank check, and left it with his wife to fill up as required. The wife directed a clerk to fill it up for 852.2 . He did so and showed it to her. She then instructed him to get it cashed. He increased the amount of the check by 2000 (inserting the necessary figure and words in spaces which he had left for that purpose), and drew the larger sum from the bank. It was held that the customer and not the bank should suifer the loss.

1 Hearen v. Pender (1853), 11 Q. B. D. $509 ; 52$ L. J. Q. B. 702.

2 Cababé on Estoppel, 81.

3 (1894) 2 Q. B. $660 ; 63$ L. J. Q. B. 649; (189.5) 1 Q. B. 536; 64 L. J. Q. B. 293: (1896) A. C. 514 ; 6 J L. J. Q. B. 593.
4 (1525) 4 Bing. 253; 5 L. J. C. P. 16.); 12 Moo. 481 .

${ }^{5}$ So Eslier, N. R., in Scholfield v. Londesborough (1595), 1 Q. B. 543; 61 L. J. Q. B. 293. 
The judgments, short and pithy as they are, have given rise to much discussion: (1) There is the greatest difference of opinion as to the ground upon which they proceed; (2) various suggestions have been malle as to the grounds upon which they should have proceeded; and (:3) several judges plainly declare that the right gronnds would have led to an opposite conclusion.' The decision, although somewhat shaken, still stands; ${ }^{2}$ but only on condition that it is confinel to checks. ${ }^{3}$

(1596) Scholfield $v$. Londestorongh. ${ }^{4}$ After much conflict of opinion the decision in the House of Lords in this ease has authoritatively declared the law to be out of barmony with Young $v$. Grote; or, at all events, that Young v. Grote must be confined to checks, and does not apply to bills of exchange. The ease was one in which a drawer of a bill availed himself of spaces (which he harl purposely left) to raise the amount of an acceptance from $£ 500$ to $£ 3,500$ ), and the acceptor was held not to be liable to a holder in due course. The drawer of a eheck is

1 See the discussions in Swan $\mathrm{v}$. N. B. Co. (1859), 7 C. B. N. S. $400: 30$ L. J. C. P. 113; (1862) 7 H. \& N. 703 ; 31 L. J. Ex. 42J; 2 H. \& C. 175; 32 L. J. Ex. 2\%3: Société v. Metropolitan (1873), 27 L. T. N. S. 849; Halifix v. Wheelwright (18\%5), L. R. 10 Ex. 1\$3; 44 L. J. Ex. 121: Baxendale v. Bennett (18;8), 3 Q. B. D. 5:33; 47 L. J. Q. B. 6:4; Mayor r. Bank of England (1887), 21 Q. B. D. 163: 57 L. J. Q. B. 418; Scholfield v. Londesborough (1894), 2 Q. B. 660; 63 L. J. Q. B. 649; (1895) 1 Q. B. 536; 64 L. J. Q. B. 293; (1896) A. C. 514; 65 L. J. Q. B. 59:; Greenfield v. Stowell (187i). 123 Mass. 196; Worrall v. Gheen (1861), 39 Pa. St. $3 s 8$.

2In Baxendale v. Bennett (Isis), 3 Q. B. D. 5:3:3: 47 L. J. Q. B. 6:4, Brett, L. J., said that "the observations made by the Lords in Bank of Ireland v. Evans have shaken Young v. Grote." but this is a mistake, as was pointed out by Charles, J., in Scholfield $r$. Londesborough (1894), : Q. 13. 663; 63 L. J. Q. 13. 619: "Upon reference, however, to the opinion of the judges in that case declared by
Parke, B., and adopted by th, IIonce of Lords, it will, I think, be found that Young v. Grote was not in any way disapproved, and it has been recornized in many subsequent casses." In fact, Lord Crauworth said: "Therefore, taking that view of the facts, the case may be well sustained, and appears to have been well deciled." It was expressly followed in Halifax v. Wheelwright (18\%ij), L. R. 10 Ex. 183; 44 L. J. Ex. 121. And in Milyor v. Bank of England (185i), :1 Q. 13. 1). $16: 3$; 5 2 L. J. Q. B. 418 , Day, J., said that he thought it "was most properly deciled." See also the reference in Vagliano v. Bank of England, 22 Q. B. D. 103; 58 L. J. Q. B. 27; 23 Q. B. D. 243; 58 L. J. Q. B. 35\%; (1891) A. C. $10 \tau ; 60$ L. J. Q. B. 145.

3 See Scholtield v. Londesborough (1894), 2 Q. B. 660; 63 L. J. Q. B. 649 ; (1\$9.5) 1 Q. B. 5:36; 64 L. J. Q. 13. 29:3: (1\$96) A. C. 514; 6.i L. J. Q. B. $39 \%$ But see Dorwin r. Thompson (1869), 13) [. C. Jurist, 26?.

4 supra. Followed in Bank of 11 annilton v. Imperial Bank (1\$99), 31 Ont. 100. 
liable (according to Young v. Grote) if he leaves spaces which are fraudulently filled up; but the acceptor of a bill is not.

\section{Ioung v. Grote.}

Examining Young v. Grote (the check case) with a view of ascertaining the ground of decision, we have to admit that those who desire to suggest estoppel as its foundation are fairly met with the statement that estoppel is not once referred to either by counsel or judges; that the decision was in 1527 , while the doctrine of estoppel was not familiar to common-law courts until Pickard v. Sears ${ }^{1}$ in 1837; and that if estoppel had been the ground, it would, therefore, naturally bave so appeared. Upon the other hand, inasmuch as principles are never first thought out and afterwards applied, but arise experimentally and empirically, it is quite possible that the decision in Young $v$. Grote may be referable to doctrines which were but subsequently formulated - to the principle of estoppel by assisted mislepresentation, which is even yet largely undereloped. And this view would account for the absence of the word "estoppel" in the case. ${ }^{2}$

Every judge in Young v. Giote refers to the drawer's negligence as being the cause of the loss. But how can negligence be material? In this way: The check was not that of the customer; it was a forgery; the banker ought not to have paid a forged check; therefore he ought to lose. But although the check was forged, yet if the customer was estopped from so saying, the result will be otherwise. And he ought to have been estopped. The check was represented to be the genuine order of the customer, and the customer having through negligence assisted the misrepresentation (provided an opportunity

\section{Ad. \& E. 469.}

2 That estoppel is the true ratio decidendi is affimed by Lord Cranworth in Bank of Ireland v. Evans (185i), 5 H. L. C. 413; and Erle, C. J., in Re Swan (1859), 7 C. B. N. S. 432 ; 30 L. J. C. P. 113; distinctly denied by Cockburn, C. J., in Swan v. N. B. A. (18(i:3), 2 H. \& C. 189; 32 L. J. Ex. 279 (but put upon a ground quite consistent with estoppel. See cliap. ter XIV); and doubted and debated hy many other judges. See per Keating and Williams, JJ., in Re Swan, 7 C. B. N. S. 441,$446 ; 30$ L. J. C. P. 117, 121; per Cleasby, B., in Halifax v. Wheelwright (1875), L. R. 10 Ex. 192; 44 L. J. Ex. 136; per Lopes, J., in Scholfield v. Londesborough (189.̃), 1 Q. B. 546; 64 L. J. Q. B. 303; per Coleridge, C. J., in Arnold v. Cheque Bank (18i5), 1 C. P. D. 586; 45 L. J. C. P. 565 . 
for it) ought to be estopped. All the judges (as has been said) refer to negligence, and two of them particularize it as follows:

Best, C. J.: "Tho much omportumity was thus given to the clerk to effect the alteration of the check."

Burroughs, J.: "She satw the check in question filled up in an musual manner, both as to the fignres and in the boly; and she gave it in that state to her husband's clerk to get changed, thus affording him an opportunity to effect the fraud."

It is useless, however, to say that "too much opportunity" for fraud was given unless there is some duty not to give "too much opportunity." I And we may, therefore, say that neglect of duty, by atfording opportunity for fraud, was the ground of the decision. If so, it is but the work of translation to couch the same idea in the langnage of estoppel: The clerk represented the check to be grenuine; the banker, upon the faith of that representation, changed his position (paid the money); the misrepresenter and those who assisted him are estopped from denying the truth of the representation; the drawer haviug given "too much opportunity . . . to the clerk to effect the alteration of the check" assisted the fraud; and he is, therefore, estopped.

If we are wrong in so saying we may at least quote the testimony of Baron Parke, who was one of the judges engagred in the case, and who afterwards sitting in the House of Lords said: ${ }^{2}$

"It was held to have been the fault of the drawer of the check that he misled the banker . . . by want of proper caution in the mode of drawing the check, which almitted of easy interpolation, and consequently that the drawer, having thus caused the banker to pay a forged check, hy his own neglect in the mode of drawing the check itself, conld not complain of the payment."

Preclusion from assertion of rights is estoppel.

\section{Scilolfield Y. Londesiorotgir.}

The reasons which, in Scholfield $v$. Londesborough, led to a contrary conclusion in the case of an acceptance may be summarized as follows:

(1) Foung v. Grote was the case of a check, not of a bill.

1 The last. English case on the sub. ject declares that Young v. Grote cannot be supported upon the ground of negiigence. Union Credit Bunk v. Mersey Docks (1899), 2 Q. B. 20.; ; 68 L. J. Q. B. 842. The court, however, distinguishes between estoppel by negligence and estoppel by misrepresentation, not observing that negligence can be a factor in estoppel only where there is representittion. See ch. IX.

2 Bank of Ireland r. Erans (1S55), 5 II. L. C. 389. 
(2) Bills are drawn not by an aceeptor but by the drawer. The aceeptor is, therefore, not responsible for the form of the bill; and it "might lead to many complications" were duty as to its form to be placed upon him.

(3) "Protection against forgery is not the vigilance of parties . . . but the law of the lancl." The general spirit of the law is opposed to individual responsibility for the crimes of others-egoism is the rule, not altruism.

(t) It is impossible to posit a duty not " to facilitate fraud."

(5) The cause of the mishap was not the carelessness of the acceptor but the forgery of the drawer.

The first and second of these reasons would almost certainly not have been thought by themselves to have been sufficient for the decision. The first is rather a ground for distinguishing Young v. Grote than for supporting the case in hand; and the seeond bas, palpably, not sufficient strength to overcome the effect of a contrary view upon the remaining points. They may therefore be passed with a few words. The fifth ground will be discussed in a subsequent chapter.'

\section{Distinction Between Checks and Bills.}

Distinguishing between a eleck and a bill ${ }^{2}$ Lord Watson said: ${ }^{3}$

"The duty of the customer arises directly out of the contractual relation existing at the time between him and the banker, who is his mandatoiy. There is no such connection between the drawer or acceptor, and possible future indorsees, of a bill of exchange."

And Lord Shand said: ${ }^{4}$

"The case of Young v. Grote, between a banker and his customer, was one in which there was the relation of parties contracting with each other."

In other words, the eontract between a banker and his customer may imply a promise on the part of the latter to use reasonable care not to give opportunity for fraudulent manipulation of his checks; whereas there is no contraet (and eannot very well be) between an acceptor and a future indorsee to the effect that he has already taken such preeaution.

I Ch. IX.

2 "A check is a bill of exchange drawn on a banker, payable on demand." The Bills of Exchange Act, 45 and 46 Vic. (Imp.), ch. 61, \$73; 53 Vic. (Can.), ch. $33, \S 72$.
${ }^{3}$ Scholfield v. Londesborough (1896), A. C. 537 ; 6.5 L. J. Q. B. 604.

${ }^{4}$ (1896) A. C. 548; 6.5 L. J. Q. B. 609. And see also Lord Macraghten (1896), A. C. $545 ; 65$ L. J. Q. B. 60 S. 
But if estoppel by assisted misrepresentation be the true ratio decidendi of the cheek case, all questions of contract are irrelevant. If an owner of property stand by and see it sold to an. other he is estopped, not because of any contract between him and the true purchaser, but because,

"When I saw the mistake into which he had fallen it was my duty to speak." 1 true."."

The question, then, is whether there can be any duty, apart from contract, not to afford "too much opportunity" to commit a fraud. If there is, it is immaterial that there was no contract. The point then is included in the large question of existence of duty.

\section{Acceptor Not Responsibieg for Form of Bill.}

Upon the sccond point Lord Watson saill: ${ }^{3}$

"In many, if not most, cases which occur in the course of business, the bill is witlen ont hy the drawer and sent hy him to the acceptor who is under an obligation to sign it. Assmming the appellant's argument to be well founded, it would be within the right of the aeceptor to return the bill unsioned. if it were not drawn so as to exclule all reasonable possibil. ities of frand or forgery. The exercise of that right might lead to very great complications in commercial transactions."

Lord Shand said: :

"An acceptor scrutinizing a bill might think it left room for a fraudulent addition and might refuse acceptance, to the serious injury of the Irawer restding at a distance or abroad, or of a drawer who might bare indorsel the bill for value given before acceptince."

With deference, it may be replied that the obligation of a drawee cannot include that of accepting an improperly drawn bill. ${ }^{5}$ But waiving that point, all that has to be insistel upon is that an acceptor, when he sees invitation to fraud in the form of spaces upon the face of the bill, should draw a pen. mark through them. He need not return the bill, or decline acceptance; he can, withont altering the bill, remerly its defect.

It will be observed, too, that the point in hand would raise a distinetion between a bill and a note with regard to liability in case of alteration; for if the acceptor of a bill be not responsible for its form, at all erents the maker of a note cannot

1 Ramsden v. Dyson (1S66), I. R. 1 II. L. 140.

eswan v. N. B. A. (1S62), т H. \& N. 657; 31 L. J. Ex. 4:5.

${ }^{3}$ Scholfield v. Londesborough, Venner (1s!2), 15 N. Y. Sup. 379.

4 (1896) A. C. 549 ; 65 I. J. Q. B. 6:0. And see also per Lord Macnaghten, (1896) A. C. $516 ; 6$; L. J. Q. B. 60\%.

5 American Water Works Co. v. (1896) A. C. $59 \pi ; 65$ L. J. Q. B. 604. 
shelter himself in that way. It may probably be assmmed that the argument in hand would not be a sufficient or satisfactory ground for upholding sueb a distinction. And it may well be asked, too, whether there is a difference between a bill written by the acceptor himself and one prepared by the drawer?

\section{No Duty to Guard Againt Crime.}

This may be said to be the principal ground of decision in the Scholfield $v$. Londesborough case. Lord Halsbury said: ${ }^{1}$

"I certainly concur with . . . the wide proposition of Borll, C. J., . . that people are not supposed to commit forgery, and that the protection against forgery is not the vigilance of parties excluding the possibility of committing forgery but the law of the land."

Lord Watson said: ${ }^{2}$

"It is not consistent with the general spirit of the law to hold innocent persons responsible for not taking measures to prevent the commission of a crime which they may have no reason to anticipate."

And Lord Macnaghten said: ${ }^{3}$

"The prevention of crime is, perhaps, better left to the operation of the criminal law."

These dicta are quite in line with some previous judicial utterances. For example Brett, J., said: ${ }^{4}$

"There is no duty on any one to suppose that those against whose char. acter there is no imputation will commit forgery. To say that there is such a duty is to enunciate a startling proposition which cannot be maintained."

Fry, T. J., said: ${ }^{5}$

"I do not know of any general rule which obliges you to assume that every person with whom you are dealing is likely to be a knave."

And Pramwell, L. J., said: ${ }^{6}$

"Is it not a rule that every one has a right to suppose that a crime will not be committed and to act on that belief?" The intervention of a crime "undoubtedly is a distinction and a real distinction."

Some dissenting opinions in Scholfield $v$. Londesborough are as follows:

Per Charles, J.: ${ }^{7}$

"It appears clear from these cases that a person who signs a negotiable instrument with the intention that it shinl be delivered to a series of

1(1896) A. C. 532; 65 L. J. Q. B. L. J. Q. B. 842; Goodman v. East601. And see Seollans v. Rollins man (1828). 4 N. H. 45); Worrall v. (1899), 5;3 N. E. R. 863 (Mass.).

$\because(1891 j)$ A. C. 5337 ; 6.j L. J. Q. B. v. Miller (1893), 137 N. Y. 332; 33 N. 6u4.

${ }^{3}(1850)$ A. C. $544 ; 6.5$ L. J. Q. B. $60 \%$.

4 Société v. Metropolitan (18\%8), 27 L. T. N. S. 858. And see Union v. Mersey Docks (1849), 2 Q. B. 20i); 68

E. R. $3 \pi 4$.

5 Union Baluk v. Kent (1888), $39 \mathrm{Ch}$. D. $248 ; 57$ L. J. Ch. $102 \%$

${ }^{6}$ Bixendale v. Bennet (1578), 3 Q.

B. D. 5:30; 47 L. J. Q. I3. 626 .

7 (1894) 2 Q. B. 661 ; 6;3 L. J. Q. B. 
holders rons incrul a duty to those who tiake the hill, note or check not to be rumlty of negrigence with reference to the form of the instrument."

Per Lopes, I. .J.: ${ }^{1}$

"It would be passing strange if a proson who accepts a nerotialble instrument. such als a bill of t'xchlinge. and whothus permuts it togoforthon

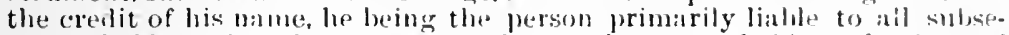
quent holders, should not owe to those subsequent holders the dutg of

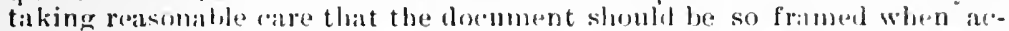
cepted as not to offer obvious oppontminties lor the commission of crme."

And in support of these upinions strong previous authority may be quoted:

Per Blackburn, J.: ${ }^{2}$

"The person putting in circulation a hill of exchange does. be the law merchant. owe a claty to all parties to the hill to take reasonable precialution agrainst the possibility of fraudulent alterations in it."

I'er Bovill, C. J.: ${ }^{3}$

"Parties cannot prevent forgery being committed; they must use reasonible care not to afford opportunity for it."

Per Cockburn, C. J.: ${ }^{4}$

"The mercantile community are as a body honorable mell; but experi. ence, unfortumitely. tells us that frauls occissionally happen when they might least he expected. In the majority of instances this occurs, as in tinis cise. frum the carelessmess of those concerned and the omission to tilke the precationary measures which the regular course of business would prescribe."

Per Dar, J.: ${ }^{5}$

"Now it has been said there can be no negligence attributable to the corporitors of this holy, beenuse it is not to be assumed that any min will commit the grave olfense of a vailing himself of opportmnities which are placed in his way - that no ma." ought to be assumed to yield to a temptation with which he is surrounded. That sort of reasoning does not commend itself to me, nor to my experience of thy world; nor, I should think, to the common sense of men in general."

Per Wills, J.: ${ }^{6}$

"A person whose negligent act has directly contributed to the forgers must, as between himself and the person who has taken the forged instrument, and acted uyon it to his own detriment as a genuine one, bear the loss."

6.i. See also Putnam v. Sullivan (1980), 4 Mass. 45; State v. Matthews (1890), 44 Kan. 596: 25) Patc. R. 36; Atchison v. Brissfiell (1893), il Kian. 167; 32 Pac. 12. 814. The Code Nilpoleon has the following: "158?. Tout fait quelconque de l'homme yui cause a autrui un dommage, oblige celui, par la faute cluapul il est arrivé a le reparer. 1988: Chacun est responsable du dommage qu'il a cilusé, non seulement par soll fait, mais encore par sa negligence, ou pir son imprudence."
I (1895) 1 Q. B. 546; 64 I. J. Q. B. 302.

-Swan r. North British (1963), 2 H. \& C. 183; 32 L. J. Ex. 27\%.

${ }^{3}$ Socjété v. Metropolitin (1873), 27 L. T. N. S. 858 .

4 Johnson v. Credit Lyonnais Co. (18\%7), 33 C. P. D. 41 ; 47 L. J. C. P. 241.

5 Jerehants v. Inink of Englind (185i), 21 Q. B. D. $162 ; 5 i$ L. J. Q. B. $4: 0$.

6I1. 167, 422. 


\section{Per Pennsrlinania crinet: ${ }^{1}$}

"It is the duty of the makor of the note to guard not only limself hut the public against framl and aiteration, by refusiner to sign negotiable paper male in surh form as to ar?mit of fradulent practice upon them with ease and without realy detertion."

Crime and Any Other Trend.- The first step towards correct appreciation of the point in controversy is to ascertain whether it is correct to say that there is no difference

"between a fraud carricd out by means of a forgery (by means of a crime) and any other fraul "'-

to ascertain whether it can be sail (with Baron Bramwell)

"that every one has a right to suppose that a crime will not be committed, and to act on that beliel;" 3

and at the same time admit that like security cannot be indulged with reference to frauds which hove not been dechared to be eriminal.

In the first place it is quite clear that no one deems it prudent "to act on the belief that a crime will not be committed" when the risk is his own. Houses are lockerl at night purely becanse one's right to trust everybody and to act upon that trust would probably induce theft. Portable valuables are carefully guarled for the same reason; and the notion is general that money is sifest in a tightly-buttoned pocket.

Every one protects himself by appropriate measures of prudence against crimes as well as against frauds. Can there be any distinction between them with reference to our duty to our neighbors? The effect of an aflimative answer is that although every one must exereise "an appropriate measure of prudence" not to afford an opportunity for fraud at the expense of third persons, yet that no prudence at all is necessary where the fraud can only be accomplished through crime. In other worls, "while every one has a right to suppose that a crime will not be committed, and to act "pon that belief," no one has a right to assume that a fraud will not be committel, and to act upon that belief.

Were the distinction well founded there wonld be this somewhat curious result, that alterations in the criminal law would entail changes in the luty of carefulness as to the interests of others. As against certain lrauds we must take reasonable

1 Zinmerman v. Rote (1874), 75 Par. St. 191. And see Liruwn v. lieed (15i5), 79 Pal. St. :30.
2 Shaw v. Port Philip (1884), 13

Q. B. D. $109 ; 53$ L. J. Q. B. $3 \% 3$.

3 Ante, p. 48 . 
precintions in the interests of our neighbors; hut shouhl parliament attach penalties to such frands then we maly altugether cease to take care! We would escape not becallise we had not been negligent, and the cause of the mischief; aml not eren becanse another remedy is supplied; but because the definurber, if caught, must go to gaol.

Test Cuses. - Perhaps the best way to deal with this question is to put a few cases, observing whether the presence or absence of "an appropriate measure of prudence" ought to depend upon the presence or absence of crime.

Young $v$. Grote, as has already been said, ${ }^{1}$ is allowed to stan! as law if its doctrine be confined to checks. In other worts, the drawer of a check must not (at his own peril) leave tempting spaces in it which may be criminally male use of to increase its amount. But to so siy is to reverse the dictum that "ere?"y one has a right to suppose that a crime will not be committel, and to act on that belief."

$A$ clerk stole an acceptance inclosed in an en velope from the office letter-box of his employer, in which it had been placed for mailing; forged an indorsement, and passed the bill. 'Tho acceptor was not estopperl. ${ }^{2}$ Suppose that the acceptance before it was stolen hat been indorsed in blank, the result wonld have been otherwise. Ifere again the lictmm is falsitierl, and this time with reference to a bill of exchange. Colerilge, C. J., in the case just referred to silil:

"There could be no negligence in relying on the honesty of thir sers. ants in the dischange of their ordiniug duty, that of conveying letters to the post." 3

But as we have seen, had the acceptance been transferible without forgery, and the fraud accomplished by mere lincen!, the negligence would have been very a j) brent and the aceptor would have been liable. In such case "an appropriate measure of prudence" (namely, a special indorsment) would have been onitted; and the decision wonld have been reversed.

This case is a good eximple of the point in hand, and well

1. inte. p. 43.

2 Arnold v. The Cheque Bunk (18:(3), 1 C. P. D. 5TS, 45 L. J. C. P. $56 \%$ Am! see Coates v. London (15i9), 41 L. T. jisi.

3 Much the same remark was made ly Fry. I. J., in The Fine Art S winty $\therefore$ Union biank (1sis(i), 17 O. H.1), i:3. 56 1. J. Q. 13. 80 : and perhalp wih less justlication than in the cas! in the lext, for the forement was much nore readily trausferible. 
illustrates the dictum of the same learned juige in the same case:

- A man may be more careless with regard to the rustoly of a thing that can ke made a railable onl by men of a for tery tian if bi mere larcens."

Butobserre tbat the distinction here made is between crimes of different clasess and not between crime and fraud. Larceny is more common, more easily accomplished, than forgery; therefore the learned judge would argue) more care must be taken to guard against the one than against the other. There must be "an appropriate measure of prudence."

The rensonableness of this may at once bs seen if we note the difference betreen filling out a note but not signing it, on the one band, and signing a blank note but not filling it out, on the other. Yither document can be used without forgery. In the latter case, however, the maker may vers well be liable;" while in the former he cannot. The distinction here is not between crime and fraud, nor vet between crimes of different legree, bat proceeds upon the duty to "order lis precaution by the measure of what appeurs litely in the known course of things."

There are many other cases in which a man may suffer, if he act upon his "right to suppose that a crime will not be com. mitter." For example, believing in another's honcsty be may lend him a horse. and find that the animal has been sold in market orert; beliering in a broker's honesty be may intrust hirn with blank transfers of shares to be used only upon instructions, and find that the trust has been violated and the shares appropriater: kelieving in a sulicitor"s honesty he may execute a document which has an effect quite different from that represented to him, and nevertbeless he is bound by it in favor of a third person to whom it has been transferred; a company believing in its secretary"s bonesty may rive him authority to issue certificates of sharcsin I guarantee the genuineness of the signatures to the certiticats, and find that he has forged the necessary names and issued a certificate for his own benefit; ${ }^{3}$ in short, a man beliering in another's bonesty may permit the

1 For it is rot only forgery to sign a name to a dorinent. but aise to write a documentorer a name. R-:. 5. Wilson (1*19, 1\% L. J. M. C. Sa; Lyles on Bills (Ijth ed.), g:4), ff.
2 See ch. XIV.

3 Shaw v. Port Philip (1891), 13 Q.

B. D. $103 ; 53$ L. J. Q. B. 363. 


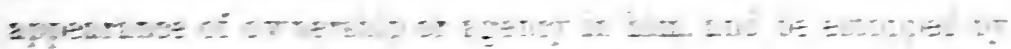
+10-3 

ב足:

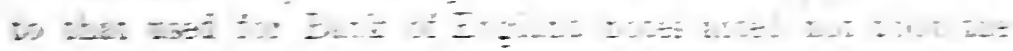

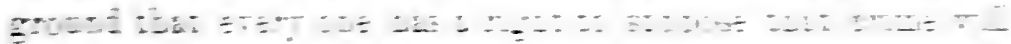

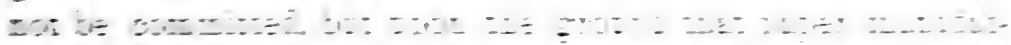
I: $\therefore$ 社

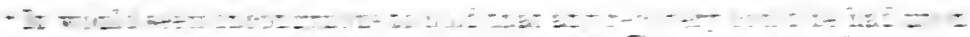

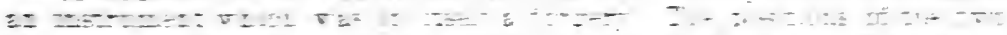
a

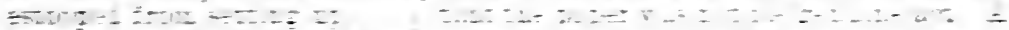
4.

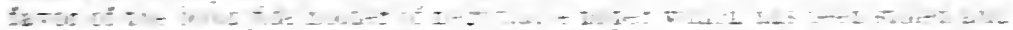

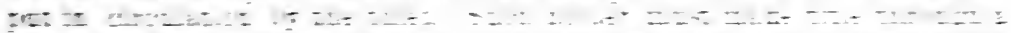
Hen

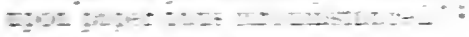

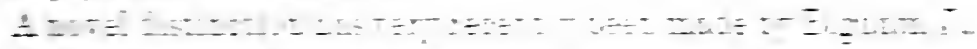

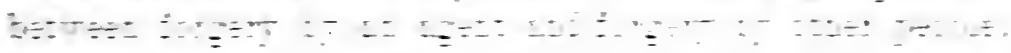

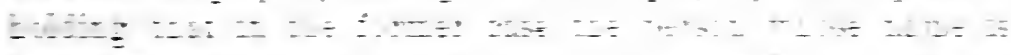

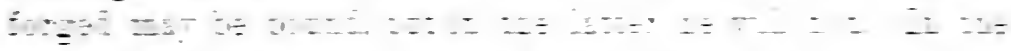

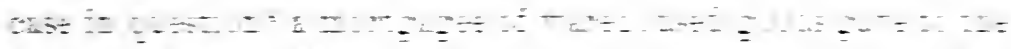

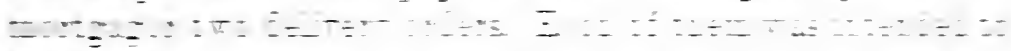

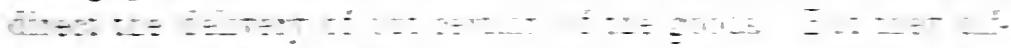

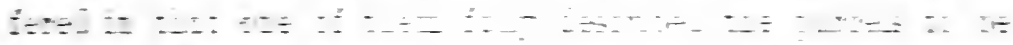

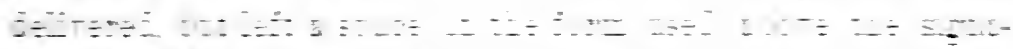

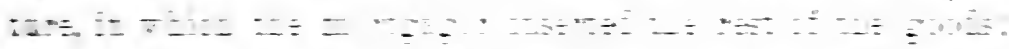
TEZ UES Z三

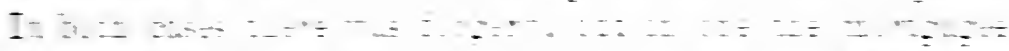

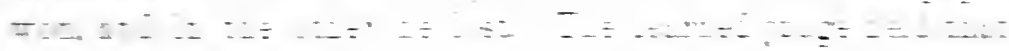

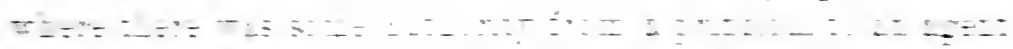

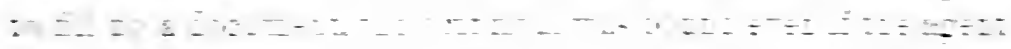
IIX

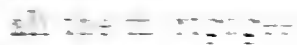

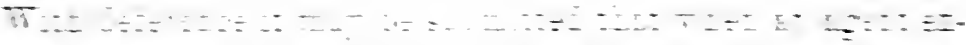

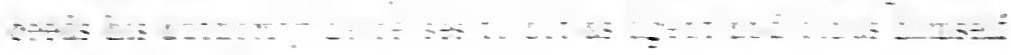

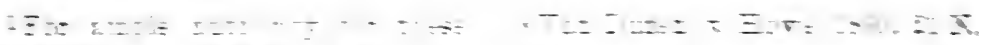

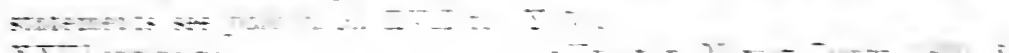
II.

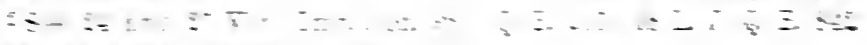

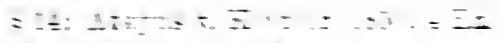

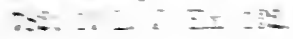


alone. Both cases are therefore the same in this, that the unanthorized act was the act of a stranger. They are also allike in this, that being unauthorized the mortgryes conld not possibly be bound by the act done in his name. The question therefore is simply whether, although the mortgagee is not bound, yet he is for some reason estopperl from so saying.

Now observe that ostensible agreney is out of the question in both cases, for there was no appearance of agency of any linut in either of them. When the orders were taken to the dock company they were complete, and appeared to hare been execnted in their perfected form. The company could not say that they relied upon the appearance of authority to fill up the bianks - they knew nothing of blanks, and nothing of agency.

The appearance to the dock company, in both cases, was that of ownership and not arency; anc? the only question therefore is whether the mortgargee can be said to have been responsible for such appearance - whether he exercised "an appropriate measure of prudence." This brings us sharply to the point: Has "every one a right to suppose that a crime will not be committed, and to act on that belief?" If so the decision with reference to both delivery orders ought to have been the samethat is, in favor of the mortgagee. And if such a right cannot be predicated in all cases, are we to distinguish upon the ground that the forger in one of them had power to do something other than what he did; and in the other had power to do nothing? Or are we not rather to say that forgery, when made easy and tempting, is not a wild improbability; that the rule of "an appropriate me:sure of prudence" requires that "a person whose negligent act has directly contributed to the forgery must bear the loss;" and that there was the same imprudence in the one case as in the other; for in both a space was left in which the description of the unreleased goods conld easily be filled in. If a vendor of land were to execute a conveyance in which a blank half-page followed the parcels, it wonld hardly be fair of him to attempt to throw upon an innocent purchaser of added property the burden of a loss mainly attributable to the opportunity he had afforded for frant.

Degrees of Probability. - There are decrrees of probability as to the commission of erime. Were I to leave money upon the desk of a publicly frequented ollice, I might safely say that it 
would be stolen within five minutes; Were notes or bomals so displayed, they might remain for half an homr; but a hat-rack would probably stand for live years in an adjoining lobby and not be carried away.

There are degrees of probilbility also among frauds known and unknown. But it cammot be sid that there is always more chance of a fraud than a erime. Some frauds for their accomplishment demand a boldness and an ingenuity that might well be thought to make them much less probable of attempt than larceny of money or bills within huing reach, or than forgery by the simple expentient of filling up a blank space.

It seens, then, to be imposible to say that there is any distinction between crimes and frands as classes, with regard to the rlegree of prublence which one must exercise to prevent injury to other people. The requisite of " an appropriate measmre of prudence" proviles for all distinctions between and among them, and has regarel to the avalability, portability and other characteristics of property as well as to all other circumstances of each particalar case. It exacts the conduct of a reasonable man guided "by a reasonable estimate of probabilities." I It is better to leave eacl case to be neasured by the standard of "an appropriate measure of prulence" than to endeavor a priori to establish some order of requisite circumspection.

The Firumls or Crimes of Amother.- The only question, then, seems to be whether there is iacumbent upon ur, in business alfairs, any diuty of care lor the interests of others? And the answer to this cannot be doubted. Sot only in the varions departments of the law aldeady indicated is this duty exacted under the penalty of estuppel, hut it may be said that the whole law of estoppel hy assisted mispepresentation is founded npon it, and that nine-tenths of the cases dealt with in this work alre u!supportable withont it.

Above Tieces Surported.- Some support for the views here alrocated may be fouml even in the julgments moler eriticisin. For example, Loml IIalsbury, in relerring to the check case (Iollugy. Grote), saill: :

"If, to use Lord Cranworth's phraseologry the contumer hy any are of

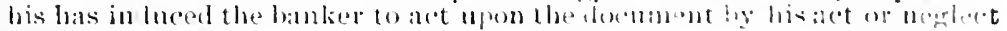
of some act usual in the course of cealoug betwent litem, at is quate intel.

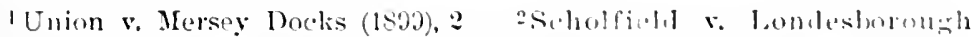
Q. B. :20i; 6s L. J. Q. B. s12.

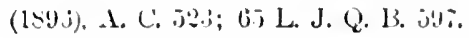


ligible that he knonld not be nermitted to set "p his own act or neg'ect to the prejulice of the banker whom he has misled or by neglect permitted to be misted."

And may it not be said that if an acceptor "by any act of his has induced" a transferee in dne caurse "to act upon the locument by his act or neglect of some act usual in the course of dealing between" merchants, "it is quite intelligible that he should not be permitted to set up his own act or neglect to the prejulice of the" trunsferee, "whom he has thus misled or by neglect permitted to be misled?" The principle is the same. In both eases a party to a negotiable instrument is guilty of the neglect of "some act usual in the course of lealing" (whether "between them" as indiriduals or as members of the public is immaterial); ${ }^{2}$ in both that neglect has been taken advantage of by another person who "has indueed the banker (or transferee) to act upon the document;" in both, therefore, there ought to be estoppel.

Further support may also be obtained from the law with reference to blanks wilfully left in a negotiable instrument, as distingnished from spaces carelessly left there. In the chapter on "Execution of Documents" ${ }^{3}$ it is shown that if an acceptance be intrusted to another, with authority to fill it up for $\$ 100$, and he fraudulently insert $£ 500$, and the bill come to the bands of a transferee in due course in complete form, the ground of the acceptor's liability is estoppel. The estoppel results from the representation malle by the negotiator to the transferee that the bill was the real, completed oblightion of the acceptor, and the acceptor is estopped by such misrepresentation (although not his) because he assisted it, provided an opportunity for it, did that which was necessary to make it credible.

The acceptor's liability in such a case is undisputed; and the only possibility of distinction between it and the case uncler discussion is that in the one (when blanks left) opportunity for fraul was wilfully given, whereas in the other (when spaces left) it was carelessly supplied. In both there was crime; in both opportunity was given for the crime; in both "the cause of the mishap was" (or was not, as one may choose to say)

It inay safely he affirmed that negotiable instruments are not w*u:lily dainu as was the one in question.

2 See ch. $X$.

${ }^{3} \mathrm{Ch} . \mathrm{XXV}$. 
the forgery, and not the blanks or spaces; in both there ought ${ }^{1}$ or ought not to be estopjel.

An acceptor may then be liable although a forgery has intervened; and the only question is: Should be be liable if he have, with careless indifference to the interests of others, supplied "too much opportunity" for the fraul - if he latve not used "reasonable care not to afford opportunity for it." Learing in mind the general principle of social life, that every one "is required to use due diligrence to aroid eausing harm to others," it is submitted that the answer onglit to be in the atlimative.

IV. Impossmitity of a Rule Nóp to Facilitate Fined.

Lord Justice Rigby, as to the possibility of framing a rule as to facilities for fram said: ${ }^{2}$

"I pass from the question of necrligence to consiner the futy that is set up. The duty as formulated is one not, in acoppling the bill, to facililate fromd. This is a diticult proposition to deal with. What is a duty not to fircilitate framl? If such a duty exists it must, of necessity, be linitel to a duty not to fiacilitate a particular lind of fraud. To illust rate my meaning. l may point out that ally one who acerepts a bill payable to order dos. in one seruse, an act which ficilitates framd: for any one into whose hallels the hill may get can commit a forgery an reirard to indorsements. There is no great difficulty in so doing. and I do not see. if the duty as formulated 'xists to its full extent, why it should not apply to the ciase I have sug. gested."

And Lord Halsbury added: ${ }^{3}$

"I caunot myself understand why the particular form of fraud adopted in this case sliould have any different opreration in giving validity to a fordere instrument, rather thin oblier forms of fraud to which instruments are sulject."

A good rule may easily be spoiled by stating it ton broally. It is a good rule that a driver of horses must use reasonable cire to aroid killing people. But changring it to a declaration that no one shall enclanger life wouki be to invite the eriticisms that that would be "a diflicult proposition to leal with," and that, if any one drove a horse at all, he did, "in one sense, an act which" endangered life. And in much the same way a rule that an acepor of a newotiable instrument must "take reasonible care that the ducument shombl ise so framed . . . as wot to offer olveions oppontunities for the commission of crime" will moloubtedly become much more vulnerable if expressed as "a dhty not to filcilitate firmbl." Such a furm of it

IVin Duzen v. Ilowe (1S60), 21 2Scholfield v. Londesborough N. Y. $5 \ddot{1} 1$. 
almost forces the remark that, if so, no one must accept a bill at all; an observation which is quite inapplicable to the rule as more carefully framed.

Beeause the law does not prohibit the use of the streets, or the making and circulation of negotiable instruments, it does not necessarily follow that it must altogether refrain from propounling regulations for the conduet of persons using or malsing them. It is true, no doubt, that

"It is impossible to curly on the common affairs of life without doing varions things which are more or less likely to cause loss or inconvenience to others, or even which obviously tend that way; and this in such a manner that thoir tendency cannot be remedied by any means short of not actiug at all." l

But although true, it is not a very convineing argument against the raliclity of a declaration that

"The liaw of negligence enforces the duty of fellow-citizens to observe in varyong circumstancesan applopriate measure of prmber to avoid causing harm to another."

Nor is it a satisfactory reply to the remark of Lopes, L. J., in an earlier stage of the Scholficld $v$. Londesborough case: ${ }^{3}$

"It would be passing strange if a person who ace pts a negotiable instrument, such as a bill of exchange. and who thus permirs it to go forth on the credit of his name, he being the person primarily liable to all suluseguent holders, should not owe to those sulsequent hoviders the duty of taking reasonable care that the document should be so framed when aceepted as not to ofler obvious opportunities for the commission of a crime."

As to highways, the rule is that

"For the convenience of mankind in carrying on the affairs of life, people as they go along roarls must expect or jut mp with such mischief as reasonable care on the purt of others cannot aroicl." 4

And in the ways of commerce may it not be said with Bovill, C. J., in a case of the chass in hand: ${ }^{5}$

"Parties cannot provent forery being committed; they must use reasonable care not to ajom olportanities for it."

A grain in the law of torts the rule is undoubted that

"A man who ordels a work to be executed, from which in the natmil conts of thome injurious consequences to his neighlor must be expected to arise. mmins means are adopted by which such consquences may be preventel, is lwaml to see to the doing of that which is necessiry to prevent the muchief." 6

And was not Cockburn, C. J., undoubtedly right when he said :

"The morcantile community are as a holly honorable men; but experience unfortunately tells us that frauds occasionally hapen when they

1 Pollock on Torts (5th ed.), i41.

2 I1], 22.

$3(1895) 1$ Q. B. 546 ; 61 L. J. Q. B. $29 \%$

4 Per Bramwell, B., in Holures v.
Mather (18\%i)), L. R. 10 Ex. 267; 44

L. J. Ex. 170.

5 Société v. Metropolitan (1S73). 27

L. T. N. S. S5.

${ }^{6}$ Per Cocklsurn, C. J., in Fower r. 
might lenst be expected. In the majority of instances this oceura. as in

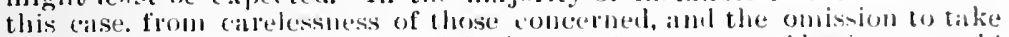
the precantionary measures which the regular course of business would priscribe." I

There is, surely, no more difliculty in applying this rule of reasonable care to the form of negotiable instruments than to the execution of them, ${ }^{2}$ or to the multitudinous incidents of every-day physical life.

Test Cases. - 'lhose who support the view that

"every one has a rimht to suppose that a crime will not be committed, and to act on that belief," 3

require some comrage to maintain it under all circumstances. For example, smppose that to a bill for 55,000 written in ink. some material comdition is alded as a foot-note in light lead pencil; the acceptor is struck with the facility offered to fiatud, but nevertheless accepts; and the drawer at once rubs ont tho foot-note and passes the bill. Or suppose that the condition is written in ink, but upon a wide matrin which may be readily ent off without aflording the slightest appeatrance of alteration.

Such cases are of frequent occmrence in the United States. Unfortunately, howerer, there is much disagreement as to the law, and jurlgges amd text-writers can be cited upon both sides of the question. Mr. Bigelow alirims that

"It miy be sifely staterl that in prineiple. and by the weight of anthority, al inaterial ialleration. . . in a note. hill or chece, lelivered as a complete intrument. by writing or printing work in a blank spatce destroys the justrument, so that no action can be maintained arainst the maker or brawer or other non-consenting parties, even by a bonce fide hohler for vithere"

"Iarrinal terms which are intended to be part of the written contract are treated by the better anthorities as insepalrable from the main writing to which the signature is given. . . Acerrlingly to remove sach terms by cutting llem off, or in any other way, without consent. will be fatal." 5

Mr. Daniel, on the other hand (more reasonably, as the present writer thinks), declares the law in this way:

"There is a general princjple which pervales the universil law merchant respertiner alterations (which when they are malterial will, as we have seen. vitiate the bill or note exen in the hamdis of a boma fide holder withont notice); a minciple necessiry to the proteretion of the innocent and prubent from the neerligrare and fratut of others. That is, that when the: drawer of the bill or makes of the note hats himself, hy careless exechtion of the instrument. left loom for any alterition to he matle, either hy

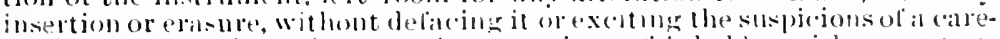
ful man, he will bs liable upon it to any bona fide hohder withoul notice,

Peate (18;6), 1 Q. B. D. 3:30: 4.) I. J. Q. 13. 446. See Ifughes r. Percivil (15s:3). 8 Apl. Cas $41: 3 ; 52$ L. J. Q. 13. 719; Black v. Christoluurcls (1s)t). A. C. 48 ; 33 L. J. P. C. 32 .
1 Ante. p. 49.

2 As to which see cl. XXIV.

atuete. 1. ts.

4 On IBills and Notes, 19?.

5 I i. 194. 
when the opportunity which he has afforded has been embraced, and the instrument filled np with a larger amount or different terms than those whic:l it bore at the time he simned it."

"The true principle applicalne to such cases is that the party who puts the paper in circulation invites the public to receive it of any one having it in possession with apparent title, and he is esfopped to urge an actual defect in that which throurh his act ostensibly has none."

"It is the duty of the maker of the note to guilud not only himself but the public against frauds and alterations, by refusing to sign negotiable pilper made in such a form as to admit of fraudulent practices upon them with ease and without ready detection."

- The inspection of the paper itself furnishes the only criterion by which a stranger to whon it is oflered cin test its character. and when the inspection revals nothing to aronse the suspiriuns of a prudent man he "ill not be permitted to suffer when the re has been an actual alteration."

Some cases no doubt may be very close to the line which sepruates the prudent from the imprudent act. For example, leaving a very small space alter the word "eight," which is marle use of to insert the letter " $y$," may to some appear in one light, and to some in another." Such border cases, however, embarrassing as they may be, are never thought in other branches of the law to vitiate the rule which requires "an ap)propriate measure of prudence to avoicl causing harm to one another." Nor do such dilliculties render impossible the assertion of a duty "to take reasonable care that a document should be so framed . . . as not to ofier obvious opportunities for the commission of crime," 3 or of a duty to keep your signature under your own control.

lin favor of Mr. Pirrelow's view are: Swaisland v. Daviılson (1882), 3 Ont. 320; Holmes v. Trumper (15i1), 2.) Viclı. 4:27; Benedict v. Cowder $\left(180^{\circ}\right), 49$ N. Y. 396 ; Greenfield v. Stowell (1877), 123 Mass. 196; Knoxville Bank v. Clark (1879), 51 Iowa, 209,1 N. IV. R. 491 ; Forlyce v. Kosminsli (1887), 49 Ark. 40, :3 S. W. R. 85); Columbia v. Cornell (1888), 1:30 U. S. (6.j); Burrows v. Klınk (1889), 7) Alu. 4is1, 17 Atl. R. 378: Simmons ․ Atkinson (1892), 69 Miss. $86 \% 12 \mathrm{~S}$. R. 263; Exchange Bank v. Bank (1593), 7 C. C. A. 111, 58 Fed. R. 140; Searles v. Seipp (1895), 6.S. D. 472; 61 N. W. R. 804; Walsh v. Hunt (1898), 1:0 Cal. 46. 52 Pace R. 115. Upon the other hand Mi: Danicl's iangruage: "It is the duty of the maker of the note to guard not only him. self but the public against frand and alterations, by refusing to sign negotiable paper made in such a form as to admit of fraudulent practices upon them with ease and without ready detection," is to be found in Goodman v. Eastman (18:2), $4 \mathrm{~N}$. H. 455; Isnard v. Torres (185.5), $10 \mathrm{La}$. Ann. 10:3: Yocum v, Smith (1872), 63 111. 321: Zimmerman v. Rote (1874), 75 Pil. St. 190: Brown v. Reed (18i5), 79 Pa. St. :3i0; Blaliy v. Johnson (187\%), 13 Bush, 197 (Ky.); Leas v. Walls (188:3), 101 Pa. St. i); Scotland v. O'Connell (1886), 23 Mo. App. 165; Lowden v. National Bank (1888), 38 Kan. 53:3, 16 Pac. R. 748; Weidman r. Sirmes (1899), 79 N. W. R. 894.

2 Societé v, Mctropolitan (1873). 27 L. T. N. S. 8.74; Leas v. Walls (1882), 101 Pa. St. 57.

3 Ante, p. 49. 
Summary-Summarizing the result of the argument relat. ing to Scholfichl v. Londestrorongh we may say:

1. "There is no difference," with rreference to estoppel, "between a fraul carried out by means of a crime and any other fraud."

2. Admittedly there is a chity to guard against fraud.

3. There are derrees of probability of fraud, and sometimes more likelihool of its perpetration by crime than by acts which are not criminal.

4. And the rules for all snch cases ought to be the requirement of "au appropriate measure of prudence to avoid eausing harm to one another."

5. "When one person is by circumstances placed in such position with regard to anothel that every one of ordinaty sense who did think would at once recornize that if he did not use orlinary cale and skith in his own conduct with regard to those circumstances he would canse dinger of in. jury to the person or property of the other, a duty arises to use ordinary care and skill to a roid such dinger." 1

6. If an acceptor "by any act of his has induced" a transferee in due course "to act upon the document, by his act or neglect of some act usual in the course of dealing between" merchicats, "it is quite intelligible that he should not be permitted to set up his own act or nerglect to the prejuclice of the transferee whom he has thus misled, or by neglect permitted to be misled."

7. There is a duty to "take reasonable care that a doeument should be so framed . . . as not to offer obvious opportunities for the commission of crime."

\section{Custody of Negotiable Ixsmumexts.?}

Is there any duty of circumspection as to the custody of signed but unissued negrotiable instruments, or of signed slips of paper which may realily be converted into documents of that character? Much reason will be found in another chapter ${ }^{3}$ for an affirmative reply. A few considerations at this place will be useful.

If a land-owner create a magnificent fish pond which erent. ually bursts its bounds and devistates neighboring territory, he will be liable if he have failed to exereise that measure of prudence which "a discreet and cautious per'son would or ought

1 Ante. p. 42.

2 Until chapter XXIV we must, in deference to current phraseolog:, continue to use the word "negoti. able."

3 Ch. XXIV. 
to use if the whole risk and loss were to be inis own." 1 And mily it not very well be said with reference to a signed bill left in a drawer or npon a dosk that the signer has brought into existence an article of dangerous and elusive character, easily jicked up, and readily made the instrument of injury to others; and that if damage ensues it is not sulficient for him to urge that, usually, people are honest; eren as in the dam cases he would not eseape because, usually, there were no fioods. Would he leave signed notes lying about "if the whole risk were his own?" In that case probably he would tear up the notes and write others when he wanted to use them The principles underlying the following excerpts from the law of torts ought to be applied to negotiable instruments:

"If I am guilty of negligence in leaving anything dangerous in a place where I know it to be extremely probable that some other person will unjustifiably set it in motion to the injury of a third, and if that injury should be brought about, I presume that the sufferer minht have redress by action against hoth, or either of the two, but unquestionably against the first." 2

"The risk incilent to dealing with fire, fire-arms, explosives, or highly inflammable matters, corrosive or ctherwise dangerous or noxious fluids, and (it is apprehended) poisons, is accounted by the common law among those which subject the actor to strict responsibility. Sometimes the tem "consummate care' is used to describe the amount of caution requiled; but it is doubtful whether even this be strong enough." 3

"The risk inciclent to dealing with" negrotiable instruments would seem to require the same standard of "consummate care," and ought not to be shoullered off upon those who innocently suffer because such care is dispegarded.

Distinction may well be made, in the lam case, between water accumulated for merely ornamental purposes and water in a mili dam; and a bigher degree of care may be exacted in

1 Per Chanceller Walworth in New Tork $r$. Bailey (1815), 2 Denio, 433. And see Rylands v. Fletcher (1869), L. R. :3 II. L. 311; 37 L. J. Ex. 161; Laphaun v. Curtis (1893), 5 Vt. 371; Shrewsbury v. Smith (18.;:3), 66 Miss. 17\%; Hoffman v. Tuolumne Co. (18.78), 10 Cal. 41:; Todil v. Cochell (1890), 17 Cal. 97; Everett v. Hydraulic (1863), 2:) Cal. 225; Gray r. Harris (18శ1), 10\% Mass. 492; Losee v. Buchanan (1573), 51 N. Y. 476; Garland v. Tuwne (18ri), 5.j N. H. 5i); Marshall v. Welwood (18r6), 38 N. J. L. 339 ; Gorhain v. Gross (1878), $12 \mathrm{~J}$ Mass. 2:32.
2 Per Lord Denm'n in Lynch $\nabla$. Nurdin (1841), 1 Q. B. :5.); 19 L. J. Q. B. 73. See Lygo v. Newbold (1854), 9 Ex. 302; :9 L. J. Ex. 108; Great Northern v. IHarrison (18.54), $10 \mathrm{Ex}$. 376; 23 L.J. Ex. 308; Caswell v. Worth (1856), 5 E. \& B. 819; 25 L. J. Q. 13. 121; Mangan v. Atterton (181:6). L. R. 1 Ex. 239; ;ij L. J. Ex. 161: Austin v. Great Western (186ĩ), L. R. : Q. B. 442; 36 L. J. Q. B. 201; Citiz.ns v. Lepitre (1898, 29 S. C. Can. 1; Makins v. Piggott (1 98 ). 29 5. C. Can. 188. 3 Pullock on Torts (5th ed.), 470. 
the former instance than in the latter. This woull be quite in aceord with the distinction between useful fires, snch as for domestic ${ }^{\prime}$ or mechanical or farming purposes ${ }^{2}$ on the one hand, and mere bonfires on the other. For the same reason if it be lield that a man is not always liable upon a note signed by him but stolen from him, distinction might at least be made between cases in which the signer had no immediate purpose to serve in retaining the note uncancelled, or in which he took little precaution with reference to its enstody on the one hand, and, on the other, cases in which during an occupied moment he allowed a doemment which he was about to use to escape his personal vigilance.

\section{Custody of Seal of Company.}

Closely associated with the subject just considered are questions relating to the duty of circumspection in the enstody of corporation seals. If it be permissible to leave signed but unissued notes within easy reach of persons whose principles may be overeome by enticing temptation, so also, no donbt, may a company be careless and indifierent as to the custorly of its seal, and may require persons who have given hard money in exchange for that which appeared to be a properly executed document to look to the crimimal law for their satisfaction.

And sucb seems, unfortunately, to be the law. It was justified in the House of Lords by Baron Parke in this way: ${ }^{3}$.

"Now we all concur in opinion that the evidence given, which was only of a supposed neghigent custoly of their torporition seal by the trustees, feaving it in the hands of Mr. Grace, whereby he was enabled to commit the forgeries, is not suficient evidence of that species of negligence which alone would warrant a jury in tinding that the plaint itfs were disentitled to insist on the trinsfer being vold. We concinr. . . in thinking that the nerlect which would deprive the plinintilf of his right to insist that the transfor was iuvalid must be neglect in or immediutely connected with the transfer itself. . . . If there was nuglect in the custoly of the seall it was very remotely connected with the act of transfer. The transfer was not the necessiary or ordinaly or likely result of that neglec't."

. Would it he contended that if he lirpt his goods so negligently that a

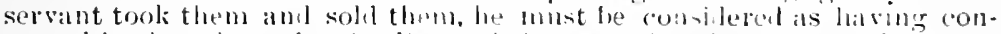
curred in the sile, and so be disentuted to sue for then conversion on a demand and refusal."

.. . . It such neglect coull disontitle the plinintiffs, to what extent is it to go? If a min lose his check-book, or nexplect to lock the desk in

ISee 14 Geo. 3 (Imp). ch. 7f. \$86. Owens v. Burress, id. 7.; Dean v.

2 See Thomats on Ne.prligence, 640 $\pi$; Booth v. Motratt (1896), $11 M_{i 11}, 2 i ;$ HeCorty (is. in, U U. C. Q. B. 4 is.

${ }^{3}$ Banti of Iritud Evans (18j5), j H. L. C. iss!. 
which it is kept, and a serrant or stmonger shoubl take it up, it is impossible, in our cpmion, to contend that a banker paying his forged check would be entitled to charge has customer with that payment."

The question, "To what extent is it to gro?" has been frequently re-echoed in later cases; ${ }^{1}$ but the answer is not difficult, and is to be found in the phrase "an appropriate measure of pruience." Such a principle supplies also a really reply to the learned Baron's other questions: (1) It would not be contended that an owner of goods would be estopped were they stolen by a servant and sold, for possession of the goods by the servant in no way misleads the purchaser. The master, therefore, has in no way accredited the title of the servant; he has in no way assisted the servant's misrepresentation of ownership; he has not omitted to observe an appropriate measure of prudence. ${ }^{2}$ Nor (2) would the owner of a check-book be estopped were it stolen and his signature forged. Ownership of a check-book cannot be silid to be the disregard of "an appropriate measure of prudence." Vary this last ease a little: suppose that the check-book owner signed a lot of checks in blank and left them so as "to offer obvious opportunity" for their theft, and that they were stolen and cashed by the banker; should not the signer be estopped from denying the making of the checks? There would be crime in both cases.

The case was followed with some misgiving in Mayor, etc. $v$. Bants of Englend, ${ }^{3}$ Willis, J., saying:

"But for that case I should hat ve thought that the mode of keeping the seal wats eminent!y calculated to facilitate if not to invite the commission of forgery."

But the law is as stated by Baron Parke. The present writer trusts, however, that the method of avoiding it adopted in Shew v. P'ort I'litip (although unavailing in a subsequent case ${ }^{5}$ ) may end in its overthrow. In that case the company was held bound by its seal, although frauchlently alfixed by the secretary, because the secretary had been "held out by the company as their agent to warrant the genuineness of the certificilte."

1 Development of the law has freguently been impeded by such a question. A good example of the argument is to be found in the julgment of Grose, J., in Pasley v. lreeman (1789), 3 T. R. 52 .

${ }^{2}$ See ch. XXL.
${ }^{3}(1887) 21$ Q. B. D. $160 ; 57$ L. J. Q. B. 418.

4 (1881) 13 Q. B. D. 103; 53 L. J. Q. B. 369 .

5 Milyor v. Bank of England (1887), 21 Q. B. D. $160 ; 57$ L. J. Q. B. 418. 
It is worth noting, too, that the Bank of Treland $v$. Evans case does not expressly deny the existence of laty with reference to the custorly of a company's seal. It proceeds upon the ground that any negligence in the custody was not sufficiently closely associated with the application which was made of it; which is another point, and is elsewhere dealt with.

In the mean while it is worth notieing that trusting your secretary with the key of your safe is sulliciently connected with his theft of your debentures as to cut out your title to them as agrainst a purchaser from the thief" - upon the ground of "negotiability," it is said; but we shall see. ${ }^{3}$

\section{Rember Stamps.}

The introlnction of rubber stamps as a methor of facilitating signature of documents has added a new terror to commercial life, if the dictum of Baron Parke is to be applied to them also. In olden days when seals were used instead of signatures, there was obligation of carefulness as to their custody imposed upon the owners of them. ${ }^{4}$ Is it now the law that a man may leave his stamp wherever he pleases, and plead to instruments to which it may be applied (1) that "every one has a right to suppose that a clime will not be committed, and to act on that belief;" (2) that, "if there was neglect in the custody of the seal (stamp), it was very remotely connected with the act;" and (3) that the neglect "must be in, or immediately connected with, the transfer (instrument) itself?" A Pennsylvania gentlemin has already escaped liability upon a check to which his stamp had been fraudulently applied, because "it is lawful to have a stamp," and because the fraudulent affixing of it to a eheck is not "the natural and probable result" of any negligence in its custody. ${ }^{5}$

\section{Misceilaneous Cases in Wincit No Estopipto}

Throughout this volume, in their appropriate places, will be found numerous cases in which the existence of a duty of carefulness or disclosure has been aflirmed. There are a few de-

1 See ch. IX.

- Bechuanaland v. London (1899), 2 Q. B. 6.5; 67 L. J. Q. B. 986.

${ }^{3}$ Ch. XXIV.

t See Mityor v. Bank of England
(1S8r), 21 Q. B. D. 166. 16r; 5\% L. J. Q.

B. 41 s; Pollock on Contratets (Gith ed.), P. 135. And see post, ch. XXIV.

${ }^{5}$ Robb v. Pennsylvania (1S9S), 156 Pit. St. $456 ; 40$ Atl. R. 969. 
tached authorities in which the existence of luty has been denied that may be conveniently collected here. The attempts in them to impose obligation to action are instructive as showing the length to which it has been thought possible to carry the doctrine of an appropriate measure of prudence.

(1551) Mangles v. Dixm." A ship owner assigned "tho amount due" upon a charter-party to a third person; the assignee gave nctice of the assignment to the charterer, who did not voluntecr the information that the charter-party was somewhat misleading, and that "the amount due" was in reality not as much as that shown by the document. No estoppel; for the charterer was not bound to assume that the assignee was unaware of the true situation. There was no duty to volunteer information to one who probably already had it.

(1S57) Simpson v. Accidental, etc. ${ }^{2}$ After the death of an insured person, the insurance company refrained from informing the executors that a premium was overdue, and that nonpayment for a few more days would vitiate the policy. Held, that there was no duty upon the part of the company to proffor the information.

(1871) Smith v. IIughes. ${ }^{3}$ Defendant agreed to buy some new oats believing that they were old oats. He bought by sample, and the seller said nothing to mislead the purchaser. Meld, that

"The passive acquiescence of the seller in the self-dereption of the buyer did not entitle the litter to avoid the contract." "Whatever may be the case in a court of morals, there is no legal obligation on the vendor to in. form the purchaser that he is under a mistike, not induced by the act of the vendor."

(1876) Polak v. Everett. ${ }^{4}$ A surety stood by while the creditor, by dealing with the debtor, released him. No duty to warn the creditor:

"To say thit a person who, heing a surety. becomes aware that the creilitor is going to give time or do something else which if done witlout his assent may discharge him, is bound to warn the creditor against doing it, is a thing for which no authority whatever has been cited."

(1Ss6) Clark v. Eckiroyd. ${ }^{5}$ Vendors shipped the goods sold, but the purchasers never received them owing to their being

13 HI. L. C. 702. And see reference to this case in ch. XI.

22 C. B. N. S. $257 ; 26$ L. J. C. P. 289.

3(1871) L. R. 6 Q. B. 597: 40 L. J. Q. B. 221. And see Potts v. Temperance (1892), 23 Ont. 73. See, however, ch. VI.
${ }^{4}$ (1876) 1 Q. B. D. 669 ; 45 L. J. Q. B. 365 .

512 Ont. App. 425. And see Durrant v. Ecclesiastical, etc. (1880), 6 Q. B. D. 23.; 50 L. J. Q. B. 30; Conf deration v. Merchants (1894), 10 Min. 69. 
misdirected. Purchasers, however, believing that they had been reecived paid for them. In reality they had been sold by the carriers for unpaid charges. It was contended by the vendor that the purchaser had by payment represented that the goorls hatd been received, and that thus tho vendors had been lulled into security and deprived of an opportunity of recovering the goods. Ileld, that the purchasers were not estopped from denying receipt of the goods:

"That it was not discovered sooner may have been negligence, but it was negligence in rolation to something which would have been prudent in respect to the plaintills themselves, but not of any duty they owed to the defendants."

\section{Sumara.}

Summing up what has been said it appears that -

1. The duty of " an appropriate measure of prudence to avoid causing harm to other's" ought to be enforeed as well by estoppel as by an action in tort.

2. Such duty has already in various departments of the law been admitted as a governing principle of decision.

3. But in many of them other reasons have been given, and these are now current and beliered to be satisfactory.

4. The existence of the duty has been altogether denied in cases in which the criminal law penalizes the resulting "har'm to others." "The prevention of crime is, perhaps, better left to the operation of the criminal law."

5. But there can be no difference in this respect "between a fraud carricl out by means of a forgery (a crime) and any other fraud."

6. And there are numerous cases in which the intervention of neither frand nor crime has been allowed to save the negligent party from the burden of the loss which his disregard of duty has brought about.

7. While it is impossible to formulate a rule "not to facilitate frand," there is no difliculty in the application of a rule requiring the exercise of "an appropriate measure of prodence."

S. A large number of well-decided eases can be supported only by the acceptance, expresserl or implied, of such a rule.

9. Withont such a rule in the realm of torts, social life would be impossible. Without it as the working principle in the law of estoppel, financial and commereial affairs wouk be much impeded and distracted. 


\section{CHAP'TER VI.}

\section{CONDITION NO. 4}

\section{The Misrepresentation Must be as to Fact or Law, Not as to Intention or Opinion.}

Fact and Intextion.

\section{Lord Selborno in Mruddison v. Alderson ${ }^{1}$ said:}

"The doctrine of estoppel by representation is applicable only to representations as to some state of facts alleged to be at the time actually in existence, and not to promises de futuro, which if binding at all must be binding as contricts."

Jorden v. Money ${ }^{2}$ is the leading authority:

"When a person possesses a legal rimht, a court of equity will not interfere to restrain him from enforcing it, though between the time of its ereation and that of his attempt to enforce it he has made representations of his intention to abanlon it. Nor will equity interfere even thongh the parties to whom these representations were made have acted on them, and lave in full belief in them entered into irrevocable engagements. To raise an equity in such a case there must be a misrepresentation of existing facts, and not of mere intention."

In that case Lord Cranworth said:

"I think that that doctrine (the doctrine of estoppel) does not apply to a case where the representation is not a representation of fact, but a statement of something which the party intends or does not intend to do. In the former case it is a contract, in the latter it is not."

Intention Mray Involve Fact.- A representation as to intention may, however, under certain circumstanees be a representation of fact. For example, in Edgington. v. Fitzmaurice a prospectus statel that "the objects of the present issue are" to make certain purchases and alterations; whereas the real in-

1 (1853) 8 App. Cits. 473; 52 L. J. Q. B. 73i. And see Prole v. Sondy (18.99), 2 Giff. 1; Piggott v. Stratton (18.59), 1 1)e G., F. \& J. 33; 29 L. J. Ch. 8; Orr v. Orr (1874), 21 Gr. 397; Mercliants' Bank v. Lucas (1888), 15 Ont. App. 586; 18 S. C. Can. 705; Liangrdon v. Doud (1965), 92 Mass. 4:3:; White v. Ashton (1873), 51 N. Y. 380.

${ }^{2}$ (1851) 5 H. L. Cas. 185; 33 L. J.
Ch. 865; approved in Citizens v. First Nat. Bank (1873), L. R. 6 H. L. 35?; 43 L. J. Ch. 269, and Chadwick v. Manning (1896), A. C. 231 ; (6j L. J. P. C. 42. See Keating v. Orme (1874), $77 \mathrm{~Pa}$. St. 89; Jackson v. Allen (1876), 120 Mass. 61. ${ }^{3}(1885) 29$ Ch. D. $459 ; 55$ L. J. Ch. (550; Old Colony v. Dubuque (1898), 89 Fed. R. 794. 
tention was to pay off liabilities. In an action of deceit, Cotton, L. J., siild:

"It was alnued that this was only the statement of an intention. and that the mere fact that an intention was mot carried into corret could not malie the defendants liable to the plaintilf. I agree that it was a state. mont of intention. but it is nceretheless a statement of fact; and if it could not be fairly said that the ohjects of the issue of the debentures were those which were stated in the prospectus, the defendants wore stating a fact which was not true: nul if they knew that it was not true, or inade it recklrssly not caring whether it was true or not, they would be liable."

Bowen, L. J., in another case ${ }^{1}$ said: tion."

"The state of a man's mind is as much a fact as the state of his diges-

Under other circumstances also an expression of intention may involve a representation of fact. For example, if a note be shown to me by one who, to my linowledge, eontemplates purehasing it, and I say that "I intend to pay it at maturity," I onglit to be estopped as against my interlocutor from denying my signature to the note; ${ }^{2}$ for the expression of intention to pay in rolved a representation that the note was a real obligation.

Intention as Ground of Estoppel.- There are some cases in which it is said that a representiation as to intention not amounting to a representation of fact will estop from afterwards chang. ing the intention. For example, in one ease ${ }^{3}$ it is said:

"The rule we believe is that a fromise to formive a debt or to forbear its collection, either temporialy or for an indetinite period, unsupported by any consideration, thomgh jutefectuil as a defense viewed merely as an arreement, yet. if the surety has heen induced by such an assurance to neglect any of the means wibich might have been used for his indemnity, the promise may have that efiect as an estoplel which it wants as a contract. and amount to a defense agilust any subsequent action brought by the creditor:"

But the answer to this is apparent. If the surety has been: induced by such an assurance "to ehange his position for the worse," then there is a consileration and a contract; for consideration includes "any detriment sustained by the plaintiff," if it be "suffered by the plaintiff with the consent, express or" implied, of the defendint." On the other hand, if there is no contract, it is impossible to say that the surety has been in-

1 Elgington v. Fitzmaurice (1855), 29 Ch. D. 483 ; 55 L. J. Cir. 6.50.

2 Preston v. Mann. 25 Comn. 118. See Krothwolll v. Dilwson (1 141$), 140$ Inıl. 1; 38 N. E. R. $46 \pi$; Austin v. bahn (1894), si Tex. 5s?; 27 S. W. R. 101\%: Perry v. Lawless (1849), $\bar{j}$ U. C.

Q. B. 51 s
3 White v. Walker (180:3), 31 Ill. 422.

+ Per Tindal, C. J.. Listhoarp r. Bryint (15;6), 3 Sc. 2.50 ; 5 L. J. C. P. 21\%. And see Gerhard r. Bates (1853), 2 E. \& 13. 45; 22 L. J. Q. B. 369; Moss v. IIIIll (1S,j)), 5 Ex. 49 ; 19 L. J. Ex. 205. 
duced to change his position, for he knew perfectly well that the creditor was not bound by the assurance and was at liberty to change his mind at any time. Stephen, J., in Alderson v. Marldison, ${ }^{1}$ said:

"The difference between the classes of misrepresentation which do and do not bincl seems to me plain. To say, 'I have cancelled this hond, "'hen you have not, is to tell an untruth. 'To say, 'I intend to cancel this bond,' is to make a statement as to a present morable intention. If a person chooses to act on such a representation withont having it reduced to the form of a binding contract, he knows, or ought to know, that he takes his chance of the promisor changing his mind."

An assurance which may be withdrawn the next or any sncceeding minute cannot be alleged as a ground for change of action. If it be urged that the creditor may have observed that the surety was reframing from enforcing his remedies, the reply is that the case (if thus altered) may hare become one of con tract - one in which there is a consideration because of the detriment sustained "with the consent, express or implied, of the defendant."

In another case ${ }^{2}$ it is said:

"If one having a richt to redeem real estate under mortgage assures a pronosed purchaser of the fee that he will not redeem, and this assurance is given for the purpose of inducing such purchaser to buy, and he is thereby induced to buy, the owner of the right will be estopped afterward to enforce it against the purchaser or his assignees."

But this is not estoppel at all, but contract pure and simple. "In consideration of your assurance that you would not redeem I became the purchaser." If there be no contract, the language cannot form the ground of estoppel, for it was known to be an expression of intention merely and so not binding - known to be nothing. It could not therefore be put forward as a reason for a change of position; and a change of position upon the faith of another's assertion is necessary to estoppel. ${ }^{3}$

Distinction must be made between the representation, "I

${ }^{1}$ (1880) 5 Ex. D. 303; 49 L. J. Ex. St. 17; 2 Atl. R. 425; College v. Tut801.

tle (1887), 71 Iowa, 596; 33 N. W. R.

${ }^{2}$ Southard v. Sulton (1878), $68 \mathrm{Me}$. 74; Moore v. Trimmer (1890), 35 S. C. 5ij. There are many other cases. 606; 11 S. E. R. 548; Shroeder v. Some of them almost avowedly pro- Young (1896), 161 U. S. 334; 16 S. C. ceed upon contract, and are not quite open to the criticism of the text. Others directly support the doctrine under consideration. See Harris v. Brooks (1838), 38 Mass. 195; White v. Walker (1863), 31 Ill. 422; Reimensnyder v. Gans (1885), $110 \mathrm{~Pa}$. R. 512; Ricketts v. Scothorn (1898), 57 Neb. 5; 77 N. W. R. 365; Gilbert v. Richardson (1898), 51 S. W. R. 134 (Tenn.). Some of these are clear cases of contract.

3 See ch. XI. 
have no interest in the land," and "I have an interest, but do not intend to assert it." In the former there is estoppel because there is misrepresentation; but in the latter there maly be no misrepresentation, for the truth ma be in accordance with the assertion. "I do not intend to assert it" may mean one of two things: (1) "In my present frame of mind and at the present time I have no intention to enforce my clain;" or (2) "I promise you that I will not enforce my claim." If the former language were used no one would sugrgest estoppel; and if the latter every one would recorgnize contract. Each case will be found to be either in one catergory or the other.'

There are several cases in which an assurance bas been given by the owner of property that he will make certilu disposition of it, if another person will reside with him.2 'The point as to consideration is clearly stated in one of them: ${ }^{3}$

"But there may be other kinds of consideration, and if the conduct of one person induce's another to alter his or her conduct that will malie a binding contract: and if the plisintiff, at an are when she was capable of gaining her livelihood eilher by going into lomestic service or into business, was induced by saral coles, who was rich enomery to conler the benefit, to altrer her conduct by the gift of a house in which she should live for the whole of her life with a view to gaining her livelihood by let ting out lodgings, the very circmustince of her having induced the plaintiff to alter her conduct and refrain trom going into business, in which she might have done well and got friends to assist her and realizad independence, would be enough to milse the agrement binding. And al though the donor received no actual consideration. the case is one to which the cited parssage by Sir John Stuart, in holfus v. Maw. 3 Gilf. 6ar; :32 L. J. Ex. 19, from Lord Cottenhan's julgment in Hammersley v. De Riel, 12 Cl. \& F. 62, 11, is applieable. A representation made by one party for the purpose of influencing the condurt of the other party. and acted on hy him. will in girlseral be sutficient to entitle him to the assistince of this $(0)$ mot for the purpose of realizing surly representation. 'lhis then is a case in which the

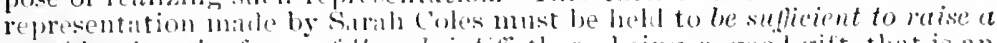

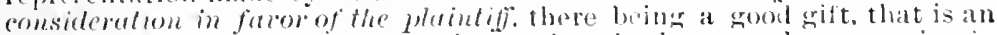
intention on the part of satrih coles to give the house and a possession in accordance with that intention." "

Were we to get away from the solid gromnd that a representation to be binding must be either as to present fact, or else amount to a contriet, it would be difficult to formulate any

1 See Pollock on Contriats (lith ed.), $50 \%$.

"Loffus v, M:L (186?), 3 Gilf, i)?: 32 L. J. Cl. 49; Coles v. Pilkingron (15\%.1), L. R. $19 \mathrm{Eq} .174 ; 4 \mathrm{~L}$. J. Ch. 381; Alterson v. Maddison (1sst)), 5 Ex. D. 29:3; $8 \Lambda$ ג). Cis. 46i; 52 1. J. Q. B. i37; Sulth v, Sulth (1896), $: 9$ Ont. :809.
${ }^{3}$ Coles r. Pilkingrtom. ante.

As.e also Brarewell v. Williams

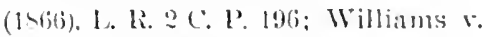
stern (18:9). is Q. i3. 1). $109: 49$ L. J. Q. 13. 6933. Xute that the change of comblact must le referable to the promise. Alderson vamblicon (18-1).

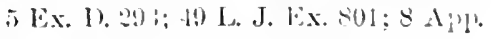
Cits. 46ii; 5:2. J. Q. 13. 33 . 
principle of action. For example, if a surety may rely upon a creditors expressed intention not to sue the debtor, although there is no contrict to that eifect, why may not a policy-holder rely upon the insurance company's expressed intention to notify him of the due-date of the premiums, althongh there is no contract to that effect? Ought the company to be estopped from saying that any preminms ever fell due if its intention is not earried out, and for year's no premiums are paid? ${ }^{1}$

\section{Fact and Opinton.}

All that need be said as to the distinction between fact and opinion is to be found in a judgment of Garbert, J.: ${ }^{2}$

"The general rule is that a representation cannot form the basis of an action for falsity unless it relates to a matter of fict as distinguished from opinion. The difficulty arises in making the distinction. The true rule appears to be that a fraululent misrepresentation cannot itself be the mere expression of an opinion entertained by the party making it; but where such party malies a statement which might otherwise be only an opinion, and does not state it is the mere expression of his opinion, but aftirms it as a fact material to the transaction to which it relates, so that the person to whom it is addressed may reasonably treat it as a fact, and rely and act upon it accordingly, then such statement becomes an affirmation of a fatet. within the meaning of the general rule, and may be a frablulent misrepresentation. ("2 Pom. Eq. Jur., 2d ell.s \$ 8.9.) If the representations are of such a character that they will hear either the construction that they were expressions of opinion or statements of fact, the question which they were must be decided by the jury (.3 Suth. Dinm., 2al el.. $\$ 116$; Tearue v. Irwin, 12\% Mass. 217: Sterne v. Shaw, 1:4 Mass. 59): lut in order to justify a finding that they were representations of fact. they must be statements susceptible of linowledge, as distinguished from opinion. (3 Sulh. Dam., supre; Sterne v. Shaw, supra; Nounnan v. Land Co., 8 Cal. 1; 2:2 Pac. R. 515: Williams v. McFadden, 23 Fla. 147; 1 S. R. 6is; Parker v. Milonlton, 114 Mass. 99.)"

\section{FaCT and Law.}

Two reasons have been put forward in support of the assertion that no relief can be grounded upon misrepresentation of law: (1) that everybody is assumed to know the law, and therefore there can be no effective misrepresentation of it; and (2) that nobody should depend or act upon what another person asserts to be the law, for it is a matter of opiuion only.

1 See Insurance Co. v. Mowry (18\%7), nf U. S. 5:4. Something in such cases inay be said in faror of waiver of punctuil payment as a ground of forleiture. Chicago r. Werner (1875), 80 III. 410; Insurance Co.v. Eggleston (18ii), 90 U. S. 572; Lyon v. Travel. lers (1834), 55 Mich. 141; $\approx 0$ N. IV. R. $8: 9$.

2 American Nat. Banl r. Hammond (1S9S), 55 I'ic. R. 1090 (Ćolo.). Ama see Akin v. Kellogg (1890), 119 N. Y. 412. Incillentally the subject is recurred to in a later part of the present chapter. 
I. Law Whall Known.- Perhaps no presumption that was ever proposed is in more flagrant opposition to indubitable fact than that propounded by Lord Ellenborough in the oftquoted case of Billie $v$. Lumley: 1

"Every man must be talien to be cognizant of the law; otherwise there is no silying to what extent the excuse of innorance might not be carried." and together with all false assumptions, it must be got well rid of before the law can be said to be scientilically alramgrel.

The fiction is supposed to be specially requisite in the lepartment of crimes. No doubt when a felum urges that he was ignorant of the law, we must have something wherewith to answer him. But we need not tell him that tise jurlye is so absurd as to presume to be true that which both of them know tu be false. It is quite sufficient and much more reasonable to remind him that he is a member of society, and that he must inform himself of the rules prescribed for sucial conduct or take the consequences.

In the department of eivil law, although Lord Ellenborougrl's assumption is constantly repeated, ${ }^{2}$ yet the books are full of its modification and contradiction; and the eases are numerons in which the plain fact that this man did not know the lilw has been allowed to assert itself. If it were to be taken to be absolutely true, then of course there could be no effective misrepresentation as to a matter of law, for the person addressed would always know that the statement made to him was false:

"A misrepresentation of a mitter of law does not constitute a fraul, because the law is presumed to be equally within the linowledge of all partit's." 3

"Now every man is supposed to know the legal effect of an instrument which he signs: and therefore this must he taken to be a representiation as to a fact uithin the knouldge of the creditor: and such mistepresentation will not hat the effect of aroiling lhis instrument, because it was not calculated to mislead the creditor."

1 180?) 2 Eilst. 4\%2.

2 Pullen v. Reitly (1749), 2 Atk. 5.1: Lewis r. Jones (18:. T) 4 B. \& C. 512: Midland Ry. r. Johuson (1854). 6 H. I, C. 811: Rashliall r. Furd (186ii), L. R. 2 Eip. i.) : 3.5 L. J. Ch. 76!); Powell 8 Smith (18:2). I. R. It Eq. 91: +1 L. J. Cl. 734; Pollock on Contracts. 40.); Kerr on Fram (2l e(1.). is: Chand on Consent. !0. 91; Grint r. Heliee (1S96), 11 M.un. 145;
Keyes r. Merrill (1896). 92 Wis. 3?; 65 N. W. R. \%

${ }^{3}$ Powell v. Smith (18.2), L. R. 14 Eq. 91: 41 L. J. Ch. 28.5. And see Camp-

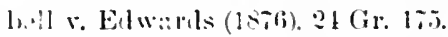

4 tewis $v$ Jomes (150.), 4 B. \& C. 5010 : 3 L. J. K. B. O. S. :7. And see per Lord Che?msford in Milland $r$. Johnson (1sis, 6 H. L. C. s11: and per (iwyme. J., in Laing v. Tay̆lü (15i6), :(i U. C. C. P. 4:99: Cole v. Pupe (1s9s), :9 S. C. Can. :91. 
But surely this is trifling with the truth, and treating as incontrovertible that which is frequently said in satire or jest. The law may be open to disparaging remark because of its proverbial uncertainty, but it is worse than unfortunate if our only reply is that the charge is untrue-unless indeed we do verily believe that every body is so perfectly familiar with every point which can possibly arise that it is inconceivable that, even under pressure of weightiest assertion, any one can ever mako a mistake about it.

Consider too whether it would not be more reasonablo to hold that every man must be taken to be cognizant of the facts with reference to which he is dealing than that "every man must be taken to be cognizant of the law." And yet that is never an answer to a man who complains that the facts have been misrepresented to him; nor is he told that he could with "ordinary vigilance and attention" have tested the matter for himself. 1

II. Law a Matter of Opinion.-This becomes apparent when we turn to the other reason for denying relief in cases of misrepresentation of law, namely, that law is a matter of opinion only, and that therefore no one ought to depend or act upon another person's representation of it. In other words (and with much greater truth than in the former case), the law is very uncertain; if anybody makes an assertion as to it, he may be right or he may be wrong; he is merely giving you his opinion; and you must not act upon that - you should go and inquile as best you can.

"A representation of what the law will or will not pernit to be done is one on which the party to whom it is marle has no right to rely; and if he does so it is his folly, and he cannot ask the law to relieve him from the consequences. The truth or falsehood of sucli a representation can be consequences. The trinary vigiance and attention. It is an opinion in regard to the law, and is always understood as such." 2

If a representation of law was always accompanied, expressly or impliedly, by the remark that it was given as a matter of opinion only, much could be said for this view; but the authorities supply us with many cases in which precisely the opposite remark is made or implied - cases in which, by purposely and strenuously misstating the law, a fraud is accomplished.

1 Bloomenthal v. Ford (1897), A. C. 159: 66 L. J. Ch. 253; David v. Park (15\%0), 10:3 Mass, 501. Anl see ch. XI, sub-tit. "Means of knowledge."
2 Fish v. Clelland (1864), 33 Ill. 243. And see Starr v. Bennett (1845), :3 IIill (N. Y.), :393: Upton v. Tribileock (13\%), 91 U.S. 45. 
One can easily understand that if a question arises upon the construction of a document as to the right of a woman to dower, and she should say that she was not entitled to it, her remark would not justify action by those hearing her.' And yet if a company should represent that its debentures were legally transferable,

"there would be an equity on the part of any person who had agreed for value to take a transfer of these debentures, to restrain the company from pleading their invalidity."'?

Law and Fuct.-There is this difficulty, if we are to have one rule as to misrepresentations of law and another as to misrepresentations of fact, that we shall have to come to some clear understanding as to the difference between them. For example, in one House of Lords case it was said that " the construction of a contract is clearly a matter of law ;" ${ }^{3}$ in a second it was thought that "private right of ownership is a matter of fact," even if you have to argue it from the construction of documents; for although it is a matter of fact "it may be the result also of matter of law;" "while in a third relicf was given because of mistake as to the meaning of a document, Lord Chelmsford declaring that "a matter of law arising upon the doubtful construction of a grant" is "very different from the ignorance of a well-known principle of law." 5

And what must be thought of a representation by a company that its shares are unassessable? Is that a statement of law, or of fact as the result of a matter of law? If the company had represented that there was a clause in its charter rendering the shares unassessable, is that a matter of fact? And will it become one of law if there is some provision there but of doubtful interpretation. ${ }^{6}$ Again, if directors should represent that their company has power to issue debentures, is

1 Fairweather v. Archbald (1868), 15 Gr. 255. And see Bigelow on Es. toppel (5ih ed.), 5 i3.

2 Per Kay, L. J., in Re Romford (1883). 24 Ch. D. 93; 52 L. J. Ch. 228 . And see ch. XXIV, sul-tit. "Negotiability by estoppel." eiting Goodwin s. Roberts, and other casses.

3 Midland s. Johnson (18.i8), 6 H. L. C. 811. And see Powell s. Smitl (1572), L. R. 14 Eł. $85 ; 41$ L. J. Ch. i3t.

+Cooper r. Phibbs (186i), L. R. 2 II. L. 170. See to same cifect, Jones v. Clifford (1876), 3 Ch. D. 792; $45 \mathrm{~L}$. J. Ch. 809. See also Barber $r$, Clark (1890), 20 Ont. 52:; 18 Ont. App. 435; Baldwin v. Kingstone (1890), 18 Ont. App. 10s; King v. Doolittle (15.js). 1 Heal (Tenu.). 86: Chand. on Consent, 104; Pomeroy, Eq. Jur. 11 it.

5 Beauchamp v. Winn (1853), L. R. 6 II. L. :34.

${ }^{6}$ In Upton r. Tribilcock (18.5), 91 U. S. 45, it was helil that a representation that shares are unassessable is a representation of liw. 
that a representation as to law or fact? Possibly either or both. For it is said that if the reason why the company had not such power was that sulficient stock (a pre-requisite of debentures) had not been subscribed, the representation was one of law; but if the right to issue had accrued and, "having exhausted that power, the direetors had stated that they still had power to issue debentures," the representation would have been one of fact. ${ }^{1}$ And what is to be said of a representation that a patent is ralicl when the point is whether it is for a "new and useful" inrention;" or a representation that a man is a shareholder in a company $;^{3}$ or a representation that a writ has been "returned in due form of law; ${ }^{4}$ or a representation that A. is the wife of B.? Perhaps this is the best that can be said :

"There is not a single fact eomneted with personal status that does not more or less involve a question of law. If you state that a man is the eldest son of a marriage, you state a qaestion of law, because you must know that there has been a valid marriage, and that that man was the first-born son after the marriage, or in some countries before. Therefore, to state that it is not a representation of fact seems to arise from a confusion of ideas. It is not the less a fact bec:ansse that fact involves some knowledge or relation of law. There is hrrdly any fuct which aoes not involve it. If you state that a man is in possession of an estate of ten thousand pounds a year, the notion of possession is a legal notion and involves knowlelge of law; nor can any other fact in connection with property be stated which does not involve snch kworledge of lan: To state that a man is entitled to ten thousund ponnds consois involves all sorts of lau:" 5

We see now sufficiently the difficulties which confront those who assert that relief will be given as against mistakes of fact but not as against mistakes of law. Categories have to be made; for we have not got them, but only the promise of immense difficulty in their construction.

There are moreover two very important points to be noticed in connection with the maxim Ignorantia juris haud excusat, if "the word ' jus' is used in the sense of denoting general law," as Lord Westbury declares is the correct sense of it $;^{6}$ or if, as Lord Chelmsford has it, the maxim applies only to "ignorance of a well-known rule of law." 7

1 Ritshdall v. Ford (1866), L. R. 2 Er. $750 ; 35$ L. J. Ch. 769.

2 Vermilyea v. Canniff (1886), 12 O!t. 16if; Huher v. Guggenheimer (1895), 89 Fed. R. 598.

3 Broughton r. Hutt (1858), 3 De G. \& J. 5\%); 28 L. J. Ch. 167.
4Starr v. Bennett (1843), 5 Hill (N. Y.). 303.

5 Eaglesfield v. Londonderry (1876), 4 Ch. D. 70 ?.

${ }^{6}$ Cooper v. Phibbs (1867), L. R. 2 H. L. $170 ; 45$ L. J. Ch. 809.

i Milland v. Johnson (1858), $6 \mathrm{H}$. I. C. 811 . 
(1) There is the criticism in Story's Equity:

"The distinction between cases of mistalke of a plinin and settled principle of law, and cases of mistake of a principle of law not plain to persons generally, but which is yet constructively certain as a foundation of title, is not of itself very intelligible, or practically speaking very easy of application, considered ats an imlependent element of decision." I

(2) And further there is the very important consideration that it is precisely in cases in which there has been a display of "ignorance of a well-known rule of law" that relief is often granted (as we shall see) because

"the ignorance of al plin and established doctrine so generally known and of such coustiant oceurrence as a common canon of descent naly well give rise to a presumption that there had heen some undue intluence, im. position, mental imbecility, or confidence ilbused." 2

We thus seem to arrive at the conclusions that the maxim Ignorantia juris leaud excusat applies only to cases of "ignorance of well-known rules of law;" that it is probably impossible to distinguish (for practical purposes) between a plain principle of haw and one "not plain to persons generally;" but that the distinction is, after all, not very important, for if ignorance of plain law will not excuse, yet advantage must not be taken of such ignorance. That is to say, people are presumed to be familiar with the plain principles, but when they are not courts must recognize that fact and will relieve upon the ground of fraud.

Advantage Taken of Ignorance.- It sometimes happens that a venerible statement of the law is allowed to persist while the cases which it ought to regulate are being lecided in opposition to it. This presumption that "every man must be taken to be cognizant of the law" still has authoritative sound; and arguing from it, in the manner above suggested, the conclusion is inevitable that nobody can be misled by a misrepresentation of law; but as we have abreally said, "the cases are numerous in which the platin faet that this man did not know the law has bee! allowed to assert itself; " and it is now

"well settled that where there is a mistake of law on one side, and either positive fraud on the other, or ineduitable, unf air and deceptive conduct which tends to confirm the mislake and conceal the truth, it is the right and duty of equity to award relief." 3

This is made sufficiently clear by Lanstonen v. Lansilown

113 th ed. 128.

2 Snell's Eq. (11th ed.), 457. And see Frigg v. Read (1845), 5 Humpl. (Tenn.) 535 .
sHaviland v. Willets (1891), 141

N. Y. 35; 35 N. E. R. 958. 
in 1750 , a case of misrepresentation as to right of succession $;^{1}$ Legge $v$. Croker in 1811, a case of misrepresentation as to a right of way; ${ }^{2}$ Champlain $v$. Litytin in 1836 , a case of misrepresentation as to dedication; ${ }^{3}$ Wheeler $v$. Smith in 1850, a case of misrepresentation as to the effect of a will; ${ }^{4}$ Southall $v$. Rigy in 1851 , a case of misrepresentation of the liability of an apprentice to make up deficiency in his master's fee; ${ }^{3}$ Coward 2 . Mughes in 1855 , a case of permitting a woman to believe in her liability; ${ }^{6}$ Jorlan $v$. Stevens in 1863 , a case of misrepresentation as to the validity of a lease commencing in futuro; ${ }^{7}$ Eur Beauchamp v. Winn in $1873,{ }^{8}$ and Conper v. Phipps in $1867,{ }^{9}$ cases of purchasers buying their own property; II irschfield $v$. London in 1876 , a case of misrepresentation as to effect of a release of damages; ${ }^{10}$ II urt $v$. Swaine in 1877 , a case of misrepresentation as to tenure of land sold; "Snell $v$. Insurance Co. in 1878, a case of misrepresentation as to a policy in the name of one partner covering the firm's interest; ${ }^{12}$ Stewart $v$. Fennerly in 1890 , a case of misrepresentation as to necessity for "ratification of the court;" 13 and in Wilding $v$. Sanderson jn 1897 , a case of misrepresentation as to the effect of a document; ${ }^{14}$ and many other cases. ${ }^{15}$

Estoppel.-The cases relating to misrepresentation of law have not so far involved the peculiar remedy of estoppel. They have been those in whicis relief by rescission and restitution principally have been awarded. There can ive no doubt, however, that the principles involved in both classes of cases are so far similar that we are safe in applying (with some little circumspection) the authorities of the one when treating of the other.

1 Mosely, 364; 2 J. \& W. 20\%. See reference in Stewart $\nabla$. Stewart (18:38), (j Cl. \& F. 960.

21 Ball \& B. 506.

36 Paige (N. Y.), 195 .

49 How. (U. S.) 55.

511 C. B. 481 .

61 K. \& J. 443.

751 . Ne. 79 .

8 L. R. 6 H. L. 233.

${ }^{9}$ L. J. 2 H. L. 149. See p. 164. 102 Q. P. D. 1; 46 L. J. Q. B. 94. 117 Ch. Div. 42; 47 L. J. Ch. 5.
1298 U. S. 85.

1315 A pp. Cas. 109.

$14(1897) 2$ Ch. 534; 66 I. J. Ch. 467, 694.

15 Laing v. Taylor (18\%6), 26 U. C. C. P. 430 ; approved in Brown v. Holland (188.), 9 Ont. 57; Champlin v. Laytin (1839), 6 Paige (N. Y.), 195, in which it is suggested that the ground of relief is fraud rather than ignorance of the law; Goodenow v. Ewer (1860), 16 Cal. 461; Boggs v. Hargrave, id. 560 . 


$$
\text { FACT, LAW, INTENTION, OPINION. }
$$

Innocent Misrepresentation.- Before leaving the subject it should be noted that it is not at all necessary for relicf that the misrepresentation should be fraululent. An innocent misrepresentation is just as disastrous to the person deceived as one tainted with falsehood; and it is equally a ground for estoppel. ${ }^{1}$

ISnell v. Insurance Co. (18i8), 08 U. S. 85 . And sce ch. VIII. 


\title{
CHAPTER VII.
}

\author{
CONDITION NO. 5.
}

\section{The Misrepresentation Must be of Something Material.}

It is not necessary to quote much authority for the proposition that a misrepresentation to bave any effect upon the relations of parties must be as to something which might bave affected those relations.

"A matter alleged, which is neither traversable nor miterial, shall not estop." 1

The test of materiality may be stated as follows:

"It must be a representation 'dans locum contractui,' that is a representation giving occasion to the contract: the proper interpretation of which appears to me to be the assertion of a fact on which the person entering into the contract relied, and in the ahsence of which it is reasonable to infer that he would not have entered into it; or the suppression of a fact the knowledge of which it is reasonable to infer would have made him abstain from the contract altogether." 2

Or, in the language of Pollock on Contracts: ${ }^{3}$

"Anything which would affect the judgment of a reasonable man, governing himself by the principles on which men in practice act in the kind of business in hand."

The following is from a United States case and represents a more rigid view of the matter:

"Still, this important question is not left to the arbitrary or accidental decision of each court in each crase, for all courts are governed or at least directed by certain precerlents and rules, among whels it is sufficient to state at present that the fraul must be material to the contract or trans. action which is to be avoided; for if it relate to inother matter, or to this only in a trivial and unimportant way, it affords no ground for the action of the court. It must, therefore, relate distinctly and directly to the contract and affect its very essence and substance. But there is no positive standaril by which to determine whether the frad be thus material or not. No better rule ean be given for deciding tle questıon than this: If the fraul be such that, hall it not been practiced, the contract could not have been made or the transaction completed, then it is material to it; but if it be shown or male probulble that the same thing would have been done in the same way if the fraul hall not been praceticerl, it cannot be deemed material. Whether the fraud be material or otherwise seems to be, on the decided wejght of authority, a question for the jury and not a question of law: but it is obvious that in many cases the jury cannot answer this question without instructions from the court." 4

1 Vin. Ab., vol. X. p. 42?.

2 Per Romilly, M. R., in Pulsford v. Rich:urds (15.53), 17 Beav., 96; $22 \mathrm{~L}$. J. Ch. 5.j9.

${ }^{3} 6$ th ed., p. 550. For examples as to materiality, see Leake on Contracts (13th ed.), 313 sq., and Royal Ins. Co. v. Byers (1855), 9 Ont. 1:0. ${ }^{4}$ Per Miller, J., in MeAleer v. Horsey (18;1), ư Ma. 4.j2. And see 
In view of a useful distinction recently made it is probably going too far to say that the misrepresentation must "relato distinctly and directly to the contract, and affect its very essence and substance." A rapacious money-lender concealed his identity (by moans of an assumed name) in order to induce a borrower to deal with him; and it was held that the fraud was sufliciently miterial to warrant a rescission of the contract.' A. L. Smith, L. J., said:

"In myopinion the first point which arises is not whether the fraud was matrial to the contrat entered mo, but whether the frad was material to the inducement which brought about the contrict."

A Manitoba case is much to the same effect. A man haring a contract for the purchase of lands resold then at a much bigher price, pretending that he was agent merely for his ventor, and procured his vendor to convey direct to the subpurchaser. The snb-purchaser woukl have malc more careful inquiries had he been aware of the facts, and was held entitled to rescind his agreement. ${ }^{2}$

It is always very difficult, when a misrepresentation has been followed by action, for the misrepresenter to contend that his misstatement was immaterial. The onus lies hearily upon him to disprove the propter hoc. ${ }^{3}$

\section{Several Representations, and One of Them Untrue.-}

"When certain statements have been made, all in their nature capable, more or less, of leanding the party to whom they are adilressed to adopt as particular line of confluct it is impossible to sily of any one of such representations so made that even if it had not been male the same resolution would have been taken or the same conduct followed. Where. therefore, in a nerutiation between two parties, one of them induces the other to contract on the faith of the representations made to him, any one of which has been untrue, the whole contract is in this court considered as having b een obtaned fraululently. Who can saly that the untrue statement may not have been preabisly that which tumed the scale in the mind of the p.urty to whom it was illinessed?"

The subject is closely associated with that treated of in a later chapter, ${ }^{5}$ to which reference may be male. There is, no doubt, distinction between questions as to the materiality of

Huber v. Guggenheim (1898), 89 Fed. R. 598.

1 Gorlon r. Street (1899), 2 Q. B. 646 ; 69 L. J. Q. B. 4.5.

2Hutchinson v. Cillder (1853), 1 Man. 17. The judgment was reversed on appeal, but not upon the ground that such a mistepresentation would not be matterial. Id. 46 .

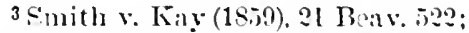
7 II. L. 750: Traill v. Haring (186t). 4 I) (i.. J. \& s. 31s: 4: L. J. Cl. 5:1:

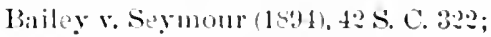
20 s. L. Li, 6:. Anl see ch. XI.

+ Per Loril Cranworth, in Rarnell v. Sipre (15:2), 1 D. A. \& G. 70\%; 21 L. J. (2h. ci:?.

s S.e trust, ch. II. 
misrepresentations and questions as to whether a change of position took place upon the faith of such misrepresentations. But it may be said that a ehange of position upon the faith of a misrepresentation proves its materiality. And, given a material misrepresentation, followed by a change, and the propter will be easily inferred. There are cases, too, in which neither factor is palpably existent, and presumptions bave to be resorted to.

Assisted Misrepresentation. - It is obvious that in cases of assisted misrepresentation, not only must the misrepresenta. tion have been material, but the assistance also must have been of such character as to have influenced the result. The formula adopted in this work to express the requisite relation between the assistance rendered by the estoppel-denier and the action of the estoppel-asserter is that the change of position must be reasonably consequent upon the assistance. This subject is treated in a subsaquent ehapter. ${ }^{1}$

$1 \mathrm{Ch}$. XIII. 


\title{
CIIAP'TER VIII.
}

\author{
CONDITION NO, 6.
}

\section{Fraud or Bad Faith is Not Essential.}

The question now to be considered relates to the moral quality of the misrepresentation. Must there be fraud or bad faith in it? or may it be of perfectly innocent chişacter? Indeed, there is a much deeper question (usually not thought of) directing our ethical inquiry, sometimes not to the misrepresentation at all, but to the assistance rendered to it by some third person - by the person said to be estopped.

Misrepresentation may be found in three departments of the law: (1) Deceit, (2) Rescission, and (3) Estoppel. The wider our survey of it the better we shall understand it.

\section{Misrepresentation and Deceitr.}

Mr. Bigelow's list of requisites of an estoppel contains the following:

"The representation must have been made with knowledge, actual or virtuil, of the facts." 1

And in exposition of that proposition he says: ${ }^{2}$

"Estoppel arising in virtue of a misrepresentation is the converse of an action of deceit. The property or interest claimed by reason of the estop. pel corresponds to the damiges sought in the action of deceit; and in order to milke good the chaim of estoppel the sime things, it should seen, are requisite that are necessary to the maintenance of the action mentioned. Now by the clear weight of authority in whach courts of equity. in reeent times at least, arree with the courts of law, it is necessilry to the rescovery of damages in an action for misrepresentation. by the current of authority, to show that the defendint made the representation (1) with aletual knowledge of its falsity, or (2) recklessly. without knowing whether it was true or talse, or (3) unifer circumstances in wh theh, from his peculiar relation to the facts, he was bound to inow the true state of things."

Passing over for a moment the stated requisite of fraud, let it be observed:

1. That in Mrr. Bigelow's classification there is no room for his third sort of case. The first two clisses exhaust the pos-

1 On Estoppel (ith ed.), p. 5\%0. And see Willmott v. Barber (1880), 15 Ch. D. $96 ; 42$ L. J. Ch. 792 , a case, how- ever, having more relation to acquiescence thatn to estoppel.

$2 \mathrm{Id} .$, p. 609. 
sible cases, for they include eases where a representation has been made which is known to be false, and those in which it is made "without knowing whether it was true or false." It is useless then to inquire whether the asserter "was bound to know the true state of things;" for whether be was or was not so bound he is estopped (1) if he make a representation which he knows to be false, and (2) which may be false. ${ }^{1}$

2. The present writer cannot agree either that an action of deceit will lie merely because the misrepresenter "was bound to know the true state of things" in the absence of that fraud which would place the instance in one of the other categories. In the leading ease of Derry v. Peek, ${ }^{2}$ Lord IIerschell said:

"I think the authorities establish the following propositions: First, in order to establish an action of deceit. there must be proof of fraud, and nothing short of that will suffice. Secondly, fraud is proved when it is shown that a filse representation bas been made, (1) knowingly, (2) withont belief in its truth, or (3) recklessly, careless whether it be true or false. Although I have treated the second and third as distinct cases, I think the third is but an instance of the second, for one who makes a statement under such circumstances can have no real belief ${ }^{3}$ in the truth of what he stites."

And although the learned judge refers to cases in which "a person within whose province it lay to know a particular fact," it is "only for the purpose of putting them aside" as being " in an altogether different category from actions to recover damages for false representations, such as we are dealing with."

3. Nor can the present writer agree that for "estoppel the same things are requisite" as in the action of deceit. The litt-

1 In Watson v. Jones, 25 S. R. 682 (Fla.), it is said: "We are therefore of opinion that proof of scienter in the third phase does not give another or different right or ground of action from that given by proof under the first phase, but that it simply establishes the same ultimate fact, viz. knowledge, by a different class of evidence; and consequently that an allegation that defendant 'knew' his representation to be false is prorable by evidence embraced in the third phase. In other words, an aver. ment that defendlant's situation or means of knowledge were such as made it his duty to know whether his statement was true or false, and an averment that defendant well knew his statements to be untrue. are but different methods of stating the same ultimate fact, viz knowledge. McBeth v. Craddock, $28 \mathrm{Ml}$. App. 380; De Lay v. Carney Bros., 100 Iowa, 687; 69 N. W. R. 1053."

2 (1889) 14 A. C. $357 ; 58$ L. J. Cll. 864. See the Derry v. Peek scholin cited with it in ch. XVI.

${ }^{3} \mathrm{As}$ to this point of reality of $\mathrm{b}:$ lief see Allcroft v. Bisluop of London (1889), 23 Q. B. D. 414; 58 L. J. Q. B. $385 ; 24$ Q. B. D. 213 ; 59 L.J. Q. B. $169 ;(1891)$ A. C. $666 ; 61$ L. J. Q. B. 62; Angus v. Clifford (1891). ? Ch. 449; 60 L. J. Cl. 443; White r. Silge (1892), 19 Ont. App. 135; Turner v. Francis (1894), 10 Man. $340 ; 25 \mathrm{~S}$. C. Can. 110. 
ter, as we bave just seen, must be based upon "fraud, and nothing short of that will suflice." In estoppel, on the other hand, as we shall abundantly see, a perfectly innocent misrepresentiltion, or even innocent assistince rendered to a misrepresentation of another person, may be guite suflicient for estoppel ${ }^{2}$

\section{Mismepriesentation and Rescission.}

In some cases of misrepresentation rescission of the contract is sought, and not dimages in deecit, nor yet estoppel. The law as to mala fides, in such cases, is explained by Lorl Hersehell: ${ }^{3}$

"I think it important that it should be borne in mind that such an action (i. e., an action for aleceit) differs essentully fron one brought to obtuin rescission of a contract on the ground of misrepresentution of a material fact. The principles which govern the two actions are wilely different. Where rescission is claimed it is only necesary to prove that there was misrepresentation; then, however hrnestly it may have been malle, however free from hame the person who mille it, the contract having been obtained by misrepresentation cannot stand. In an action of deceit. on the contrary, it is not enongly to establish misrepresentation alone: it is conceded on all hamels that something more must be proved to cast lialibity upon the defentant, tholgh it has been a matter of controversy what al. ditional elements are requisite."

\section{Misrepresextation and Estopiel.}

Misrepresentation as a basis for an action of deceit then must, according to the present state of the law, be fraululent. On the other hand, misrepresentation as a ground for rescission

I Reference, of course, is made to the present stite of the law. See, howerer, the chapter on Deceit, ch. XVI.

2 Ir. Bigelow at page 629 , note 1 , limself siys: "As there need not be any actual design that the representation should be acted upon, there need be no design to def ramb."

3 Derry v. Peek (1s5:9). 14 App. Cars. 359: 58 L. J. Ch. Afil: Rese v. Snith (1869), L. R. 4 H. L. 81 ; 39 L. J. Ch. sis (per Lord Cairns): Petrie r. Guclph, 11 S. C. Carn. 450: Jordan v. Provincial (1898), 28 S. C. Can. 554; Budel v. Melanughlin (1896), 10 .I: i.). A very ("apable jurist (Stromg. C. J.) has surerested a distinction between executed and executory contracts, holding that for rescission of the former the misrepresentation must be fraudulent (as in deceit), but otherwise where the contrinct remains executory. Bell v. Marklin (1s\$9), 15 S. C. Can, jel. This may at all events be said: That resciscion onght to include restoration to the stectus quo ante; thit where the contrart has been executed, complate restoration is frequently imposible: and that if there has been bal faith the court might be less careful upon that point than if the misiepresen. tation had been made innocenty. If the point is well taken it will in. volve the consideration of contracts partly executed: and perlalpa a distinction as to the heinomsness of the fraul as eompared with the com. plexities of the change of position perhings to the exercise of juhlubl discretion in such eases. 
of a contract may be innocent. What is the law with reference to misrepresentation as a ground of estoppel?

Diverse Views. - Upon such a fundamental point as the necessity for fraud as an element of estoppel we would expect to find the anthorities agreed. For plainly little can be done towarls a philosophy of estoppel without settlement of this main question, Is moral culpability essential to estoppel ?

In Smitl's Leading Cases it is said:

"But if the representation was made under a mistake, and in ignorance of the fincts. there will be no estoppel." I

Story's Equity has the following:

"This doctrine of estoppel in pais in ordinary cases grows out of a frambulent purpose and a fraudulent result.".2

In a Canarlian case it is said:

"The general rule is that fraud is necessary to the existence of an estoppel by conduct. 'The person must have been deceived; the party to whom the representation is made must have been ignorant of the truth of the matter, and the representation must have been made with knowledge of the filcts." 3

\section{And in the United States Supreme Court it is sairl that:}

"For the application of that doctrine there must generally be some intended deception in the conduct or declaration of the party to be estopped, or sucl gross neglinence on his part as to amount to constructise fratud by which another has been misled to his injury." 4

Upon the other hand there is in many cases the flattest contradiction of this doctine. For example Lord Cran worth said: ${ }^{5}$

"It is not necessary that the party making the representation should know that it was lalse; no fraud need have been intended."

19th Am. ed., III, 2116. And see Holcomb v. Boynton (1894), 151 Ill. 294; 3 T N. E. R. 1031.

213 th ed. 1544 . The cases in the United States are conflicting. In faror of the above quotation may be found: Hill v. Epley (18:), 31 Pa. St. 3:31; Biddle Boggs v. Merced (1859), 14 Cill. :36\%; Zuchtman v. Roberts (1871), 109 Mass. 5\%; Stepluens v. Dennett (18\%2), 51 N. H. 324; Brant v. Virginia (1586), 92, U. S. 335; Staton v. Bryant (187i), 5j Miss. 261; Kingman $\vee$ Gralıam (1881). 51 Wis. 232; 8 N. W. R. 181; Powell v. Rogers (1983). 105 Ill. 322: De Berry $\mathbf{}$. Wheeler (189i), 128 Mo. 34; :20 S. W. R. 3.39; Brigham Young v. Wagner (199.), 12 Utah, 1; 40 Pac. R. 704. It is sometimes thought that negli- gence as evidence of fraud will suffice. Sullivan v. Colly (1896), $18 \mathrm{C}$. C. A. 193; 71 Fed. R. 460 . For the contrary opinion: Pitcher v. Dove (1884), 99 Ind. 175, 178; Trustees v. Smith (1890), 118 N. Y. 640; 23 N. E. R. 1103; Stiff v. Ashton (1891), 1i55 Mass. 130; 29 N. E. R. 203; Moore r. Brownfiełd (1894), 10 Wash. 489: 39 Pac. R. 113. Anrl see cases cited with Brant v. Virgrinia, post, ch. XII.

3 Per Ferguson, J., in II.Gee v. Kane (188i), 14 Ont. 234. And seo IIoward v. Hudson (185:3), 2 E. \& B. 11; 22 L. J. Q. B. 341.

${ }^{4}$ Brant v. Virginia (1876), 93 U. S. 33\%.

5 Jorden $\nabla$. Money (1854), 5 H. L. C. $212 ; 23$ L. J. Cl. 805. 
And Lord Cairns said:

"If persons take upon themsolves to make assertions as to which they are ignorant whether they are true or motrur. they must in a eivil point of view be held as resonsible as if they had asserted that which they linew to be true."1

Attempted Reconciliation.- Attempts have been marle to reconcile these conflicting views by retaining the word "fraud," and dispensing with its reility - in this ingenious fashion:

"All that is meant in 1 he expression that an estoppel unst possess an element of fratud is thit the cilse must be one in which the cirenmstances

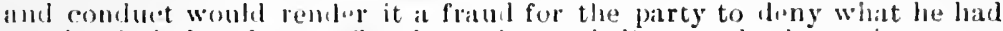
movionsly indued or sulfered anothre to believe and take action upon; the door is shat atganst asiserting a right that would result in doin a an injury by the party assirling it to some other jerson, or when in good con. scrence and honest dealing he onglit not to be permitted to gatinsily his previous eonduct. This is sulficient to work an estoppel and bring in the alement of moral wrong, and there need be no precedent, corrupt motive or evil desinn."?

It will be observed that the reconciliation is effected by removing the so-called fratud from one end of the transaction to the other-from the misrepresentation, which may now be innocent, to the harvest of its fruits, which, if permitted, wonld be fraudulent - from the original purpose to the final result. But it would be just as accurate to say that there must be an "element of moral wrong" in a debtor before he can be compelled to pay his debts - "the case must be one (it would be said) in which the circumstances and conduct would render it a fraud for the party to deny (payment of) what he had previously induced or suffered another to" lend him. This word "fraul," after being emptied of all meaning, is often used in explanation of that which is imperfectly understood, but which would be clear enough were it completely omitted. ${ }^{3}$ We can dispense with it here. $A$ little care in distinction and classification is all that is necessary.

Reconciliation.-Readers will remember that misrepresentation may be either personal or assisted, and that the assistance may be either active or passive. Learing the proof to

1 Reese v. Smith (1899), L. R. 4 H. L. $79 ; 39$ L. J. Ch. 849 . Anı see per Jessel, M. R., in Ealylesfield v. Londonderry (18;6), 4 Ch. D. $\% 04$.

2 Herman on Estoppel and Res Judicatia, sec. 7is. And see Patterson $\therefore$ Lytle (1849). 1 Jones, 53; Dezell $v$. O.lell (154:2), 3 Hill, 215; Hill r. Epley (1858), 31 Pa. St. 334.

\section{${ }^{3}$ See chs XVIII and XIX.}

4 Ante, p. 18. Assisted misrepre. sentation occurs where the misrejresentation lias been made by somo third person, but it has been ande credible by some act or omission by some assistance, of the estoppel. derier. This assistince mily be active, as where a mortgagee hands to 
follow let it be at once said: (1) that where the misrepresentation is that of the estoppel-denier (personal misrepresentation), a misrepresentation will not the less work an estoppel because it is honest and innocent; (2) thit where the misrepresentation is that of a third party (assisted misrepresentation), the assistance, if active, will not the less work an estoppel because it was renclered honestly and innocently; (3) and that the dicta which require culpability or bad faith as a pre-requisite of estoppel must be contined to cases of assisted misrepresentation where the assistance is of pissive sort.

If with this classilication in view the authorities are again consulted the conflict among them will almost entirely disappear. Where, as in Story or the United States Supreme Court, it is asserted that fraud is requisite to estoppel, it will be found that the kind of estoppel in view was that usually referred to as estoppel by standing-by, that is to say, cases of misrepresentation by passive assistance. And when Lord Cranworth and many others deny the essentiality of franl, it will be found that they are speaking with reference to cases of personal misrepresentation, or those when the assistance is active.

Applying then the dicta to their particular cases inerely, we might be led to saly generally with Lord Cranworth, that "no fraud need have been intended," but that cases of standing-by seem to be an exception to the rule.

\section{Misrepresentation by Passive Assistance.}

When, howerer, we examine more closely this exception we shall see that it is such in appearance merely. We shall find incleed that there must be culpability in all cases of standingby, but, carefully distinguishing, we shall discover that it is a requisite of existence of the misrepresentation, and not at all an essential element in the estoppel. In other words, there is culpability in such cases because they are a category of culpable actions, and not because fraud or evil intent is necessary to estoppel.

Whether estoppel will ensue when an owner of land stands

the mortgagor the title deeds, and, thus equipped, the mortgagor represents himself as unincumbered owner. Or it may be fassire, as where the owner of property stands by while it is sold to another to an innocent purchaser. 
by while it is solit to an innocent purchaser cepends, no doubt, upon whether the by-stander intencled to misleal; and too hastily it may be silid that the case shows therefore that fraud is essential to the estoppel. But it must be observed that fraul (in the case in hand) is neecssary to the existence of the misrepresentation on the part of the by-stander; and all that can be said as to the estoppel is that there must be a misrepresentation - moral quality of it unessential.

The point is important. Observe what it is that $I$ allege when I silently stand by. Do I assert that I have no interest in the property? If so, I would of course be estopped. But that is not the proper interpretation to pat upon silenee. In America, at least, where land is designated almost exclusirely by figures, few property owners can bear in mind the deseription of their holdingrs. If one of such persons witnessing a salo of land were asked whether he had an interest in it, his answer would probably be: "I do not know; if you wish I will look it up and tell yon." P:? such a statement he would not be estopped. Innocent silence means nothing further, if indeel it even goes as far as that. ${ }^{1}$ I: imnocent silence, therefore, there is no misrepresentation or assistance to mispepresentatio:s. It therefore cinnot estop.

Consider two of the leading dicta as to estoppel by standingby. In one important case Lord Cranworth said: ${ }^{2}$

"If a stranger hegins to build on my land supposing it to be his own, and 1. perceiving his mistake, abstain from setting him right and leave hum to persere in his crror, il court of equity will not allow me alterwards to assert my title to the land on which he had expended moner. on the sup position that the land was his own. It consilers that when I sto the mis. take into which he had fallen it was my duty to be active and to state my adrorse titie; and that it would be dishonest in me to remain wilfully passive on such an occasion, in order afterwards to profit by the mistake which 1 might have prevent.ul."

\section{Aud Chancellor Kent is to the same effect: ${ }^{3}$}

"If a man knowingly, though passively by lockiner on, suffer another to

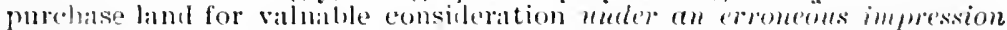
ol title withont making known his clatm. he will not be permitted thereafter to exereise his legal right agrajust such person."

1 Willmott v. Barber $(1880), 15 \mathrm{Ch}$. D. 96 ; $4: 2$ L. J. Cl. 792 ; Low v. Bouverie (1891), 3 Cl. 82 ; 60 L. J. Ch. 6.i 4.

2 Rimslen v. Dyson (1866), L. R. 1 II. L. 140. And see Fast India, etc. Co. v. Vincent (1740), 2 Atk. 8:; Pir kard v. Sears (1837), 6 . \& \& E. 469; the Bussehe v. Alt (18;8), 8 Ch. D. 314;
47 L. J. Ch. 381; Gray v. MeLennan (1886), 3 Man. 3as; Hill $r$ Epley (1858), 31 Pa. St. 334.

${ }^{3}$ This statement of the law has been widely adopted in the United States. lipinelow on Estoppel (jth ed.), 1. 380 , and note. 
Observe the condition for estoppel: "When I saw the mistalie into which he had fallen," or when I "suffer another" to act "under an erroneous impression of title." Standing by merely will not estop, for although near-by I may not see that there is any mistake or any erroneous impression - will not estop, therefore, because there is no misrepresentation.

In order to see "the mistake" three things seem to be requisite:

1. I must be aware of my own right.

2. The other party must be unaware of my right.

3. I must have reasonable ground for assuming the other party's innorance. ${ }^{1}$

A few cases will help to an appreciation of these points:

Willmott $v$. Barber. ${ }^{2}$ A lease contained a clause prohibitive of sub-leasing; a sub-lease was made; the sub-lessee entered and expended money to the knowledge of the head landlord; both the head landlord and the sub-lessee were unaware of the prohibitory clause: held, that the head landlord was not estopjed. Observe that the head landlord had made no representation of any kind. The utmost that was charged against him was that he stood by and allowed his tenant's misrepresentation of a right to sub-let to take effect.

This case illustrates two of the points in hand: (1) The estoppel-denier was unaware of his own right; and (2) he had no reason for assuming that the other party was ignorint of that which a prudent man would bave ascertained. As to the first of these, Fry, T. J., said:

"The defendint, the possessor of the legal right, must know of the existence of his own right which is juconsistent with the right claimed by the plaintiff."

And as to the second he added:

"He might well have supposed that the plaintiff was a prudent man, and that he had made inquires as to the provisions of Barber's lease. . . I cannot therefore conchule that the mistaken belief of the pliantiff was bronght home to Bouyer's (the owner's) mind, and that being so I cannot restritin Bouyer from exercising his legal right."

Mangles $v$. Dixon." A ship-owner assigned "the amount due" to him under a certain charter-party; according to the charter-party the amount due was $\$ 1,(0 v)$; the assignee notified the charterer of the assignment, and the charterer said noth-

1 See reference to Bigelow on Estoppel in ch. XI, sub-tit. "Means of Knowledge."
2 (1880) 15 Ch. D. 96 ; 42 L. J. Ch. 79:.

3(1852) 3 H. L. C. 702. 
ing. The assignee might well now think that he had an assignment of $\$ 1,000$. The facts, howerer, were that the owner and charterer were jointly interested in the renture, although the charter was otherwise drawn; \$500 therefore, and not $\$ 1,000$, was the amount due from the charterer to the owner. The assignee, having relied on the charter-party, climed that the charterer was estopped from denying liability for the whole $\$ 1,000$. He urged that he was misled by a document executed by the charterer, and by the fact that when he gave notice of his assignment the charterer continued the misrepresentation by his silence.

Seprate the grounds: First, the charter-party was misleading. Yes, but that was a contract between two persons who perfectly understood one another. It was a chose in action, and a transfer of the debt evidenced by it would carry with it all the equities; ${ }^{1}$ the assignee knew this, and knew that there might be equities; he made no inquiries; no estoppel, therefore, thus far. Secondly, when notice of the assignment was given to the charterer, was he bound to state, withont question put to him, that there were equities? The IIouse of Lords replied in the negative - the charterer was not bound to assume or imagrine that a fraud hal been practiced upon the assignee; he might well have taken it that he had satisfied himself as to the true position of the matter; he was not aware of the assignee's ignorance. ${ }^{2}$

Proctor $v$. Bennis. ${ }^{3}$ This was also a case of standing-by. It was claimed that a patentee was estopped from setting up his patent as against persons who had purchased an infringing machine. And it was suggested by Cotton, L. J., as a reason against estoppel, that the patentee had no reason to suppose that the purchaser was maware of the patentee's rights. Not distinguishing between estoppel by passive assistance and estoppel by personal misrepresentation, Mrr. Bigelow says of this point: ${ }^{4}$

"Can it be necessary to an estoppel under the law of the scienter that the party to be estopped should also know that the other party is acting

1 Unless it was intended to be of L. J. Q. B. 221: Polts v. Temperance ambulatory character. See ch. (159:), :3 Ont. 73.

XXIV.

"See upon the same line, Smith $\mathrm{v}$ Hughes (1871), L. R. 6 Q. B. $59 i ; 40$
3(188\%) 36 Ch. D. 740; 5i I. J. Ch. 11.

4 On Estoppel (5th ed.). p. 610, n. 2. 
in ignorance? So jt appears to hare been supposed hy Lord Justice Cot. ton in Pructor v. Bennis. . . An anctioneer makes a fialse representattion scienter: must a buyer show that the auctioneer knew that the buyer wals ignorant of the facts?"

'The auctioneel case is totally different; it is one of personal misrepresentition; the auctioneer himself makes the representation; and the only requisite for estoppel is that position should have been changed upon the faith of the representation. In the patent case there was no misrepresentation by the estoppel-lenier, and the question involved is, Under what circumstances is it "my duty to be active?" And the answer is, When I see another person falling into mistake; and I see no mistake unless I have reason to believe that the other party does not understand his situation.

It must be observed, too, that Lord Jastice Cotton did not suggest that an estoppel-denier must "know that the other party is acting in ignorance." He said:

"In my opinion it must be taken that they (the purchasers of the machine) did know it; but if they did not I cannot find anything from which we onght to draw the conciusion that the plaintiff lad reason to suppose that they did not." 1

The case involves two of the three points under consideration, namely: (1) That the estoppel-asserter must be unaware of the estoppel-denier's right; ald (2) That the estoppel-denier must have had reasonable ground for believing in the other party's ignorance.

Summarizing, let it be observed that frand or bad faith is not essential to estoppel, although it is a necessary ingredient in misrepresentation by passivity. There is not in such cases a real exception to the general rule that for estoppel "no fraud need have been intended." Upon the other hand, howerer, it would be quite correct to say (in such cases) that there "must have been knowledge actual or virtual of the facts," and that the estoppel "grows out of a fraudulent purpose and a fraudulent result." Reconciliation of the conflicting dicta is accomplished by classification.

1 Mr. Justice Fry, in another case (Willmott r. Barber (1890), 1,j Ch. D. 96 ; 42 L. J. Ch. 792$)$, puts the point more strongly: "Fourt!ny. the defendant, the possessor of the legal right, must know of the plaintiff's mistaken belief of his riglits. If he does not there is nothing which calls upon him to assert his own right."
Were this language to be taken absolutely, it would be only in the very rarest of cases that a by-stimler could be estopped. He could al ways urge that he attributed the purchaser's action to rash stupidity or reckless aggression, and not to ignorance. 


\section{Personat, Misrejpiesentation.}

It was unfortunate that the leading case of estoppel in pais (Pickerd $v$. Sects ${ }^{1}$ was a case of misrepresentation assisted by passivity; for, that fact being orerlooked, the rule there laid down has been taken to be of greneral applieation. ${ }^{2}$ It is this:

"The rule of liw is clear that where one hy his words or conduct uilfully causis another to believe the existence of al certain state of things, amb in. duces him to act on that belief so as to alter his own previons puition. the former is conclulul from averring against the latter a different state of things as existingr at the same time."

The word "wilfully," or some other word indicative of a desire to mislead - indicative of framl, was there necessary; for the ease, as we say, was one of passivity (in which fraul is necessary to the fact of misrepresentation, although not to the law of estoppel); but that the word was out of place in cases of personal misrepresentation became apparent upon the first occasion in which the rule was applied to an instince of that lind. Unfortmnately, however, in that case the word itself was qualified, or rather almost eliminated from the general definition, instead of being left to its operation in the class of cases to which it hat been applied and to which it properly belonged. This was said:

" By tise term 'wilfully, howerer, in that rule we must understand, if not that the party represints that to be true which he knows to be untrue, at least that he imeans his representation to be acted upon, and that it is acted upon accordingiy." 3

\section{1 (1S3i) 6 A. \& E. 469.}

2 It is not here asserted that the rule was not intended to be of general applicition. No loubt its language ("by his words or conduct") covers cils 's of both active and passive misrepresentation. Two years afterwarils, however, the sinne court had to deal with another case of passice misrepresentition (Gregg $r$. Wells (18:39), 10 A. \& E. 97: S L. J. Q. B. 193), and the language there used was carefully contined to that class of cises, and was intended to supersede the expression in Pickird v. Sears. Lord Denman the sime judge whose language is quoted from in the earlier case) said in the later: "Pickind v. Sears was in my mind at the time of the trial and the principle of that case may be stated even more broislly" - also more narrowly - "thin it is there laid down. A party who negligently or culpably stands by and allows another to contract on the fitith of an understanding of a fact which he can contradict cannot afterwards dispute that fict in an action against the persou whom he has himself assisted in deceiving." Estonpel by passive assistance must be based on culpibility. Nothing is predicated of otlerer sorts of estopluel.

3 Freem:un r, Coolie (19.45). 2 Ex. 6.it; 18 L. J. Ex. 11. And see Howarle. HIII] son (IST), 2 lil. \& B. 1; 2:2 L. J. Q. B. 311: Continentil Bank $\vee$ National Bank (15ia). ju N. Y. 5.j. 
This language perfectly fits the case in which it was used (one of personal misrepresentation); and the only objection to it is that it assumes to alter a rule which had been formulated in view of another class of cases (misrepresentation assisted by passivity) in order to make it suitable for the one in hand. For, as the writer sees it, both rules were correct. In the case of misrepresentation :assisted by passivity, the misrepresentation must from its naturo (but for no other reason) be wilful; whereas, in cases of personal misrepresentation (which may be either honest or dishonest), it is sullicient that it was intended to be acted upon.

In these cases of personal misrepresentation, then, we get away altogether from any question of fraudulent intent in the misrepresentation. And the question is merely, Did he intend what he said or did to be acted upon? or, as we shall hereafter more accurately put it, Had he reasonable ground for anticifating a change of position in consequence of what he said or did??

"Even where a representation is made in the most entire good faith. if it be made in order to induce another to act upon it. or under circumstances in which the party making it may reasonably suppose it will be acted upon, then prima facie the party mating the representation is bound by it, as between himself and thuse whom he has misled."2

\section{Actively Assisted Misrepresentation.}

Cases of passive misrepresentation have already been dealt with; and it has been shown that the bad faith which appears in them is a requisite of the existence of the alleged misrepresentation and not of any rule of estoppel. Personal misrepresentation has just been disposed of. There remains to be dealt with those cases in which estoppel is claimed because of active assistance rendered by the estoppel-denier.

For example, cases in which a railway company or a warehouseman has issued delivery orders for goods which were never received, and some third person has advanced money

1 Post, ch. XII.

${ }^{2}$ Per Shadwell. V. C., in West v. Jones (1851), 1 Sim. N. S. 207; 20 L. J. Ch. 362 . And see per Parke B., in Freeman v. Cooke (1848), 2 Ex. 66:; 18 L. J. Ex. 114; Mangles v. Dixun (1952), 3 H. L. C. 734; Low v. Bou- verie (1891), 3 Ch. 111; 60 L. J. Ch.

654; Horn v. Cole (1868), 51 N. H. 297;

Blair v. Wait (1877), 69 N. Y. 113;

Anderson v. Hubbles (1883), 93 Ind. 5r6; Clark v. Dillman (1896), 163 Mich. $625 ; 66$ N. W. R. 570. 
Iyon the representation of the holker of the orders (assisted by the documents) that he was the owner of the groods.' Or a company has issued a certilicate that, $\Lambda$. was the owner of certain shares, although he was not; and upon the representation of $\Lambda$., assisted by the certificate, he has sold the shares to an imnocent purchaser. ${ }^{2}$ Or a mortgarge has given up the deeds to the mortgagor, who, thus equipped, has mortgaged the land as though he were the mincumberel owner of it. ${ }^{3}$ In all such it is clear" that for estoppel "no fraud need have been intended" on the part of the person to be estoppeal. Ile is frequently not eren aware that a misrepresentation has been male.

Indeed the law may with confidence be satid to be that if the assistance has been rondered, not only is the question of fraud immaterial, but that such exeuses as oversight, or mistake, or even that the assistance was the result of deception practiced upon him, will not arail the estoppel-denier. A few cases from various departments of the law will be useful here.

Mortgages. - A mortgagor will be estopped as against an assignee of the mortgage from alleging that the whole consideration expressed in it has not been advanced to him, if in the deed and by indorsement upon it he has acknowledged receipt of the money. In such a case Fry, L. J., said:

"Trat the plaintills (the mortgagees) were in a moral point of view excusable for these acts is beyond doubt: and that they were deceived by those whom they trusted, and as such are ohjects of sympathy, is edpully clear. But they were inexact and careless, and placed $m$ the hanis of Bites, or Astiey, the meins of deceiving otier persons, and these are in the view of a court of equity demerits."

Certificate of Shares. - So also a company will be estopped by its certilieate of ownership of shares, althongh the seal may have been fraulukently affixed by the secretary of the company, and the signature of a director forged. The complany has sulticiently, although innocently, assisted in the misrepreseutation. ${ }^{5}$

I Coventry v. Great Eastern (1883). 11 Q. B. D. 775: 52 L. J Q. B. 694; Hen lerson v. Williams (189.5), 1 Q. B. fie1: tit L. J. Q. B. 30S; Silderquist v. Ontario(185i), 14 Ont. 586; Fourth Nitional v. Compress (188:), 11 Mo. Aple.333. But see Sereond National v. Wallbridge (1869), 19 Ohio st. 419.

Infira.

${ }^{3}$ Injira
4 Bickerton r. Walker (1885), 31 Ch. D. 151; is L. J. Ch. 2:2. Se cases cited with this one in ch. IV.

3 shaw $\therefore$ Port Philip (1884), 13 Q. B. 1). 10:3; 53 L. J. Q. B. 3ij!?. Distinguish Evans $v$ Bank of Iretand (18i.j). 5 H. L. C. 348 , and Merchints v. Batnk of Englitnd (1887), 21 Q. 13. I). $160 ; \pi$ L. J. Q. I3. 418 , as pointed out in the latter case. 


\section{Ostensible Ownership.-}

"It is faniliar law that if the owner. although induced thereto by fraud, invests another with the apparent legal title to chattels, in pursuance of a contract, the person so clothed may transfer an unimpeachable title to a good-faith purchaser. We are unable to discover any good reason for a clistinction in that regard between chattels and such instruments as may be assigned by indorsement so as to give the assignee a complete legal title." 1

"The rule is, that if a man so conduct himself, whether intentionally or not, that a reasonable person would infer that a certain state of things exists, and acts on that inference, he shall be afterwards estopped from denying it." 2

l'artnership. - A person who is induced by fraud to hold himself out as a partner cannot eseape estoppel merely beeatuse lie was misled by the friud. ${ }^{3}$

Trustee.-A trustee of a fund was asked as to its conclition, and replied erroneously, having forgotten that he had been formerly advised of a charge upon it. His forgetfulness was not allowed to arail him. He was estopped by his answer.

"Negotiable" Instruments. - An acceptor of a forgerl bill, who by his conduct had intimated to his banlier that it was grentine and would be presented for payment, was estopped as agrainst the banker (who had paid it) from denying his liability upon it. ${ }^{5}$ Lord Selborne said:

"If the plaintiffs misled the bank upon a material point, however innocently. and althongh they were themselves deceived by the traut which had been committed, 1 think that they, and not the bank, ought to bear the loss which has been the consequence." 6

\section{Infancy.-}

"Where a person represents to another that he is of age, and executes a release upon which the latter acts, held, that he could not afterwards

1. Noore v. Noore (1587), 112 Ind. 152; 1:3 N. E. R. 6ir3. And see Sheppard v. Union Bank (1862), 31 L. J. Ex. 154; Baines v. Swainsoll (186:3), 32 L. J. Q. B. $2 \$ 1$; Tiabeock v. Lawson $(18 \subseteq 0), 5$ Q. B. D. 2sł; 49 L. J. Q. B. 408; Kings. lord 5.21 rry (1856), $11 \mathrm{Ex} .577 ; 1 \mathrm{H}$. \& N. 5t1:3; 25 L. J. Ex. 166; Pease v. Gioahec (1866), L. R. 1 P. C. 229, 230; 2.) L. J. P. C. 166; Root v. French (18:3ij), 13 Wend. 5\%0, approved in Henterson v. Williams (1895), 1 Q. B. 5.9: 61 L. J. Q. B. 308; Trustees v. Smith (1990), 118 N. Y. 640, 2:3 N. E. R. 1619; Brant v. Virginia (18;6), 9:3 U. S. 327. And see the discussion in ch. XXI.

2 Cornish v. Abington (1859), $4 \mathrm{H}$.
\& N. 556; 28 L. J. Ex. 262; Sheppard v. Union Bank (1S62). 31 L. J. Ex. 154: Baines v. Swainson (1803), $32 \mathrm{~L}$. J. Q. B. 281. But see McGee v. Kane (1887), 14 Ont. 234.

${ }^{3}$ Ellis v. Schmoeck (1929), 5 Bing. 521; 7 L. J. C. P. 22:1; Collingwood v. Berkeley $(1 \leqslant 63), 15$ C. B. N. S. 145: Maddick v. Malshall (1864). 16 C. B. N. S. $38 \%: 17$ id. 829.

${ }^{4}$ Burrowes v. Lock (1805), 10 Ves. $4 \pi 0$.

5 Vagliano v. Bank of England (1883), 22 Q. B. D. 10:3; 58 L. J. Q. 13. 27: 293 Q. B. L. 243; 58 L. J. Q. B. 35\%; (1891) A. C. $10 \tau$; 60 L. J. Q. B. 1.i.

${ }^{6}$ Id. (1891), A. C. 123 ; 60 L. J. Q. B. 145. 
impeach the validity of the release on the rorund of his minority, and that it was immateriat uhether he uas ancare or not of the incorrectuess of the representation."1

\section{Mrr. Poneroy's Point.}

Mr. Pomeroy distinguishes between lands and goods:

"Frandulent conduct is essential in cases in which an owner of land is precluded from asserting his legil title by reason of intentionally filse representations or concealment by which another has been induced io de al with the land. These cases are at the present day treated as exanples of equitable estoppel;"

but he thinks wrongly so, for the case is one which belongs to earlier equitable doctrine, and "is contined to estates in land." ?

In reply it may be said: (1) It seems to be haldly worth while making a categrory of cases in which "f raudulent conduct is essential" merely to fill it with cases "of intentionally filso representations or concealment." (2) It would be difficult to support a distinction between goods and lands with reference to the application to them of the prineiples of estoppel, or the necessity for fraud in misrepresentation. (3) Mr. Pomeroy himself says that standing by in silence may estop an owner of "property;" that this is "a true estoppel in equity;" and that in such cases "a fraudulent intention to deceive or mislead is not essential." 4 The result would thus be that standing by in silence without intent to defraud would estop; but that a frandulent assertion to help the deception would not - at all erents if land were the subject of the transaction. Such a case would belong to "earlier equitable doctrine."

\section{Conclusion.}

Summarizing it may be said:

1. That fraud or bad fiath is not a requisite of estoppel;

2. Although it is often found in misrepresentation, and is a necessary element in cases of misrepresentation by passivity; and misrepresentation is of course essential to estoppel.

1 Wright v. Snow (1848), 2 De G. \& ${ }^{3}$ Il., see. 807. Sm. 321 .

Hli. sece. Sis.

2 On Eq. Jur., sec. 805. 


\section{CHAPTER IX.}

\section{CONDITION NO. 7.}

\section{Negligence (Carelessness) is Sometimes Essential.}

The subject of "Estoppel by Negligence" is in a most confused and peculiar condition. Rules and amendments of rules have been devised and elaborated by the judges; the authors hare been quoting, applying and illystrating those rules; ${ }^{1}$ and yet the principal writers on estoppel are far from sure whether cases of estoppel by negligence can exist. If possible, at least they "must be uncommon;" "and "it may be going too far to say that in the nature of things there can be no such case." 3 The present writer believes that with the help of some short preliminary investigations the subject can be male intelligible.

Negligence. - Before entering upon an exposition of the subject, it is essentially necessary that we should arrive at an understanding of the sense in which the word "negligence" is beingr used.

It is to be regretted that the connotations of the term lead off in two different directions. On the one hand, all neglect of duty is negligence, and embraces, therefore, intended wrong. Upon the other hand the action of negligence is usually considered as being limited to that class of cases in which the act complained of has been due rather to carelessness than to intention.

Confusion has arisen from this double signification of the word. In one case, ${ }^{4}$ for example, Lord Eldon spoke of "that gross negligence that amounts to evidence of a fraudulent intention."

Of which Fry, L. J., said ${ }^{5}$ that the expression was

"certainly embarrassing, for negligence is the not doing of something from carelessness and want of thought or attention; whereas sa fraudulent in-

1 Bigelow on Estoppel (5th ed.), 65;3659; Cababé on Estoppel, 93-101; Everest \& Strole on Estoppel, :353-370; Smitli's Leading Cases (8th erl.), 90i911; Beven on Negligence (2d ed.), 15ti8-1619; Adlison on Torts (fith ed.), 745; Lindley on Companies (5th ed.), $4 \leqslant 6$.
2 Bigelow (.ith ed.), 6.j3.

3 Calrabé on Estoppel, 10.

${ }^{4}$ Evans v. Bicknell (1801), 6 Ves. 190.

${ }^{5}$ Northern Counties v. Whipp (1884), 26 Ch. D. 489 ; 53 L. J. Ch. 620. 
tention is a design to commit some fraud, and leads men to do or omit doing something, not carelessly but for a purpose."

Lack of care is the more frequent signification of the word "negligence;" and the action of negligence is based upon that meaning of the term. Sir Frederick Pollock silys:"

"If a man will set about actions attended with risk to others, the law casts on him the duty" of care and competence. . . . Froin this rout we have, as a direct growth, the whole molern doctrine of nerligence."

We see, therefore, that when we speak of an action of negligence the word "negligence" is not used as synonymous with all breach of duty, but in the sense of carelessness in the discharge of some duty. If it meant all breach of cluty, the action of negligence would embrace the whole field of torts, and historically, of contracts also; whereas in reality it is an action for carelessness in the discharge of some duty merely. (Jur ideas would be clarified were we to use the terms "negligence" and "carelessness" to express respectively the two ideas; for at present we either risk misconception, or we have to explain, when using the word "negligence," in what sense it is employed. For example, Sir Frederick Pollock, aflirming that

"Culpe is exactly what we mean by "negligence," the falling short of the care and circumisection which is due from one man to another.".

". Thus we arrive at the generial rule that every one is bound to exerciso die care towards his neighbors in his acts and conduct, or rather omits or falls short of it at his peril "3 -

places "negligrence," in his classification of torts, as a subdivision of "Group C." " But negligence, in the wider sense of the breach of duty, would embrace all torts and not constitute merely a sublivision of them. Perhaps it would be better to confine nerrigence to the generic use of the word, and adopt carelessness for the specific subdivision.

Mr. Beren's book on "Negrligence," too, is not a survey of all the cases in which there is a breach of duty, as from its title one might expect, but is

"primarily occupied with considering defaults in conduct, and only secondirily with the alequate discharce of obligations. It deals with an aspect, not with a division, of law. A complete treatise on negligence in law

1 On Torts, 433.

2 On Torts, 17.

3 Page 353. "Negligence is the absence of care, accurding to the circumstances" Willes, J., in Vaughan v. Tilf Vale Ry. Co. (1s60), 5 H. \& N. 6ss; 29) L. J. Ex. 248.

4 Pollock on Torts, 7 . The cases treated of under that title are those which are embraced within the rule that "One who enters on the doing of anything attended with risk to the persons or property of others is held answerable for the use of a certain measure of cation to guard against that risk." Id. 353 
would be a commentary on the whole law of England from the standpoint of a non-fulfillment of legial duties, excluding only intentional wrongdoing." 1

Having thus determined that the action of negligence (or better, carelessness) is, in reality, but one of various elasses of actions for neglect of duty (that is of negligence), we may define carelessness, when it arises in connection with duty, as

"the omission to do something whicls a reasonable man, guided by those considerations which ordinarily regulate the conduct of human alfuirs, would do, or doing something which a prudent or reasonable man would not do." 2

Or, as put by Mr. Cooley:

"The failure to observe for the protection of the interests of another that degree of care, precaution and vigilance which the circumstances justly demand." 3

Estoppel by Carelessness. - We are now realy for the statement that estoppel by negligence means estoppel by carelessness - that is by

"the omission to do something which a reasonable man . . . would do, or doing something which a prudent and reasonable man would not do;" it being understood, of course, that such carelessness is in breach of some duty arising out of contract, relationship or otherwise.

Following the lead of Mr. Justice Lindley, ${ }^{4}$ then, and actuated by the considerations just referred to, estoppel by negligence will hereafter be referred to as estoppel by carelessness. The change will enable us to get rid of the idea that we are speaking of estoppel with reference to all breaches of duty. We are dealing with "an aspect, not with a division, of the law." 5

Misrepresentation. - Note next that in estoppel, carelessness is only important when it is associated with misrepresentation. Carelessness without misrepresentation may indeed give rise to an action for negligence. But for estoppel you must say that you were misled by some falsity, al.J that your opponent ought

$12 \mathrm{~d}$ ed. 3. Consider Austin's division into negligence, recklessuess, and heedlessness. Lecture $20, \$ 632$.

2 Per Alderson, B., in Blyth v. Birmingham (1856), 11 Ex. 783; 25 L. J. Ex. 213. And see per Brett, J., in Smith v. London, etc. Ry. Co. (18\%0), L. R. 5 C. P. 102; 39 L. J. C. P. 63. "There is no absolute or intrinsic negligence; it is always relative to some circumstances of tine, place or person." Per Bramwell, B., in Degg v. Midland Ry. Co. (1857), 1 H. \& N. 781; 26 L. J. Ex. 151.

${ }^{3}$ Cooley on Torts, 630. See Jag. gard on Torts, 810, n., $820,826$.

4 On Companies (5th ed.), 486.

5 Using "negligence" in its wider signification, every case of estoppel would be one of "estoppel by negligence," for there could in no cise be the penalty of estoppel unless there had been some breach of duty something wrong done. 
to be precluded from asserting the facts, because of lis action or inaction - that is, by the carelessness of which you complain.

P'rsonal and Assisted Misrepresentation.- The only other preliminary necessary to consideration of the main question is the observation of the distinction between personal and assisted misrepresentation. I hold myself out as a partner and am es. topped from denying membership in the tirm - that is personal misrepresentation. A mortgagree hands over the titledeeds to the mortgagor, who uses them as evidence of the truth of lis (the mortgangor's) representation of unineumbered ownership, and so misleads an innocent purchaser; and the mortgagee is estopped. But not, observe, because of any misrepresentation male by him, but because merely of the assistance which he has rendered to the misrepresentation of the mortragor be has furnished an opportunity for fraud, he has done that which has made the misrepresentation of another person credible. $^{1}$

Personal Misreprescntation.- Perusal of a previous chapter ${ }^{2}$ will leave little room for doubting that it is not in cases of this class that we are to look for instances of estoppel by carelessness. ${ }^{3}$ The assertion is not intended that every case of personal misrepresentation is the result of eril intent, and that there are no instances in which misrepresentation is not due to carelessness rather than to dishonesty. What is meant rather is that personal misrepresentation will estop, whether it is due to one cause or the other, and that consideration of "hnw the representation came to be made" - whether through careless. ness or intention - is therefore immaterial.

For example, a trustee of a fund, with a riew to deceive, rep-

I Waldron v. Sloper (1S5:), 1 Dr. 193; Fitrand v. Yorkshire, etc. (ISSS), 40 Ch. D. $18:$; 58 L. J. Ch. 238.

2 (h. VIII.

3 Manulacturers v. Hazard (1S61), 30 N. Y. 226. may appear to contridict this statement. An indorser of a note wrote his name so badly that the initial " M." looked like " A. C.," and he was held to be estopped by his carelessuess from denying notice of default, which miscarried be. cause of the defective autogralph. It may be said that the sender of the notice was misled by carelesiness, and that the estoppel was rightly aldudged. The case would be tho same if the mislealing was due to carelessness in oral communication; but it is preferabie to relemate : uch cases to the principle (ante, p. 15) that reasomableness of inference from stitements or conduct justi. fies action aceorling to such infer. ence, and will carry estoppel with it. 
resents that the fund is uncharged, and he is estopped from asserting otherwise. But if he had made the same representation in perfect good faith but carelessly (having for the moment forgotten), he would have been likewise estopped.' Again, were there both the presence of good faith and the absence of carelessness (which might happen in some cases by the misrepresenter being himself fraudulently misled), yet even in that case there would be estoppel.2 The element of carelessness, therefore, is immaterial where the misrepresentation is personal.

"The man who has made the misrepresentation, under whatever circum. stances, must bar the consequences of those representations, and nut the man who has trusted to the representations so made." 3

Assisted Misrepresentation.- It is in this class of cases then, if at all, that instances of estoppel by carelessness are to bo found. But hitherto the existence of the class itself has not been sufficiently recognized, nor has it till now ${ }^{4}$ received a distinguishing name; and it is therefore not matter for much surprise that that of which we are in search has not been with precision disentangled, nor its true affinities observed.

As in cases of personal misrepresentation, so also in those of assisted misiepresentation, the general rule regards merely the act done, and is entirely indifierent to the motive or reason for. it, or the earelessness or diligence that may be in it.

"Tlue rule is that if a man so conducts himself, whether intentionally or not, that a reasonable person would infer that a certain state of things exists, and acts on that inference, he shall be afterwards estopped from denying it." 5

For example, if a company were to issue a false certificate as to ownership of shares, upon the faith of which a third person changed his position, it would be estopped whether wrongful intent or good faith, carelessness or diligence underlay the act. $^{6}$ $4 \pi 0$.

${ }^{1}$ Burrowes r. Lock (180.j), 10 Ves.

${ }^{2}$ Per Lord Selborne in Bank of England r. Vagliano (I891), A. C. 123; 68 L. J. Q. B. 14.5; Ellis v. Schmoeck (1829), 5 Bing. 521; 7 L. J. Q. B. 231; Collingwood v. Berkeley (1863), 15 C. B. N. S. 145 ; Maddick v. Marshall (1864), 16 C. B. N. S. 387; 17 id. 899.

${ }^{3}$ Per James, L. J., in Hunter $v$, Walters (1871), L. R. 7 Ch. 85. And see per Lord Cairns in Reese v. Smith

(1869), L. R. 4 H. L. 64; 39 L. J. Cl. 849; and per Jessel, M. R., in Eaglesfeld v. Londonderry (18i6), 4 Cl. D. i04.

${ }^{4}$ This chapter in somewhat modified form was first published in The Law Quarterly Review, October, 1899.

${ }^{5}$ Cornish v. Abington (1859), $4 \mathrm{H}$. \& N. 556; 28 L. J. Ex. 262; West v. Jones (18.51), 1 Sim. N. S. 207.

${ }^{6}$ Re Bahia, etc. (1869), L. R. 3 Q. B. 
Close inspection, however, of the categrory of assistel misrepresentation will discover various lines of cases in which the operation of estoppel by carelessness may be observel. Not that the principles by which most of the cases have been decided have any relation to estoppel - indeed quite other principles and rules have been involied. Nevertheless the present writer believes that his ratio decidendi will be readily accepted, can he but clearly present it to the profession.

Acceptince unfortunately involves something of a bouleversement: to what extent it may be as well frankly at once to indicate:

1. Although no case of estoppel by carelessness has been discovered, yet there are many clisses of them; some passing at present under other designations and at least one existing in England by statute.

2. And there are others (one very notably), from which many courts have excluded all questions of carelessness; but which the present writer would leave in almost sole possession of the field.

1. Execution of Documents. - Opening the first class of cases in which estoppel by carelessness may be found, suppose that a man is tricked into executing a document which is afterwards by the knave passed on to an innocent transferee; who is to lose, and why?

The present law dividing the cases into roid and voidable documents (so much frand - amount very uncertain - and the document is voidable, more fraud and the document is altogether roid) declares that if the document be voidable only its creator must suffer; if it be voil the loss falls on the innocent, transferee. And the discussion for the most part expends itself upon distinctions between cases in which the dupe was deceived as to the actual contents of the document, and in others as to its legal effect; ${ }^{2}$ between cases in which the deception was as to the land affected by the locument, and in others as

58.1 37 L. J. Q. B. 176. And see eases cited with this one, chanter XX1I.

1 Kennedy v. Green (1S34), 3 M. \& K. 713; Vorley v. Cooke (1S5i), 1 Giff. 230; 27 L. J. Ch. 185; Ogilvie v. Jeaffreson (1860), 2 Giff. 353 ; $29 \mathrm{~L}$.
J. Ch. 905; Foster v. McKinnon (1869). L. R. 4 C. P. $704 ; 38$ L. J. C. P. 310 ; Iunter v. Walters (1si1), L. K. 7 Ch. s2; 11 L. J. Ch. 175.

2 Torley v. Cooke (185i), 1 Giff. 230; 2i L. J. Ch. 185; Herchmer v. Elliott (1S8i), 14 Ont. 714. 
to the disposition made of it, ${ }^{1}$ and so on. The character of the dupe, whether he is "layman or lettered;" 2 the character of the occasion, whether it was one "in which no extraordinary caution was necessary;" 3 and similar points are also referred to, but in order for the most part to ascertain whether the document is void or voidable.

Here and there, indeed, the applicability of estoppel is to be noted. For example, Mellish, J., in 1871 declared it to be "a doubtful question of law" whether the dupe "may not by executing it negligently be estopper ;" ${ }^{4}$ and Erle, C. J., in a case in which blank but executed transfers of shares were improperly filled up, said that although they were originally

“null and void, yet as between Swan and a purchaser . . . they may be valid to pass the property, if not directly yet indirectly by estopping Swan from setting up his right." 5

To the present writer the matter assumes the following form: No document obtained by misrepresentation (whether it be the vilest, the most complex, the most simple, or the most innocent) is bincling upon the dupe; its character remains constant (it cannot change), accompanying it into whatsoever remotest hands it may come; nerertheless, as against persons who have been led by the document to change their position, the dupe ought to be estopped from denying its validity. The authorities declare that negligence on the part of the dupe is an essential part of the case agrainst him. If so, then the estoppel occurs where carelessness exists, and we thus have an instance of estoppel by carelessness. ${ }^{6}$

2. Priorities. - Another class of cases may be typified by the mortgage case already referred to: A mortgagee hands over the title-deeds to the mortgagor upon some trumped-up excuse; and the mortgagor, fraudulently using them as evidence of his assertion of unincumbered ownership of the property, conveys it to an innocent purchaser. The present writer woukl say that in all such cases the mortgagee ought to be estopperl from setting up his title to the property. The decisions, however, distinguish between cases in which his conduct was

1 National v. Jackson (1886), $33 \mathrm{Ch}$. D. 1.

2 Thoroughgood's Case (1582), 2 Coke, $9 a$.

3 Ogilvie v. Jeaffr $\in \operatorname{son}(1860$ ), 2 Giff. 353: 29 L. J. Clı. 905.
4 Hunter v. Walters (1871), L, R. 7 Ch. 8:) 41 L. J. Ch. 175.

5 Swan v. N. B. A. (1859), 7 C. B. N. S. 431; 30 L. J. C. P. 113.

${ }^{6}$ See the subject treated at length in chanter XXV. 
reasonable and those in which it was negligent.' And thus again is there estoppel by carelessness.

But the principles usually applied in such cases are not those of estoppel. The rule that "possession of the deeds gives tho better equity" is that most usually invokel." Giffird, V. C., however, properly protests that mere possession of the deeds will not give priority.

"There must be some act or default on the part of the first mortgagee to have this effect." 3

And Fry, L. J., has deelared the law to be:

"That the court will postpone the prior legal estate to a suhsequent equitible estate when the owner has assisted in or connived at the fraud which has led to the creation of a subsequent equitable estate."

Estoppel is at the foundation of such language: the oivner of the first estate is first; but he is estopped from so saying.

3. It is no doubt the duty of every person - at the peril of estoppel - not to render assistance to the misrepresentation of authority to act for him which may be made by other persons. But what are we to say when a man does not intend to aid the misrepresentation, but nevertheless through carelessness does so? In a recent case ${ }^{5}$ it is said that

"ostensible authority to act as agent nay be conferred if the party to be charged as principal aflirmatively or intentionally or by lack of ordinary care canses or allows third persons to trust and act upon such apparent agency."

This is not couched in the langruage of estoppel, which would not say that "ostensible authority - . . may be conferred;" but that, there being ostensible authority, the ostensible principal is estopped by his carelessness from denying its real existence.

4. Maryland supplies us with the suggestion of another example. We shall see that there is some substantial ground for the opinion that bank customers are under obligation to examine their pass-books at the usual monthly balancing, and

I Evans v. Bicknell (1801), 6 Ves. 17t; Waldron v. Sloper (15.5), 1 Dr. 193: Clarke v. Palmer (1852). $21 \mathrm{Cl}$. D. 124; 51 L. J. Cl. 634; Newnan v. Newman (1885), 28 Ch. D. 674 ; 54 L. J. Ch. 598.

2 Goodtitle v. Morgan (175\%), 1 T. R. r6?; Layard v. Malud (186i5), L. R. 4 Eq. 397, 406: 36 L. J. Ch. 669; Spencer v. Clark (18Ts), 9 Ch. D. 142 ; 4 i L. J. Ch. 692: Lloytl v. Jones (1885), 29 Ch. D. $2: 29 ; 5+$ L. J. Ch. 931. s'riorpe v. Houldsworth (1868), L. R. T Eq. 147; 38 L. J. Ch. 194.

4 Northern Comnties r. Whipp (1884), 26 Ch. D. 494; 53 L. J. Ch. 6:9.

5 Thomplson v. Sikelton (1S96), 49 Neb. 64t: 68 N. W. R. 10\%. See also IIolt v. Schneider (1S99), 7i N. W. R. 1056 (Neb.); Lester v. Snyder (1S9s), 55 Par. R. 615 (Colo.): Colo. Civil Corle. \$2300: IIeald v. Henley (1591), 89 C.al. 63:; 2r Pac. R. 6r. 
then to make known their objections. ${ }^{1}$ Sometimes forged checks. are paid by bankers, and the customers to whom they are charged, after permitting their accounts to be balancel from time to time without troubling tha $m$ ielves with their veritication, finally refuse to be debited with the forgeries. In such a case ${ }^{2}$ it was held that it should have been left to the jury

"to find either that the appellants had knowledge in fact that the forgeries had been committed. or that from carelessness and indifference to the rights of others they failed to inform themselves from sources of information readily accessible to them, and which by the exercise of ordinary diligence as business men would have disclosed to them the fact that the forgeries had been committed."

5. Termont suggests still another case. The owner of land stood by while a house was built on his property by the adjoining proprietor, but he did not know that it was upon his side of the boundary. Held, that be had been guilty of

"such gross carelessness and indifference to the rights of others that would estop him from setting up title in himself." 3

The court does not seem to have been so much impressed as is the present writer with the gross carelessness of the builder of the house. Had the holding been essential to the decision of the case the point might have received closer consideration.

6. For a further class of cases we are indebted to legislation. Suppose that a shipowner issues a bill of lading for goods not shipped, and that the bill is transferred for value to a bona fide purchaser; who should lose, the signer of the bill or the purchaser of the goods? Our general rule ${ }^{4}$ wonld condemn the signer "whether intentionally or not" he led the purcbaser to infer the existence of the groods. By statute, however, "the master or other person signing may exonerate himself in respect of such misrepresentation, by showing that it was calused without any defitult on his part, and whilly liy the fault of the siipper, or of the holder, or some person under whom the holder claims." 5

In the United States authorities differ, but probably the weight of them is in favor of the proposition that the ship. owner will be estopped by signing a false bill of lading whether he was careful or negligent. ${ }^{6}$ In England the estoppel is founded upon carelessness.

1 Devaynes v. Noble (1815), 1 Mer. 536. And see cases cited with this one in ch. XI.

${ }^{2}$ Hardy r. Chesapeake (1879), 51 MId. 562.

${ }^{3}$ Greene v. Smith (1831), 57 Vt. 268.
4 Ante, p. 103.

318 and 19 Vic. (Imp.), ch. 111, § 3 ; 52 Vic. (Cin.), ch. $30, \$ 3$.

6 Porter on Bills of Lading, \$\$ 432- 
7. Bills and Notes.- The Engrish authorities ${ }^{1}$ have excluded all questions of carelessiess from a class of cases in which there is strong minority opinion for asserting that it ought to play a most important part. Accorling to the decisions the acceptor of a bill may leave spaces in it which would tempt the virtue of many an one who would shrink from bolder feats of forgery ${ }^{2}$ he may attach conditions in lead pencil, or upon marginal spaces, and if they are rubbed out or cut off throw the ensuing loss upon the shoulders of the innocent purchasers of them $;^{3}$ and he may leave signed notes or executed blanks where they may easily be picked up, and swear that he did not think that any bolly would avail himself of them;

"and that, too, though the acceptor or maker may have made the theft or fraud easy by putting the pilper in an unlocked drawer in a desk to which clerks and servants and others had access." 4

There is, no doubt, the case of Young v. Grote, ${ }^{5}$ in which the duty of carefulness as to tempting spaces is imposed upon the drawer of a eheck; and the case of Ingham v. Primrose, ${ }^{6}$ according to which if you wish to destroy your acceptance you ought to do it effectively, and not merely by tearing it in half, which would give it the appearance of separation for safe transmission merely; but these cases are far from baring that subsequent sanction which the present writer could wish them. There are also some comforting cases in the Pennsylvania courts. ${ }^{7}$ The majority opinion, however, is that of Lord Inalsbury: ${ }^{8}$

"People are not supposed to commit forgery ... the protection against forgery is not the vigilance of parties exchuling the possibility of committing forgery but the law of the lasd."

The present writer, bearing in mind the general rules relating

1 See all the cases discussed in chapters $\mathrm{V}$ and $\mathrm{XXV}$.

2 Scholfield v. Londesborough (1894), 2 Q. B. 660; (1895) 1 Q. B. 536; (1896) A. C. $514 ; 63$ L. J. Q. B. $649 ; 64$ id. 293 ; 65 id. 593 .

3 IHarvey v. Smith (1870), 55 Ill. 224; Zimmerman v. Rote (1874), 75 Piı. St. 188; Cochrane v. Nebeker, 48 Int. 459; Walsh v. Hunt (1898), 120 Cal. 46; 52 Pac. R. 115; Swaisland v. Davidson (1883), 3 Ont. 320.

1 Bigelow on Bills and Notes, 177.
5 (1897) 4 Bing. 253; 5 L. J. C. P. 165; 12 Moo. 484.

${ }^{\circ}(18.59)$ 7 C. B. N. S. 82 ; 28 L. J. C. P. 294.

7 Brown v. Reed (1875). 99 Pa. St. 3r0; Leas v. Walls (184:), 101 Pa. St. 57; Robb v. Pennsylvania, etc. (1898), 40 Atl. R. 969.

8 Scholtield v. Londesborough (1896), A. C. $532 ; 65$ L. J. Q. B. 601. See the matter fully discussed in ch. V. 
to social relations, would rather agree with Mr. Justice Blackburn and others who hold that

"The person putting in circulation a bill of exchange does by the law merchant owe a duty to all parties to the bill to take reasonable precautions against the possibility of fraudulent alterations of it." l

Were this the law, then breach of it would furnish a clear case of estoppel by carelessness. For we would have to say, not that the forged aceeptance was that of the defendant, but that by his carelessness he was estopped from denying it.

\section{The Leading Cases.}

Passing on to consider the rules framed for estopnel by negligence, a short statement of the facts in the two leading cases and a citation of the rules in judicial language will be of advantage.

1. (1S55) Bank of Ireland v. Evans. ${ }^{2}$ The secretary of a company having been allowed the custody of the seal fraudulently affixed it to powers of attorney for the transfer of bank shares owned by the company. In an action between the company and the bank, which had acted upon the transfers, Parke, B., saicl:

"It is clear, we think, that the negligence in the present case, if there be any, is much too remole to affect the transfer itsell and to cause the trustees to be parties to misleading the bank in making the transfer on the forged power of attorney . . We concur with Mr. Justice Jackson and Justices Ball, Compton and Towns, and the Chief Justice Leroy. iu thinking that the negligence which would deprive the plantiffs of their right to insist that the transfer was invalid must be negligence in or im. merliat ly connected with the transfer itself." 3

2. (1859) Ex parte Swan; ${ }^{4}$ (1862) Swan v. North British A. Co. ${ }^{5}$ The owner of shares in two companies, A. and B., employed a broker to sell those in A. and gave him ten executed transfer forms in blank. The broker fraudulently used two of

1 Swan v. North British (1869), $2 \mathrm{H}$. \& C. 15:3; 3:2 L. J. Ex. 277. The present writer would not, however, in. voke the law merchant. See post, ch. XXIV.

25 H. L. C. 289 . See a similar case, Merchants, etc. v. Bank of Encrland (185i), 21 Q. B. D. 160; 5 i. J. Q. B. 418. But see Shaw v. Port Philip (1984), 13 Q. B. D. 103; 53 L. J. Q. B. 369.

${ }^{3}$ Lord Esher thought that Parke, B., meant by "immediately connected with the transfer itself" something almost equivilent to "in the trans. fer itself," and he said "that the way to construe it is that the negligence must he proximately connected with the transfer itself." Merchants, etc. v. Bank of England (1887), 21 Q. B. D. 172 .

47 C. B. N. S. 400 ; 30 L. J. C. P. 113.

57 H. \& N. 603; 2 H. \& C. 175; 31 L. J. Ex. 42J; 32 L. J. Ex. 273. 
them to transfer the P. company shares, stealing the certificates to enable him to accomplish his purpose. Company I3. acted upon these transfers, and in the action between it and the original owner of the shares it was held that the owner was not estopped from denying the execution of the transfer. Baron Wilde, in the Exchequer, formulated a rule as follows:

"That if he has led others into the belief of a certain state of ficts by conduct of culpable neglect, cialenlated to hiave that result, and they hiare acted on that belief to their prejudice, he shall not be heard af terwards, as against such persons, to show that that state of facts did not exist."

Upon appeal ' Blackburn, J., referring to Baron Wilde's language, said as follows:

"This is very nearly right, but in my opinion not quite, as he omits to qualify it by saying that the neglect mist be in the transuction atself and be the proximate cause of the leading the party into that mistake; and also, as I think, that it must be the neglect of some dluty that is owing to the person leal into that belief, or, what comes to the same thing, to the general public of whom the person is one. ${ }^{2}$ and not merely neglect of what would be prudent in respect to the party himself or even of some duty owing to third persons with whom those seeking to set up the estoppel are not privy."

Rules.-Summarized from the principal cases, then, ${ }^{3}$ the rules may be stated as follows:

1. There "must be the nerlect of some duty that is owing to the person led into that belief."

2. "The neglect must be in the transaction itself."

3. "The omission must be the proximate cause of the leading of the person in to the mistake." 4

Let us now look at the criticisms of these rules by the principal text-writers:

Mr. Bigelow's Criticism. - Referring to these rules, MIr. Big. elow says: ${ }^{5}$

"It is clear. however, that cases of estoppel arising out of negligence without a ripresentation must be uncommon. They cannot fall within

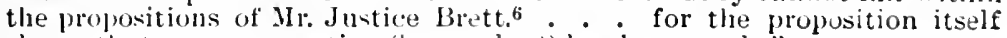
shows that a representation (by conduct) has been made."

I 2 H. \& C. 181: 32 L. J. Ex. $2 \pi 3$.

2 The learned julge illustrates this point by reference to the case of the maker of a blank note which he intends to be filled up "and delivered to a series of holders."

${ }^{3}$ Bank of Ireland v. Evans (19.5,5), j H. L. C. 931; Ex parte Swan (1859), 7 C. B. N. S. $400 ; 30$ L. J. C. P. 113 ; Swan v. N. B. A. Co. (1S62), T II. \& N. 603; 31 L. J. Ex. 42J; 2 II. \& C:
175; 32 L. J. Ex. 273; Carr v. London (1873). L. R. 10 C. P. 307; 44 L. J. C. P. 109: Scholfield v. Londesborough (1894), 2 Q. B. 660; (1595) 1 Q. B. 536 ; (1\$96) A. C. 514:63 L. J. Q. B. 649; 64 id. 293: 6.5 il. 593.

4 See Scollans v. Rollins (1599), 53

N. E. R. S6.3 (Mass).

${ }^{5}$ On Fstoppel (5th ed.), 653, 654.

'In Caltr v. London, supra. 
Mrr. Bigelow seems to be in search of some instance "of estoppel arising out of negligence without a representation;" and he appears to assume that the rules were formulated for cases of that sort." This is the more remarkable because he observes that the cases in which the rules were formulated "cannot fall within the proposition of Mr. Justice Brett, . . . for the proposition itself shows that a representation (by conduct) has been made." Inasmuch, then, as the cases themselves involved a representation, it would be extremely improbable that the rules framed by them should hare been intended for cases in which there was no representation; more particularly when, as is asserted, it is extremely dilficult to find such a case.

The solution of Mr. Bigelow's difficulty lies in the difference between personal and assisted mispepresentation, without regard to which it may be said with equal truth that there may or may not be estoppel by carelessness without misrepresentation. We may say first that there can be no estoppel of any lind unless there has been some misrepresentation - that is, unless the estoppel-asserter has by somebody been deceived. Some fact must be misrepresented before there can be estoppel against the assertion of that fact. But we may also say that there may be estoppel by carelessness without misrepresentation-by the estoppel-tenier. In other words, there may be estoppel by carelessness where the misrepresentation is that of a third person; that is, in cases of assisted misrepresentation.

Not being able to find a case of "Estoppel by Negligence," Mrr. Bigelow imagines one: ${ }^{2}$

"Let it be supposed that a man has been fixed with constructive notice, which by reason of his neg.igence has not become knowledge to him, of the existence of some right in his favor; that this right is, to his knowlexlre, about being disposed of by another as that other's property; and that it is so disposed of to a purchaser for value. without notice of the right, and in the absence of the negligent party. Here would be a case of negligrence which could hardly be treated upon the footing of a representation; but wouhl not an estoppel arise, supposing all the other elements of it present?"

But the case is clearly one of misrepresentation - misrepresentation by a third party. The vendor is posing as owner of property in which the estoppel-denier bas some interest; that

1 See the whole context, 653, 654. tempted to he set up. . . . The Righam, J., too, thought with Mr. present case is one of estoppel by Bigelow. He said that Swan v. representation." Union v. Mersey Nurth British was a case "in which (1899), 2 Q. B. 210; 68 L. J. Q. B. 842. estoppel by negligenre was at- 25 th ed. 654 . 
is to say, the rendor is representing that he is the absolute owner, whereas he is not. And the question is, Whether the bystander is, or is not, estopped by the assistance rendered to that misrepresentation by bis silence? The very foundation of the complaint is that the purchaser was misled.

Moreover it is far from clear that the case is one of estoppel at all. Strengthening the case for estoppel, let us assume that the bystander's conduct is to be taken as an actual representation by him (in aldition to the misrepresentation of the vendor); the question will then be, What was the representation that he malle? Was it a representation that he hall no right; or merely that he did not, at the moment, know of any? If the latter, then all he would be estopped from asserting wonld be that at that time he did know of his right. If he had in words asserted that he did not at that time know of any rights, he woudd not have been estoppel from asserting that he had subseguently discorered them. IIis conduct cannot be talien to mean more than that. ${ }^{1}$

Mr. Cababé's Criticism. - Mr. Cababé's criticism of the rules ${ }^{2}$ follows that of Mr. Bigelow, but improves upon it:

"It appeirs to have been hardly sufficiently noted that the conditions to be complied with hefore conduct can be male the foundation of the es. toppel, by reason of its being negligent, are of such a character as to wellnigh eliminate 'estoppel by negligence' as a sepatrate head; or in other words, that negligent conduct is only allowed to give rise to in estoppel in cases in which the conduct would give rive to the estoppel, even thongh it were not negligent. Yet this is clearly the case if it be true that for conduct to be the proximate calue of lealingr a party to believe in the existence of a state of lacts, such conduct must amount to a representation of those facts. It may be going too far to say that, in the nature of things, there can be no such cases; if so it will suffice to sily that negligence can only lar ve any specific efficacy in giving rise to an estoplen, in those ralre cases in which it proximately causes another to believe in the existence of facts, although it (the negligence) does not amount to a representation of those facts."

Mr. Cababé describes the sitnation necessary for estopleel by carelessness with very considerable accuracy in his last sentence, and considering that he had no concrete case in riew the language is singularly fortunate. Observe how completely it fits the cise of assisted mispepresentation (already sugyested), in which the mortgrigee allowerl the mortgargor to have the deens with the aid of which he posed as mineumbered owner of the property. Here the delivery of the deeds " proximately" eanses

1 Wilmott v. Barber (1880), 15 Ch. Robinson v. Nail (1899), 52 S. W. R. D. 96 ; 49 L. J. Ch. 792; Low v. Bouverie (IS91), 3 Ch. 8:; 60 L. J. Ch. 594; 2On Estoppel, 100, 101. And see 97. 
another to believe in the existence of facts (namely, unincumbered ownership), although it (handing over the deeds) does not amount to a representation of these facts." Such cases are by no means rare: they are legion.

But Mr. Cababé's language is somewhat too inclusive, as another of his sentences suggests. For there are many cases within his deseription (widle enough for all eases of assisted misrepresentation) which could not be said to be cases of estoppel by carelessness; because in them the conduct would have given rise to estoppel, "even though it were not negligrent" - cases therefore in which the presence or absence of negligence is altogrether immaterial; cases within the general lule which "regards the act done, and is entirely indifferent to the motive or reason for it, or the carelessness or diligence that may be in it." 1 Estoppel by carelessness is not coextensive with estoppel by assisted misrepresentation, although included in it.

We are now prepared for an examination of the rules.

\section{Rute No. 1.}

"There must be the neglect of some duty that is ouing to the person misled."

This rule is undoubtedly valid, but it cannot be limited to any class of cases - to cases of personal, or assisted, misrepresentation, or to cases of estoppel by carelessness. For it is impossible that there can be estoppel of any kind unless there be a breach of some duty to the person misled. To say otherwise would be to affirm that the penalty of estoppel should be inflicted upon a person who had acted quite properly. The rule itself is indisputable; but it is not one applicable to estoppel by carelessness only.

\section{Rule No. 2.}

"The neglect must be in the transaction itself." 2

It is in cases of assisted misrepresentation alone, as we have seen, ${ }^{3}$ that we are to look for instances of estoppel by careless-

1 Ante, p. 102.

2 This rule having been so frequently approved, it requires the courage of strong conviction to criti- cise it. See Agricultural v. Federal (18s1), f Ont. App. 200.

3 Ante, pp. 101, 102. For cases of personal misiepresentation the rulo 
ness: and yet it is not too much to say that it is impossible to find a case of ausisted misrepresentation in which the carelessness can, witl any accuracy, be said to be "in the transaction itself."।

Various cases have already been noted in which carelessness is a ground of estoppel, but in all of them, as if to despite the rule, the carelessness was not and conld not be "in the transaction itself:" (1) A man, owing to his carelessness, is tricked into executing some document, or (2) a mortgagee without reasonable exeuse hambs over to the mortgagor the title-deeds; afterwarls the document or the deeds are fraudulently passed on to an innocent purchaser; and the signer of the document or the mortgingee is estopped. Now "the transaction itself" took place between the knave and the purchaser, while the carelessness wits prior to that, namely, in the execution of the document, or the delivery orer of the deeds by the estoppeldenier.

And the same remark is true of all cases of assisted misrepresentation (the only class in which there ever is estoppel by carelessness); for in them it is always impossible that the carelessness can be in the transaction itself. Observe that in that elass of cases the estoppel-denier (the person charged with the carelessness) is never even a party to "the transaction itself." IIe is estopped because he has afforded opportunity or occasion for the transaction, which is brought about by the misrepresentation of some other person - estopped because he has done that which was necessary to make the misrepresentation credibio; not because he has made the misrepresentation himself, or indeed knew any thing about it.

The carelessness may possibly be subsequent to the transaction, eren as it may be prior to it, although it cannot be in it. For example, were a forged note discounted by a banker. and were the person whose name was forged carelessly to remain

which most nearly approaches the one in hanil is that the estoppeldenier must have had reasonable grou:d for supposing that the representation would be acted upon.

1 This statement would justify. Ir. Cabalie's remark "that the conlitions to be complied with before conduct can be made the forndation of the estoppel, by reason of its being negligent, are of such a character as to well-nigh eliminate "Estoplel by Negrigence' as a separate head;" but not for the reason which he gives (sce ante, p. 111). 
quiescent, not alvising the banker of the forcery until after the banker's position had been changed, he would be estopped.' In such cases it is, of course, impossible to say that the carelessness was in the transaction itself.

Conclusions. - We have thus reached the following conclusions: that there are no cases of estoppel by carelessness under the heading personal misrepresentation (in that department the question is not as to the state of mind of the estoppel-denier, but whether he had reasonable ground for supposing that his representation woul( be acted upon); that among cases of assisted misrepresentation there are instances of estoppel by carelessness; that in none of them, however, is the carelessness in the transaction itself; nor is it possible for it to be so; it always either precedes the transaction or is subsequent to it. The only alternative to this assertion is to say that, in the instances given, the carelessness was "in the transaction itself." But to so say is to affirm that which our leading cases ${ }^{2}$ deny; for in them (parallel cases of assisted misrepresentation) the alleged carelessness was said not to be "in the transaction itself," and for that reason it was held that there was no estoppel. ${ }^{3}$

1 McKenzie v. British Linen Co. (1881), 6 App. Cas. 82; Cairncross v. Lorimer, 3 Macq. 8:27,830; Merchants' Bank v. Lucas (185i), 13 Ont. 520; 15 Ont. $\Lambda$ pp. $573 ; 18$ S. C. Can. 705. Distinguish between ratification and estoppel in such cases: Scott v. Bank of N. B. (1894), 23 S. C. Can. 287; Fo:syth v. Day (1858), 46 Me. 196. See ante, 1. 106.

2 Ante, p. 108.

3 There is a certain ambiguity in the phrase "in the transaction itself" which in Coventry v. Great Eastern Ry. Co. (1883, 11 Q. B. D. 7\%6; 52 L. J. Q. B. 694) was made use of to overcome the application of the rule. A railway company (through carelessness) issued two delivery orders for the same goods and the plaintiffs allvanced money upon the faith of the second of them to its holder. Brett, M. R., said: "Then was the negligence of the defemlant the "proximate' cause of the loss sustaine.l hy the plaintiffs? I use the expression 'proximate cause as meaning the 'direct and inmediate cause.' Here the production of the document was the direct and immediate cause of the adrance of the money." And the learned judge held the case to be within the rule-that the negligence was in the transaction itself. But distinction is here overlooked be. $t$ ween the negligence in issuing the certificate, which was the act of the company, and "the production of the document," which was the act of its lolder. The learned judge says that "the production of the document" was the direct and immediate cause, etc. Granted. Then the negligence was not. The negligence was not "in the transaction itself," but in a document executed prior to the transaction, which another person made fraudulent use of, and yet the company was estopped. The same reasoning applied to the Swan case would vary its result. 
Let us look again at these eases, and see what, with their belp, we can make of the rule in hand.

In the Bank of Ireland $v$. Evans case, ${ }^{1}$ the secretary of the company fraudulently alfixed its seal to a transfer of shares, and sold them to an innoeent purchaser. The company was not estopped because its carelessness in trusting the seeretary with the seal was "not in the transfer itself." Very well. Now reeall the mortgage case, in which a mortgagee, who allowed the mortgagor to have possession of the title-deeds, was estopped as against an inmoeent depositee - was estopped although his carelessness in trusting the mortgagor with the cleeds was not "in the transaction itself, but prior to it."

In the one case the company intrusts its seal to its secretary; the secretary makes fraudulent use of it; and the company is not estopped. In the other a mortgagee intrusts bis titledeeds to his mortgagor; the mortgagor makes fraululent use of them; and the mortgagee is estopped. It seems to be suficiently clear that any distinction between these cases is not to be found in the fact that in one of them the carelessness was in the transiction itself and in the other that it was not; and that the point of difference (if there be any) must arise from a comparison of the conluet of the estoppel-cieniers-by the conclusion that the company in intrusting its seal to its secretary was not guilty of carelessness at all (for the seal must be intrusted to somebody); but that a mortgagee cannot quite so easily justify his unnecessary and unusual conficlence in his mortgangor. In other words, that there is not in the one case, but there is in the other, something done "which a prudent and reasonable man would not do" — that is, some carelessness.

Turning now to Swan's case, note that he was not estopped for the reason that his carelessness in executing the blank transfers and giving them to the broker was not negligence "in the transaction" between the broker and the innocent purchaser. Vary the case a very little. Suppose that Swan, when giving to the broker the blank transfers, with instructions to sell the A. Company shares, had also given him, not only the A. Company certificates, but also (as custodian merely) the B. Company certificates. There is very little doubt that 
Swan would now be estopped, for he has perfectly equipped his broker for fraud.' But his negligence can no more be said to be "in the transaction itself" now than it was before. In this case also, then, it cannot be said that the absence of estoppel was due to the carelessness not being "in the transaction itself." The question again would be one of reasonable care reasonable to hand over blank transfers if you retain the certificates, but unreasonable to band over both. The question of in, or out of, the transaction seems to be quite irrelevant.

The present writer by no means agrees that there was no carelessness in the Bank of Ireland $v$. Evans case. Upon the contrary, he adopts the language of Day, J., in a subsequent case: ${ }^{2}$

"The grossest negligence seems to have accompanied this confilence, because, notwithstanding all the warnings which most men experienced in the affairs of the world have had. that no man is to be trusted without the exercise of reasonable care by those who have to look after the affairs of other people, it seems to have been thought that the common seal and the affairs of the company might be intrusted to their clerk without any check or superintendence of any sort or kind being exercised over him by the corporators or any of the officials of the company. One can scircely imagine a case of grosser negligence than the negligence of all connected with the affairs of this company in their dealings with their clerk. It is not for me to suggest that every clerk, or any clerk, is to be suspected of evil doing, but it is idle to talk of the absence of necessity for exercising due and reasonable care over the officers of any corporate or other body. A person who was looking after his own affairs would take very good care to see that his seal, if it himl any value, was looked after; but here a corporate body, who can only speak and act by its common seal, are content, one and all. to intruse the common seal to an ufficer over whom they exercise not the slightest superintendence."

If this criticism be just, and if for estoppel it be not neces. sary that carelessness should be in the transaction itself, then the Bank of Ireland v. Evans case should have been otherwise decided.

Swan in his cases seems to have been freed from the charge of carelessness because of his retention of the certificates, without which it was thought the blank transfers would be useless. With that reasoning no fault is at present found.

Iicsult and its Explanation.-Our reasoning has produced the extraordinary result that a rule so well established, de-

1 The judgments largely turn upon the fact that the broker had to steal the certificates in order to perpetrate the fraud, and that therefore Swan had a string to lis blank transfers. And see Colonial Bank v. Cady (1890), 15 A. C. 297; 60 L. J. Ch. 131; Marsh- all v. National (1892), 61 L. J. Ch. 465 ; Pennsylvania Railway Co.'s Appeal (1878), 86 Pa. St. 80.

2 Mayor, etc. v. Bank of England (1887), 21 Q. B. D. 162; 57 L. J. Q. B. 418. 
fined and explained as the one in hand is quite impossible of application. An investigation of its origin will unravel the mystery, and reveal the fact that inattention to a somewhat palpable distinction was responsible for the confusion.

Foung $v$. Grote, "that fount of bad law," ${ }_{2}$ was at the bottom of the trouble. A drawer of a check left spaces in it, which were fraudulently made use of to raise the amount of it, and it was held that the drawer, because of his carelessness, and not the banker, must lose. The earelessness was in the drawing of the check - in the document itself.

Then came Bank of Ireland v. Evans, ${ }^{3}$ in which the secretary of the company fradulently applied its seal to certain transfers of shares. The company was not estopped because (per Parke, B.)

"the negligence which would deprive the plaintiff of his right to insist that the transfer was invalid must be negligence in or immediately con. nected with the transfer itself. Such was the case of 5 oung $v$. Grote."

Note that the learned Baron does not say "in the transaction itself," but in "the transfer itself," that is, in the document of transfer. In other words, the negligence must not be merely in leaving a seal in the hands of a secretiry - that is too remote-but in the transfer itself. He distinguishes between Young v. Grote, in which the neglect was in the check itself, and the case in hand, in which it was not "in the transfer itself," but in learing the seal with the secretary.

Shortly afterwards came Suan v. N. B. $A$., in which the broker used the executed but blank transfers to assign shares which he had no authority to deal with. Here now was a case in which, if there was any negligence at all, it was "in the transfer itself," that is, in leaving blanks in the transfer. The court hell, however, that there was no estoppel notwithstanding the blanks; that is, notwithstanding that the neglect was "in the transfer itself." The previous rule, therefore, had to be changed, and it was said "that the neglect must be in tho transaction itself." s

1 (1S2\%) 4 Bing. 253, 12 Joore, 484; 5 L. J. C. P. 16.5.

2 So Esher, M. R., in Scholfield v. Londesborough (1895), 1 Q. B. 536; (it J. J. Q. B. 293.

${ }^{3}(1555) 5$ H. L. C. 389.
( $(1 S 59) 7$ C. B. N. S. $400 ; 30$ L. J. C. P. 113; (186:) 7 H. \& N. 603; 31 L. J. Ex. 425: (1563) 2 H. \& C. 175 ; 32 L. ย. Ex. 273.

5 It was made still more definite afterwirls in Carr v. London (18ij, 
But so to say was entirely to alter the rule and create one that would apply in cases to which Baron Parke had no idea of extending it. It is clearly one thing to say that where a fraud has by some knave been perpetrated by the help of some document, the ostensible signer of the paper is not estopped unless he has been careless with regard to it (which was the ground of distinction between Young v. Grote and Bank of Ireland $v$. Evans); and quite another thing to say that for estoppel by carelessness the neglect must be in the transaction between the knave and the innocent purchaser. It is completely to change the period and place at which the carelessness is required to appear, and to transfer it from the document and its execution (if there be a document in the case) to some fraudulent transaction in which it was subsequently used by some other person.

The change was unconscionsly made. The ambignity of the word "transfer" was not observed. Baron Parke intended by it the document of transfer, but he has been taken to have used it in the sense of the transaction by which the transfer of the shares had been accomplished. ${ }^{1}$

Observe the effect of the amendment of the rule upon some of the cases of estoppel by carelessness. We have seen that a man who, through his own negligence, is tricked into signing a document, may be estopped by it as against an innocent purchaser. This is quite in harmony with Baron Parke's rulethe negligence is in the clocument itself. But according to the amendment there coukl be no estoppel because the negligence was not "in the transaction itself," that is, in the subsequent transaction between the knave and the innocent purchaser.

The effect is still more marked in the mortgage case. To it Baron Parke's rule has no application whatever, for it is not a case in which there is a document with which to connect negligence. And again, the amendment would reverse well-settled decisions; for the mortgagee's carelessness in handing over the deeds to the mortgagor cannot possibly be said to be in the

L. R. 10 C. P. $307 ; 44$ L. J. C. P. 109), it which it is said that the negligence must be "in the transaction itself uhich is in dispute."

1 See how the phrase "in the transaction itself" is held down to the final act and is denied to extend to the negligence which prepared the way for that act, and made it pos. sible: Saderquist v. Federal Bank (1889), 15 Ont. App. 615; Agricultural v. Federal (1881), 6 Ont. App. 200. 
subsequent transaction by which the mortgagor pledges tho deeds to an innocent depositee.

Analogy from Law of Torts.- If the point that the rule in hand cannot apply to eases of estoppel by assisted misrepresentation has not been made sulficiently elear, a reference by way of analogy to the law of torts will supply the defect. Suppose that in carelessly handling some explosive I discharge it and wound a neighbor; I am liable; the carelessness was in the transaction itsell, and the ease is onc in which I have personally infleted the injury. Suppose again that I had so carelessly packed and labeled an explosive that a carrier in handling it with accustomed care discharged it and injured some people; I should again be liable, ${ }^{1}$ although I did not personally inflict the injury, and although the carelessness was not in the transaction itself. The negligence was in the previous packing and labeling (as in the Swan case it was in the previously prepared document); it was not in the explosion, although the explosion was reasonably consequent upon the carelessness (just as in the Swan case it was not in the broker's transaction, although that, in order to estop, would have to be reasonably consequent upon leaving blanks in the transfer).

That negligence must be in the transation itself will not answer as a rule in torts, nor will it in estoppel, which in many of its aspects is very closely allied to tort.

\section{Rule No. 3.}

"The neglect must be the proximate eause of the leading of the person into the mistulie."

We have arrived at the conclusions (1) that it is among cases of assisted misrepresentation only that we ean find instances of estoppel by carelessness, and ( 2$)$ that in such cases it is impossible that the carelessness can be "in the transaction itself." And we are now to see that the present rule is also an impossible one, for" "the neglect" in catses of assisted misrepresentation never can "be the proximate eatuse of the leading of the person into the mistake." There is always interposed the misrepresentation of some third person. In fact the word "prox-

1 Farrant r. Barnes (1862), 11 C. B. N. S. 553; 31 L. J. C. P. 137. 
imate" has been felt to be altogether inappropriate, and proposal has been made to change it. Said Lord Esher: ${ }^{1}$

"I think I should prefer to insert in the proposition the word 'real' in. stead of the word "proximate."

And Lopes, L. J., agreed with him. But Fry, L. J., said:

"I do not feel sure that the term 'real' is any more free from difficulty than the term "proximate."

With this last the present writer agrees. Neither word is applicable for the reason alrealy given. "Proximate," the carelessness and the result can never be (in the line of cases in hand)." And there is no single "real" cause, but always two canses. In the mortgage case the innocent purchaser was deceived by (1) the misrepresentation of the mortgagor that he was the unincumbered owner; and (2) by the mortgagee's assistance in handing over the deeds. In Swan's case (as amended for purposes of illustration) the innocent purchaser was deceived by (1) the misrepresentation of the broker, and (2) the assistance of Swan, who executed the blank transfers and handed over the certificates. In both of these, and in all other such cases, there are two efficient or real causes, and the negligence is not the proximate one.

If the word "proximate" is to be retained at all, it must be in some such sentence as that of Keating, J., in the Swan case. ${ }^{3}$ We must not say, as abore, that

"the neglect must be the proximate cause of the leading of the person into the mistake;"

but with Keating, J.:

"The negligence directly and proximately enabled the broker to effect the transfers;"

altbough the sentence is not a fascinating one.

But for the fact that it is difficult to think in such cases as those in hand of two proximate causes, ${ }^{4}$ there would be less objection to the following:

"Where $t$ wo efficient proximate causes contribnte to an injury, one who,

1 Seton v. Lafone (1887), 19 Q. B. D. $71 ; 56$ L. J. Q. B. $415 ; 19$ Q. B. D. 74. But see the L. J. report, p. 417 .

2 The witer is not unmindful of a criticism of Lopes, J., in Scholfield v. Londesborough (1895), 1 Q. B. 5.52: "It might as well be said that . . . when a sack fell from a house and injured a passenger in the street, through the negligence of the de- fendant's servants, that the sack was the proximite cause of the injury, and not the negligence." In the cases referred to in the text there is an intervening and independent act, of a new actor.

${ }^{3}$ Swan v. N. B. A. (1863), 2 H. \& C: 175: 32 L. J. Ex. 273.

4 Cold and humidity may be two proximate causes of rain; but it is 
by his own negligent act, brourht about one of such causes, is liable for the in jurious consequences risulting therefrom." 1

Upon the whole the present writer suggests that the word "proximate" should be discarded, and offers as a substitute for the rule under consideration the requisite that

" the estoppel-asserter's change of position must have been reasonably con. seguent upon the carelessness;"

to the elucidation of which a chapter will be devoted.?

Observe the distinctions between the two rules - the one under discussion and that suggested. Orthodoxy requires that the negrlect should be the proximate cause of the mistake; lout such close association is, as we have seen, impossible. Innovation demands merely that one thing should have been reasonably consequent upon the other. Another alteration is perhaps more verbal, althongh not without substantiality. It suggests that it is the change of position, and not merely the change of thought (some mistalie), that has to be reasonably consequent upon the carelessness.

\section{Summarr.}

The result of the foregoing considerations is as follows:

(1) There can be no estoppel without misrepresentation; there can be no such thing as estoppel by carelessuess unless some one bas been deceived.

(2) It is not, however, at all necessary that the person said to be estopped by the carelessness should have himself male the representation, or should have been in any way a party to it.

(3) Upon the contrary, estoppel by carelessness nerer arises where the misrepresentation is chargeable to the careless party. That would be a case of personal misrepresentation; and in such cases estoppel would ensue whether there was carelessness or not.

(4) It only arises where the carelessness is by one person and the misrepresentition by another; that is, in cases of assisted misrepresentation.

(5) Rule No. 1: "That there must be neglect of some duty

not quite so clear that in Swan's case it would be correct to say that the broker's fraud and Swan's negligence were both proximate causes of the injurv dowe to the purchaser.
1 Waller v. Missouri, etc. Ry. Co., 59 .IO. A Pp. 410; 1 MIo. App. 56.

$\approx$ Ch. Xill. 
that is owing to the person misled," is of general application, and is not confined to cases of estoppel by carelessness.

(6) Rule No. $:$ : "That the neglect must be in the transaction itself," is not a rule possible in estoppel by carelessness the neglect is necessarily always either prior or subsequent to "the transaction itself."

(7) Rule No. 3: "That the neglect must be the proximate cause of the leading of the person into the mistake," is impossible of application in cases of estoppel by carelessness. The proper rule is that "the estoppel-asserter's change of position must have been reasonably consequent upon the carelessness."

(S) Cases of estoppel by carelessness are not at present uncommon. They should be determined upon the ground well known in actions of tort that people ought to be punished for "the omission to do something which a reasonable man, guided by those considerations which ordinarily regulate the conduct of human affairs would do, or doing something which a prudent and reasonable mau would not do"-

punished sometimes by damages, and sometimes by estoppel. 


\section{CHAPTER $\mathrm{X}$.}

\section{CONDITION NO. 8.}

The Estoppel-asserter Must be a Person to Whom, Immediately or Mediately, the Misrepresentation usas Made.

Immediately. - The mere fact that there has been a misrepresentation, and that someboly has acted on it, will not be sufficient to work an estoppel. As was said by Lord Cranworth: ${ }^{1}$

"It will not do if he merely said something, supposing it to be quite riglit, and then that some stranger, having heard and acted upon it, should afterwards come to him to make it good."

And as was said by Cleasby, B., in Ilosegood v. Bull: ${ }^{2}$

"When A. asks B. his opinion in confidence, respecting the solvency of C., and the question is answered by $B_{\text {. }}$, without any intimation having been given to him that the information was songht for the purpose of its being communicated by $A$. to any particular individual, $I$ camnot belp thinking that the case does not come within any class of cases in which relief on the ground of misrepresentation can be obtained against B, by the individual to whom the information has been communicated to A."

In Le Lievre v. Gould ${ }^{3}$ a surveyor gave to his employer certificates as to the progress made in building two houses, which certificates were untrue. Upon the faith of these certificates another person (the mortgagee of the employer) advanced eertain moneys. It was held that the surveyor was not liable to the mortgigree. It had not been intended that the certificate should be acted apon by any person other than the person to whom it was given. The mortgagee was a stranger to the misrepresentation. The decision would be the same, no doubt, were a subsequent purchaser of land to act upon a certificate as to the title given by a solicitor to a previous purchaser. The solicitor would be liable to his client, but not to others. ${ }^{4}$

1 Jorden v. Money (1854), 5 H. L. C. 212; 33 L. J. Ch. 865. And see Kinney v. Whiton (18i\%), 44 Conn. 262: Märuire v. Selden (1886), 103 N. Y. 64?; 8 N. E. R. 517; Starr v. Newman (1899), 3:3 S. E. R. 42i (Ga.).

$2(18 \pi i): 6$ L. T. N. S. $6 \geq 0$.
3 (1893) 1 Q. B. 491 ; 62 L. J. Q. B. 353. To same effect is Atkins $v$. Payue (1899), 190 Pa. St. 5; 42 Atl. R. 3is.

+ But an abstracter of titles wou!d be under obligation to a third person if he knew that the abstract was 
Mediately; Intended to be Passed on.- Upon the other hand, it would be a grievons mistake to assume that there will be estoppel only as against the particular person to whom the misrepresentation is immediately made. As there are ambulatory promises, ${ }^{1}$ that is to say, promises intended to be redeemed to persons other than the immediate contractor, so also are there ambulatory representations; that is to say, representations that are intended to be passed on, intended to influence the action of third persons.

"It is now well established that in order to enable a person injured by a false representation to sue for damages it is not necessary that the representition should be made to the plaintiff directly: it is sufficient if the representation is made to a third person to be communicated to the plaintilf, or to be communicated to a class of persons of whon the plaintitf is one, or even if it is made to the public generally with a view to its beingr acted on, and the plaintiff as one of the public acts on it and suffers damages thereby." 2

Current methods of explanation would suggest the phrase "estoppels bind parties and privies" as a sufficient solution of the law as to ambulatory representations. That phrase, however, was not originally intended to apply to estoppel by misrepresentation, and a portion of a subsequent chapter ${ }^{3}$ will be devoted to proving its inapplicability to that subject. For the present it will suffice to point out that "privity" assumes the existence of some property to which the estoppel is, as it were, annexed, and with which it runs. The icleas of an estoppel in gross and of its being transferred in unattached form to some third person are, of course, quite foreign to the usual use of the phrase under consideration. Such phenomena are, however, by no means uncommon in the law of estoppel. Take a few cases:

Misrepresentation as to Solvency. - For example, let us vary a little the Ilosegood v. Bull case. Let us suppose that when A. asked B. as to C.'s solveney it had appeared to B. that the information was being obtained in orler to be passed on to some one else. This variation would ehange the result, and $B$. would now be estopped as against this other person. Some-

required for his purposes and was to be used by him. Brown . Sims (1899), 5:3 N. E. R. 779 (Ind.).

1 See ch. XYIV.

2 Per Quain, J., in Swift v. Winter- botham (1873), L. R. 8 Q. B. $253 ; 42$ L. J. Q. B. 111; approved in Richardson v. Silvester (1573), L. R. 9 Q. B. 36 ; 43 L. J. Q. B. 1.

${ }^{3} \mathrm{Ch} . \mathrm{XV}$. 
times usage alone would suffice to indicate to B. the purpose of the inquiry:

"It must be intended that the answers to such inquiries would he sent not merely for the use or benefit of the bank making the inquiry, but for the use and benefit of the customer on whose behalf the inquiry is made. - . In the present case it lats been proved to be the usage aunougst bankers to make infuiries of this kind on belalf of their customers."

Pertmerslip. - In earlier times the application of estoppel to partnership (i.e., a person not in fact a partner being liable nevertheless as such, because of his having been so representerl) was not clearly comprehended; and it was laid down that if the alleged partner had been held out "to the world" as a member of the firm, he would be liable to everyboly upon its obligations. ${ }^{2}$ But this is not the modern doctrine; and if a ereditor of a firm now assert that a person was a member of the partnership when in fact he was not, it must be upon the ground that the latter misled him, and not that everybody elso was misled. But the holding out need not be directly to the person deceived.

"The defendant would be bound by an indirect representation to the plaintiff arising from his coniluct, as much as if he had stated to hi:n directly and in express terms that he was a partner, and the plaintifi hid acted upon that statement." 3

Commercial Instruments, etc.- Another class of documents intended to be passed on embraces delivery orders, warehouse receipts, bills of lading, and other instruments known to commerce.

Delivery Orders.-For example, a railway company, by mistake, issued two delivery orders for the sime goods. Upon

1 Swift v. Winterbotham (1873), I. R. 8 Q. B. 241; 42 L. J. Q. B. 111 ; L. R. 9 Q. 13. 301; 43 L. J. Q. B. 56. Compare First Nat. Bank v. Marshall (1895), 108 Mich. 114; 65 N. WI. R. 604. The cases cited are not the most satisfactory examples of the point in hand, as they may be referred to the law of principal and agent - the inquiring bank was the agent for the real inquirer. It is just as well. however, to note that estoppel by misrepresentation may exist in favor of all undisclosed principal.

2 Waugh v. Carver (1793), 2 H. Bl. 2:3); De Berkom v. Smith (1793), 1 Esp. 30. And see ch. XXVII.
3 Dickenson v. Valpy (1829), 10 B. \& C. 140;8 I. J. K. B. 51. And see Vice v. Anson (18:\%), ; B. \& C. 409; 6 L. J. K. B. 24; Martyn v. Gray (186:3), 14 U. B. N. S. 839; Re Fraser (189\%), 2 Q. B. 63i; McLean v. Clark (189.3), 20 Ont. App. 6il: Hannali v. Baylor (188i), 27 Mo. App. 302; Denishorne v. Hock (1846), 11: Pa. St. 240: $3 \mathrm{Atl}$ R. Tr; Burrows v. Grover (189\%), 41 S. IV. R. 8:2 (Tex.); Nofsinger v. Goldman (1895), jj Pac. R. 45i). And see ch. XXVII.

4 Goventry v. Great Eastern Ry. (18S3), 11 Q. B. D. 776 ; 52 L. J. Q. B. 6)4. 
the faith of the second of them a third person adraneed money, and the railway company was estopped as against him from denying the refresentation contained in the order. "There was evilence of custom to sell or pledge gools upon the faith of a document of this kind"- evidence that it was intended to be passed on. Brett, M. R., said:

"It is true that there can be no negligence unless there be a duty; but here the documents have a certain mercantile meaning attached to thein, and therefore the defendints owed a duty to merchants and persons likely to deal with the documents."

Wrarehouse Receipts. - Where a warehouse receipt is giren for gools not actually received, knowing that the receiver would produce it to

"intending purchasers; or, in other worls, take it into the market and, on the faith of the truth of the representation therein contained, . . . sell that quantity so stored to any person desirous of purchasing it,"

the warehouseman is estopped, as against any person purchasing on the faith of the receipt, from denying its truthfulness. ${ }^{1}$

Letters of Credit. - It has been well held that, whatever may be the effect of a letter of credit at law, it constitutes a contract to the benefit of which all persons taking and paying for bills on the faith of it are entitled in equity, without regard to the equities between the bank and the holder of the letter.'

Bills of tading.- Representations in bills of lading are to be taken as having been

" made to any one who, in the course of business, might think fit to make advances on the faith of them." 3

Certificates of Shares. - Company's certificates of shares are intended "to be acted upon by the purchasers of shares in the market," ${ }^{4}$ and consequently the company is estopped by them, as agrainst persons who purchase upon the faith of them. A share certificate issued

"to give the shareholder the opportunity of more easily dealing with his shares is a declaration by the company to all the worlil that the person in whose name the certilicate is made out and to whom it is given is a shareholder." 5

1 Holton v. Sanson (1862), 11 U. C. C. P. 606. See ch. XXII.

${ }^{2}$ Re Agra \& Masterman's Bank (189\%), L. R. 2 Ch. $391 ; 36$ L. J. Ch. 222. See also Re Blakely (1867), L. R. 3 Ch. $160 ; 36$ L. J. Ch. 66.5; Quebec Bank v. Taggart (1896), 27 Ont. 162.

3 Armour v. Michigan, etc. Ry.
(1875), 65 N. Y. 111, 122. See ch. XXIV.

4 Per Lord Herschell in Balkis, etc. Co. v. Tomkinson (1893), A. C. 403; 6:3 L. J. Q. B. 134.

${ }^{5}$ Per Cockburn, C. J., in Re Bahia, etc. (1868), L. R. 3 Q. B. 584 ; 37 L. J. Q. B. 166 . See cases cited with this in ch. XXIL. 
Prospectuses. - The law upon this subject will appear from the following eases:

(1855) Scott v. Dixon.' Plaintiff bought some shares in a company upon the faith of statements contained in a report malle by the directors to the shareholders. Copies of it were left at the bank and were to be had by share brokers or anybody applying for them who was desirous of information with regard to the atfairs of the bank with a view to the purchase of shares. Plaintiff had obtained a copy of the report before purehasing his shares. The direetors were, upon evidence griven of the intention to circulate the report, held to be liable; but the case would probably hare been decided in the same way in the absence of such evidence upon the ground that (per Campbell, C. J.)

"Reports of joint-stock companies, though addressed to the shareholders, are genterilly meant for the information of all who are likely to have dealings with the company." 2

This was a case of a report. But distinguish between a report and a prospectus:

(1573) P'eek v. Gurney.3 The promoters of a company issued to the public a prospectus for the purpose of obtaining subseriptions for shares. After the shares had been allotted the plaintilf purchased some shares in the market. Ileld, that he was not one of the persons to whom the prospectus was adilressed. Lord Colonsay said:

"The proper office of a prospectus is to invite persons to become original partners in a company, that is to say, allottees of shares; and I do not think that the responsibility towards these allottees, which attached to the directors who issited the prospectus, followed the shares when they were transferred to any number of persons, however distaut from the allottees, persons who ultimately purchised those shares."

(1596) Andrews v. Mocliford: 5

"It is, however. a tot 11 ly different matter when the conclusion is arrived at that the prospectus was not intended solely, or even primarily, for the purpose of getting the public to subscribe to the shares."

In such ease the directors would be liable to subsequent purchasers of the shares.

129 L. J. Ex. 62.

2 See also New Brunswick, etc. $\mathbf{v}$. Conybeare (1862), 9 H. L. C. $711 ; 31$ L. J. Ch. 297; Western Bank v. Addie (1S67), L. R. 1 Sc. \& D. 145.

${ }^{3}$ L. R. $13 \mathrm{Ey} .79 ; 41$ L. J. Ch. 436 ; L. R. 6 H. L. 3 \%7; 43 L. J. Ch. 19.
4 The allottee himself, no doubt. could have sued. Gerlard v. Bates (1552), 2 El. \& B. $476 ; 2:$ L. J. Q. B. 364: Henderson v. Lacon (186i), L. R. 5 Eq. 249.

${ }^{5}$ Per Rigby, L. J. (1896), 1 Q. B. 372; 65 L. J. Q. B. 30:. 
Commercial. Agencics. - Representations made to a commercial agency are intended to be acted upon by the patrons of the anency, and will operate as estoppels in favor of such of the patrons as may, upon the faith of them, change their position. ${ }^{1}$

Stock Exchange.- In the same way representations to a stock exchange are intended for the members of it. In one case ${ }^{2}$ Bramwell, B., said:

"It would be a strange thing to hold that if a man makes a verbal untrue statement to any person, as for instance that the shares in a particular compiny are a valuable security, if that person buys and recommends his friends to buy. that he is to be liable to any one who buys on the faith of such representiations. But it is not a bad rule that a person who makes a friludulent representation, which is intended to be generally circulated, shall be liable to any person injured by acting upon it, however remote the consequences may be."

Anel Pollock, C. B., said:

"All persons buying shares on the stock exchange must be considered as persons to whom it wis contemplated that the representations wonld be made. I am not prepared to lay down, as a general rule, that if a per. son makes a false representation, every one to whom it is repeated and also acts upon it may sue him. . . Generally, if a false and fraudulent stitement is made with a view to deceive the party who is injured by it, that affords a ground of action. But $I$ think that the re must always be this evidence against the person to be charged, viz.: that the plaintiff was one of the persons to whom he contemplated that the representation should be made, or a person whom the defendant ought to have been aware he was injuring or might injure."

Of this and a similar case Lord Chelmsford said:

"The decisions, and the grounds on which they procecded, appear to me to be extraordinary, and I cannot bring my mind to agree with them; 3 but it is apprehended, nevertheless, that the law is well founded.

Title Deeds.-Title deeds are clearly documents which are intended to be passed on; and a duty of carefulness, therefore, exists in regard to persons who may subsequently aequire an interest in the land. The subject is discussed in a subsequent chapter."

" $N$ o Defenses." - Frequently, in the United States, an obligor indorses upon his obligation a certificate to the effect tbat be has "no defenses, equities or set-offs of any lind." The plain intent of such certificates is that they shall be acted upon by transferees of the ubligation; and such transferees are entitled to take advantage of them by way of estoppel. ${ }^{5}$

1 Stevens v. Ludlum (1891), 46 Minn.

$160 ; 48$ N. W. R. 771 ; Irish, etc. Bank v. Lullum (1892), 49 Minn. 255; $51 \mathrm{~N}$. TV. R. 1010 .

2 Bedford v. Bagshawe (18;9), $4 \mathrm{H}$. \& N. 5:8; 29 L. J. Ex. 59.
3 Peek v. Gurney (1873), L. R. 6 II. L. 397 ; 43 L. J. Ch. 19.

${ }^{4} \mathrm{Cl}$. XIX.

5 Gray v. Bank of Kentucliy (1857), 29 Pa. St. 365; Penn. R. R. Co.'s Appeal (1878), id. 80; Robertson v. Hay 
"Negotiable Instruments." _ Pills and notes are instrmments which, in an especial matruer, are intenderl to be passed on; and a remote holder is frequently a person who, within the rule, is one to whom a mispepresentation (in connection with the instrument) may be sairl to have been marle. The authoritios upon this subject are treated of in the chapter mpon choses in action." At this place a single indicative reference must sullice.

"It is suffeient to point nut that a party signing in blank a cliecle or

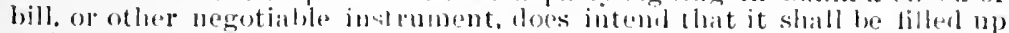
and holvered to at series of hollers. and therefole he stamls to all theses holders in the position imbiated in the first branch of the julloment of Freeman $v$ Cooke. Ho means the bolker to be induced to take the instrument as if it had been tilled up from the first." 3

Choses in Action. - The learal recognition of the assignability of choses in action is rapilly increasing the classes of ducuments which are made with the intention of being passed on to others. The assignees of such toemments take them free from equities existing betweon the parties to them. And the tendency is to hold the parties to them estopper by the representations eontaned in them. Consider under this heading the case of Biclerenton v. Wallier.5 A mortgage debt is no rloubt a chose in action, but it is one which the mortgagor may well believe will be assigned to other holders, and if he execute a mortgage for a sum greater than that actually adranced, he may be estopued as against an assignee from denying that the security is for the larger amount. The case is a distinct alrance upon, perhaps departure from, the older doctrine; but it is in line with the prevaling tendeney to impose a duty of carefulness for the interest of people who may be misled by your action.

Misrepresentation to P'erson 1 Tho Wrill Probubly be spplied to for Information. - A lessee of a public house owned certin tittings in it. He leased his interest, and procured the landlord

(1879), id. 244; Hutclinson v. Gill, id. 250: Rigigs v. Pursell (1878), si N. Y. $3 \% 0$.

IUntil we reach chipter XXIV. the word "negotiable" and its derivatives must be used.

$20 \%$. XXIV.

"Por Blackburn, J., in Swan v.
Nortl British (186:3), 2 II. \& C. 183 $3: 1$. J. Ex. 2:i3.

+ Re Arria \& Masterman's Bank

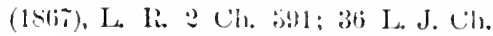
in:s. And see the who!e matter dis. cussed in chinpter $\mathrm{XXiV}$.

5 (158.5) 31 C\%. D. 1.31; 5.5 L. J. Cl. 29i. And see the castes referrecl to with this one in chapter IV. 
to accept the purchaser as tenant. By the agreement between the landlord and the new tenant the former was to be ontitled, at the end of the term, to deduet any arrears due from the tenant from a valuation of the fittings. The original lessee was aware of this agreementand male no objection to it. Clearly then, as between him and the landlord, be wonld have been estopped from setting up his ownership. But the question did not arise between them. The new tenant afterwarls sold the good-will of the business and the fittings upon the misrepresentation that he was the owner thereof; and he referred his purchaser to the landlord, who informed him that the person assuming to sell was in fact the tenant. It was held that the owner of the goods was estopled.'

In this case it is not, at first sight, quite clear why the owner of the grools should be estopped by what the landlord said; but when it is eonsilered that the owner misled the landlord, and that he knew that any persons desirous of dealing with the tenant would, in the usual eourse, go to the landlord for information as to the ownership of the goods, the soundness of the decision becomes mure apparent.

Misrepresentation by Appearing to Subscribe for Shares.Where shares are subscribed in order to induce others to invest and the seheme is successful, the decoy is estopped as against the dupes from asserting a secret arrangement with the eompany. ${ }^{2}$

Ambulninry and Non-ambulatory.-That there are ambulitory as well as non-ambulatory representations may now be taken as having been suffieiently established.

1 Gregg v. Wells (1839), 10 A. \& E. $\quad 2$ (18j8) 31 Pa. St. 493. 90 ; 8 L.J. Q. B. 193. 


\title{
CIIAP'TER XI.
}

\author{
CONIITION NO. 9.
}

\section{The Estoppel-asserter Must, on the Faith of the Misrepresenta- tion, Have Changed II Position P'rojudicially.}

"To create an estoppel in pris, the party in whos favor it opreates must have altered his position through reliance on the words or conduct of the pirty e'stopperl." I

" Nobody ought to be estopped from averring the truth or asserting a just demand unless by his acts, ar words. or neglect, his now areering the truth, or asserting the demand, would work some wrong to some other person who his been induced to do something. or to abstinin from doing semething, by reason of what he has said or done, or omitted to say or do."

Let us consider the matter under the following headings:

I. Change of position.

II. On the faith, ete.

III. Prejulicially.

IV. Purchatser for value withont notice.

\section{Cinagge of Position.}

Change of position to misrepresentation bears somewhat the silme relation as consideration to contract. A misrepresentation without consequences must surely remain without consequences. But the point nust be noted, and even dwelt upon, for it sometimes in practice escapes observation. Note its application in the following case. Defendant, having the plaintiff in custody, gave to him a statement of the causes of detention, in which he admitted having a warrant for plaintili's discharge on a certain date. Plaintiff, believing this warrant to be insullicient (not acting upon the admission), applied for

r ILingonner v. Ambler (1\$9.5), 44 Neb. $316 ; 62$ N. IV. R. 436 . Aul see 'Tower v. Hoskin (18!11), 84 MLe.86; 2t Att. K. 5s7; Staluton v. Estey (159:), 90 Mich. 12: 51 N. W. R. 101: Pearson v. Brown (1S9S), 10; Gi1. s0: 31

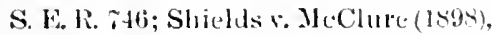
7) Mo. Аpp. 63; Jamition v. Miller (188.). 6t Iowa, 40: :90 N. W. L. 4.11.

2 Per Jannes, L. J,,in Ex parte $\Lambda$ Uam- son (18is). 8 Ch. D. s1i: 4r L. J. Bk. 10:\% And see Low : Bouverie (1891), 3 Ch. 111; 60 L. J. Ch. 5:)4: Conrad r. Fisher (1Ss9). 87 Mo. Аpp. 352; Dean v. Crall (18!1), 98 Mieh. 531; $37 \mathrm{X}$. W. R. sı; Barry v. Kirklatnd (1\$94), 22 Pale. R. तT (Ariz); Wills vitter (1s99), 1so Ill. 616; 54 N. E. R. 565; Oak (reek v. He'mer (1899, Neb.), so N. W. R. s91. 
an order for his discharge when the date should arrive, which order was refused. Having been detained three diys beyond the date mentioned in the warrant, he sned for damages. In this action the defendant denied baving the warrant, and it appeared that he had a copy of it only. IIetd, that he was not estopued by his previous admission or representation, for the plaintiff had in no way acted upon it.'

There can of conrse be no such change of position as will result in estoppel if it chronologically preeedes the mispepresentation complained of." It is impossible, too, that any representation can be acted upon if its existence be unknown to the estoppel-asserter. In a case, ${ }^{3}$ therefore, in which it was said that a principal was estopped from denying that his agent had certain powers, because he, the agent, had been intrusted with certain general authority, from which the existence of these powers would naturally be inferred, it was held that the principal was not estopped as against a person who was not aware of the general authority, and who, therefore, could not have drawn the inference.

It bas been held in jurislictions in which registration of a transfer of shares is necessary to the passing of the property in them, that creditors of the transferrer can attach the shares prior to registration. If the creditors hal advanced their money - changed their position - upon the faith of their debtor's ownership of the shares, something could be said for them; but the cases often ignore the necessity for change of position of any sort. ${ }^{4}$

1 Howard v. Hudison (1853), 2 El. \& B. 1 ; 22 L. J. Q. B. 341.

2 Barnard v. Camplell (18\%4), $55 \mathrm{~N}$. Y. 456; Ehrler v. Braun (1887), 120 111. 503; 22 Ill. App. 319; 12 N. E. R. 503: McManus v. Watkins (1893), 55 Mo. App. 92.

3 Miles r. McIlwraith (1883), 8 App. Cas. 1:0; 52 L. J. P. C. 17. And see Stewart v. Rounds (1882), 7 Ont. App. 515; Murpliy 5. Barnard (1894), 162 Mass. 72; 38 N. E. R. 29. But see Hanover Nat. Bank v. American (1\$96), 148 N. Y. 72; 43 N. E. R. 612.

4 Skowhegan v. Cutter (1860), 49 Me. 315; People's Bank v. Gridley
(1879), 91 Ill. 459; Union Bank r. Laird (1887), 2 Wheat. 390 ; Hirsch r. Norton (1888), 115 Ind.341: 17 N. E. R. 612; Pierce v. Horner (1895). 142 Ind. $626 ; 42$ N. E. R. 223. See, however, Lightner's Appeal (1876), $82 \mathrm{~Pa}$. St. 301; Hoore v. Albro (1880), 1 9 Mass. 9; Sibley v. Quinsigamon (1882), 133 Mass. 515; Burgess v. Selygman (1882), 107 U. S. 20; Masury v. Arkansis (1899). 35 C. C. App. 476; 9:; Fed. Rep. 603; Colebrook on Col. Sec. 25:. In Milssichusetts legislation was passed to correct the departure of the cases from principle. Newel] v. Williston (1885), 138 Mass 240. 
"Inlled into Security." - It is frequently said that a misrepresentation must have been "acted upon" in order that it may produce estoppel. That is not quite accurate; for, if the misrepresentation arrested action, it would have the same effect. A change of position - relative position - is the requisite.

"It is not necessary that a party should act affirmatively upon a declaration to claim an estoppel. If he has not acted in reliance upon it, but has means in his power to retrieve his prosition, and, relying upon the statement and in consequence of it, he refrins from using these means, lis claim will be uphehl."1

There are many cases of estoppel in which a person has been "Julled into security" and has "rested satisfied"-cases in which he has not pirted with money or property on the faith of the representation, but in which he has lost some chance of recovering it. A careful examination of one of these ${ }^{2}$ will enable us to pass the others more hurriedly. Some solicitors had a client (No. 1) possessed of a moltgare; they agreed for the sale of it to another client (No. 2) and received the purchase-money from him; they then procured No. 1 to execute an assignment of the mortgage to No. 2 by fraudulently mis. representing its nature; the assignment was afterwards handed to No. 2. Both clients now thought that they owned the mortgare, and they remained for five years afterwards of that opinion, the mortgagor paying interest to one of them and the solicitors to the other.

Then the question arose, Who is to lose? No. 1 took the ground that although he might be bound by the assignment, yet that No. 2 had not pail the purchase-money; he (No. 1) had not received it, and the solicitors had no authority from him to do so. No. 2 had to admit that that position was valid; but he contended that No. 1 was estopped from asserting that the money had not gone to him, because, in the assignment of the mortgage, he had acknowledged the receipt of it. No. 1 replied that that also was true, but that No. 2 had not changed his position upon the faith of that misrepresentation, for he had paid over his money to the solicitor before the assignment

${ }^{1}$ Continental Bank v. National Bank (18\%2), 50 N. Y. 5\%5. And see Lonton v. Suffielı (1897), 2 Ch. 605; 66 I. J. Ch. 790 ; Tobin r. Allen (15;6), 53 Miss. 563; Bank of U. S. v. Bank of Georgia (1535), 10 Wheat. 33:; Farmers : Orr (1899, Ind.), j.j N. E. R.
2 Gordon v. James (1885), 30 Ch. D. 249. See also Herchmer r. Elliott (1ssi), 14 Ont. i14; lie Swinbinkis (1879), 11 Ch. D. 59.): 45 L. J. Bk. 1:0; Iie Bellamy (1583), 24 Ch. D. 85i: 52 L. J. Ch. Sio; lie Itetling \& llerton (1s93), 3 Ch. 2\%5; 62 L. J. Ch. 20 
was executed. Once more No. 2 had to admit the fact alleged, but he urged that after he prarted with his money he receired the deed; that it then appeared to him that the money harl reached No. 1, and that he (No. 2) was, by such appearance, lulled into inactivity. The question then was narrowed to this: Had No. 2 acted upon the misrepresentation contained in the assignment? If he had, No. 1 would be estopped. The judges said as follows:

Cotton, L. J.:

"By putting that deerl into the hands of their agent (the solicitors) they (No. 1) enableil him to represent to James (No. 2) that that money . . . was really paid to them on the transfer of this security."

Lindley, I. J. :

"The plaintiffs. by their carelessness you may say, but I should rather say by their act, enabled Dorlge (the solicitor) to deceive Jamps (No. "2) and luil him into security. and prevent him having recourse to those who got lis money from him by a trick."

Fry, L. J.:

"I think the result of that would naturally be that James (No. 2) would not make that incuiry and search after the money which he would have made if he hall foumd that after paying it to Dodge \& Phipps (the solicitors) it had not been invested. I think, therefore, that the defendant Jumes (No. 2) hats an equity which he may rightly set up in this case against the equal equity of the plaintiffs as unpaid vendors."

This reasoning is worth examination. It was arlmitted in the case that if No. 2 had paid his purchase-money to the solicitors at the time that he received the assignment he would have had no case. He would have had none, because ho would bave known that the misrepresentation contained in the assignment could not be true, and he could not, therefore, have acted upon it; he would have known that although the assignment represented that the money bad been paid, it had not in fict been paid, for he had not then paid it; he would not bave been misled, and so there could have been no estoppel. The only question in such case would have been whether the solicitors had authority to reeeive the purchase-money; and by hypothesis they had not. In such ease, therefore, the purchasemoney not having been paid and No. 1 not being estopped from denying that it had, his right to payment would have been indisputable.

Putting the case more shortly: A purchaser receives through the vendor's solicitor a conveyance containing an acknowledgment of receipt of the purchase-money, and simultaneously or subsequently pays the purchase-money to the solicitor; the solic- 
itor had no anthority to receive the money and the rendor is entitled afterwaris to enforce payurnt. On the other hatnd, a purchaser paly his purchase-money to the solicitor and afterwards receives a conveyance containing an acknowledgment of payment, and the vendor is not entitled to enforee payment.

What is the distinetion? It is this: In the former ease the purehaser was not misled.' In the latter he was. In both cases the deed represented that the vendor had reeeived the purchase-money at the time of its execution. So far they are alike. But in the former case the purchaser was not deceired, for he knew the fact to be otherwise; whereas in the latter, having previonsly paid his moner, he believed, when he reeeired the deed, that the representation which it contained (that the ventor had received the money) was true. Ile was misled; he acted upon the misrepresentation to his disadvantage (by remaining (puiescent), and the vendor was estopped.

Note the eharacter of the disadvantage which the purchaser in the case just dealt with sustained. He dil not lose property or money, but he lost an opportunity to reeorer his moneyhe abstained from making "that inquiry and search after the money which he would have made" - that was enough.

Note, seeondly, that the action of the min estopped was, in the two supposed cases, precisely similar; and yet in the one he is estopjed and in the other he is not. In both cases he executed the assignment without receiving the money; in both the assignment, contrary to the fact, represented that he had received the money; in both he acted honestly; in both there is long lelay; in both, therefore, tinere is the same degree of carelessness; and in both the same innocence of intentional misrepresentation. The difference in the cases lies in this: that misrepresentation does not necessarily result in estoppel: that it so results only when it is the cause of misleading another person to his disadrantage; and where that has happened the question of fraul or ball faith is immaterial.

Not Advising of Forgery. - The cases will now be easily understood which determine that if a man's name be forged, and after himself becoming aware of the fact he reflain from adrising the holder of the doeument, and by reason of such in-

1 He may have miscalculated as to the solicitor's authority to receive the moneys. But that is not the point here. He ouglit to have made inquiries. There is no grotud of es. toppel in that connection. 
action the holder's position is changed (by the death, escape or bankitutey of the forger, or otherwise), there will be estoppel of the man whose name was forged.

"It would be a most unreasonable thing to permit a man. who knew the bank was relying unon his forged signature to a bill, to lie by and not to divuige the fact until he saw that the position of the hank was altered for the worse. I3ut it appenirs to me that it would be equally contrary to jus. tice to hold him responsible for the bill because he did not tell the bank of the for he did so, the bank was in no worse position than it was at the time when it was tirst within his power to give the informintion." 1

Not Objecting to Accounts. - Suppose that a man whose forged checks have been paid by his banker had no actual notice of the forgeries, but thit had he examined his bank pass-book he would have found them charged against hins; is he estopped by reason of his inactivity? It has been said that

"a depositor owes no duty to a bank to examine his pass-book or canceled checls w.th a view to the detection of forgeries."

And even if the depositor should execute from time to time, at the instance of the bank, the usual certilicate that the balance shown by the pass-book is correct, it may well be said that such transaction is nothing but an account stated, which may be rectified if it be erroneous.

Custom, however, must be reckoned with here as elsowhere. As early as 1815 it was reported by the master in chancery ${ }^{3}$ that

"for the purpose of having the pass-books made up by the bankers from thear own bouks of account. the customer returns it to them from time to

$1 \mathrm{Mc}$ Kenzie v. British Linen Co. (1881), 6 App. Cas. 82; Cairneross v. Lorimer (1860), 3 Macq. 830; London v. Sufiield (1857), 2 Ch. 608: 66 L. J. Cl. .90; Pratt v. Drake (1859), 17 U. C. Q. B. 2̃: Merchants' Bank v. Lucas (189\%), 13 Ont. 520: 15 Ont. $\Lambda_{p \mid}$. iris; 18 S. C. Can. 70.7 ; Forsyth ×. Day (1858), 46 Me. 196: Bank v. Buffington (1867), 97 Milss, 498; Continental v. National (15:2). 50 N. Y. 5.5; Hardy v. Chesapeake (1879), 51 IId. 562; Leather, etc. Bank v. Mlorgan (1885), 117 U. S. 96 ; 6 S. C. R. 6ri; Schway v. Bank (188T), 6r Tex. 21\%; 2 S. W. R. 865; Kuriger v. Joest (1899, Ind.), 52 N. E. R. 76.t; Firmers v. Orr (1\$99, Ind.), 5i) N. E. R. 3\%. Distinguish between estoppel and ratification in such cases: Scott v.
Bank of N. B. (1894), 23 S. C. Can. 287: Forsyth v. Day (1858), 46 Me. 196: Wiechers v. Central T'rust Co. (189.t), $80 \mathrm{Hun}, 576 ; 30 \mathrm{~N}$. Y. Supp. 59.5. Distinguish Mangles v. Dixon (18:2), 3 H. L. C. 102.

2 Wachsman v. Columbia Bank (1893), 56 N. Y. 601; 26 N. Y. Supp. 85.5: 28 id. 711. And see Devalyne's v. Noble (1815), 1 Mer. 530; Manitoha v. Bank (1889), 17 S. C. Can. 692; Agricultural v. Federal (1881), 6 Ont. App. 192; Merchants v. Lucas (188i), 13 Ont. 520; 15 Ont. App. 573; $18 \mathrm{~S}$. C. Can. 70j; People v. Bank (18i9), 5. N. Y. 5.18; Viele v. Judson (1880), 8.2 N. Y. 3:2: Leather v. Morgan (1586), 117 U.S. $96 ;$; 6 S. C. R. 65\%; Janin v. LonJon (1891), 92 Cal. 14; 27 Pac. R. 1100. ${ }^{3}$ Devalynes v. Nuble (1815), 1 MIer. 
time as he t!inks fit: and the proper entries being made hy thom up to the day on which it is left for that purpose, they deliver it arain (u) the customer, who thereupon examines it, alld. if there alpe:ar ally aryor or omission. hrings of sends it back to be rectilind: or if not, his silenee is resgariled as an id mission that the entries are correct."

This being the custom, there may well be argued from it as follows:

"Without impugning the general rule that an account renlered which has become an account stater is open to correction for mintakm or friml, - . other principles come into operation where a palty to at stated acecount who is under a duty. from the usires of business or ollerwise, to examine it within a reasonable time after laving an opportunity to ulo so, and rive timely notice of his objections thereto, neglects allowether to make such examination himself, or to have it made in gnod liath by an. other for lim: hy rason of which negligence the other pal $t y$, relymo mpon the acrount as having been acquieseed in or approved, has failed to talie steps for lis proteretion, which he rould and would have taken hal motiee been riven. In other worls, parties to a statral aconnt may be estopled by their combuct from questioning its conchusiveness." I

Merms of Knomledlye. - It is sometimes said that change of position will not work an estoppel if the estoplel-asserter could reasonahly have ascurtained the falsity of the misrepresentation made to him. On the other hand, it is broally laid down that a misrepresentation, acted upon by the estoppel-asserter, "is not the less a ground for relief because he had the means of knowledge." ?

"Iy lords, I cannot myself think that, where an unequirocal statement is made by one party to another of a particular fact, the party who made that statt ment can get rill of the estoppel which arises from another man acting unon it, hy salying that if the person to whom he malle the statement had reflected and thought all about it he would have come to see that it conlly not he true." 3

"The very representation relied on may have causel the party to desist from inquiry and neglect his means of information, and it does not rewt with him who made them to say that their falsity might have been ascertained, and it wis wrong to credit them." 4

536. In Leather, etc. Billk v. Mor-

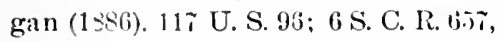
it was sail that "This report is quite as applicable to the existing usiges of this country as it was to the nsiches of business in London at the time it was mille."

1 Leath.r, etc. Banle v. Morgan (1S86). 11 \% U. S. 10\%; 6 S. C. R. 6.T. Anl see Weinstein va National Banis (18ri). 69 Tex. 38; Harily v. (hesatpeake (1879), 51 Md.58s; Dane v. Bank of the Repullic (1881), 132 Mass. 156; Frank v. Chemical, etc. Pank (1\$81), 8t N. Y. 209; First National Bank v. Allen (1S93), 100 Ala. 4i6; 1.1 S. K. 335; Clark v. National Bank (1998), 5. N. Y. Supp. 10,jt.
2 Willmott v. Barber (1.990), 1,5 Ch. D. 106; 49 L. J. Cl. 79:. And ste Dyer v. Hargrave (1s0i). 10 Ves. j0); Dobell v. Sterens (1825), 3 B. \& C. 623; Directors of Central Ry. Co. v. Kisch (1867). L. R. 2 II. L. 120: 36 L. J. Ch. 8f9: Rellirave v. Hurl (1881), :0 Ch. D. 1 ; ii I. J. Ch. 113; Smithv. Chadwick (18s2), 20 Ch. D. 2т; 9 App. Cas. 1si; 51 L. J. Ch. הir. But see MIe. Lean s. Clark (1891), 21 Ont. 683; 20 Ont. Appogio.

3 Per lorl llerschell in Blnomenthal $\because$ Ford (1s:0), A. C. 15s: $66 \mathrm{~L}$.

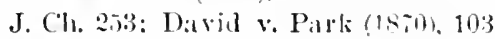
Mass. 501: Strand v, (irillith (1809), 9i Feel. R. 8.it.

Graham s. Tisompson (1\$92), 55 
Observe, however, that these quotations refer to cases of active misrepresentation only - you must not turn a man away from his means of information. As to cases of passivity, Mr Bigelow says:

"It is settled law that standing-by in silence will not har a man from asserting a title of record in the public registry, or other like ofice, so long as no act is done to mislead the otater party; there is no duty to speak in such case." 1

But probably it would be more correct to limit the statement to cases in which there was no " reasonable ground for anticipating some change of position," without reference to the record." For example, if the owner was not only aware that no scarch of the records had been made or was intended, but, on the contrary, stood by while the transaction was actually completed and the money paid over, without any search, he ought to bo estopped.

"When I saw the mistake into which he had fallen, it was my duty to be active." 3

And there seems to be no good reason for distinguishing, in this respect, between information in a registry oflice and information anywhere else ${ }^{4}$ when the "silence is treacherously expressive." 5

Registration does not interfere with the operation of that statutory estoppel founded upon the doctrine of reputed ownership in bankruptey cases. ${ }^{6}$ The fact, too, that a partnership bas been registered is no answer to a creditor who has sold his goods upon the faith of a representation as to its constitution.?

Ark. 299; 18 S. W. R. 58. The court referred to Gammill v. Johnson, 47 Ark. 335; Bigelow on Est. 627; Dodge v. Pope, 9:3 Ind. 480; David v. Park, 103 Mass. 501; Holland v. Anterson, 38 Mo. 55; Evans v. Farstall, 58 Miss. 30: Kiefer v. Rogars, 19 Minn. 32.

1 On Estoppel (.)th ed.), 594.

2 Kingman $\vee$ Graham (1831), 51 Wis. 232: 8 N. W. R. 181; Markham v. O'Connor (18it), 52 Ga. 183.

${ }^{3}$ Ramsden v. Dyson (1866i), L. R. 1 II. L. 141. And see cases cited with this one, ante, p. 89.

${ }^{4}$ The aises to which Mr. Bigelow refers are arlmittelly contralictory. The surgestion in the text will help to reconcile those of them which are not referable to other principles. See also Knouff v. Thompson (1851), 16 Pa. St. 55i: Fisher v. Mossman (1860), 11 Ohio St. 42; Grihlam v. Thompson (1592), 55 Ark. 296: $18 \mathrm{~S}$. W. R. 58; Wymne v. Mason (1895), 72 Miss. 424; 18 S. R. 422; Two Rivers Co. v. Daly (1899), 102 Wis. 328 ; 78 N. V. R. 440 .

${ }^{5}$ Per Thompson, J., in Niven v. IBelknap (180\%), 2 Jolıns. 589 (N. Y.). And see Guffey v. O'Reilly (1885), 88 Mo. 418, 425.

6Stansfeld v. Cubitt (1858), ¿ De G. \& J. 222; 97 L. J. Cl. 266; Ex parte Harding (1973), L. R. 15 Eq. 223; 42 L. J. Bk. 80.

7 McLean v. Clark (1891), 21 Ont. 
Probably each case must rest upon its own circumstances. The fact that my claim is upon public record may be some ground for assuming that it is known, and therefore for believing that it is unnecessary that I should say any thing abont it. But there will often be circumstances which will rebut that assumption and require aetivity at my hands. ${ }^{1}$

What is a Change of l'osition? -- Tet us now note two cases as to the charneter of the change of position necessary to estoppel - not recommending, however, implicit confidence in them.

Change of Style of Living-Dhe paymaster of a military corps erroneously gave credit to an oflicer for moneys which had not been received on his account; and not only did not advise him that the moneys had not been received, but dirl not notify him that that part of his allowance hat been expressly stopped. It was held that the paymaster was estopped from denying his receipt of the money, althongh the only change of position was that probably the officer had accommodated his living to his supposed income.

"It therefore works a great prejudice to any man, if, after having had crellit given him in question for certain sums, and having been allowed to draw on his agent on the faith that those sums belonged to him, he may be called upon to pay them back."."

Change by Bringing an Action.- A man who had been bitten by a dog asked a woman who owned it? and she said it belonged to her. He accordingly sued her. IIeld, that she was estopped from denying ownership, if she knew that the inquiry was made for the purpose of finding out who was liable for the injury. ${ }^{3}$

68:3: 20 Ont. App. 660. Legislation may, of course, otherwise declare. Caldwell v. Accident, etc. (1S94), 24 S. C. Can. 263. See also Bissell's Ex'rs v. Warde (1595), 129 $\mathrm{W}$ o. 4:39.31 S. W. R. 928; Weelis v. Palmer Bank (1595), 44 Neb. 68t; 62 N. W. R. sit: Armstrong v. Potter (1894), $103 \mathrm{Mich}$. 409; 61 N. W. R. $65 \%$.

I See the subject discussed in ch. VIII.

? Skyring v. Greenwood (182.5), \& B. d. C. 289. And see Shaw v. Picton (1825), id. 715; 4 L. J. Q. B. 29; Daniel r. Sinclair (1881), 6 App. Cas. 190; 50 L. J. P. C. 50; Cave v. Mills (18(i2). $\tau$ II. \& N. 913; 31 L. J. Ex. $\because 6 . \overline{5}$; Van Hasselt v. Sack (1859). 13 Moo. P. C. 18.5. But see IIume v. Bolland (153?), 1 C. $\&$ M. 130, and Reg. v. IBl(ntiinsop (1892), 1 Q. B. 43; 61 L. J. Q. 13. 311. in which it is said that the calse had gone to the full extent of the lis

${ }^{3}$ Robb v. Sheppard (1883), 50 Mich. 189. The misrepresentation might well have affected the question of the disposition of the costs of the action. 
A Possible Change of Position.- It is clearly not sufficient that there might have been a change of position, if in reality there was none. For example, if a company upon the faith of a forged document transfers some shares, and the true owner, although aware of the transaction, loes not advertise the company until after the declaration of dividends which might have been, but were not, paid to the transferee, there will be no estoppel. ${ }^{1}$

\section{On tile Faitil, eto.}

Change of position will not estop unless it can be attributed to faith in the misrepresentation complained of. It is clear, therefore, that there will be no estoppel if, notwithstanding the existence of misrepresentation, the estoppel-asserter had knowledge of the truth; ${ }^{2}$ or if the misrepresentation were withdrawn before it was acted on $;^{3}$ or if it were not believed, but on the contrary investigated and testel. ${ }^{4}$ And the fact that one person changed his position upon the faith of the representation will not enable another to set up estoppel. ${ }^{5}$

Observe this case closely: Safe-makers transferred possession of a safe to a bargainee under a contract of hire and sale, and, at his request, painted his name upon it. The bargainee afterwards sold the safe to a purchaser who relied upon the painted name as evidence of title. He was nevertheless defeated because he could not show that he was aware that it had been painted there by the sufe-makers:

"The painting of the name on the safe was a perfectly innocent act in itself, and obtained significance only from the circumstances of its being lone by the phaintiffs: if not known to the defendant it was no representation, which is the gist of the defense." 6

1 Davis $\nabla$. Bank of England (1824), 2 Bing. 393; 5 B. \& C. 18j. See also Barton v. London, etc. Co. (1889), 24 Q. B. D. 77 ; 59 L. J. Q. B. 33.

2 Proctor v. Bennis (188\%), $36 \mathrm{Ch}$. D. $740 ; 57$ L. J. Ch. 11; Cooke v. Eshelby (1887), 12 A p). Cas. 271: 56 L. J. Q. B, 50.5: Re African Gold Co. (1899), 1 Ch. $414 ; 68$ L. J. Ch. 215; Cooper v. (ireat Falls (189.j), 94 Tenn. 585; 30 S. IV. R. 35:3. As to means of knowlerge see supra.

${ }^{3}$ Freenin v. Cooke (1819), 2 Ex.
654; 18 L. J. Ex. 114; Sanitary v. Cook (1897), 169 Ill. 184; 48 N. E. R. 461.

4 Small $\quad$. Attwood (1832), 1 Younge, 407: $6 \mathrm{Cl}$. \& F. 282; Royal Ins. Co. v. Byers (1885), 9 Ont. 120. But there is no obligation to investigate, supra.

5 Heane v. Rogers (1829), 9 B. \& C. 577; 7 L. J. K. B. 285.

6 Walker v. Hyman (187\%), 1 Ont. App. 345. 
'Ile had not acted upon the misrepresentation of the manufacturers, for he did not know that they had made it.

In another class of cases the rule receires confirmation. I buy goods from a man who sometimes sells for limself and sometimes as agent for others. Upon the occasion in question I make no inquiry as to ownership or agency. It turns out that my vendor was an agent merely; and when the true owner sues for the price the question arises whether I can set off a debt due to me by my vendor, the agent. I plead that the plaintiff allowed the agent to appear to be the owner, and that he (the plaintiff) is therefore estopped from assertinin otherwise. But the sufficient reply is that I did not act upon the faith of any representation of ownership - no one sail that the agent was the owner, and the facts did not imply it.

A common sort of case is that in which a company issues (usually by mistalie) a false certificate of shares. Upon the faith of the certificate an innocent transferee purchases the shares. The company is estopped from denying the truthfulness of its certificate. ${ }^{2}$ The point will be appreciated by observing a case in which a share transfer to a bonu fide purchaser is forged; the purchaser reristers the transler, obtains a certificate of ownership, and afterwards with the help of the certilicate resells the shares. Here the company is not estopped as to the first purchaser, for he did not act upon the certilicate; in fact it was he who by means of a forged transfer procured the company to issue the certificate; but the company is estopped as against the second purchaser, for be changed his position upon the faith of the certificate. ${ }^{3}$

"It will thus be seen that in all cases where such a question arose the liability of the corporation wis not made dependent on the fact whether the person in whose favor the registry of the shares was changed was a transferee or al subtrinsferee. but on the question whether he pirted with value on the faith of the new registry. under circumstances which give ris to an estoppel on the part of the corporation." 4

Sceming Exceptions.- Some cases, in which not an individual but a class of persons claims the estoppel, seem to depart from the rule. For example, where one person took shares

1 Cooke r. Eshelly (1985), 12 App. Cils. 271: 56 L. J. Q. B. 50j. A nal s:e the matter discussed in ch. XXVI.

2 Re Bahia (186s), L. R. 3 Q. 13. is1; 37 L. J. Ch. 176. And see cases cited witls this one in ch. XXII.
${ }^{3}$ See Thompson on Colporitions,

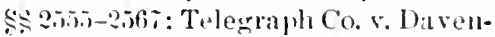
port (1sis), 9i U. S. 369.

tTrimble s. Bank (1S9i), il Mo. App. 4.0: approved in Humbleton v. Central (15i6), 4i Mal. 5.51. 
in a company in order to induce others to subscribe, upon a secret agreement that he was to pay for the shares by commissious to be allowed him, be was estopped in winding-up proceedings from setting up his contract as against other shareholders, although it did not appear that any shareholder had changed his position upon the faith of the action. ${ }^{1}$

And so where a judgment creditor conveyed some property to his debtor by a deed which appeared to release the debt, he was estopped as against subsequent judgment creditors from asserting otherwise, although it did not appear that the deed had affected their action. ${ }^{2}$ It was saicl that

"it is not an unreasonable presumption that the judgment creditors acted on it."

The "reputed ownership" elauses of the "Bankruptey Act, 1883 " (Imp.) form another instance of the same kind. ${ }^{3}$ Section 111 of that statute declares that

"all goods being at the commencement of the bankruptcy in the possession. Order or disposition of the bankrupt, in his trale or business, by the consent and permission of the true owner, under such circumstances that he is the reputed owner thereof,"

shall form part of the estate. The goods may have come into the possession of the bankint after every debt had been incurred, and it may therefore be impossible to say that any creditor had been misled or had aeted upon the appearance of ownership; but that eonsideration is immaterial.

Departure in these cases from the rule under consideration can be'justified, if at all, only because of the necessity of placing a number of persons in a class, and of examining the relition of that class to the estoppel-lenier. Were the relation of each individual creditor to the true owner of goods (in reputed possession cases) to be investigated, very possibly it would be found that some had aeted upon the appearance of ownership in the debtor and some had not. Those who had acted upon it would alone be entitled to set up estoppel; and they would

1 Re General Provident (1869), L. R. 9 Eq. 74; 38 L. J. Ch. 589.

2 Water's Appeal (1860), 35 Pa. St. $5 \div \%$.

3 S e the subject discussed in chapter XXI.

${ }^{4}$ Uyon the other hand the true owner may, so far as the statute is concerned, subtract his goods from

the estate (althongh credit may have been obtained upon the faith of them) after an act of bankruptcy has been committed, provided he does so before the date of the receiving order. Young v. Hope (1845). 2 Ex. 10.; Graham v. Furber (185:), 14 C. B. 134: 23 L. J. C. P. 10; Ex parte Montigu (1576), 1 Ch. D. 554. 
alone, then, obtain the benefit to be derived from a sale of the grouls. But that superiority over other creditors they never expected to get. They thonght that the goods were the debtor's; and in case of bankruptey would be shared in by all creditors alike. If then the groods are to be talien away from the true owner because he is estopped as against some creditor's, fairness seems to require that they should be shared in by all the creditors; and this may be nodetriment to the true ownerthe only other person interested.

There are many cases in widich a creditor having actially been deceived by the appearance of ownership, estopled ats against the true owner has been declared. To them there can be no objection; but there are some in which the presence of that factor has not been thought to be essential and the statute makes no such requirement.

The law upon the subject is in much confusion owing principally to the cross-currents of legislation and estoppel. Safe ground for comm...ncement may be found (as so often happens) in an early decision. A bankrupt bought his estate from his assignees, but did not get his discharge; he continued to trade for four years when he amain failed; held, that the creditors under the second bankruptey were to be preferred to those under the first. Lord Camden sitid

-they lnew that the banklupt continued to trade and that the elfects were delivered over to him ant that he was trabing with a multibule of persons. and in order to do that it was necesary he should titke as woll as give credil. . . It falls within the principle that if a man having a fien stands by and lets another make a new security he shall be postponed." In other words, the first creditors were estopped to set up their title to groods which they might bave seized (heing covered by the first assignment) as a gainst subseruent creditor's who hat dealt with the debtor upon the faith of his ownership of the grods; the subsequent creditor's had changed their position upon the faith of that appearance; and those who migit have prevented the mislealing appeatrance were estopped.

For estompel of this kind it is sometimes sail that it is necessary that the first ereditors shombl know that the debtor was deceiving other persons." But that holding is not in hatrmony

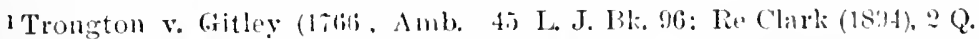
63: And see Wachussett y. Sionx T. 408: (i.) L. J. Ch. sub: Sliney 5 City (is94), 6:; Fedl. R. 36tit.

Dil vis (1S!) 11 Col. Alp. tso: 5:3 Pace.

$2 \mathrm{Ex}$ parte Ford (18;0), 1 Ch. D. 521; R. 6s5; Moore v. Albro (1580, 129 
with the principles of estoppel as applied in other departments of the law. ${ }^{1}$ According to these it would be quite sulficient that the debtor should have been permitted to occupy such a position as enabled him to obtain credit upon the faith of his appearance of ownership. It is quite clear thit if an owner of property permit some other person to appear to be the owner, he will be estopped from asserting his title as against a purchaser who las changed his position upon the faith of such appearance. ${ }^{2}$ And it would be no answer to say that the true owner was not aware that a fraud was being committed.

For example, if the debtor (in the case above under consideration), instead of incurring new debts, had sold the goods, the purchaser would be secure and the old creditors would be estopped. It would not be suggested that the case would be different if they did not know of the sale. ${ }^{3}$ They are estopped because of the ostensible ownership - of the opportunity to defraud which they have supplied.

Perhaps the true line is to be drawn, not between cases in which the first creditors knew that fresh debts were being incurred, and those in which they were ignorant of that fact; but that the point for observation is whether or not they were aware that the debtor had acquired property which they might take, and upon the ostensible ownership of which be might obtain eredit.

The Actuating Motive.-It is frequently a nice question whether the action was or was not taken "on the faith of the misrepresentation." For questions of fact it is impossible to lay down exhaustive rules; but a few points may advantageously be noted. It was held in Redgrave v. Murl ${ }^{4}$ that

"If it is a material representation calculated to induce him to enter into the contract, it is an inference of law that he was induced by the representition to enter into it."

But the later authorities bold that the inference is one of fact, and not of law. ${ }^{5}$

Mass. 13; Breeze v. Brooks (1586), 71 Cill. 169; 9 Pac. R. 6r0; 11 id. 88ĩ. But see Pierce v. Horner (1895), 142 Ind. 626; 42 N. E. R. 223; McAdow v. Hassard (1897), 58 Kan. 171; 48 Pac. R. 840 .

'Ante, p. 90 et seq.

s Sue clis. XXI, XXII.

3 Ke Morganv Knight (1861), 15 C.
B. N. S. 669; 33 L. J. C. P. 168; Cohen v. Mitchell (189)(1), 25 Q. B. D. 262: 59 L. J. Q. B. 409; Re Clark (1894), 2 Q. B. 409 : 63 L. J. Q. B. 806 .

${ }^{4}$ (1881) 20 Ch. D. 21; 51 L. J. ('). 113.

5 Smith v. Chadwick (1881), 9 App. Cas. 196: 53 L. J. Cl. 863: Srivith ฯ. Land \& House Corp. (1586). 23 Ch. 1). 
In a great many cases it is exceedingly dificult to ascertain whether, hall the truth been known, the action of the person leceived would have been altered. In such calses this at least may be sitil: that the position of the estoppel-asserter was necessarily affected to the extent that he was deprired of his right of consilleration. This itself, in a doubtful instance, may be thought to be a suflicient change of position within the rule. In one case Turner, L. J., saill:'

"Had this representition of what had occurred, and of the cliange of intention on the part of the defendants, been communicated to the plaintiffs, it is impossible to saly what course the plaintiffs would have pursuedwhether they would, or would not, have accepted the policy. They might have done so: but it is equally clear they mirrat not; and we cannot sily whether ther wonld or would not; but it was to them that the commmication should have been made, in order that they might exercise their option upon the subject."

Onus of Proof.- An interesting point arises in connection with the onus of proof. Suppose a misrepresentation to be followed by a change of position; must the estoppel-asserter prove that it was the misrepresentation which induced the change of position? or must that be assumed until the contrary is shown? Probably mucb depends upon the facts of each case, but a glance at Smith $v$. $K^{\prime} t y^{2}$ may aid in their consideration. An infant of extravagant habits arranged with an intimate friend to borrow $\$ 53,000$. He gave to this friend several acceptances for various sums, which, unknown to the infant, were discounted by the friend and two associates. As the infant's majority approached, the three persons (still holders of the bills) became anxious; the friend represented to the infant that the bills were in many hands; that they would be presented at his banker's, where there was no money; that it would be adrisable to get some one to buy them up, upon a promise of security after majority, and that this somebody should be another of the three. The infant agreed, and was informed of the attempts said to be made to get in the bills. The day after he came of age he gave security for the amount, believing that the bills had in fact been bought up. In his action to set aside the securities it was contended that the misrepresentations were immaterial; and that had the infant known that the bills were always

16: Hughes v. Twisden (18S6), 34

W. R. 500 ; 5.5 L. J. Ch. 481 .

1 Traill v. Baring (1884), 4 De G., S. C. 322; 20 S. E. R. 62.
2 (1556) 21 Bear. 522; 7 H. L. C. 750.

And see Bailey v. Seymour (15'4), $4:$

J. \& S. 330; 33 L. J. Ch. 521. 
held, rather than recently bought up, he would have given the security all the same. The Master of the Rolls agreed that "it is highly probable" that the infant would have done so. But it was held in the IIouse of Lords (per Lord Cranworth) that

"the issue is not whether the plaintiff has shown that he would not have executed the securities but for the representition of Smith; but whether Smith has satisfied us, or can satisfy us, that the plaintiff would have executed them witho:t. The onus proband is on Smith in this case."

"But the question is, would he have given the securities if the whole truth had been toh to him? I think even this youns man, when called upon to execute the bond, would have started if he liad known all that was going on. But at the same time it is quite unimportant. It does not lie in the mouth of these persons to say what he would have done if they har not concocted the fraud, and if there had never been any deception at all practiced."

\section{Per Lord Chelmsford:}

"How is it possible to say in what manner the disclosure would have operated upon Kay's mind, that he had been the dupe of a scheme of deception, which up to that moment had been successful in inducing him to believe that Adams had befriended him in taking up the bills, and that Smith had kindly co-operated with him."

Several Reasons for Changing Position.-Altbough the estoppel-denier in changing his position may have relied not only upon the misstatement complained of, but also upon some mistake of his own,

"his loss none the less resulted from that misstatement. It is not necessary to show that the misstatement was the sole cause of his acting as he did." 1

In another place it is said that:

"If, howerer, the plaintiff mainly and substantially relied upon the framdulent representation, he will have his action for damages, though he was in part influenced by other causes." 2

\section{III. "Prejudicially."}

The change of position, to effectuate estoppel, must have been prejudieial to the estoppel-asserter. If he really benefited by the change or was in no way hurt by it, he bas nothing to complain of. This is plain enough, but is not always remembered. For example, it seems to be reasonably clear, as above noted, that a company will not be estopped by an erroneous certificate of shares unless some person has, upon the faith of it, come to some damage. But in the last English case upon the subject ${ }^{3}$ the point is overlooked. In it the certiticate

1 Edgington v. Fitzmaurice (1885), 29 Ch. D. $481 ; 55$ L 4 J. Ch. 650.

2 McAleer v. Horsey (1871), 3ij Ma. 453. And see Thomas v. Grise (1898), 41 Atl. R. 88:3 (Del.).
3 Parbury's Case (1896), 1 Ch. 100; 6.5 L. J. Ch. 104. See an opposite conclusion in Hambleton v. Central (18;6), 44 Md. 551, and in Wright's

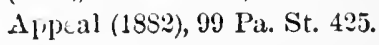


issued to a purchaser of the shares after the purchase-money for them had been paid. It may be said that, upon the faith of the certificate, the purchaser accepted the shares; but there was nothing to show that that was "a change for the worse." That he was "lulled into security," and so lost some chanee of recovery of his money from the fraudulent grantor, was not argued.

Damage, Real or Assumed.-Difference of opinion exists as to the necessity for proof of actual damage in cases of estoppel by "lulling to rest." It would, in many cases, be absolutely impossible to prove that, had the estoppel-asserter been active, he would eventually have been any better off than if he had lone nothing, although the result might have actually been so. The question is, again, one of speculation rather than of fact. A bank-depositor's name is forgel to a check; the bank pays the money; the depositor becomes aware of the forgery, but allows some time to elapse before notifying the bank; and meanwhile, it is said, a chance of some civil remedy or an opportunity to arrest the forger is lost. Is the depositor estopped?

In one case ${ }^{1}$ it was said:

"If the plaintiff had been met by a refusal on the part of the defendant. he could have gone to Marais (his venlor) and have demanded back his money; very likely he might not have derived much benefit if he had done so; but he had a right to do it."

On the other band it has been held that it is not sufficient evidence of damage to prove that the forger was within the jurisdiction, and had exigible property there, at the time when notice should have been given to the bank, without proof of "how long the payee and the property remained within reach." 2

Probably the true view lies between these two extremes. As to the former case, Brett, L. J., would say: ${ }^{3}$

"Possibly they have been put to rest, but it seems to me that is not sufficient: it must be clearly shown not only that they have been put to rest, but also that they have been damaged by being put to rest."

The mere postponement of the civil remedy by delay in disclosure does not necessarily and of itself constitute a change

1 Knights $\nabla$. Wiffen (18\%0), L. R. 5 Q. B. 665; 40 L. R. Q. B. 51. And see Merchants' Bank v. Lucas (185i), 13 Ont. 526.

2 Indiana, etc. v. First Nat. Bank (1894), 9 Ind, App. 185; 36 N. E. R. 382.
$3 \mathrm{Simm}$ v. Anglo-American Co. (18\%9), 5 Q. B. D. 211; 49 L. J. Q. B. 400. And see Ex parte Adamson (15.8), 8 Ch. D. 817; 47 L. J. Bk. 103. 
of position. ${ }^{1}$ The contrary indecd was held in a court of first instance, ${ }^{2}$ where the chief justice said:

"They might have sued for money had and received before the maturity of the note, and thus earlier right of action might have ben greatly to their benefit. The defendants who, by their conluct, deprived the plaintifs of the opportunity of resorting to that remedy, are not to be permitted to repuire the plaintilfs to prove that resort to that remedy would have been productive of gain or advantage to them."

And in the court of appeal the chicf justice, in a dissenting judgment, approved this language ${ }^{3}$ but by the majority of the judges it was thought to be

"a suggestion too speculitive to be the foundation of a lemal right." 4

The case of London, etc. v. Bank of Liverpool ${ }^{5}$ is not quite consistent with the broadest statement of the law. There a bill was paid althongh the inclorsements were forgeries, and the action, which was for repayment, failed, Mathew, J., saying:

"It may be that no legal right may be compromised by reason of the payment. For instance, the acceptor may pay the bill and discorer, on the same day, that the bill is a forgery, and so inform the hold $\mathbf{r}$ of it, so that the holiler would have time to give notice of dishonor to the other parties to the bill: but even in such a case it is manifest that the position of a man in business may be most seriotisly compromised even by the delity of a day."

A distinction, no doubt, must be made in cases relating to "negotiable" instruments upon the ground that the lapse of a day may mean the expiry of the period within which to give notice of dishonor ${ }^{6}$ but is there distinction upon any other ground? Must there not always be damage in order that there may be estoppel? ?

Although in many jurisdictions it is illegal to compound a criminal charge, yet it must be admitted that, aside from that point,

"the arrest and detention of a swinller are powerful means in coercing restoration of property he has unlawfully obtained, and the loss of these

1 Merchants' Bank v. Lucas (18s1), 3 B. \& C. 428; Mather v. Mairlstone 13 Ont. 520; 15 Ont. A pp. 573; 18 S. (18.56), 18 C. B. 273; 25 L. J. C. P. 310 ;

C. Can. 704 .

213 Ont. 532.

${ }^{3} 15$ Ont. App. 576.

4 Id. 587.

${ }^{5}$ (1896) 1 Q. B. 11 ; 65 L. J. Q. B. 84. See also Smith v. Mercer (1815), 1 Taunt. 76; Cocks v. Masterman (1829), 9 B. \& C. 905; Clark v. Eckroyd (1856), 12 Ont. App. 4:9; Bink of United States v. Bank of Georgia (182.), 23 U. S. 333.

${ }^{6}$ See Wilkinson v. Johnson (1824), (18.j6), 18 C. B. $273 ; 25$ L. J. C. P. 310 ;
London v. Bank of Liverpool (1896), 1 Q. B. 7; 6j L. J. Q. B. 80; Ryan v. Bank of Montreal (18s 7 ), 14 Ont. App. 560 ; Irving Bank v. Wetherald (1861), 34 Barb. 323; (1867) 26 N. Y. 335: Merchants' Bank v. National Bank (1869), 101 Mass. 281.

7Salem v. Gloucester (1820). 17 Mass. 1; Corser v. Paul (1860), $41 \mathrm{~N}$. II. 24; Bank v. Wentzel (1892), 151 Pa. St. 142; 24 Atl. R. 1087; Kuriger v. Joest (1899), 52 N. E. R. 764 (Ind.). 
means in consequence of a reliance upon the declarations of another estops that other from denying the truth of the declarations." 1

And so it is thomght that the eseape of the swindler is a sufficient change of position.2 But the following is worthy of consideration:

"In the case at bar it is the merest conjecture, with scarcely a possibility to support it, that the defendant or those from whom it received the bill conld at any time after the transmission of the foreinn bill of exchange to Biltimore have taken any effectual measures either for arresting the swindler or reclaiming the lill hought and paid for upon the credit of the bill. Estoppels cannot he based upon mere conjectures, even if a proper foundation is laid for them in other resperts." 3

In general it may be said that there must have been some change of position; and perbaps it can be said that that requisite will be satistied if the estoppel-asserter has "lost a fair chance to retriere his position."

\section{Purciaser for Value Without Notice, and Falsîvert.}

The phrase "purchaser for value without notice" has been used in two connections. In one of these it may be said to have described an effective legal situation; and in the other, to deseribe a person merely who may or may not be entitled to succeed in his litigation. We must shortly distinguish these and get rid of the former, in order that we may deal clearly with the latter. Observe then the difference between -

1. The defense of purchiser for value without notice, when pleaded to a bill appealing to the old auxiliary jurisdiction of the court of chancery; and

2. The position of purchase for value without notice, when it arises in a suit in which relief (not discovery merely) is sought.

The now useless subtleties which belonged to the former class of cases have, in must jurisdictions, been sent to limbo by the prorisions of judicature and other acts; and it seems to the present writer that the learning as to the latter class ought to be merged in, for it forms part of, the law of estoppel. It may

l Continental Bank v. Nittional Bank (187:), 50 N. Y. 5\%6; Bank v. Keene (1865), 53 Me. 103.

2 Third Nat. Bank r. Merchants (1894), 6 Hun, 4i.; 27 N. Y. Supp. 1070; Harlem v. Mercantile (1895), 31 N. Y. Supp. 790. But see Van
West v. First Nat. Bink (1891), 6 Ohio C. C. 130; Grabill v. Bearden (189.i), 62 Mo. APp. 459.

3 White v. Cuntinental Nat. Bank (1576). 64 N. Y. $3: 3$

\section{Ante, 1. 133.}


survive for a time because of its association with the legal estate; but tuat is an unbealthy conjunction, from which longevity, luclily, cannot be expected. ${ }^{1}$

Auxiliury Jurisdiction. - A defendant at law often found it necessary, for the proper conduct of his case, to obtain discovery from the plaintiff. As (in the earlier days) the practice at law made no provision for such discovery, the defendant was driven to the court of chancery, where be filed his bill in aid of his defense at law. To such a bill the plea of purchaser for value without notice was, of itself, a sufficient defense. The court held that it would do nothing that might affect the prospects in another forum of a man who was a purchaser for value without notice. ${ }^{2}$ The court made no investigation into the merits of the case or the rights of the parties. It was not called upon, and in fact held that it had no jurisdiction, to do so. It found its defendant in a complete legal situation and it merely left him there.

The union of the courts has abolished this auxiliary jurisdiction of the chancery, and has thus ended the necessity for considering purchaser for value without notice from that point of riew.

Concurrent Jurisdiction. - It will readily be seen that the court of chancery could not maintain the attitude just referred to when it was asked not to assist in the conduct of a suit in another forum, but itself to decide the dispute, and for that purpose to adjudicate upon the rights of the litigants.

For example, two mortgagees are claiming priority over one another. No. 1 brings ejectment at law against No. 2; and No. 2 , in aid of bis defense, files a bill against No. 1 for discovery. The bill will be dismissed if the defendant in it (No. 1) be a purchaser for value without notice. Nothing is decided

1 See ch. XVIII.

2 There was some doubt as to whether the plea was effectual if the plaintiff had the legal estate and the d-fendant only the equitable. In the fourteenth edition of Sugden's Vendors and Purchasers (vol. II, 584 et seq.) will be found a strong argument in favor of the proposition that equity "regards not the quality of the estate, but the character of the person," by which is of course meant his merits. See also per Lord Cranworth, in Colyer v. Finch (1856), 5 H. L. C. $920 ; 26$ I J. Ch. 65 . If the plaintiff had not the legal title it seems to have been immaterial whether or not the defendant had it. Bowen v. Evans (1844), 1 J. \& L. 263, 264; Hunter v. Walters (1870), L $\mathrm{R}$. 11 Eq. $314 ; 41$ L. J. Ch. 175. 
except that equity will not help No. 2's defense in the ejectment suit. But if No. 2's bill had sought relief, and not merely discovery - bad asserted priority and prayed for foreclosure, for example, - the court would have had to pass upon the merits of the case; and it would not have been prevented from so doing by proof that the defenrant was a purchaser for value without notice. The fact would not be ignored. It would be taken into account and given its proper effect in considering the right of priority. It clid not of itself oust jurisdiction. ${ }^{1}$

In other words, it was not and is not a complete legal situation (as when discovery merely was sought), but half of one only. For example, a seeond purchaser cannot say to the first: "I purchased without notice of your conveyance, and therefore I am entitled to priority over you" - that is but one-half of a legal situation, and may be called the subjective half as describing the mental attitude of the claimant. To succed he must also say that his opponent was in some way to blame for his haring been misled, which is the other, or objective, half of his position.

A very common case is one in which a first mortgagee has intrusted the title-deeds to the mortgagor; and the mortgagor has fraudulently deposited them with some innocent third person as security for a loan. In such case the depositee's position is, (1) subjectively, I had no notice of your claim; and, (2) objectively, you were to blame for that.

Another class of instances is that in which the owner of property stands by while a third person sells it to an innocent purchaser; and the latter says (1) I had no notice of your title, and (2) the fault was yours.

Estoppel. - But we are already clearly within the lines of estoppel. The latter case is alway's so recognized, and the former is an instance of estoplel by assisted misrepresentation; ${ }^{2}$ for

1 Some of the cases are: Williams v. Lambe (1791), 3 Bro. C. C. :264; Collins v. Archer (18:30), 1 R. \& M. ¿S4: Phillips v. Phillips (1\&61) 4 De G., F. \& J. :05: 34 L. J. Ch. 896; Srackhouse v. Comntess of Jersey (18(i1), 1 J. \& H. $2: 1$; 30 L. J. Ch. 421; Colyer v. Finch (18.54), 19 Beav. 500; 5 H. L. C. 905; 25 L.J. Ch. 65; Newton v. New- ton, L. R. 4 Ch. 144; 38 L. J. Ch. 145 ; Frizer v. Jones (1848), 17 L. J. Ch. i5i); Heath v. Crealock (18;8), L. R. 10 Ch. 22; 44 L. J. Cl. 1ist; lnd r. Emmerson (195i), :3:3 Ch. D. 393: 12 Аpp. Cas, 300 : j6 L. J. Ch. 989; Cive v. Cave (1ssu), 1.j Ch. D. 639; 49 L. J Ch. 50.).

¿see ch. III. 
when the mortgagee handed over the deeds to his mortgagor he did that which made eredible the representation of the mortgagor (that he, the mortgagor, was the unincumbered owner of the property), and he (the mortgagee) is estopped by the assistance thus rendered to that misrepresentation.

Observe the association of purchaser for value without notice with estoppel: There are two factors neeessary to an estoppel by misrepresentation: (1) The estoppel-asserter must (subjectively) be one who has changed his position upon the faith of something, and (2) (objectively) that something must be the misrepresentation or assistance to misrepresentation of another person. And this is but a more comprehensive, and therefore better, way of saying (1) that the estoppel-asserter must (subjectively) be a purchaser for value without notice; and (2) that (objectively) the estoppel-denier must be responsible for the mishap. A word as to each of these two points.

The first is probably clear enough. A "purchaser" in its wider sense includes, of course, a mortgagee, a lessee, and so on. But we must still extend its signification and make it embrace "one who changes his position," even if the change be nothing but a forbearance to act. For, as we have abundantly seen, a man may be estopped if under certain circumstances he bas been "luiled into security" - into inactivity - by the estoppelasserter. ${ }^{1}$

The second point will become obvious when it is noticed that purchaser for value without notice never arises exeept in cases in which the purchaser says that he has been misled by somebody's misrepresentation. His case always is, "I bought from a man who pretended to be the owner;" "the person with whom I dealt appeared to be entitled to bargain with me," etc. In other words, misrepresentation is always the prime factor in the "purchaser"s" position.

And so it is in estoppel.

Note next that the misrepresentation complained of in such cases is not that of the estoppel-denier, but of some third person. For example, in the mortgage case (in which the mortgagee loaned the deeds to the mortgagor, who fraudulently deposited them with a banker) the misrepresentation is that of the mortgagor, and the banker wins beciuse (in the older phraseology) 
(1) he was a purchaser for value without notice, and (2) the mortgagree was blamable; or (in the language of estoppel) (1) he had changed his position upon the faith of the misrepresentation of the mortgagror, and (2) the mortgagee had assisted the misrepresentation - had done that which had marle it credible.

Legal Estate.- Purchaser for value without notice is, according to the present state of the law, one-half of another lecal situation. For a second purehaser may say not only (as we have seen) "I bought the property relying upon a misrepresentition of ownersbip, for which the first purchaser was responsible;" but he may say "I bought it upon a misrepresentation for which the first purehaser was not responsible; nevertheless I have got hold of the legal estate; and I am for that reason entitled to priority."

This subject is fully dealt with in another chapter; ${ }^{1}$ and all that need be here said is to point out that again "purchaser for value without notice" is but one-half of the legal situation which is allegerl: ${ }^{2}$ and that pending the disappearance of that situation (as indicated in the chapter referred to), purchaser for value without notice must cortinue to be a legal factor, and one not to be saperseded by the larger phrase, "one who changes bis position upon the faith of a misrepresentation."

We now sec:

\section{Semmatir.}

(1) That purehaser for value without notice is not of itself a legal situation, and never was, exeept when plearled to the auxiliary jurisdiction of the court of chancery. It is one-half merely of a legal situation.

I Ch, XVIII.

2 It is again the subjective half, reguiring for its complement the pos. sersion of the legal estate. Or. to put it the other way, " leing pmychasers for value without notice. they camot succed mulesi they cau make ont that, having an inferior equity, they have clothed it with legal estate" (The man is no use without the clothes; nor are the clothes without the man. Eich is one-half of the situation): Per Kay, L. J., in Powell v. London (1593), L. R. 2 Ch. 564: 6: L. J. Ch. 79.5. See also Phillips r. Phillips (1-(61), 4 De Cr. F. \& J. :08: 34 L. J. Ch. s96: Cive v. Cave (1840), 15 C.ı. D. 639: 49 L. J. Ch. 50.); Happlam v. Chacklock (1ss1), 19 Ch. 1). 20r: Rools v. Williamson (1885), 38 Ch. D. 455; 52 L. J. Ch. 995; Forse v. Surereign (Issi), 14 Ont. Apl. 48:; Utterson v. Remnie (1ะ9:), 21 S. C. Cin. 218. 
(2) It was only effective when conjoined with (a) legal estate, or (b) misrepresentation.

(3) The doctrine of legal estate, owing its existence to the former defective administration of justice in England, ${ }^{1}$ must needs wither and die now that the defects are gone. Purchaser for value may be allowed to live meanwhile.

(4) But no longer; for the alliance between the purchaser for value and misrepresentation has been superseded by estoppel; and bis identity has been lost in the larger phrase, "one who changes his position prejudicially upon the faith of the misrepresentation" - that is, as suggested in the preface, a falsûvert.

${ }^{1}$ See ch. XVIIL. 


\section{CHAPTER XII.}

CONDITION NO. 10.

The Estoppel-denier Must Hace Reasonable Ground for Anticipating Some Change of Position Upon the Faith of the Representation.

\section{Distixction.}

The previous chapters have made familiar the propositions that estoppel may occur (1) because of some personal misrepresentation, or (2) because of some assistance renclered to the misrepresentation of another person; and we have now to inquire as to the character of the relation which must exist between the change of prosition of the estoppel-asserter on the one hand, and the misrepresentation or the assistance of the estoppel-denier on the other.

Manifestly such relation will have one of two aspects: First, it may be regarded from the standpoint of the estoppel-denier, and for him the rule will be that he must have had reasonable ground for anticipating some change of position upon the faith of the misrepresentation. And secondly, it may be regarded from the standpoint of the estoppel-asserter, for whom the rule will be that the change of position must be reasonably consequent upon the misrepresentation or assistance.

Confining ourselves in this chapter to the first of these aspects, observe that there are two sorts of cases which may arise:

1. Inquiries may be made of the estoppel-denier, but the purpose of them not being known to him he may make a careless and inaccurate reply - be had no reason to anticipate action of any kind. The case is one of personal misrepresentation.

2. The estoppel-denier observes action or preparation for action; but he is maware that certain facts known to him are unknown to the actor, and he is silent and thus misleading he had no reason for assmming that the action was because of faith in his passivity. The case belongs to the class of estoppel by passive assistance. 
In the first of these cases the estoppel-denier is aware that he has made a misrepresentation, but he has no reason for thinking that it is to be followed by action. In the second he is aware of intended action, and by his silence he has misled the actor, but be has no reason for believing that the action is being taken upon the faith of his silence.

\section{Persoxal Misiepresentation.}

Suppose that a stranger asks me as to the ownership of a horse that I am riding, and I tell him that it belongs to my brother. Afterwards the stranger, who turns out to be a bailiff, seizes the horse under an execution against my brother, and claims that I am estopped from denying the truth of my assertion. I am not estopped. ${ }^{\mathrm{I}}$ I had no ground for anticipating any change of position. Had I known that the stranger had a purpose in making his inquiry, my answer might have been different.

“Certainly no one can be estopped by a deceptive answer to a question which lie may rightly deem impertinent and propounded by a meddling intruder." 2

And so it was held ${ }^{3}$ that

"a bank which received a letter from another bank asking in regard to the character and financial standing of a certain person. without any intimation as to the maling of a loan, is not estopped as against a loan subsequently made by the inquiring bank to claim a chattel-mortgage lien on the man's property."

It will be seen that the inquiring bank's object might as well have been with a view to collecting a debt as of making a loan. The answering bank had no reason for anticipating a change of position.

For a similar reason, if the maker of a note is asked if it is all right and he says it is, he will not necessarily be estopped from denying liability. It may be that the inquirer, after the conversation and upon the faith of, bought the note; but for

1 Allum v. Perry (1878), 68 Me. 232; Tillotson v. Mitchell (1881), 111 Ill. 518 ; Fountain v. Whelpley (1885), 77 Me. 132.

${ }^{2}$ Per Metcalf, J., in Pierce v. Andrews (1850), 60 Mass. 6. And see New Brunswick v. Conybeare (1862), 9 H. L. C. 726 ; 31 L. J. Cl. 29 ; Florida v. Hope (1898), 18 Tex. Civ. App. 161;
44 S. W. R. 10; Nicols v. Peck (1898). 70 Coun. 439; 39 Atl. R. 803; Shields v. MeClure (1898), 75 Mo. App. 631.

${ }^{3}$ First Nat. Bank v. Marshall (1895), 108 Mich. $114 ; 6.5$ N. W. R. 604. Compare Swift v. Winterbotham (1573), L. R. 8 Q. B. 244; 42 L. J. Q. B. 110 : L. R. 9 Q. B. $301 ; 43$ L. J. Q. B. 56 , in which usage har some effect. 
all the maker knew the question might have been one of illo curiosity.

This iloctrine may casily be carried to excess. For example, the statement that

"merely holding out a person as agent does not estop the alleged principal from denying such person's authority to contract in his helalf, unless the representiations were male under sich circumstances that the principal should have expected that thry would be relied upon in good faith, to the injury of an innocent party,"

can be agreed to only if qualified by saying that most usually when one holds out another as his agent he ought to assumo that he will be taken seriously, and as intending to produce a real impression which maty be acted upon by the person to whom the representation is made. And so where a person who was about to purchase some property wrote to another asking the amount of his claim agrainst it and was told $\$ 50$, the court said : ${ }^{3}$

"But the transaction itself was sufficient to advise libelant that the letter was not a 'mere busyboly' inquiry. Here was a business firm in a near-by city writing a letter which npon its face is apparently about a husiness matter. Is the court to assume that business men write, or that buij. ness men receive, such inquiring letters as a mattro of mere curiosity wit 'out a desire to use, or a reasonable expectation that use will be made of the respons as a basis for action in business matters? Libelant, while not required to respond, did respond."

Considerations such as these amply justify the dictum of Lord Cranworth (upon which the condition in hand is modeled):

"I think it is not necessary that the party making the representation should know that it was false; no fraul nevil have been intended at the time. But if the party has unwittingly misled another, you must add that he has misled another under such circumstances that he had reasonible grotind for sulposing that the person whom he was misleading was to act upon what he was saying."

This is but put in another form when Baron Parke said:

"If, whatever a man's real meaning may be he so conlucts himself that a reasonable man would talie the representation to be true, and believe

1 Andrews v. Lyons (186ij), 11 Allen (Mass.), 3.9; Ehrler v. Bram (185i). 22 Ill. Alp. 391; 120 Ill. 503: 12 N. E. R. 996; Smith v. Roach (1894). 59 No. App. 115. It would be otherwise if the maker knew that the incuirer contemplated purchasing: Freeny $\mathrm{r}$. IIall (1891), 93 Ga. 706 ; 21 S. E. R. 163; or if he knew that the inquirer was the holder, and the inguirer was "lulled to rest" or inactivity by the answer. See Plumer v. Loril (1s6t, 91 Mass. 455), in which there hald been representations as to the exist- ence of a partnership before credit given, and with no intent to procure it - no estoppel. See also cases in ch. XI, under sub-title "Lulled into Security."

2 Clarke v. Dillman (1896), 109 Mich. 625: 66 N. W. R 5io.

3 Jississippi $v$ Ottumwa Belle (1S97), is Fed. R. 613.

4 Jorden $x$. Money (1854), 5 II. L. C. 212; 33 L. J. Ch. 86.i. Anl see West ․ Jones (1851). 1 Sim. N. S. 20.5; 20 L. J. Ch. 36: M: Ingles v. Dixon (1859), 3 II. L. C. 702; Manufacturers' Bank 
that it was meant that he should act upon it, and did act upon it as true, the party making the representation would be equally precluded from contesting its truth." 1

To the same effect an American case has it, that

"if thrs circumstinces are such that a reasonable man under the circumstinces would anticipate that it was to be acted upon, that will be suf. licient." 2

Horn v. Cole ${ }^{3}$ is an important case upon the subject in hand because of the valuable judgment of Perley, C. J., which it contains, whaterer one may think of the justness of the conclusion arrived at. The owner of certain goods represented to Cole that they were the property of $A$.; he clid so in order to avoid their attachment by his own creditors, of whom Cole was not one; thereupon Cole sued $\mathrm{A}$. (who happened to be his (lebtor), and attached the goods; the owner of the goods was not aware that Cole was a creditor of $\mathrm{A}$., and had no intention of misleading Cole - it was his own creditors that he was contriring to deceive. IIeld, that the owner was estopped, for "whatever the motive may be, if one so acts or speaks that the naturil consequence of his words or conduct will be to influence," etc.

The case is out of harmony with those already referred to. The deflection is probably due to the too sweeping assumption that all natural consequences are to be debited to any one wh's makes a misrepresentation, whether the person deceived had or had not reasonable ground for believing that the representation was intended to produce action upon his part. The circumstances of the case (for which see the report) make it perfectly clear that the misrepresentation was made by the owner of the goods, not for the purpose of producing action by A.'s creditors, but in order to insure inaction upon the part of his own; and that Cole, to whom the misrepresentation was male, had no

จ. Hazard (1864), 30 N. Y. 226; Wallerich v. Smith (189(i), 97 Iowa, 308; 66 N. W. R. 184; Moore v. Spiegel (1887), 143 Mass. 413; 9 N. E. R. 827.

1 Freeman v. Cooke (1818), 2 Ex. 651; 18 L. J. Ex. 114 . To the same effect: Preston v. Mann (15i6), 25 Conn. 128, 129. And see the third proposition in Carr $\mathrm{r}$. London (1875), L. R. 10 C. P. $316 ; 41$ L. J. C. P. 109. Consult Bigelow on Estoppel (5th ed.), pp. 629, 629, and the cases there cited; and the later cases of Ford $r$. Fellows (1859), 34 Mo. Apl. 630; $8 \mathrm{~S}$.
W. R. 791; Westbrooke v. Gurdereau (1893), 3 Tex. Civ. A pp. 406; 22 S. W. R. 59; Kiersky v. Nichols (1895), 29 S. W. R. 71 (Tex.); Daugherty v. Yates (1896), 13 Tex. Civ. App. 646; 35 S. W. R. 937; Sessions v. Rice (1886), 70 Iowa, $305 ; 30$ N. W. R. 735.

2 Two Rivers Co. г. Day (1899), 102 Wis. 328 ; 78 N. W. R. 442. And see Kingsman v. Grabam (1881), 51 Wis. 232; 8 N. W. R. 181; Tracy v. Lincoln (1857). 145 Mass. $357 ; 14$ N. E. R. 122. 3 (1868) 51 N. H. 297. 
reason to suppose that there was any intention that he should act upon it.

Zuclitman $v$. Roberts ${ }^{1}$ errs in contrary fashion. A rendor (by hire and sale agreement) gave to the purchaser a receipted bill for the goods, which was exhibited to a sub-purchaser as evidence of ownership; and it was held that the original vendor was not estopped, because there was no design to mislead and no intention that anybody should act upon the fatith of the document. The point that "a reasonable man under the circumstances would anticipate that it was to be acted upon" was overlooked.

Mr. Markby's View.- There is some curious confusion with reference to this subject in Markby's Elements of Law : ${ }^{2}$

"It has been said to be the law in England that wherever A. so conducts himself towards $B$. that $B$. may reasomably infer the existence of an intention on the part of $A$. to do something, the legal result is the sameas if that intention existed. whether it really exists or not. And these cases are always put as cases of estoppel; that is, the intention to do this thing is assumed to exist. whether it exists or not. It wonld be much simpler to attribute the lexal result to the act without any reference to the intention of consequences, but no one has ever thought of this, so wediled are we to the view that the learal result of an act must depend on the mental condition of the doer of it as regards these consequences."

The most obvious comments upon this passage are:

1. The view that "the legal result is the same" (namely, estoppel) whether the intention really exists, or from the estoppel-deuier's conduct it may reasonably be inferred to exist, cannot fairly be translated into, "that is, the intention to do this thing is assumed to exist whether it exists or not."

2. Nor can such translition be debited to estoppel; which indeed is constantly pointing out its inaccuracy, and insisting that the reason for attributing legal consequences to the conduct in question is precisely not because intention existed, or is assumed to exist, but because the estoppel-denier is estopped from denying that it did exist - haring misled another person into the belief of a certain state of facts, he is precluded from denying their existence. ${ }^{3}$

3. The proposed alternative is "to attribute the legal result to the act without any reference to the intention of consequences." But the only "act" which is attended by legal results is the conduct from which " $\mathrm{L}$. may reasonably infer the

1(1871) 109 Mass. 53. And see cases cited with this one in ch. XXI.
2 4th ed.. 5333.

${ }^{3}$ See ante', cl. L. 
existence of an intention (of consequences) on the part of A." The "act" therefore is inseparable from "the intention of consequences," and can only be spoken of with reference to it.

4. Mr. Markby replies to himself (although somewhat defectively), when, after referring to an example, he says: ${ }^{1}$

"Such cases might seem to suggest thit the reference of an act to the mental attitule of tho doer of it in relation to the consequences is but a pretense after all. This, however, would be an erroneous conclusion. If an act prorluced a legal result merely becanse a particular person did it, and not at all because of the mental attitude of that person as regards the consequences when he dicl it, then the existence of circumstances affect. ing that at titude woukl bave no effect."

Intention or Negligence. - It is frequently said that

"there must generally be some intended deception . . or such negligence . . as to imount to constructive fritud." ${ }_{2}$

But the word "fraud" is here, as very frequently elsewhere, ${ }^{3}$ used in wholly artilicial fashion, and as a cloak merely to the lack of elearness of perception; for in some of the instances in which it occurs, as well as in many of those already referrel to in this chapter, there was not the slightest tinge of ball faith. Those in which real fraud is put forward as the grounit of decision are, for the most part, cases of passively assistel misrepresentation, in which, as we have seen, fraud is a necessary ingredient in the misrepresentation, although sometimes upon that account thought to be an essential requisite of estoppel. ${ }^{4}$

\section{Assisted Misrepresentation (Passive).}

In this class of cases the estoppel-denier observes action or preparation for action, but he is unaware that certain fact: known to him are unknown to the actor, and he is silent and so misleading. In such case there is no estoppel because he had no reason for assuming that the action is being taken upon the faith of his passirity.

This subject has already been sufficiently treated. ${ }^{5}$ It is there-

1 Elements of Law, $§ \$ 38$.

${ }^{2}$ Brant v. Virginia (ISr6), 93 U. S. 335. And see Evans v. Ficknell (1801), 6 Ves. 190, commented on in Nortlern Counties v. Whipp (1894), 26 Ch. D. 489: 593 L. J. Cl. 6\$0: Patterson v. Hitcheock (18ĩ), 3 Colo. 5:3:3; Hardy v. Chesapeake (1879), 51 Mil. 56:; Griffith v. Wright (188:), 6 (Colo. '248; Greene v. Smith (1884), 57 Vt. 268;
Birch v. Steppler (1888), 11 Colo. 400;

Griffith v. Brown (1885), 76 Cal. 260; Montgonıery v. Keppel (1889), 75 Cal. 128; Sullivan v. Colby (1896), 18 C. C. A. 193; 71 Fed. R. 460; Am. \& Eng. Euc'y. (2d ed.), vol. 11, p. 432.

${ }^{3}$ See ch. XVIII, sul)-title "Nothing but Fraud," and ch. XIX.

4 See ante, ch. VIIL.

${ }^{3}$ Ante, p. 133. 
fore unnecessary here to do more than to remind readers that there is no duty to be active and communicative unless "I perceive his mistake;" I and that I cannot be said to "perceive his mistake" unless I have some reasonable ground for assuming that he is ignorant of his situation - that is, unless I " have reasonable ground for anticipating some change of position upon the faith of " $\mathrm{my}$ silence."

\section{Assisted Misrepresentation (Active).}

There is a thircl class of cases, namely, of those in which there is estoppel because of some active assistance rendered to the misrepresentation. In such cases the estoppel-denier is usually quite as innocent as the estoppel-asserter; he has been guilty of no misrepresentation; he was unaware probably that it was being made; and he was ignorant of any action being taken in derogation of his own rights.

For example, a mortgagee permits the mortgagor to have possession of the title-deeds; and the mortgagor, in fraud of the mortgagee, deposits them with a banker as security for a loan. Here the mortgagee knows nothing of either misrepresentation or action upon the faith of it, and yet he is sometimes estopped.

Such cases must be dealt with from the standpoint of the estoppel-asserter, and will thus fall to be treated of in the next succeeding chapter. If we cannot say in such cases that the estoppel-denier must have had reasonable ground for anticipating a change of position upon the faith of the misrepresentation (he in fact not intending any misrepresentation at all), we can nevertheless require for estoppel that the change of position of the estoppel-asserter must have been reasonably consequent upon the assistance which has been rendered by the estoppel-denier.

\section{Scminar.}

Conclusions from the foregoing are as follows:

1. "No one can be estopperl by a deceptive answer to a question which he may rightly deem impertinent." He must have bad reasonable ground for supposing that the person whom he 
was misleading was going to act upon what he was saying; that is to say, reasonable ground for anticipating some change of position. This is a rule for personal misrepresentation.

2. In cases of estoppel by passive assistance there is no duty to speak unless "I perceive his mistake;" that is to say, unless I have reasonable ground for anticipating some change of position upon the faith of my silence.

3. The requisite under consideration is not applicable to cases of estoppel by active assistance. A rule for them will be found in the succeeding chapter. 


\title{
CIIAPTER XIII.
}

\author{
CONDITION NO. 11.
}

\section{The Change of Position Must be Reasonably Consequent Upon the Misrepresentation or the Assistance.}

We have seen that, in order to effect an estoppel, the estoppel-asserter must have changed his position upon the faith of the misrepresentation. We have also seen that in two classes of cases the estoppel-denier must have had reasonable ground for anticipating that some change of position would take place. But suppose that the ehange which ensues is not only not that expected, but that which could not reasonably have been anticipated. For example, a railway company inadrertently and untruly informs an expectant consignee that his goods have arrived, and he, instead of acting upon that notice by senciing for them as the company intencled, acts upon it by making a sale of them; would the railway company be estopped by such a change of position? Or supposing that a warehouseman, believing that he had in store certain goods, demands payment of rent for them from a person who did not own them; and that such person, instead of paying the rent as the warehouseman intended, purchases the goods from the real owner; is the warehouseman estopped by such change of position?!

\section{The Barry v. Croskey Rules.}

In $1861, \mathrm{~W}$ ood, $\mathrm{V}$. C., said that the regulating principles were as follows: ${ }^{2}$

"First. Every man must be beld responsible for the consequences of a false representation made by him to another, upon which that other acts, and so acting is injured or damnified.

$1 \mathrm{Mr}$. Bigelow's language is too general. He says (on Estoppel. 5th ed., p. 639): "And it matters not. if the party acting upon the representition was justified in so doing, hou he has changed his position." The 1; $31 \mathrm{~L} . \mathrm{J} . \mathrm{Cl} .121$. circumstances in Moore $v$. Spiegel (158i), 143 Mass. $413 ; 9$ N. E. R. 82i, would form a fair test of the statement.

2 Barry v. Croskey (1S61), 2 J. \& H. 
"Sccoridly. Every man must be held responsible" for the consequences of a false representation made by him to another. upon which a third person acts, and so actiug is injured or damnified - provilled it appear that such false representation was male with the intent that it shonld be acted upon by such third person in the manner that occasions the injury or loss.

"Thirdly. But to bring it witlin the principle, the injury, I apprehend, must be the immediate and not the remote consequence of the representation thus made."

This language was quoted by Iord Cairns in $1873^{1}$ with the remark that the principles

"appear to me to be consistent with what is stated by all the authorities that might be referred to."

It was also quoted with approval by Lord Esher in $1896 .^{2}$ According to Barry v. Croskey, then, the law is as follows:

1. Where the misrepresentation is made directly to the estoppel-asserter, it is immaterial whether the change of position was or was not that which was intended; provided that it be the immediate and not the remote consequence of the misrepresentation.

2. But where the misrepresentation is made indirectly to the estoppel-asserter, then the change of position must be not only the immediate and not the remote sonsequence of the misrepresentation, but it must also be that which was intended by the person who made the misrepresentation.

In other words, if the misrepresentation be made directly, there will be estoppel, whether the action was that which was intended or not; but if the misrepresentation be made indirectly (made to some one else but passed on), then the action must be that which was intended.

\section{The Carr v. London Rules.}

The text-writers almost unanimously omit reference to the Barry v. Croskey rules. They all quote the better known anil more frequently cited rules formulated by Brett, L. J., in $C a r^{\prime \prime}$ $v$. London, ${ }^{3}$ which are as follows:

1. "One such proposition is, if a man by his words or conduct wilfully. endeavors to cause another to believe in a certain state of things which thic first knous to be false; and if the second believes in such a state of things. and acts upon his belief, he who knowingly made the false statement is: estopped from averring afterwards that such a state of things did not in fact exist.

1 Peek จ. Gurney (1873), L. R. $6 \mathrm{H}$. I. 413; 43 L. J. Ch. 19. $3(1875)$ L. R. 10 C. P. $316 ; 44$ L. J.

2 Andrews v. Mockford (1896), $1 \mathrm{Q}$. C. P. 109.

B. $378 ; 65$ L. J. Q. B. 302. 
2. "Another recognized proposition seens to be that if a man, either in express ternis or by conduct, makes a representation to another of the existence of a certinn state of facts. which he intends to be aeted upon in a certuin way, and it it be acted upon in that $x$ aty in the belief of the existence of such a state of facts, to the damage of him who so believes and acts, the first is estopyed from denying the existence of such a state of facts.

3. "And another proposition is that if a man, whatever his real mean. ing may be, so conduets himself that a reasonable man would take lins conduct to mean a certain representition of facts, and that it was a true representation, and that the latter was intenled to act upon it in a particular woy, and he with such belief does act in that woy to his clamage, the first is estopped from denying that the facts were as represented."

It will be observed that these Curr $v$. London rules were formulated in 1575 . The Barry $v$. Croskey rules had been enunciated fourteen years earlier (in 1561); and twenty-one years later (in 1896) they were approved by the same judge who formulated the Carr v. London rules. Lord Cairns too, as we have noted, in that last named year said that the Barry $v$. Croskey rules were "consistent with what is stated by all the authorities."

\section{The Rules Compared.}

A eomparison, however, of these rules shows that they proceed upon widely different principles. The Barry v. Croskey set distinguish between cases of direct and indirect misrepresentation, and assert that where the misrepresentation is direct there will be estoppel, whether the action taken is that intended or not; but that where it is indirect the action must be that which was intended. In the Curr v. London propositions there is no trace of this distinction. The seeond of them indeed does leave room for the introluction of the idea, but that it is not there is shown by the application male of it to the case under consideration, and by comparison of it with the third rule.

The distinction made by the Carr $v$. London rules is one of wholly dissimilar sort, namely, between cases in which the estoppel-denier "wilfully" represents that which he "knows to be false" (Rule 1), and those in which there is no moral culpability (Rules 2 and 3). Where there is wilful misrepresentation (Rule 1) there will be estoppel, whether the action taken is that intended or not; but where the misrepresentation is honest (Rules 2 and 3 ) the action must be that which was intended, or at all events that which to a reasonable man would seem to have been intended. In the Burry $v$. Croskey rules there is no trace of such a distinction. 
Now it is quite apparent that these two sets of rules cannot subsist togrether. For if we apply them to a case (of frequent sort) in which there is a direct and honest misrepresentation, but no intention or seeming intention to produce the particular action which ensued, then, according to the Barry $v$. Croskey rules, there would be estoppel; but according to the Carr $v$. London rules there would not. And contrariwise, if we assume a case in which the misrepresentation is indirect and dishonest, and the action not that intended, then according to Barry v. Croskey there would be no estoppel, but according to Carr v. London there would.

\section{Classification Necessart.}

A review of the cases will show that neither set of rules has been consistently acted upon; and this further, that they are not, in their form, eren adapted to a large number of the cases to which they have been applied. The confusion has arisen from an insufficient classification of the subject. It has been assumed that in all cases of estoppel by misrepresentation the estoppel-denier must hare communicated with the estoppelasserter, either directly or indirectly, and in so doing must have been either honest or dishonest. But this is not true, for in the largest class of cases the misrepresentation is not made by the estoppel-denier at all, and therefore neither directly nor indireetly, neither honestly nor dishonestly.

The class of cases just referred to is that spoken of in this work as that of actively-assisted misrepresentation. It embraces those multitudinous instances in which the misrepresentation has been made by some third person who has through some action or inaction of the estoppel-denier been enabled to make his misrepresentation credible. For example, a mortgagree hands the title-deeds to the mortgagor, who, in fraud of the mortgagee, deposits them as security for a loan. In this case the misrepresentation is that of the mortgagor in asserting that he was the unincumbered owner of the land; and the depositee can obtain priority only if it be held that the mortgagee, by having parted with the deeds (by Laving assisted the misrepresentation), is estopped from asserting his title. In other words, if the depositee's action was reasonably consequent upon the assistance rendered by the mortgagee to the misrepresentation of the mortgagor. 
In such cases, as will be seen, there is no misrepresentation, either direct or indirect, either honest or distronest, so far as the estoppel-denier is concerned. Neither of the two sets of rules contemplates such a case; and yet the class to which it belongs is of much greater importance than the simple cases of personal misrepresentation, for which alone they are possible.

\section{Personal Misiepresextation.}

And it may therefore be that for such cases one set or other of the rules is valid. To ascertain this, and also to evolve, if possible, some principle for the cases not provided for (those of actively-assisted misrepresentation), let us review a few of the cases, commencing with the two which contain the rules under discussion.

Baring v. Croskey. In this case a company by misrepresentation persuaded the Stock Exchange to quote its shares and to fix a settling day. The directors, preparing for such action, "cornered" the shares; and made various contracts for future purchases which they knew the rendors would be unable, because of the "corner," to carry out. One of the vendors sued the company for his losses, alleging that but for its misrepresentation to the Stock Exchange the settling day could not have been fixed; and that his contracts (which were dependent upon the fixing of a day) conld not therefore have been enforced.

Here it will be observed the misrepresentation was by the company to the Stock Exchange, and only indirectly to the plaintiff; and the company was held not to be responsible to him upon the ground that the misrepresentation was not made with the intent (by the company) that it should be acted upon in the manner in which the plaintiff had acted upon it. The company's purpose (as distinguished from that of the directors) "was that they might be a company of sufficient repute to have their shares "quoted," as it is called, on the Stock Exchange, and there bought and sold and dealt with; and not that time bargains, snch as have been entered into by the pliantiff in this case, should be made for their benefit still less that such birgains should be enforced by a given day to the injury of the parties who have entered into them."

The misrepresentation was indirect; it had not been acted upon by the plaintiff in the manner intended by the company; the company, therefore, was not estopped. 
Were we to apply the principles of Carr $v$. London to this case we should have to arrive at a conclusion contrary to that of the court. We should have to say that the company would have been estopped; for the misrepresentation was dishonest, and in such case, aecorling to that authority, it is immaterial that the action was not that intended.

Carr v. London.' A railway company by mistake sent to plaintiff an advice note indicating the arrival of certain goods for him. Upon the faith of this advice note the plaintiff sold the goods. Hell, that the company was not estopped from showing that the goods bad never reached their hands. Brett, L. J., said :

"It cannot, as it seems to us, be truly affirmed that the defendants intended any representation of theirs to be acted upon by the plaintiff in the uay of reselling the goods. . . . The only intention on the part of the defendants which can be properly inferred from the sending of an advice note is that the consignee should send for the goods."

In this case the representation is made honestly; and there is no estoppel because it was not acted upon in "the particular" way" intended. But under the Barry v. Croskey rules there would bave been estoppel; for, the misrepresentation being direct, the character of the action taken is immaterial.

\section{The Rules Criticised.}

Here then we have two eases, both of them decided, as one would think, properly; and yet the rule upon which each proceeded would reverse the decision in the other case. This rather suggests that both the rules must be defective.

Barry v. Croskey. A priori it is not easy to see why the nature of the change of position of the estoppel-asserter (that intended or not intenderl) should be dependent upon whether the misrepresentation was made to him directly by the estoppeldenier, or made to someone else with the intention that it should be passed on to him. ${ }^{2}$ In both cases the misrepresentation is the same; in both it is made by the person held responsible for it; and in both it is acted upon by the person whom the estoppel-renier intended should act upon it. In both cases then there should be estoppel if (may we not add?) the change

1(1875) L. R. 10 C. P. $17 ; 44$ L. J. C. P. 109 .

2 If it is not intended to be passed 
of position is reasonably consequent upon the action of the estoppel-denier.

Curr v. London. The other proposition, that the character of the change should be dependent upon whether the misrepresentation was honest or dishonest, is not more reasoliable. It asserts that if the misrepresentation be honest there is estoppel only where it is aeted upon in the manner intended (or in the manner which a reasonable man might assume was intended); but that if it is dishonest there is estoppel anyway. As a moral and punitive rule this may be unobjectionable; but apart from that view is it reasonable that a man is to be held responsible for everything done upon the faith of his misrepresentation (eren if dishonest), no matter how remote or extraordinary or inconsequent the act may be? - for cxample, for that which followed upon the misrepresentation in Barry $v$. Croskey. There must be some limit even in cases of dishonest misrepresentation; and if so, must it not be to those actions which are reasonclly consequent upon the misrepresentation?"

Again, in the case of lionest misrepresentation, supposing it to be true (Rule 3) that there will be estoppel where the action is that which "a reasonable man would take" it was that intended, is this not another way of saying that the action must have been reasonably consequent upon the misrepresentation?

For both honest and dishonest representation then may we not say, in cases of personal misrepresentation, that the change of position must be reasonably consequent upon the misrepresentation?

\section{Assisted Misrepresentation (Passive).}

To affirm, in cases of standing-by, that the change of position must be reasonably eonsequent upon the passivity, is but

1 In Bedford v. Bagshaw (1859), 4 H. \& N. 548; 29 L. J. Ex. 59, Baron Bramwell said: "But it is not a ball rule that a person who makes a fraudulent representation which is intended to be generally circulated shall be liable to any person injured by acting upon it, however remote the consequences may be." Ohserre that the learned Baron does not say however remote the action may be from the misrepresentation, but this: that if the representation be acted upon, then there is liability for the remotest consequence of that action. Possibly this distinction was not present to the mind of Wool, V. C., when he said of the dictum: "That may be sound doctrine in mensuring the limits of moral responsibility." Barry r. Croskey (1561), 2 J. \& II. 1') $31 \mathrm{~L}$. J. Ch. 1:1. 
insisting upon one of the data of the case. For the case is that the true owner stood by and witnessed a disposition by another person of his interest in the property to one who purchased upon the faith of the misrepresentation of ownership. In a preceding chapter ${ }^{1}$ we saw that in such a case there is estoppel where (1) the estoppel-denier was aware of his own rights; (2) the estoppel-asserter was unaware of these rights, and (3) the estoppel-denier had reasonable ground for assuming the existence of such ignorance. Where these facts co-exist the estoppel-denier has " reasonable ground for anticipating some change of position," and the particular change plainly is " reasonably consequent upon the assistance" rendered by the silence of the estoppel-denier, for it was the change which he anticipated.

\section{Assisted Misrepresentation (Active).}

As has already been suggested, neither of the two sets of rules (above quoted) is adapted to cases of actively-assisted misrepresentation, for in these it is impossible to make the distinction between direct and indirect, honest and dishonest, misrepresentation. The question in such cases involves primarily the conduct, not of the person making the misrepresentation at all, but of a third person - the person rendering the assistance who sometimes has no cognizance of the misrepresentation.

Recurring to the case of the deeds hancled over by the mortgagee to the mortgagor, and the mortgagor pledging them, it will at once be seen that we cannot determine the question of the mortgagee's estoppel (1) by considering the moral quality of the misrepresentation (for the misrepresentation was that of the mortgagor); nor (2) by asking whether the depositee would, as "a reasonable man," have taken it that the mortgagee intended him to advance money upon the deeds (for the depositee knew nothing of any mortgagee, and indulged, therefore, and could indulge, no speculations as to his intentions). ${ }^{2}$ Conceiv-

1 Ante, ch. VIII.

2 A partner who has retired is estoppen from denying that he is a party to a contract made with a cus. tomer in the partnership name unless the customer has notice of lis retirement; yet it cannot be sup. posed that he intended that the continuing partners should pledge his credit in fraud of him. See per Parke, B., in Freeman v. Cooke (1848). 2 Ex. 664: 18 L. J. Ex. 114 . See also Hoig v. Gordon (18r0), 17 Gr. 599. 
ably, the good or bad faith of the mortgagee might be a factor in the problem, but we shall presently see that that also is sometimes immaterial. ${ }^{1}$

That there must be some relation between the act of the estoppel-denier and the change of position of the estoppelasserter is erident; and as it is quite impossible to apply either of the orthodox sets of rules, it is here submitted that the change must be reasonably consequent upon the assistance rendered to the misrepresentation.

\section{Aprlication to the Cases.}

Applying retrospectively this suggested rule to the two principal cases, we find it sullicient for them. In Barry v. Croskey the action taken was held not to work an estoppel, because it was not the action contemplated; but it was clearly also that not reasonably consequent upon the misrepresentation. And the valility of the competing rules may be tested by asking: Whether, if the action had been reasonably consequent but not that intended, there should not have been estoppel? The rule suffices also for Curr v. London, because if sending for goods and not selling them was that which was intended, it was also that which was reasonably consequent upon the misrepresentation. We pass on to a few other cases:

Seton v. Lafone. Wharfingers who (mistakenly) believed that they had on hand certain goods, wrote to the plaintiffs who they (mistakenly) thought owned them, intimating that the goods were on hand and demanding rent. On the faith of this demand the plaintiffs bought the goods from the real owner. Meld, that the wharfingers were estopped from denying that they had the goods.

This is a case of direct and honest misrepresentation. Accorling to Barry v. Croskey, therefore, the wharfingers will be estopped, although the misrepresentation was not acted upon in the manner intended; but according to Curr $v$. London there will be no estoppel, for although the misrepresentation was lonest it was not acted upon in the manner intended, nor probably as "a reasonable man would have taken it," that he was intended to act upon it.

i Ch. XIX.

2 (185i) 18 Q. B. D. $139 ; 19$ Q. B. D. 65 ; 56 L. J. Q. B. 415. 
Compare this case with Carr v. London, in which it was said that the railway company was not estopped by sencling inadrertently an advice-note of the arrival of goods, although the supposed consignee acted upon the note by selling them, because such action was not that intended by the railway company - the intention was "that the consignee should send for them, not that he should sell them." In both these cases the misrepresentation was direct and honest, and in neither was the act done that which was intended. How comes it then that in the one there was estoppel and in the other not?

The result can be justified only by attending to a feature of the Seton v. Lafone ease, which in the decision of it was overlooked, namely, that the wharfingers had issued warrants for the goods which were held by the person from whom the plaintiffs purchased. Now suppose that the wharfingers had not demanded the rent at all, had had no communication of any sort with the plaintiffs, and that the plaintiffs upon the faith of the warrants alone had purchased the goods, the wharfingers would still be estopped from denying their custody of the goods. We may say then that the letter demanding rent had nothing to do with the true ratio decidendi; and that the true ground of deeision is that the wharfingers having issued warrants for the goods, and the purchase of the goods being a reasonable consequence of such warrants, the wharfingers are estopped.

Carr v. London was right then, because making a sale of goods is not reasonably consequent upon the reception of an advice-note from a railway company announcing their arrivalthe only reasonable consequence is that be should send for them. And Seton $v$. Lafone is right because the purchase of goods is reasonably consequent upon the existence of warrants for them in the hands of a person claiming to own them. The judgment in this latter case indeed may be cited against the Carr v. London rule as to the necessity for the action being that intended - although that is now probably unimportant. Lord Esher said that it

"was reasonable as a matter of business for the plaintiff to do what he did as a result of his belief in the defendant's statement." 2 "I do not think

1 Corentry v. G. E. Ry. Co. (1883), 11 Q. B. D. $7 \pi 6 ; 52$ L. J. Q. B. 694. And see ch. XXIIr.
2 The present writer does not here affirm that the plaintiff's act was reasonably consequent upon the mis- 
it is necessary that the person making the statement should have intended the person to whom he made the statement to act in any particular way upon it." 1

Coventry v. G. E. Ry. Co. ${ }^{2}$ A railway company, by mistalie, accepted a delivery order in respect of groods which it had not received; the plaintiff advanced money upon it and the company was estopped. This case is somewhat similar to the Carr v. London case, in which an advice-note was sent by a railway company in respect of goods which it had not received. It will be remembered that in this latter case the railway company was not estopped. Now, however, in the Coventry case the defendant is estopped.

The reason sometimes given is that in the Coventry case there was negligence, and in the Carr case no negligence; ${ }^{3}$ but in that respect the cases are identical. The distinction really lies elsewhere, as, from what has just been said, will readily be seen. In the Coventry case "there was some evidence of a custom to sell or pledge goods upon the faith of a document of this kind." That is te say, the railway company was aware when accepting the delivery order that the acceptance might be used as evillence of the truth of the representation that they held certain goods on account of the person offering them for sale. (It is the case of the wharfinger's warrants over again.) The action of the purchaser therefore was reasonably consequent upon the misrepresentation of the railway company (it could not be said that the company intended any action to be taken), and it was therefore estopped.

Waldron v. Sloper." A mortgagor upon pretended excuse obtained from the mortgagee possession of the deeds; the mortgragee neglected to get them back again, and the mortgagor

representation. What is suggested is that reasonable consequence was thought to be sufficient for the dec. laration of an estoppel in a case (of direct and honest misrepresentation) in which it was impossible to say that the act was inteuded by the es. toppel-denier. The case is thus made use of to assist the writer's formula, and not because he is of opinion that (in eases of direct mispepresentation) there is any real distinction between it and that other phrase that "a reasonable man would take it" that he was "intended to act upon it in a particular way."

1 (15si) 19 Q. B. D. 72; 56 L. J. Q. B. 417.

2(1883) 11 Q. B. D. 776; 52 L. J. Q. B. 694 .

${ }^{3}$ Everest \& Strode on Estoppel, p. 335. note.

$4(1552) 1$ Dr. 193. See also Kettlewell v. Watson (1582), 21 Ch. D. 685; 51 L. J. Ch. 2S1: 26 Ch. D. 501 ; 52 L. $\mathrm{J} . \mathrm{Ch} .81 \mathrm{~s}$, and other cases in chapter IIX. 
fraudulently deposited them with a third party as security for a loan. Here the first mortgagee is estopped because (the other conditions being present) the action of the second mortgagee is reasonably consequent upon the assistance given to the misrepresentation. It would be impossible to say that the action taken by the second mortgagee was that which be, "a reasonable man, would take it" was intended by the first mortgagee, for the second knew nothing of any first, and could not possibly, therefore, have speculated as to bis intention.

Sinith v. Grouette. 'The real owner of a business permits it to be so carried on that another person appears to be the proprietor of it; and he is estopped from asserting his ownership as against persons dealing with this ostensible owner, for their action is reasonably consequent upon the appearance of ownership. Here again it would be impossible to say that the action of persons dealing with the ostensible proprietor was that which they (as reasonable men) would take it was intencled by the real owner; for again they knew nothing of any owner other than the ostensible one. At the furthest such a person might have reasoned thus: If the ostensible owner of this business is not the real owner (and I have no reason to suspect anything of the sort), then $I$, as a reasonable man, may take it that the real owner, whoerer he may be, intends that I should sell to this ostensible owner as though he were the real owner, and if $I$ do so the real owner will be estopped from asserting his ownership." Needless to say no such process takes place.

\section{Proximate Cause.}

This chapter to be complete should deal with the phrase "proximate cause" and the cases in which it is employed. It has been thought, however, to be more advisable to treat of that subject in the chapter on "Estoppel by Negligence," 2 for it is in connection with " the negligent act or omission," rather than with the misrepresentation, that the phrase has been

1 (1885) 2 Man. 314; Vineberg v. Anderson (1890), 6 Man. 355. And see Dunlop v. Lambert (1838), 6 Cl. \& F. 600; Ramazatti v. Bowring (1860), 7 C. B. N. S. $851 ; 29$ L. J. C. P. $30:$ Ex parte Dixon (1876), 4 Ch. D. $133 ; 46$
L. J. Bk. 29; Howland v. Woodruff (1875), 60 N. Y. 73; Rogers v. Robinson (1895), 104 Mich. 329; 62 N. W. R. 402 .

2 See ch. IX. 
usually employed. It will be profitable, however, quoting from the law of torts, between which and estoppel there is mueh analogy, to say that changes of position which are "reasonably consequent" are those

"which a person of average competence and knowledge, being in the like case with the person whose conduct is complained of, and having the like opportunities of observation, might be expected to foresee as likely to fol. low mon such conduct. This is only where the particular consequence is not known to have been intended or foreseen by the actor. If proof of that be fortheoming. whelluer the conseguence was "indirect" or not does not matter. That which a man actually foresees is to hin at all events natural and probable." 1

Or as put in the United States:

"The injury must be the natural and probalsle consequence of the nezligence-such a consequence as under the surrounding circumstances of the case might and ought to have been foreseen by the wrong-doer as likely to flow from his act." "

"Whatever the motive may be, if one so acts or speaks that the natural consequence of his worls and conduct will be to influence another to change his condition, he is legally chargeable with an untent, a wilful de. sign. to induce the other to believe him, and to act upon that belief, if such proves to be the actual result." 3

\section{SumMary.}

From what has been said it may be affirmed that:

1. The Barry v. Croskey and Carr v. London rules are incompatible the one with the other.

2. The requisite as to the character of the change of position should not in any way be affeeted by the directness or indirectness of the misrepresentation, as held in Barry v. Croskey.

3. Nor by its honesty or dishonesty, as affirmed in Carr v. London.

4. Neither set of rules is applicable to the large number of cases classed under actively-assisted misrepresentation; for in these the estoppel-denier malies no representation either direet or indirect, either honest or dishonest.

5 . In the preceding ehapter we saw that for cases of personal misrepresentation, and passively-assisted misrepresentation, a condition of estoppel is that "the estoppel-denier must hare reasonable ground for antieipating some change of position upon the faith of the representation."

6. In the present chapter we have seen that in cases of per-

1 Pollock on Torts, 28. 2 Robb v. Pennsylvania (18^९), 186128.
${ }^{3}$ Preston v. Minn (1856), 25 Conn.

Pa. St. $456 ; 40$ Atl. R. 969. 
sonal misrepresentation the change of position must bave been that "reasonably consequent upon the misrepresentation."

7. In cases of assisted misrepresentation by passivity the rule is ex necessitate rei that the change must bire been reasonably consequent upon the assistance rendered to the misrepresentation.

8. And in cases of actively-assisted misrepresentation the same rule must apply.

9. The rule therefore for all classes of cases is that "the change of position must be reasonably consequent upon the misrepresentation or assistance."

10. If the "particular consequence" has been "intended or foreseen by the" estoppel-denier, that " is to him at all events natural and probable." 


\section{CHAPTER XIV.}

THE LICKBARROW $v$. MASON, AND HALIFAX $v$. WHEELWRIGHT IRULES.

\section{The Lichlatrow v. Mason Rule.}

There are few rules which have been so frequently quoted and so wilely applied as that formulated by Ashhurst, J., in 1787, in the case of Lickbarrow v. Mason: ${ }^{1}$

"We may lay it down as a broad general principle that whenerer one of two innocent persons minst suffer by the acts of a third, he who enables such third person to oceasion the loss must sustain it."

Those who have read the preceding pares, more particularly chapter IV, will at once see that the rule is intencled to apply to the cliss of cases which the anthor has styled "Estoppel by Assisted Misrepresentation." These are cases in which the misrepresentation is not that of the estoppel-denier but that of some third person, and in which estoppel is declared because of some assistance rendered by the estoppel-denier - something by him sail, done or furnished which has made the misrepresentation credible. The language of the rule, "enables such third person to occasion the loss," or, as it is sometimes put, "gave the aggressor the means of doing the wrong," 2 may be taken to express this iclea of assistance given to the misrepresentation of some other person.

We find nothing, howerer, in the rule (explicitly at least) with reference to various conditions which we have seen to

12 T. R. $63 ; 1$ H. Bl. $35 \pi ; 6$ East. 21. The case was preceded in principle by Fitzherbert $v$. Mather (175i), 1 T. R. 12. For references to the rule see, in addition to the cases referred to thronghout this (liapter: Tayler v, Great Eastern (15.59), 2S L. J. Cl. 259; Gordon v. James (158.5), 30 Ch. D. 258; Henderson v. Willams (i89.), 1 Q. B. 529; 64 L. J. Q. B. 308: Dows r. Greene (1862), 24 N. Y. 645; Trustees of Union College v. Wheeler
(18\%4), 61 N. Y. 111: Friedlander v. Texas (1885), 130 U. S. 42.; 9 S. C. R. 5\%0; Bangor $v$. Robinson (1892), 52 Fed. R. 5:0; Miller v. Parker (15!13). 155 Pa. St. 208; 26 Atl. R. 303: Timpr son v. Allen (1s96), 149 N. Y. 513: it N. E. R. 17t; Robb v. Penusylrania (1s9s), 1 s6 P'al. St. 456; 40 Atl. R. 969. The rule is to be fount in the Calsforma Civil Cole, sec. 3iti3.

2 Pennsyluania R. Co.'s Appeal (18.8), 36 P. St. 103. 
be essentially requisite in estoppel - that there must have been a change of position on the part of the estoppel-asserter; that such change must have been reasonably consequent upon the misrepresentation; that the misrepresentation must have been as to some matter of fact; that the fact must have been a material one; that the assistance rendered must have been in breach of duty, etc. But most of these are sufficiently implied by the language of the rule. That there has been a "loss" implies that there was a prejudicial change of position; and that the third person was enabled "to occasion the loss" implies that the assistance rendered was material and that the loss was consequent upon it. We find, indeel, nothing about the misrepresentation being one of fact as contradistinguished from intention, nor about breach of duty; but the rule is to be taken as a short statement of "a broad general principle," and may well be excused for omitting that which may have been deemed to be obvious. It must be remembered, too, that it was formulated in 1787 , or just fifty years before the case to which, more to than any other, we are indebted for the conscious introduction of the modern law of estoppel by misrepresentation. ${ }^{1}$

The rule then appears to be but a short and pregnant statement of the essential principles of estoppel by assisted misrepresentation. But this has been stoutly lenied. Two assertions have been made with reference to it: (1) That it is a rule quite disparate from and independent of the law of estoppel; ${ }^{2}$ and (2) that either it is "not to be understond at all in its generality" or else that it "cannot be supported." 3

\section{That the Rule is Disparate from Estoppel.}

Lack of sufficient classification has produced the impression that for estoppel the misrepresentation complained of must have been that of the estoppel-denier himself. It is overlooked

1 Pickard จ. Sears (1837), 6 A. \& E. 469.

${ }^{2}$ London r. Wentworth (1880), 5 Ex. D. $96 ; 49$ L. J. Q. B. 65\%. And see Swan v. N. B. A, (1859), 7 C. B. N. S. 446; 30 L. J. C. P. 113.
3 Per Lord Field in Bank of England v. Vagliano (1891), A. C. 169; 60 L. J. Q. B. 177 . And see per Lord Coleridge in Arnold v. Cheque Bank (18;6), 1 C. P. D. 597; 45 L. J. C. P. 565. 
that much more frequently estoppel arises because of the misrepresentation of some third person, which has been assisted (usually unwittingly) by the estoppel-denier; and when eases of that sort clo occur, other principles than those of estoppel are applied to them. Look at some of them:

Priorities.-A legal mortgagee hands the title-deeds to the mortgagor, who (using them as evidence of his assertion of unineumbered ownership) deposits them with a banker as security for advances; and the legal mortgagee is postponed to the banker. Justice indicated the result, but in the absence of estoppel by assisted misrepresentation the principle assigned, or rather the rule formulated, was that "the possession of the deeds gives the better equity." 1 A better ground-one following the lines of estoppel, but still not acknowledging its presence - was afterwards (1sst) put forwarl, namely:

"'That the court will postpone the prior legal estate to a subsequent. equitable estate, where the owner has assisted in, or connived at. the fraud which has led to the creation of the subsequent equitable estate." 2

And this is estoppel by assisted misrepresentation. For if we ask why it is "that the court will postpone the prior" to the subsequent, the only reply is that just as direct personal misrepresentation would estop the first mortgagee, so also assistance rendered by him to the misrepresentation of the mortgagor will estop bim.

And obserre that this is also within the Lickbarrow rule; for when we say" "that the court will postpone. . . where the owner has assisted in . . . the fraud," we are but giving an example of the Lickbarrow general rule that

"Whenever one of two innocent persons must suffer by the acts of a third, he who enables such person to occasion the loss must sustain it."

In other words, the mortgagee enabled the mortgagor to occasion the loss, and he (the mortgagee) must sustain it.

Bills of Exchange.-Cases arise in which an acceptance, handed to the drawer in blank, is fraudulently filled up for too large an amount. In such a case Pollock, B., excludes the

1 Layard v. Maud (186\%), L. R. 4 Eq. 39 i, 406; 36 L. J. Ch. 669: Hunter r. Walters (18\%0). L. R. 11 Eq. 316; 41 L. J. Ch. 175; Spencer v. Clarke (1878), 9 Cl. D. 142; 47 L. J. Ch. 69?;
Lloyds r. Jones (1885), 29 Cl. D. 2:99; 54 L. J. Ch. 931 . And see ch. XlX.

2 Forthern Counties v. Whipl (1584), 26 Ch. D. 494; 53 L. J. Ch. 629. And see Powell v. London (1893), 1 Ch. 615; 53 L. J. Ch. 629. 
operation of estoppel, and declares in favor of the Lickbarrow rule. $^{1}$

"In many of the cases and text-bnoks in which the liability of the acceptor of a bill of exchange, under circumstances similar to those which occurred in the present. case, has been discussed, it has been rested upon the gromnd of estoppel: and with reference to this Bramwell, L. J.. has recently said with great force in the case of Baxendale v. Bennett.2 "Estoppels are odious, and the doctrine should never be applied withont a necessity for it.' it never can be applied except in cases where the person against who:n it is used has so conducted himself either in what he has said or done, or failed to sily or do, that he would unless estopped be silying something contraly to his former conduct in what he had said or dove or failed to sily or do. This language might be, not improperly, applied to the present cise; but for our own part we should prefer not to use the word estoppel. which seems to imply that a person by his conduct is excluled from showing what are the true facts: but rather to say that the question is whether, when all the facts are admitted, the acceptor is not liable upon the well known principle that where one of tio innocent persons must suffer for the fraud of a third, the loss should be borne by him who enables the third person to commit the fraud."

But, with deference, estoppel does not exclude facts. ${ }^{3}$ Its action is to preclude some one, "when all the facts are admitted" or proved, from availing himself of them: A man is sued upon an acceptance which is not his; he so pleads; a verdict goes for plaintiff (that plaintiff dicl accept); but this is contrary to the fact, and can only be upheld because the defendant upon the evidence (not by exclusion of it, for it is all given) is estopped from relying upon the truth of his plea. Moreover the Lickbarrow rule, upon which the learned judge relies, cannot make the defendant liable upon the acceptance, unless it is to be taken as saying to the acceptor, "You assisted in the frad ; therefore, although the acceptance is not yours, you are precluded from so saying." But that is clearly estoppel. If the acceptor had himself represented that the instrument was obligatory upon him, there would be no hesitation in applying the word "estoppel" to his conduct. It is equally appropriate when be assists the misrepresentation - when be "enables the third person to commit the fraud."

Principal and Agent. - There are many cases in which an agent may bind his principal although instructions are exceeded. This is, as the writer sees it, clearly upon the ground of estoppel by assisted misrepresentation. The agent bas mis-

1 London v. Wentworth (1880), 5 Ex. D. $104 ; 49$ L. J. Q. B. 66 l.

2 Baxendale $\nabla$. Bennett (1878), 3 Q.

B. D. $529 ; 47$ L. J. C. P. 625-6.
${ }^{3}$ See ch. XV, sub-title " Estoppel as a rule of evidence."

"See ch. XXVI. 
represented the extent of his anthority; the principal has, in some way, male credible the misrepresentation; and he is es topped for that reason from denying that the agent had not the authority allegred. Mrr. Justice Story' nevertheless, and some of the other judges, ${ }^{2}$ refer it to the Lickbarrow rule; and MIr. Bigelow refers it to the law of principal and agrent.

The reader will perceive that the principal is liable becauso he enabled the agent to appear as having anthority to do the act in question. Suppose that he hal personally made the misrepresentation - bad said in so many words that the agent had a power of attorney which gave the requisite anthority; that upon production of the docuraent no snch authority was to be found in it; and that the principal thereupon repudiated liability. There can be no question that in such case estoppel would be the ground of his condemnation. And it is not the less so becanse his conciuct, instead of his language, has misled the estoppel-asserter - he has enabled the agent to occasion a loss, and he must sustain it, that is, be estopped.

Sale of Goods. - Although in the lines of catses above referred to as well as in others the application of estoppel is denied, it is nowhere suggested that the results to be arrived at would be affected by pursuing the principles of estoppel. Nerertheless occasions frequently arise in which the benefit of a clear view of the specitic application of correct principle becomes very apparent. For example, in a case in which a man trieked the owner of goods into a sale of them, and afterwarls sold them to a bona, fide sub-purchaser, Cockburn, C. J., in decilling against the original owner, said: ${ }^{4}$

"If the matter rested on abstract principle, it might be open to be contended that. inasmuch as to make a valid contract both parties must intend to be bound by it, conseguently when in an ajparent contract of sale the buyer intends fo get the croods but not to pay for them but to deliaud the seller the contract fails to take effect, and though the seller intended

IStory on Agency (9th ed.), \$ุ127. Bently (1SS6). 18 Q. B. D. 322; 12 App.

2 Gordon v. James (1885). 30 Ch. D. 258; Erb v. Great Western Ry. (1s81), 5 S. C. Can. 200.

3 On Estoppel (5th ed.) pp. 45\%, 50:3. n., 565, 566. See the point discussed in ch. XXVI.

4 Moyce r. Newington (1s;8), $4 \mathrm{Q}$. B. D. $32 ; 48$ L J. Q. B. 125. The case was overruled in Vilmont $v$.

Cas. $471 ; 57$ L. J. Q. B. 18, because of the stitute 24 \& 25 Vic., c. 96 , $\$ 100$ : but the reasoning of Cockburn, C. J., remains umaffected. See Benjamin on Sales (4th Eng. ed.), 425, n. It was followel in Babcock v. Lawson (18i9), 4 Q. B. D. 394; 5 Q. B. D. 2S4; 49 L. J. Q. B. 408. 
the property to pass, yet that, the contract failing to take effect, the property still remains unaltered; yet the question is now so concluded by authority as to be no longer open to discussion. We must now take it to be settled . . . that thourh a seller is induced to sell by the fraud of the buyer, and although it is competent to the seller by reason of such fraud to avoid the contract. yet till he does some act to avoid it the property remains in the buyer; 1 and that if he, in the meantime, has parted with the thing sold to an innocent purchaser, the title of the latter cannot be defeated by the original selles. The reasoming on whrh this ronclusion is based mi!y not appear altogether consistent with principle, and agreeing in the result we should prefer to alopt the view of the American courts as stated in the case of Root $v$. French, ${ }^{2}$ a case decided in the Supreme Court of Judicature of the State of New York, according to which the preference thus given to the right of the innocent purclatser is treated as an exception to the general law, and is rested on the principle of equity that where one of two innocent parties must suffer from the froud of a thirel, the loss should fall on him who enables such third party to commit the fraud."

With great respect for so learned a judge it must be said that if the Lickbarrow rule which he invokes had been seen to be but the law of estoppel, not only would the reasoning to which he refers appear to have been quite consistent with principle, but the case would not have to be put in the unsatisfactory position of "an exception to the general law." No doubt the reasoning would show that, there being in fact no contract, "the property still remains unaltered," and therefore that the sub-purchaser conld take nothing; but the case is one of assisted misrepresentation, and the law of estoppel provides that under such circumstances, althougb the property is in the original owner, yet he is estopped from so asserting. This is the general law, and not an exception to it.

The case is this: "The contract failing to take effect, the property still remains unaltered." in the first owner; nevertheless he has "intended the property to pass" - has intended that his purchaser should appear to be the owner; and has thus enabled the purchaser to hold himself out as having the right to sell. This is, then, a case of estoppel, not indeed by the misrepresentation of the estoppel-denier himself, but by reason of the assistance rendered by him to the misrepresentation of ownership made by his vendee.

Mr. Pomeroy's Concurrence.-The present writer is glad to have the concurrence in the abore conclusions of so able a writer as Mr. Pomeroy. In his Equity Jurisprudence he says:

"When all the varieties of equitable estoppel are compared, it will be found, I think, that the doctrine rests upon the following general princi-

1 But how can it remain there 2 (1835) 13 Wend. 570. when, by hypothesis, it has never got there? 
ple: When one of two innocent persons, that is, persons each guiltless of an intentional moril wrong. must sutfer a loss, it mast be borne by that one of them who by his conduct, acts or omissions has rendered the injury possible. This is confessedly the foundation of the rules concerning the inplied anthority of agents, which are leclared by judges of the highest ability to be applications of the doctrine of anuitable estoppel. This most righteous principle is sutlicient, and is lone sufficient, to explain all instances of such estoppel." I

\section{Tilat the Rule Canxo't me Supported, at All Events in} its Gexeralitr.

In 1576 , Coleridge, C. J., referring to the Lickbarrow rule, saicl: ${ }^{2}$

"It las received illustration and explanation in subsequent cases on the subject which sliow that the words enabling a person to oceasion the loss' must be understoo I to mean by some act, conduct or default in the very trausaction itself. Sae Freeman v. Cook, 2 Ex. 6.4; 18 L. J. Eq. 117. The correct rule seems to us to be that which is thus stated by Blackburn, J., in lis judgment in Swan v. N. B. A. Co., 2 H. \& C. 151: 32 L. J. Ex. 277, where, referring to the julgment of Wilde, B., below, he says that he omits to qualify the rule (he had stated) by saying that the neglect must be in the transaction itself, and be the proximate cause of leading the party into that mistalie; and also must be the neglect of some duty that is owing to the person led into the belief, or, what comes to the same thing, with the general public of whom the person is one, and not merely neglect of what would be prudent in respect to the party himself. or even of some duty owing to third persons with whom those seeking to set up the estoppel are privy." ${ }^{3}$

And in 1891, Lord Field, in the House of Lords, said as follows:

"No doubt in one case (Lielibarrow r. Mason, 2 T. R. 70) Ashhurst, J., stated, as a broad general principle. that whenever one of two innocent parties nust suffer by the act of a third person. "he who has enabled such person to oceasion the loss must sustain it.' But more recent decisions, and one of this House of great importance, have either shown that this proposition is not to be understood in all its generality or cannot be supported; and this was very clearly pointed out in two eises which were not. I think, cited in argument (Arnold v. Cheque Bank and Arnold v. City Bank, 1 C. P. D. 578)."

$121 \mathrm{ed}$, S803. Mr. Markby exhibits little appreciation of the Lickbarrow rule, and none of estoppel by assisted misrepresentation. He says (Elements of Law, 4th ed., $\$$;16): "The liability is not placed upon the ground of misconduct. but of calls:tion. If this principle were once ac. knowledged the door would 'e open to a very large axtension of legal liahility." And in the note referring to Balicock s. Law won (15i9).4Q. B. D. 394: 5 Q. B. D. 284; 49 L. J. Q. B. 408, he says that the chief justice " seems to have thought that the right of an innocent purchaser to retisin groods which he had bouglit and of which he had ubtained possession, from a person who had himself obtitined them by frad, also rested upon the principle that the original owner had enabled the seller to commit the fraud. I should doubt the correct. ness of this view; at any rate it is quite a molern riew." For a dis. cussion of the puint see ch. XXI and XXII.

2 Arnold r. Cheque Bank (15:6), 1 C. P. D. isi: 45 L. J. C. P. 510 ?.

${ }^{3}$ Bank of England v. Vitgliano, (1591), A. C. 169; 60 L J. Q. B. 173. 
All that will be said at present with reference to the cases from which these extracts are taken is that the former of them very specifically treats the Lickbarrow rule as being a part of the law of estoppel. The qualifications of the rule said to be necessary are fully discussed in another part of this work.'

\section{Tine Lickbarrow Case.}

The above references to the ubiquity of the Lickbarrow rule will justify the assertion that it "has admitted of very general application." 2 It was, as the writer vicws it, a very remarkable attempt to formulate that doctrine of estoppel by assisted misrepresentation which still stands in need of much clear explanation. For it was not the simple case of personal misrepresentation, but the more complicated application of estoppel as against not the person who made the misrepresentation, but against the one who had furnished the opportunity for it and made it credible.

The facts of the case were that an unpaid vendor of gools shipped them to the purchaser and inclorsed tu him the bill of latling; the purchaser transferred the bill to a sub-purchaser; pending the transit the first purchase became insolvent and the original venclor asserted a right to stop in transitu. He argued that he had the right to stop as against his purchaser, and that the purchaser could not deprive him of it - in other words, that no one claiming through the purchaser could be in a better position than the purchaser himself. Ile was, however, unsuccessful, because the original vendor bad, by indorsing over the bill $\mathrm{c}$ lading, enabled his purchaser to represent that he had a clear title to the goods. Grose, J., said:

"A bill of lading carries credit with it; the consignor, by his indorsement, gives credit to the bill of lading, and on the faith of that money is advanced." 3

The case itself, then, is an excellent example of estoppel by actively assisted misrepresentation, and is decided in accordance with the rules applicable to that branch of the law.

1 Ch. IX.

2 Per Channell, B., in Swan v. North B. A. (1862), 7 H. \& N. 658; 31 L. J. Ex. 42:5.

${ }^{3}$ Lickbarrow v. Mason (1787), 2 T. R. 76. Kemp v. Falk (1882, 7 Apl. Cas.
573 ; 52 L. J. Ch. 167) decides that there is a right to stop notwithstanding an assignment of the bill of lading. but not to the prejudice of the assignee - only as against other persons interested. 
Summary.- We may then say:

1. That the Lickbarrow rule was a first attempt at formulation of the principle of estoppel by actively assisted misrepresentiation.

2. That it is not in conflict with, nor is it a competitor of, the law of estoppel. It is not suggested that they lead to divergent conclusions.

3. Whether the rule can be supported in all its gencrality, or must be subjected to the modilicitions sugrgested, is discussed elsewhere.

\section{The Inalifax v. Whecheright Rule.}

Malifax $v$. Wheelworight ${ }^{1}$ was a case in which spaces carelessly left in a check were fraudulently filled up and the increased amount drawn from tho bank. The drawer was made to suffer the loss. The applicability of the law of estoppel was questioned, and the following general principle held to be that which governed the case:

"A man cannot take advantage of his own wrong: a man cannot complain of the consenucnces of his own default agiinst a person who was wisled by that default without any fault of his own."

Although this mle was approved of by Lopes, J., in Scholfield v. Londesborough, ${ }^{2}$ yet, with deference, it is submitted that it has no validity. If the words "wrong" and "default " imply the disregrard of some legal duty, and the "consequences" referred to are the reasonable consequences of that disregard of duty, then indeed it may be said that the rule, although insufficiently expressed, is not altogether wrong, for the prineipal elements of estoppel are now present in it. But it would rither seem, from the explicit exclusion of estoplpel, that some less stringent signification of these worls was intended - that although there was no estoppel, yet that the drawer should sutfer. But it wonld be dillicult to say which one of the requisites of estoppel could be dispensed with.

In any event the rule is insullicient for its purposes; for its language is inapplicable to the case to which it is applied. When the drawer of a check, the careless spaces in which have been filled up, is sued upon it, and he pleads forgery, the case

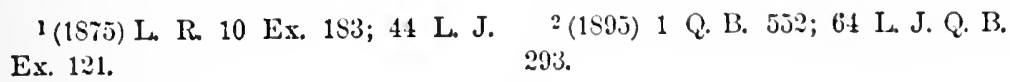


is not one in which he seeks to "talie advantage of his own wrong," or indeed to obtain an adrantage of any lind. He is rather contending against his opponent's claim to advantilge. His plea is, "I did not draw that check," which is perfectly true; and the only reply to him is that he is estopped by his carelessness from so saying. He has not himself represented the check to be genuine; but he has given opportunity for the misrepresentation - has assisted it, and is therefore estopped. 


\section{CHAPTER XV.}

\section{NATURE AND EFFECT OF ESTOPPEL}

\section{Lord Justice Brett in 1879 said: ${ }^{1}$}

"In my view estoppel has no effect upon the real nature of the transaction; it only creates a cause of action between the person in whose favor the estoppel exists and the person who is estopped."

But in 1887 the same learned Judge (then Lord Esher) said: ${ }^{2}$

"An estoppel does not in itself give a cause of action; it Irevents a person from denying a certain state of facts."

Lord Justice Lindley in 1891 said: ${ }^{3}$

"Estoppel is not a cause of action - it is a rule of evidence, which precludes il person from denying the truth of some statement previously made by himself."

\section{Estopipel as a Cause of Action.}

Whether an estoppel does, or does not, "create a cause of action" is, to the writer, largely a matter of worls. In one sense it does, and in another it does not.

Take a concrete case: A company inalvertently issues a certificate which untrutbfully declares that $A$. is the owner of certain shares. Upon the faith of this certificate some one purchases the shares. The company is now estopped from denying the purchaser's title. For remedy the purchaser cannot sue the company directly upon the misrepresentation in deceit, for there was no fraud." Nor can he insist upon the company giving him shares, for (as we may assume) all the authorized shares have been issued to others. His action is for damages for refusal to register him as a shareholder. ${ }^{5}$ To this the company's only possible defense would be that he was not

1 Simm v. Anglo-American (18r9), 5 Q. B. D. $207 ; 49$ L. J. Q. B. 392.

"Seton r. Lafone (1887), 19 Q. B. D. 70; 56 L. J. Q. B. 415.

3 Low v. Bouverie (1891), 3 Ch. 10I; 60 L. J. Ch. 594. See also per lowen, L. J. (1891), 3 Ch. 10.5; 60 L. J. Cin.601; Howarl s. Hudion (1853), 2 El. \& B. 9; 22 L. J. Q. B. 341; Langdon v.
Dowd (1865), 92 Mass. 433; Andrews v. Lyons (1865), 93 Mass. 349.

4 Derry v. Peek (1889), 14 A pl. Cas $33 \pi ; 58$ L. J. Ch. 864.

3 Re Bahial (1865), L. R. 3 Q. B. 584; 37 L. J. Q. B. 176; Balkis v. Thompson (1591), 2 Q. B. 691: (1593) A. C. $48.5 ; 63$ L. J. Q. B. 134; Re Ottos, etc. (1893), 11 Ch. 61s; 62 L. J. Ch. 166. 
entitled to be registered; and, as the company is estopped from so saying, the purchaser succeeds.

Nominally, the cause of action in the case is the refusal to register the shares. In reality the cause of action is based upon the misrepresentation, for it was impossible for the company to register the shares. Technically, no action could be brought upon the misrepresentation because there was no fraud. Really, the action was brought upon the misrepresentation; but that fact was well concealed and only brought in by way of reply. The method was this: The purchaser alleged (knowing it to be false) that he owned the shares; the company pleaded that the purchaser was not the owner; and the purchaser succeeded because the company was estopped from so saying.

If now we are to ask whether or not the estoppel created the cause of action, we may answer as we please. It may be said that the estoppel created the cause of action, in the sense, at all events, that it was the principal feature of the case. But just as reasonably we may say that it was the refusal to register which created the cause of action (although registration was impossible), and the estoppel merely the reason for its success.

Further consideration of the point, however, is unneccssary, for if the subject be well understood it is a matter of comparative indifference what view we take of the quoted propositions.

\section{Estoppel as a Rule of Evidence.}

We have seen that Lindley, L. J., declared that "Estoppel is not a cause of action - it is a rule of evidence which preclu les a person from denying the truth of some statement previously made by hiimself." 1

Estoppel, in this view, is a rule as to the admissibility of evidence - one in preclusion of certain testimony. In this sense it has been asserted that

"Where the doctrine of estoppel applies to a case, any testimony at rariance with its full application thereto becomes incompetent." 2

And Bigclow, C. J., said:

"Such a representation is sometimes, though not rery accurately, said to operate as in estoppel; but its effect is rather to shut out a party from offering evidence in a court of justice contrary to his previous statements." 3

1 And see Onward v. Smithson (1893), 1 Ch. 14; 62 L. J. Ch. 138; Hermann on Estoppel, $\$ 96$.

2 Gaston v. Brandenbury (1894), 42 S. C. $348: 20$ S. E. R. 158 . And see
International v. Bowen (18ĩ), $80 \mathrm{Ill}$. 541.

3 Langdon v. Doud (1865), 92 Mass. 435. 
With proper respect, the present writer submits that this view is untenable, for the following amongst other reasons:

I. $\Lambda$ s a matter of practice the question does not usually arise by way of objection to evidence, and most frequently cannot so arise. Take the conerete case above referrel to (where a company issued an untruthful certificate as to shares) and observe its course: The purchiser (from the certificate-lsolder) sues the company for damages for refusal to register. In opening his case he proves his title to the shares by producing the company's certificate and the transfer to himself, and he proves demand and refusal; the company disproves the plaintifr's title by showing that the certificate was erroneous, and that the original holder of it had in reality no shares; the purchaser, in reply, proves that he acted upon the faith of the certilicateproves estoppel. Mark that the purchaser could not precludo the company's proof of the untruthfulness of the certificate, for it had not then appeared that he had acted upon the faith of it, and that feature was necessary to the estoppel. Of course the purchaser might have proved this in opening, but it would have not only been unnecessary but impolitic for him to do so. The estoppel then, in this case, does not arise as a question of evidence. It is a deduction from, or legal consequence of, tho evidence. ${ }^{1}$

II. If estoppel be a rule in preclnsion of eridence, how is it to be applied? There can be no estoppel unless there has been a misrepresentation; unless the misrepresentation has been acted upon; unless all the other various requisites are present. Clearly it is for the jury to find the existence of the facts necessary to the estoppel; ${ }^{2}$ and it cannot be thought that it would be proper for them, pending the trial, to interpose a verdict upon that point. But the evidence could not otherwise be precluded.

1 The law as to waiver, as to elec. tion, as to "blowing hot and cold," are clearly not part of the law of evidence, although in this connection we use the phrase, familiar in estoppel, that a man will not be al. lowed to assume or assert two in. consistent positions.

2In Pennsylvania it is said that "whether an estoppel results from established facts is a question for the determination of the court." Lewis v. Carstairs (1843), 5 Watts $\mathbb{E}$ S. 209) Keating v. Orme (15it). ir Pa. St. 93. And see Gunn v. Pates (1856), 6 Cal. 263; Ollin r. Gove (1560), 41 N. H. 465. In this view the eri. dence would all go to the jury; the jury would find as to misrepresenta. tion, action upon the faith of it, etc., and the court would apply the law of estoppel. 
III. Nor is estoppel a rule of evidence, in the sense of being a test or aid in the weighing of evidence when admitted. The question is not one of weight of evidence. It is rather this, that although the eridence proves indubitably that the fact is so and so, other evidence requires the court to act contrary to the fact. For example: An infant defendant pleads his nonage as against his conveyance; he is allowed to prove it (the evidence is arlmissible); the plaintiff proves representation of full age, acted upon; and the infant is estopped from denying it. Here is no question of admissibility or weight of evilence, but a mere question of law - who upon these facts is to succeed?

IV. The testimony which would be shut out by the rule under examination is sometimes necessary in the consideration of (1) the nature of the relief to be granted; and (2) the amount of damages to be awarded. In such cases it would be impossible to exclude the evidence.

(1) The Nature of the Relief.- The nature of the relief sometimes depends upon whether or not success is attributable to estoppel. Take the case of a warehouseman giring, by mistake, a certificate that he holds goods for one man, whereas in reality he holds them for another; upon the faith of the certificate a third party buys the goods from the certificate-holder, and the warehouseman is estopped from denying that the purchaser has obtained a good title. Consider now the warehouseman's position. On the one hand he holds the goods for the true owner; and on the other he is estopped from denying that he holds them for the purchaser. Plainly he cannot give them to both; and just as plainly, no court will wittingly order him to do so. Now, if estoppel be a mere rule of evidence - if it does not affect the nature of the relief to be granted - the purchaser, in the case supposed, will be entitled to specifie delivery of goods which do not belong to him, and which the defendant ought not to deliver to him; and the court must so award.

But this is precisely that which the courts decline to do. It was in a case of this sort that Lord Justice Brett said:

"In a similar manner a person may be estopped from denying that certain goods belong to another; he may be compelled by a suit in the nature of an action of tiover to deliver them up if he has them in his possession and under his control; but if the goods in respect of which he has estopped himself really belong to someborly else, it seems impossible to suppose that by any process of law lie can be compelled to deliver over 
another's goorls to the person in whose favor the estoppel exists against him; that person is entitled to maintain a suit in the nature of an action of trover against him; but that person cannot recover the goods, becal us . no property has really passed to him; he can recover mely damages. In my view, estoppel has no effect upon the real nature of the transaction: it only creates a cuuse of aclion between the person in whose favor the estoppel exists and the person who is estopped."1

We are here very close to something like fiction, a sure indication of undeveloped law. The plaintiff cannot directly suo for damages for the misrepresentation (absence of fraud is insuperable), but he may sue in trover for the goods in the sure and certain hope that the court will deny him the restitution which he claims, and give him the damagres which he dare say nothing about. The damages which he asks are based upon his right to the goods, and are alternative for their detention; but the damages which he gets are based upon the fact that ho has no right to the goods; that his only right is to clamages because he was misled by the warehouseman. If this be not a rery thinly veiled action in deceit, it is something rery nearly alin to it. ${ }^{2}$

(2) Amount of Damages.--It has been said that estoppel cannot be merely a rule of evidence because, in some cases, it is a necessary factor in the consideration of the amount of damages to be awarded. It seems to be somewhat extraordinary that in the diseussion of estoppel we are led into a consideration of measure of damages, but that is unavoidable in the present state of the law. An action of deceit lies for misrepresentation and the damages are so and so. Is there also an action in estoppel for misrepresentation resulting in damages? If not, there is something that bears that appearance. It differs from deceit in this: that fraud is not a necessary ingrelient in it. It resembles deceit in this: that it is based upon misrepresentation and sounds in damagres. We are perilously close to contradiction heie: No action for misrepresentation in the absence of fraud; some such action although nofraud. ${ }^{3}$ As to the amount of clamages consider the following cases:

(1570) Mart v. Frontino. Plaintiff bought and paid for shares; in doing so he did not rely upon any representation of the company; he did not at once register his transfer; afterwards

1 Simm v. Anglo-American (1879), 5 Q. B. D. 207 ; 49 L. J. Q. B. 398 . And see Reg. v. Charuwood (1884), $1 \mathrm{Cab}$. \& E. 419.
2 Sre ch. XVI.

${ }^{3}$ For further discussion of this anomaly see cli. XVI.

4 L R. 5 Ex. 111; 39 L. J. Ex. 93. 
a call was made and the vendor (still appearing upon the register) paid it; the purchaser now registered and obtained a certificate of ownership of the shares; on the faith of the certificate he pail the amount of the call to the vendor; afterwards the company ascertained that it had made a mistake (another person in reality owned the shares) and it removed the purchaser's name from the register. The purchaser sued the company for the wrongful removal of his name; the company's defense was that he did not own the shares; the purchaser replied that upon the faith of the certificate he had changed his position. Now observe that the extent of the change was not the purchase of the shares and payment for them (that had taken place prior to the issue of the certificate), but payment of the calls only. Nevertheless the purchiser recovered the full value of the shares. Having changed his position, although slightly, the company was estopped from denying his title to the shares, and being estopped the company had no defense to the action for the wrongful removal of the name from the register.

Grissler $v$. Power's ${ }^{1}$ is to the same effect: A mortgage for $\$ 20,000$ was purchased for $\$ 16,000$, and an assignment taken upon the faith of a representation by the mortgagor that the oxpressed consideration was the amount really due upon the mortgage. The assignee sold the mortgage to a sub-purchaser for its face value, and the morteragor sold his equity of redemption. In reality nothing had been alvanced upon the mortgage. Creditors of the mortgagor then claimed tbat although the mortgagor was estopped by his representation, it was only to the extent to which the representation bad caused damage; that the assignee had only paid out $\$ 16,000$ upon the faith of the representation; that to that extent alone was there estoppel; and that their debtor (the mortgagor) was therefore entitled to the difference between that amount and the amount for which the assignee sold the mortgage, namely, $\$ 1,000$; which money they demanded from the assignee. It was held that the mortgagor was altogether estopped, and not merely to the extent to which money had been paid out. In this case it was said that

"the estoppel created by a false representation, acted upon, is commen. surate with the thing represented, and operates to put the party entitled 
to the benefit of the estopmel in the same position as if the thing repre. sentrol was true; and that when the representation is made on the sale of a chattel. or security. the remedy of the purchaser is not limited to a recovery, simply, of the money allianced, if the purchaser would receive a benefit beyond that, if the fact had been as represented."

The true way to look at this ease is not to fix attention upon the amount of money paid out, but to ask, What did the assignee do upon the faith of the representation? The answer is that he bought the mortgage. If, then, you cut the mortgagre down from $\$ 20,000$ to $\$ 16,000$ you damagre him to that extent. ${ }^{1}$

In connection with this case Mr. Bigelow says:

"The fact shoul be remembered that this esteppel by conduct. when fully marle out, operates hy natule (that is whenever it can so operite) like all other estoppeis, specifically: it gives to the party entitled the rights he would hise arainst the one estopped supposing the representation true."

Sir Frelerick Pollock in his work on Torts ${ }^{3}$ expresses the opinion that, with reference to "certain cases of fraud, • • . the Court of Chancery . . . would awarl pecuniary compensation, not in the name of damages, indeed, but by way of restitution or "making the representation gool," "and adkls:

"Since the Julicature Acts it does not appear to be material whether the relief administered, in such a case, be called clamages or restitution. unless indeed it were contended in such a case that (accolding to the rule of damages is regards injuries to property) the plaintilf was entitled, not to be restorell to his former position, or to have his just expectation fulfilled, but only to recover the amount by which he is actually the worse for the defeudant's wrong doing. Any contention of that kind would, no doubt, be effertually excluiled by the iuthorities in equity; but even without them it wonld scurcely be a hopreful one."

Notwithstanding these opinions there seem to be rarious reasons for believing that the principle proceeded upon is open to discussion, and, at the least, to qualification. Observe that the action is really founded upon mislepresentation; and that the rerdict is really in damages for that misrepresentation although well hidien under other appearance. Why, then, should the damages be assessed upon a principle different from that acted upon in deceit, where also the foundation is mispep)resentation? The following authorities, moreover, are not consistent with those just cited.

(1Ss6) Seton $v$. Lufone. A wharfinger, believing that he held certain goods, wrote a letter to a broker whose name had been comnected with them, for storage rent; upon the faith of

1 Anl see Fall River v. Buffioton (186i), $9 \pi$ Milss. 493.

2 (r. Estoppel (jth ed.), 651.

13
3 Pullock on Torts (ith ell.), $18 .$.

415 Q. 13. 1). 139 ; 19 Q. B. D. 68 ; 06

L. J. Q. B. 41 J. 
this letter the broker purchased, for a trille, the warrants which the wharfinger had issued; the wharfinger then ascertained that he had not the goods; and the broker sued for them. The parties had fixed the damages, but the court intimated that those recoverable were probably not the value of the goods, but the amount disbursed by the broker.

Lord Lyndhurst, in IIume v. Bollund, ${ }^{1}$ said:

"If your situation is not altered you cannot maintain an action. If it is alterel. must not the amount of damages to be recovered depend upon the extent to which it is altered?"

In Smith`s Leading Cases is the following: ${ }^{2}$

"It is suggested that the truly equitable mole of dealing with such cases would be to ascertain, where practicable, the amount of actual damnification sustained in consequence of the representation relied on, and to this extent only to give relief."

In some cases other doctrine would work injustice. For example, in Re Romford ${ }^{3}$ upon the faith of certain representations of a company as to the validity of its debentures, money was loaned upon a deposit of some of them. The lender, in suing upon the debentures, contended that, the company being estopped, he was entitled to recover their face value; but he was awarded the amount of his advances only. Observe that if the lenter had recovered more than his debt, the excess would have gone into the borrower's poeket. But that would have been inequitable. for the company, upon the facts, was not estopped as against the borrower. If estoppel were a mere rule of evirlence, and had been applier in this case to the exclusion of the facts, the borrower would have unjustly got the advantage of the estoppel.

Consider the following case: Shares in a company are transferred by forgery; the shareholder, after becoming aware of the forgery, omits to notify the company; the company pays dividends to the transferee, but is not otherwise damnified; afterwarls the shareholder notifies the company of the forgery. The legal situation, now, is this: The true owner is entitled to have the shares restored to his name in the sharebolders register; ${ }^{4}$ he is entitled to future dividends; but he cannot require the company to pay a second time the dividends alrearly paid

1 (1S32) 1 Cr. \& M. 138.

2 Sth ed. 912. Omitted from 10 th ed.

3 (1883) 24 Ch. D. S5; 52 L. J. Ch. 729. And see Smith v. Slavin (1893), 69 Hun, 311; 23 N. Y. Supp. 538.
4 Unless, indeed, by his inactivity the complany has lost an opportunity to indemnify itself by proceed. ings against the forger. See ch. XI, sub-title "Lulling to rest." 
to the assignee, for as to these he is estopped by his inaction from asserting title to them. If, however, estoppel were a matter of evidence merely, the true owner would lose not only the past dividends, but the shares themselves; for his inactirity, while dividends were being paid, would constitute an estoppel as arrainst his title, and thus exclude all evidence of it.

There is another elass of eases which illustrates the necessity for admission of the evilenee as to the estopjel; namely, that class of eases in which, although there has been a misrepresentation and consequent estoppel, yet the misrepresentation has, as it were, been withdrawn before all the damage has oecurred. Evidence therefore must be given not only of the misrepresentation, but of its withdrawal. The law is clearly stated by Williams, J.:

"I think there is nothing to prevent the party who made the representation from afterwarls saying, 'I was mistaken in the representation I made to you, and so far as you liave not acted upon the faith of it, I retract it. ind require you so to act as if the representition had never been male." "2

For example, a landlord represents that the rent is payable to another person; the landlord would be bound to the extent to which the tenant had paid, or become bound to pay, rent to the other person, but not in respect of rent as to which the tenant had not changed his position. ${ }^{3}$ So if a person represent to a sherilf that he is the defendant against whom the sheriff has a warrant, and is consecjuently arrested, he may be estopped from suing for the arrest; but the sheriff could not justify the detention of such person after notice that he was not in reality the lefendant. So, too, it is said that if a patentee sells certain of his patent rights he may be estopped to deny the validity of the patent in an action against him for breach of agreement, but, upon the assessment of his vendee's damages, he may show that, notwithstanding the patent, other persons have the right to manufacture and sell. ${ }^{5}$

\section{Parties ani Privies.}

Further complication of the subject in hand arises from the statement (above quoted) that "estoppel has no effeet upon the

l Daris s. Bank of England (1824), 2 Bing. 393.

2 White v. Greenish (1501), 11 C. B. N. S. 302 .

3 Ibid.
4 Duuston v. Paterson (185i), 2 C. B. N. S. 495: 26 L. J. C. P. 267.

5.Jackson r. Allen (15ib), 120 Mass. $0 \pm$. 
real nature of the transaction." Suppose that I purchase a horse from a man who has no title while the true owner stands by. In such case, as is well known, the true owner is estopped from setting up his title as against me.

I. Suppose, however, that the true owner subsequently sells the horse to a third person, is that person estopped as against me?

II. Or suppose that subsequently a creditor of the true owner obtains a judgment against him, and the sheriff seizes and sells the horse under that judgment, is the purchaser estopped as against me?

III. Or suppose that after my purchase I resell, is the true ow ner estopped as agrainst my vendee?

\section{Does Estoppel Bind Purchasers front the Estoppel-denier?}

In considering the first $t$ wo of these cases a distinction must, at the outset, be made. The conduct of the true owner may be such as to justify the inference that he was a party to the sale. In such case no question of estoppel arises - the purchaser, of course, takes a good title. The cases we have to deal with are those in which no such inference can be madecases in which the purchaser has no title, and can defend bis possession upon the estoppel only.

Parties and Privies. - The rule usually accepted for the cases in hand is that "estoppels are binding upon parties and privies." " If this be a sulfieient rule we have only to inquire, Who are privies? and the answer to this question being (as one would think) simple enougb, there ought to be no dilfieulty in solving all such questions. Let us see.

Lord Mansfield, in the leading case of Taylor v. Needham, ${ }^{2}$ said:

"He who takes an estate under a deed is privy in estate, and therefore never can be in a better situation than he from whom he takes it."

And in later times Mr. Tiedeman declares that estoppel "can only operate upon. and be claimed by, parties to the transaction in which the misrepresentation or concealment was made and their privies, whether by blood, by estate or by contract." 3

1 See Richards v. Johnston (18;9), 4 H. \& N. 663; 28 L. J. Ex. 32:2; Richards r. Jenkins (1887), 18 Q. B. D. 451 ; 56 L. J. Q. B. 293; Welland v. Hathaway (18:32), 8 Wend. (N. Y.) 480; Union v. Wilmot (1883), 94 N. Y. 228.
The text-writers proceed in the same way. Bigelow on Estoppel (5th ed.), ch. 8, 512, 597; Everest \& Strode on Estoppel, 52.

2 (1810) 2 Taunt. 283.

3 On Equity Jurisp., $§ 114$. 
Mr. Bigelow, however, in his work on Estoppel says that

"it does not in molern times constitute a case of privity, for the purposes of estoppel, to show that one man holds a conveyance from another."l

And agrain he says: ${ }^{2}$

"By analogy to the position heretofore taken concerning the relation of grantor and grantere in conveyances of real estate, it wonld seem that a purchaser of goods is not a privy in estopnel, or otherwise. with his vendor, so as to be affectea by an estoppel in puis resting on the vendor in respect of the goorls. Thus if a man stand hy and allow his goods to be sold as the goods of another to one $u / h$ oloes not take possession. and the actual owner afterwarls sells the same to another parson for value wilh. ont notice of the previons transaction, the litter would be entitled to the goods as against the first purchiser."

The eareful wording of Mr. Bigelow's illustration implies that if the second purchaser had notice, or harl not given value, he would not " be entitled to the goods as against the first purchaser." But this result is contrary to the principle illustrated, which puts all cases (notice or value or none) in the same category, and says, generally, that "a purchaser of goods is not a privy in estate or otherwise with his vendor."

Mr. Hermann exhibits the same incongruity - persons who claim under an estoppel-fenier are privies, and therefore estopped, but not if they had no notice. At section 793 of his work on Estoppel he says:

"An estoppel embraces in its conclusive effect parties and privies, and estops all who claim under the person originally barred. Thus, the buyer of a chattel was held to be within the bar of an estoppel in pais rowing out of the acts and declariations of the vendor. And the rule is the same in regard to an estate in land; but as the interest conferred by an estopnel of this description is, where real estate is involved, essentially equitable, subsequent purchisers will not be bound without notice."

The contradiction is here shaded by the interposition of an alleged difference between personalty and realty. But it is surely impossible to say that "an estoppel of this description is, where real estate is involved, essentially equitable," and that it has some other character when personalty is in question. To the same effect as these text-writers are some of the cases in which it is bollly said that estoppels bind "those in privity with him, unless purchasers for value without notice."

15 th ed. 345 ; and see p. 492 . Everest \& Strole on Estoppel. p. 5\%, do not agree with Mr. Bigelow. They s.ty: "Lord Coke classes privies under the three heads: 1. Privies in blood; 2. Privies in l:a ; and 3. Privies by estate. But as regilds estoppel, the same doctrine applies to each class, viz., that one who clains through another is, to the extent of his claim, subject, ant able to tike alvantage of all estoppels atrecting the person through whom he clinins."

2 İl., p. 609.

3 Thistle r. Buford (1S:2), 50 Mo. $2 i s$. 
These quotations leare the investigator in much perplexity. Estoppels bind parties and privies; a privy formerly was one who took an estate from another; but in modern times, and with reference to estoppel, one who takes an estate from another is or is not in privity aceording as he is or is not a purchaser for vilue without notice. This has not a rery satisfactory or convincing appearance. It seems to indicate that any question of privity may be dispensed with; and that attention should be directed to "purchaser for value without notice."

The familiar attempt to make old rules fit new lines of cases is here very apparent. Estoppel by misrepresentation was not thought of when the rule as to parties and privies was formulated, and it does not suit such sort of estoppel. For confirmation of this statement one has not vainly to endeavor to apply it to estoppel by misrepresentation, but merely to read it. It was as follows: ${ }^{1}$

"Erery estoppel ought to he reciprocal, that is, to bind both parties; and this is the reason thal regularly a stranger shall neither tak. advantage of or be hound by the estoppel; privies in blood, as the heir; privies in estat? as the feolfee, lessee, etc.; privies in law . . . shall be bound and take advantige of estoppels."

But estoppel by misrepresentation is essentially and neeessarily unilateral (cannot be reciprocal) ${ }^{2}$ and we thus see that the reason why estoppels should bind parties and privies does not and cannot apply to estoppel by misrepresentation. ${ }^{3}$

If for any reason, then, we are to apply the rule, that estoppels bind parties and privies, to estoppel by misrepresentation, it will be to solve the useless question "Who are privies?" rather tlian, by knowing the answer to that question, therefrom to argrue the existence of estoppel. For no one would guess that while a purchaser without value, or with notice, is in privity with his venclor, yet a purchaser for value and without

${ }^{1}$ Coke on Lit., L. 3, c. $12, \$ 667$. has, with reference to estoppel by And see Com. Dig., Estop. B.; 10 Vin. Ab. 4.2.?.

2'The old language, howerer,- "estoppels must ordinarily be mutual"is still sometimes employed with reference toestopel by misrepresentation. See Hermann on Estoppel, $\$$ i9:; Wright v. Hazen (18.52), $24 \mathrm{Vt}$. 119.

judgment, been held to include, not merely the actual parties to the suit and their representatives, but other persons in the same interest who lave stood by while the fight proceeded, ready to take advantage of the result had it been favorable to them. Re Lart Wilkinson r. Blades (1826), 2 Ch. r\&s; 6j L. J. Ch. 816.

3 The rule as to parties and rrivies 
notice is not, did we not see that in the former be ought to be estopped, and in the latter he should not. In fact we are arguing not from a rule uli privity, ibi estoppel; but from $u$ hi estoppel, ibi privity; which lealves us very much in the preslicalment of the proverbial searcher for the hoe and the shovel.

Methol of Solution.- The on!y alternative seems to be the abandomment of the rule of privity as an aid to the solution of the question. And in truth nothing is lost by its abandonment. Start from this, that only one of the competing parties can, ats a matter of fact and law, have the title; then ask, Is there any reason why it slould be taken away from him? and the solution will come without reference to privity.

An owner stamls by while I purchase his property; he has the title yet (I have not got it); but he is estoppeci as against me from setting it up; the true owner sells to another; is this second purchaser "bound by the estoppel?" To this question the answer may appear to be uncertain. Change the form of it; ask, Which purchaser is entitled to the property? and the dilficulty disappears; for the mind at once reverts to a welllinown rule which is sufficient for the solution of the problem. Rule for I'riority. - That rule is that the holder of a prior equitable right has priority over the purchaser of a subseguent estate (whether legal or equitable) without value, or with notice of the equitible right, but not as against a subsequent purchaser for value and without notice."

Equitalde Pight.- The first question then must be whether an estoppel-asserter can be said to have an equitable right. If

1 Mr. Bigelow malies this very clear (on Estoppel, 5th ed., 4:20): "Privity" in estoppel, it cannot be too strongly laid down, is a different thing from privity in contract. The position of privity in contract is one of mutual relation, as between contractor and contractee, and camnot be supported without a consideration, actual or (as in deel) implied. . . . Privity in estoppel, on the other hand, is purely a relation of succession or subordination of rights. and is inronsistent with consideration, or at least independent of it. The heir is the type of a privity in the law of estoppel. He is bound because he takes withont value. It is right that he should be bound; no injustice is done him." With respeet the present writer suggests that first ascertaiung upon gener:1 principles whether a third person "should be bound" by the estoppel, and then declaring that such this 1 person is for that reason a privg, is an inverted and valueless proceed. ing.

2See chs. XVIII, XIX, XX; and Peary v. Seigler (189i) ts S. C. 496; 26 S. E. R. 855 ; Stone v. Georgia (1s99), 33 S. E. L. 861 (Ga). 
he has, then the rule just mentioned applies to his case, and questions of privity are superfluous.

And first let us understand the distinction between the terms "equitable right" and "equitiale estite." Omitting the adjectives I may say that I have a "right" to an "estate," which implies that I bave not the estate, but only a right to get it. An "equitable right" then means a rigbt to get an estate, enforceable in equity merely; while an "equitable estate" is something alrealy in possession, although formerly recognized only by the court of chancery. For example, a mortoragee was induced by fraurl to release his mortgage; the mortgagor afterwards made equitable mortgages of the estate, and the first mortgagee upon discovery of the fraud claimed priority over the subsequent incumbrancers. In this case the first mortgagee had an equitable right, as against the mortgagor, to set aside the release, but, baving no equi table estate or interest, he was postponed to the other mortgagees. ${ }^{1}$

Estoppel an Eluitable Right.- There are many reasons which support the assertion that an estoppel-asserter has, at the least, an equity or equitable right.

1. Perusal of a subsequent ehapter ${ }^{2}$ will show that that which is in reality estoppel has beretofore been well hidden under the term "the equities." Not only can there be no objection to saying that a purchaser (claiming an estoppel) bas "an equity" against an owner who stands by and allows bis property to be sold by a third party, but the term bas much propricty. It is a loose term, no doubt; but what we mean is that estoppel is sufficiently of the nature of "an equity" to be so classed when considering a question of priorities. In other words, if one were formulating a law of priorities, he would not distinguish between a right by estoppel and other rights linown as "equities," and say that while "an equity" under certain circumstances might give priority, yet that a right by estoppel was not sufficiently of "an equity" to have that effect.

2. The words "an equity" are frequently used to express the right to an estoppel. For example, in the House of Lords there is the following:

"To raise an equity in such a case there must be a misrepresentation of existing facts, and not mere intention." 3

1 Eyre v. Burmester (1861), 4 D., J. \& S. $435 \cdot 10 \mathrm{H}$. L. C. 9.J.
2 Ch. XVIII.

3 Jorden v. Money (1Sid), 5 II. L. C. 
It is not surprising that the word should be so used, for, as is said in Bigrelow on Estoppel:"

"The origin of the estoppel is to be found in the doctrine of equity that if a representition be male to another, who deals upon the fat h of it. the former must malke the representation goud, if he knew or was bound to know it to be false."

And Lord Eildon spealis of estoppel as "a very old head of equity.".

3. There can be no question that if I contract to sell land to $\Lambda$. he has "an equity" agiainst me. It might eren be assertel that he has acquired an equitable estate - at all events sub modo, and as between the parties:

"When the owner of an estate contracts with a purchaser for the im. mediate sille of it, the ownership of the estate is, in equity, transferred by that contract." 's

"It wis argued at the bar that the plaintiff was. in equity, insesterl with all the riflits of $M 1 \mathrm{r}$. Small, mpon the principle thiat. by a contract of purchitse, the purchitser becomes in expity the owner of the property. This rule applies only as between the pirties to the contract. and cannot be extended so as to iffect the interests of others. If it coukl, a contract for the purchase of in equitible estate would be equivalent to a conveyance. Before the contrict is carried into elfect the purchiser cannot, against a stranger to the contrict, enforce equities attiching to the property." 4

Suppose, then, that insteal of myself contracting to sell, I stand by while a third person (pretending to be the owner) sells and conveys the property. Has the purchaser "an equity" against me, or is the only fit language "I am estopped?" Observe the principle npon which the court of equity would originally have proceeded against me:

"The person maling those representations shall. so far as the powers of a court of equity extenl, be treated as if the represent.ution were true, and shall be compelied to make them good." 5

$185 ; 23$ L. J. Ch. S65. See also IIigrgs v. Northern (1:69), L. R. 4 Ex. $35 \%$; 39 L. J. Ex. 2:33; Citizens v. First National (15i3). L. R. 6 J1. L. 3599,43 L. J. Cl. 269; Re Romforl (185.3), :24 Cl. D. $85 ; 52$ L. J. Ch. T:9: Chatlwick s. Manning (1593), A. C. 231 ; 65 L. J. P. C. 4 ?.

1.jth ed., p. 5isi.

2 Evins v. Bicknell (1801), 6 Ves. 183. And see Keate 1. Phillipis (18s1), $18 \mathrm{Cl}$. D. 550; 50 L. J. Cl. 665 t.

${ }^{3}$ Per Lord Westbury in Rose $:$ Watson (1864). 10 H. L. C. 678; 83 L. J. Ch. 38.5. And see Lysaght v. El. warls $(15 \pi 6), 2 \mathrm{CH}$. D. 499: $43 \mathrm{~L}$. J. Cl. 554; Tatilly r. Official Receiver (1588), 13 Apr. Cas 523; 58 L. J. Q.
B. 5 ; White v. Southend Hotel Co. (1897), 1 Cl. $76 \pi$; 66 L. J. Cl. 35\%.

4 Per Lorl Cottenham in Tasker 5 . Smill (18:3i), 3 Mly. \& Cr. i0; i L. J. Cl. 19. And see Re Citrenter (15:5.1), Kily, 418; Re Cuming (1869), L R. 5 Ch. i2; Re Colling (iss6), 32 Ch. D. 3:33; 5.5 L. J. Ch. 456; Canadian P. Ry. v. Burnett (1859), 5 Man. 426; Ilill v. Cumberland (1868), 59 P'i. St. 4 it.

${ }^{5}$ Per Lord Solborne in Citizens' Bank r. First Natt. Bank (18;3). Lo R. 6 H. L. 360: 43 L. J. Cl. 269 . A nil see Favill y. Roberts (185.5), 50 N. Y. 2:2: and the livecussion of the subject in ch. XVI. 
Note now the rery close parallel between contract and estoppel. In contract, equity regards the estate as "transferred by that contract." In estoppel, the representation is treated as if it were true - that is, as if the estate had been transferred. In both cases the doctrines are peenliar to courts of equity. In contrict, the estate passes - sub morlo no doubt, and only as between the parties. In estoppel, the same thing ma be saill. In contrict, a conveyance in accordance with its terms may be enforced. In estoppel, the by-stander shall be compelled to make the misrepresentation good - that is, to execute a conveyance. In neither is there an actual transfer. In both a transfer will be directed. In view of all this, is it possible to say that contract will give rise to "an equity," hut that estoppel will not? or that the rights acquired by estoppel are less complete than those acquired by contract?

If there is to be a distinction between contract and estoppel in this respect, the results should be reversed. In contract, there is no pretense that the estate has passed - there is a mere agreement to pass it; and it is the court, and not the parties, that proclaims that it has alrealy passed. In estoppel, on the other hand, the parties to the transaction intend and stipulate for the passing of the estate - the purchaser believes that the transaction is completed and closed, that he has in fact and in reality got the estate; and the by-stander is to be "treated as if the representation were true." There is, therefore, in estoppel stronger reason than there is in contract why the court should declare the existence of an equity to the thing purchased.

The Question Answeren.-We may take it, then, that the effect of an estoppel is to give the estoppel-asserter "an equity," and further, that it passes the estate, but sul modo only and merely between the parties. And we are now in a position to malie reply to our question: "An owner stands by while I purchase his property; he has the title yet (I have not got it); but he is estopped as against me from setting it up; the true owner sells to another; is this second purebaser "bound by the estoppel?",

We reply that the data are insufficient and that the question is erroneous. For explanation we add: The first purchaser has an equity against the vendor capable of enforcement against 
him. Whether that equity is enforceable against the seeond purchaser (who hats the title) depends not upon any guestion of estoppel binding parties and privies, but upon this merely (and according to familiar rule): Was the second a purchaser for value without notice of the prior equity?

"The result, therefore in solid sense and justice, is this: the value of an equity, while it subsists ats an equity, cin vuly be fixed by the accident of notice." 1

Mr. Bigelow's statement, then, that "a purehaser of groods is not a priry in estoppel or otherwise with his vendor, so as to be affected by an estoppel in pais resting upon the rendor in respect of the goo!s," is not eorreet - that is, if "privity" is to determine priority. Nor is the atiirmative of that proposition correct. For the truth is that the purehaser is, or is not, affected by his rendor's estoppel according to cireumstances.

"The rule being that the privies of a grantor who is estopped are not estopped if they are subseciuent purchasers for value, and have no notice that lie is estopiped."

Applications. - Let us now apply our principles and method to the ease of heate $v$. Plillips. ${ }^{3}$ Its somewhat complieated facts may be (sulficiently for our purposes) summarized as follows: The owner of an equity of redemption stoor by while a confederate, elaiming as tenant under a fietitious lease, mortgaged his apparent estate to one who made no inquiry into the title; the confederate afterwards got in the legal title (he is now estopped as against the mortgagee, or in other words the mortgagee has an equity against him), and subsequently he (the confederate) deposited the deeds with a banker (who had no notice of the prior mortgage) as security for a loan. Observe that the competing elaims (of the mortgagee and banker) are both equitable; that if the equities (i.e., the merits) are equal, the first in time should prevail; that the mortgage was only ereated, if at all, by estoppel of the owner of the land;

${ }_{1}$ Per Lord IIenley in Stimhope v. Verney (1761), 2 Eden, 85. Aul see Mackieth v. Symmons (1809), 15 Ves. 328; International v. Bowen (18ii), 80 Ili. 511.

2Rutz v. Kehr (1890), 143 Ill. 55s: 2.5 N. E. R. $955 ; 29$ id. 553; MeCravey v. Remson (1851), 19 Ala. 430; Shortbard v. Sutton (1878), 68 Me. 57j. See also Tied. Real Prop., $531 ; 3 \mathrm{~W}$ isl. Real Prop. 91. Clark v. Kirby (1s98),
18 Utah, 258: 55 Pac. R. 372. may be cited for the proposition that pur. chasers from an estoppel-clenier will be bound even without notice of the estoppel. Possession of the estoppel. asserter may, however, in that case, have been thought to constitute notice; but the julgment is not put upon that gromul.

${ }^{3}(1881) 18 \mathrm{Ch} . \mathrm{D} .560 ; 50$ L. J. Ch. 664. 
and that something may be said in depreciation of the mortgagee's merits, for he made no inquiry as to the title. How, then, are the rival claims of the mortgagee and banker to be settle!l?

Obscrve that the mortgagee (the first in time) has an equity merely as against the true owner (he has no estate, for he claims through one who had none); and that the banker has an equitable estate. We say then that the banker has the estate in dispute; and (following our method) we ask, Is there any reason for taking it from him? And none can be assigned, for his merits are at least equal to those of the mortgagee (probably superior, for the mortgagee took no precaution and made no inquiry as to title) - he is a purchaser of an estate for value without notice of an equity. He is therefore entitled to priority.

This seems to be simple enough. But when the word "estoppel" instead of "an equity" is used, and when the other question is put: Whether the second purchaser or the estate is "bound by the estoppel?" confusion ensues. For example, in the case in hand we have the following in the judgment of Bicon, V. C.:

"It cannot be said that because a man commits a misdemeanol with relation to a certain estate that the estate is thereby forever bound. No case has been quoted that roes anything like that length. The equitable right and the equitable estate are distinguisbed in some of the cases which have been mentioned. Stanlope v. Ear) Verney (2 Eden, 81), an old ('ase, but a case decided by one of the most eminent judges that this jurisidiction has possessed (Lord Chancellor Northington, in June. 1761). clearly makes a distinction between an equitable right, a personal obligation, and a right whieh attaches itself to the land, or to the substance of the thing which is the subject of the contract or transaction. I have heard no such case men. tioned."

"Admitting, as I have no reason to doubt, that Dims lale was a malefactor, and that he had committed a gross fraud and male use of tait as an instrument, and that he load imposed upon the plaintiff and upon Plillips, what of that? How does that touch the estate? It would be misconduct for which he could be punished, and a wrong which coult be redressed acrainst him personally; but I am at a loss to see how it touches the estate. This brings it close to the loctrine of estoppel which has been argued at such length and with great ability."

"There are many observitions in the cuses that have been citer to me, some of them little better than commonplaces, others highly interestme, most of them curious and entitled to great attention: but I have never heard that, becanse a man commits a personal wrong, that he therefore diprives humself of all right of dealing with property which is his in favor of a subsequent purchrser. Now thist is the whole case before me. . . It cannot be said that there is a representation which so deprives the ownel of the efuity of redemption, that is all that Dimsdale had, as he canmot afterwards ileal with that for value to a person who pays him or lends him money on the security of it." 1

1 Keate v. Phillips (1881), 18 Ch. D. 578: 50 L. J. Ch. 669. 
The last few words are significant. They partially reveal the real point of the ease, and qualify all that has been said. If a man "commits a personal wrongr" (such as that in hand), - dloes he "deprive himself of all right of dealing with the property . . . in favor of a subsequent purchaser?" And tho answer is not a categorical negative, as the judgrnent assumes, but this: that it depends upon circumstances - depends upon whether the purchaser is or is not one for value without notice. Suppose that the subsequent purchaser, in the case in hand, had known all the facts - had known that the true owner, through a confederate, had induced the first mortgatgee to lend money upon a fictitious lease of the property, and knew therefore that the first mortgagee had an equity against the true ownerit would have been impossible for him (the subsequent purchaser) to obtain priority. In such ease it might be said (in opposition to the conclusion arrived at in the judgment) that the true owner had deprived " himself of all right of dealing with the property;" but it would, of course, be better to say that the purchaser of a subsequent estate has no priority over a prior equity of which be has notice.

Reference to another case, in which it was said that estoppel did operate as argainst those claiming under the estoppel-denier, will be useful. A land-owner handed to a lady, as security for a loan, a package which he untruly represented to contain the title-deeds; afterwards he deposited the deeds with another person who had no notice of the first transaction. In such a case Lord Selborne said: 1

"As hetween Edward Ifucklestone [the land-owner], who signed that letter, and the representative of Mrs. Shaw [the package holder]. to whom it was addressed. I have no hesitation whatever in holding that, whatever were the deeds in Mrs. Shaw's hands. a good equitable security on the Peunyhank estate was created as between those persons. which Edward Mucklestone and those claiming under him would be estopped from at any time whatever disputing. I will even go to the length of saving that if the deeds had not been truly leesls relatiug to the Pennybank eistate at all, but stated by him in writing to be so, still the same security would have been effected."

The contest here (as Lord Selborne puts it) is between two equitable estates. Applying the ordinary principles of prior-

1 Dixon v. Mucklestone (18;2), L. R. De G. \& J. 1; 27 L. J. Ch. 220: Hunt r. 8 Ch. 159; 42 L. J. Ch. 210 . See also Sharp r. Foy (1868), L. R. 4 Ch. 3i. The facts cannot be understool without reference to 19 L. T. N. S. 5t1. Compare Roberts v. Croft (1857), 2 Elmes (1860), 2 D., F. \& J. 5is: 30 L. J. Ch. 2.5.); Re Ingham (1893), $1 \mathrm{Cl}$. 35:2 6:2 L. J. Ch. 100): Colyer r. Finch (1si6), j H. L. C. 905; 26 L. J. Ch. 6j. 
ity, we would say that the ease ras simple - the first in time has of course priority. Introducing estoppel, we have to say that the depositor of the deeds was estopped in faror of the first purchaser, and (in opposition to other dicta) that "those clitiming under him" are likewise estopped.

Comparing the two cases, then, we see that it is impossible to affirm, generally, that estoppel does or does not deprive the estoppel-denier of "the right of dealing with the property;" or that "those claiming under him" are bound by his estoppel. Everything depends upon (1) whether the eompetitors are equal in position with reference to the estate, and (2) whether the second purchaser gave value or had notice. In fact it becomes apparent that under the word "estoppel" we are concealing "an equity;" and that when we use that term, and apply the ordinary prineiples, all difficulty disappears.

An Equity or an Equitulle Estate.-For the sake of clearness in the preceding exposition, estoppel has been treated as equivalent to "an equity," merely; but there is much to be said in farol of the view that estoppel by misrepresentation may frequently pass an estate. The point is somewhat outside the soope of the present work and ean be touched apon but slightly. The main objection to such view is that some sort of conveyance is essentially necessary for the transfer of land. But there are several answers to that:

1. Estoppel by deed is usually thought to pass an estate, although the rery point is that the deed itself does not convey it." "Inurement" is the word whieh seems to belp us over the difficulty - the title will inure

"by direct operation of law with the same effect to all intents and purposes as if such estate had originally passed by the deerl." 2

2. In Smith's Leading. Cases it is strongly maintained that covenants in a deed run with the land, although the title passes not by the deed but by estoppel. ${ }^{3}$

l "Estoppels which run with the land, or work thereon, are no mere conclusions: they pass estates and constitute title; they are muniments of title, assuring it to the purchaser." Favil v. Roberts (1855), 50 N. Y. 222.

2 Rawle on Covenants for Title (jth ed.), § 248 (citing a cloud of cases): Kerr on Real Property, \$2275; Maupin on Marketable Titles, $\$ 213$;

Am. \& Eng. Ency. (2d ed.), vol. 11, p. 418 , n. 1 ; Boulton v. Hamilton (1864), 15 U. C. C. P. 125. There is legislation in some of the states upon the subject. See Am. \& Eng. Ency. (2d ed.), vol. 11, p. 419.

${ }^{3}$ See notes to Spencer's Case (10th ed.), vol. 1, p. 5\%. And see Trust \& Loan Co. v. Ruttan (1877), 1 S. C. Can. 581. 
3. Rights in land may be acquired by dedication, and so withont converance.

4. A "parliamentary title" is obtained by protracted adverse possession without conveyance.

5. A deposit of title deels creates an equitable estate, and not a right merely.

6. Recovery in trover and satisfaction of the judgment passes title to groods without conreyance.

7. The United States Supreme Court has held that a title restmg upon estoppel by misrepresentation is sulficient to support an action of ejectment." And in a later case the same conrt, after referring to the effect of estoppel by deed as a transfer of the estat te, said:

"Why may not a like transfer be held to have heen matle in this case? The reason iriven for the rule of inurement and estoplel by virtue of conreyances is that it avojls circuity of action. Does not thes same consider. ation apply with equal force in case of estoppel in press Why is it necessary to gro into equity in one case. and not in the other? It has never been held thit the statute of framls applies to cases of inmrement, and it has been conceded that it does not alfeet cases of dedication. Where is the dillerence in principle in this respect between those cases and the one betore us?" 3

Whatever difference there may be as to the usual effect of estoppel by deed passing a subseruently aequired estate, ${ }^{4}$ it appears to be conceded that in the case of leases estoppel does pass the estate. ${ }^{5}$ The explanation of this is sail to be the fact of the possession of the lessee; possession being " notice of an interest, the nature or extent of which a prarchaser is bound to ascertain." "But this reasoning is inrerted, for it is this: Because possession gives notice, therefore a lease passes an estate by estoppel; and it is a rule, therefore, for linding out, upon consideration of the rights of the parties, when the estate

1 Keys v. Williams (1838), 3 Y. \& C. Ex. 5is: Hockley r. Bantock (18:6), 1 Russ, 141. Such a mortmage may be foreclosed. James r. Jamese (18:33), L. R. $16 \mathrm{E}$ ]. 1033: 42 L. J. Ch. :386; backhutse v. Chatrlon (1Sis). \& Ch. D. 44t: Lees v. Fisher (1582), 些 Ch. D. 233 .

"stodiard v. Chambers (1814), 43 U. S. 316 .

${ }^{3}$ Dickerson v. Colgrove (1879), 100 U. S. 5s:3. And see Kitk v. Hamilton (1S80). 102 U. S. 65: Cleveland s. Clevelatud (1599), 93 Fed. lis 13:3.
4 See discussion in Bigelow on Es. toppel (ithed.). 381 li.: R Ris le on Corenati for Title (tth el, ), 104 ff.; Bonl. ter v. Humilton (1864), 15 U. C. C. P. 125; Fitherstone v. MeDonnell (18(6.) ), jal. 16:; Baxter v. Brathury (1541), 20) Me. :(i): Bink of Uticiar. Mersereatu (18ts), 3 Barb. (N. Y.) ins.

5 liggelow on Estopluel (jth ed.). 4:0: Trevivian s. Liarence $(1,06), 1$ Salk. $2 \pi 6$.

¿ Bigelow un Estoppel (jth ed.), 4:l. 
passes; instead of one by which to ascertain the rights of the parties.

Probably upon close in restigation it will be found that the difference between estoppel by misrepresentation and estoppel by deed is to be found merely in the fact that in the latter the subsequent purchasers have more frequently notice of the estoppel than in the former; and it has become usual, therefore, to say in the one ease that the purchasers are bound, and in the other that they are not.

It may be found too that in some cases "an equity" may arise by estoppel and sometimes "an equitable estate." And it is hardly necessary to add that where estoppel has the effect of passing an estate, the same rules will apply to contracts for priority as in other cases in which estates are by other means transferred.

Effect Under the Factors and Sale of Goods Acts.-These statutes do not proceed upon any of the lines which have been discussed. They provide that under certain circumstances of ostensible ownership and ostensible agency an unauthorized disposition of goods is to bave the same effect "as if such person were the owner of the goods," or "as if he were expressly authorized by the owner of the goods to make the same." " The effect of these provisions is not only to estop the true owner from setting up his title as against an innocent purchaser, but to pass the legal title to the purchaser. In such eases a subsequent purchaser from the true owner, even if he had no notice of the prior disposition, would have no claim to the goods; for he has not, as in cases outside the statute, the legal or in fact any title to them.

\section{Does Estolpel Brid Creditors of tire Estoppel-denier?}

The solution above offered eannot, unfortunately, be said to be quite in harnony with the eases with which we have now to deal involving the following question: Suppose that the owner has become estopped (by standing by while his property is sold by another) from setting up his title as against the pur-

1 Factors Act, 52 \& 53 Vic. (Imp.), 57 Vic. (Imp.), ch. 71, § 25 (1); 59 Vic. ch. 4., 2 (1), ז, 8; Rev. St. Ont., ch. (Man.), ch. 25, 24 (1). $150,55,11$; Sale of Goods Act, 56 \& 
chaser; that a crelitor obtains julgment against the owner; and that the sheriff sells the property under execution against him,- is the sherifr's purchaser of the owner's interest likewise estopped as agianst the first purchatser?

Privity. - Working along the line of privity we would find it hard to grive an answer, and might possibly proceed as in the cases alrealy considered; that is, ascertain upon general principles who ought to have priority, and then, in accordance with the conclusion so arrived at, declare that the sherifi's purchaser was, or was not, in privity with the vendor, and so bound by the estoppel.

For the existenen of privity in such a case (if we were to investignte this first) one might say that a purchaser at a sherifr's sale grets that which the debtor had, subject to all equities of every sort; that he can be in no better position than the debtor; that privity of estate exists, not only when the grantor himself conveys the estate, but also when under legal authority it is conveyed by some one else for him: ${ }^{1}$ that therefore the sheriff's purchaser is in privity with the lebtor; and that he is for that reason bound by the estoppel which affected him whose estate he has acquired. Plainly, if we are going to come to the conclusion that the sheriff's purchaser is estopped, and argue that he is so because of his privity, we can make something of a case. ${ }^{2}$

No P'rivity - Against the existence of privity in such a case (if we are going to say that the sheriff's purchaser is not in privity with the rendor, and consequently is not estoppel), we may reason somewhat in this fashion:

"The legal relation between debtor and creditor is one of antagonism rather than of contidence or mutual depentence." 3 "The fi. fa. ilirects the sheriff to seize the gools of the debtor. The sheriff is a stranger to the debtor, and the only question for him is. Are these the goods of the dabtor or not?" "If the execution creditor could for this purpose be said

1 "He would hare been estopped from setting up his own fraud: and as he would have been estopped, his trustee in bankruptcy, who is suing upon the relation between him and the defendant, is just as much estopped as he was." Per Brett. L. J., in Harris v. Trumin (1882), 9 Q. 13. D. 2it; 51 I. J. Q. B. 338. And see Re South Essex Estuary Co. (1871). L. R. 11 Eq. 15r; 40 L. J. Ch. 153; Re Whenl Unity Co. (1S30), 15 Ch. D. 13; Bloon- enthal r. Ford (1897), A. C. 156:66 L. J. Ch. 253; Wachusett, etc. r. Sioux City. etc. (1594), 63 Fed. R. 366, 371.

2 Parker v, Crittenden (15r0), $3 \pi$ Com. 14s; International Bank $\therefore$. Bowen (1575), 80 11l. int.

${ }^{3}$ Per Woodward, J., Water's Appeal (1\$60), 35 Pa. St. 526

+ Per Martin, B., Richards v. Johns-

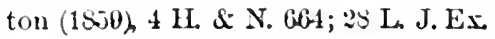
322 
to clain through. and under, the execution dehtor. so as to be in privity with him, he might be estopped. But I do not think that he can he said so to claim: he claims through, and by, the law, as against the execution debtor, and not through, and under, him." 1

Solution of the question in hand, by a discussion of the existence of privity, does not appear to promise great success.

The Cases.-Distinguishing among the authorities which proceed largely upon that line, we find that in England it is thought that there is no privity and no estoppel. In the former of the cases cited in the notes, ${ }^{2}$ Martin, B., said:

" No authority has been cited to show that a judgment creditor is party, or prirs, to the act of the judgment debtor."

The latter of the cases was one in which a bailee, being estopped to deny the title of his bailor, was held not to be upon that account estopped as against an execution creditor of the bailor. Lord Esher said:

"But eren then there would be nerely an estoppel between those par. ties. and such an estoppel would give the claimant no real title to. or interest in, the goods. Snch an estoppel nuerely prevents the party who is estopped from saying, as against some other party, that the groods do not belong to such other party, though in fact they lo belong to him: and it clearly takes effect as between parties and privies."

So also in Nebraska ${ }^{3}$ the owner of a business, by representing that it belonged to his wife, induced persons to sell goods to the wife and to take a mortgalge as security. Other persons (baring no knowledge of the misrepresentation) sold goods to the husband, and afterwards issued attachments against hin. Ileld, that the attaching creditors were not bound by the estoppel, and consequently took priority over the mortgage.

And in New York ${ }^{4}$ an owner stood by while another mortgaged his estate; afterwards the owner's interest was sold under execution against him; and the purchaser under execttion was held to be entitled. O'Brien, J., said:

"The rule that estoppel binls parties and their privies in estate an! blood applies only when subsequent parties represent the rights and es. tate of the party who created the estoppel, and nothing more. It dwes not apply to a party who, in the process of transferring real estate, has acquired a better title than his predecessor had."

With respect, it may be said that this is reverting to the hoe-and-shovel process. For the question is whether the sberifir's purchaser did acquire "a better title than his predecessor

1 Per Lord Esher, Richards v. Jen. kins (1856), 18 Q. B. D. 456; 56 L. J. Q. B. 293.

2 Richards v. Johnston (18.59), $4 \mathrm{H}$. \& N. 661; 28 L. J. Ex. 32:; Richards v. Jonkins (18s6), 18 Q. B. D. $451 ; 56$

L. J. Q. B. 293.

${ }^{3}$ Oberfelder $\nabla$. Kavanagh (1890), 29

Neb. $42 \pi ; 45$ N. W. R. $4 \pi 1$.

${ }^{4}$ Lyon v. Morgan (1891), 113 N. Y. 509 ; 39 N. E. R. 961. 
had." To ascertain that we must (following the method in vogue) first ascertiin whether there was privity between theso two persons. But the learned judge says that there was n', privity because a better title did pass. Tho answer to the question in judgment is assumed in order to ascertain whether there is privity, instead of ascertaining whether thero is privity in order to answer the question in judgment. Perhaps both methods are wrong.

Upon the other hand, in Connecticut, where the owner of a chattel was estopped by standing by while it was so sold, the purchaser was held to be entitled to maintain replevin for it as against attaching creditors of the owner. ${ }^{1}$ The ground taken was the existence of pricity of estate between the creditors and their debtor, the owner.

In Kentucky it is held

"that when the firm or the partners have done any act which precludes each aud all $j$ ts members from asserting their lien, or when from any other canse they are in a position in which they cannot assert it, that firm's crel. itors are equally unible to do so."?

A Pennsylvania ease ${ }^{3}$ has been cited for the proposition "that no privity exists between creditor and debtor." " Thit is strictly accurate, but must be carefully interpreted. In the case in question a vendor conveyed to a purchaser by a deeil with general warrinty and containing a receipt for the purchase-money. The money in reality was not paid, and the vendor took judgment against the purchaser for the amount. other judgment creditors of the purchaser contended that the vendor was estopped by his deed from asserting that the mone was not pail, and sought priority over his judgment. It was held that they could not set up the estoppel which their debtor might hare set np. That seems to be clear enough. ${ }^{5}$ The purchaser (possibly) might have defended the action of the rendol upon the technical ground that although he had not paid the money, yet that he held a receipt for it. But not having lone so, it is hard to see how his other creditors, after the jucliment had been obtained, could get any benefit from such a point. ${ }^{6}$

1 Parker v. Crittenden (15\%0), 37 Conn. 148. And see Kern v. Day (1893), 45 La. Ann. $71 ; 12$ S. R. 6.

${ }^{2}$ Couchman v. Maupin (1879), is Ky. $3 \%$.

3 Water's Appeal (1860), 35 Pa. St. 523.
4 Bigelow on Estoppel (5th ed.), $34:$

5 See also Sunderlin v. Strutlers (1\$64), 47 Pa. St. 411.

${ }^{6}$ The case is one of a cliss to which Heane $r$ Rogers (18:9), 9 B. \& C. jir: ; L. J. K. B. 2S3, belongs, althoug? that is not always quite recognizen. 
Ground of Error.- To the present writer it has always appeared that much of the error encountered in the derelopment of the law is attributable to an excess of deductive reasoning. That method is right enough, provided that by induction your major premise has been made perfectly secure. The certainties of yesterday, however, are the dubieties of to-day; and it behoores the lawyer (perhaps of all others), by frequent scrutiny, to keep himself free from formulas that have ceased to be true.

Had we never heard that estoppels bind parties and privies, there would, one would think, be little doubt that a sheriff's purchaser could occupy no better position than that of the execution debtor. But the old rule, formulated for totally different lines of cases, is appealed to as though it were a statute, and other principles are overridden that it may have full sway. The result, as one may imagine, bas been unsatisfactory.

True Position.- The position is this: The owner who stands by continues (after his estoppel) to have the legal title in the property; but he has no equitable interest in it, or at all events no equitable right to it; upon the contrary, as between him and the other party, be can claim neither property nor possession. Subsequently, all bis interest in the chattel is sold by the sheriff; and now it is said that the sheriff's purchaser bas acquired not only the legal title which the debtor had, but also the beneficial, which he had not.

It is trite law that the sheriff can sell nothing but that which the debtor has. But it is argued that the debtor had, as a matter of fact, both the legal and the beneficial title; and was merely under a disability, personal to himself, to set it upthat, by virtue of an estoppel as against him, he was precluderl from asserting his rights. Translate, however, "estoppel as

See Richards v. Johnston (1859), 4 H. \& N. 66:3; 28 L. J. Ex. 322. Suppose that a defendant is sued upon a contract entered into upon his behalf by one who had no authority to make it, but who was held out by the defendant as having such au. thority. The defendant is now liable by estoppel. But it could hardly be contended that his other creditors could exclude the plaintiff from the debtor's estate upon the ground that there was in fact no agency, anl that by the estoppel they. at all events, were not bound. Such cases are entirely distinct from those with which we have been dealing, viz., those which involve ownership of property. See also Allan v. McTav. ish (1883), 8 Ont. A pp. 440; Young v. Ward (1896), 24 Ont App. 147. 
against him "into "an equity in favor of the other party," and the reasoning disappears. For the position then in this: The debtor has the legal title to the property, but in equity he has no right whatever to it. So stated the difficulty is grone.

Suppose that instead of standing by while the chattel was being sold (as in the case under assumption) the owner had contracted that he would never question the validity of the sale. Here also the title would have remained in him, but ho would be bound by his contract not to set it up, and the purchaser would have an equitable right to the property. If, afterwards, the sheriff sold the property under execution against the former owner, no beneficial interest would pass. And would the law be reasonable which provided that if the owner had induced the first purchaser to take the title by contracting that he would never question it, the result would be entirely different from what it would be if he had induced him to take the same property by misrepresentation, the legal effect of which is to preclude him from questioning it.

Joint and Separate Creditors of Partners. $-\Lambda$ further difficulty is presented by such a case as this: $R$. is the proprietor of a business, and has certain creditors as such; to other creditors C. has been held out as a partner of R.; R.'s creditors claim that the assets are separate assets of R., and the other ereditors claim that they are partnership assets of $R$. and $C$.

Upon the principle of parties and pricies being bound by estoppel, and creditors not being in privity with their debtors, R.'s creditors have clearly the best of it, for the fact is that the assets are separate. In lie liowland $d$ Crankshaw," howerer, Lord Cranworth arrived at a contrary conclusion. But the judgment is uninstructive, for the learned judge rested his decision on the argument that

"as C. suffered $R$. to trate in the name of the firm, any persons trading with him are entitled to say that $R$. and $C$. are the persons with whom they deait, and the goods are joint groods."

They are so entitled, no doubt; but can they so say, as against persons who traded with $R$. alone upon a different representation (one according to the very fact), and who knew nothing of the misrepresentation upon which the joint ereditors say that

1 See, however, the Scotch law: $2(1866)$ L. R. 1 Ch. 424. Inglis r. Robertson (1898), A. C. 616; 67 L. J. P. C. 108 . 
they traded? If the joint creditors are entitled to say that they acted upon a representation of partnership and that the assets are therefore joint, why may not the separate creditor say that he acted upon the contrary representation and that therefore the assets are separate? The doctrine of "reputed ownership" would go far to settle the difficulty in cases of bankruptcy. The question then would be one of general repute, and would bind ererybody. But Lord Cranworth distinetly said that "the question of reputed ownership bas nothing to do with the case."

In a subsequent instance of somewbat similar character, Ex parte IIayman, ${ }^{1}$ a business which really belonged to a father was so carried on that nine creditors out of eighty-two "deposed that they had . . always treated the son . . . as being in partnership with the father." A separate creditor of the father desired to prove against the assets of the business as being the separate estate of the father, but he was unsuccessful. Bagallay, L. J., rested bis judgment upon the principle of Re Rowland \& Crankshaws. James, I. J., also approved of that case, but said that the principle of reputed ownership secmed to underlie it. ${ }^{2}$ Thesiger, L. J., alone met the real question when he said:

"If the consequence that the stock-in-trade is to be held to be joint property, where there is an ostensible partnership. is merely an offshoot of the joctrine of reputed ownership, then I can well understand that, in such a case, the rights of the separate creditors shonld be debarred, and that they should not be entitled to prove in competition with the joint creditors. But if this result is supposed to flow from the doctrine of ostensible partnership per se, then I must say, for myself, that I cannot see why, in such a case, the rights of the separate creditors should be any less than the joint creditors. The law relating to ostensible partnership is founded on the cioctrine of estoppel; and although the doctrine of estoppel might be perfectly good as between those who contract with the joint creditors themsolres. I do not see why, in the event of bankruptcy, that estoppel should arply to the separate creditors, whose rights before bankruptcy stand very luuch in the same position as those of the joint creditors. On the one hand you have a joint creditor who had, before the bankruptcy, a right of action against his particular debtor; and a right, upon obtaining judgment in that action, to scize the property which was in fact separate estate. On the other hand you have joint creditors who are entitled to sue the two partvers on the ground of the ostensible partnership, and who, in the event of their obtaining a judgment, would be entitled to seize the same property nithough separate estate. But when the bankruptey arises, and there is to $f \in$ an administration of the estate, it would seem to be just that the separate creditors should have a right against the estate which was in fact separate estate, and the joint creditors should have a right against the estate which was held out to them as joint estate."

This would no doubt be just, but it is unobtainable. For there is but one estate; and if the separato ereditors are to 
take it because it is "in fact separate estate," and the joint creditors are to talie it beciuse it "was held out to them as joint estate," there will not be as much left as usual for the assignee. The present writer suggests that it is impossible to exclucle the separite creditors, for the estate is in fact separate, and ther have done nothing to preclucle them from so saying. Upon the other hand, the joint ereditors cannot be excluded. As a matter of fact they are not joint, but separate, creditors; having, in addition, a right by estoppel to hold some other person also liable if they so desire. They cannot be compelled to assert that they are joint creditors in order to oust them from participation in the assets.

In some instruetive cases" in the United States the matter is put in this way: The right which partnership ereditors have to priority over separate erelitors in respect of partnership assets is founded upon the right of each partner to require partnership assets to be applied to partnership debts before any partner can participate; partnership creditors are subrogated to this partnership right, and so exclude the separate creditors from liartnership assets; but this reasoning cannot, of course, apply where there is in reality only one partner, for in such caso there is no partnership right to which creditors may be subrogited; therefore ereditors of a partnership by estoppel only cau have no right to exelude separate creditors. For cx. ample, if $A$. represents that $B$. is his partner, and thus misleads creclitor No. 1, A. is of course estopped to deny the partnership; but creditor No. 2 (of A. alone) would of course be in no way estopled to deny it; and Yo. 2 would take the assets as separate, because, there being no real partnership, No. 1 can have no right by way of subrogation to exclude him.

No objection to this reasoning or its result can be marle so far as it inclicates that No. 1 camnot exchicle No. 2. But the inference must not bo drawn that No. 2 can therefore exelude No. 1; for, as has just been saill, he is in fact a separate ereditor also, and only by an estoppel, which he may or may not (as he pleases) set up, can he be said to be a partnership ereditor.

licputed Ownership Clauses. - Obserre the effect of the reputed ownership clauses in relation to the palties and privies

1 See . Weridian Nat. Bank v. M'Con. icil (Ls91). \& Ohio C. C. 14 ?

Grabenheiner r. Rindsliouf (18\$5), 6.1 Tex. 49.

2 Glem v. Gill (1552), 2 MLd. 1; 
rule. The act declares " that all goods " in the possession, order or disposition of the bankrupt in his trade, or business, by the consent and permission of the true owner, uncler such circumstances that be is the reputed owner thereof," shall form part of "the property of the bankrupt, divisible amongst his ereclitors." This law proceeds upon a rough application of the prineiples of estoppel. The true owner of the goods bas allowed the bankrupt to represent himself as the owner of the goods; upon the faith of this apparent ownership, credit has been given; and the true owner having assisted in the misrepresentation is estopped. ${ }^{2}$ Upon the priuciples of estoppel, then, the true owner ought to be estopped. ${ }^{3}$ But if estoppels bind only parties and privies, and if creditors are not in privity with their debtor, then any creditors of the true owner ought not to be estopped. The effect of the statute, nevertheless, is to estop such creditors equally with their debtor - the true owner. Here then is a most important inroad upon the doctrine that estoppels bind only parties and privies; or else upon the holding that creditors are not in privity with their debtors; and will be some help, it is hoped, to the reconsideration of the decisions which enable a sherilf's purebaser to take property as to which the execution debtor had not a shade of equitable title that he himself could enforce.

In the absence of legislation it bas been held in Massachusetts ${ }^{4}$ that

"all assignment under the insolvent laws does not vest in the assignees property which has been put into the liands of the debtor for the fraudulent purpose of giving him a false credit, although some of the creditors may have been defrauded thereby;"

$146 \& 47$ Vic. (Imp.), cl. 52, \& 44 (3).

2 See Robson on Bankiuptcy (7th ed.), 513. In Ex parte Hayman (1878), 8 Ch. D. 23, 47 L. J. Bk. 54, James, In J., said: "The doctrine of reputed ownership is only an application of the common principle that people must make good their representations." In the text it is said that the statement "proceeds upon a rough application of the principles of estoppel." It is not always true that credit has been given upon the faitl of the apparent ownership. For es- toppel, strictly. there must be action by the estoppel-asserter upon the faith of the apparent ownership. There could be no estoppel without such action but for the statute.

${ }^{3}$ Ex parte Ford (1876), 1 Ch. D. 521; 45 L. J. Bk. 96. The case show's that the determining factor, here as elsewhere, is whether the true owner had notice of what was being done. And see Re Clark (1894), 2 Q. B. :993; 63 L. J. Q. B. 806.

4 Aurlenried v. Betteley (1862), 87 Mass. 38:. 
ind that that i.s the case eren where the local law provided that

"tlse assignment shall vest in the assignee all the property of the delstor, real and personal, which he cuuld lawfuily have sold, assigned or conveyed. or which might have tenn taken on execution upon a juignent agaiust him, at the time of the first publication." 1

Bona Fide and Fraudulent Debentures. - The subject under consideration has arisen in still another form. Suppose that a company, having excented certain debentures, so deals with them that one of the directors is enabled fratudulently to dispose of them for his own use, under such circumstances as would estop the comprany from disputing their valiclity in the hands of a bonc fule assignee; and suppose that there are other debenture hollers of the company whose holdings are good withont estoppel; are, or are not, these other debenture holders "bound by the estoppel" of the company? In other words, will the holders of the fraudulent debentures rank with the holders of the valid ones? In Mowatt $v$. Castle ${ }^{2}$ it is said:

"If, after issuing debentures" (valid ones), "the company issued otliers" (good only by estoppel), "they could not by estoppel bind those who had previously acquired rights aquinst them. The company might bind themselves by an almission: but a man cannot bind by his admission those who do not claim under him, but who before the admission had acquired a right."

The judgment leaves undecided the point whether holders of subsequently issued (honest) debentures would be estopjed to deny the validity of a prior fraudulent isste, with an indication that probably they would. This would lead to the confusion that, of three classes of holders, those prior to the fraudulent issue wonld take priority orer that issue; those subsequent to that issue would rank equally with the frambulent issue; while of necessity those issued both prior and subsequent to the fraudulent issue (being both regular) would rank equally; that is to say, A. would be prior to B. and equal to C.; but B. and C. would be equal, which is something of a tangle.

What would be the law ind the debtor been an individual insteald of a company? Suppose that a hankrupt's liability to one claimant depeuds upon estompel; is the clamant any the less a ereditor? A warehonseman, for eximple, bas given a certiticate that he bolds goods for one man, whereas in reality he holds them for another. On the faith of the certificate $\mathrm{X}$.

1 General Statutes, ch. $118, \$ 44$.

2 (1886) 34 Ch. D. 63 . See ColunlLia r. Curmell (18ij), 91 U. S. 104. 
purchases the goods and sues the warehouseman in trorer for refusal to deliver. X.'s case depends upon the warehouseman being estopped from denying the representation of ownership contained in the certificate. Is he any the less a creditor because of the nature of his case?

Again, suppose that an agent is permitted to represent himself as having certain authority, which in reality he has not; the principal, being sued upon the contract of the agent, denies the agency, but is held to be estopped by his confluct; is the plaintiff any the less a creditor because of the character of the arguments which lead up to his judgment? ${ }^{1}$

And so in the case of a company: It has not issued debentures, but it has done that which, so far as it is concerned, is the exact equivalent - debentures hare been issued uuder such circumstances that the company cannot deny that it has issued them. This clearly appears when we consider that if tho company were sued upon the debentures judgment rould certainly be giren against it, and the decision would be that it had issued them. The argument of the other debenture holders would be that by their agreement with the company their debentures wero to rank with all other debentures which the company might issue, and that in very truth the company did not issue any others. But is not that a question between the company and these other claimants; and if as a matter not of consent, or of arrangement, or of compromise, but of strict law, as evideneed by the julgment of the court, the company did issue them, can a third party say that it did not?

Suppose that some prerequisite of internal arrangement of the company had been omitted in making the issue, but that the purchaser was unaware of the omission and gave full value for the debentures; conld other debenture holders insist that the debentures were not really issued? ${ }^{2}$ Strictly, of course, they were not, but under the cases ${ }^{3}$ the company could not set up the omission. In both of these cases the company is liable

1 See Heane r. Rogers (1829), 9 B. \& C. $5 \%$; 7 L. J. K. B. 283 , and other cases cited ante, p. 212, note.

2 It was thought that, the company being estopped, its creditors were also estopped in Sioux City v. Trust Cu. (1907), 82 Fed. R. 124. And see
Robinson v. Moutgomery (1836), 2 Ch. 841, 819, 850: 65) L. J. Ch. 915: Re South Essex (18;0), L. R. 11 Eq. 157: 40 L. J. Ch. 153.

${ }^{3}$ Of which Royal v. Turquand (1856), 6 El. \& B. 32 : 25 L. J, Q. B. $31 \%$ is the lading eximple. 
because of estoppel, ${ }^{1}$ and the fact that in one ease it did not get the money, and in the other that it did, cannot make any difforence in the application of the principle under discussion.

Shares Not Fully Paid Ficept by Company's Estoppel.Strong support for the above view is afforded by the decisions ${ }^{2}$ which determine that if a company is estopped from denying that certain shares are fully paid uj) the holder of them cannot be put upon the contributory list in winding-up proceedings. Not only, therefore, is the company estopped, but otber sharebolders and creditors suffer because of it. Nothing may have been paicl to the company upon the shares; nevertheless, if tho company is estopped from so saying, the other shareholder's and creditors cannot interpose a defense not available to the company.

Another Case.-A noteworthy and curious case is Merchants' Bank $v$. Monteith. ${ }^{3}$ 'The owner of a eellar and of some goods in it procured a friend to issue a walehouse receipt for the goods as though that friend was really the proprietor of the cellar. Lpon the security of the receipt a bank adranced money. Buti the owner and the friend were then estopped from denying that the goods were ralidly pledged. Afterwards the owner absconded (and was subsequently found dead); the friend took possession of tho goods and handed them to a bank, and the bank sold them. Otber creditors subsequently obtained julgments against the owner, and required the bankto account for the proceeds of the groods. Their case looked well (if the law be that a man's ereditors can occupy a better position than himself, for the goods never were, in fact, pledged to the bank, and when the owner died the goods must, therefore, havo pissed to his administrator and have become assets for the payment of all creditors alike. But the court held otherwise.

"The receipts were good between thw parties, and. by the result of the subsequent de'ilings, they were rehabilitited so as to be valid aganst creditors, by the act of intervention on his the friend's) part during the life of M. (the owner): but in any erent, there being no creditor who had any locus standi when the bank sold under the recejpts, they had the roflit to apply the proceeds to reduce their chatim against II. 's estate."

In the latter cuse, by selling the debentures it has represented that all necessary preliminarios have been observed and is bouml by the representation.
2 Sre lie London. etc. (1S89), 39 Ch. D. 2013; if L. J. C'l. 843: Bloomeltthat s. Furd (1597), A. C. 156 ; $62 \mathrm{~L} . \mathrm{J}$. Ch. :5is.

${ }^{3}(1883) 100$ ot. 629. 
The second ground of decision is probably unassailable. The creditors might possibly have followed the goods into the hands of the bank's purchaser, but the bank itself could only be liable for conversion, and at that time (the time of its sale of the goods) the creditors had no judgment, and so no locus stanci for complaint.

To the first part of the decision it may well be replied that nothing which the friend did could affect the situation. He had given the receipt, which (save by estoppel) amounted to nothing. Afterwards taking possession of the goods and handing them over could add nothing more.

The case thus illustrates an inclination to uphold a title against the creditors of the owner which is good against the owner himself; and a disinclination to permit creditors to occupy a better position than their debtor. But the supporting principle is overlooked; the principle, namely, that would treat estoppel as an equity, and so relegate the case to the ordinary rule that a creditor can take nothing but that to which his debtor is in equity, as well as at law, entitled.

And the decision suggests this further: Whether, in many of such eases, it could not fairly be held that the title really passed. The owner intended that the goods should be pledged to the bank; the bank intended the same thing; the owner indorsed and handed to the bank a document which the owner represented and the bank believed to have that effect; is there not here, in reality, a pledge of the goods? In a somewhat similar case Mrartin, B.,

"would have been better pleased if the jury had found that there had been in reality a passage of the title." 1

\section{Does Lstoipel bind in Favor of an Assianee of the Estopped-ASSEliter?}

So far we have been considering the right of the estoppelasserter to urge the estoppel, not only against the estoppeldener, but against his assigns and other persons. Wo have now to deal with the converse case, namely, the right of an assignee of the estoppel-asserter as against the estoppel-denier.

For example, the true owner stands by while I purchase his

I Kichards v. Johriston (1859), $4 \mathrm{H}$. too Pickard v. Sears (1887), 6 A. \& E. $\&$ N. 665; 28 L. J. Ex. 323. Consider 469. 
horse from another; I resell the horse; is the true owner estopped as against my purcinase?

Upon this subject the following commends itself to one's judgment:

"The rule is elementary that when the principle of estoppel relied on exists in favor of the holiler of a note, against the defense of the maker to the payment thereof, it is avalable in faror of the person to whom the holder assigns it. The reason of this rule is obvions; for, if the estoppel did not operate in favor of the assignee, the value of the note, in the hallds of the assignor or holder, would be materially decreased, and the right to sell and transfer all his thtle thereto would be inpaired. This principle of the law is fully supported by the autlorities cited in the original opinion." 1

So also it has been held that if the true owner stand by and allow his property to be sold to an innocent purchaser, the true owner is estopped not only as agrainst such purchaser, but as against any other persons to whom he may convey it. ${ }^{2}$ Getting away from the uncertain question of privies, and applying everyday principles to the ease, a similar conclusion is reached: We would say that although the title remained in the true owner, yet that his purchaser was in equity entitled to the property; that an equity is capable of transmission; that the purchaser in selling to a sub-purchaser placed him therefore in the same position as he himself was; and that, for this reason, the owner could not claim the property against the sub-purchaser. When estoppel is viewed as an equity many things become clear.

1 Krothwohl v. Dawson (1895), 140 Richards r. Jolunston (1859), 4 H. \& N. Ind. 1; 38 N. E. R. 467; 39 N. E. R. 497.

2 In Wood r. Seely (1865), 22 N. Y. 116, Denio, C. J., said: “ Estoppels by record and by deed, as is well known, run in favor of and against the priv. ies in estate of the inmediate parties to the estoppel, as well as for, and against, the parties personally; and I see no reason why estoppels in pais should not be within the rule as they clearly are within the principle." In

664 ; 28 L. J. Ex. 323, Martin, B., said: "In such a case the party is estopled from disputing their truth with re. speet to that person, and those claim. ing under him, and in that transaction." See also Kinnear v. Markey (187i), 85 Ill. 96; Wortham v. Curley (1883), 75 Ala. 356. Distinguish The John Shillito Co. v. McClung (1892), 2 C. C. App. 5?6; 6 U. S. App. 1:8; 51 Fed. R. 868 . 


\section{CHAPTER XVI.}

\section{DECEIT AND ESTOPPEL.}

Misrepresentation may, with regard to its ciril punishment, be considered as (1) griving rise to an action of deceit; (2) as giring rise to a bill in equity for restitution; and (3) as giving rise to an estoppel.

1. Actions of Deceit. - Ever since Pasley v. Freeman, ${ }^{3}$ courts of law have been familiar with actions of deceit based upon misrepresentation; for example, a misrepresentation as to the financial ability of a third person, whereby the plaintiff is induced to give credit, and thus suffers damage.

2. Restitution.-Courts of equity always exercised jurisdiction in cases of fraud. And two years after Pasley $v$. Freeman (above referred to) had been decided, it was said that that case, "and all others of that elass, were more fit for a court of equity than a court of law."

I'asley v. Freman was, nevertheless, a case in which the remedy seemed to be peculiarly in damages: "You misrepresented the financial ability of liny debtor; on the faith of your misrepresentation I gave him credit; pay me the damages which I have sustained." Courts of equity were not accustomed to award "damages." The word implied legal, rather than equitalls, jurisdiction. But the worl conld be changed and the reality veiled; so, instead of "damagres," the conrt of equity decreed "restitution;" and "breach of duty" gave way to a sort of performance of the representation: "Because of your misrepresentation I have lost so much money; I have an equity (not an action) against you, to make the representation good not to pay me damages for my loss, but, by making the representation gnod, to keep me free from damage." Thus, referring to Pasley v. Ifreeman, Lord Eldon said: ${ }^{2}$

"It has arcurred to me that that case, upon the principles of many decisions in this cout, might have been maintained here; for it is a very

1 (1is9) 3 T. R. 51.

2 Erans v. Bicknell (1801), 6 Vcs. 18:; approved in Burrowes $v$. Lock
(180.5). 10 Ves. 475. And see Pulsford

v. Richarls (18.53), 17 Lear. 87; 22 L. J. Ch. 553. 
old head of equity, that if a representation is male to another person, going to da+al, in is matter of interest, upon the faith of that representation, the former shall make that represedtation goud if lie knows it to be false."

In later vears the subtlety of this excuse for equitable jurisdiction was, to some extent, lost sight of. For example, in a case $^{1}$ in which directors of a company were being sued in equity for a misrepresentation, apon the faith of which tho plaintiff had taken certain shares, Ioril Chelınsford said:

"This case is entirely different from suits either to be relieved from, or for the enforcement of, contracts induced by the fiadulent concealment of facts, which ourht to have been disclosed; nor does it resemble such oases as Burrowes v. Lock, ${ }^{2}$ and Slim v. Croucher ${ }^{3}$ where a person making an untrue representation to another, about to deal, in a matter of interest, upon the faith of that representition, has boen compelled to make good his representation, whether he knew it to be false, or made it through forgetfulness of the fact. It is a suit instituted to recovel lamages from the respondents for the injury the appellant has sustained by baving been deceived, and misled, by their misrepresentation and suppression of ficts. to become a shareholien in the proposed company, of which they rere the promoters It is preciscly analogons to the common-law action for deceits. There can be no doubt thrit equaty exercised a concurrent jurisdiction in cases of this description, and the some principles andicable to them must prevail. both at law' and in cquity."

3. Estoppel. - Misrepresentation, acted upon, may also give rise to an estoppel, as is strioiently well known; and estoppel is so nearly allied to deceit that Baron Parke in one of the leading cases ${ }^{+}$said :

"I think you will find that the person who makes a statement on which another alters his position is not estopped unless he so induces the latter to alter his position that the former would be responsible to him in an actiou for it."

Estoppel will be declared then under circumstances similar to those requisite for an action of deceit; and restitution is a remedy which may rery well supplant deceit altogether. This seems simple enough. But let us see.

Various liemerties in Same Cave.- I.et it then be observed that the same misrepresentation may give rise to an action in deceit, to a claim for restitution, and to an estoppel. For example, an intending mortgagree of a fund inguires of the trustee of it as to incumbmances, and is fradulently told that there are none; whereas in fact the fund has already been charged. The mortgagee may now sue the trustee for damages or for

1 Peek v. Gurney (15\%3), L. R. 6 IL. L. 390 : 43 L. J. Ch. 33.

$2(180.5) 10$ Ves. $4 \% 0$.

${ }^{3}$ (1S60) 1 De G., F. \& J. 518; 29 I. J. Ch. 273.
Treeman $\because$ Coolie (1S18), 2 F.x. 659: 18 I. J. Ex. 117. And see Evaus r. Bicknell (1801), 6 Ves, 191: Lee v. Taylor (1590), 32 N. Y. 165; 11 N. Y. Sulp. 131. 
restitution, or, aided by estoppel, he may require the trusteo to hand over the fund. In the last alternative the trustee's only possible defense is that the fund has already been charged; and this defense he is precluded from setting up because of the misrepresentation. ${ }^{1}$

But Conditions Diverse.-There being, then, these various remedies for misrepresentation, one would naturally be led to think that the conditions or requisites of the misrepresentation would, for the application of each of them, be identical. But such is not, unfortunately, the present state of the law. On the contrary, the authorities seem to leave no room for escape from the embarrassing conclusion that for cleceit there must be, but for estoppel there need not be, mula fides; while for restitution - well, we shall see.

1. Deceit.-According to the leading case of Derry v. Peek, ${ }^{2}$

"In order to sustain an action of deceit there must be proof of fraud, and nothing slort of that will suffice."

It has been said that deceit will lie in cases in which fraud may be imputed, although it does not actually exist: namely, in cases where the party making the representation was "a person within whose special province it lay to know a particular fact." 3 But Derry v. Peek lends no countenance to that view. ${ }^{4}$ It does, indeed, deal with such cases, but only to put

1 Burrowes v. Lock (1S05), 10 Ves. $4 \pi 0$.

2 (1887) 14 App. Cas. $3 \pi t ; 58$ L. J. Ch. 886 .

3 See Bigelow on Estoppel (5th ed.), 610; Gerner v. Mosher (1899), is N. W. R. 384 (Neb.).

4 Nor do any of the English or Ca. nadian Derry r. Peek scholia: Glasier v. Rolls (1889), 4: Ch. D. 436; 59 L. J. Ch. 325, 820; Tomkinson v. Balkis (1891), 2 Q. B. 614 ; (189:) A. C. 405 ; 60 L. J. Q. B. 558; 63 id. 134; Angus v. Clifford (1891), 2 Ch. 475: 60 L. J. (li. 443; Low v. Bouverie (1891), 3 Ch. 82; 60 I. J. Ch. 594: Le Lievre v. Gould (189:), 1 Q. B. 491 ; 62 L. J. Q. B. 35.); Onward v. Suitlison (189:3), 1 Cl. 1; 62 L. J. Ch. 188; Garland v. Thompson (1885), 9 Ont. 376; Gold Medal v. Lumbers (1899), 26 Ont. App. \%8.
In the United States some of the cases exact the presence of real fraud; in others, fraud of very diluted character suffices; and in others it is dispensed with altogether. A good deal to the following effect may be found: "An action to recover damages for deceit cannot be maintained without proof of fraud as well as injury. . . . But while there must be a furtive intent. it may exist when one asserts a thing to be true which he does not know to be true, as it is a frand to affirm positive knowledge of that which one does not positively know." Hadcock v. Osmer (1897), 153 N. Y. 608; 47 N. E. R. 923; Chatham v. Mofratt (1888), 147 Mass. 403; 18 N. E. R. 168. The following extract from a juchnent in Florida of Carter, J. (Watson . Jones, $1899,25 \mathrm{~S}$. R. 682), is 
them aside as being "in an altngether different category from actions to recover damages for false representations such as we are dealing with." The general statement that for deceit "there must be proof of fraud, and nothing short of that will sulfice," is left unqualified.

2. Riestitution.- One of the lealing cases as to restitution is Burrowes $v$. Lock, in which the trustee of a fund, upon being applied to by an intending chargee, falsely answered that there were no incumbrauces upon it. The answer, although false, was given in grood faith, for the trustce had forgotten the fact of a previous charge. Restitution was decreed, but whether upon the ground that there was "gross negligence" in the representation or not is far from clear. ${ }^{2}$ An action of deceit would not lie under such circumstances. ${ }^{3}$

Sir Frederick Pollock limits the cases in which the court of equity, prior to the Judicature Acts, decreed restitution to

well worth its length: "In Alabama, Colorado, Nebraski and some other states the courts do not seem to require proof of scienter in cases where the party making a false representation professes to speak from his own knowledge. Munroe v. Pritcliett, 16 Alia. 78.j; Jordin v. Pickett, 78 Ala. 331; Goodale v. Millaugh, 8 Colo. App. 2:3; 46 Pac. R. 11; Johnson v. Gulick, 46 Neb. 817 ; 65 N. W. R. 883. In other states the charge of fraudulent intent in actions for deceit may be maintained by proof of a statement made as of a party's own knowledge which is false, provided the thing stated is not merely a matter of opiuion, estimite or judgment. but is susceptible of actual knowl. edge, in which case it is deemed that the fraud consists in stating that the party knows the thing to exist when he does not know it to exist. and in such cases a belief in its existence will not warrant or excuse a statement of actual knowledge. Fisher v. Mellen, 103 Miss. 503; Furnace Co. v. Moffatt, 14 T Mass. 403; 18 N. E. R. 168; Haldeocls v. Osmer, 153 N. Y. 604; 47 N. E. R. 923; Bullitt v. Farrar,
42 Minn. 8; 43 N. W. R. 566 . It is also held in these states that if the representations were not made as of the party's own knowledge, then the evidence must show that the party knew them to be untrue. and evidence that he had reasonable caluse to believe that they were untrue will not constitute suficient proof of scienter. Pearson v. Howe, 1 Allen, 20r; Stone r. Denny, 4 IIet. (Mass.) 151; Tryon v. Whitmarsh, 1 Met. (Mass.) 1; Marsh v. Falker, 40 N. Y. 562; Marshall v. Fowler, i Hun, 237; Mckown v. Furgason, 4i Iowa. 636." And see Braley v. Powers (1598). 92 Me. :03; 42 Atl. R. 362; Pieratt v. Young (1899), 49 S. W. R. 964 (Ky.): MeCord v. Levi (1899), $50 \mathrm{~s}$. W. R. $60 \tau$ (Tex.): Krause s. Busacker (1900). 81 N. W. R. 406 (Wis.); Grinuell on Deceit, 22, 198.

1 (1805) 10 Ves. $4 \% 0$.

2 The earlier case of Erans v. Bick. nell, above quoted from, seems to show that the ground of relief would be that "he knows it to be false."

${ }^{3}$ Low v. Bouverie (1891), L, R. 3 Ch. 82; 60 L. J. Ch. 5ist. But seo Pollock on Torts, 244-248. 
"certain cases of fraud (that is, wilfully or recklessly false representation of fact)." But the equity doctrine of constructire fraud enabled the court to find guilty a man as against whose moral purity of action not a word could be said. And "conduct fraudulent in the eye of this court," varied so frequently with the eye which the court happened for the moment to be employing, ${ }^{2}$ that it is impossible to say that for restitution there must be mala files, as in deceit; ${ }^{3}$ or, as in estoppel, that "no fraud need have been intencled."

3. Estoppel.-For estoppel it is reasonably clear that "it is not necessary that the party making the representation should know that it was false; no fraud need have been intended."

Comparison. - We thus see that fur deceit there must be fraud; that for estoppel there is no necessity for fraud; and that for restitution there must be frand, but that it may be fraud of constructive character - fraud "in the eye of this court." 5

Peculiarity in Application of Remedies.-These anomalies in the requisites for relief find some parallel in those discovered in the application of the various remedies. For, observe that, very frequently, the remedy by estoppel may not be applicable to the particular case, although estoppel may actually exist. That is to say, although the misrepresenter may be estopped from denying the truth of the misrepresentation, yet sometimes such inhibition will not hurt him nor help the other party.

For example, suppose that a man agrees to lend money upon mortgage of a house in course of erection, and to advance the money, as the building progresses, upon the architect's certilicates of the amount expended; that the architect is aware of the arrangement; and that he, inadvertently, issues false cer. tificates, upon which the mortgagee advances so much money that he loses some of it. Under these circumstances the architect will not be liable in deceit, ${ }^{6}$ for there was no fraud ${ }^{7}$ and

IOn Torts, 167.

'See the subject discussed in ch. XVIIL

Since the Judicature Acts, Derry v. Peek, 37 Ch. D. 541; 14 App. Cas. 397 ; 59 L. J. Ch. 864, is. no doubt, the governing authority. Restitution can no longer be looked upon as a distinct remedy.

4 Per Lord Cranworth, in Jorden v. Money (1854), 5 H. L. C. $212 ; 23$ L.

J. Ch. 868. And see ante, ch. VIII. ${ }^{5} \mathrm{As}$ to the analogous methods of employing the word fraud, see ch. XVIII.

${ }^{6}$ Le Lievre v. Gould (1893), I. R. 1 Q. B. 491; 62 I. J. Q. B. 353. And see Athins v. Payne (1899), $190 \mathrm{~Pa}$. St. 5: 42 Atl. R. 378.

'The reason stated in the judg- 
although he will be estopped from denying the truth of his certiticates, the estoppel will not hurt bim nor benefit the mortgagree.

$\Lambda$ gain, suppose that a warehouseman, through inadvertence, represents to you that he is holding certain goods for A., whereas he is really holding them for B.; and that upon the faith of this representation you buy the goods from A. Under these circumstances you cannot sue the warehouseman for damages in deceit, for there was no fraud. But in this case estoppel will help you to relief. Your course is to bring trover against him for the goods; to allege (quite contrary to the fact) that the groods are yours; and, when the trial comes on, estop him from denying your ownership, by showing that you acted upon his misrepresentation.'

Observe that in the case of the architect you were unable to turn to practical account the estoppel which you could undoubtedly fix upon him. He was estopped, but you could make no use of the estoppel. You could not sue him for anything, and succeed by preventing assertion of some fact. You had to sue him in deceit or not at all. The wrongs in the two cases are identical; yet in the one case there is a remedy and in the other there is none.

The Anomalous Result.-The anomalous result then ensues that an innocent misrepresentation will or will not be attended by punitive consequences, according as the chance circumstances will or will not permit use to be made of the peculiar principles of estoppel. If fraud be absent you cannot sue in deceit; you cannot, therefore, base your action upon the allegation that a representation was made to you, and that it was false. But if by alleging certain truths and adding to them as a further truth the representation made to you (which is in reality false), you can frame a cause of action, you will suceed; because the defendant will be estopped from denying the truth of the only false statement in your claim. In other work, you cannot suceed by alleging that the defendant made a representation

ment is that there was no duty as between the architect and the mort. gagee. That remark is appropriate to the suggestion of the existence of contract, but not altogether as a roply to a demand in deceit. If the architect knew that his certificates were to be relied upon, and he friudulently falsified them, he would havo been liable.

1 Simm v. Anglo-American (18\%9) 5 Q. B. D. 188 ; 19 L. J. Q. B. 392. 
which was false; but may (sometimes) succeed by alleging the false to be true. In the former case, could you succeed, you would have to prove that the representation was false; while in the latter you win by preventing the defendant from showing the same thing!

The present tangle may well be illustrated by three cases:

Burrowes $v$. Lock (already cited). The beneficiary of a fund wanted to borrow on it. The intending lender applied to the trustee of the fund for information as to charges; and the trustee, through forgetfulness, wrongly stited that there were none. The trustee had to make good the loss. Observe that, under Derry v. Peek, the trustee could not be sued in deceit, for there was no fraud. In estoppel, however, the lender could say to him: "Pay me over the fund;" and the trustee could not defend himself (by setting up the prior charge), because of his misrepresentation (that there was none), which estops him.

Slim v. Croucher. ${ }^{1}$ An intending borrower offered, as security, a lease which he said he was about to get. The lender required a written intimation from the landlord that he would grant the lease; and this the landlord signed. Afterwards it turned out that the landlord had previously leased the land to the borrower, and that the borrower had already assigned the lease to another person. The landlord bad forgotten about the previous lease when signing the intimation that he would grant one. The landlord was held to be liable in damages.

These two cases seem to be very much alike. In both a man within "whose province it lay to know the particular fact" (if that has anytbing to do with it) had forgotten it, and by misrepresentation bad induced an innocent person to change his position for the worse. But it seems now to be clear that while the decision in the former case was right, that in the latter was wrong. ${ }^{2}$ The explanation is this: In the case of the trustee of the fund, the misled mortgagee could sue for the money; and the trustee, being estopped from setting up the earlier charge, would have no defense; while in the case of the landlord the action was (necessarily) purely for damages for the deceit, and it ought to have failed for want of fraud. If Slim (the mort-

${ }^{1}(1860) 1$ De G., H. \& J. 517; 29 L J. Ch. 273.
2 See Low v. Bouverie (1891), L $\mathrm{R}$. 3 Ch. 82; 60 L. J. Ch. 594. 
gagee of the lease) could have framed his action against the landlord so as to gret the benefit of the estoppel, he would haro been all right. But he could not.

Another Illustration.- Suppose that I have a mortgage, and that upon being applied to, by a proposed subsequent incumbrancer, I erroneously tell him (believing such to be the fact) that my debt has been paid. In such case I would not be liable in deceit (for there was no frand); but I would be estopped from setting up iny mortgage as agrainst the subsequent incumbrancer; and this would be the exact equivalent of damages, in deceit, for the misrepresentation. Suppose, however, in the same case, that $\mathrm{my}$ mistake arose from the fact that $I$ had assigned my mortgage to a purchaser of it - the debt had not (as I represented) been paid, but had been transferred to a third person, to whom it was still due. In such case I would not be liable in deceit (because of no fraud); and there is no way to get at me throngh estoppel. I am estopped, no doubt, from ever saying that the debt is not paid, but that (under the circumstances) cannot injure me nor benefit the person to whom I made the misrepresentation.

A Third Illustration. - A warehonseman issues a warehouse certificate in which, by mistake, he acknowledges the receipt of more grain than be actually received; a third party buys the larger quantity upon the faith of the certificate; he sues the warehouseman in deceit, and is beaten because of the absence of fraud. ${ }^{\prime}$ Better adrised, another purchaser in a precisely similar situation demands the grain and sues for its delivery; the warehouseman says that he never had the grain; but the purchaser estops the assertion with the certificate, and recovers (not the grain, for there was none, but) damages. ${ }^{2}$ It is not permissible, however, to sugrgest that he got damages for the misrepresentation in the receipt, for the other case shows, of course, that that could not be done.

Anomaly Induces Harmony.- Law of this sort, which declares for relief, not upon the basis of the wrong, but upon the chance of the situation, is unsatisfictory in all but this: that ingenuity and judicial inclination are thereby directed to the

1 McLean s. Bufralo (1S64), 23 U. C. 2 Holton v. Sauson (1862), 11 U. C. Q. B. $448 ; 24$ id. 220 . C. P. 606 . 
expansion of the law in one direction or another, and thus to the establishment of harmony.

For example, what is to be done with this case?' A corporation (by mistalie) gives to $A$. a certificate that he is the owner of certain shares; so armed, $\mathrm{A}$. sells the sbares to $\mathrm{X}$.; and the corporation, having discovered its mistake, refuses to recognize $X$. as a shareholder. Now, what can $X$. do? He cannot sue the corporation for deceit (for there was no fraud). Can be force the corporation to put him on the register? The only defense the corporation could make to such an application would be that the applicant is not entitled to be a sharebolder; and from this the corporation is (in the supposed case) estopped by its representation. This seems, then, to be a likely remedy. But if, as may be the case, the company's register is already full — all its authorized shares have been issued - such remedy is impossible. ${ }^{2}$ What then? Why this: that ingenuity and inclination will discover that $X$. can sue the company for damages for refusing to put him on the register; and (the company being estopped from saying that he ought not to be there) that $\mathrm{X}$. will recorer exactly the same damages as if he had sued in deceit. The company is not liable for damages in deceit for the innocent misrepresentation; but it is liable for damages because of the deceit - although in round-about fashion. Lord Macnaghten said:

"The company are not asked to make good their representation by transferring shares to Tonlinson. They are called upon to pay damages in order to compensate Tomkinson for loss to which he has been put by reason of their misrepresentation." 3

And that is precisely what Derry v. Peek declares cannot be done in the absence of fraud.

Observe closely the modus operandi in this last case. The purchaser of the shares cannot say: "The company represented to me that $\Lambda$. was the owner of the shares; I acted upon that representation; that representation was false; I am entitled, therefore, to damages." But he can say: "The company represented to me that $A$. was the owner of the shares; I acted upon that representation; that representation was true (at least the company cannot say that it is not); the company will not

1 Re Bahia (1868), L. R. 3 Q. B. 584; 37 L. J. Q. 13. 176. And see cases cited with this one in $\mathrm{ch}$. XXII.
2 Reg. v. Charnwood (1884), 1 Cab. \& E. 419.

3 Balkis v. Tomkinson (1893), A. C. 410; 63 Is J. Q. B. 141. 
register me; I am entitled, therefore, to damages." The former would be an action of deceit, and will not lie; because, although the plaintiff asserts misrepresentation, he cannot prove fraud. The latter is an action for refusing to register the plaintiff as owner of the shares, and will lie, hecause the plaintiff refrains from asserting misrepresentation (which is his real ground of complaint), and the company is estopped from avowing it. Al. thongh the damages in both eases are the same, they can be recovered, not by alleging the real grievance, but only by a careful and enforced suppression of it. An innocent misrepresentation in this way results in clamages in spite of Derry $v$. Peek, and circuity is once more the road to harmony.

The P'resent Situation. - The result, then, seems to be that a misrepresentation

(1) May be suflicient for, and available in, both deceit and estoppel; or,

(2) May be sufficient for both, but unavailable in estoppel; or,

(3) May be insuflicient for deceit, and yet sulficient for, and available in, estoppel.

It seems that one factor in each case is the presence, or absence, of fraud; that the other factor is cbance; that where there is fraud there is always an action of deceit, but only sometimes effective estoppel; and that where there is no fraud there is no action of deceit, but, aecording to merest chance, there may or may not be estoppel accompanied by damages identical with those which would be reeorered eould an action of deeeit be brought.

These are consilerations which ma y lead to a revision of the principle laid lown in Derry v. P'eek, and to the establishment of the action of deceit upon the same ground as estoppel, namely:

"Even where a representation is male in the most entire good faith, if it be made in order to induce another to act upon it, or under circum. stances in which the party making it may reasonably suppose it will he acted on, then prima facie the party making the representation is bound by it, as between himself and those whom he his misled."?

Otherwise the anomalies above presented must remain. At present fraud is necessary to an action of deceit, but is unnec-

1 The fact that the case itself was at once partially revised by Parliament may belp to get rid of its principle. See 53 \& 54 Vic. (Imp.), ch. $6 \downarrow, 33$.
2Per Lord Cranworth in West v. Jones (3Nit), 1 Sim. N. S. 20i; :0 L. J. Ch. 363 . 
essary in estoppel. It is, as the writer thinks, impossible to introduce the element of frand into estoppel as a prerequisite. And if deceit will not lie without fraud, then we must be content to say that

"an innocent misrepresentation will, or will not, be at tended by punitive conseguences, accorling as the chance circumstances will, or will not, pernit use to be made of the peculiar principles of estoppel."

This is not the best conceivable example of stable equilibrium. Some judge some dily will breathe upon it.

So also with the equitable doctrine of restitution. If the word "fraud," tempered and qualified by construction, may be applied to cases in which there is no element of fraud (in the sense of bad faith), the breach between the requisites of restitution and estoppel may be bridged. Not the lawyer, in this case, but the etymologist only, will be required to make the situation comprebensible.

A Suggestion.- The following line of thought has much engilged the writer's mind in pondering the anomalies above referred to:

Can it be said that the idea of duty has nothing to do with estoppel? Follow this: For breach of duty the law provides punisbment (awards damages); but in estoppel there is no breach of duty, and there is no punishment, but merely sequence, or consequence. For example: When I stand by while another sells my property to an innocent purchaser, I am guilty of no breach of duty. I have a right to stand by if I like. I may, if I choose, allow another to sell my property. I can do as I please with my own; and permit another, if I wish, to do as he likes with it. I am gnilty of no breach of duty in allowing him to sell my property, and therefore cannot be punished as for a breach of duty. But if $I$ allow another person to sell my property a consequence ensues, namely, that I cannot afterwards assert $m y^{\prime}$ title; that is, that I am estopped.

Further observe that this view seems to obviate inquiry into the question of punishment in damages: I have permitted another to sell my property; I cannot afterwarls set up my title; no injury then has been done to the purchaser; he thought that his vendor had the title; I am precluded from asserting otherwise; the title then is as the purchaser understood; and he has not been injured; there is no question of damages.

Consideration of estopyel by contract, too, furnishes analogy. 
For example, a bailee is estopped from denying the title of bis bailor. That is because, in the contract of bailment, the title of the bailor is taken, as between the parties, to be a fact. The bailor may bave misrepresented his title; but that is immaterial; no guestion of duty not to misrepresent is involved; the point is, that that which between the parties was taken to be a fact is, and remains, a fact.

And so in estoppel, not by contract but by misrepresentation, may it not be said that in this also the question of duty is not involved. I misrepresent if I choose, and the consequence is merely this: that that which I have represented to be a fact is, and remains, a fact, so far as I am concerned.

Take an example:' A mortgage purports to secure $\$ 250$, and the receipt of the amount is acknowledged upon the document by the mortgagor; but $\$ 100$ only was alvancel; the mortgagee assigns the mortgage, representing that $\$ 250$ is due upon it, and the mortgagor is estopped from asserting otherwise. What is the rationale of the decision? Is it that the mortgagor, in exccuting the mortgage and the receipt, owed a duty of carefulness to those into whose hands the mortgage m ght come? Or is it that the mortgagor, having assisted in the misrepresentation (having made it credible), is really a party to it, and is visited with the usual consequence, namely, that that which he has represented to be a fact is, and remains, as to him, a fact?

Test the case in this way: If there was a duty of carefulness, and a breach of that duty, then an action of negligence will lie; for such an action is based upon breach of daty. But (assuming that there was no fraudulent intent in the mortgagor) no such action could be maintained (while Derry r. P'eck stands). And, if not, it would seem that there can have been no duty of carefulness such as suggested. The estoppel, then, must hiare arisen as a consequence, and not as a punisbment for breach of duty.

Again, recurring to the architect's case in which a mortgagee allancel money to the owner of buildings upon the faith of the architect's certiticates of amounts expended upon them, observe that the reason given for the absence of liability

1 Bickerton v. Walker (188.j), 81 Ch. D. 151 ; 55 L. J. Ch. 22\%. See cases cited with this une in ch. IV. 
on the part of the architect was that he owed no duty to the mortgagee. Yet there can be little doubt that the architect would have been estopped by his certificate had the case been one in which his estoppel would have been of any benefit to the mortgagee. There was no breach of duty; but there was the usual consequence attending the misrepresentation.

Finally, returning to the mortgage case: Suppose the mortgagor had executed the mortgage, and given the reccipt, for the purpose of enabling the mortgagee to represent that $\$ 250$ was adranced upon it; he would be liable in an action of deceit ${ }^{1}$ because he was a party to the misrepresentation. This involves, as we have seen, the idea of a breach of duty towards the assignee. If the mortgage and receipt had been given withont intention to defraud, the mortgagor would clearly not be liable in deceit. Those propositions involve these: that if the mortgagor was, knowingly, a party to the misrepresentation he was guilty of some breach of duty; and if be was innocent of intent to deceive he was not so guilty. But this is equivalent to saying that (for the purposes of an action of deceit), although there is no luty not to misrepresent, there is a duty not, wittingly, to do so.

The idea of duty, then, is linked to some extent with misrepresentation. And is the solution of our difficulties this: that there is a duty not fraudulently to misrepresent; for a breach of this duty action will lie; that apart from frand there is no duty of carefulness not to represent; but that all representation as to fact carries with it the obligation of consistency and the consequence of estoppel.

Suggested Solution Unsatisfactory. - Such solution is unsatisfactory, for while it may apparently have the merit of symmetry yet it in reality leaves all the anomalies above referred to in full operation. In fact it takes no cognizance of the most striking of them.

In the Bahia case the company was estopped by its certificate; and the result was, not the mere "consequence" that it had to registe the purchaser of the shares (for it could not do so, the register being full), but the result was damages damages for the loss occasioned by the misrepresentation. An innocent misrepresentation thus resulted in damages; while

1 Evans v. Bicknell (1801), 6 Ves. 191. 
Derry v. Peek has authoritatively determined that only in cases of fraud can there be damagres for misrepresentation.

If, in the Bihia case, the frame of the action had been, "The company represented to me that $\Lambda$. "as the owner of the shares; I acted upon that representation; that representation was false; I am entitled, therefore, to damages," the company would have won, because there was no fraud. Put, however, in another form, and the company loses: "The company represented to me that $A$. was the owner of the shares; I acted upon that representation; the representation was true; the company nevertheless refuses to register me; I am entitled, therefore, to damages." State the case naturally, and you lose. State it artificially, and you win!

Were Re Bahia but a solitary case we might, for the time, shut our eyes to it, upon the ground that "questions dangerous to all theology ought not to be raised." But Simm v. Anglo-American' (typical of many cases) must also be reckoned with. Not a company this time, but a warehouseman, innocently issued an erroneous certificate of ownership, upon the faith of which a purchaser of the goods referred to in it changed his position. The purchaser demanded the goods, and the warehouseman replied that, since issuing the certificate, he had ascertained that the groods really belonged to some one else. The warehouseman now is not liable in deceit, there having been no frand. And it is impossible that he can be ordered to deliver up the goods, for they belong to a person who is in no way implicated in the misrepresentation. The purchaser seems to be remediless. Ife cannot complain of the deceit, for it wis innocent; and he cannot have the goods, for they belong to a stranger. Nevertheless bis course (although tortuous) is clear; and his goal (although not the one he may strive for) is well assured. He cannot have the groods, and will not gret them, but he must sue for them as though he could. On the other hand, the damages which will finally be awarded to him because of the misrepresentation must meanwhile remain unclaimed. With artful indirection he sues for delivery of the goods; the warehouseman answers that the goods are not the plaintiff's, which is the fact; the plaintiff replies estoppel. Log-

1(18ז9) 5 Q. B. D. 188; 49 L. J. Q. B. 392. And see Reg. v. Charnwood (1S84), 1 Cab. \& E. 419. 
ically, now, the plaintiff ought to be awarded the goods. But Lord Justice Brett gives judgment as follows: ${ }^{1}$

"In a similar manner a person may be estopped from denying that certain goods belong to another: he may be compelled by a suit in the nature of an action of trover to deliver them up, if he has them in his possession and under his control: but if the goods in respect of which he has estopped himself really belong to somebody else, it seems impossible to suppose that. by aluy process of law, he can be compelled to deliver over another's goods to the person in whose favor the estoppel exists against him; that person is entitled to maintain a suit in the nature of an action of trover against him; but that person cannot recover the goods, because no property has really passed to him: he can recover only damages. In my view estoppel has no effect upon the real nature of the transaction; it only creates a cause of action between the person in whose favor the estoppel exists and the person who is estopped."

The warehouseman is not liable for damages in deceit for the innocent misrepresentation; but be is liable for danages because of the deceit - in round-about and artificial fashion.

In such cases as the two just dealt with, there seems to be no escape from the conclusion. (wbile Derry v. Peek stands) that if the facts are stated naturally and in support of the real ground of complaint the plaintiff will be beaten; whereas he will succeed if he state the case artificially - asserting as his grievance that of which he cannot complain. His grievance is the misrepresentation. Of misrepresentation he must say notling. To the shares, or to the goods, he has no right. These he must assert to be his. Damages for the deceit (if anything) are what he is entitled to. Of such claim he must not say a word. Damages for not giving bim the shares or goods he ought not to get (because such damages are given in lieu of specific delivery, and to delivery he is not entitled). Such damages are awarded him.

\section{Principal and Agent.}

There is another point at which the orbits of deceit and estoppel intersect, and there too a third factor must be taken into account. The ensuing problems will be merely stated bere. Their solution will be suggested in a later chapter.'

The law of principal and agent supplies many cases in which the act of the agent, being admittedly unautborized, the question is whether or not the principal is bound by it. Answer of general sort is sometimes made to the effect that the prin-

1 Simm v. Anglo-American (1879), 5 Q. B. D. 207; 49 L. J. Q. B. 392.
${ }^{2}$ Cl. XXVI. 
cipal is bound if the act was "for the master's benefit." But this statement is of course much too loose; for according to it liability would depend upon the mere intent of the argent, apart altogether from the nature of his authority. More narrowly it is said that if the anent is employed to perform "a class of acts," liability for an act within the class is to be determined by a consideration of master's benefit or arent's benefit.

But we must distinguish. The case may arise in three ways: (1) In an action of pure tort; (2) in an action of deceit; (3) in estoppel.

(1) Pure Tort.-An omnibus driver, in defiance of instructions, upsets a rival omnibus, or runs over a pedestrian; the master is liable

"proviled that what was done, was done not from any caprice of the serv. ant, but in the course of his employment." $!$

(2) Deceit.- A secretary of a company made a false reply to questions relating to certain debenture stock of the company; he had been authorized by the company to answer such questions, and the company was held not to be liable because he "did not make the statements for the defendant but for himself " - that is, for his own frandulent purposes."

(3) Estoppel.-A secretary of a company, not baving been intrusted with the seal, got possession of it and affixed it to a certificate of shares, forming also the signatures of the necessary directors. He was acting entirely for his own benefit; but the company was held to be estopped by his action."

The form of the remedy ought not to require such anomalons conclusions.

1 Limpus v. London (186?). 1 П. \& B. D. 714: 56 L. J. Q. B. 449. And see C. $526 ; 32$ L. J. Ex. 35: Bayley v. cases cited with this one in ch. Manchester (18\%2), L. R. 7 C. P. 420; XXVI.

42 L. J. C. P. 78; Weir v. Bell (18i8), 3Shaw v. Port Phillip (1854), 13 Q. 3 Ex. D. 245; 47 L. J. Ex. 708; Bar- B. D. 108; 53 L. J. Q. B. 37.2. And see wick v. English (1867), L. R. 2 Ex. cases cited with this one in ch. 259.

2 Reg. v. Charnwood (1887), 18 Q. 


\section{CHAPTER XVII.}

\section{OSTENSIBLE OWNERSHIP AND AGENCY.}

Maving now some clear understanding of the principles of estoppel by misrepresentation, let us carry them into the various departments of the law to which they are applicable.

Observe first that it is (1) title to property, and (2) liability upon contract, with which we have to deal; or rather the preclusion of the assertion of (1) rights to property, and (2) nonliability upon contract. And next, that all the cases arise in one of two ways; either

1. Some person has appeared to be the owner of property, when in reality he was not. This class may be referred to the title "Ostensible Ownership;" or

(2) Some person has appeared to have authority to do something, when in reality be had not. Such cases will be dealt with under "Ostensible Agency."

Application of estoppel to such cases might be thought to involve little difficulty. Twenty years prior to the leading case upon estoppel by misrepresentation, ${ }^{1}$ Bayley, J., in Boyson $v$. Coles ${ }^{2}$ had said with reference to ostensible ownership: ${ }^{3}$

"It is laid down as a general rule that the pawnee cannot have a better title than the pawner. And so it is of vendor and vendee, except in the case of a sale in market overt. But this rule will certainly not apply where the ouner of goods has lent himself to aceredit the title of another person by placing in his power those symbols of property which have enabled him to hold himself out as the purchaser of the goo:ls."

Lord Herschell, in a recent case, ${ }^{4}$ uses similar language:

"If the owner of a chose in artion clothes a third part! uith the ap. parent onership, and right of disposition of it, he is estopped from asserting his title as against a person to whom such third party has disposed of it and who received it in good faith and for value."

The law of ostensible agency, too, has upon many occasions been more or less accurately laid down:

"If a man by his conduct holds out another as his agent, by permitting

1 Pickard v. Sears (183i), 6 A. \& E. (1896), 27 Ont. 166; Moore v. Metro463.

2 (1817) 6 M. \& S. 23, 39.

${ }^{3}$ Colonial Bank v. Ciady (1890), 15

App. Cas, 267; 60 L. J. Ch. 131. See also Ontario Bank v, McTaggart politan (1873), $55 \mathrm{~N}$. Y. 47; Mott 5 . Clark (1848), 9 Pa. St. 399.

4 Colonial Bank v. Cally (1890), 15 App. Cas. 2s5; 60 L. J. Ch. 141. 
him to art in that chinarter' and deal with the worlel as a general agent, loe must be taken to be the general atgent of the person for whom he so alets, and the latter is bound though 11 a particular instance the agent may hate exceeded his anthority. It is even soin the cose of a special agent."

"The genelial rule of litw is that where a person has obtained the prop erty of another from one who is dealing with it without the anthority of the true owner. no title is acquired as against that owner. even though full value be given and the property be taken in the belief that an unquestionable title thereto is being obtained; unless the jerson taking it can show that the true owner has so acted as to mislead him into the belief that the person dealing with the property had authority to do so. If this can be shown, a good tille is acquired by personal estopyel against the true owner." 3

\section{Confusion.}

Although these doctrines seem to be sufficiently clear and manifestly just, yet much confusion exists concerning them, due largely to the following considerations: (1) Ostensible ownership and ostensible agency are frequently confounded the one with the other; (2) other principles, to the exclusion of those of estoppel, are in vogue in various branches of the law, notably in the law of real property and choses in action; (3) instead of ostensible agency, unfounded distinctions between general and special agents and rarious other considerations are frequently inroked.

Ostensible Ownership and Ostensible Agency. - That the distinction between ostensible ownership and ostensible agency is sometimes overlooked may be noted in a judicially indorsed * paragraph from such a substantial work as Chitty on Contracts: ${ }^{5}$

"It is said that if the real owner of goods suffers another to have possession thereof, or of those documents which are the indicua of property therein, thereby enabling him to hold himself forth to the world as having not the possession only, but the property, a sale by such a person without notice will bind the true owner. But probably this proposition onght to be limited to eases where the person who had the possession of the goods uets one who, from the nature of his employment, might be taken prima facie to have had the right to sell."

But, with submission, it is difficult to see that the nature of the employment of an ostensible owner has anything more to do with the case than has the style of his clothes. If the owner of goods represents (or assists some other person to represent) that a clergyman owns them, and thereby induces an innocent

1 Or in any other way.

2 Smith r. Mc(iuire (1858), 3 H. \& N. $562 ; 27$ L. J. Ex. 465 .

3 Simmons v. London (1892), A. C. $215 ; 61$ L. J. Ch. 723.
4 Higgins r. Burton (185\%), $26 \mathrm{I}$ _ J. Ex. 342: Johnson r. Credit (15ii), 2 C. P. D. 224; 3 C. P. D. $41 ; 47$ L. J. C. P. 241.

${ }^{5}$ See 10 th ed. 355 , and 12 th ed. 442. 
purchaser to pay over his money, can the result be different from a case in which the ostensible owner was a lawyer, a broker, a judge, or a footman?

Probably the learned writer never intended to say that it would; and the explanation of his use of the language quoted is to be found in inattention to the distinction between ostensible ownership and ostensible agency. The two things are in the passage confused together. If an owner represents that somebody else is the owner, the nature of the employment of that other person is clearly immaterial. Estoppel by ostensible ownership, therefore, has nothing to do with nature of employment.

But it may have something to do with ostensible agency. Suppose that I hand over a bill of lading of my goods to a factor with instructions not to sell the goods, and he does sell them; I am estopped from setting up my title against the purchaser. But why? Not because the factor appeared to be the owner of the goods, for being a factor he did not so appear (every one knew him to be an agent merely); but because being a factor and having possession of indicia of title to my goods with my assent, he appeared to have authority to sell. Note that if the person who had the bill was not "one who from the nature of his employment might be taken prima facie to have the right to sell," there would have been no appearance or authority to sell, and no estoppel. There might of course be ostensible ownership. ${ }^{1}$

"Nature of his employment" may therefore be a factor in cases of ostensible agency, but can bave nothing to do with ostensible ownership - with a case in which the owner has enabled another "to hold bimself forth to the world as having not the possession only but the property."

Confusion in Factors Act.- Some of the provisions of the English Factors Act proceed upon the principle of ostensible ownership, and others upon the principle of ostensible agency. Some of the clauses provide that sales and other dispositions of goods, made under certain circumstances by persons intrusted with goods or documents of title to goods, shall be as valid "as if such person were the owner of the goods;" while others declare that sales shall be "as valid as if he (the person selling)

1 See the point referred to in ch. XXII. 
were expresily authorized by the owner of the grods to make the same."

To some extent the distinction between cases in which the vendor appears to be acting as agrent and those in which he appears to be acting as owner is in the acts properly observed. In clause 2, for example, which provides for cases of sales, etc., by persons whose business is that of an agrent, the langriagre is appropriate - the transaction is to "be as valicl as if he was expressly authorized by the owner of the goods to make the same." But there is not the same consistency in the clanses providing for sale by persons who may appear to be the owner of goods. Here one of the clauses, 7 (1), procects upon ostensible ownership, while two others, 8 and 9 , proceed upon ostensible angeney."

Confusion in "The Sale of Goods Act."-In "The Sale of Goods Act" (England and Manitoba) there is the following: ${ }^{3}$

"Subject to the provisions of this Act, where gools are sold by a person who is not the owner thereof, and who does not sell them under the authority or with the consent of the owner, the buyer acquires no better title to the goods than the seller had, unless the owner of the goods is by his conduct precluded from denying the seller's anthority to sell."

The draftsman of this provision had in view the case of an agent with ostensible anthority to sell, and he provided that the owner is to be precluded from denying the existence of real "authority to sell." He overlooked the fact that an owner may be estopped by ostensible ownership as well as by ostensible agency, and made no provision for the case.

Confusion Elsewhere.- The following is a fair example of many passages in which the same confusion is apparent:

"The owner of negrotiable securities payable to bearer and transferable by mere delicery, who intrusts the agent with the possession thereof, gives him ipso faclo in law towards third parties in gool filth the right to effectual $y$ sell or pledge them. In constituting his agent the apparent absolute ouner of these securities and conferring on him all the indieia of ownership, le precludes himself from disputing the title of any subseguent bona ficle trinsferee. Or to put it in another way, the arent stands in the same position as if he had a poure of attorney from the owner authorizing him to deal with the securities in his own name as he might think til."t

153 Vic. (Imp.), ch. 45, 2 (1). And see $\leqslant$ s. 8,9 .

"Similar confusion is to be found in the Ontario statute (R. S., ch. 150), by which it is declared that an agent intrusted with possession "shall be deemed the owner . . notwith. standing the purchaser has notice that he is contracting only with an agent." In such case the assump;tion ought to be of authority to sell, and not of ownership.

356 \& 57 Vic. (Imp), ch. $71, \$ 21 ; 59$ Vic. (MIan.), ch. $25, \pm 21$.

4 Young v. MacNuler (1895), 25 S. C. Cin. $2 i 9$. 
Observe that "the agent" is said to become "the apparent absolute owner," wherefore the owner is estopped "from disputing the title;" and this is put "in another way" by saying that " the agent stands in the sime position as if he had a power of attorney from the owner." This is not another way of putting the same case, but is a remark with reference to a totally different case.

Another example occurs in the third quotation at the commencement of this chapter. It is said that

"if the owner of a chose in action clothes a third party with the apparent ownership and right of disposition of it, he is estopped."

If the third party has the "apparent ownership" he would of course necessarily have the apparent "right of disposition of it." The word or substituted for "and" would probably more accurately express the idea grasped at. The sentence would then apply to the two cases of ostensible ownership and ostensible agency, instead of redundantly to one of them only.

Confusion - A Further Point.- In distinguishing between ostensible ownership and ostensible agency, special care must be taken in cases in which (as is possible) the ostensible owner may be in reality an agent - confusion is more probable in such cases. An example will illustrate: An agrent of a policy-holder instructed a brolier to collect from the insurance company; the broker thought that the agent was the real owner of the policy; the broker collected and set off against the agrent; held, that the principal could not compel him to do otherwise. ${ }^{1}$ The agent here, although an agent, was the ostensible owner; the broker dealt with him upon the faith of such appearance; the real owner having permitted the appea rance, was estopped. Bowen, L. J., said:

"If A. has allowed his agent B. to appear in the character of a principal he must take the consequences."

\section{Benefit of Distinction.}

This then is the first point to which to direct attention and indeed to insist upon, namely, the difference between ostensible ownership and ostensible argency. For the distinction, although

1 Montagu v. Forwood (1893), 2 Q. B. Bowring (1860), 7 C. B. N. S. $851 ; 29$ 350. For other cases of this nature L. J. C. P. 30; Smith v. Grouette see Ex parte Dixon (1876), 4 Ch. D. (1885), 2 Man. 314.

$133 ; 46$ L. J. Bk. 20; Ramazotti v. 
sufficiently obvious, is, as we hare seen, very frequently disre. garded, and its oversight involves much confusion. Observation of it would reliere sereral departments of the law of some difficulty. Take a few examples:

Negutiable Instruments. - A note is signed in blank; authority is griven to "Galley" Galley fills it up for $\mathfrak{5} 500$ and passes it on; and the signer is (we shall say) liable for the $£ 500$. The reason given for this is that

"a person who gives another possession of his signature on a bill stamp
primu facie authorizes the latter as his agent to fill it up. and give to the
world the bill as accepted by him. He enables his agent to represent him-
self to the world as acting with a general authority; and he cannot saly to
a bon fide holder for value who has no notice of any secret stipulitions
that there were secret stipulations between himself and the agent. any
more than can a principal in the case already put, where he enables his
agent buying or selling on his behalf to represent himself as acting under
a general authority."

But the reason is not always this. Everything depends upon the circumstances of the case. Did the transferee know that the bill had been given to Galley in blank? Then he knew that Galley was an agent; the case is one of ostensible arrency; possession of the bill is evidence of authority to fill it up; Galley therefore appears to have the requisite authority, and the principal is estopped from asserting otherwise. But if Galley had filled up the bill before offering it in negotiation, then the transferee knew nothing of agency; he believed that the bill wats issued in completed form; he beliered Galley to be the owner of the note; and the law of ostensible agency has nothing to do with the case; the question becomes one of ostensible ownership. This distinetion has of ten been disregarded. The subject will be dealt with in a subsequent chapter. ${ }^{3}$

Priorities. - In another department of the law we meet with the two following eases:

Perry-Herrick v. Attwood. - A legal mortgagee of real estate handed over the deeds to the mortgargor, with the intention of enabling him to ruise $£ 15,000$ upon them. The mortgargor bor. owed $£ 50,000$ upon them from one who knew nothing of the mortgage. Held, that the true owner of the deeds (the legral $5: 4$.

1 Russell $v$, Langstaffe (1780), Doug.

2 Montague v. Perkins (1853), 22

L. J. C. P. 187.
3 Ch. XXIV.

$4(18.5)$ :5 Beav. 205; 2 De G. \& J. 21 ; 22 L. J. Ch. 1:21. 
mortgagee) was the one to suffer. The case is one of ostensible ownership.

Brocklesby v. Temperance. ${ }^{1}$ - The owner of certain title-deeds employed an agent to raise money upon them; and at the same time directed him not to borrow more than a specified sum. The agent went into the market and, upon the deposit of the deeds, obtained a loan in excess of the amount prescribed from a bona fide lender who knew of the agency, but who had neither notice nor know ledgre of its limitation as to amount. The agent pocketed the excess. Meld, again, that the owner of the deeds, and not the lender of the money, was the one to suffer. But is that right? The case is one of agency, not of ostensible ownership as was the previous case, but the distinction is not observed. Indeed, Lord Herschell said:

"I confess I am quite unable to see any distinction in principle between the two cases which would render it right, proper or reisonable that in the former case a lender should not be bound by a limitition of authority of which he was unaware, but that in the latter case he should be so bound."

With great respect for the opinion of so eminent a judgre, the present writer cannot but think that the distinction is very apparent. In the one case the lender of the money believed that he was dealing with an owner. In the other case he believed that he was dealing with an agent. To the latter of these the ordinary law of principal and agent applies; but to the former it has no application, for the case is one of ostensible ownership. In the agency case the law says to the lender: "You are aware that you are dealing with an agent. You must, as in other cases of agency, ascertain, at your peril, the extent of the agent's authority." In the ownership case such language is altogether inapplicable; for the lender knows nothing of a principal or of an arrent. He believed in ownership, and had no suspicion of agency.

But what is the effect of such a distinction? Observe that in both cases the real owner of the deeds has not personally pledged them, and that no one having his authority has done so. If, then, the real owner is to be bound by the pledge of " the deeds, it must be because he is estopped from denying that the person pledging had power to do so. Now he can be estopped only if he is in some way responsible for the fraud of 
the person pledging - if he has assisted the misrepresentation of power or right to pledge. In Lord Herschell's case (in which the pledgee knew that the person he was dealing with was an agent) the reasoning then would have to follow this course: "The real owner authorized his agent to borrow a certain sum; the agent improperly represented that his anthority was more extensive than it really was; the lender, upon the faith of this misrepresentation, changed his position; the real owner was in some way responsible for the misrepresentation - had done something to assist it, to make it credible, and is therefore estopped from denying its truth." But what did he do? (1) He gave authority to borrow a certain sum of money, and the question then is, Does that in any way assist the misrepresentation that the agent had power to borrow a larger amount? Suppose that the principal had authorized the agent to sign a promissory note for $£ 100$, and the agent, misrepresenting his authority, signed his principal's name to a note for $\$ 500$; the principal would clearly not be liable. And the reason is that giving authority to sign for the smaller amount in no way assists a misrepresentation of any greater authority. (2) Nor does the agrent's possession of the deeds render any assistance to the misrepresentation as to the amount to be borrowed. Possession by one person of the deeds of another may imply that the possessor has advanced money upon them, but not that he has authority from the owner to pledge them for unlimited amounts.

The case is, in fact, one of simple agency, and the reasoning ought to be as follows: "The owner did not himself borrow the money, nor did any one having his authority borrow it; nevertheless, if he has represented or assisted the misrepresentation that the agent had such authority, he is estopped; but he did neither the one nor the other, and he is therefore not responsible for nor bound by the act."'s

The other case (Perry-Iterick v. Attwood) is entirely different. In it the mortgagor represented himself to be the unincumbered owner of the property and the title-deeds. Upon this representation the lender changed his position; the first mortgragee assisted the misrepresentation and made it credible

1 This line of reasoning was overlooked in Robinson v. Montgomery (1596), $2 \mathrm{Cl} .811 ; 65 \mathrm{~L} . \mathrm{J}$. Ch. 915. 
to all men by handing over to the mortgagor all the titledeeds. He was therefore rightly estopped. The case is one of ostensible ownership.

Sale of Goods.-In still another department an erroneous decision was given because of the confusion of ostensible ownership and agency. ${ }^{1}$ The owner of a table-top sent it to a dealer in such things, to be sold upon certain specified conditions. The dealer disregarded his limitations, and the owner was held not to be bound by the sale. The case was one of ostensible ownership, and the owner ought to have been estopped by the assistance rendered to the dealer's misrepresentation of ownership. If I permit my goods to appear upon a bargain counter, I am surely estopped by a sale, whatever my instructions may be. The judgment, howerer, proceeds upon ostensible agency, and results in favor of the owner. Willis, J., said:

"The true test is, I take it, whether the authority given in fact is of such a nature as to cover a right to deal with the article at all. . . The foundation, however, of the whole thing is that the agent should be authorized to enter into some transaction;"

and inasmuch as there was no authority at all to sell (the conditions not having arisen), the learned judge decided that the owner was not bound by the sale.

But the test and foundation of ostensible ownership is not this. Nor is it true even of ostensible agency that the agent must "be authorized to enter into some transaction." Ostensible agency proceels upon misrepresentation, and there may be misrepresentation as to the existence as well as to the extent of agency. ${ }^{2}$ Lord Ellenborough's dictum is good and reasonable law:

"If the principal sends his commodity to a place where it is the ordinary business of the person to whom it is consigned to sell, it $m$ ust be intended that the commodity was sent thither for the purpose of sale. . . . When the commodity is sent in such a way and to such a place as to exhibit an apparent purpose of sale, the principal will be bound and the purchaser safe." 3

The necessity for a clear understanding of the principles under discussion was very apparent in the recent case of Watteau $v$. Fenwick. ${ }^{4}$ One would think that nothing could be clearer than the following propositions:

"Where there is neither agency in fact, nor any holding out as agent,

1 Biggs v. Evans (1894), 1 Q. B. 89. See also the reference to Watteau $\mathbf{v}$. Fenwick, ch. XI.

2 See ch. XXVI.
3 Pickering v. Busk (1821), 15 East, 43. And see cases cited with this one in ch. XXI.

$4(1893) 1$ Q. B. 348. 
and the dealing is with the party as principal, there can be neither undis. closed principal nor principal hy estoppel."

In other words, a man cannot be liable upon contract unless (1) he himself makes the contract; or (2) some one with his authority, or (3) some one who appears to have his authority, makes it for him.

But these propositions are practically denied in the case in band, the court being misled by a false analogy. The facts were that a brewer allowed his manager to appear as owner of the business, but forbid him to buy goods from third persons; the manager did buy from a person who believed the manager to be the owner; and it was held that the brewer was liable to the rendor for the price of the groods.

- Now the only misrepresentation (the only false appearance) was as to the manager's ownership. The brewer, therefore, might well be estopped from denying such ownership; and if judgment had been obtained for the price of the grools against the manager, the vendor might rery well have seized under his execution the goods in the shop as belonging to the debtor. But there comld be no liability on the part of the brewer for the money; for (1) be did not contract, nor (2) did any one having his authority contract, nor (3) did any one having the appearance of his autbority contract. Willis, J., however, said: ${ }^{2}$

"The principal is liable for all the acts of the agent which are within the authority usually contided to an agent of that chanacter, notwithstand. ing limitations as between the principal and the agent the principal puts upon that anthority. It is said that it is only so where there bas been a holding out of authority, which cannot be said of a case where the person supplying the gools kuew nothing of the existence of a primcipal. But I do not think so. Otherwse in every calse of mudisclosed principal, or at least in every case where the fact of there being a principal was undisclosed, the secret limitations would preval and defeat the action of the person dealing with the agent, and then discovering that he was an algent and had a principal. But in the case of a dormint partuer it is quite clear law that no limitations of authority as between the dormant and the active partner will avail the clormant partner as to things within the ordinary authority of a partuer. The law of partuership is on such a question nothing but a branch of the general law of principal aud agent; and it appears to me to be undisputed and conclusive on the point now under discussion."

But the distinction between the two cases is clear: A partner, althomgh dormant, is a member of the firm, and when a contract is made by an active partner the dormant member is as much a party to it as if specially named in it. If, there-

1 Per Osler, J., in Bechererv. Asher 34s. See also Elmunds v. Bushell (1596), 23 Ont. A Ip. 210. And see (18(ij), L. R. 1 Q. 13. 9i; 35 I. J. Q. B. note in 9 Law Quarterly Rev. 111.

20: Hubhard \&. Tenbrook (1889), 124

2 Watteau v. Fenwick (1593), 1 Q. B. Pit. St. 291; 16 Atl. R. S1\%. 
fore, the contract be within the ostensible purposes of the firm, the dormant partner is estopped to set up secret arrangements. The appearance of real authority in the active partner is the determining factor; and the case is not outside the three requisites of liability above referred to - it is an example of the third of them. The language of the learned judge indeed so indicates when he says that the dormant partner will be liable "as to things with respect to which there was appearance of authority to contract."

The brewer's case is entirely different. In it the brewer was not a party to the contract - as was the dormant partner. It was not therefore a case in which a certain person, being admittelly and as a mere matter of fact a party to the contract, the question is whether there had been the appearance of authority to put him in that position; but a case in which he was not a party to the contract at all, and the question is whether he ought to be liable upon it. He was not a party, because (1) he had not made the contract; and (2) no one with his authority had made it for him; and (3) no one baving any appearance of his authority had pretended to make him a party to it - how then could he be liable?

\section{Ostensible Ownersinte.}

Before proceeding to practical exposition let us have a clear idea of estoppel by ostensible ownership. Why is it that the real owner of property is sometimes bound by a sale of it marle by another person - by a person who bal no authority from the real owner to sell and who did not pretend that he had any such authority?

The reason is not, as is sometimes said, that the true owner has by his conduct really assented to the sale; that he is in some sense a party to it; and that therefore be is as much bound by it as if he were the sole vendor. No doubt the circunstances may in some cases warrant the implication of the true owner's concurrence in the sale. It may even be that such concurrence ought to be inferred in very many cases in which it is not. But so long as there is a case in which the assumption cannot be made, we must find some scientitic ground upon which we are entitled to say that, although the true owner was not a party to the sale, yet he is bound by it. 
Nor is the reason that the true owner has by his conduct in effect authorized the sale: that the ostensible owner las, in this view, acted under the authority of the true owner. There are indeed cases in which the principle of ostensible agency has to be invoked; but for cases (1) in which there is no relation between true owner and vendor, and (2) in which the purchaser has no reason to believe in the existence of any such relation, this explanation is insullicient.

The real facts point to the true conclusion. They are: (1) The vendor represented that he was the owner (not that he had authority to sell); (2) the purchaser believed that representation to be true; (3) upon the faith of that representation the purchaser changed his position; ( $t$ ) the true owner in some way assisted the misrepresentation of ownership; and (5) be is estopped by reason of this assistance.

\section{Universal Apreicability.}

There is nothing in the statement of this principle that would indicate its applicability to one kind of property rather than another; and it will be one of the chief objects of the succeeding chipters consistently to carry it through the various departments of the law, and to apply it to every sort of property.

The difliculties in the way, however, are almost overwhelming. Although the justice that underlies the law of estoppel has always in some degree actuated the judicial mind, yet time and multiplicity of cases were essential for the development of its true principles: and it is not surprising that that development should in various departments have taken somewhat different courses, and sometimes gone awry.

For example, when estoppel is mentioned in connection with the law of real property, the mind at once reverts to the one case of a true owner standing by while another person purchases an interest or erects buildings upon the by-stander's land.' And when questions of priorities arise we think not of

1 Ramslen v. Dỵson (1866), L. R. 1 H. L. 129. rises automatically to the tongue. The iden of estoppel is so often associated with this particular phase of it that it somctimes exchules other aspects from riew. A decision of Lord Cottenhan was re- versed in the House of Lords (Mangles r. Dixon (1548). 1 MeN. \& G. 437: 3 H. L. ( . 70?), beciluse the point of estoppel upon which he decided the case was laken to be estoppel by standingr by. 
estoppel, but of the old maxims, "When the equities are equal," ete., "Prior est tempore," etc., and we make inquiry as to the locality of the deeds. An effort will be made to supersede these maxims by the law of estoppel.

From the subject of bills and notes, estoppel is almost unanimously excluded. "Negotiability," in sharp antagonism to the general law, is said to rule this department. It is the author's riew, however, that the "law merchant" must give place to estoppel by ostensible ownership and agency, and that thereupon barmony will replace antagonism.

Questions of title to goods obtained by means of bills of lading or other documents of title are now decided (1) by analogy to the law of goods themselves; (2) by considerations of seminegotiability; and (3) by Factors and other Acts. The view will be alvanced that the law as to goods acquired by means of paper title ought not to be different (for the purposes in hand) from the law as to real estate, title to which is always documentary. In other words, that the principles of estoppel by ostensible ownership and agency apply to both alike, as well as to all other sorts of property. 


\section{CHAPTER XVIII.}

\section{OSTENSIBLE OWNERSHIP AND AGENCY - LAND - THE LEGAL ESTATE.}

Few rules are better known, and thought to be more firmly establishęd, than that whieh preseribes that where the equities are equal the law will prevail. Yet we shall see that it is open to at least four objections: (1) that it owes its origin to imperfect alministration of justice; (2) that all reason for its existence ceased with the recent removal of that imperfection; (3) that it is an irrational, incongruous, and disturbing factor in our system of jurisprudence; and $(t)$ that it is inconsistent with the modern principles of estoppel by ostensible ownership, by which it ought to be supplanted.

From the standpoint of estoppel (which heretofore, howerer, hits had little place in the discussion of the subject) we would sily that, as between two competing grantees of an estate (legal or equitable is wholly immaterial), one of them, namely, the first alone, can have it; and that, if the second is to bo preferred, it must be not because the second has the estate (for be has it not), but because, for some reason, the first is estopped from setting up his priority.

The rule above quoted, bowever, proeeds in wholly different fashion. Note three points:

(1) It inquires into the equities of the competitors (that is, into their respective merits ${ }^{1}$ ); and, finding them to be equal, awards priority, not to the man who really bas the estate in question (baving first got it), but to the one who, through chance, luck, or otherwise, has or can grab the legal estatewhether he be first, second, or fortieth.

(2) Nor is this the full offense of the rule; for in examining into the merits of the contestants it is held that "nothing but fraud, or gross and voluntary negligence, will oust the priority

1 Rice r. Rice (1853), 2 Dr. 73; 23 L J. Ch. 2s9; Bailey v. Barnes (1894), 1 Ch. 25; 63 L. J. Ch. 73. 
of the legal claimant." There are therefore different balances wherein to weigh the merits of legal and equitable claimants. The merits may be far from really equal; the legal claimant may, as we shall see, be negligent in very high degree; the equitable claimant as diligent and as careful as possible, and first in point of time; and yet a happy clutch of the legal estate will discomfit the one who has not only the greater merit, but also the natural priority.

(3) The phrase just used ("a happy clutch") is not inappropriate; for the doctrine that the legal estate carries priority with it has led to this singular and anomalous result, that it resembles the greasy pig which being, in general scramble, seized by some lucky competitor, gains for its captor the prize, provisled that he has seized it according to rule, and bas not too soon let it slip.

\section{The Scramble.}

This third point may be dealt with first. Rooper $v$. Marrison ${ }^{2}$ gives a good view of the sport. A first mortgagee had the legal estate, and a power of sale with the usual declaration of trust as to surplus moneys. He devised the estate to the third mortgagee, who now having the pig (and for that reason only) became entitled to priority over the second mortgagee. In ignorance of the rules of the game (as he afterwards learned) this third mortgagee sold the property under the power in the first mortgage. The second mortgagee then contended that he was back again in second place, for the contest now was over the purchase-money, and not over the land - the pig baving foolishly been let slip. If it were over the land, of course the third mortgagee was prior, for he had had the legal estate. But if over the money, and the pig gone, -? Sir W. Page Wood said:

" Harrison (the third mortgagee) might have advanced the money (to pay off the first mortgagee) out of his own pocket, and have held the

1 Plumb v. Fluitt (1791), 2 Anstr. 440. And see Evans v. Bicknell (1901), 6 Ves. 174, 190; Martinez v. Cooper (1826), 2 Russ. 198; Farrow v. liees (1840), 4 Beav. 18; Hew1t v. Loosenore (1851), 9 Ha. 458; $21 \mathrm{~L}$. J. Ch. 69; Colyer v. Finch (1856), $5 \mathrm{H}$. L. C. $905 ; 26$ L. J. Ch. 6j; Dixon v.
Muckleston (1872), L. R. 8 Ch. App. 155; 42 L. J. Ch. 210; Northern v. Whipp (1884), 26 Cl. D. 494; 53 L. J. Ch. 629.

2(1855) 2 K. \& J. 107. And see Bailey v. Barnes (1891), 1 Cl. 25, 63; 63 L. J. Ch. 73. 
whole legal estate for the two debts. . . Or he might have raised the money by transfer of the mortgitge, and have procured the persun who took the jegal estate to execute a declaration that he would hold it on trust to secure himself his mortgage debt, and secondly, to secure that of IItlrison; and had he taken this course Harrison would now be the person having the best right to call for it. . . . It is sail that this would render it a mere matter of machinery: but that in truth is the result of the whole doctrine of this court about the legal estate, ind a very singular machinery it sometimes $i s$. It is merely a question of how far a person, who has dexterously managed to la! hold of this tabula in namfragio, is allowed to seize it. Even after bill filed by a second incum. brancer he is allowed to seize it, but it is on that he rests. It would seem to militate very much against the vieus which this court enterlains of not allowing rights to be disturbed by third persons; and there was some legal hesitation and doubt as to allowing a person holding the legal estate to hand it over to the one or the other, as he thinlis fit. All that is a very peculiar part of this doetrine: but the court has never gone beyond this; and if it does not find the legall estate interposed it deals with the money according to priorities."

The pig had been let slip, priority had gone with it; the court did "not find the legal estate interposed;" and Harrison was relegated to the third place, from which, indeed, nothing but the pig theory had ever removed him. ${ }^{2}$

The rules which govern the scramble for the legal estate; under what circumstances it is fair to seize it ${ }^{3}$ at what time it may be seized ; "what persons may, or may not, help you to seize it ${ }^{5}$ whether or not you must give value for it; to what extent it must be complete when you get it $;^{6}$ and what per-

1 Freely translated in this ccnnec. tion-pig.

2 "Being purchasers for value without notice they cannot succeed un. less they can make out that, having an inferior equity, they have clothed it with a legal interest." This wis said with reference to the purchase of shares. Per Kay, L. J., in Powell v. Londion (1593), 2 Ch. 564; 62 I. J. C'l. 80:.

3 Saumlers v. Dehew (1692), 2 Vern. 2r1; Willoughby v. Willoughby (1787), 1 T. R. 763; Allen $v$. Knight (1846), 5 Ha. 272; 15 L. J. Ch. 4:30: 16 L. J. Ch. 370; Baillie v. Mcliewan (196.)). 35 Beav. 17\%; Dodds v. Hills (1865), 2 H. \& M. 424; Pease v. Jackson (1868), L. R. 3 Cl. 5\%6: 37 L. J. Ch. 725; Pilcher v. Rawlins (1970), L. R. 11 Eq. 53; L. R. 7 Ch. 259; 40 L. J. Ch. 105; 41 L. J. Ch. 485; Colonial Bauk v. Hepworth (1887), 26
Ch. D. 36; 56 L. J. Ch. 1089; Taylor v. Russell (1891), 1 Ch. 8; (1892) A. C. 244: 60 L. J. Ch. 1; 61 L. J. Ch. 65i; London v. Goddard (1897), 1 Ch. 643; 69 L. J. Ch. 261; Merchants' Bank v. Morrison (1872), 19 Gr. 1.

4 Dodds s. Hills (186.5), 2 H. \& M. 424; Baillie v. IICKewan (186.j), 3.) Beav. 177; Reg. v. Shropshire (18;3). L. R. 8 Q. B. 4:0; L. R. 7 H. L. 496; 45 L. J. Q. B. 31; Blackwool v. London (1S\%4), L. R. 5 P. C. 92 ; 43 L. J. P. C. 23; Mumford v. Stohwasser (18;4), L. R. 18 Eq. 5.56; 43 L. J. Ch. 694: IIarpham v. Shacklock (1831), 19 Ch. D. $20 \pi$.

5 Sharples v. Adams (186:3), 32 Beav. 213: Mraxfield v. Burton (1873), L. R. 17 Eq. 15; 43 L. J. Ch. 16: Mumford v. Stoluasser (1E.t.t) L. R. 18 Eq. 556 ; 43 L. J. Ch. 694; Garmham v. Skip per (1885), 55 L. J. Ch. :263.

- Roots v. Williamson (1888), $38 \mathrm{Ch}$. 
sons hare the best right to seize it, ${ }^{1}$ do not interest us here. They may in all their subtle refinement be found in the cases noted below as well as in countless others.

\section{A General View.}

A more general view of the operation of the rule under consideration is furnished by the case of Cave $v$. Cave." Trust property was, in fraud of the beneficiaries, mortgaged by the tristee to several innocent persons in succession. The first of these, of course, alone had the pig; that is, the legal estate. His mortgage was good against the beneficiaries. The others ha' no pig, but equitable estates only. Their mortgages were bat as against the beneficiaries. ${ }^{3}$ Why should the law not be the same in both cases? In both the trustee did the same wrong. In both the beneficiary had to bear the same (if any) blame, namely, that he had a fraudulent trustee. In both cases the mortgagee was innocent, pairl his money and completed bis transaction. But in the one case the courts decide for him, and in the others against him. And if the man with the pig hatd chosen to hand it over to a third, fourth or fifth-incumbrancer the courts would have declared in favor of the one so selected. Uti pig, iti priority.

Contrast with this the result to be arrived at by the application of the manifestly reasonable principles of the law of estoppel by ostensible ownership:

"Where the owner . . . has lent himself to accredit the title of another person by placing in his hands those symbols of property which have enabled him to hold himself out as the purchaser,"

he is estopped as against any person who upon the faith of the ostensible ownership has changed his position. Applying this principle to Cave v. Cave we should say that t'ie beneficiaries were estopped as against all the mortgagees from setting up their title. They had permitted their trustee to pose as the owner of the land; upon the faith of his ostensible ownership

D. 495; 5 r L. J. Ch. 995; Powell v. London (189:3), 1 Cl. 610; (1893) 2 Ch. 55: 62 L. J. Ch. 80 ?.

1 Moore v. Northwestern (1891), 2 Ch. 599; 60 L. J. Ch. 627; Newman v. Newman (1885), 28 Ch. D. 674; 54 L. J. Ch. 598.
${ }^{2}(1880) 15$ Ch. D. $639 ; 49$ L. J. Ch. 505.

${ }^{3}$ And see Re Morgan (1881), $18 \mathrm{Ch}$. D. 93: 50 L. J. Ch. 651, 834.

4 Boyson v. Coles (1817), 6 M. \& S. 24. The language refers to goorls, but the principle is the sime as to all property. 
innocent persons bad been induced to change their position; therefore estoppel; pig consideration - zero.

The present law, however, declares that the beneficiaries and the mortgagrees have equal merits; it takes no notice of the doctrine of estoppel by ostensible ownership which would bold them to be most unequal; and everybody's merits being thus said to be equal, it adjusts the rights of the parties according to the uli pig $i b i$ priority notion, and not with the slightest regard to any prineiples of justice or fair play.

It is with reference to dilliculties and anomalies such as these that the language of Lord Selborne in Dixon v. Muckleston' is peeuliarly applicable:

"It is impossible to reflect on this injustice without finding rery cogent arguments in favor of some attempt to improve the state of the law is to title to real estate, and to get rid of the difticulty which arises from the distinction between al legal and an equitable estate;"

as also the language of Lindley, L. J.: ${ }^{2}$

"The reasoning is technical and not satisfactory; but as long ago as 1728 the law was judicially declared to be well settled and only alterable by act of Parliament. See Brace v. Duchess of Marlborough." 3

The Imperial Parliament at one time did enact that

"After the commencement of this act, no priority, or protection, shall be given, or allowed, to any estate, right, or interest, in lind, by reason of such estite, right. or interest, being protected by, or tacked to, any legal or other estate, or interest, in such land: and full effect shall be given in every court to this provision, although the person claiming such priority, or protection, as aforesilid, shall claim as a purchaser for valuable consid. eration and without notice."

But the statute was short-lived. It was repealed at the ensuing session. ${ }^{5}$ The seramble still goes on.

\section{Origin of the Doctrine.}

As has been already said, the priority aceorded to the legal estate originated because of the defective administration of justice. Equitable estates and interests were those

"which were enforceable under the separate jurisdiction of the courts of equity. and which in the courts of common law were either not enforceable, or if enforced were enforced only is contracts giving a right to damages for a breach, not as giving any specitic chaim to or orer tle lands or hereditaments affected by them." 6

An equitable claimant, therefore, was compelled to seek his remely in a court of equity. There he asserted that the holder

1(18;2) L. R. 8 Ch. App. 158; 42

L. J. Ch. 213.

2 Bailey v. Barnes (1894), 1 Ch. 36 ;

63 L. J. Ch. 78.

${ }^{3}(1 ; 28) 2 \mathrm{P}$. Wms. 491.
$437 \& 38$ vic., ch. $78, \leqslant 7$.

$539 \& 39$ Vic., ch. $87, \$ 129$.

6 Ency. of Laws of Eng., rol. 39. And see Goodere's Real Property (3d ed.), 258 et seq. 
of the legal title ought to be compelled to convey it to him. But the holder of the legal title might also have merits - he might also be an innocent purchaser, although subsequent in point of time. And the question was whether the court of equity, as between two innocent persons, would exercise its extraordinary jurisdiction and compel a conveyance of the legal estate. It held that it would not. It left the parties to such slimp justice as the law afforded. It felt "itself checked - . and an obstacle thrown in its way" by this legal view of the case.

If neither contestant had the legal estate, the court, relieved of all embarrassments, administered unfettered justice, and decreed as between two innocent holders that he had the estate who harl first acquired it. What else could it declare? ${ }^{1}$

The situation is well described by Sir W. Page Wood: ${ }^{2}$

"The whole doctrine of this court about the protection afforded by means of the legal estate is simply this: A party getting the legal estate acquires no new right in equity in any way. But equity regarding all the persons who have incumbrances according to their priorities, considering that the equitable interests pass just as the legal interest does ${ }^{3}$ by the effect of the deeds, finds itself checked at times and an obstacle thrown in its way by an incumbrancer's saying: 'I have got the legal estate interposed; I insist it is mine at law, and there must be a superior equity shown in order to deprive me of my legal estate.' It is merely staying the han's of the court by resting on that legal estate which this court will not deal with unless a superior equity can be shown; and although the court holds that priority will give equity, yet it does not hold that it gives so superior an equity as between several incumbrancers as to endble a person who has an anterior char'ge to wrest the legal estate from the person who has ol,tained it without notice of the anterior charge, and who hals not parted with it. This is the whole effect of the doctrine, and none other."

The defect then in the administration of justice out of which grew the doctrine of the priority of the legal estate was that courts of law refused to recognize equitable interests. The court of equity, on the other hand, doing what it could in this and other ways to improve and rationalize the law, did reeognize such interests. In contests for priority between alverse claimants of equities, inasmuch as the law regarded neither of them, the court of equity was unhampered, and was able to say that the first was first, unless his conduct had deprived

1 It took a peculiar idea, however, Ex. Eq. 59; Pryce v. Bury (18j4), of inuocence. See ch. XX.

2 liooper v. Harrison (185j), 2 K. \& J. $10 s$.

3 See as to this, Hockley v. Bantock (18:6), 1 Russ. 141; Keys v. Williams (1839), 3 Y. \& C. Ex. 55, 46:; 7 L. J. Equity (11th ed.), 343.

L. R. 16 Eq. 153, n.; 23 L. J. Ch. 676 : James v. James (1873), L. R. 16 Eq. 15i;: 42 L. J. Ch. 3\$6; Backhouse $\because$ Charlton (18;8), 8 Ch. D. 444 ; Lees v. Fisher (1882), 22 Ch. D. 283; Snell's 
him of that position. But where the second in point of ime of the contestants had the legal estite, what was to be done? Courts of law held not merely that the legral claimant was first, but that he was the only one that had any title at all. The court of equity, on the other hand, "considering that equitable interests pass just as the legal interest does," would fain have decreel, in this case also, that the first was first. But it found "itself checked" by the opposing doctrine of the courts of law - courts having power to enforce their judgments just as had the conrt of equity.

Ostensibly the court of equity submitted; but in reality it set to work one of its most potent jurisliction-augmenting weapons, with which it cut deeply in to the legal priority. The court silid, "Yes, the legal estate has, of course, the priority; but not when its owner has been guilty of fraul." Courts of law could hardly dispute that position; and, once fairly established, equity under cover of the word "fraud" diecreed postponement of legal estates, eren when there was no fraud, or such semblance of it only as was "conduct fraudulent in the eye of this court."

The word, however, still remains as the ground of the jurisdiction - the word which was used as a mask to an attack upon imperfect administration of justice. The time has arrived when it ought to be thrown off f for the courts as now constituted are no longer ehecked by opposing and defective doetrines of any other court. All courts now recognize that "equitable interests pass just as the legal interest does." It was lack of that recognition by courts of law that gave the lega! estate its dominating influence. Cessat ratione legis, cessat ipsa lex; especially when the lex is of sheh ineongruous character.?

1 It was not without a protest, here and there, that the failure of the law to notice and enforce equities was allowed to continue and breed anomalies. As early as 1isi, Ashburst. J., said (Goodtitle r. Morgan (1isi). 1 T. R. at p. 762$)$ : "It is true that formerly the courts of law did not take notice of an equity or a trust, for trusts are within the original juristiction of a court of equity; but of late years it has been 17 found productive of great expense to send the parties to the other sile of the Hall; whenever this court has seen that the justice of the case has been clearly with the plaintilf. they have not tursed him round upon this objection. Then if this court will take notice of a trust, $u \cdot l_{y}$ should they not take notice of an equity?"

${ }^{2}$ Lord Hardwicke (than whom there could be no better authority) 


\section{Cessat Ratione Legis, Cessat Irsa Lex.}

Legal estates were those cognizable by courts of law; and equitable estates, those of which courts of equity alone took notice. When, then, we ceased to have courts of law and courts of equity, it might have been anticipated that distinction between the estates would have vanished. But its annihilation was hardly eren suggested. A large part of the jurisprudence of the country had grown up upon its foundation; and the courts continued to speak of legal and equitable estates just as though there still were such things, and to apply the rules developed in connection with the phrases. $\Lambda$ recent writer, referring to the Judicature Act, ${ }^{1}$ has well said : ${ }^{2}$

"Section 24 of the above-mentioned act in effect enacted that, in future, courts constituted by the act, whi l embraced the previously existing courts, both of law and equity, should give to all equitable estates, rights, titles and claims the same effect which would have been given thereto by the court of chancery before the passing of the act. Since the coming into operation of the act, equitable estates and interests have therefore been equally enforceable with legal estates and interests and in the same forum; and it follows that, in this sense and to this extent. lxing enforceable in the courts of law, they night now be styled tegal estates and interests."

Another writer (whose book is highly creditable to him) thinks that

"the important thing is to get rid of this double ownership as quickly as possible; and now that the conflict of jurisdiction out of which arose this conflict of law is abolished, it ought not to be difficult to accomplish this reform." 3

That which had made distinction between legal and equitable estates was thus sent down to oblivion; the distinction had always been an incongruous and disturbing factor in our jurisprulence; courts of equity had found themselves "checkerl - . and obstacles thrown in their way" because of it; fraud-fictions had been invented and elaborated wherewith to minimize the evils of it; and judicial tears had been shed over $i t$, because thereby priorities were oft-times settled not accord-

has sairl: "It could not happen in any other country but this, because the jurisdiction of law and equity is administered here in different courts. - . But if this had hajpenel in any other country, it could never have made a question: for if the law and equity be administered by the same juristiction, the ruie qui prior est tempore, potior est jure must hold." (Wortley v. Birkhead (17i4), 2 Ves. Sr. 573.) Unfortunately Canalia and the United States inherited the anomaly with the divided jurisdiction of the courts.

1 Imp. St. 36 \& 37 Vic., ch. 66.

2 Ency. of Liaws of Eng., vol. 39. And see Emmerson v. Ind (1886), 33 Ch. D. 323 ; 5 j L. J. Ch. 903.

3 Markhy's Elements of Law (4th ed.), sec. 335. 
ing to principles of justice, but according to the faror or whim of the pigr-possessor - "a mere matter of machinery . • and very singular machinery," it was said. A chance here, one would think, for cessat ratione legis, cessat ipsa lex; but it was missed, and we still conjure with the ghost of the legal estate, treating him as if he were still alive and of such stout sulstantiality as to command our continued deference and respect. Hunters for the origin of religions might cogitate, with profit, the cult of the legal estate.

\section{“Nothing bet Fraed," etc.}

Reference has been made to the flank morement by which courts of equity succeeded in turning, to a certain extent, the position oceupied by the legal estate. "The legal estate has, of course, priority, but not when its owner has been guilty of fraud." From this it results that the maxim "Where the equities are equal the law will prevail" is too narrow, for where they are not equal the law will still prevail. Fraud is necessary to turn the scale. The rule, then, may be better expressed in the language already quoted:

"Nothing but fraud, or such gross and voluntary negligence as is eridence of fraud, will oust the priority of the legal claimant."

That is to say, the legal claimant, whetiner he be first, second or forticth in point of time, is to be first in fact, unless he has offended agrainst th is rule. And Mr. Pomeroy has a paragraph entitled "Fraudulent intent necessary in an estoppel affecting the legal title to land." 1

But why say "fraud or evidence of fraud?" The court cannot say that there is fraud unless there is evidence of it; and surely evidence of fraud will be useless unless it be suflicient to prove fraud. The only answer to which is that we are dealing with "a mere miatter of machinery, . . . and a very singular machinery it sometimes is," about which we must be content to find some mystery. We may observe, however, that the fraud in question may be of purely fictitious character; that the word "fratu " does not neeessarily imply that there was "an actunl intention to conmit a fraul;" " that the "gross and voluntary negligence" spolien of mist indeed

1 On Eq. Jur. (2d ed.), $\$ 80 \pi$.

2 Dowle v. Saumlers (1861), 2 II. \& 2I. $251 ; 34$ L. J. Ch. $8 \pi$. 
be such as will be eridence of frand, but that the fraud of which it is evidence may be absolutely non-existent. ${ }^{1}$ For example, in a very recent case, ${ }^{2} \operatorname{Sir}$ F. II. Jenne said that there was

"negligence so gross as would justify the court of chancery in concluding thit there had been fratud in an artificial sense of the word. . . . I do not mean to suggest that there was any fraul in fact."

Mr. Beren has said all that can be said ${ }^{3}$ in defense of this seeming confusion, but, it is thought, with scant success. The argument may be put in this way: No man can claim an estate against another person whom he has defrauled out of the estate; a purchaser acts for himself, and owes no duty of carefulness to anybody else; there are, however, certain well-known courses of procedure usually adopted by purchasers; and if they depart from those well-known courses, with the result that they come into competition with other claimants to the property, their action may be taken as evidence of an intention to defraud those other claimants, although in admitted fact there was no such intention." The startling result of which is that, altbough evilence of that which does not exist is usually associated with perjury, here it becomes the foundation of judicial decision. Lord Justice Bramwell's vigorous language ought to have ended further perversion of the word "fraud," and would have done so bad the roal been clear without it:

"I am of the opinion, with an exception I will presently avert to, that to make a man liable for fraud moral fraud must be proved against him.

1 In Pollock on Contracts (6th ed.), 504 (see also pp. 401, 402), it is said: "It must also be remembered that for a long time equity juches and text writers thought it necessary or prudent for the support of a beneficial jurisdiction to employ the term 'frand' as nomen generalissimum. 'Constructive fraud' was made to include almost every class of cases in which any transaction is disallowed, not only on grounds of fair dealing between the parties, but on grounds of public policy." For judicial condemnation of "subterfuges and contrivances and evasions to wheh judges in England long resorted in struggling against" other rules, see the languige of Lord Campbell in Ramloll v. Soo- jumnull (1848), 6 Moo. P. C. 310 , and of Parke, B., in Egerton v. Earl Brownlow (1853), 4 H. L. C. 124; 23 L. J. Cl. 348. And see per Williams, J., id., p. 77, and per Alderson, B., id., p. 109. Mr. Pomeroy agrees that courts of equity "have always treated the word 'fraud' in a very elastic manner." On Equity Jur. (2d ed.), \$ 803 . And see per James, L. J., in Torrance v. Bolton (1872), L. R. 8 Ch. $\Lambda$ pl). 124 ; 42 L. J. Cl. 179. 2 Oliver v. IIinton (1899), 2 Ch. 264 ; $68 \mathrm{~L}$. J. Ch. 583. In the same case Lindley, M. R., substituted "gross negligence" for frand.

3 On Negligence, 1634. And see $900 \mathrm{tf}, 16: 4-1628$.

${ }_{4}^{4}$ See Agra Bank v. Barry (1874), L. R. 7 H. I. 135. 
I do not urlerstand legal fraud. To my mind it has no more meaninz than legill heat or legal cold, legal light or legal shatle. There never can be a well-founded complaint of legal fraul, or of anything else, except where some dinty is shown and correlative right. and some violation of that rluty and right. And where these exist it is much better that they

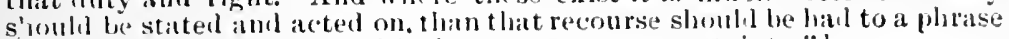
illorical and unmeaning, with the consequent uncertainty."

For example, the owner of an estate deposits the title-rleeds as security for a loan (that is, makes an "equitable" mortgage of the property ${ }^{2}$, and afterwards convers the legal estate to a subsequent mortgagee, who makes no inquiry for the deeds. Now it may be as clear as possible (indeed it may be admitted) that the subsequent mortgagee had not the slightest idea of defranding anybory; that he was absolutely unaware of the existence of the equitable mortgage; and yet he will be refused priority, because it is said that not asking for the deels was "evidence of an intention" to defraud a possible holder of the deeds. ${ }^{3}$ It maly even be that as a trustee he thought the solicitors of the estate bad the deeds; nevertheless his inaction will be ascribed to fraud." Fictitious fraud is thus postulated in order that justice may be done. There must be something more rational than this, somewhere.

And observe further, as to frauds of this sort, that had the sceond mortgagee asked for the deeds and been put off with some excuse, the stigma of bad faith would not have attached to him; ${ }^{5}$ and if, upon asking for them, he had been given a bundle which was said to contain them, but did not, his char-

1 Win v. Bell (1Sis), 3 Ex. D. 243; 47 L. J. Ex. 707.

2In Pirlier v. Catrolina (1899). 59 S. C. 583 ; 31 S. E. R. 6r6. it was said that "the rule is well established in England, and has received some support in this country, that an equitible mortgage on the land is created by the deposit of title-deeds as security for deht; but the doctrine is generally rejected in the United States. The rule as administered in Eugland grew out of the fact that there was no general system of registration, as in this country. and the system of conveyancing rendered it necessary to have possession of the muniments of title." And see Tiedeman on Real Property (Pd ed.), $\$ 8: 289$,
290. For those accustomed to the American law the supposititious case in the text may be varied by subst $i$. tuting a contract for a mortgage in. stear of a deposit of the deeds.

3 Worthington v. Morgan (1819), 16 Sim. 547; 18 L. J. Ch. 233.

Lloyds Bank v. Jomes (1885), 29 Ch. D. 221; 51 L. J. Ch. 931.

5 Plumb v. Fluitt (1791), 2 Anstr. 4::2; Hewitt v. Loosemore (18.j1), 9 Ha. 449: 21 L. J. Cl. 69; Espin r. Pemberton (18:9), 5 Jur. N. S. 15i; 29 L. J. Ch. 308: 28 id. 311: Agra Bank v. Barry (1874), L R. $\tau$ H. I 135 ; Garnhian v. Skipper (188.5), 55 L. J. Ch. 203; Newman v. Newman (1885), 28 Ch. D. 674; 54 L. J. Ch. 098. 
acter, though he nerer untied the string, would have romained unstained.' Fictitious fraud is plainly of somewhat ambiguous and refractory character.

For we seem by these results to be compelled to say that it is the duty of a mortgagee to inquire for the deeds, and not his daty to look at them when he gets them; that he will lose priority if he does not ask for the deeds, but gain it if he does, though he never gets them, but only a bundle of other things; that he will be declared to have acted fraudulently if he carelessly leaves the deeds outstanding, but to have comported himself as a gentleman if he receives a parcel which be thinks contains them, and never bothers himself to open it.

Ingenious and elaborate as all this is, its radical defect surely is its lack of reality. ${ }^{2}$ And its lack of reality is attributable to the fact that a wrong principle is being applied - fiction is employed (once more) to aroid the disastrous effect of rooted ideas. As between two claimants, one has that sort of an estate which in former days and because of defective administration of justice had a tactical but unmerited advantage; the advantage in those days could be taken away only upon the ground of fraud; in many cases, however, in which there is no fraud, justice plainly requires a decision against the legal title; fraud is therefore imagined or imputed; and with the help of fictitious fraud justice is done.

Until a recent decision of Mr. Justice Kay ${ }^{3}$ a further refinement existed of most annoying and elusive sort, namely, between the character of the fraud which would postpone a prior owner if he held the legal estate, and the character of the frand which would postpone him if he had the equitable estate only. It was thought that as the legal title was stronger than the equitable it would take more fraud to postpone it. And when it is remembered that the fraud necessary to postpone the legal estate did not necessarily imply the existence of "an actual intention to commit a fraud," " but was itself of a most special and imaginary description, it is with a sense of great relief that we wel-

1 Ratcliffe v. Barnard (1871), L. R. 6 Ch. 6.52; 40 L. J. Ch. 777; Colyer v. Finch (1856), 5 H. L. C. $905 ; 26$ L J. Ch. 65.

3 Taylor v. Russell (1891), 1 Ch. 8; 60 L. J. Ch. 1 ; (1892) A. C. $261 ; 61$ L. J. Ch. 6.37.

4 Dowle v. Saunders (1861), 2 H. \&

2 See the subject discussed in ch. M. 2J0;34 L. J. Ch. 87. $\mathrm{XIX}$ 
come the deeision of the learned judge that distinctions between lictitious frauds which will postpone the legal estate, and frauds still less fictitious which will postpone the equitable estate, are for the future unnecessary. ${ }^{l}$

The relief is, however, but partial; for all that we can yet say is that aecording to the law of priorities there must be some fraud, or legal fraud or color or evidence of fraud; but not necessarily any "fraul in fact." Further speeification is impossible, which is perhalps not to be wondered at, the thing itself being not real but fictitious.

\section{Estoppet.}

Such a state of the law may well be sail to be "irrational, incongruous and disturbing." "That it is inconsistent with the modern principles of estoppel is sulficiently apparent when it is remembered that, as between two competing grantces of an estate (legall or equitable is wholly immaterial), one of them, namely the first, alone can have it; and that if the seeond is to be preferred, it must be, not becanse the seeond has the estate (for he has it not), but because for some reason the first is estopped from setting up his priority. The substitution of estoppel would relieve the liuw of all difficulty with reference to imputed fraud. Its introduction would no doubt in volve a good deal of change, not only in the treatment of the cases, but sometimes in their results. Nevertheless, somer or later harmony must be established between the law of estoppel by ostensible ownership and the law of priorities. Notice a lew points:

Aceording to the law of estoppel, if the true owner of property stand by and permit another to deal with it as owner, he will be estopped as against a purehaser for value. Estoppel in no way requires for its operation that the purchaser shall have acquired the legal estate. It is sulifient that he have in some way changed his position ${ }^{2}$ - he may have acpuired the merest eguity, or indeed aequired, in very fact, notlung at all. Estoppel aets wholly irrespective of such considerations - change of position is all that is essential.

'Lord Macnaghten, however, dissented from the view of Mr. Justice Kaly. Taylor v. Russell (189:), A. C.

262. It receives suprort in Beren on Negligence, 1630-163j.

"sue ch. XI. 
Observe the law with reference to "non-negotiable" choses in action. Until the statute permitting their assignment, it was impossible for a purchaser to acquire a legal estate in them, and yet a purchaser from an ostensible owner of them might estop the true owner from setting up his title. If the true owner had assisted the ostensible owner in his misrepresentation of ownership, by furnishing him with the indicia of title to them, he would be estopped. ${ }^{1}$ Change of position, not the acquisition of the legal title, is all that is required for estoppel.

Note, too, the law of principal and argent with reference to estoppel. A principal in some way assists a misrepresentation of his agent as to the scope of his authority; a third person acts upon that misrepresentation, and the principal is bound. It is not necessary that the third person should have acquired any legal estate. In fact, frequently the question is not one of estate at all. Change of position is all that is essential.

So also in regard to the law with reference to the execution of doenments. An owner is tricked into executing a deel; the deed is not binding because of the fraud; upon the faith of the deed some third person clianges his position, and the owner is estopper from asserting that the deed is not his. In this department of the law it has not been thought necessary as a prerequisite of estoppel that the purchaser should have the legal estate. Change of position is sufficient.

\section{Application.}

Suppose the owner of property, real or personal, transfers it absolutely - title, evidence of title, and possession - to a trustee in such a way that there is no trace of a trust visible; and that the trustee afterwards fraudulently disposes of some estate in the property to an innocent purchaser for value. This, according to the law of estoppel, is a clear case; the owner is, of course, estopped, - he has accredited the title of his trustee and cannot deny it. ${ }^{2}$ According to the rule under diseussion, however, the case depends upon the natmre of the estate which the purchaser obtains. The competing prineiples are here in sharp conflict. One of them must eventually give way.

1 See ch. XXII.

${ }^{2}$ Dillage v. Commercial Bank(1873),
51 N. Y. 845: Clarke v. Roberts (1881), 25) Hun (N. Y.), 86. 
The case of Cave v. Cave, alrealy referred to, well iliustrates the situation: A trustee mortgaged the trust property suceessively to several persons; the first mortgagee got the legal estite; the others, of course, did not; in the general settlement the first mortgagce was held to be prior to the beneficiaries, aud the other mortgagees to be subsequent to them. Estoppel would have given priority to all the mortgatgees.

It is impossible by any process of reasoning to justify the conflicting results arrived at in the case just mentioned. We $\mathrm{m} ı \mathrm{y}$, if we wish, say that every purehaser is aware that his vendor may be a trustee and may be acting in violation of his trust; therefore caveat emptor, for if such be the fact he grets no title to any sort of estate." Or we mily say that " where the owner has lent himself to accredit the title" of the trustee he will be estopped from setting up his title arginst any estate which the trustee may wrongfully convey to an innocent purchaser. But it is irrational to apply one of these principles to a case in which the trustee framdulently transfers one estate in the property; and the other to a case in which he fraudulently transfers another estate.

Either view is logical and comprehensible. It may be said that the law of trusts is well recognized; that there is no negligence in having trustees, or eren a single trustee; nor any in allowing him to act witbout cbeck or oversight. Careat emptor. Let all purehasers of all estates talie care of themselves.

"The imprudence of the plaintiffs in having a single trustee of their settled property is not sufficient lo deprive tinem of their property or to enible their trinstee to dispose of it as his own." 3

"The very tirst principle of trusts is that the cestui que trust places confidence in his trustee. and if it is to be held that a ccstui que trust is to be postponed upon the more gromml that he di.l not impuire into the acts or condnct of his trustee, thilt principle would, as it seems to me, be in great measure, if not wholly, hestroyed." 4

Such reasoning is good. But it is applied only when the purchaser has taken an equitable estate - in such cases it is supposel to be unanswerable. In one instance ${ }^{5}$ not only were shares absolutely transferred to a trustee, but he qualitied upon

1 (1s80) 15 Ch. D. 639; 40 L. J. Clı. $50 . \overline{5}$

2 Reg. v. Shropshire Ry. Co. (1873). I. R. 8 Q. B. 420 ; L. R. 7 H. L. 496 ; 45 L. J. Q. B. 31.

${ }^{3}$ Per Lord Romilly, in Baillie r. McKewan (1865), 35 Beav. 18\%. Anl see Eradley v. Riches (15is), 9 Cl. D. 189;
4 \% L. J. Ch. 811: Carritt v. Real (1s\$?), 42 Ch. D. :26i3: is L. J. Ch. lis8; Re Richarts (1890), 45 Ch. D. 589; 59) L. J. Ch. 728; Muore r. Finne (1894), 2t O it. itl.

+ Per Turner. L. J., in Cory r. Eyze (18(i3). 1 De G.. J. \& S. 169.

${ }^{5}$ Howarl r. S.udler (1893), 1 Q. B. 1. 
them and acted as a director; yet the true owner was not estopped to deny the trustee's ownership as against an equitabio interest in the shares wrongfully created by the trustee. The law permitted directors so to qualify; acting as a director was therefore no evidence of ownership; the purchaser knew that the ostensible owner might be a trustce. Caveat emptor.

In another case the deed by which the trust was constituted indicated that the purchase-money had been paid by the trustee. It therefore, to that extent, negatived the idea of a trust; and yet the true owner's estate was upheld as against the equitable estate of a purchaser from the trustee. The indications were misleading, but might have been suspected to be such. Caveat emptor.

In yet another case ${ }^{1}$ a solicitor took a mortgage in the name of his clerk, and left it and the deels in the clerk's possession; the elerk frimdulently deposited the deeds (created an equitable interest); and the solicitor was not estopped. The clerk might be a trustee. Cavert emptor.

All that can be said as against such reasoning is (1) that it is just as applicable to the case of a purchaser of the legal estate as to a purchaser of an equitable estate, while it is applied to the latter only; (2) that it onght, therefore, to be applied to both such cases, or else be discarded altogether; and (3) that the principles of estoppel are those properly applicable to all such cases, and would have decided the other way the cases which have just been cited.

According to the law of estoppel,

"where the owner has lent himself to accredit the title to another person, by plicing in his power those symbols of property which have enabled him to hold himself ont as a purchaser of the gools;"

such owner will be estopped from setting up his title; and it is quite immaterial, in the application of such law, what sort of an estate has been acquired by the purchaser - change of position upon the faith of the representation is all that is recguisite.

Estoppel says that if a man selects a rascal as his trustee, and supplies him with completest cleating apparatus, he must himself bear the burden of the ensuing rascalities, and is not to be allowed to shoulder them off upon snch persons as may be swindled, and that the difference in the sort of swinlle cannot affect the result.

1 Carritt v. Real (1889), 42 Ch. D. 263; 58 L. J. Ch. 683. 
To much the same effect as the remarks just quoted is the langruage of Lord Cairns in Reg. v. Shropshire. ${ }^{1}$ It was a case in which shares of a company were placed in the name of one of the directors (IIolyoke), who borrowed money upon the shares, and promised to execute a transfer of them. The transferee, therefore, had but an equitable estate. The Lord Chancellor said that the purchaser

"ought to have known that although Holyoke's name appeared upon the register as the owner of these shares, and although Ifolyoke could present to him the certificate of this ownership, still it was perfectly possible either that these shares were the beneficial property of Holyolie himself, or that they were the property of some other person. If he dealt merely by equitable transfer or equitable assignment with Holyoke, and if it turmed out that the beneficial ownership of IIolyoke was coincident and co-extensive with his legal title, well and good; his right would be accordingly, so far is Holyoke was concerned, complete. But if, on the other hand, it should turn out that Ilolyoke's beneficial interest wits either nil, or was not cu-extensive with the whole of his apparent lewal title, then I say any person dealing with Holyoke by way of equitable frar arin or con. trict shonld have known that he could only obtain a title which was imperfect, and would not bind the real beneficial owner."

With all deference this reasoning does not touch the real question. No doubt the purchiser knew that Holyoke might be a trustee (for every ostensible owner may be a trustee); but that may as well be said when the purchaser takes the legal title as when he talies the equitable. And the question is: Why should such knowledge ruin an equitible title and have no effect upon a legal title? There is the same ostensible ownership in both cases; the same responsibility in both on the part of the true owner for such appearance of ownership; and in both a third person, on the faith of such appearance, has changed his position.

\section{Sulistitute for Fraud or Evidexce of Fraud.}

If we are to get away from "fraud or such gross and roluntary negligence as is evidence of fraud," as a prerequisite of postponement of the legal (o1" auy other) estate, what standard of conduct shall we set up?

The answer is not difficult. For if, as has been contended, tho true principles applicable to the cases in hand are those of estoppel by assisted misrepresentition, then the conduct exacted is that prescribed by the law of estoppel in all other departments of the law. The standard is a high one. It imposes tho

1 (1873) L. R. 8 Q. B. 420; L. R. T H. L. 505; 45 L. J. Q. B. 31. 
social duty of exercising "an appropriate measure of prudence to avoid causing harm to others;" 1 and it makes little allowance for mistakes and oversights which have resulted in damagre to other people.

The introduction of such ideas into the law of priorities will probably not be at once conceded by the profession. But eventually it will be recognized that in the application of estoppel to the various branches of the law there must be some one standard of conduct for all of them. A greater degree of prudence may be required in some departments than in others; but that will be because of some greater probability of danger to other people, and not because it is impossible to point to a general principle such as that requiring "an appropriate measure of prudence to avoid causing harm to others."

And further, we shall eventually, by comparison of cases from the different departments, arrive at some unifying understancling as to the "measure of prudence" which will be considered to be "appropriate." Here the egoistic and the altruistic views of conduct will meet in sbarp conflict; but the battle will be to the latter, for man's development tends now strongly in that direction. $^{3}$

\section{Apologies for the Old Rule.}

The usual defense of the rule which favors the legal estate may be stated as follows:

"When we hear, therefore, of a purchaser for valuable consideration taking the title free of every trust, or equity, of which he had not notice, it is intended that he is a purchaser of a title perlect on its fice: for every purchaser of any imperfect title takes it with all its imperfections on its head. It is his own fault if he contides in a title which appears defective to his own eyes; and he does so at his peril. Now every equitible title is incomplete on its face; it is in truth nothing more than a title to go into chancery to have the legal estate conveyed, and therefore every purchased of a mere equity takes it subject to every clor that may lie on it, whether he has had notice of it or not. But the purchisser of a legial title takes it discharged of every trust, or equity. which does not appear on the face of the conveyance, and of which he has not had notice either actual or constructive." 4

I See ch. V.

¿See ch. VIII.

3 See $\mathrm{cl} . \mathrm{V}$.

${ }^{4}$ Chew v. Barnet (1824), 11 Serg. \& R. (Pa.) 392; quoted in $\mathrm{E}$ ans v. Roanoke Sav. Bank (1897), 9j Va. 294; 28 S. E. R. 325. And see per
Eyre, C. J., in Plumb v. Fluitt (1791), 2 Anstr. 432. "The person who takes the legal estate without the deeds, in a case like this, appears to me, unless there be fraud, to be less blamable than lie who takes the deeds without the estate." 
To this several answers may be marle:

1. It is but a method of alleging the former imperfection of the administration of justice. If the equitable title was imperfect, it was only because the law was imperfect in refusing to recognize equitable titles - an imperfection which has now been remored.

2. The major premise of the argument is that a purchaser who takes with knowledge of one imperfection ought, for that reason, be held to have taken it subject to every other imperfection which it may have - a man takes a title imperfect in its legill aspect, therefore he "takes it subject to erery clog." A purchaser of the legal estate, then, subject to a lease (one imperfection) ought to take it "subject to every other clog that may lie on it?" That would not be pretended; but it is just as rational as the contention that a purchaser subject to a legal mortgage takes the property "subject to every other clog."

3. The contention presupposes that all purchases are of the whole estate in the property: "It is his own fault if he conficles in a title which appears defective in his own eyes." But if a purchaser has agreed to purchase subject to a legal mortgage, the title to the thing sold does not appear to be defective. On the contrary it appears to be perfect.

\section{Actual and Contractual Estates.}

From what has been said it might be inferred that "legal" and "equitable" estates had become altogether solecisms and anachronisms. $\Lambda$ legal estate was once recognizerl by courts of law; an equitable estate was recognized by courts of equity only; there is now but one court; therefore the distinction must be at an end.

It must be remembered, howerer, that although the phrases connoted much that was unreal and defective, yet that they servel to separate two sorts of estates between which there was real distinction; and that such distinction still remains and must remain, although it can no longer be said that there exists a court whose juristiction is limited by it.

For there must always be a clifference between a conveyance of land and a contract to convey it. In the former case the transferee has the land; while in the latter he has only a contract under which he is entitled to get it. And if we are con- 
tent to attach misleading, or at best non-significant adjectives for the purposes of elassification, we may still continue to call the one a "legal" and the other an "equitable" estate. But it would be abstird and unscientific to perpetuate phrases that have lost their meaning, and that are assoeiated with all sorts of irrationalities. Other and more appropriate names must bo found.

The present writer ventures to suggest that where the title has been transferred the purchaser has an actual estate; and where he has but a right to get the title he bas a contractual estate. ${ }^{1}$

Now it must be observed that the language which we have been suggesting is not inconsistent with the statement that where the equities are equal the actual will prevail over the contractual. For the position assumed was that, as between two competing grantees, one of them has it and can lose it only by estoppel. The defects of tha current rule are those pertaining to its origin, principally the failure of the courts of law to recognize in any way the existence of those estates in land which were known as equitable estates. For example, if land already under mortgage were subsequently sold to two persons, each having no notice of the other, the rule awarded priority to the one who succeded in getting the mortgagee to convey the logal estate to him. It was said that this one had the only estate which a court of law would recognize; that the equities were equal, and that the law must prevail. To unsophisticated people it is very elear that a mortgagor has often a very substantial estate in the land, and that the law is irrational which declines to regarl that fact.

Applying the proposed phraseology to the same case, we would say that the first of the purchasers from the mortgagor acquired the estate which he haul to sell (had the actual estate); that if the second purchaser is to be preferred it must be because the first is in some way estopped from setting up his estate; and that nothing which the mortgagree may do ean in any way affect that result.

And we lo not say that the first purchaser wins because of the incapacity of any court to recognize estates in land that to

It is a curious coincidence that might be involied to support the an. fanciful etymology (contra-actual) tithesis here suggested. 
ordinary people have solid substantiality; but merely because the possessor of an estate naturally retains it, unless somebody can present a reason for depriving him of it - melior est conditio possintentis.

We would say that the first purchaser leas the estate in question and that the other has nothing, and has no means of getting it which are not open to anybody else. That a contrary conclusion is at present accepted is due to the rule under consirleration, which, howerer necessary during the discord between courts of law and equity, has now lost all its raison d'itre.

If we wish to keep as close to the old phraseology as possible, we may say that where the merits are equal the actual will prevail over the contractual.

\section{Support for New Mermods.}

The rule as to the priority of the legal estate having arisen and been most frequently applied in cases relating to real estate, its pre-eminence and dominating function in that branch of the law has rarely been attacked, and never (save for a year by statute) overthrown. In other departments of the law, however, in which the principles of estoppel are frequently applied, the courts have dealt the legal-estate theory some notable blows.

For example, in cases relating to transfers of company shares, the supremacy of the legal estate, although still fairly acknowledged, has been much shaken. Questions have arisen in this way: An executed transfer, but blank as to the purchaser's name, has been handed to a broker for a particular purpose; the broker fraudulently disposes of the shares; and the question is, "Who is to lose - the real owner or the purchaser?" In such a case Lord Watson would substitute considerations of estoppel for those relating to negotiability and legal estate:

"Even when the delivery (that is. by the persons intrusted with the transfers) has been fraudulent, as in the present case, the siupeme Court of New York has held that the registered owner cannot reclitim the document from a holder who has given valuable considerition in good faith and without notice of the framl. But it is necessitry to observe thit the decision of the court did not attribute to the instrunent any privilege or negotiabitity, in the legal sense of the term. It was bissed upon the curcumstance that the reisistered owner had so deall with the certificate as to lead the purchaser for vilue to believe that he was taking a good title

1 Reg. v. Shropshire (18i3), I. R. 8 (188\%), 36 Ch. D. 36; 56 L. J. Ch. 10S9; Q. B. 4:0; L. I. 7 H. L. 496; 45 L. J. Powell v. Lonton (1s93), 2 Ch. 564; Q. B. 31; Colonial Bank v. IIepwortl 62 L. J. Ch. 802. 
to it. In other words, the foundation rests in the principle of estoppel. Thus far the manciples of American cases appear to me to be in harmony w'th the minciples of Engiish lau."

"Cases. . which relite to competition between equitable and legal rights to stock or shares have really no bearing here. Whether the respondents are estopped from saying that Blakeway had not their authority to dispose of the certificates in question is in my opinion the sole question presented for decision in these appeals." 1

Lord Herschell in the same case adopts estoppel as the true ground of decision:

"If the uwner of a chose in action clothes a third party with the apparent ownership, and right of disposition of it, he is estopped from asserting his title as against a person to whom such third party has disposed of it and who received it in good faith and for valu. And this doctrine hass been held by the court of appeals of the state of New York to be applicaible to the case of certificates of shares with the blank transfer and power of attorney signed by the registered owner, handed by him to a broker who fraululently, or in excess of his authority, sells or plerlges them. The banks, or other persons taking them for value withont notice, have been entitled to hold them as agaiust the owner. As at present advised I do nut see any difference between the law of the state of New York and the law of England in this respect."

In a similar case in Illinois, Scott, C. J., said:

"The effect of what was done was to place the equitable title to the stock in the assignee, and if it was done for a valuable consideration it will surely be obligatory on the assignor, if living. In such cases it is a matter of no concern to the assignor whether the assignee ever avails him. self of the power of attorney embotied in the assignment to have the stock transferred to him on the books of the corporation, so that he may become the legal as well as the equitable owner. Equity will certainly give the assiguor no relief against the bona fide sale of stock in that way, although the assignee may never choose to have the stock transferred to him under the by-laws of the corporation." 2

To the same effect is the later case in the same state:

"So far as concerned third persons dealing with him without notice of the secret agency and trust he was the absolute owner in his own right. with full power and authority to convey, lease or otherwise contract in regard to the property, or any part thereof, or any interest therein." 3

This principle sometimes leads in Canada and the United States to the complete disregard of the argument derived from the position of the legal estate." For example, in one case in which the legal title to land was outstanding in the Crown, a trustee made a fraudulent disposition of the property and the purchaser was held to be entitled as against the beneficiary. Boyd, C., said:

"Briggs v. Jones illustrates the very reasonable proposition that where the owner of land transfers it to another so as to enable him to deal with it as his own, he is guilty of such culpable imprudence that he cannot afterwar is assert his title as against rights which that otlier may have created for value in favor of an innocent third party." 5

1 Colonial Bank v. Cady (1890), 15 App. Cas. 267: 60 L. J. Ch. 131.

2 Otis v. Garlner (188:3), 105 IIl. 442.

4 See Tiffany \& Bullard on Trusts, $197 \mathrm{ff}$.

3 West Chicago v. Morrison (1896),

5 Moore v. Kane (1894), 24 Ont. 544.

160 III. $288 ; 43$ N. E. R. 397. 
In England it would usually be said that the legal estate was outstanding, and that in such case the beneficiary, having equal equity and being first in time, would be preferred. But the case referred to by Boyd, C., is something of an exception, and makes use of the language of estoppel: A leasehold mortgagee lent the lease to the mortgagor for the purpose of raising money upon it, but at the same time told the mortgagor to give notice of the prior charge; the mortgagor, concualing the mortgage, borrowed from a bona fide depositee; held, that the depositce had priority, because

"a person who puts it in the power of another to deceive and to raise money must talie the consequences." 1

If fraud only will postpone the prior legal estate then the decision in the case should be reversed. And if it be true that "the imprudence of the plinintiffs in having a single trustee of their settled property is not sufficient to deprive them of their property, or to enable their trustee to dispose of it as his own," "2

then also the decision is wrong. But the decision is right and has the sanction of the House of Lords. ${ }^{3}$

As the principles of estoppel by ostensible ownership are better understood, it will become increasingly apparent that the customary reasoning with reference to the legal estate is so rery "technical and unsatisfactory" that it cannot much longer survive; and it will be more and more difficult to make answer to the following excerpt from a notable judgment of Grover, J.: ${ }^{4}$

"Where one known to he the owner of shares or chattels delivers to another the scrip or possession of the chattels together with an absolute written transfer of all his title thereto, he thereby enables him to lold himself out as owner, and as such obtain credit and make sales of the property; and if after he had so done the owner was permitted to come in and assert his title against those dealing upon the faith of these ippearances, the dishonest might combine and practice the greatest frauts. An. other reason is that it presents a proper case for the application of the legal maxim that, when one of two innocent parties must sustain a loss from the fraud of a third, such loss shall fall upon the one, if either, whose act has enabled such fraud to be committel. All these reasons, it is obvious, apply with all their force to choses in action. Why should the owner of a horse or of bank shares, who has given to another an absolute written transfer of all his rights thereto, for some mulpose other than that of lassing the title, be precluded, as arainst a bona fide purchaser from such per-

1 (1870) L. R. 10 Eq. 92. See also Perry-Herrick v. Attwood (185i), 25 Beav. 205: 2 De G. \& J. 21: 2ז I. J. Cl. 121; Kettlewell v. Wation (185:?), $21 \mathrm{Cl}$. D. 685 ; 26 Ch. Div. $50:$.

2 Ante, p. 265.

${ }^{3}$ See Perry-Herrick v. Attwood (18:i7). 2.) Beav. 20.7: 2 De G. \& J. 21; 2i I. J. Ch. 121; Brockleshy v. Temperance (1893), 3 Ch. 130: (189.5) A. C. 173: lit L. J. Cl. 433.

Hoore v. The Metropolitan (1Sr3), 5.) N. Y. 4i, And see Armour 5 Yichigan Ry. (15i5), 65 N. Y. 1223. 
son. from asserting his title, while under the same state of faots be may reclaim from such purchaser a bond and morturage, or a certific $\cdot$ ate of indebtedness like the one in question? As to the former he us estopped, while as to the latter the same state of facts, it is insisted, will work no such result. The counsel for the plaintiff insists that such distinction should be made for the reason that the purchaser of corporate shares and chattels from the apparent owner obtains a legal title which is valid and may be asserted in il court of law, while the assignee of a chose in action. not negotiable at common law, obtained an equitable title only; and that "tlue equity of the former owner, being prior in time to that acquired by the purchaser. is superior thereto, the rule in equity being that. where the equities are equal, the first in time shall prevail; but upon uhat grounl the same stule of facts that will estop a party from the assertion of a legal title will wot estop him from the assertion of an equitable. the counsel fuils to shon, for the rery good reason that no such ground exists. It is so obvious that the estoppel should upon principle apply to the latter equally with the former, that a distinction can only be justified upon authority."

Factors Acts. - It is worth noting that the Factors Acts, ${ }^{1}$ proceeding as they do upon rough principles of estoppel, operate quite independently of considerations of legal estate. They proride that under varying circumstances "any sale, pledge or other disposition" of goods by an ostensible owner or agent shall be as vilid "as if such person were the owner of the goods," or "were expressly authorized by the owner of the goods to make the same."

As we have seen, the present law declares that if a trustee should fraudulently create an equitable mortgage of the estate, the mortgagee and not the beneficiary would be the one to suffer; for be has not acquired the legal estate, the equitics are equal, and the bencficiary is first in time. Estoppel would otherwise decide; for the mortgagee upon the faith of ostensible ownership had changed bis position. The Factors Acts similarly protect, not merely where there bas been an absolute sale, but where also there bas been a "pledge or other disposition" of the property.

American Law. - With the dual system of courts it was ineritable that some of the resulting anomalies above referred to should be introduced into the United States. Registration systems with respect to transfers of real estate; the greater inclusireness of the application to choses in action of the laws of "negotiability;" 2 and the complete recognition of the principles of estoppel in the same department, have, however, in later years reduced the number of cases in which appeal is made to the legal estate almost to zero; and their vanishing

$152 \& 53$ Vic. (Imp.), ch. 45; Rev. 2 See ch. XXIV. St. Ont. (1897), ch. 150. 
infrequency has been accompanied by decreasing regard for its authority.

No doubt it could, with some appearance of justness, be said in Pennsylvania in 1824 that

"the distinction between legal and equitable titles is as accurately marked and as carefully preserved here as in England;"1

and in some of the courts the distinetion is still kept operative by the duplication of the methods of administration $;^{2}$ but upon the whole the considerations above referred to have induced the frame of mind in which it is said that

"an equitable estate may be mortgaged, and the lien of that mortgage will not be defrated by a subsequent conveyance of the naked legal title, where the rights of innocent purchasers are not involved." 3

I Chew v. Barrett, 11 Serg. \& R. 389.3 Arlington v. Gates (1899), 57 Neb. 2 Cleveland v. Cleveland (1899), 93 286; 77 N. W. R. 67 .

Fed. R. 118. 


\section{CHAPTER XIX.}

\section{OSTENSIBLE OWNERSHIP AND AGENCY - LAND - POSSESSION OF THE DEEDS.}

Tarious rules, or various statements of the same rule, have been formulated with reference to possession of the title-deeds in contests for priority.

I. In 1787 Buller, J., said:

"It is an established rule in a court of equity that a second mortgagee who has the title-deeds, without notice of any prior incumbrancer, shall be preferred: because if a nortgagee lends money upon mortgage without taking the title-deeds, he enables the mortgagor to commit a fraud." 1

II. In 1853 Kindersley, V. C., said:

"As between two persons whose equitable interests are of precisely the same nature and quility, and in that respect equal, the possession of the deeds gives the better equity."2

III. And in 1867 Malins, V. C., said:

"I have not a shadow of doubt that where there is merely an equitable mortgage unaccompanied by the legal estate in erery case where the equi. table mortgagee either omits to get, or, having got. gives up possession of the deeds. he must always be postponed. . . . I decide this case on the general principle that one equitable mortgagee without possession of the deeds must be postponed to another who has that possession." 3

The first of these rules at once suggests estoppel by ostensible ownership. A mortgagee leares the title-cleeds in the hands of the mortgagor; he thus, as is said, "enables the mortgagor to commit a fraud," - he enables him to pose as the unincumbered owner; upon the faith of this appearance a thirl person changes his position, and the mortgagee is properly estopped.

For estoppel, however, it is essentially necessary that the subsequent mortgagee should have become such upon the faith of the mortgagor's possession of the deeds - upon the faith of his

\footnotetext{
${ }^{1}$ Goodtitle v.Morgan (178\%), 1 T. R. L. R. 11 Eq. 316; 41 L. J. Ch. 175: 762 . cited in Spencer $\checkmark$. Clark (1878), 9

2 Rice v. Rice (1853), 2 Dr. 77 ; 23 L. Ch. D. 142; 47 L. J. Ch. 694; and conJ. Ch. 291.

${ }^{3}$ Layard v. Maud (1867), L. R. 4 Eq. 397,406 ; 36 L. J. Ch. 669 . Dissented from in Thorpe v. Holdsmith (1868), L. R. 7 Eq. 139; 38 L. J. Ch. 194: reasserted in Hunter v. Walters (18:1). sidered to be too clear for proof in Lloyd v. Jones (188.), 29 Ch. J. 2:9; 54 L. J. Ch. 931, which, in its terms, was thought to go too far, Re Cas. tell, Roper v. Carstell (1898), 1 Ch. 315: 6 ז. J. Clı. 169.
} 
ostensible ownership of the property. All the above rules omit this factor and apply to cases in which it is absent. For example, suppose that a second mortgagree advanced his money upon the unsupported statement of the mortgagor that he was the unincumbered owner, and that afterwards the mortegagor obtained the deeds from the first mortgagee and handed them over to the second, the rules would give the second priority. But estoppel would not; for he had not, upon the faith of the leeds being in the hands of the mortgagror, changed his position. The rules associate priority mechanically with possession of the deeds. Estoppel asks: How they got there?

The second rule (in some respects the best of the three) is very difficult of application because of the requirement that the equitable interests shall be "of precisely the same nature and quality." This language might be taken to mean that in addition to the fact that both estates were equitable both of them were of identical character; for example, that they were both mortgage estates. But that was not the meaning of the learnel juclge, for the case he had in band was one between an unpaid vendor claiming a lien for purchase-money, and an equitable mortgagee with whom the deeds had been deposited by the purchaser. These equitable estates the learned judge held were "of precisely the same nature and quality," and he gavo priority to the mortgatgee because, having the deeds, he had the better equity.

If this second rule (that of Kindersley, V. C.) is defective, much of the judgment in which it is found is, nevertheless, of the greatest value; and although stated by way of exception to, or modification of, the rule there laid down, it is, as the writer thinks, the best exposition anywhere to be found of the true view of the subject. 'The Vice-Chancellor's rule is quoted everywhere; the extracts from the judgment given below are almost never met with. The learned julge said:

"I must, however, guard against the supposition that I mean to express an opinion that the possession of title-deeds will, in all cases and under all circumstance, give the better equity. The deeds may be in the possession of a party in such a mumner and under such circunistunces as that such possession will confer no ad wantiage whatever."

"In examining into the relative merits (or equities) of two parties having adverse equitable interests, the points to which the court must direct its attention are obviously these: the nature and comlition of their respective equitable interest, the circumstunces and manner of their acquisition. and the uhole conduct of each party with respect thereto. And in examining into these points it must apply the test, not of any technical rule or any rule of partial application, but the same broad principles of right and 
justice which a court of equity applies universally in deciding upon contested rights."

"Indeed, it appears to me that in all cases of contest hetween persons having equitable interests, the conduct of the parties and all the circumstances must be taken into consideration in order to determine which has the better equity."

And after stating that the text-writers mislead, "when an opinion is expressed that the one or the other has the better equity,"

he adds:

"If I am right in my view of the matter, neither the one nor the other has necessarily, and under all circumstances, the better equity. Their equitable interests, abstractedly considered, are of equal value in respect of their nature and quality: but wlsether their equities are in other respects equal, or whether the one or the other has acquired the better equity, must depend upon all the circumstances of each particular case, and especially the conduct of the respective parties. And among the circumstances which may give to one the better equity, the possession of the title-deeds is a very material one."

We have still no reference, by name, to the law of estoppel; but we hare conduct (the ground upon which estoppel proceeds) as the basis of decision, and we have the conduct of the prior equitable owner put forward as a reason for postponing him to a subsequent purchaser, who was misled by that conduet and changed his position upon the faith of it. That is estoppel.

\section{Possession of Deeds a Circumstance.}

Adopting then (provisionally, and subject to a modification to be afterwards noticed) the language of Kindersley, V. C., just quoted, the next question is as to the proper weight to be attached to possession of the deeds. If we cannot say "that the possession of title-deeds will, in all cases and under all circumstances, give the better equity,"

in what cases and under what cireumstances will it do so?

Going back to 1801, we find Lord Eldon declaring that there is no ground for the postponement of the prior claimant, "unless there is fraud or concealment or some such purpose, or some concurrence in such purpose; or that gross negligence that amounts to evidence of a fraudulent intention." 1

At the other extreme we have the rule of Malins, V.C., above quoted, that

"in every case where the equitahle mortgagee either omits to get, or, having got, gives up possession of the deeds, he must be postponed."

Between these, estoppel urges that (1) if, even without fraudulent intent, the first mortgagee accredits the title of the mortgagor by allowing him the custody of the deeds; and (2) if the second mortgagee be misled to his damage by such permitted custody, then the first ought to be postponed to the second.

1 Evans v. Bicknell (:S01), 6 Ves. 191. 
The seeond part of this proferred rule of estoppel (that the second mortgagee must bave been misled) will be easily accepted once the applicability of estoppel to the subject is admitted; but justification of the first part (the non-essentiality of fraudulent intent) will probably have to be based upon a general survey of estoppel throughout all the departments of the law, upon a recognition of the universality of the principle. The following tabulated result of the principal authorities will give at a glance a tolerably comprehensive view of the present state of the law:

A. Legal Estate $v$. Equitable Estate.

\begin{tabular}{|c|c|c|c|c|c|}
\hline \multirow{2}{*}{$\begin{array}{l}\text { CASES WHERE EQUTTABLE } \\
\text { MORTGAGEE FIRST AND } \\
\text { LEGAL HORTAGGE SEC- } \\
\text { OND. }\end{array}$} & \multicolumn{2}{|c|}{$\begin{array}{l}\text { WHO HAD } \\
\text { DEEUS. }\end{array}$} & \multicolumn{2}{|c|}{ WHO WON. } & \multirow{2}{*}{ REMARKS } \\
\hline & $\begin{array}{l}\text { Eq. } \\
\text { Vitg. }\end{array}$ & $\begin{array}{c}\text { Legal } \\
\text { Mitg. }\end{array}$ & $\begin{array}{l}\text { Eq. } \\
\text { Mtg. }\end{array}$ & $\begin{array}{c}\text { Legal } \\
\text { IItg. }\end{array}$ & \\
\hline $\begin{array}{l}\text { (1) } 1849 . \text { Worthington } \vee \\
\text { Morgan..... }\end{array}$ & $x$ & & $x$ & & $\begin{array}{l}\text { Legal omitted to make } \\
\text { all inquiry for deeds. }\end{array}$ \\
\hline (2) 1791. Plumb v. Fluitt & $x$ & & & $x$ & $\begin{array}{l}\text { Legal made inquiry, but } \\
\text { reaso nable excuse } \\
\text { made for non produc- } \\
\text { tion. }\end{array}$ \\
\hline $\begin{array}{r}\text { (3) } 1851 . \text { Hewitt } \mathbf{v} . \text { Loose } \\
\text { more.......... }\end{array}$ & $x$ & & & $x$ & Ditta. \\
\hline $\begin{array}{r}\text { (4) 1859. Espin v. Pember- } \\
\text { toll.......... }\end{array}$ & $x$ & & & $x$ & Ditto. \\
\hline $\begin{array}{l}\text { (5) 1874. Agra Bank } \\
\text { Barry ......... }\end{array}$ & $x$ & & & $x$ & Ditta \\
\hline $\begin{array}{l}\text { (6) 1885. Garnham } \\
\text { Skipper..... }\end{array}$ & $x$ & & & $x$ & Ditto. \\
\hline $\begin{array}{r}\text { (7) 18:1. Ratcliffe v. Barn- } \\
\text { ard ......... }\end{array}$ & $x$ & & & $x$ & $\begin{array}{l}\text { Legal receired bundle } \\
\text { and thought he had all } \\
\text { the deeds. }\end{array}$ \\
\hline $\begin{array}{l}\text { (8) 1859. Lloyd } \\
\text { wood........... }\end{array}$ & & $x$ & & $x$ & $\begin{array}{l}\text { Mortgagor got deeds } \\
\text { from equitable by } \\
\text { fraud and gave them } \\
\text { to legal. }\end{array}$ \\
\hline
\end{tabular}

(1) 16 Sim. $547 ; 18$ L. J. Ch. 233.

(5) L. R. 7 H. L. 135.

(2) 2 A nst. 432.

(6) 34 WV. R. 135; 55 L. J. Ch. 263.

(3) 9 Ha. 449; 21 L. J. Ch. 69.

(i) L L R. 6 Ch. 652; 40 L $\_$J. Ch. $14 \%$.

(t) 5 Jur. N. S. $15 \%$.

(8) 3 De G. \& J. 614; 29 L. J. Ch. 97. 
A. Legal Estate v. Ezurtable Estate-Continued.

\begin{tabular}{|c|c|c|c|c|c|}
\hline \multirow{2}{*}{$\begin{array}{l}\text { CASES WHERE LEGAL MORT- } \\
\text { GAGEE FIRST AND EQUI- } \\
\text { TABLE MORTGAGEE SEC- } \\
\text { OND. }\end{array}$} & \multicolumn{2}{|c|}{$\begin{array}{l}\text { WHO HAD } \\
\text { DEEDS. }\end{array}$} & \multicolumn{2}{|c|}{ WHO WON. } & \multirow{2}{*}{ REMARKS. } \\
\hline & $\begin{array}{l}\text { Eq. } \\
\text { Mtg. }\end{array}$ & $\begin{array}{c}\text { Legal } \\
\text { Mtg. }\end{array}$ & $\begin{array}{l}\text { Eq. } \\
\text { Mitg. }\end{array}$ & $\begin{array}{l}\text { Legal } \\
\text { Mtg. }\end{array}$ & \\
\hline $\begin{array}{r}\text { (9) 1Ss5. Lloyds' Bank v. } \\
\text { Jones......... }\end{array}$ & $x$ & & $x$ & & $\begin{array}{l}\text { Legal omitted to make } \\
\text { all inquiries for deeds. } \\
\text { They were trustees } \\
\text { and thought the solic- } \\
\text { itors had them. }\end{array}$ \\
\hline $\begin{array}{r}\text { (10) 1885. Newman } \nabla . \text { New- } \\
\text { man........... }\end{array}$ & $x$ & & & $x$ & $\begin{array}{l}\text { Legal parted with deeds } \\
\text { on reasonable excuse } \\
\text { and deposited with } \\
\text { equitable. }\end{array}$ \\
\hline (11) 1856. Colyer v. Finch. & $x$ & & & $x$ & $\begin{array}{l}\text { Legal received bundle } \\
\text { and thought he had all } \\
\text { the deeds. }\end{array}$ \\
\hline
\end{tabular}

(9) 29 Ch. D. 221.

(11) 19 Beav. 500; 5 H. L. C. 905 ;

(10) 28 Ch. D. 674 ; 28 L. J. Ch. 674.26 L. J. Ch. 65.

B. Legal Estate v. Legal Estate.

\begin{tabular}{|c|c|c|}
\hline \multirow{2}{*}{$\begin{array}{l}\text { TWO MORTGAGEES CLAIM } \\
\text { LEGAL ESTATE, SECOND } \\
\text { HAS DEEDS. }\end{array}$} & \multicolumn{2}{|c|}{ WHO WON. } \\
\hline & $\begin{array}{c}\text { 1st } \\
\text { Mtg. }\end{array}$ & $\begin{array}{c}2 d \\
\text { Mitg. }\end{array}$ \\
\hline (1) 1882. Clarke $\nabla$. Palmer & & $x$ \\
\hline (2) 1860. Hunt $\nabla$. Elmes... & $x$ & \\
\hline
\end{tabular}

First allowed mortgagor to retain deeds, and was postponed not only to second, wlio got the deeds, but to third, who did not. And see Goodtitle v. Morgan (1787), 1 T. R. 762.

Solicitor mortgaged to first, his client,and gave him bundle in which client thought deeds were.

(1) $21 \mathrm{Ch}$, D. 124; 51 L. J. Ch.

(2) 2 De G., F. \& J. 578; 30 L. J. Ch. 634. 255. 
B. Legal Estate v. Legal Estate-Continued.

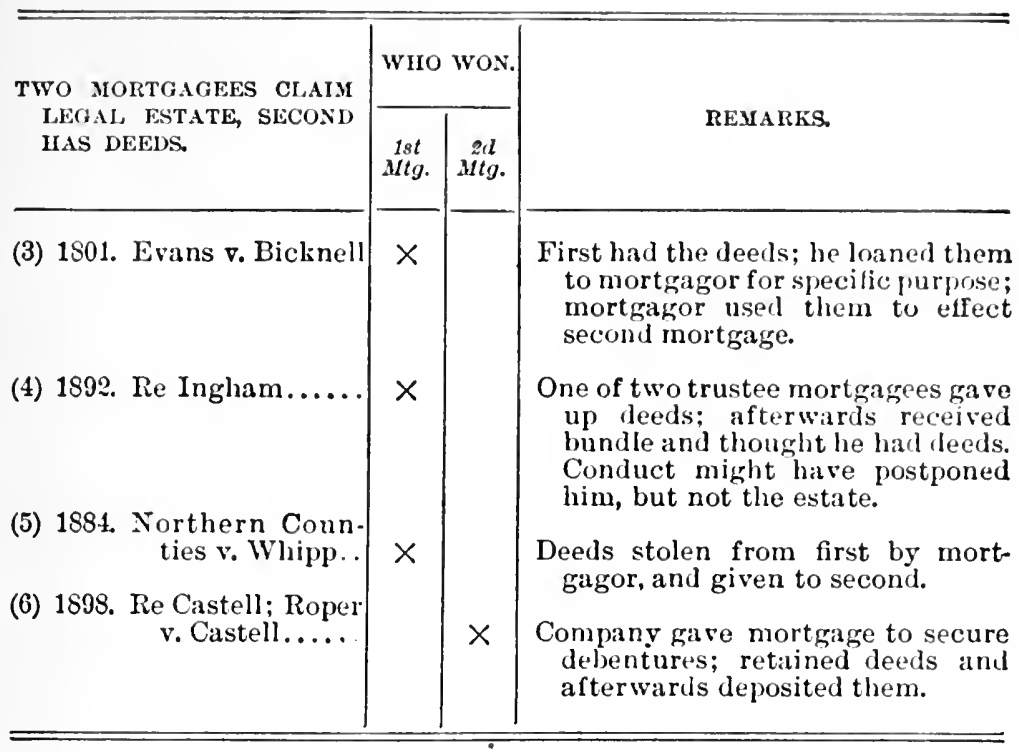

(3) 6 Ves. 174 .

(4) (1893) 1 Ch. 352; 62 L. J. Ch. 100. 629.

(5) 26 Ch. D. $482 ; 52$ L. J. Ch.

C. Equitable Estate v. Equitable Estate.

\begin{tabular}{|c|c|c|c|c|c|}
\hline \multirow{2}{*}{$\begin{array}{c}\text { CONTEST BETWEEN EQUITA } \\
\text { BLE MORTGAGEES. }\end{array}$} & \multicolumn{2}{|c|}{$\begin{array}{l}\text { WHO HAD } \\
\text { DEEDS. }\end{array}$} & \multicolumn{2}{|c|}{ WHO WON. } & \multirow{2}{*}{ REMARKS. } \\
\hline & ist. & ift. & 1st. & $2 d$. & \\
\hline (1) 1820. Frere v. Moore.. & $x$ & & $x$ & & $\begin{array}{l}\text { Where no legal estate, } \\
\text { Qui prior est tempore. } \\
\text { etc. }\end{array}$ \\
\hline (2) 186\%. Layard v. Maud & & $x$ & & $x$ & See ante, p. 276. \\
\hline (3) 1846. Allan v. Knight & & $x$ & $x$ & & $\begin{array}{l}\text { In absence of evidence } \\
\text { that first improjerly } \\
\text { gave up deeds no such } \\
\text { assumption. }\end{array}$ \\
\hline (4) 1853. Rice v. Rice.... & & $x$ & & $x$ & $\begin{array}{l}\text { Unpaid vendor gave } \\
\text { deeds to purchaser. }\end{array}$ \\
\hline
\end{tabular}

(1) 8 Price, 475.

(3) 5 Ha. 272; 15 L. J. Ch. 430.

(2) L. R. 4 Eq. 397; 36 L. J. Ch. 669.

(1) 3 Dr. 73; 23 L. J. Ch. 289. 


\section{Equitable Estate v. Equitade Estate-Continued.}

\begin{tabular}{|c|c|c|c|c|c|}
\hline \multirow{2}{*}{$\begin{array}{l}\text { BETWEEN EQUITA- } \\
\text { ZIORTGAGEES. }\end{array}$} & \multicolumn{2}{|c|}{$\begin{array}{l}\text { WHO HAD } \\
\text { DEEDS. }\end{array}$} & \multicolumn{2}{|c|}{ WHO WON. } & \multirow{2}{*}{ REMARIKS. } \\
\hline & $\begin{array}{l}\text { 1st. } \\
\text { Mttg. }\end{array}$ & 2t. & $\begin{array}{l}\text { 1st. } \\
\text { Mtg. }\end{array}$ & $\begin{array}{l}2 d . \\
\text { Mttg. }\end{array}$ & \\
\hline (5) $185 \%$. Roberts v. Croft & & $x$ & $x$ & & $\begin{array}{l}\text { First believed he had the } \\
\text { deeds. }\end{array}$ \\
\hline $\begin{array}{c}\text { (6) 1sr. Dixon v. Muck- } \\
\text { leston....... }\end{array}$ & & $x$ & $x$ & & Ditto. \\
\hline (テ) 185i. Carter v. Carter & & $\times$ & $x$ & & $\begin{array}{l}\text { Deeds may be left with } \\
\text { mortgagor if he be one } \\
\text { of several owners. }\end{array}$ \\
\hline $\begin{array}{r}\text { (8) 1852. Waldron } v . \text { Slo- } \\
\text { per............ }\end{array}$ & & $x$ & & $x$ & $\begin{array}{l}\text { First gave up deeds on } \\
\text { excuse and neglected } \\
\text { to get them back. }\end{array}$ \\
\hline $\begin{array}{r}\text { (9) 1864. Dowle v. Saund- } \\
\text { ers............ }\end{array}$ & & $x$ & $x$ & $x$ & $\begin{array}{l}\text { Deeds given up by solic- } \\
\text { itor of first; client not } \\
\text { postponed; but solic- } \\
\text { itor (as assignee of } \\
\text { client) postponed. }\end{array}$ \\
\hline (10) 1886. Re Vernon....... & & $x$ & $x$ & & $\begin{array}{l}\text { Solicitors of first gave up } \\
\text { mortgage, etc. }\end{array}$ \\
\hline (11) 1890. Re Richards.... & & $x$ & $x$ & & $\begin{array}{l}\text { Ditto. And see Frith v. } \\
\text { Cartland, } 2 \text { H. \& M. } \\
\text { 417; 34 L. J. Cl. 301. }\end{array}$ \\
\hline (12) 18\$1. Re Morgan ..... & & $x$ & $x$ & & $\begin{array}{l}\text { Trustee of first deposited } \\
\text { deed for loan to hiin- } \\
\text { self. See also Cave v. } \\
\text { Cave (1880), } 15 \text { Ch. D. } \\
\text { 639. }\end{array}$ \\
\hline $\begin{array}{l}\text { (13) 1888. Union Bank of } \\
\text { London } \\
\text { Kent......... }\end{array}$ & & $x$ & $x$ & & $\begin{array}{l}\text { First had equitable mort- } \\
\text { gage of leaseholds } \\
\text { prior to the execution } \\
\text { of the lease. After its } \\
\text { execution it was de- } \\
\text { posited with second } \\
\text { mortganee. First did } \\
\text { not know when second } \\
\text { created that lease had } \\
\text { been executed, and so } \\
\text { not negligent in leav- } \\
\text { ing it with lessor. }\end{array}$ \\
\hline $\begin{array}{r}\text { (14) 1888. Farrand v. York- } \\
\text { shire Banking } \\
\text { Co } \ldots \ldots \ldots \ldots\end{array}$ & & $x$ & & $x$ & $\begin{array}{l}\text { First stipulated to get } \\
\text { deeds, but neglected to } \\
\text { enforce delivery. }\end{array}$ \\
\hline
\end{tabular}

(5) 2 De G. \& J. 1; 27 L. J. Ch. 220.

(6) L. R. 8 Ch. 155; 42 L. J. Ch. 210.

(7) 3 K. \& J. 18; 27 L. J. Ch. 74.

(\$) 1 Dr. 193. And see Hall v. West End (185:3), 1 Cab. \& E. 161; Ex parte Reid (18.15), 17 L. J. Bk. 19.

(9) 2 H. \& M. $242 ; 34$ L. J. Ch. 87.
(10) 32 Ch. D. 165; 33 id. 402; 56 L. J. Ch. 12.

(11) 45 Ch. D. 589; 59 L. J. Ch. 728. (12) 18 Ch. D. 93 ; 50 L. J. Ch. 834. (13) 39 Ch. D. 238; 57 L. J. Ch. 10:2. (14) 40 Ch. D. 182; 58 L. J. Ch. 238. 
In studying these three tables (they will be referred to as A., B. and C.), it must be observed that the $A$. and B. cases are complicated by the respect paid to the legal estate. In these, although the equitable mortgage is first in point of time, yet the legal mortgage has prima facie priority because of the legal estate; and the question always is whether there is any reason for depriving the legal mortgagee of such priority. In other words, the legal mortgagee is in reality second; the law says he shall be first; is there anything in his conduct which relegates him to the second place?

The C. cases, on the other hand, are free from any distmrling feature. In them priorities are declared free from any check or interposed obstacle. In them first in time is first in fact unless - as we shall see.

In investigating the effect of possession of the deeds upon priorities we must take it, then, that where the legal estate somes into play (A. and B. cases) the holder of that estate has prima facie priority. In the C. cases, first in time has prima facie priority. And the question in all the eases is, What effect upon such priority has possession of the deeds?

That possession of the deeds has no effect whaterer upon priorities is not too sweeping a reply; if, at all erents, it be added that conduct with reference to such possession has frequently overpowering inlluence. What is meant is that from the mere fact of possession of the deeds nothing ean be argued; but that the circumstances under which possession has been parted with or acquired constitute the essential element. At the furthest possession unexplained may sometimes be evilence of these circumstances; but careful distinction must be male between possession as a factor in the inquiry (which it never is) and possession as some evidence of a factor (which it may be). ${ }^{2}$

'Estoppel cannot follow here. Es. toppel operate's when he who would otherwise have been first has misled his rival. But in the $A$. catses he who would otherwise have been first (the legal mortgagee) has not misled anybody, for his opponent's mortginge was taken prior to the legal mortgagee acquiring his interest. That estoppel seems to halt here is not due to its defective powers, but to the anomalous and disturbing effect of the legal estate.

2 In Allen r. Knight (1846), 5 Ha. $222 ; 15$ L. J. Ch. 430, it was held that from possession of the deeds by the mortgagor it could not be assumed that the mortgagee had improperly handed them over. 
In other words, as between competing grantees the first in time (or the holder of the legal estate) alone can have it; if the other is to be preferred it must be, not because such other has the estate (for he has it not), but because, for some reason, the first is estopped from setting up his priority; and such estoppel nay arise from conduct with reference to possession of the deeds. That is the whole effect of the possession of the deeds in questions of priority.

Let us get a firm foundation:

"If a man makes a mortgage, and afterwards mortgages the same estate to another, and the first mortgagee is in combination to induce the second mortgagee to lend his money, this fraud will without doubt, in equity, postpone his own mort rage. So if such mortgagee stands by, an I sees another lentling money on the same estate without giving him notice of the first mortgage, this is such a misprision as shall forfeit his priority." 1

This language (used in 1716) should since 1837 have given place to the phraseology of estoppel:

"Where one by his words or conduct wilfully causes (induces, per Pollock, C. B., in Bill v. Richards, 3 Jur. N. S. 522) another to believe the exist. ence of a certain state of things and induces him to act on that belief so as to alter his own previous position, the former is concluded from averring against the latter a different state of things as existing at the same tinie."2

The next step is this: that if an owner may be estopped by standing by while another poses as entitled to deal with the property, so also he may be estopped by furnishing this other with the title-deeds under such circumstances as will enable him to represent himself as the true owner.

For example, if a mortgagee were to deliver up the deeds to the mortgagor in order to enable the mortgagor to hold himself out as the unincumbered owner, ${ }^{3}$ the mortgagee ought to be estopped from setting up his mortgage as against the person duped by the mortgagor. Observe that it is not the possession of the legal estate or possession of the deeds in these cases which enables the second mortgagee to claim priority; but the fact that the first mortgagee has, by his conduct, enabled the mortgagror to hold himself out as the unincumbered owner. Giving to the mortgagor possession of the deeds is but one

1 Peter v. Russell (1716), 1 Eq. Ca. Ab. 322; 2 Vern. 726. See also Ibbotsen v. Rhodes (1706), 2 Vern. 554; Berisford v. Milward (1740), 2 Atk. 49; Stronge v. Hawkes (1853), 4 D., II. \& G. 186; Ilooper v. Gumm (1866), L. R. 2 Ch. 28:; 36 L. J. Ch. 605.
2 Pickard v. Sears (1837), 6 A. \& E. 474.

3 This qualification was made in Re Castell (1898), 1 Ch. 321; 67 L. J. Ch. 169. 
of the ways in which the first mortgagee may assist in deceiring the second mortgagee. It is an example, merely, of the operation of the rule of estoppel, and is in no way dependent upon any magical influence attaching to title-deeds.

"The possession of the deeds does not indeed prove that a person is owner in fee, as a tenant for life has a right to the fee; but it anthorizes the inference that there is wo prior mortgrage, as, had there been any, the mortgagor would not have had the deeds." i

And as the mortgagee, by leaving the deels with the mortgagor, has authorized this inference, he is estopped from denying the fact. That is rational. It is the law of estoppel. All the cases must be sustained by parity of reasoning; and the rules are invalid which proceed upon possession of the deeds, and not upon conduct with reference to such possession.

Proceeding in wholly different fashion the cases above tabulated may be taken to have established the following propositions:

1. Nothing but fraud, or such gross and voluntary negligence as is evidence of fraud, will oust the priority of the first claimant: A., $2,3,11 ;$ B., 3,$5 ;$ C., $6 .^{2}$

2. Fraud will be imputed if you do not ask for the deeds: A., 1,9 .

3. Unless indeed you are not entitlod to them (as in the case of one of several owners mortgaging his share): C., 7 .

4. Frand will be imputed if you do not get the deeds, even if you believe that your solicitors have them: A., 9 .

5. Fraud will not be imputed if you ask for the deeds, and, not getting them, are given some apparently reasonable but really untrue excuse: A., $2,3,4,5,6$.

6. Nor if you ask for the deeds and, receiving a bundle in which you are told they are, you do not discover that they are really not there: A., 7, 11 ; B., 2, 4; C., 5 .

7. Fraud will be imputed if you give up the deeds: B., 1; C., 4 .

8. But not if the mortgagor alleges some apparently reasonable but really fictitious purpose in asking for then: A., s, 10; B., 3.

9. Fraud will be imputed if, giving them up, you do not insist upon their return within a reasonable time: C., 8.

12 Dav. Con. (4th ed.), 239, 240.

2 See also Taylor v. Russell (1891),

1 Ch. 8; 60 L. J. Ch. 1, per Kay, J.; and (1S92) A. C. 262; 61 L. J. Ch. 65\%, per Lord Macnaghten. 
10. Or if for any reason you could not originally get the deeds, you negleet to obtain them within a reasonable time after it becomes possible to do so: C., 13, 14.

11. Frand will not be imputed if you leave the deeds with your solicitor, and he gives them up to the mortgagor. The solicitor, did he afterwards take an assignment of your mortgage, would be postponed: C., 9, 10, 11.

12. Fraud will not be imputed if you leave the deeds with the trustees of your estate, who deposits them as security for a loan to himself: C., 12.

13. Nor if the deeds are stolen from you: B., 5 .

14. If the mortgagor be allowed to retain the deeds the mortgagree will be postponed, not only to the second mortgagee, to whom they are delivered, but also to a third mortgagee who never got them: B., 1.

It is not necessary to repeat what was said in the preceding chapter ${ }^{1}$ as to the unreality of much of this. If jurisprudence is to maintain its claim to rank as a science, its exponents must discard fictitious fraud and learn to build with more solid material.

One essential and valuable point extractable from the above cases is that, not possession of the deeds, but how they got there, is the important and determining factor. ${ }^{2}$ For example, a mortgagor, in fraud of his mortgagee, deposits the deeds with a banker; does the banker acquire priority over the mortgagee? Nobody can tell without further information; and yet the rules quoted at the opening of this chapter expressly cover the case. What can be said?

1. If the mortgagor stole the deeds from the mortgagee, the mortgagee has priority: B., 5 .

2. If the mortgagee never asked for the deeds, and so never had them, the banker probably has priority: A., 1, 9; but see C., 7 .

And so on, and so on, throughout the illimitable variety of cases, some only of which are to be found in the foregoing tables.

Were there still room for doubt that it is conduct with

1 Ch. XVIII.

2 See Thorpe r. Houldsworth (1868), L. R. 7 Eq. 147; 38 L. J. Ch. 198; National v. Jackson (1886), 33 Ch. D.
13; Farrand จ. Yorkshire (1888), 40

Ch. D. 189; 58 L. J. Ch. 241; Powell v. London (1893), 1 Ch. 615; 62 L. J. Ch. 795. 
reference to the deeds and not possession itself that affects priority, a consideration of case 13. 1 would eertainly dispel it. In that case the first mortgagree allowed the mortgagor to retain the deels; the mortgagor, in fraud of this mortgagee, mado two subsequent mortgares; the second mortgagee got the deeds, and the third, of course, did not; but he knew where they were. Now if it be possession of the deeds that gives priority, the second mortgagee will be preferred to the lirst, for he (the second) has the deeds; but the third mortgatgee will not be so fortunate, because he bas not the deeds. 'The decision, however, is otherwise, and third mortgagee as well as second was given priority over the first. Estoppel would so say, for the third as well as the second mortgagee was misled by the locality of the deeds, for which the first mortgagree's carelessness or trustfulness was responsible.

\section{Estopipel the Applicable Doctrine.}

But, having eliminated fictitious fraud from our philosophy, to what principle of judicial action are such cases to be referred? If a mortgagee stands by and allows the mortgagor to appear as the unineumbered owner, the mortgarree is said to be estopped. And if the mortgagee furnish the mortgagor with the deeds and so enable him to pose as the unineumbered orner; or if, by not asking for the deeds, or by conduct of any other sort, he give the mortgagor equal assistance, shall we not say that, in these eases also, the reason for his postponement is estoppel?

In the case above referred to (where the third mortgagee, who had not the deeds, as well as the second, who had them, obtained priority over the first beeause he had allowed the mortgagor to retain them), Hall, V. C., said:

"Having made inquiry into the matter, and having acted in the belief that the mortgagee who had got the first benefit of postponement by having obtained the deeds - he, and anybody else wlso bona fide advanced his money founded on the like belief, and arising out of the transaction in regard to the deeds, and connected with it, is entitled to the same benefit on the like principle of equity."

The "principle of equity" to which the Vice-Chancellor referred cannot be that as between persons with equal equities he who has the deeds is to be preferred, for the third mort-

1 Clark r. Palmer (18s2), 21 Ch. D. 129; 51 L. J. Ch. 636. 
gagee had not the deeds. It is only by fixing attention upon the locality of the deeds, instead of upon the conduct of the first mortgagee, that one misses the fact that it is such conduct that, according to the principles of equity (estoppel), determines priority; and that it must have been to such principles that the Vice-Chancellor referred.

And there is much in the language of many of the judges which may be appealed to in support of the view here advocated. Estoppel is not, indeed, directly inroked, but the language frequently not only demonstrates that it is conduct with reference to the possession of the deeds and not the mere possession of them that is important (as we have alrealy seen), but that such conduct has the effect of inhibiting assertion of priority - which is estoppel. For example, in National Provincial Bank of England v. Jackson, ${ }^{1}$ Cotton, L. J., said: .

"As between equitable claims the question is whether one party has acted in such a way as to justify him in insisting on his equily as against the other."

The only criticism to which this statement seems to be open is that it ought not to be confined to "equitable claims;" for with reference to legal estates as woll as equitable the question must always be whether the first owner "bas acted in such a way as to justify him in insisting on his '(estate)' as against the other."

In Northern Counties Fire Ins. Co. v. Whipp ${ }^{2}$ the law is stated to be

" that the court will postpone the prior legal estate to a subsequent equitable estate, where the owner has assisted in or connived at the fraud which has led to the creation of a subsequent equitable estate; of which assistance or connivance the omission to use ordinary care in inquiry after or keeping title deeds may be, and in some cases has been held to be, sufficient evidence, where such conduct cannot otherwise be explained. - . But that the court will not postpone the prior legal estate to the subsequent equitable estate on the ground of any mere carelessness or want of prudence on the part of the legal owner." ${ }_{3}$

And if we ask, Upon what scientific ground will the court, in such cases, decree postponement of the incumbrancer who has the legal estate? there can be no answer but that supplied by the law of estoppel:

"Where one, by his words or actions, wilfully induces another to believe the existence of a certain state of things, and induces him to act on

${ }^{1}(1886) 33 \mathrm{Ch}$. D. 13, approved in Farrand v. Yorkshire (1888), $40 \mathrm{Ch}$. D. 189; 58 L. J. Ch. 238.

${ }^{2}$ (1881) 26 Ch. D. 494; 53 L. J. Ch. 321; 67 L. J. Ch. 169.
3 See also the language in Powell v. London (1893), 1 Ch. 615; 6: L. J. Cl. F.); and Re Castell (1893), 1 Ch. 635. 


$$
\text { LAND - POSSESSION OF DEEDS. }
$$

that belief soas to alter his own previous position, the former is concluded from averring against the latter a different state of things as existing at the same time."?

\section{Fraud and Careiessifess.}

For a discussion of the grounds upon which a prior ought to be postponed to a subsequent estate - whether fraud is necessary or whether carelessness ought to suffice - the reader is referred to preceding chapters. ${ }^{2}$

1 Pickard v. Sears (1837). 6 A. \& E. 2 Clis. VIII, IX, XVIIL. 474; Bill v. Richards (185i), 3 Jur.

N. S. 522 . 


\section{CHAPTER XX.}

OSTENSIBLE OWNERSHIP AND AGENCY - LAND-QUI PRIOR EST TEMPORE POTIOR EST JURE.

This rule seems to be so transparently just and reasonable as to require no support. Closer inspection, however, more especially as to its conventional meaning and application, may lead us to a contrary conclusion. The two foregoing chapters have made it clear that, as the law at present stands, the rule in hand is not only not of primary importance, but that it is subsidiary to two other rules. The three rules, in their accepterl order of importance, may be shortly thus stated:

Rule I. Where the equities are equal, the law (the legal title) will prevail.

Rule II. Where the equities are equal, possession of the deeds gives priority.

Rule III. Where the equities are equal, the first in time has priority.

Now, supposing that the equities (the merits) being equal, A. has the legal estate, $B$. has the deeds, and C. is prior in point of time; then the first rule will give priority to $A$., the second rule to $B$., and the third rule to $C$. This conflict bas been aroided by subordinating rule II to rule I, and rule III to, both of them. They therefore should be understood in this way:

1. When the merits are equal, be with the legal estate will be prior.

2. If neither competitor has the legal estate, then he with the deeds will be prior.

3. If neither competitor has the legal estate or the deeds, then he who is first in time will be prior.

The preceding chapters have presented some reasons against the continuation of the dominating influence of that which is still called the legal estate; and some reasons for the contention that the possession of the title-deeds is of much less importance than the conduct which placed them there. We are 
now to see whether the present rule, at all events as it is understood and applied, can be allowed to stand.

Conventional Meaning and Application.-A priori and apart altogether from the authorities, one would say that the rule in hand must be a valid one. It seems moreover to be in perfect harmony with the principles of estoppel, which (as has already been pointed out) may be taken as saying that, as between competing grantees of an estate, one of them alone, namely, the first, can have it; and that, if the second is to be preferrel, it must be not because the second has the estate (for he has it not), but because for some reason the first is estopped from setting up his priority. With like meaning the rule in hand declares that where the equities are equal $(i . e$, where there is no ground for estopping anyboly) the first in time (i.e., the one who has the estate) shall prevail.

The propositions being thus identical, estoppel can have no quarrel with the rule - unless indeed its interpretations and applications offer grounds for objection. And in these respects there is the widest divergence, arising principally from disagreement as to the word "equities" (or merits), which seems entirely to change its meaning as we pass from the rule in hand to the principles of estoppel. For in the law of priorities merits are often said to be equal which in the law of estoppel are thought to be widely unequal; and a first purchaser may es(ape moral condemnation and consequent loss of priority under the former law, while under the latter he would be said to have so conducted himself as to be estopped from setting up his title.

This divergence is traceable to discrepant underlying principles. Accorling to one law (estoppel) misrepresentation or assistance in misrepresentation, however innocent, will estop ${ }^{1}$ while according to the other it is said that "nothing but fraud, or such gross and voluntary negligence as is evidence of fraud, will oust" the prior claimant." And these results are clerived from conflicting ideas as to the duty of a purchaser of property with reference to other people who may become interested in it and be misled by his action.

Of this duty (as is at length pointed out in a preceding chapter $)^{3}$ an egoistic or an altruistic view may be taken. According

I See ch. VIII.

2 Ante, p. 259.

s Ch. V. 
to the former I may do as I like with my own, allowing all other persons to look after themselves; I may take such precautions as will insure my safety and leave to others the care of their own well-being; I must not defraud others, no doubt, but I am under no obligation to protect them from fraul. According to the other view, and in harmony with the law of torts, it may be said that

"the whole modern law of negligence, with its many developments. enforces the duty of fellow-citizens to observe, in varying circunistances, an appropriate measure of prudence to a void causing harm to one another." 1

The rule under consideration (as developed by the cases) reflects the egoistic riew, while estoppel strongly tends towards the altruistic. Hence the opposing deductions: (1) Fraud, or evidence of it, is necessary to postpone the prior estate; (2) Fraud is not necessary for that purpose.

Law of Priorities. - The origin and restricted development of the principles hitherto applied to the law of priorities are partially responsible for the view of merits adopted in its applications. As we have already seen, equity, in order to mitigate the injustice arising ont of the refusal of the courts of law to recognize trusts, intervened even to the disparagement of the legal estate upon the ground of fraud, and under cover of that word declared in favor of beneficiaries where there was, in reality, no fraud at all. ${ }^{2}$ Nevertheless, the ground of juristiction was fraud, and it was impossible for equity courts aitu. gether to dissociate their lecrees from moral obliquity, or at least the imputation of it.

This explanation does not hold good in cases of contests between merely equitable claimants. But it can well be understood that that which was necessary to jurisdiction in the one class of cases should find expression and place in the other; and that fraud, being deemed essential to displace the priority of the legal estate, should also be thought to be in some measure indispensable to the deposition of the priority of the first in point of time.

Law of Estoppel.-In subsequent chapters ${ }^{3}$ many authoritie:; are quoted in support of the proposition that

"where the owner of goods has lent himself to accredit the title of an. other person by placing in his power those symbols of property which have enabled him to hold himself out as the purchaser of the goods,"

he is estopped from setting up his title. The same reasonable

1 Pollock on Torts (5th ed.), 22. $\quad{ }^{2}$ Ante, p. 259 ff. $\quad{ }^{3}$ Chs. XXI-XXIV. 
principle is applicable to land. We have in it nothing abont fraud, or evidence of fraud, nor yet of negligence. The owner may have been perfectly innocent, may indeed himself have been defrauded or tricked into accrediting the title of the ostensible owner - it is immaterial; he has accredited the title, and he is therefore estopped.

This rule has, however, made little headway in transactions relating to real estate; and in cases involving shares and stockis sometimes the law of priorities (as above spoken of) and sometimes the law of estoppel gains the victory - usually an ex parte one, for the discussion goes off upon one line or the other, and seldom, or never, are the opposing principles brought face to face. ${ }^{1}$

Opposing Conclusions.- The divergent results arrived at by application of the present law of priorities and the law of estoppel may best be appreciated by observation of a concrete case. For that purpose Cave $v$. Cuve may be selected. It is typical of many such.

Land is conveyed to a trustee in such a way that no trace of the trust is visible; in fraul of the beneficiaries the trustee makes several successive mortgages to various people, none of whom have notice of the trust; and the courts in settling the priorities say that the first mortgagee is first, the beneficiaries are second, and the other mortgagees follow in their order.

The reason given for the first part of this peculiar result (the priority of the first mortganee) is his possession of the legal estate. But that reason (objectionable as resting upon previous defective administration of justice) is quite unnecessary to the conclusion. The law of estoppel is amply suflicient; for it says to the beneficiaries that they had accredited the title of the trustees, hall assisted his misrepresentation of ownership, and that they are therefure estopped from asserting their title. ${ }^{3}$

1 See chs. XXII, XXIII. XXIV.

2 (1880) 15 Ch. D. $639 ; 49$ L. J. C'h. 505.

${ }^{3}$ In Newall v. C. P. R. R. Co. (1Sit), 51 Cal. 350, Crockett, J., said: “Lut it is further settled by these anljulications that if a bill of lading is assimned and the ligil title passed to a bone fide purchaser for a valuable consinteration before the right of the stoplatge is exercised, the han of the remher cousts as analust the assignee on the well known pranciple that a secrea trust will not be enforced as aramst a bona fide ho!ler for value of the legal title. In such a caste, if the equities of the vuluor and assignee be considered equal (and this 
The other part of the decision (tbe postponement of the later mortgagees to the beneficiaries) rests upon the maxim in hand (first in time, first in law). It declares that the merits of the opposing claimants are equal, and that the beneficiaries are first in time; both parties were innocent of fraud and the equity of the beneficiaries was the earlier. But estoppel denies the equality. It asserts (in the earlier language in which it was couched)

"that whenever one of two innocent persons must suffer by the acts of a third, he who enables such third person to occasion the loss must sus. tain it."1

It asserts that where the orner of property

" has lent himself to accredit the title of another person by placing in his power those sym.,ols of property which have enabled him to liold limself out as the purchaser" 2

of the property, he is estopped from setting up his title as against persons who bave changed their position upon the faith of the misrepresentation of ownership.

In other words, Cave v. Cave ${ }^{3}$ would be decided one way under the present law of priorities, and another way under the law of estoppel by ostensible ownership. For the former law nothing can be urged but its unfortunate origin and tortuous history. The latter is solidly founded upon reason and justice.

Suppose that in Cave $v$. Cave the creator of the trust had rested the title in a trustee with a view to the commission of a fraud - with the design that the trustee should create equitable mortgages which would be invalid as against the beneficiaries, it would then be very clear that the merits would not be equal, ${ }^{4}$ and that all the mortgagees ought to have priority. Are the merits equal if without such design the settler fully equips his

is certainly the light most favorable to the vendor in which the transaction can be regarded), the rule applies that where the equities are equal the legal title will prevail. But in such a case it would be difficult to maintain that the equities are equal. The vendor has voluntarily placed in the hands of the vendee a muniment of title, clothing him with the apparent ownership of the goods, and a person dealing with him in the usual course of business who takes an assignment for a val. uable consideration "without notice of such circumstances as render the bill of lading not fairly and honestly assignable' has a superior equity to that of the rendor asserting a recent lien, known perhaps only to himself and the vendee."

1 See ch. XIV.

2 Ante, p. 292.

${ }^{3}$ And very many other cases.

4 Kettlewell v. Watson (1881), 21 Ch. D. $685 ; 51$ L. J. Ch. 281 ; 26 Ch. D. 502; 53 L. J. Ch. 717. The decision well illustrates the absence of the principles of estoppel from current methods of dealing with such cuses. 
trustee with the completest means for commission of the fraud? Does he owe no duty of exercising "an appropriate measure of prudence to avoid catusing harm to others?" An answer maly be helped by perusal of a previous chapter,' and by consideration of the ensuing paragraph.

An Involuntary Trustee. - It is a remarkable fact that if a trustee be voluntarily constituted, a fraudulent disposition by him of an equitable interest in the property will not affect the beneliciary (as we have just seen); but that the result will be different if the trustee has become such by means of a fraud upon the settler.

In Hunter $v$. Walters ${ }^{2}$ a solicitor obtained by fraud from a elient a conveyance of certain lands. Afterwards the solicitor made an equitable mortgage of the lands, and this mortgracre was upheld as arrainst the true owner. Now, as we bave seen, an owner may vest the title of property in a trustee without fear of any equitable mortgage which the trustee may create. But the case in hand shows that if the owner is defrauded out of the title the perpetrator of the fraud may make a good equitable mortgage as against the owner. A trustee appointed voluntarily cannot create a valid equitable incumbrance in fraud of the beneficiary; but a person who has involuntarily been constituted a trustee (or quasi-trustee) may do so.

Tested by the rules of estoppel (which treat of conduct) the decisions, if diverse, ought to be reversed. In both cases the owner has put it in the power of another to borrow money upon the faith of apparent ownership. In both cases then it might be said that as between the two innocent persons the owner ought to suffer. But in the second case (where the owner has involuntarily parted with the estate) he might fairly urge that he did not knowingly do so; that he did not intend to enable a fraud to be committed. In the first case the owner knew perfectly well that he was equipping his trustee for frud.

Estoppel would, however, not so distinguish. In both cases it would declare the true owner estopped by the assistance renlered to the trustee's misrepresentation of ownership; and the fact that the owner had himself been defrauded would not enable him to escape. ${ }^{3}$

$1 \mathrm{Ch} . \mathrm{V}$.

3 See chs. VIII, XXII, XXIV.

$2(1572)$ L. R. 11 Eq. $315 ;$; Ch. App.

$75 ; 41 \mathrm{~L}$ J. Ch. 175. 


\section{CHAPTER XXI.}

OSTENSIBLE OWNERSHIP AND AGENCY - GOODS - POSSESSION.

Cases involving estoppel because of ostensible ownership of goods may be divided broadly into:

1. Those in which some one other than the owner is in possession of the goods themselves.

2. Those in which some one other than the owner is in possession of documents of title to the goods.

The present chapter will be devoted to the former of these branches of the subject, leaving the latter to succeeding pages.

Land and Goods. - In the three preceding chapters we bave been dealing with the rules at present in vogue with reference to priorities in cases relating to land. Two of these rules, however, are sometimes applied to the decision of cases involving chattels, namely, those relating to the legal estate and to priority in point of time. But it is very curious to notice that in cases concerning goods the principles of estoppel are much more frequently appealed to than in litigation relating to land. Perbaps one might have so anticipated, for the rules were evolved in real-estate cases, while the principles of estoppel by misrepresentation had their origin very largely in actions relating to personal property.

Having already said all that is necessary with reference to the rules, and having shown that even in relation to land they should be superseded by the principles of the law of estoppel, we shall in the present chapter deal with questions of ostensible ownership (by possession) of goods as determined by those principles. Indeed, the cases that we shall meet themselves usually so proceed, although here and there the old rules are brought into requisition. ${ }^{1}$

Accrediting the Title.-For example, we are quite familiar, in the law of personal property, with the statement that the maxim nemo dat quod non labet

"will certainly not apply where the owner of goods has lent himself to accredit the title of another person."'

I See notably Reg. v. Shropshire (1873). L. R. 8 Q. B. 420; L. R. 7 H. 14.

2 Boyson v. Coles (1817), 6 M. \& G.

L. $490 ; 45$ L. J. Q. B. 31. 
But such a dictum, although transparently reasonable and just, could hardly have been uttered in a real-estate case. There the courts would have distinguished between legal and equitable purchasers; and between frauds, actual, constructive and incomprehensible; ${ }^{1}$ about all which, as will be observed, our dictum says nothing. Taking it, nevertheless, as sound, we have now to inquire as to the circumstances under which it may be said that possession of goods will accredit the title to them.

Mere Possession.-And we may commence with the broad assertion that mere possession, apart from special circumstances, does not accredit title, or in other words, is no eviclence of title usually a man cannot be said to be the ostensible owner of goods merely because he has them in possession. ${ }^{2}$

"The mere possession of chattels, by whatever means acquired, if there be no other evidence of property, or authority to sell from the true owner. will not enable the possessor to give a good title." 3

If it did, and if I loaned my horse to a friend, I might be estopped from asserting my title as against an innocent purchaser; for I would have accredited the title - I would have assisted in the fraud by giving to $\mathrm{my}$ friend evilence of his ownership of the horse. But that is not the law.

"If I hand my watch to a man to keep for me, thongh $I$ in a sense enable him to appear to be the owner, yet if he sells or pledges it I do not lose my property." "4

It is for this reason that when chattel property is sold and possession delivered upon hire-and-sale contract, with an agree-

1 Ante, p. 259 ff.

2Newbold v. Wright (1833), 4 Rawle (Pa.), 212; Saltus r. Everett (1838). 20 Wend. (N. Y.) 267; Peerless, etc. v. Gates (1895), 61 Minn. 124; 63 N. W. R. 260; Baker v. Taylor (1893), 54 Minn. 71; 5.5 N. WV. R. 823; Hedderly s. Backus (1893), 53 Minn. 27; 53 N. W. R. 116; Sage v. Shepherd (1896), 39 N. Y. Supp. 453; 4 A pp. Dir. 290 ; 52 N. E. R. 1126 ; Atlanta $:$ Hunt (1897), 100 Tenn. 89; 42 S. W. R. 482. Article 1599 of the French Civil Code declares that "La Vente de la chose d' antrui est nulle;" but article $22 \pi 9$ proviles that "En fait de meubles, possession raut titre." There are special provisions as to lost or stolen goods, but, with these exceptions, an innocent purchaser from one in possession is protected. See also the German Code, 1896, \$s 931-935.

The Indian Contract Act of 18\%2, section 108 (2), provides that, if one joint owner of goods "has the sole possession of them by the permission of the co-owner," a purchaser for value without notice acquires a good title.

${ }^{3}$ Per Bronson, C. J., in Covill v: Hill (1547), 4 Denio (N. Y.), 3:7. And see McNeil v. Tentl Nat. Bank (1sil), 46 N. Y. 330.

+ Per Bramwell. B., in Gabarron v. Kreeft (18;5), L. R. 10 Ex. 2\$1; $4 \$$ L. J. Ex. 243. 
ment that the title is not to pass until the price is pail, the vendor is not estopped from setting up his title as against subpurchasers. ${ }^{1}$ Owing to the very general adoption of this method of sale, howerer, the legislatures have in some jurisdictions interrened and altered the law in respect to possession of goods by vendees (and also by vendors) as indicative of title.?

Possession Implying Ownership. - The cases in which possession may be talien as indicative of ownership usually turn upon (1) the character of the goods; or (2) the character of the place to which they are sent; or (3) the customary employment of the person to whom they were intrusted. Other cases arise, but they are usually those in which circumstances other than that of possession point to ownership.

I. Character of the Goods.- The reasonableness of the following is clear:

"Goods which from their nature are intended to be fixed to and become part of realty are given into possession of a bargainee under a contract of conditional sale: and if these goods are attached to the realty, the vendor may be estopped from setting up his title as against an innocent purchaser for value." 3

And the distinction between allowing furniture to remain in the house of a jeweler and permitting him to expose your diamonds among his own in his shop can readily be appreciatel. In Meggy v. Inperial, ${ }^{4}$ where a trustee in bankruptcy had allowed furniture to remain in the hands of the bankrupt, who had mortgaged it, Bramwell, L. J., said:

"If a wine merchant be Jeft in possession of wine, the fair inference is that it is his own, and a person nay be justified in advancing money upon the security of it: here the goods being household furniture, no inference would be drawn that the insolvent had them in lis possession for the purpose of selling them."

II. Character of the Place.-The character of the goods is usually important, however, only in connection with the character of the place to which they are sent. For example, in the

1 Mason v. Bickle (1878), 2 Ont. App. 291; Austin v. Dye (1871), 46 N. Y. $500 ;$ Zutchman v. Roberts (1871\} 1 0 9 Mass. 53; Miller v. Parker (189:3), 155 Pa. St. 208; 26 Atl. R. 30.3; Rodgers v. Bachman (1895), 109 Cal. 352; 42 Pac. R. 448; Ensley v. Lewis (1899), 25 S. R. 729 (Ala.); Cottrell v. Carter (1893), 5;3 N. E. R. 375 (Mass.). See a distinction in Comer v. Cunningham (189i), 79 N. Y. 391.

\section{See ch. XXIII.}

3 McDonald v. Weeks (1860), 8 Gr. 297. But see Vulcan v. Rapid City (1894), 9 Man. 577. Distinguish Stevens r. Barfoot (1885), 9 Ont. 69 ?; $1: 3$ Ont. App. 366; Polson v. Degeer (1886), 12 Ont. 275.

4 (1878) 3 Q. B. D. 717. And see 47 L. J. Q. B. 119 . See Giannone v. Fleetwood (1893), 93 Ga. 491 ; 21 S. E. R. 76. 
case just referred to, it was not merely because the goods wero classed as furniture that the true owner eseaped; for if they had been sent to the shop of a furniture dealer the result would certainly have been different from what it was. The true rule (for all sorts of goods) is that laid down by Lord Ellenborough as early as 1812:

"If the principal ${ }^{1}$ sends his commorlity" to a place where it is the ordinary business of the person to whom it is consigned to sell, it must ba intended that the commorlity was sent thither for the purpose of sale. . . . When the commodity is sent in such a way and to such a place as to exhibit an apparent purpose of sale, the principal will be bound and the purchaser safe.".

The same rule is manifestly applicable not merely to a case in which goods are intrusted to the proprietor of a business, but also where some person (in truth an agent mercly) is provided with a shop and a stock, and so becomes in appearanco a trader and the proprietor of the business. ${ }^{3}$

And not only by permitting a trader to present the appearance of ownership of property will the true owner be estopped as against purchasers, but he may also be estopped as against creditors of the trader who, upon the faith of such appearance, have given him credit. ${ }^{4}$

III. Usual Employment of the Person.-There are many cases in which possession of goods will be evidence or appearance of their ownership, because of the nature of the usual employment of the person intrusted with them. Factors are not within the scope of the present chapter. Their possession does not indicate ownership, but agency merely. Their case therefore falls under the heading of ostensible agency, and will be dealt with in another chapter. ${ }^{5}$

1 It would be better to sily "If the owner."

2 Picliering v, Busk (1812), 15 East, 43. And see Lausatt v. Lippincott (1821), 6 Serg. \& R. (Pa.) 39:2; Towle v. Leavitt 1851), $23 \mathrm{~N}$. H. 358: Taylor v. Pope (1s6s), 45 Cold. (Tenn.) 416; Quinn v. Davis (1875), 78 Pa. St. 15; Spooner v. Cummings (1S90), 151 Mass. 313 ; 23 N. E. R. 839; Lewenberg v. Hayes (1897), 91 Me. 499; 39 Atl. R. 469; Atlanta v. Hunt (189\%). 100 Tenn. 89: 42 S. W. R. 483; Heath v. Stoddiard (1898), $91 \mathrm{Me}$ 499: $40 \mathrm{Atl}$. R. 547; Van Duzen v. Inngleblut (1899), 7\% N. W. R. 970 (Minu.).
3 Smith $\nabla$. (rrouette (1895), 2 Man. 314. And see Ramazotti v. Bowring (1860), 7 C. B. N. S. 851 ; 89 L. J. C. P. 30; Ex parte Dixon (1\&z6). 1 Cl. D. 133; 46 L. J. Bk. 20. Merely finding a person in charge of a shop does not warrant the conclusion that he has anthority to purchise goods. Vineberg v. Anderson (1590), 6 Man. 33.

4 Troughton v. Gitley $(1 ; 66), \mathrm{Amb}$. 630. See the subject discussed ante. ch. XI.

5 Scientifically it should be dealt with in chapter XXVI, which treats of ostensible agency. The Factors Acts, however, do not accurately dis- 
Traders.- Bankruptcy acts sometimes contain provisions known as reputed-ownership clauses. They constitute a sort of statutory estoppel peculiar to persons in trade or business, and varying in its principles from those beaten out by the courts. The English act has the following: ${ }^{1}$

"All goods being at the commencement of the bankruptcy in the possession, order or disposition of the bankrupt in his trade or business by the consent and permission of the true owner, under such circumstances that he is the reputed owner thereof,"

shall form part of the estate. Observe the points of agreement and difference between this provision and the law of estoppel:

1. They agree in requiring the consent and permission of the owner - goods stolen or borrowed, or otherwise wrongfully placed as part of the trader's stock, will not affect the owner.

2. They agree in requiring an appearance of ownership; that is, the existence of such a state of affairs as might mislead creditors.

"The policy of the Bankrupt Act . - never was so unjust as to take his property, unless it was left by lim in such circumstances as that credit might liave been obtained upon it." ${ }_{2}$

And so where it is customary to leave goods in the possession of persons in a certain line of business, possession does not indicate ownership; no one would be deceived, and the statute does not apply. ${ }^{3}$

3. Estoppel requires that the estoppel-asserter should have been actually misled by the appearance of ownership; but for the operation of the statute that condition is altogether unnecessary. For example, the statute applies although the goods may have come into the possession of the tracler the day before his bankruptcy and after every debt has been incurred; and it is not only unnecessary that every ranking creditor shonld have given credit upon the faith of the appearance of ownership, but it is quite unimportant whether any one creditor did so.

4. Under the law of estoppel, if the owner of goods were at

tinguish between ostensible ownership and ostensible agency, and they contain, moreover, provisions applicable to persons other than factors. For these reasons the points to be noticed in connection with the acts are grouped together in chapter XXIII.

146 \& 47 Vic. (Imp.), ch. 52, \$111. See ante, ch. XI.

2 Per Lord Blackburn in Colonial
Bank v. Whitney (1886), 11 App. Cas. 4:36: 56 L. J. Ch. 47.

${ }^{3}$ Re Goetz, Jonas \& Co. (1898), 1 Q. B. 787; 67 L. J. Q. B. 577; Ex parte Watkins (1873), L. R. 8 Ch. 520; 42 L. J. Bk. 50. Compare the statute which declares for estoppel where a vendor remains in possession of goods "under those circumstances which create a representation of ownership" (ch. XXIII). 
any time estopped by the appearance of ownership (in another person) acted upon, he would necessarily remain in that position. The statute, however, permits the owner to retalie his goods at any time prior to the date of the receiving order, even after the commission of an act of bankruptcy and after creditors have been misled. ${ }^{1}$

It may be said that the statute is a rough approach to that justice which is meted out by the law of estoppel. It is difficult to offer any reason for handing over to creditors goods in which their debtor had not a sharlow of an interest, which in no way affected their dealings with him, and which, as most frequently happens, they had never heard of. And it is just as hard in cases in which the debtor notoriously obtained all the credit he had upon the faith of his ostensible ownership of the goods to suggrest that the true owner shall be allowed to subtract them the day before the receiving order. The best perhaps that can be urged is that for bankruptey proceedings some arbitrary rules must be set, and that these are as good as others. It would be a rare case in which all the creditors would be found to be in the same position with reference to goods in possession of the bankrupt - that all, or that none of them, would prove their right to an estoppel. Some general stanclard apart altogether from considerations of individual situation therefore is formulated."

Vendors and Vendees. - A purchaser may be estopped from asserting his title as against a subsequent purchaser from the same vendor if he permit the vendor to remain in possession of the goods. And similarly, a vendor baring made a contract to sell groods may, by delivery of possession to the purchaser, be estopped from asserting his title or lien as against a subsequent purchaser. Such cases should properly be treated of in the present chapter, but for convenience they are relegated to another. ${ }^{3}$

\section{Possession Accompanied by Other Circumstances.-}

"Mere possession alone does not invest the agent with power to gire the purchaser, however innocent, the right of property against the owner. Nor is it enough so to do that the owner put the agent into the possession. Something more must be coupled with such possessivn to enable the arent to effect a valid sale to the purchiser against the will or instructions of

1 Young v. Hope (1848), 2 Ex. 105; Graham v. Furber (155:3), 14 C. B. 410; 23 L. J. C. P. 51; Ex parte Montague (15;6), 1 Ch. D. 55 t.
¿See ante, ch. XI, p. 142.

3 Ch. XXIII. 
the owner. That something more exists in the cases where the owner has inrested his agent in possession with an apparent pover to sell, or with the title to the property, or with the customary indieia of title, which purport that the title or right of property is in the party having the possession. The obvious justice is that if the owner has put the agent in possession and he has by acts of any kind held out the agent as having authurity to sell, or has given the agent the means of holding himself out as the owner, in such cases the purchaser who has been thereby misled and been iniluced by reason of such apparent authority or indicia of title to part with his noney or the property, without notice of the real fact that the agent lias no authority to sell, or that the seller in possession is not the real owner, upon plain principles of natural justice is entitled to hold the property against the owner." 1

Obtuined by Fraud.- The most important line of cases which may be noted under this heading are those in which the owner of goods has been prevailed upon to hand them over upon some misrepresentation, and the swindler has disposed of them to an innocent purchaser. Who is to lose?

Some of the authorities turn upon the distinction between cases in which there is a contract for the sale of goods (although in(uced by fraud), and those in which there was no contract at all, although sometimes the appearance of one. For example, where a broker got possession of goods from the owner by pretending to have sold them on account of the owner to S., which was not the fact, it was said that there was no contract at all. ${ }^{2}$ So also where one Blenkarn bought goods, knowing that the vendors thought that they were selling to a reputable firm known as Blenkiron \& Co., it was held that there was no contract. ${ }^{3}$ Following this distinction it is said that where there is a contract, the title of the goods passes; that it therefore passes also to the sub-purchaser; and that this latter, haring the legal title, and as good an equity as the original vendor, is entitled to maintain his purchase. In the alsence of a real contract, on the other hand, it is sairl that the title is still in the original vendor, and that there are no equities superior to his. It is therefore held that in order to defeat the true owner,

"he must have parted with possession of his property with intent to pass the title to the wrong-doer, thus giving him the apparent right of disposal." 4

1 Taylor v. Pope (1868), 45 Cold. (Tenn.) 416. Approved in Atlanta v. Hunt (1897), 100 Tenn. 89; 42 S. W. R. 483.

${ }^{2}$ Hollins v. Fowler (1872), L. R. 7 Q. B. $616 ; 41$ L. J. Q. B. 277 ; L. R. 7 H. L. $757 ; 44$ L. J. Q. B. 169; Soltau v. Gerdau (1830), 119 N. Y. 380; 48 Hun, 5.37 .
${ }^{3}$ Cundy v. Lindsay (1876), 1 Q. B. D. 348 ; 2 Q. B. D. 96 ; 3 App. Cas. 459 ; 45 L. J. Q. B. 381 ; 46 L. J. Q. B. 233; 47 L. J. Q. B. 481 . See Bush v. Fry (1888), 15 Ont. 122.

4 Baruard v. Camplell (1874), 58 N. Y. 76. See S. C., 55 N. Y. 456; Neal v. Williams (1841), 18 Me. 591 ; Coombs v. Chandler (187i), 33 Ohio, 
"Where a vendee olstains possession of a chat tel with the intention by the vendor to transfer both the property and possession, although the veri. dee las committed a false and fraudulent misrepresentation in order to effect the contract or obtain the possession, the property vests in the vendee until the vendor has done sonething to disutlim the transaction." 1

Some of the legrislation is in line with this view:

"When the seller of goods has a voidable 2 title thereto, but his title has not been avoided at the time of the sale; the buyer accmires a gond title to the gools, provided he buys them in good faith and without nutice of the seller's defect of title." 3

But there is another and a very important view, according to which the distinction between contract and no contract becomes, under certain circumstances, unimportant. For if the result of the transaction (whatever it may be) is that the swindler appears to bave the title, then the question of estoppel by ostensible owner'ship arises. Here we must distingruish between cases in which the swindler obtains possession merely, and those in which the true owner hands over to him some evidence of the title. In the latter case there is no reason to doubt that a subpurchaser woukl be protected by estoppel of the true owner.

"It appears to me that quite apart from any contract which might be af firmed or disallirmed afterwilds, the question here is whether the true owner of the goods has so invested the person dealing with them with the indicia of property as that when an innocent person enters into a negotiation with the person to whom these things have been intrusted with the indicia of property, the true owner cannot afterwards complain that there was no authority to make such a barrain. Where that is the case it is nolonger a question of uffirming or disclfirming any contract between the owner of the goods, but a question whether the ouner of the goods has by his conduct allowed the person. who has either cheated him or to whom he has intrusted the goods, to hold himself out as the owner, so as to give a good title to a bona fide purchiaser for value." 4

But if the swindler obtained possession merely, and under such circumstances that it could not be said that there being a contract he acquired the legal title, the result is usually diflerent. The case then may be said to become one in which the innocent sub-purchaser relied upon mero possession as evidencing title, and that he has himself to blame; for (apart from market overt) the possession, even of a merchant, is not a sulfi-

178; Holland v. Swain (1879), 94 Ill. 154; Tiedeman on Sales, $\$ 327$, and the many cases there cited.

1 Kingsford v. Hery (18.j6), $11 \mathrm{Ex}$. 577: 25 L. J. Ex. 166. Approved in Pease v. Gloahec (1866), L. R. 1 P. C. $229 ; 35$ L. J. P. C. 66 . And see ante, ch. VIII.

2 As to the meaning of the word "voidable," see ch. XXV.
3 See $56 \& 57$ Vic. (lmp.), ch. 71 , sec. 23.

${ }^{4}$ Henderson r. Williams (1895), 1 Q. B. 525; 6t L. J. Q. B. 310; Vicker's v. Hertz (18i1), L. R. 2 S. \& D. 113; Quirk v. Thomas (15,58), 6 Mich. 120; Prentice v. Pirge (1895), 164 Mass. 276; 41 N. E. R. 279. 
cient foundation for title. A corollary from this is that if the swindler, after thus aequiring possession, should himself warehouse or ship the goods and so procure a document of title to them, the sub-purchaser's position would not be improved. ${ }^{1}$ It will be observed that it was not with the assistance of the true owner, in this ease, that the swindler became possessed of the document of title. It has been held, however, that if the goods had been warehoused by the original owner, and he assented to the transfer of them in the books of the warehouseman, he would be estopped, even although there was no other evidence of title. ${ }^{2}$

It must not be thought, howerer, that this line of decision at all interferes with the validity of the distinction between cases of contract and no contract. It merely reminds one that even in cases in which there is no contract the true owner may by his eonduct be estopped from setting up his title.

Other Cases. - There are many other cases exemplifying the principle uncler consideration. For example, if a safe manufacturer, besides handing over possession of a safe under a hireand-sale contract, should paint the purchaser's name upon it, he would be estopped. ${ }^{3}$ A distinction is made, however, where a sub-purchaser has no reason for thinking that it was the manufacturer who had painted on the name; because, in such cases, even if there had been a misrepresentation by the manufacturer, the sub-purehaser was not aware of it - for all he knew his own vendor might have painted on the name, and he therefore did not act upon the representation as being that of the manufacturer. ${ }^{4}$

So also possession coupled with a receipt for the purchase price would accredit the title and estop the true owner, even although the money had not in fact been paid, nor had the title passed. "Settled by note" would be sulficient for such purpose. ${ }^{5}$

1 Soltau v. Gerdau (1890), 110 N. Y. St. 318; 32 Atl. R. 1029. As to hire$380 ; 48$ Hun, $53 \%$.

${ }^{2}$ Henderson v. Williams (1895), 1 Q. B. 525; 61 L. J. Q. B. 309.

3 O'Connor v. Clark (1895), $170 \mathrm{~Pa}$. and-sale contracts see supra.

4 Walker v. Hyman (1877), 1 Ont. App. 345. And see ch. XI.

5 Quebec Bank v. Taggart (1896), 27 Ont. 169. 


\section{CIIAP'TER XXII.}

\section{OSTENSIBLE OWNERSIIP AND AGENCY - GOODS-DOCUMENTS OF TITLE.}

It is somewhat surprising that nowhere is there to be found any aldequate explanation of the nature and purpose of documents of title and their true relation to the transactions which they represent. There are no doubt text-books which treat with more or less completeness of title-rleeds to real estite; and several that are devoted to bills of lading, dock warrants, transfers of shares, ete.; but no synthesis has been attempted, and no general principles have been established which would be of assistance in dealing with the questions which we are now to encounter.

Classes of Documents.- Observe first that there are three classes of documents of title: (1) those which certify as to the condition of title; (2) those which pass property or title; and (3) those which melely ericlence the fact that property has already passed. Certificates of ownership of ships and shares are examples of the first class; conveyances of land and transfers of shares are instances of the second (although they may also be said to evidence the transactions); while indorsements of bilis of lading, dock warrants, etc, are examples of the third.

Estopucl by Trunsers. - Omitting for the moment the first of these categrories, let it be noted that documents of the second and third classes have this in common: that whether they operate as, or are merely evidence of, a transfer of property, they authoritatively indicate to subsequent purchasers that the arantors have parted with their interest in the thing conveyed. In other words, if a grantee should represent to an innocent subpurchaser that he (the grantee) wats the absolute owner of certain property, and should, as evilence of such representation, produce a conveyance or record of a conrerance from $A$. to himself ; and if the sub-pureluaser shoukt, upon the fuith of the representation so accredited, change his pusition prejulicially, then $A$. ought to be estopped from setting up any claim incon- 
sistent with the conveyance or record. It is a clear case of estoppel by assisted misrepresentation. Reeognize that bills of lading, warehouse receipts, delivery orders, lock warrants, transfers of shares, ete., are documents of title in the sense above inclicated, and that estoppel applies to them as just pointed out, and mountains of diffieulty will disappear.

Such law (although not its method of statement) is quite familiar in its relation to real estate. It is there termed "estoppel by deed," which is said to bind "parties and privies." It bas already been treated of at some length, ${ }^{1}$ and it is recurred to here merely for the purpose of contrasting it with the more comprehensive ground of estoppel above suggested, which, it will be observed, applies whether the subject-matter of the transaction is real or personal estate, whether the document of title is or is not a deed, and whether the sub-purcbaser does or does not aequire a "legal" or any estate. ${ }^{2}$

And probably apart from profound learning upon the subject, this estoppel view of the matter would evoke little opposition. But the accumulation of precelents involving other prineiples, the diversity and antagonism of those precedents and principles when applied to different sorts of documents of title, and the existence of statutes which proeed upon no principle at all, render the establishment of our suggested method of treatment impossible, or nearly so, - at all events for the present.

We have alrealy seen that in the law of real property the guiding prineiples are (1) a factitious reverence paid to the "legal" estate with reasoning very "teehnical and not satisfactory ;" 3 (2) mechanical rules as to the possession of the titledeeds $;{ }^{4}$ and (3) astonishing juggleries with the word "fraud." 5 We are now to see that the law as to bills of lalling hovers between a view of symbolism, and a notion of negotiability with accompanying antagonism to the general law; that in the realm of dock warrants, ete., we have confusion plus distracting statutes, while to share transfers alone has the doctrine of estoppel been at all adequately applied - helped therein by the absence, from so modern a subject, of ancient formulas and perplexing

\footnotetext{
$1 \mathrm{Ch} . \mathrm{XV}$.

2 As to "legal" and "equitable" estates, see ch. XVIII. 
acts of parliament. It should be added that the American cases are, for the most part, less open to the criticisms of this paragraph than the English.

\section{Division of time Subject.}

Before entering upon exposition it is very necessary that we should understand exactly what kinds of documents of title we are to deal with, and to justify their inclusion in one chapter for some of them are not usually thought to be very closely associated. Let us notice four classes:

1. Documents usually referred to as conveyances, whether of lands or goods.

2. Bills of lading.

3. Dock warrants, warehouse-kecper's certificates, warrants or orders for the delivery of goods and other such documents. These will be grouped under the phrase "dock warrants, etc."

4. Certificates and transfers of shares.

1. Conveyunces. - While it may rery well be said that a written document is necessary to the transfer of land, yet in its original purpose a deed was rather intended to be evidence of the transfer than the transfer itself, and its eridential character is still maintained by its form. ${ }^{2}$ With regard to such title-deeds we may safely say that they are regarded as evidence of the ownership of the person in whom they show title, and are intended to be representations of that fact to all persons dealing with the grantee. The reason therefore for the estuppel for the grantors, as against persons who purelsase upon the faith of such deeds, is very apparent. Let us observe whether the same thing camnot be said of the other documents to which we have referred.

2. Bills of Lading.- A bill of lading is a receipt given by a common carrier for the goods shipped; it shortly describes

IFor the purposes of the Factors Act. the phrase "locument of tit le" includes "any bill of lasling, dock warrant, warehouse-keeper's certificate and warrant or order for the delivery of goods, and any other documents used in the ordinary course of business as proof of the possestion or control of groods, or authorizing or purporting to authorize, either by indorsement or by delivery, the pos. sessor of the document to transfer or receive the goods thereby represented." 52 \& 53 Vic. (Imp.), ch. 45, $\$ 1$ (4). And see Rev. St. Ont., ch. $150, \lessgtr 1(3)$.

2 "This indenture witnesseth." 
the goods; indicates the place of shipment and delivery; and usually it contains a number of conditions regulating the obligations of the parties, amongst the rest that certain freight is to be paid. The most notable part of it, for our present purpose, is some such phrase as "deliverable to A. B. or order."

A bill of lading is sometimes said to be a contract, and legislation so treats it, ${ }^{2}$ while Baron Bramwell declares that the statute is inaceurate:

"To my mind there is no contract in it. It is a receipt for the goods stating the terms on which they were delivered to and received by the ship, and therefore excellent evidence of those terms, but it is not a contract; that has been made before the bill of lading was given." 3

Whether a receipt only, or a contract, it is at all events a document that is not intended to be operative merely between the original parties to it. It is intended to be a representation to the commercial world that the goods mentioned in it have been shipped on account of the person to whom they are made deliverable. And when the person to whom it is issued indorses it and hands it over to another person, such action is regarded as a declaration or representation that the transferee is entitled to the groods, and that the transferror has thenceforward no interest in them. In other words, a bill of lading is a document of title, ${ }^{5}$ and its indorsement ought to estop a

1 Without some such words a bill of lading is not ambulatory, and no person ought to take it to be a rep. resentation intended to be passed on to others. Henderson v. Comptoir (1873), L. R. 5 P. C. 260 ; 42 L. J. P. C. 60. See as to bills of exchange and promissory notes, $45 \& 46 \mathrm{Vic}$. (Imp.), ch. 61, §8; 53 Vic. (Can.), ch. $33, \lessgtr 8$.

$218 \& 19$ Vic., ch. $111, \lessgtr 1$.

${ }^{3}$ Sewell v. Burdick (1884), 10 App. Cas. 105; 53 L. J. Q. B. 399. But see per Lord Esher in Leduc v. Ward (1888), 20 Q. B. D. 480; 57 L. J. Q. B. $3 \% 9$.

${ }^{4}$ This is now perfectly clear. See $18 \& 19$ Vic. (Imp). cl. 111, §3. It is the chief postulate in the cases of which Grant v. Norway (1851), 10 C. B. $665 ; 20$ L. J. C. P. 93, is the leading example. See Hubbersty v. Ward (1853). 8 Ex. 330; 22 L. J. Ex. 113; Holton v. Sanson (1862), 11 U. C.
C. P. 606; The Schooner Freeman v. Buckingham (1855), 18 How. (U. S.) 182; Pollard v. Vinter (1881), 10, U. S. 7; Bank of Batavia จ. New York (188\%), 106 N. Y. 195. Arkansas, California, Dakota. Kentucky, Maryland, Minnesota, Missouri, New York, Pennsylvania and Wisconsin have statutes declaring that bills of lading are negotiable. Porter on Bills of Lading. $\$ \$ 43-451$. There is some judicial opinion contrary to the text. See Erb v. Great Western Ry. Co. (1882), 3 Ont. App. 456, 459, 468, 483; 5 S. C. Can. 193; Gunn v. Bolckow (1875), Lـ R. 10 Cl. 491; 44 I. J. Cl. 730.

5"A bill of lading is a transferable document of title." Per Lord Blackburn in Glynn v. East \& West India (1882), 7 App. Cas. 644; Hatfield v. Phillips (1845), 12 Cl. \& F. 361; Cole v. North Western (1875), L. R. 10 C. 
transferror from asserting any interest in the groorls as arrainst persous who, upon the faith of the indorsement, have chingred their position, just as a conveyance of land estops its grantor.

3. Dock Warrants, etc.- The third elass of documents (referped to as dock warrants, etc.) are sometimes in the form of receipts, but sometimes merely as follows:

"Warrant for two cases of lye. Importel in the Hartfell. Entered by Petrocombino, 24 Sept., 15\%.). Deliverable to Petrocochino or assigns by indorsmont thereon. . .

"N. 13,-Tlis warint is the only document issued by us as a legal symbol of these goods." I

Such instruments, too, are sometimes called contraets; ${ }^{2}$ and although there are usually no express contractual stipulations in them, such as are to be found in bills of ladling, the present witer raises no objection to their being so styled. But whether contractual or not, it is quite clear that of these documents also it may be said that they are evidenees of title, ${ }^{3}$ and intended to be representations of that fact to persons dealing with their hollers; they are to goods at rest what bills of lading are to goods in transit.

4. Shares in Companies. - Certificates and transfers of shares are not usually classed with such documents of title as those of which we have been speaking; but they are for our purpose closely associated with them. Corporations issue certilicates of shares in order to enable their shareholders the more easily to deal with their shares. These, too, are not merely receipts or contracts, operative only as between the company and the particular shareholder; but are intended as representations to third persons as to the ownership of the shares. A company's certificates of shares, therefore, are documents of title in the same sense as are bills of lading, doc's warants, etc.; that is to say, they are representations by the signers of them as to the owner-

P. 363: Merchants' Bank v. Phœnix (18\%7), 5 Ch. D. $216 ; 45$ I. J. Ch. 41 s; Michigan $r$. Phillips (1871), 60 Ill, 19:.

1 Seton v. Lafone (185i), 18 Q. B. D. 140: 19 il. $68 ; 56$ L. J. Q. i) 4 ii. See another form in Merchants' B.mk v. Phonix (18i⿰), 5 Ch. I. : (9).5; 46 I. J. Ch. 418.

2 Jlackburn on Sales (

${ }^{3}$ So long ago as $181 \%$. D.llas, J., said that a dock warrant "is the title deed of the property;" and
Park. J.. said: "No man liring would have purchased these gools unless the dock warrants had been jroducel. They were the key to this property." Lucis v. Dorrien. i Taunt. 290 . 391. In some stiltes war house receills are by statule negotiablo. Collins r. Rosezbatum (1897), $43 \mathrm{~S}$. W. R. 700 .

+ Re Bahia (1868), L. R. 3 Q. B. 594; sิ L. J. Q. B. 181. 
ship of the property referred to in them. A bill of lading indicates that the goods are being carried on behalf of $A$. B. or order; and a company's certilieate indieates that certain shares are owned by A. B. To these extents the doenments are representations as to title.

That sueb documents are usually transferred by different methods is not a distingnishing factor of any importance for our purpose. A bill of lading is transferable by indorsement of signature merely; and shares by a separate document (although sometimes inclorsed upon the eertificate) which expresses that which an indorsement implies. One form is more compendious than the other, that is all. And the effect (for our purposes) is identical. When A. B. indorses over his bill of lading to another be enables that person to pose as the owner of the goods, and he ought to be estopped as against any third person who is subseifuently misled by such ostensible ownership. And when A. B. executes a transfer of his shares to another, the effect is the same so far as third persons are concerned.

Resemblances.-Of certificates and transfers of shares, then, we may say as well as of bills of lading, dock warrants, etc., and conveyances of lands and goods:

1. That they are documents of title.

2. That they are used in the ordinary course of business as proof of the ownership of the property they describe.

3. And that they are ambulatory - that is, intended to be passed on to other persons, and to be acted upon by strangers to them. ${ }^{1}$ In fact all the documents to which reference has been made are title papers. Bills of lading, doek warrants, ete., and share transfers bear the same relation to goods and shares as do title-deeds to real estate. And the law of estoppel as to all of them ought to be the same - that is to say, the same principles of estoppel by ostensible ownership sbould apply equally to all such eases.

"The ground of these decisions is the same in relation to real and personal estate. It is that the delivery of the thing by the owner to one who

1 Questions are mooted as to whether shares are, or are not, choses in action; it being suggested that they are choses prior to registration, and property afterwards. Colonial Bank v. Whinney (1886), $30 \mathrm{Ch}$. D. 261; 55 L. J. Ch. 585; 11 App. Cas.
426 ; 56 L. J. Ch. 43; Robinson v. Jenkins (1890), 24 Q. B. D. 275; 59 L. J. Q. B. 14\%. With such questions we have nothing to do. We are dealing with the title to shares, and for that purpose the inquiry is immaterial. 
has also the eridence of ownership by the act of the party transferring.

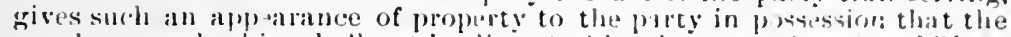
purchaser under him shall not be disturised by the antecedent laud." I

The diserepancy, however, between the law as at present understood relating to real estate and that which obtains with reference to documents of title to groods and shares is so greatt that it would be impossible to combine the former with the latter in one method of treatment. Real estate title-deeds have alrealy been dealt with; we shall now as far as possible unite all other documents of title in one chapter, premising merely that even amongst these we must be prepared for annoying divergencies and departures from common principle.

\section{The Treue View.}

It will be well at the outset to explain more fully tho author's view of the principles applicable to the subject in hand. It has already been said that the maxim nemo dat quod non habet,

"will certainly not apply where the owner of goods has lent himself to accredit the title to another person." 2

Now there are two methods of accrediting the title of another person: (1) by really, and (2) by ostensibly, vesting it in him. For example of the former: I convey certain land absolutely to a person, wbo is to hold it subject to my orders, and the trustee uses the deed to accredit his representation of beneficial ownership. For example of the second: A mortgagee lends the title-deeds to the mortgagor, who fraudulently presents them to a banker as evidence of unincumbered title. In both cases the result to the third person is the same: that is to say, he is deceived by the appearance of beneficial ownership, and for that appearance the true owner is responsible, and by it ought to be estopped.

'There are, of course, many other ways in which the appearance of ownership may be presented; but for present purposes it is not necessary to do more than to remind the reader of the next preceding chapter, in which possession, as a prime factor in appearance of ownership, is treated of.

1 Per Parker, C. J., in Somes r. Brewer (1824), 19 Yass. 201; and see Williams v. Given (1849), 6 Gratt. 2 Boyson v. Coles (1817), 6 II. \& S. (Va.) 272. 
We hare now to apply the general principle above quoted to documents of title to goods and shares.

Purchase of Merchandise from a Merchant.-Commence at the beginning. Suppose that a merchint has in his warebouse certain groods bclonging to a class in which he usually deals; and suppose that, secing them there, you purchase them. What is your position as to title? Apart from considerations of estoppel one would say that you acquired exactly the same title that the merchant had - nothing more, for nemo dat quod non habet. But observe three things:

(1) Our leading principle that the maxim nemo dat quod non habet

"will certainls not apply where the owner of goods has lent himself to accredit the title to another person."

(2) Therefore, if the real owner of the goods has permitted the merchant to present the appearance of ownership of them by having them in possession as if for sale, he (the true owner) will be estopped as against innocent purchasers.

(3) And this will be the case even if the true owner has been induced by fraud to permit the appearance of ownership. ${ }^{1}$

We may say, then, that in the case supposed you will be reasonably sure that your purchase from the merchant will give you a perfect title to the groods. For either (1) the goods really belong to the merchant; or (2) the true owner will probably be estopped from otherwise saying, either because be has voluntarily permitted the appearance of ownership, or (?) because he has been defrauded into permitting such appearance. You will run the risk, in some jurisdictions, of the merchant baring stolen the goods; in others (upon considerations of market overt) you will be safe against even that possibility; and there may, in rarest cases, be some extraordinary concatenation of circumstances that will work your disappointment. On the whole, however, it may be said that your title will be unassailable - the case, remember, being that of a merchant having merchandise on hand and ostensibly for sale.

Vary a little the case just put: Suppose that the goods are not upon the merchant's own premises, but are in a public warehouse and beld there for him. 'The merchant is now none the less in possession of the groods; they are none the less os- 
tensibly his; and none the less ostensibly held for sale. Your rights, therefore, will be exactly the same as in the former ease. Nor, clearly, ean such result be altered if, instead of the goods being in a warehouse upon land, they are in a difierent structure upon the water, and moving there.

But a matter of convenience interposes in the cases last supposed. When the goods were in the merehant's own custody you could see then, and be thus realily assured of their existence under circumstances as to appearance of title satisfactory to you. But when the groods are in other places, and more especially when at sea, how are you to be assured of the truth of what the merchant represents to you as to existence and custody? Observe that it is precisely for the purpose of answering your question that he has provided himseif with a bill of lading, dock warrint, etc.; and he presents it to you as an instrument which aceredits his representation. ${ }^{1}$

First Conclusion. - It is thus a document which assists the merchant's representation. It was signel by the ship-owner or dock-owner for the very purpose of being used in that way; and the first conclusion, therefore, which we arrire at is that he (the ship- or dock-owner) ought to be estopperl, as against persons who change their position upon the faith of it, from denying the truthfulness of its contents. For example, if such a document has been signed in error, or has been obtained by means of false representations, purchasers from the holder of it ought not to be affected. They relied upon the document. What the signer of it relied upon is his own affiair.

Second Conclusion.- Having purchased the goods you take a transfer of the document. Why? Not beeatuse you have bought it. Keep very clear of that ilea - it has made much trouble. You bought the goods, upon the representation contained in the document, which was that the goods were held on

1 The Factors Acts, 52 \& 53 Vic. (Imp.). ch. 45, $\$ 1$ (4); Rev. St. Ont., ch. $150, \leqslant 1$, are sufficiently accurate in speaking of suc! documents as being "used in the ordinary course of business as proof of the posses. sion or control of goods." The word "control," however, is eitlier redumbant or moiningless. And the latter part of the same sentence is not right. It can hardly be said that such documents are used as "authorizing or purporting to allthorize, either by indorsement or delivery, the possessor of the document to transfer . . . the goods." A warehouseman (that is, a batlee) cannot grant to, or wilhhohl from. the owner of gools the power to transfer them as he pieases. 
behalf of your rendor. And you require a transfer of the document in order to be able to prove to persons dealing with you that the merchandise is now held for you, and also, if you so desire, to obtain the attornment of the dock-owner. The document is in ambulatory form (redeemable to "order" or "assigns"), and it was thus drawn so that it might answer your purpose by attending any subsequent disposition of the goods.

It has become now more clearly a document of title. Previously it might be taken to be a sort of certificate of ownership (to the extent of possession at all events, with all that is thereby inplied). Now, however, it is being used as a record of an as. signment of the goods. The indorsement upon the document is not in itself (as we shall shortly see) a transfer of the goods. It is a record merely of that transfer. It is a declaration by the transferror that he has assigned the goods and that he has no claim upon them. Moreover it is a declaration which the transferror intends that other persons shall act upon, and upon the faith of which subsequent purchasers are entitled to rely. And so we arrive at the second conclusion, that as against such subsequent purchasers the transferror ought to be estopped from asserting any right to the goods.

Remember these two conclusions:

1. The signer or issuer of a dock warrant, etc., is estopped, as against persons dealing with the goods upon the faith of it, from lenying its correctness; and

2. A transferror of such a document is also estopped as against such persons from asserting any interest in the goods.

Shares.- The foregoing remarks have had relation to documents of title to groods; but much that has been said may be repeated with reference to documents relating to company's shares. We do not incleed in this case, as in the other, commence with possession by the owner of the thing itself (the goods), for shares are wholly incorporeal and intangible. We fix attention merely upon the documents - the certificate of shares and the transfer of them.

Observe that a company issues its certificate not merely nor principally for the satisfaction of the owner of the shares, but as evidence of his ownership with the intention that it shall be presented to and acted upon by other people.

"This power of granting certificates is to give the shareholders the opportunity of more easily dealing with their shires in the market, and to 
afford facilities to them of selling their shares by at once showing a marketable title." 1

First Conclusion. - It is therefore (in higher degree than a bill of lading or clock warrant, for it relates to absolute title and not to possession as evidence of title merely) a certificate of ownership; or in other words a representation by the company upon which persons dealing with the person named in it aro entitled to rely. ${ }^{2}$

"It is a declariation by the company to all the world that the person in whose name the certificate is male ont, and to whom it is given, is a shareholder in the company: and it is given by the company with the intention that it shall be so used by the person to whom it is given, and acted upon in the sale and transfer of shares." 3

We thus again arrive at our first conclusion that the signer of a certificate of ownership is estopped by it as against persons who have acted upon the fitith of it.

Second Conclusion. - Alienation of shares, in order to be quite complete, is frequently required (by statute, charter or by-law) to be transacted at the oflice of the company. But, owing to the great frequency of the traling in stocks, a very general practice has sprung up of executing transfers in wbich a blank is left for the name of the assignee, and accompanying them with a power of attorney to lill ap the blank, and do all else necessary to the completion of the transfers. In such condition the papers may pass through many hands before they reach some one who desires to have himself registered. And it will be observed that until that is clone the pa;) rers are available to any bearer of them, for any bearer may fill the blank with his own name.

Possession of a certificate of shares, then, accompanied by a blank transfer, places the bearer in a position similar to that occupied by the holder of a dock warrant, etc., for they both have a certificate of ownership which will estop the signer of it; and both have a transfer of title which is intended to be acted upon by subsequent purchasers, and is therefore a rep-

1 Per Cockburn, C. J., in Re Bahia, Per Bowen, L. J., in Re Ottos, etc. etc. (1S68), L. R. 3 Q. B. 594, 595: 37 L. J. Q. B. 181. And see per Lord Herschell, in Balkis v. Tomkinson (1593), A. C. 403 ; 63 L. J. Q. B. 137. "A certificate is not like a promissory note; it does not transfer a chose in action; it is only a representation."

(1893), 1 Ch. 628; 62 L. J. Ch. 170.

2 Because it is a certificate as to perfect title; while the bill of lading is only as to possession, from which you may draw your own inferences. ${ }^{3}$ Per Cocliburn, C. J., in Re Bahia, etc. (1865), L. R. 3 Q. B. 595 ; 37 L. J. Q. B. 181. 
resentation to them which will estop the transferror's assertion of any claim which he may have.

This all seems to be reasonably clcar and satisfactory. Let us turn to the law as it is, observing (more particularly as to the second of the results just mentioned) not only the very general absence from the cases of the law of estoppel which should govern them, but the great and fundamental differences between the principles which bave been applied to the respective documents.

\section{Estoppel of the Signer.}

Not much difficulty exists with reference to the position of the signer of a document of title. Upon the whole it is fairly well recognized that he is estopped from denying the truthfulness of the statements which the document contains. ${ }^{1}$ Bat there are some points that deserve notice.

1. What is the effect upon the liability of the signer of a document, if the document has been obtained from him by fraud and passed on to ignorant purchasers? As to bills of lading an English statute provides that they

"shall be conclusive evidence of such shipment . . . notwithstanding that such goods or some part thereof may not have been so shipped;"

but contains a proviso,

"that the master or other person signing may exonerate himself in respect of such misrepresentation by showing that it was caused without any default on his part, and wholly by the fraud of the shipper, or of the holder, or some person under whon the holder claims." 2

Upon the other hand, no legislation regulates the decision of similar questions in the cases of dock warrants, etc., and certificates of shares; and the courts have arrived, as to them, at a result quite different from that declared by the statute. The authorities ale clear that a company cannot escape from the representation in its certificates upon the ground of presence of fraud and absence of negligence; ${ }^{3}$ and although neg-

1 Merchants Banli v. Phoenix (1877), 5 Ch. J. 205; 46 L. J. Ch. 418; Coventry v. Great Eastern (1883), 11 Q. B. D. $\tau \tau 6$; 52 L. J. Q. B. 694; Holton v. Sanson (1\&6\%). 11 U. C. C. P. 606; Mc:Lean v. Buffato (1965), 23 U. C. Q. B. $448 ; 24$ id. 220; St. Louis v. Larned (1882), 10:3 I1l. 293. The shipper may of course protect himself by the form of the bill of lading.
For example, he may add to the description of the goods such words as "quantity and quality unknown;" The Prosperino (1873), 29 I. T. 622; The Ida (1875), 32 L. T. 541.

$218 \& 19$ Vic. (Imp.), ch. 111, §3. See 52 Vic. (Can.), ch. $30, \$ 3$.

${ }^{3}$ Re Ottos, etc. (1893), 1 Ch. $618 ; 62$ L. J. Ch. 1 i。. 
ligence is in one instance (a case of a dock warrant ${ }^{1}$ ) treated as a factor, the better rule is that the person issuing a document upon which others are invited to act inust take the responsibility of its correctness, and will not be permitted to fulfill with excuses his undertaling to deliver goods. ${ }^{2}$ A part from legrislation there can be little doubt that there is no distinetion between a bill of lading and a dock warrant with reference to the estoppel of the signer of them. ${ }^{3}$

2. It is a curious instance of the tendeney to associate a point of general applicability with that braneh of the law only in which it has first arisen to find that when a bill of lating for goods not actually shipped is signed not by the carrier himself, but by an agent for him, the defense of no authority in the agent is at once raised ; ${ }^{4}$ while similar defenses are never thought of in cases of doek warrants, etc., ${ }^{5}$ or of eertificates of shares ${ }^{6}$ issued in error. And yet the point is of course of as much importance in these classes of eases as in that.

\section{It might be assumed from Seton $v$. Lafone ${ }^{7}$ that the signer}

1 Seton $v$. Iafone (188\%), 18 Q. B. D. 139; 19 id. 68: 56 L. J. Q. 13. 41\%.

2 See ehs. VIII and IX; Wichitis v. Atchison (18\%8), 20 Kinn. 519. It should be remembered that none of the documents can in any way estop persons who are not parties to them. They are not evidence of title as against other persons, as, for example, a bill of lading is not evidence as agitinst persons from whom the con. signor has siolen the groods. Orler. Atkinson (1814), 5 Tiunt. 7is); Finlity s. Liverpool (15\%0), 23 L. T. N. S. 251. The representations in them moreover are to be taken as of the date of their issue. A company by its share certificate represents that on the day of its date a certain per. son was entitled to certin shires. Whether such person has sulise. guently solel them or not is a matter for inquiry by the purchaser. And even if the certificate should inti. mate that no transfer would be permitted without surrender of the certificate, the purchaser may not assume that the company las not waived that formality and pernitted a transfer to be made. Smith $v$. Walkerville (1\$96), 23 Ont. App. 102. ${ }^{3}$ Dean v. Driggs (1893), $13 i \mathrm{~N}$. Y. 28:3.

${ }^{4}$ See post. ch. XXVI, citing Grant v. Norway (15.51), 10 C. B. 685 ; 20 L. J. C. P. 98: etc.

5 See Merchants' Bank v. Phoenix (187i), 5 Cl. D. 205 ; 46 L. J. Ch. $41 \mathrm{~s}$; Coventry v, Great Eastern (1843), 11 Q. B. D. $756 ; 52$ L. J. Q. B. 694; IICLean v. Buffalo (186.5), 23 U. C. Q. H. 44s: $2+\mathrm{id} .2 \pi 0$.

6 Re Bahia, etc. (IS6s), L. R, 3 Q. B. 584; $3 \pi$ L. J. Q. B. 176: IIart r. Frontino $(18 ; 0)$. L. R. 5 Lx. 111; 89 L. J. Ex. 93; Simm v. Anglo-American (1880). is Q. B. D. 188: 49 L. J. Q. B. 392: Re Ottos, etc. (189:3), $1 \mathrm{Ch}$. 61s; 6: L. J. Ch. 166; Tonkinson v. Billk is (1\&91), 2 Q. B. 614; (1893) A. C. 396; 63 L. J. Q. 13. 134; Re Concesvions Trust (1s96), ¿ Ch. ijĩ; 65 L. J. Ch. 9)...

Т(1ヘோ 18 Q. B. D. 139; 19 id. 65; 56 L. J. Q. B. $41 \mathrm{~J}$. 
of dock warrants, etc., would not be estopped by them. In that case a warehouseman, believing that a certain broker beld the warrants for certain goods, wrote to him for rent; the broker had not the warrants, but after receiving the letter he purehased the groods from the holder of the warrants; afterwards he demanded the goods from the warehouseman and was told that the letter had been written by mistake, that there were no such goods. The question debated was, Whether the warehouseman was estopped by his letter - was this letter the proximate cause of the purchase of the goods? It was held that it was; although in another case a railway company having sent to a consignee of goods an advice note of their arrival, in consequence of which the consignee sold them, it was held that the reasonable consequence of sueh a note was not that the consignee should sell the goods, but that he should send for them. ${ }^{1}$ In the same way it might well have been said (with reference to the letter to the broker asking for rent) that the reasonable consequence was that he should pay the rent, not that he should buy the goods.

But the true point of the case was overlooked. The warehouseman could not be estopped by his letter, for the reason just given - beeause purchase of the goods was not the reasonable consequence of a demand for rent. But he was estopped by his outstanding warrants upon which, as well as upon the letter, the broker relied. Had the broker received no letter at all, but bought the goods upon the faith of the warrants alone, the warehouseman would have been estopped. The letter upon which the cise turned was an immaterial factor. The warrant was all-important, for as was said in another case:

"If he choos's to issue it in this shape, he tells all the trade that they may safely deal on the faith of that warrant: and whether or not it becones a negotiable instrument at common law as distinct from equity is to my mind utterly immaterial." 2

4. It should be observed that the statement that the signers of the documents under discussion are estopped to deny their truthfulness applies only to those matters of which it might be supposed that they had cognizance. No one imagines, for example, that the master of a vessel opens all the packages

1 Carr v. London (1875), L. R. 10 C. Bank v. Phoenix (1877), 5 Ch. Div. P. $307 ; 44$ L. J. C. P. 109. $205 ; 46$ L. J. Ch. 418.

'Per Jessel, M. R., in Merchants' 
shipped, or that he has any special information as to their contents. If, therefore, he shomlal issue a bill of lading for barrels of "Portland cement," and il the barrels (although so labeled) contained something else, the ship-owner would not be liable."

If, however, a doek warrant indicated that the goods were in "free warehonses," meaning thereby that they were not subject to duty, the dock-owner would be estopped by the assertion. ${ }^{2}$

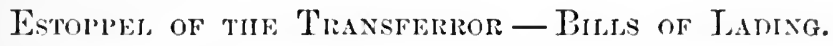

In Licklarrow v. M $/$ (son, ${ }^{3}$ an early and most important case, this question arose: A vendor of goods sent to the purchaser a bill of lading to the latter's own order; the purchaser sold the goods and transfered the bill; and afterwards the first vendor elaimed a right to stop in transitu for non-payment of his purchase-money. From the point of view of estoppel this is a clear case - the seeond vendor's representation of unincumbered ownership had been assisted by the transfer to him of the bill of lading, and the first vendor ought to be estopped because of the assistance. And it was so held; for, although the word " estoppel" is not used, the judgment of Ashhurst, J., contained that memorable sentence which was in reality the earliest formulation of the principle which in the present work is referred to as "estoppel by atssister misrepresentation:" 4

"We may lay it down as a broal. general principle that whenever one of two innocent persons must sufler by the acts of a third, he who enables sucl third person to occasion the loss in ust sustain it." 5

Observe that this is a principle which will apply not merely to the case of a consignor depriving himself of a right to stop in trunsitu, but that it is equally applicable to all cases in which the holder of a bill enables a third person, by transferring it to him, to pose as owner of the gools. It is noteworthy, however, that althongh the wicle generality of the rule has been observed and male much use of in almost every other branch of the law, it has been very largely limited, in the de-

1 Dean v. Driggs (1893), 13i N. Y. 274. See also Warlen v. Greer (183i). 6 Watts (Pa.), 424; Hale s. Milwalukee (1868). :3: Wis. $276: 29$ Wis. $48 \%$.

2 First Nat. Bauk v. Deau (1593), 13 i N. Y. 110. 3(1;8i) 2 T. R. 63; 1 H. Bl. 357; 6 Eist, 21 .

4 See ch. IV.

5(lisi) 2 T. R. 63. And see ch. XIV. 
partment in which it originated, to the particular case then in hand, namely, to the preclusion of the consignor's right to stop in transitu; other rights of the consignor are not supposed to be affected. The principal reason for this no doubt is that one ground assigned for the cessation of the right to stop in transitu was that bills of lading were negotiable, and that the transferee of it therefore might take a greater right than that of his transferror (the consignee). When, however, attempts were made to affect other rights of the consignor, it was said (in opposite sense) that a bill of lading was merely a symbol of the goods, and that a person in possession of goods could give no better title than that which bo himself had. Underlying both of these opposing views was the idea (still very prevalent) that the indorsement of a bill of lading passes title to the goods. We must come to some very clear understanding upon these three points.

Passing the Property.- In the leading case of Lickbarrow $v$. Mason it was said that "the delivery of a bill of lading is a delivery of the goods themselves." I In 1823 it was conficlently stated that

"a bill of lading is exactly like a bill of exchange, and the property it refers to passes by indorsement of it, but not by delivery without indorsement." 2

In a later case Alderson, B., declared that the "negotiability" of a bill of lading was something different from the "negotiability" of a bill of exchange, and affirmed that it meant merely the "passing property in the goods:"

"Because in Lickbarrow v. Mason a bill of lading was lield to be negotiable, it has been contended that that instrument possesses all the properties of a bill of excliange; but it would lead to absurdity to carry the ductrine to that length. The word negoliable was not used in the same sense in which it is used as applicable to a bill of exchange, but as passing the property in the goods only." 3

'This langlage passed into many of the cases and much of the literature. For example it was (1S86) said in the Privy Council: ${ }^{4}$

"A bill of lading for the delivery of goods to order and assigns is a negotiable instrument, which ly indorsement and delivery passes the property in the goods to the indorsee, subject only to the right of an unpaid vendor to stop them in transilu."

1. Supre.

2 Ackerman v. Humphery (1823), 1 C. \& P. 5i3. And see Jenkyns v. Usbune (1814), 8 Sc. N. S. $521 ; 13$ L. J. C. P. 196; Blake v. Belfast (1880), 5 L. R. Ir. $4 \geq 0$.
3 Thompson v. Dominy (1845), 14 M. \& W. 408; 14 L. J. Ex. 820.

4 Pease v. Gloahec (1866), L. R. 1 P. C., 227; 35 L. J. P. C. 66 . See also Bank v. Henderson (1874), L. R. 5 P. C. 512. 
And the same idea found expression in some of the statutes:

"A bill of lading of gools being transferable ly iudorsment, the property in goods may thereby pass to the indorsee." i

Similar language is current in the United States:

"Bills of lating are not negotiable instruments in the full sense that promisivory notes are. yet they are justly styled negotiable. Among the reasons for this are that they are well recognized commercial instruments. that where indorsed in blank they carry title by mere delivery from hand to hand, and that the community gives credit in reliance on what appears on the face of them." 2

Lord Bramwell did much to turn the current when he said:

"There is some inaccuracy in the stitute. ${ }^{3}$ It recites that by the custom of mescrante a bill of la ling, bein' transferable by indorsement, the property in the go nls math thereby piss to the indorsee. Now the truth is that the property does not pass by the indorsement, but by the contract in jursuance of which the inlorsement is made. If a cargo afloat is solil, the property would pass to the vendee even though the bill of lading was not indorsed." 4

\section{Indeed as long ago as 1805 Lord Ellenborough held that}

"a hill of lading inleed shall pass the proporty upon a bona fude indorsement and delivery where it is intended so to operate. in the same manner as a direct delivery of the goods themselves would do if so intended, but it cannot operute further." 5

Although the old phraseology is still very general, yet it ean easily be shown that Baron Bramwell's assertion is correct. For it is clear (1) that if a bill be indorsed but without intent to pass the property, it will not pass; and (2) if the bill be not indorsed and yet the parties intended the property to pass, it

$118 \& 19$ Vic. (Imp.), ch. 111, \$1. It recites that "by the custom of merchants, a bill of lading of goods being trausferable by indorsement, the property in groods mathereby pass to the indorsee; but nevertheless all rights in respect to the contract contained in the bill of lading continue in the original shipper or owner:" and enacts that " 1 . Erery consignee of goods named in a bill of lading, and every indorsee of a bill of latling to whom the property in the goods therein mentioned shall pass upon or by reason of such consignment or indorsement, shall have transferred to and vested in him all rights of suit, and be subject to the same liabilities in respect of such goods, as if the contract contrined in the bill of lading had been mate with himself." And see 52 Vic. (Can.), cl. 30 .
2 Pollard v. Reardon (1895). 13 C. C. App. 17f; 65 Fed. R. 8.50. See also Adams v. Folly (1856), 4 Iowa, 44; Gibson v. Bank (1860), 11 Ohio S. C. 311: Michigan r. Phillips (18\%1), 60 III. 193; American v. Henderson (1899), 26 S. R. (Ala.) 498.

3 The statute above referred to.

4 Sewell v. Burdick (1 $\$ 84), 10 \mathrm{App}$. Cas, 10.): 54 L. J. Q. B. 156.

${ }^{5}$ Per Lord Ellenborough in Newson v. Thornton, 6 Ealst, 1\%. Aul see per Lawrence, J., id. p. 42. See to the same effect, Jenkyms v. Usborne (18.14). 8 Sc. N. S. 505; 13 L. J. C. P. 196: Sinders v. Mc:Lean (1883), $11 \mathrm{Q}$. 13. D. 327; 52 L. J. Q. B. 481; Sewell v. Burdick (1884), 10 App. Cass. 74:53 L. J. Q. 13. 399; Porter on Bills of Lading. \$ 498 ff. Lord Hatherly's dictum in Barber s. Meyerstein (18:0), L. R. 4 H. L. 32i; 39 L. J. C. P. $18 \pi$, is too broadly stated. 
will pass. ${ }^{1}$ And the correct view of the effect of an indorsement of a bill of lading is no doubt that ${ }^{2}$

"it confers upon him an authority to receive the goods, and that authority may, as a matter of evidence. go very far to show that the person who his got it bas also acquired a right of property and possession ${ }^{3}$ in the goods; but unless there be such a bargain as would, independently of the assignments of the bill of lading, give an interest in the goods, the assignee of the bill acquires no interest in the goods."

We may say then that the indorsement of a bill of lading has no effect whatever upon the passing of the property in the goods. If the intention was that the title should pass, it has already gone by the contract; and if it was not so intended, the title remains unchanged, even if the bill be indorsed. In other words, goods alloat or ashore, covered or uncovered by bills of lading, are transferred in the same way; that is, by agreement to that effect. The most that can be said is that an indorsement of a bill of lading evidences a transfer of the goods:

"The indorsement of the delivery order upon these evidences of his title, like the inlo:sement upon a bill of lading, sufficiently manifests the intention of the pirties that the title and possession should pass to Gibson." 4

Negotiability.-The jury in the leading case of Lickbarrow v. Mason is to some extent responsible for the idea that bills of lading are "negotiable," for they found that

«by the custom of merchants, bills of lading . . . to order or assigns have been and are... negotiable and transferable by . . such shipper . . . indorsing such bills of lading . . . and delivering or transmitting the same so indorsed." 5

Ashhurst, J., in the same case said that

"the instrument is in its nature transferable; in this respect, therefore, this is similar to the case of a bill of exchange." 6

As we have already seen, Alderson, B., corrected this, saying that although

"in Lickbarrow v. Mason a bill of lading was held to be negotiable . . .

1 For example, an indorsement to the agent of the consignor for some particular purpose will not pass the property. Coxe v. Harden (180:3), 4 East, 211; Branlt v. Bowlby (19:3t), 2 B. \& Ad. 932: Moakes v. Nicholson (1865), 34 L. J. C. P. 273. "Delivery of a bill of lading with intent to pass the title has that effect although the bill is drawn to order and is not indorsed." See City Bank v. Rome (1870), 44 N. Y. 136. And see Bank of Green Bay v. Dearborn (15i4). 11j Mass. 219; Holmes v. German (1878),
87 Pa. St. 525; Porter on Bills of Lading, $\$ 496$ ff.

2 Blackburn on Sales (2d ed.), 391.

"The words "and possession" should be omitted. The indorsement does not "go very far to show" a right to take possession, for it is itself "an authority to receive the goods" - that is, to take possession. It goes far to show " a right of property."

${ }^{4}$ Gibson v. Stevens (1850), 8 How. (U. S.) 400.

$$
\begin{aligned}
& { }^{5} \text { (1797) } 2 \text { T. R., p. } 63 . \\
& { }^{6} \mathrm{Id} . \text { p. p. } 71 .
\end{aligned}
$$


the word was not used in the sense in which it is used as anplicable to a bill of exchange, but as passing the property in the goods only." 1

So, also, it was said in the United States that

"bills of lading are not negotiable instrunents in the full sense that prom. issory notes are, yet they are justly styled negrotiable." 2

In these and many other cases the word was being userl to cover the inability to explain how it could be that although nemo dat quod non habet, yet that where thero was a bill of lading the result seemed sometimes to be otherwise. 'The best that Tindal, C. J., could say for such a curious effect was as follows:

"The actual owner ${ }^{3}$ of an indorsed bill of lading may undoubtedly by indorsement transfer a greater title than he himself has. It is at variunce with the general principles of law 4 that a man should be allowed to transfer to another a right which he himself has not; but the exception is founded on the nature of the instrument in question, which being, like a bill of exchange, a negotiable instrument, for the general convenience of commerce has been allowed to have an effect at variunce with the ordinary principles of law. But this operation of a bill of lading, being derived from its negotiable quality, appears to us to be confined to the case where the person who transfers the right is himself in possession of the bill of laling, so as to be in a situation to transfer the instrument itself, which is the symlol of the property itself." 5

This idea was reproduced in the Privy Couneil, where it was said: ${ }^{6}$

"Doubtless the holder of an indorsed bill of lading may, in the course of commercial dealing, transfer a greater right than he himself has. The exception is founded on the negotiable quality of the document."

Very little consideration, bowever, will make it clear that this notion of the negotiability of a bill of lading is dependent upon the view that the transfer of a bill has some effect upon the title to the goods and must fall with it. The last quotation, for example, spealis of the holder of a bill of lading transferring a greater right than he himself has, because of the negotiable quality of the document. Observe that the greater right that is transferred is not to the bill but to the goods; and that this passes becanse of some quality of the bill. But if transfer of the bill has nothing to do with the transfer of the goods the effect is clearly attributed to the wrong cause. Nore-

1 Ante, p. 320.

2 Ante, p. 321.

3 The words "the actual owner" do not mean the owner of the goonls, for if so there woukl no point in the reference to "variance with the general prineiples of the law."

As to negotiability and its "va. riance with the general principles of the law," see ch. XXIV.

5 Jenkins v. Usborne (1\$4t), \& Sc.

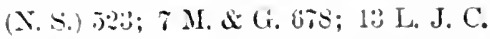
P. $1: 16$.

(i) R. Iger v. The Comptoir (1\$69), L. R. : P. C. 405; 35 L. J. P. C. 30; approvel in Bank v. Henderson (1sit), L. R. J P. C. 512. 
orer to speak of negotiability as a reason is merely to raise the questions, "What is negotiability?" and "How can it produce such an effect?" In another chapter ${ }^{1}$ will be found sufficient ground for suspecting that the word "negotiability" merely masks that which is misunderstood, and that by itself it explains nothing.

Symbolism.- There remains the other view of bills of lading. It is said that they are symbols merely of goods, and must be governed by the law of that which they symbolize; and inasmuch as an unauthorized disposition of goods intrusted to another person will not affect the title of the true orner, so neither can a wrongful disposition of the symbol. Lord Campbell upheld this view in a passage often referred to:

"It is not enough that they had become bona fide holders of the bill of lading for valuable consideration. A bill of lading is not. like a bill of ex. change or promissory note, a negotiable instrument which passes by mere delivery to a bona fide transferee for valuable consideration without regard to the title of the parties who male the transfer. Although the shipper may have indorsed in blank a bill of lading deliverable to his as. signs. his right is not affected by an appropriation of it without his authority. If it be stolen from him or transferred without his authority, a subsequent bona fide transferee for value cannot make title under it as against the shipper of goods. The bill of lading only represents the goods; and in this instance the transfer of the symbal does not operate more than a trans. fer of what is represented." 2

It will realily be seen how far we are now from negotiability. We are in fact at the other extreme - title to goods can be acquired in certain ways only; a bill of lading "only represents the goods;" and "the transfer of the symbol does not operate more than a transfer of what is represented." Bills of lading in this view are no more negotiable than are the goods themselves.

But this theory leaves completely unexplained and inexplicable the undoubted and seemingly peculiar effect which the existence and transfer of a bill of lading has upon rights of parties to goods; for, as we have just seen,

"an actual owner of an indorsed bill of lading may undonbtedly, by indorsement, transfer a greater title than he himself has," which is "at variance with the general principles of the law."

To meet this difficulty, Mr. Porter, in a very good book upon Bills of Lading, endeavors to establish a via media between

$1 \mathrm{Ch} . \mathrm{XXIV}$.

2 Gurney v. Behrend (1854), 3 E. \& B. 633; 23 L. J. Q. B. 26.\%. See to same effect, Blackburn on Sales (2d ed.), 398. And see Burton v. Curyea (1866), 40 Ill. 320; Western v. Wagner (1872), 65 Ill. 197. 
negotiability on the one hand and mere goods on the other. IIe contends that the law relating to such instruments is

"controlled by considerations peculiar to symbols alone, and not, on the one hand, solely by the principle's regulating the possession and transfer of actual goods and cliattels; nor, on the other hand, solely by those regulating the possession and transfer of instrunents representing pure value meisured by a monetary standard." 1

But Mr. Porter does not indicate in what quarter we are to look for the law "peculiar to symbols alone." Negotiability we are supposed to be familiar with; and the law relating to chattels can be ascertained; but we have no book upon "symbols," and the word is not, as a heading, in the digests. ${ }^{2}$

\section{Nkgormability, Srabolisu, and Estorpel.}

Effectively to consider these various riews of a bill of lading we must recall the phenomena that they are supposed to account for. There was in the tirst place the decision in Lickbarrow v. MLason. ${ }^{3}$ A vendor of groods ships them to the purchaser, and indorses to him the bill of lading; the purchaser, during the transit, resells the goods and indorses over the bill of lading to the sub-purchaser; the first purchaser fails, and the first vendor asserts a right to stop in transitu. Now the point to be observed is that although such right would clearly exist if there had been no bill of lading, yet that the existence and indorsement of a bill have taken that right away. Why?

The answer seems to be simple enough: Because the first vendor has accredited the title of his purchaser - by indorsing in his favor the bill of lading he bas indicated to third persons

I Porter on Bills of Lading, $\$ 41 \%$. See also Am. \& Eng. Ency. (니 ed.). IV, 546; Barnard v. Campbell (15it), 5.5 N. Y. $46^{\circ}$; Shaw v. Railroad Co. (1879), 101 U. S. 564; Friedlander v. Texas Ry. (1888), 130 U. S. 4:3; Pollard v. Reardon (1895), 13 C. C. App. 171; 65 Fed. R. 845; Raleigh v. Lowe (1s97). 101 Ga. 320; 2s S. E. R. $86 \%$.

2 There can be no objection to the use made of the word in Michigan 5. Phillips (1871), 60 Ill. 198, where it is said that "the delivery of the bill of lading to the bank was a good symbolical delivery of the highwines, so as to vest the property in the bank.
It was as effective in transferring the possession as the delivery of the keys of a warehouse is of the goods contained in it, or of the store-keeper's receipt of the goods described in it." But it will readily be seen that when so used the word affords no assistance in the problem which Mr. Porter had in hind; for when we have said that symbolical delirery has the same effect as actual delisery we have deprived the word of all its mystery.

${ }^{3}$ (1;87) 2 T. R. $63 ; 1$ H. Bl. 35i; 6 East, 21. 
that he has sold the goods and has no furtber interest in them. He is estopped by the ostensible ownersbip of his purchaser. For lack of such elucidation the idea of the "negotiability" of the bill was seized upon. The word had seemed in some way to explain why it was that a transferee might acquire a better title to bills of exchange than his transferror had. Why might it not be as effective and comforting in the case of bills of lading?

Unfortunately for such a doctrine it involved conclusions that the courts declined to admit. For example, if a bill of exchange were fraudulently transferred by its custodian to an innocent purchaser its "negotiability" provided the transferee with a good title. The courts, however, refused the same result in the case of a bill of lacling; and for such cases it was said that a bill of lading was a symbol of goods, and that a "transfer of the symbol does not operate more than a transfer of what is represented." 1

But, in its turn, this doctrine will not suit the other case; for in it the transfer of the bill of lading does "operate more than a transfer of what is represented." The two views are thus seen to be quite antagonistic; and neither of them will explain the phenomenon to which the other of them alone can be applied. They are both therefore incorrect.

Observe finally that the symbolic view rests upon two ideas: (1) The notion that the indorsement of a bill of lading bas some effect upon the property in the goods - "a transfer of the symbol does not operate more than a transfer of what is represented"-(which, as we have already seen, is a mistake); and (2) the notion that inasmuch as a good title to chattels cannot be given when "transferred without his (the true owner's) authority," it cannot be transferred either where the goods are represented by some symbol.

But the assumption that title to goods themselves cannot be so passed is erroneous. It is a matter of most frequent occurrence (as we bave abundantly seen ${ }^{2}$ ) that ostensible owners and ostensible agents confer perfectly good titles to property which they neither own nor bave any authority to deal with.

\footnotetext{
ISee Pease v. Gloahec (1866), L. R. and also The Argentina (1867), L. R. 1 P. C. 219; 35 L. J. P. C. 66, in which 1 A. \& E. 3i0; 59 L. J. P. C. 17. the dictum is practically reversed; $2 \mathrm{Ch}$. XXI.
} 
The Liclibarrowe v. Mason case, as has been shown, was an example. Another is furnished by a very recent ease. ${ }^{1}$ An owner of goods at a warehouse was induced by fraud to transfer them in the books of the warehouse lieeper to the name of the swindler. It was held that there was no contract between the dupe and the swindler, and that therefore the property in the goods had not passed; but nevertheless that the dupe was estopped from so saying (by 1 auson of the ostensible ownership of the swindler) as against an innocent purchaser. In the same way the holder of an indorsed bill of lading may have no title whatever to the groods, but he has been accredited as the ownerbeen supplied with that which makes his assertion of his ownership credible; and the real owner is estopped by the assistance so rendered to the misrepresentation of ownership.

The True View. - Neither "negotiability" then nor "symbolism" affords us any help in dealing with questions involving the title to goods covered by bills of lading. And we are therefore left free to adopt that which may be termed the eommercial view of the matter:

1. It is the goods that are sold and not the bill of lading.

2. The bill is a document of title which usually accompanies the ownership of the goods it refers to, and is therefore indicative of title to them.

3. Consequently it estops the signer or issuer of it from denying the representations which it contains - the first conclusion.

4. And an indorsement of it will estop the true owner from asserting any elaim as against innocent purchasers by reason of the doctrine of estoppel by assisted misrepresentation - the second conclusion.

Estoppel.-It is the more surprising that this commercial riew of the subject was overborne by the notions of negotiability and symbolism above referped to, when it is remembered that a most excellent start upon the right roal was made as early as 1757 , Ashhurst, J., salying with reference to the alppearance of ownership created by possession of a bill of lading:"

"We may lay it down as a broal. creneral principle that whenever one of two innocent parties must suffer by the acls of a third, he who enables such third person to occasion the loss nust sustain it."

1 Henderson v. Williams (1S95), 1 2Lickbarrow v. Mason (1isi), 2
$\begin{array}{ll}\text { Q. B. } 521 ; 64 \text { L. J. Q. B. } 30 \text { S. R. } 63 . & \text { T. }\end{array}$ 
Consider this case (Liclibarrow $v$. Masmn), for it is the leading one with reference to indorsed bills of lading, although its chief principle has been widlely departed from. The case was prior to the modern formulation of the doctrine of estoppel, but observe liow closely in the quotation just given it follows lines now fimiliar; and althongh it introduces the idea of negotiability, and the passing of property by the indorsement of the bill, yet the law merchant is repudiated, and the rationale is "because it would be enabling either of the original parties to assist in a fraud." Ashburst, J., sair: ${ }^{1}$

"As between the rendor and third persons the delivery of a bill of lad. ing is a delivery of the goods themselves; if not, it would enable the consignee to make the bill of lading an instrument of fraud. The consignee of a bill of lading trusts to the indorscment; the instrument is in its nature transferable in this respect, therefore this is similar to the case of a bill of exchinge. If the consignor had intended to restrain the negotiability of it, he should have continerl the delivery of the goods to the vendor only, but lie has made jt an indorsable instrument. So it is like a bill of ex: change, as in which case between the drawer and the payee the considerat ion nay be gone into, yet it cannot between the drawer and an indorser; and the reason is because it would be enabling either of the original parties to assist in a fraud. The rule is foumded purely on principles of law and not on the custom of merchants. The custom of merchants only establishes that such an instriment may be indorsed; but the effect of that indorsement is a question of law, which is that as between the original parties the consideration may be inquired into, though when third parties are concerned it cannot. This is also the case with respect of a bill of lading."

And Grose, J., more pertinently said: ${ }^{2}$

"A bill of lading carries credat wilh it; the consignor by his indorsement gives credit to the bill of lading, and on the faith of that money is advanced."

Unfortunately the "broad general principle" of estoppel so admirably embodied in these quotations was not appreciated by succeeding judges. To them "negotiability" and antagonism to the general law was all that could be said in explanation of the fact that an owner might lose his title by the ostensible ownership of another.

American Law.- In the United States, although there are many cases in which the judgments proceed upon considerations of "negotiability," there are others which seek to combine "negotiability" with estoppel; and there are a few which may

\section{T. R. 71.}

22 T. R. 76. Buller, J., in one paragrapli takes lower ground and bases the right to stop in transitu upon the fact that the indorsee has the legal property in the goods, whereas the vendor-shipper has an equitable right only. 6 East, 30 (n.), 36 (n.). This is not elsewhere put forward, and is inconsistent with Kenup v. Falk (1881), 5 App. Cas. 577; and the Sale of Goods Act, 56 \& 57 Vic. (Inı).), ch. $71, \Im 47$. 
be cited in support of the present writer's view. The following is an example of the combination referred to:

- Bill of lading in the usual form being a neyotialle instrment, although not in the stme sense as promissory notes or bills of exchange, une who voluntarily puts it out is estopped to claim the gools as agrinst one who innocently alvances value on it, if one of the two must sulfer."

Mr. Colebrook, with an uncommonly clear view of the application of the principles of estoppel (but still holding on to "quasi-negotiability"), thus summarizes some of the cases and says:

"It has hecomr a very common transaction in the commurcial world to use documents and indicia of title, quasi-negotmable under blank imlolsesment, as certificates of stock, bills of ladinir. Warehouse and (")t ton-purs receipts, and other like symbols of property, as collaleral security for the payment of loans. and discounts of commercial papers. Such colliteral securities are readily converted into fumbs, and the value thereof is easily determined by the quotations of the great exchanges. The rules of estoppel in pais or equitible estoppel are involied for the profection of the pledgee for value without notice of such quasi-negrotiable collatelal securties. The representations contained in such documents of title under jndorsement in bink and delively are regarded as of equal weight as representations contained in commercial paper, and the transfer thereof carries some of the privileges enjoyed by uh jndorsee for value of negotiable securities. An innocent pledgee for value of certificates of stock thus indorsed in blank with an irrevocable power of attorney to transfer is vested with an unimpeachable title to the shares of stock. The presumption arises by the possession of certificates of stock indorsed in blank that the pledgor is the owner, althom the certificate and indorsement are in the nane of another person. The pledgee's title is protected as against the owner in cases of fraud and misippropriation where such owner through his mistalien confidence has intrustad to a third person documents or indicia of property indorsed in blank, so that lie has the legal title and apjarent ownership, and is thus enabled to deceice an innoeent pledgee advancing lis money mon the faith thereof. The rules of equitible estoppel are also alplied in favor of the bona fide pledgee for value of bills of lading. warehouse roceipts, cotton-press notes, and other quasi-negotiable collateral securities." 2

To this may be added a paragraph from a recent American decision. It quotes from Lord Ierschell ${ }^{3}$ as follows:

"The general rule of the law is that where a person has obtained the property of another fron one who is dealing with it without the authority of the true owner, no title is acquired as mginst that owner, even thourh full value be given and the property be taken in the belief that an unquestionable title thereto is being obtained: unless the person taking it can show that the true ouner has so acted as to misleal him into the belief that the person dealing acith the property hal authority to do so. If this ean be shou'n, a gool title is acquired by persoual estoppel against the true ouver."

And then proceeds:

"The peculiar form and phraseology of ordinary bills of lading, and the generally linown reliance pliceel 11 pon them. and credit given them in commercial communties, render the principles of these expressions especially

1 Pollard $v$ Reardon (1895), 13 C. C. See the cases there cited; and see A. $171 ; 65$ Fed. R. 848.

2 On Collateral Securities, p. 34. 3 Simmons r. London (1892), A. C. $215 ; 61$ L. J. Cl. 723. 
applicable to them: and common honesty, in the light of modern business and tinancial methods, throws a special burden on those who put them out."1

Such and similar langruage is having its effect in breaking down that view of the law which is well represented both in England and America by the following quotations from Smith's Mereantile Law:

"Therefore, save in cases within the Factors Act, delivery by a person who has improperly obtained it, or without anthority from the owner, of a bill of lading indorsed in blank to a bona fide transferee for value, confers no title to the goods which it represents."2

By the American annotators of the same work it is said:

"Nothing can in fact be a greater departure from the principles and analogies of the common law than to treat bills of lading or other documentary evidences of title to chattels perional as negotiable instruments. Instruments which represent choses in action may be negotiable because the right camnot be separated from the instrument. and has no distinct or actuil physical existence. And even there negotiability only exists in the case of absolute promises for the payment of money, a thing negotiable in itself and which cannot be reclaimed by the true owner of any one who has received it bonc fide and in exchange for valuable consideration. But chat tels personal are wholly insusceptible of negotiation ${ }^{3}$ in themselves, and it is manifestly inconsistent to give the documents which represent them a different character. The result of the cases, therefore, as a whole seens to be that while on the one hand the possession of bills of lading or other documents of the same nature may be evidence of title, and equivalent for some purposes to actual possession, yet that on the other it cloes not constitute titie nor dispense with the rile nemo plus juris ad alium transferre potest, quum ipse habet." 4

\section{Some Later Cases.}

Although it cannot yet be said in England that there has been any substantial recognition of the principles here advocated, yet the cases are moving in the direction which these principles justify; and there is much in analogous departments of the law which can be cited in iheir favor. As we have already noted, the only qualification of the doctrine of "symbolism" was that indorsement of a bill of lading would deprive a consignor of his right to stop in transitu; any other rights which he or anybody else might have were unaffected.

But observe the entrance of the wedge in 1866: A bill of

1 Pollard v. Reardon (1895), 13 C. C. A. 171; 65 Fed. R. 850.

210 th ed., vol. I, 346.

3 Observe how a change from the usual expressions "negotiable" and "negotiability" to "negotiation" at once challenges attention, and makes us wonder whether after all goods are incapable of being the subject of negotiation - are not "negotiable." Cannot they be sold and transferred? See the phrases discussed in chapter XXIV.

4 8th Am. ed., § 1226. And see $\$ 1750$. 
lading was sent to the vendor's agent with authority to transfer it to the rendee; he did transfer it, but retook it as security for the purchase-money; by means of a fraudulent pretext the purchaser again got possession of it, and with its help sold the goods. Now apparently it was almitted that if the bill had been obtained by the same sort of fraud from the shipper ho could have successfully claimed the goods; but the shipper, having indorsed the bill to an agent (from whom it was taken). Lord Chelmsford told him that Lord Campbell's previous dictum ("The transfer of a symbol does not operate more than a transfer of what is represented")

" is very carefully confined in its terms to the original transfer of a bill of lading deliverable to the assigns of the shipper. In the calses which it cupposes there could be no lawful assigns of the shipper, and consequently the bill of lading could have no existence as a negotiable instrument. But in the present case the shipper of the goods, having obtained a bill of lalling, indorsed it to order and assigns and forwarded it to $S$. (the agent) for the express purpose of it being indorsed by him and handed over to $S$. \& T." (the original purchasers).

The next step was to hold (1867) that although the agent had express instructions not to part with the bill of lading without receiving payment, yet if he did so an innocent transferee was safe." Clearly, if an agent (apart from special circumstances) hal been intrusted with goods to be handed over to some one only upon receiving certain moneys, a breach of his instructions would in no way affect the principal. This last decision can be justified upon the principles of estoppel only. It goes beyond the legislation which provides

"that where a locument of title to goods has been laufully transforred to any person as buyer or owner of the goods. and the person transfers the document to a person who takes the document in good faith and for valuable cousilterition. . . . the unpaid seller's right of lien, or retention, or stoplye in transitu, can only be exercised subject to the rights of the transteree." 3

Noving still further away from Lord Campbell's view is the ease of Bank of India $v$. Henderson (1sit) in the Pricy Conneil.4 Goods were sold and shipped upon the agreement that they were to be sent to the purchaser's agent, who was

1 Pease $:$ Gloahec (1S66), L. R. 1 P. C. $219 ; 35$ L. J. P. C. 66 . See similar distinction taken as between a hill of exchange intended to be issued and one not so intended, in chapter XXIV.

2 The Argentina (186r), L. R. 1 A. \& E. 375; 59 L. J. P. C. 17.
${ }^{3}$ The Factors Act, $52 \& 53$ Vic. (Imp.), ch. 45, \$10.

4 L. R. 5 P. C. 501. See similar cases, but disposed of upon other grounds: Rolger v. Comptoir (1869). I. R. 2 P. C. $393: 38$ L. J. P. C. 30 ; Henlerson v. Comptoir (18i3), L. R. 5 P. C. 253 ; 42 L. J. P. C. 60. 
to remit the proceeds for application upon the purchase-money; the purchaser having received the bill of lading for this specific purpose, fraudulently pledged the goods and indorsed the bill to a bank; held, that the bank had acquired a good title.

In further development of the same principle is the recent (1595) case of Itenderson $v$. IVilliams. ${ }^{1}$ It was a case of goods not at sea, but in a warehouse, in which the owner was tricked into a transfer of them. The court held that the transfer was not made in pursuance of any contract, and therefore that no title passed, but

"the true owner having enabled F. to hold himself out as the owner could not set up his title against that of the purchaser;"

In other words, ostensible ownership will estop even where the appearance of title is not only not with the assent of the true owner, but has been obtained by fraud upon him.

With such cases in view what ought to be done with such a point as this? A vendor sent to his purchaser a bill of lading, and also for acceptance a bill of exchange for the price; the purchaser ought to have retained the bill of lading unless he accepted and returned the dlaft; be did neither, but wrongfully transferred the bill of lading to an innocent purchaser. The case seems to be simple enough - the original vendor is of course estopped, for be has permitted the appearance of ownership in another person. Unfortunately, bowever, there is a provision in the Factors Act ${ }^{2}$ which declares that

"where a person having bought or agreed to buy goods, obtains with the consent of the seller possession of the documents of title;"

from which it was assumed that the only question was whether the first purchaser was or was not "with the consent of the seller in possession of the documents of title;" it was held that he was not; that the act did not help the sub-purchaser; and that he must lose - not a word about estoppel, or the case of ITenderson $v$. Williams above referred to. ${ }^{3}$ Upon appeal a dif. ferent reading of the statute led to an opposite conclusion. ${ }^{4}$

1(1895) 1 Q. B. 521; 64 L. J. Q. B. 309. And see the discussion in chapter XXI.

$252 \& 53$ Vic., ch. 45, \$ 9; The Sales of Goods Act, 56 \& 57 Vic. (Imp.),

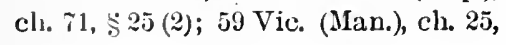
$\S 24(2)$.
${ }^{3}$ Cahn v. Pocketts (1898), 2 Q. B. 61: 67 L. J. Q. B. 625 . For other instances of the baneful effect of the Factors Act, in diverting attention from principle, see chapter XXIII. ${ }^{4}$ (1899) 1 Q. B. 643; 6s L. J. Q. B. 515. 
American Authorities. - Although it cannot be said that any early exposition of the law equals in value the sentence which we have several times quoted from Mr. Justice Ashlurst's judgment in Licklarrow v. Mason, yet fortune so willed that a dictum of Mr. Justice Story in 1828 should bave in America a greater effect in rightly directing the law as to bills of lading than that of the English judge had in his country.' Judge Story said:

"By the well-settled principles of commercial law the assignee is thus constituted the authorizel agent of the owner, whoever he may be. to receive the gools; and by his indorsement of the bill of lading to a bona fide purchaser for a valuable consileration without notice of any arlverse interest, the latter becomes as anainst the world 2 the owner of the goods. This is the result of the principle that bills of lading are transferable by indorsement, and thus may pass the property. It matters not whether the consignee in sueh ease be the buyer of the goods or the factor or agent of the owner. His transfer in such cises is equally capable of diverting the property of the owner and vesting it in the indorsee of the bill of lading." 3

It will be seen that we are by this statement of the law at once away from the mere question of the effect of the transfer of a bill of lading upon the right to stop in transitu; and although we have wrong basic principles: (1) that the indorsement of a bill of lading passes the property in the goods; and (2) that the assignee is an agent, yet that is a defect, not in the statement of the law but in the reasons given for it.

The error nevertheless had its effect; so that even after estoppel was thought to be the true ground of decision, its principles were not at once completely grasped. For example, a bill of lading was handed to an agent to be delivered to a purchaser of the goods when a draft for the purchase-money was paid; the agent gave it up upon receiving an acceptance merely of the draft; the purchaser pledged the goods; and it was beld that the pledgee could not retain the goods as against the original vendor, for the agent had no authority to transfer the bill. Estoppel would of course decide the other way.

More in harmony with the prineiples of estoppel is a later case: The owner of gools, in pursuance of an arangement with

1 As to the effect upon the general 385. See Munroe v. Philadelphia law of Mr.Justice A shhurst's dictum, see ch. XIV.

2 This is too wide. If the gools had been shipped by a thief of them, no transfer of the bill of lading could oust the true owner. (1896), 75 Fed. R. 546.

4Stollenwerck $v$. Thacher (1874), 115 Mass. 224. No objection upon the ground of estoprel can be mate to Siltus v. Everett (18:8), 20 Wend. (N. Y.) 268.

${ }^{3}$ Conard v. Atlantic (1528), 26 U. S. 
a purchaser, delicered them to a carrier, taking a receipt indicating that "bills of lading will be issued on return of this receipt;" the owner retained the receipt; the carrier notwithsuanding his receipt issued a bill of lacling to the purchaser, who pledgred it; held, that the pledgee was entitled as against the owner. ${ }^{1}$

To the same effect is a very recent case in the federal courts. Goods in process of shipment were transferred by bill of sale; the purchaser neglected to ask for a bill of lading; the vendor got it, and with its assistance fraudulently resold the goods; the second purchaser was preferred. Proceeding upon the principles of estoppel the court inquired

"whether the plaintiffs had by their own conduct enabled Smith to hold himself forth to the world as having, not the possession only, but the property?" and added: "When Pollard, Pettus \& Co. accepted from Miansfield a bill of sale of the hides in question, they knew that in the regular course of business a clean bill of lading for them would issue to him, clothing him with the customary indicia of absolute ownership. They took the chances arising from this. They must stand as though they assenterl to it, and they can claim no right against any one who dealt with Mansfield in good faith relving upon it. Their presumed assent to the issue of the hill of lading to iransfield is emphasized by their laches in applying for it. Whatever may he the nature of their right it cannot prevail against Reardori's title uniler the bill of lading." 2

Similar to the P'rivy Council case of Bank of India $v$. Menderson above referred to ${ }^{3}$ is that of Munroe $v$. Philadelphia, ${ }^{4}$ in which a transfer of goods, and indorsement of its covering bill of lacling in breach of trust, was beld to give a good title to the transferee.

One further American case. Its dicta relate to warehouse receipts, but the same principle governs all sorts of documents of title. Notes payable in property were by the law of the state transferable but not negotiable. They were left with an agent for collection, who fraululently transferred them to an innocent purchaser. It was held that the true owner

"having put its agent in possession of the notes, which showed on their face that the latter was owner, was estopped from questioning the title of the transferee."

"A pledgee himself may, by his neglect or through misplaced confidence, bring himself within the rule of equitable estoppel; as where he has

1 Fourth Nat. Bank v. St. Louis (1882), 11 Mo. App. 333. In England in a somewhat similar case (Schuster v. McKellar (18,5), 7 E. \& B. $704 ; 26$ L. J. Q. B. 281). where the vendor had the mate's receijt, and a bill ought not to have been issued until receipt had been given up, the decision was the other way - the vendor won.

2 Pollard v. Reardon (1895), 13 C. C. A. 185; 65 Fed. R. 852.

- 3 Ante, p. 331.

475 Fed.R. 54J. 
permitted the pledger to take possession of the property and to olstain warehouse receipts for the same. In such cases the pledgee is estopled to sel up his title as against a subsequent pledgee, receiving the receipt in good faith for value advanced on the credit of his tille and possession. The Iike rule applies where the owner of property allows a patly to talie warehouse recejpts in his own name. being deceived by his fradulent conduct, and the receipts are negotiable as collateral security to a bona fide pledgee for vilue without notice of the fraud."

Observe how easy it is to dispense with "negrotiability" and "symbolism."

The extent to which we have departed both in England and America from the idea that "the transfer of a symbol does not operato more than a trinsfer of what is represented" will now be appreciated. It is hoped too that what has been said wil! sufficiently prove that such departure is to be in no way attributed to the "negotiability" of bills of lading; but that it must be set down to elearing apprehension of the principles of estoppel by ostensible ownership and ostensible agency.

\section{Dock Warraxts, etc.}

The law as to dock warrants, etc., has pursued a course somewhat similar to that just traced in dealing with bills of lading. That is to say, it commenced with the enunciation of sound general principles; those principles were speedily lost sight of, to reappear here and there as ineffective dicta or for the mere purpose of being condemned; while nerertheless some "stream of tendency which maketh for righteousness" was accomplishing useful work - a tendency this time manifesting itself in acts of Parliament and thwarted by the courts.

The Early Law. - What can be better than the declaration of Lord Ellenborough in 1812:

"Strangers can only look at the acts of the parties and to the external indicia of property, and not to the first communicalions which may pass between a principal and his broker; and if a person authorize another to assume the apparent right of disposing of property in the ordinary course of tride, it must be presumed that the apparent authority is the real authority." 2

Unless, indeed, it be the statement of Payley, J., in 1S17, that nemo dat quod non habet

"will certainly not apply where the owner of goods has lent himself to accredit the title of another person by placing in his power those symbols of property which have enabled him to hold himself out as the purchiaser of the groods." 3

1 Atlanta v. Hunt (1S97), 100 Tenn. $89 ; 42$ S. W. R. 482. And see cases there cited.

2 Pickering v. Busk (1S12), 15 East, 33.

${ }^{3}$ Boyson v, Coles (181i), 6 M. \& S. 
To the same effect Abbott, C. J. (1S24), held that the question which ought to have been left to the jury was

"whether the plaintitrs had by their own conduct enabled Smith to ho'd himself forth to the world as having not the possession only, but the property..

Nothing eould be more satisfactory than these expositions of the law. And for the future it seemed as if the only question was to be one of fact: Did the true owner "accredit the title" of the ostensible owner (by handing over to him documents of title or otherwise)? If so he is estopped.

Unfortunately, however, the law as thus stated was almost immediately overlooked. Afterwards it was qualified and minimized, then overruled, and finally underwent partial and incongruous resuscitation by acts of Parliament, which well-nigh sent to oblivion the principles upon which it restel.

Submergence. - In 1525 (one year only after the decision of Abbott, C. J.) Best, C. J., had a case before him very much like those alrealy referred to, and he decided against the innocent purchaser, deploring that the state of the law gave him no alternative:

"Had I authority to alter the law, as the mode of carrying on commerce has altered, I wouli say that when the owner of property conceals himself, whoever can prove a good title under the person whom the concealed owner permits to hold it should retiin that property against the owner; but this is not yet the law of England." 2

The decision may be taken to be the commencement of a most curious struggrle (still unfinished) between Parliament and the courts, the former endearoring (by its Factors Acts) to bring the law into harmeny with mereantile usage, and the courts, with minutest criticism, declaring that Parliament has not yet effectively done it. Not prineiple nor commercial usage, but inclusion within literal and narrow interpretation of statutes, became the test of ownership of merchandise, with such results as we might expect. Unfortunately, too, some of the states of America and provinces of Canada became involved in the contest.

24. Compare the finding of the jury in that case with the finding in Spear v. Travers (1815), 4 Camp. 251: "That in practice the indorsed dock warrants and certificates are handed from seller to buyer as a complete transfer of the goods."
1 Dyer v. Pearson, 3 B. \& C. 38.

2 Williams v. Barton (1825), 3 Bing. 139. See also per Parke, B., in Phillips v. Huth (1840), 6 M. \& W. 596; 9 L. J. Ex. 326. 
Here and there no doubt during this unsalisfactory period the old prineiples are cited, and even satid to be still in elfective service. For example a well-known judgment of Mr. Justice Blackburn in 1575 contains the following:

"If the owner of the gools had so acted as to clothe the seller or plergee witl apparent anthority to sell or pledge, he was at common law prcelnifeld, as against those who were induced boma firle to act on the finith of that apparent athority. from denyiner that he hat given such an authority. and the risult was the sime as if he had really given it."1

But all such declarations are in 1877 specifically and elaborately discarded, with the remark that if leaving documents of title in the hands of another might estop the owner of the groods as against an innocent purchaser of them,

"there would have been, as it seems to me [Cockburn, C. J.], no necessity for giving effert by statute to the unathorized sale of goods by a factor." 2

The chief eflects then of these Factors Aets (passed for the purpose of accomplishing that which Best, C. J., declared was beyond the power of the eourts) were in the first place to divert attention from principles which were in reality quite sufficient for the eases, and secondly to furnish proof that no such principles existed. The case from which the above extract is taken was incleel at once ${ }^{3}$ reversed by Parliament (forming an interesting episode in the struggle); but the decision remains as a formidable obstacle should we again try to proceed upon principle. ${ }^{4}$ IIal the learned chief justice observed the dicta in a IIonse of Lords case of but six years before, we might, instead of barricale, have had from him as much help as he bas eontributed to other departments of the law. For Lord Hatherly had declared for the old principles when he said:

"When, however. one person arms another with a symbol of property he should be the sufferer, and not the person who gives credit to the operiation and is misled by it:" 5

and Lords Chelmsford and Colonsay had agreed with him. The case, however, went off in the Lords upon misleading analysis of the Factors Aets, and the dieta (the only parts valuable) were overlookel. They may still be of service.

I Cole s. North Western (18r5), L. R. 10 C. I'. $363: 44$ L. J. C. P. 23:3.

2 Per Cockburn. C. J., in Johnson v. Crejit (15ij), 3 C. P. D. $40 ; 47$ L. J. C. P. $24 \pi$.

3 Before it was heard in appeal. 40 \& 41 Vic. (Imp.), ch. 39. \$ุ 3. See now Fitctors Act, 53 \& 53 Vic. (Imp.), clu. 45,58 : Sille of Goouls Act, $56 \mathbb{E} 5 \tilde{5}$
Vic. (Imp)., cl. 71, § 25 (1); 59 Vic. (Man.), ch, 25, $\$ 25(1)$. And see Burton r. Curyea (1866), 40 Ill. 3:0; Western v. Wagner (18\%2), 65 III. 19\%.

+ Henderson v. Williams (1895), 1 Q. B. 521; 64 L. J. Q. B. 308, will however be of much service.

5 Vickers s. Hertz (1\$i1), L R 2 Sc. $\Lambda_{\text {pp. }} 115$. 
Let us consider for a moment the case from which Chief Justice Cockburn's words are taken. The owner of warehoused goods sold them, but retained the warrants, and the purchaser took no steps to have the appearance of title in the warehousewan's books changed in his own favor; the vendor resold the goods to an innocent purchaser; and the first purchaser, notwithstanding his assistance to the ostensible ownership of the vendor, was held to be entitled to the goods. The learnerl chief justice is quite satisfied as to the demands of justice; and that there was wanton inattention to the interests of other persons; but he declares that he is not satistied that

"at common law the leaving by a vendee goods bought, with the documents of title, in the hands of a vendor . . would on a fraudulent sale or plelge by the party so possessed divest the owner of his property. or estop him from asserting his right to it. If this had been so ther would have been, as it seems to me, no necessity for giving effect by statut. to the unauthorized sale of goods by a tactor."

From the standpoint of estoppel the case is of course a very. clear one; and as we have said, the "stream of tendency" operating through Parliament at once corrected the decision. But Parliament declared no principle. The court had said that il a purchaser of goods misleads people by leaving the documents of title in the possession of the vendor he is nevertheless safe. and the second purchaser must lose. And Parliament with categorical negative declared that if a purchaser leaves the dociments with his vendor he should lose, and the second purchaser should have the groods.

The effect of the statute then is to leave the matter in very. incongruous and unsatisfactory form; for a single instance (f) the application of a general principle is separated from all other instances, and the law as to it, being arbitrarily declared by Parliament to be so-and-so, the inference is suggrested that other cases ought to be otherwise determined.

Resemblance to Bills of Latling.- In fact the ditficulties encountered in dealing with dock warrants, etc., were threefold: (1) The law as to bills of lading had not been placed upon a proper basis; (2) the essential resemblance between bills of lading and other documents of title was not observed; and (3) the unifying principle of estoppel was not applied to them. For example, although as we have seen a transfer of a bill of lading to an innocent purchaser would clearly cut out the right of the consignor to stop in trensitu, yet it was said that 
it was otherwise in the ease of a delivery order.' This ruling in its turn was reversed by Parliament; but again no principle is enunciated, agrain a mere catergorical contraliction:

"The last mentioned transfer shall have the same efiect for defeating any vendor's lien or right of stoppage in transituas the transfer of a bill of lading has for defeating t!e riglit of stoppage in transitu.".2

The result is that when some other documents (certificates, for example) are met with, which are thought not to be within the letter of the statutory provision (although in trade they are used for exactly similar purposes), the statute does not apply and injustice is again done. So capaule a judge as James, L. J., argues in this way:

"The whole equity of the bill . . . is this: that it is said that such certificates, according to the custom of the iron trade in similar cases, are in fact warrants. To say that is in truth to say a thing which cannot be. No custom of the tralle can make a certificate a bill of exchange or a warrant. What is evilently meant by that allegation... is that people deposit the certificates is if they were warrants. That is really what it comes to. Everybody knows that warrats are things walmanting a wharf. inger or warranting somebody else who las possession of the gools to deliver them. The owner of the goods gives an authority to the person who is the bitilee of the goods to deliver them. That is what is meant by a warrant. Such warrants are constantly dealt with, and if they are negotiable they are properly and validly dealt with as a security. And what is meant by saying that such certificates. according to the custom of the iron trade in similar cases, are in fact warrants, can only be this: that persons lend money upon warrants. They may lend money as much as they like, but they cannot alter the nature of the documents. No practice of the persons who have got those certificates and money lenders as between them, would in any way affect the manufacturer unless you can show that the manufactmrer has in some way authorized something to be done." 3

So also in Furmeloe v. Buin unpaid vendors gave to their purchaser the following doeument:

"We hereby undertake to deliver to your order indorsed hereon 25 tons . . . zinc, off your contrilct of this dite."

It was admitted that the vendors signed the document,

"intending that the same should operate as a representation to all persons to whom the same should he shown that the goods therein mentioned were the property of B. \& Co. (the first purchisers) free from all lien or claim;" and the purchaser resold the roods and indorsed the document to his rendee. Under these circumstances estoppel ought to preclude the vendor from asserting his lien as against any one

1 Jenkyns v. Usborne (1844), 8 Sc. N. S. 505; 13 L. J. C. P. 196; approved in Barnard v. Campleil (18\%1). is $\mathrm{x}$. Y. Supp. 461, 462. And see M.EW:i:? r. Smith (1849), 2 II. L. C. :it)?.

2The present statute is 52 \& 53 Vic. (Imp.), ch. $45, \$ 10$.

${ }^{3}$ Gumm v. Bolckow (18ij), L. R. 10

Ch. $491 ; 44$ L. J. Ch. 732.
4 (15i6) 1 C. P. D. 445: 45 L. J. C. P. 264. Merchants v. Plicnix (15:i), 5 Ch. L. :16; 46 L. J. Ch. 418, which followed in the next year, is almost identical with Farmeloe r. Bain, except thiat the document was of more faniliar character; and the vendors were estopped. 
changing his position upon the faith of the instrument; but the case goes off upon the ground that the instrument was not one of customary character.

The point missed in such cases is the generalization of the quotations above given, and the application of these quotations to commercial usages as they arise and develop.

Under previous headings will be found further discussion of the subject in hand, and in a later chapter the Factors Acts (without discussion of which the present chapter would be palpably defective) are treated of at length. ${ }^{1}$ The reader is requested to refer to those other parts of the book for that which might very well appear here, but which is too long for repetition, and is more necessary elsewhere.

\section{Simares in Companies.}

Estoppel, in its application to shares, has the same two aspects as have been noted when dealing with other documents of title, namely: (1) Estoppel of the company that issues share certificates; and (2) estoppel of the transferrors of shares.

Estoppel of the Company.-Upon this we need not dwell. Let it suffice at this place to say that the law now is clear that a company is estopped by its certificates from denying the fact represented by it as against persons who change their position upon the faith of it. ${ }^{2}$

Estoppel of the Transferror.-Cases in which a transferror of shares may be estopped may be divided into two classes: (1) Cases in which shares have been completely transferred to a trustee, who, in breach of his trust, makes some disposition of them; and (2) cases in which blank transfers bave been intrusted to some one who misuses them.

Shares Transferred to a Trustee. - There ought to be no difference between lands and shares in cases of priorities arising out of breaches of trust; but yet the assertion may well be ventured that if a case involving land were put to a well-read

1 Ch. XXIII.

2 Re Bahia (1868), L. R. 3 Q. B. 584; 37 L. J. Q. B. 176; Bishop v. Balkis (1890), 25 Q. B. D. 77,$512 ; 59$ L. J. Ch. 56.5; Tomkinson v. Balkis (1891), 2 Q. B. D. $614 ; 60$ L. J. Q. B. 558; Re Ottos
(1893), 1 Ch. 618; 62 L. J. Ch. 166; Re Concessions (1896), 2 Ch. 757 ; 65 L. J. Ch. 909; Moores v. Citizens (1883), 111 U. S. 156 ; 4 S. C. R. 345; Trimble v. Bank (1897), 71 Mo. App. 467. 
lawyer, he would at onee inquire about the legal estate, and if it related to shares be would probably commence to think about estoppel.

With reference to land no doubt the law is at present firmly founded upon various "technieal and unsatisfactory" ' rules as to legal and equitable estates. If the purehaser from the trustee acquired the "legal" estate he is safe; and if he dicl not he loses. A former chapter has dealt at length with that subjeet. $^{2}$ And there are not wanting cases relating to shares in which the same rules hare been applied. ${ }^{3}$ But the rational principles of estoppel by ostensible ownership are superseding these "teehnical and unsatisfactory" rules; if indeed (as seems probable) they may not alrealy be said to be in possession of the field.

Reserving julgment upon this point for a moment, let us pass on to the consideration of cases in which the trustee not merely misappropriates shares, but in order to do so fraudulently fills up blank transfers intrusted to him. For if in such an instance a purchaser (upon principles of estoppel) is safe irrespective of questions of legal estate, we shall have no difficulty in the simpler case which we are learing behind.

The Swan cases in 1859-1863' with reference to shares are interesting and instructive. The owner of shares in two companies - A. and B.-employed a brolier to sell the A. shares, and garo him several signed but blank transfers; the broker fraudulently filled up one of the transfers with the B. shares, and sold them to an innocent purchaser. After much doubt it was determined that the true owner of the shares was not estopped by handing over the blank transfers. But the judgments leave little room for doubt that had the true owner further equipped the broker for the fraud, by intrusting him with the $\mathrm{B}$. certilicates. be would have lost his shares.

1 Ante, p. 255.

2 Ch. XVIII.

${ }^{3}$ Reg v. Shropshire (1873), L. R. 8

Q. B. 420 ; L. R. 7 II. L. 496 ; 45 L. J. Q. B. 31 ; Marshall v. National Bank, etc. (1892), 61 L. J. Ch. 46.); Weaver v. Barden (1872), 49 N. Y. 286 . Whatever the true ground of decision chere is no doubt that the purchaser will be safe if he acquire the "legal" title. Crocker v. Crocker (1865), 31 N. Y. 507 .

4 Ex parte Swan (1859). $\tau$ C. B. N. S. $400 ; 30$ L. J. C. P. 113; Swan r. North British (1862), 7 H. \& N. 603; 31 L. J. Ex. 425; 2 H. \& C. 175; $32 \mathrm{~L}$ J. Ex. 273. 
A few years afterwarls (1S71) a New York case of much importance (Mci Teil v. Tenth National Bank ${ }^{1}$ ) was decided. The owner of shares pledged them with bankers, giving to them the certificate upon which was indorsed a blank assignment and power of attorney to do "all necessary acts of assignment and transfer;" the bankers fraudulently disposed of the shares; and the owner was held to be estopped upon the ground "that where the true owner holds out another or allows him to appear as the owner of or as having full power of disposition over the property, and innocent parties are thus led into dealing with such apparent owner, they will be protected."

The principle of this decision has been approved in Pennsylvania Ry. Co.'s Appeal (1878), ${ }^{2}$ in Otis v. Gardner (18s3), ${ }^{3}$ in Colonial Bank v. Hepworth (1887), ${ }^{4}$ and Williams v. Colonial Bank $(1887,1890),{ }^{5}$ in Mone v. Boyle $(1890),{ }^{6}$ in Waterhouse v. Bank of Ireland (1892), ${ }^{7}$ in Robinson v. Montgomeryshire (1896), ${ }^{8}$ in Cotfey v. Coffey (1897), ${ }^{9}$ in Boultbee v. Gzowski (1897), ${ }^{10}$ in Gilbert v. Erie (189s), in Smith v. Rogers (1899), ${ }^{12}$ in Brown v. Equitable (1899), ${ }^{13}$ in Musury v. Arkansas (1899), ${ }^{\text {"A }}$ and may now be said to be firmly established.

The interesting question now arises, Upon what principle can such decisions rest? It seems to be impossible to stretch the word "negotiability" so as to account for a transferee of shares acquiring a better title than that of his grantor. ${ }^{15}$ The doctrines associated with distinctions between legal and equitable estates too are insufficient, for in many of the cases only an equitable interest (as it is still called ${ }^{16}$ ) in the shares was transferred. Both of these suggestions moreover have been distinctly repudiated in the IIouse of Lords as well as in the United States.

${ }^{1}(1871) 46$ N. Y. 325.

286 Pa. St. 80 . And see Darey's A ppeal (1881), 97 Pa. St. 153.

3105 Ill. 436.

436 Ch. D. 53 ; 56 L. J. Ch. 1097.

536 Ch. D. 659 ; 38 Ch. D. 388 ; 57 L. J. Ch. 826 ; s. C. sub nom. Colonial Sank v. Cady (1890), 15 App. Cas. 207; 60 L. J. Ch. 131.

${ }^{6} 27$ L. R. Ir. 137.

т 29 L. R. Ir. 384 .

8 (1896) 2 Ch. 841 ; 65 L. J. Ch. 915. 974 Ill. App. 241.
1024 Ont. App. 502; 29 S. C. Can. 54. 11184 Pa. St. 554; 39 Atl. R. 291. 1230 Ont. 256.

1378 N. W. R. $103 ; 79$ N. W. R. 968. 1493 Fed. R. 603.

${ }^{15}$ See the remarks of Jessel, M. R., with reference to warehouseman's warrants in Merchants v. Phœuix (1877), 5 Ch. D. 205; 46 L. J. Ch. 418. See ch. XXIV as to this word "negotiability."

16 See the remarks in $\mathrm{ch}$. XVIII. 
The only remaining ground seems to be estoppel; but this in its turn was repudiated by Kekewich, J., saying that it was not applicable (to a case in which certain executors intrusted Messrs. Thomas with blank transfers) in

"the strict technical sense of the worl, as it cannot be suggested that the executors are precluded from assertmo the truth. On the contrary, my judgunent goes on an examination of the real facts. What they are prescluded from asserting, in my julgment, is that Messrs. Thomas were not by the custorly of these documents, with their assent, authorized to deal with them as they from time to time considered desirable." I

But this is precluling them from asserting the truth; for the admitted fact is that the brokers were not so authorized. They appeared to be aluthorized; and upon the faith of that appearance a third person changed his position - that is estoplpel.

Mr. Justice Chitty almits estoppel as the governing principle, but states it in this way:

"What then is the estoppel here? Having regard to the practice proved and the condition in which these documents are when they fiass from hand to hamd, the right principle to adopt with reference to them is to hohl that where (als is the cise before me) the transfers are duly signed by the regristered hohlers of the shares, ench prior holder confers upon the bona fide bolder for value of the certificates for tl e time being an anthorily lo fill in the mame of the transferee, and is estopped from denying such anthority; and to this extent and in this manner, but not further, is estopled from denying the title of such holder for the time being."

But there is confusion here. If "each prior holler confers - . . an authority to fill in the name of the transferee," it is ineorrect and mnnecessary to add that be "is estopped from denying such authority." If he has really given authority he camnot deny it anyway. The question only arises when there is no anthority in fact; and then there is estoppel, not because there is anthority, but because there is the appearance of authority, and by that the true owner is estopped.

Mr. Justice Chitty's solution is open to the criticism that it imports as a fact that which is admitted to be untrie. It is said that "each prior" holker . . . confers an authority to fill in the name of the transferee;" but that is precisely what he does not do - it is exactly because it was not done that the trouble arises maling necessiry an appeal to estoppel, which admits that there was no authority, and prechdes the owner from so alleging. 'That is better than changing the lacts.

This remark supplies the answer to Mr. Justice Lindley's suggested explanation of Mr. Chity's languluge - that the per-

1 Williams ^. Colonial Bank (1585), 36 Ch. D. 6i1; 57 L. J. Cis. S43?. 
son upon whom authority is supposed to be conferred must not only be "the holder for value of the certificates," but also " the person entitled to the certificates." I If it be necessary to prove the existence of authority, then no doubt it is only persons rightfully entitled to the certificates that can exercise that authority, for to them alone was it given; but if the estoppel arises from the appearance of authority, then it may exist apart altogether from the rightfulness of the title.

One further point: The suggested solution will not apply at all under certain circumstances. If the person intrusted with the blank transfer exhibits it in its incomplete condition to a purchaser, there is no cloubt appearance of (even if no real) authority to fill up. But suppose that the person intrusted bas filled up the blanks with his own name before exhibiting them, there is then no appearance of authority, and no necessity for any. The clocument appears to have left its signer's hands in complete form. The case has now changed from one of ostensible agency to one of ostensible ownership. ${ }^{2}$

We thus arrive at the conclusion that the true rationale of the decisions in band is ostensible agency. where the purchaser is aware of the existence of blanks; and ostensible ownership, where he has no such notice; and that "negotiability" and legral estate have nothing to do with the questions. Perhaps it is too much to hope that the mere dicta of Lords Watson and Herschell will put a sudden termination to "negotiability" and legal estate as factors in such problems. Nevertheless they will certainly help powerfully the present trend of the law in that direction. Lord Watson has saicl:

"Even when the delivery (that is by the persons intrusted with the transfers) has been fraudulent, as in the present case, the Supreme Court of New York has held that the registered owner cannot reclaim the document from a holiler who has given valuable consideration in good faith and without notice of the fraud. But it is necessary to observe that the decision of the conrt did not attribute to the instrument any privilege or negotialuility, in the legal sense of that term. It was based . . . upon the circumstance that the registeret owner has so dealt with that certificate as to lead the purchaser for value to believe that he was taking a good title to it. In other words, the foundation rests in the principle of estoppel. Thus far the principles of American cases appear to me to be in harmony with the principles of English law." 3

Lord Watson added that cases

"which relate to competition betueen equitable and legal rights to stock or shares have really no bearing here. Whether the respondents are estopped from saying that Blakaway had not their authority to dispose of the cer-

1 Williams v. Colonial Bank (1883), 38 Ch. D. $40 \%$ : 5\% L. J. Ch. 8?6.

2 See ante, ch. XVII.

3 Colonial Liank v. Cady (1890), 15 
tificates in question is. in my opinion, the sole question presented for decision in these appeals."

Than these quotations there are few in all the books moro acceptable to the present writer." Were they generally applied, all questions of "negotiability," and legal and equitable estate, in the determination of eases which involve the loss by one of two innocent parties on account of the fraud of a third, woulil soon bo seen to be parts merely of obsolete systems and idleas.

Seals. - A very technical difliculty presents itself in the case of blank transfers of shares, which has not to be encountered in dealing with blanks in notes and bills of lading: for transfers have sometimes to be under seal, and it is salil that the authority to fill up a locument under seal must itself be under seal. If there be no such sealed authority (as is msmally the case), and if there be no redelivery of the transfer after its completion, it is said that it is not sulliciently executed.2

Distinction must, howerer, again be malle between cases in which the purehaser is aware of the insufficiency of the execution and those in which he is not. Suppose that I execute a transfer of shares in blank and hand it to a broker, who, before handing it over, and unknown to the purchaser, fills in the purchaser's name. My execution of the document is irregular, and it may even be said that the deed is not mine at all. But that is not the question. Estoppel is not troubled with facts. It deals with appearances. The document appears to hare been properly executerl; I am responsible for such appearance; and I ought to be estopped. ${ }^{3}$

Some discussion of the alternative case - where the purchaser is aware that the deed was filled up after delivery will be found in another chapter."

\section{Documexts of Tite Lost or Stolex.}

Speaking very generally, the law of England, the United States and Canadia as at present received is correctly stated

App. Cas. 2\%8; 60 L. J. Ch. 18\%. And see per Lord Herschell to sime effect.

1 Negotiability was esmbered also by Jessel. M. R., with jeference to warehousemen's warrants in Mer. chants r. Pheenix (185i), j Ch. D. :05; 40 L. J. Ch, 41 s.
2Socicté Generale v. Walker (18S5), 11 Apl. Ciss. :0.

${ }^{3}$ See per Lord Herschell in Colonial Bank ․ Carly (1890). 15 App. Cas. 242. See also llie discussion as to blanks in bills and notes in cln. IV: and as to estoppel with reference to deeds in ch. XXV.

4 Ch. XXV. 
in the following extract from a valuable judgment of Senator Tanderplanck:

"The honest purchaser who buys for a valuable consideration in the course of trade without notice of any adverse claim or any circumstances which might lead a prudent man to suspect such adverse clain will be protected in his title against the original owner in those cases, and in those only, where such owner has by his own direct voluntiry act conferred upon the person from whom the bona fide vendee derives title the apparent right of property as owner or of disposal as an agent."1

Mr. Justice Bayley's dictum, it will be remembered, ${ }^{2}$ is not so explicit. The test there proposed is whether "the owner has lent bimself to accredit the title of another person" - nothing as to the act beingr voluntary.

One of the clauses of the Factors Acts, ton, is outside the Senator"s rule; for by it if a vendor of goods "continues or is in possession of the documents of title" - whether with or without the knowlelge or assent of the purchaser is immaterial a resale by the same vendor to an innocent purchaser will cut out the first buyer. ${ }^{3}$

In the Supreme Court of the United States it has been calltiously remarked that

"it may be that the true owner by his negligence or carelessness may have put it in the power of a finder or thief to occupy ostensibly the position of a true owner, and his carelessness may estop him from asserting his right against a purchaser who has been nisled to his hurt by that carelessness;"

and the point has been distinctly decided in accordance with this view in the state of Georgia. ${ }^{5}$

In England, too, it must be said that even where by statute an owner of gools is to be estopped by the possession by another person of the documents of title, the consent of the owner (which is sometimes made a prerequisite) may be of very qualified character, namely, one obtained by fraud. ${ }^{6}$ And where it is sought to estop a company by its certificate of shares, it is not sulficient answer that the certificate was obtained by the

1 Siltus v. Everett (1838), 20 Wend. 279. See also Gurney v. Behrend (1854), 3 E. \& B. 634; 23 L. J. Q. B. 265; Pease v. Gloabec (1866), L. R. 1 P. C. 219 ; 35 L. J. P. C. 66 ; Commercial Bank v. Colt (18ji), 15 Barb. (N. Y.) 506 .

2 Ante, p. 312.

$352 \& 53$ Vic. (Imp.), ch. 45, \$8. And see the Sale of Goods Act, $56 \& 57$ Vic.
(Imp.), ch. 71, § 25 (1): 59 Vic. (Man.), ch. 25. $\$ 24(1)$.

4Shaw v. Railroad Co. (1879), 101 U. S. 565 .

${ }^{5}$ Lowe v. Raleigh (1897), $101 \mathrm{Ga}$. 320 ; 28 S. E. R. $86 \%$.

6 Sheppard v. Union Bank (1862), 31 L. J. Ex. 154. And see Baines v. Swainson (186:3), 32 L. J. Q. B. 281, and ante, ch. VIII. 
grossest fraud, or even by mans of a forged transfer from the true owner. 1

Upon the other hand, where a stock certificate indorsed in blank was taken from a safe by a person who usually had access to it, it was held that the thief could give no title; ${ }^{2}$ although it would be otherwise were the certificate, with the assent of the true owner, made out in the name of the thief. ${ }^{3}$

Upon what principle onght we to proceed? In treating of ambulatory contracts we shall see reason for reaching the conclusion that

"the ratio decidendi in all cases of lost or stolen securities must be the same. The docmments are transferable; they carry with them (by being redeemable to the holder) ostensible ownership of them, or (in the case of hrokers) ostensible agency: the true owner has assisted in this appearance (by careless custody or by lack of restriction upon the transferibility of the documents); and he is, therefore. as against an innocent purchaser for value, estopued from asserting his title."

The same principle is applicable in the case of lost or stolen documents of title. I may keep the documentary title to $m y$ goods in my own name, in which case I am safe; or I may put it in the name of another, in which case I ought to be estopped as agaiust any person deceived by the appearance of ownership given to that other; or I may have my documents in such form that any person baving possession of them shall appear to be the owner of the groods, in which case also I ought to be estopped. One of the reasons given in our now familiar Lickbarrow $v$. Mason case for depriving the consignor of the right to stop in trunsitu was that

"if the consiznor hal intended to restrain the negotiability of it (the bill of lading). he should have confined the delivery of the goods to the vendee only, but he has made it an indorsable instrument." 5

The linguage of Best, C. J., with reference to misappropriated exchequer bills is apposite:

"It is the plaintiff's own negligence in not filling up the blank" with his own name " that has remered it impossible for the delendant to ascertain that he (the plaintilf) hall any right to it." 6

${ }^{1}$ Re Ottos (1893), 1 Ch. 618; 62 L. J. Ch. 160.

2 Bangol v. Robinson (1892), 52 Fed. R. 520 ; Young v. Brewster (1895), 62 Mo. App. 628 .

3 W'inter v. Beimont (1879), 53 Cal. 4:8. Compare Re Swan (1559), 7 C. B. N. S. 400 ; 30 L. J. C. P. 113; and
Swan v. North British (1S62), 7 H. \& N. 603; 31 L. J. Ex. 425; 2 H. \& C. $175 ; 82$ L. J. Ex. 273.

$4 \mathrm{Cl}$. XXIV.

$5(1750) 2$ T. R. 71. See the same reasoning applied to notes in Grant v. Vaughan (12:6), 3 Burr. 1526.

6 Wokey v. Pole (15:0), 4 B. \& Ald. 1. 
The contrary view is put by Fuller, C. J., of the United States Supreme Court, in this form:

"They (bills of lading) are regarded as so much cotton, grain, iron or other articles of merchandise, in that they are symbols of ownership of the gonts they cover; and as no sale of goods lost or stolen, though to a bona ficle purchaser for value, can divest the ownership of the person who lost them or from whom they were stolen, so the sale of the symbol or mere representitive of the goods can have no such effect." 1

But the answer to this argument is not difficult. Possession of goods is, usually, no representation of ownership of them. I may lend a friend my horse without any danger of misleading anybody by the change of possession. Were I to give my friend a bill of sale of the horse, to be used only after the happening of some contingency, the situation would be entirely different. I ought in such case to be estopped, although unauthorized use was made of the document. ${ }^{2}$ And so also if my title to certain goods is evidenced by a bill of lading to me or my order, and I indorse it to my friend with a view to certain application of it, and my confidence is abused, again I ought to be estopped. The distinction, therefore, between possession of goods and possession of a document of title to the goods is the distinction between goods and evidence of title to goods between no appearance of title to the goods and ostensible ownership of them.

The law as to mere possession is the same as to real estate. I am in possession of certain land - that is not a representation by anybody that I am the owner of it; and if some one were to purchase from me, depending upon my possession as proof of my title, he would merely disclose very unusual ignorance of our system. If, however, the documentary title stands in my name, there is a representation by the true owner that the land is mine, or at all events such strong assistance rendered to my representation of ownership that he ought to be estopped as against an innocent purchaser. ${ }^{3}$

It is quite apparent, then, that the thief or finder of a document of title deliverable to bearer is in a very different position, so far as the public is concerned, from the thief or finder of goods. In the one case be is the ostensible owner, and in

1 Friedlander v. Texas (1888), 130 U. S. 423. See also Shaw v. Railroad (1879), 101 U.S. 5i7; Raleigh v. Lowe (1897), 101 Ga. 329; 28 S. E. R. $86 \%$.
2 Davis v. Bradley (1851), 24 Vt. 55;

Nixon v. Brown (1876), 57 N. H. 34.

3 Clarke v. Palmer (1882), 21 Ch. D. 124; 51 L. J. Ch. 634. 
the other he is not. In other worls, he is in a position to mislead people in the one case, while in the other he is not. And if it be urged that at all events the true owner is not responsible for the situation, the reply is that he is - that he might have kept his documents more securely, and at all erents might have rendered them, by special or restrictive indorsement, unavailable to frauduleut people, of whom, as he knew, there is no lack. ${ }^{1}$

Further light upon the subject in hand may be had by reference to the discussion of the reasons which underlie the law as to title to bills and notes when such instruments are passed by a thief or finder. ${ }^{2}$ The same reasons are equally applicable to documents of title. Reference is also asked to other chapters in which the necessity for fraud or even voluntary action ${ }^{3}$ on the part of the estoppel-denier is discussed and denied, and in which the duty which one member of society owes to another in the commercial as in the physical world is insisted upon." Much will be found in these chapters to lead the mind to the conclusion that for estoppel neither fraud nor voluntary action is essential; that Mr. Justice Ashburst's dictum -

"We may lay it down as a broad, general principle that whenever one of two innocent parties must suffer by the acts of a third, he who enables such third person to occision the loss must sustain it" 5 -

ought to be taken as a "broad and general principle;" that the word "enables" should receive no narrow signification; and that the principles of the law of torts -

"The whole modern law of negligence, with its many developments, enforces the duty of fellow-citizens to observe, in varying circumstances, an appropriate measure of prudence to avoid causing hatrm to others." 6

" Ile who enters on the doing of any thing attended with risk to the persons or property of others is hell answerable for the use of a certain measure of caution to guard against the risk" *-

are not limited to physical relations, but have equal application to commercial intercon'se.

1 Ex parte Banner (1875), L. R. 2 Ch. 288.

2 Ch. XXIV.

3 Ch. VIII.

4 Ch. V.
5 Ante, p. 327.

6 Pollock on Torts, p. 2 ?.

7Dean v. McCarty (18 $\$ 6), 2$ U. C. Q. B. 448 . 


\section{CHAPTER XXIII.}

\section{OSTENSIBLE OWNERSHIP AND AGENCY - GOODS - LEGISLA. TION.}

Development of the law has been due in very large measure to the courts rather than to the legislatures; and the names of Mansfield and Marshall remind the student that there are large departments of our jurisprudence which are luckily open to the charge of having been "judge-made." We have now in hand, however, a subject which has for many years been a battlefield upon which legislatures, struggling against the courts, have made many endeavors (although not of the happiest sort) to conform the law to the necessities of mercantile usage.

The Questions and the Rules for Them.- Shortly stated the questions at issue relate to the position of persons in whose faror factors and others have mate unauthorized disposition of goods. In the preceding chapters we have seen that the courts, without the aid of statutes, worked out principles of estoppel which seemed to be of sufficiently general import to include faetors and everybody else. Recalling them, sufficiently for present purposes, we may say that they are as follows:

1. Nemo dat quod non halet.

2. But that rule

"will certainly not apply where the owner of goods has lent himself to accredit the title to another person."

3. "Where a principal has by his voluntary act placed an agent in such a situation that a person of ordinary prudence, conversant witl business usages and the nature of the particuliar husiness, is justitiel in presuming that such arent has authority to perform is particular act and therefore deals with the agent, the principal is estopped, as against such third person, from denying the agent's authority."

Rules Wide Enough for Fuctor Cases. - These rules, embracing as will be observed the two principles of ostensible ownership and ostensible arrency, plainly enough cover the case of factors; for fatetors when they deal with the goods of other people must either (1) be the ostensible owners of them, or (2) the ostensible agents of the persons who do own them; and they are therefore within the principles provided for all such 
cases. That a factor is one who is usually intrusted with possession or the inlicia of possession of the groods is not a reason for drawing a distinction between factors and other arents; for (1) proprietors of sales-stables are also usually intrusted with horses that are to be sold (Many other such cases might easily be mentioned); and (2) the fact that an agent is intrusted with possession does not in the slightest degree affect the application to his case of the general principles.

The correctness of this latter statement may require a little explanation, for which it is necessary to observe some distinctions. Let us consider the following cases:

(1) The person intrusted with the goods or the documents of title to them usually operates as a factor, and in no other way.

(2) Add to that case the circumstance that the owner of the goods has in some special manner accredited the title of the factor - that is, made him appear to be the owner.

(3) The person intrusted is a merchant, and not a factor at all.

(4) The person intrusted is both a factor and a merchant.

We must lieep well in mind, too, the difference between ostensible ownership and ostensible agency.

1. Case of a Factor.-A man is well known to be a factor and not a trader; and nevertheless he is in possession of bills of lading indorsed to himself or in blank. In this case the possessor of the bills appears to be not an owner, but an arrent; and the extent of his agency must, of course, be inquired into; for if he exceed his anthority, or at all events his ostensible authority (of which more in a moment), his principal cannot be bound. If it be said that the factor having the bill of lading is therefore the ostensible owner, the answer is that of Lord Ellenborough :

"By the terms of the bill of lading . . . the gooris were consigned to Vos (the factor), and for anything that appears to the contrary to the use of Vos: . . but it is so usual to dothis in cases where the party is only a factor, that $i$ camnot rely on this argument." 1

The case is one of known agency. The law governing such cases is general, and covers the case of factors ats of all other agents.

2. Case of a Factor Specially Accredited.--The man is a factor, but besides holding the bill of lading he is otherwise ac- 
credited as owner. The law in this case is, or ought to be, that

"where indeed a factor, by the assent of his principal, exhibits himself to the world als owner, and by that means obtains credit as owner, the principal will be lialble who furnished the means." 1

The case is one of ostensible ownership. The law is clearly of general application. That is, it would apply to persons other than factors who were permitted by the owner of goods to present the appearance of having title to them.

3. Case of a Merchant. - The man in possession of the bills is known to be a merchant who trades in his own goods, and does not usually act as a factor. He is now an ostensible owner, although perhaps in truth a factor in the particular case. He may, indeed, happen to be known to those dealing with him as an agent, and if so he is, to them, an agent; but to persons witbout special information he appears to be the owner of the goods, and the true owner may be estopped as against an innocent purchaser upon that account. The case is one of ostensible ownership. The law relating to all such cases is comprehensive, and includes all cases of ostensible ownership.

4. Case of a Factor and Merchant.-The man is both a factor and a merchant. In such case possession of the goods cannot indicate eitber ownership or agency specifically, but it does indicate either one or the other alternatively - in other words, you cannot tell whether the possessor is bolding the goods as a merchant or as a factor; you cannot say, therefore, whether be is an ostensible owner or an ostensible agent; but he is one or the other, and whichever he is the purchaser is safe. There is no necessity here for any special provision in the law for the case of factors. The law is quite general.

These distinctions are of prime importance, but are hardly ever alluded to, ${ }^{2}$ although in other branches of the law they are to some extent familiar. In fact, it is sometimes denied that such distinctions exist. Were it but observed that intrusting a factor with possession is but giving to an agent an appearance of authority to sell; that that is but one of the many ways in which such an appearance may arise; that the law

1 Martini v. Coles (1813), 1 M. \& S. tice than the others. Lord Ellen147. 148; Kent's Com. (13th ed.), II, borough makes reference to the 900; Gray v. Agnew (1880), 95 Ill. 320. fourth in Martini v. Coles (1813), 1 M.

2 The second las received more no- \& S. 140. 
of estoppel applies to all cases of ostensible agency (that is, of appearance of agency to do the act done), and that the differences among the cases is not one of law but merely as to what constitutes appearance of agency (a mere question of usage), then much of the dilficulty about factors and all the statutes relating to them would disappear.

\section{Revilw of the Legislation.}

For it is not too much to say that steady application of the principles of estoppel would have rendered unnecessary all the legislation which has been passed, and that it might now all be safely repealed with a recital to such effect.

The courts bald (as we have seen), prior to the first of the Factors Acts in $1823,{ }^{1}$ blocked out the main lines of the principles of estoppel. Pickering v. Busk in 1S12, ${ }^{2}$ Martini v. Coles in $1813,{ }^{3}$ Spear v. Travers in $1815,{ }^{4}$ and Boyson v. Coles in 1517,5 leave little to be added beyond the formal reference of their methods to the law of estoppel. But the courts bad made one, if not two, mistakes in the application of these principles. For the purpose of rectifying these Parliament intervened; and thenceforward, with here and there a courageous outburst of principle, we have nothing but the dreariest interpretation of amending statutes.

Factors Could Lot Pledge.-The first mistake was in declaring that a factor could not pledge goods intrusted to him. Upon principle this is the simplest question of usage: A factor (known to be such) is in possession of goods; has he power to pledge? Of course not, if no such power was given to him. How could he? Bnt if by the custom of the place in which he operates factors usually have such power, then the principal by giving possession of his goods to such a person will be estopped from denying the existence of authority in the particular instance. It is the common case of estoppel as to extent of an agent's authority. ${ }^{6}$

In the scores of cases upon the "power to pledge," however, it is ditiicult to find the question approached in this way. The

1 .1 Geo. IV., ch. 23.

215 East. 38.

31 M. \& S. 140.
44 Camp. 251.

56 M. \& S. 24.

${ }^{6}$ See ch. XXVL. 
law is alway:s arbitrarily enunciated as though it had been revealed from heaven that "a factor cannot pledge." It so commenced in a case of which the following is the whole report; and it so yet remains where statutes bave not repealed it: ${ }^{1}$

"It was held by Chief Justice Lee that though a factor has power to sell and thereby bind his principal, yet he cannot bind or affect the property of the goods by pledging them as security for his own debt, though there is the formality of a bill of particulars and a receipt; and the jury found accordingly."

Lord Mansfield incled seems to have ignored this decision $;^{2}$ but other judges, although they bave regretted it, and complained of it, and even in a surreptitious way hinted that it was misreportel,${ }^{3}$ have devoutly followed it and declared it to be too firmly settled for question. Said Lord Ellenborough in 1811:

"It was a hard doctrine when the pawnee was told that the pledger of the goods had no authority to pledge them, being a mere factor for sale; and yet since the case of Patterson v. Tash that doctrine has never been overturnel." 4

Similar complaints may be found all through the books ${ }^{5}$ and the solidity of the law is thus referred to in an Illinois case:

"In fact there can be no question of the rule. It is true that in England and some of the states of the Union the rule has been changed by legislation. but that only shows that the rule was too firmly fixed to be abrogated by decision of the courts." 6

And when evidence was offered to show a custom at a particular place for a factor to pledge, it was rejected as

"an attempt to set up a custom in opposition to a general principle of law, which cannot be permitted." 7

Sometimes indeed reasons are offered in support of the law. They are usually as follows:

"The reason why the factor is not permitted to pledge is that his authority is only to sell." 8

"Tỉis doctrine results from the fact that the factor is but an agent, and as such can bind his principal only when his acts are witlin the scope of his authority." 9

1 Patterson v. Tash (1742), 2 Str. 1170.

2 Wright v. Camplell (1767), 4 Burr. $2017 ; 1$ H. Bl. 628.

${ }^{3}$ Gibbs, C. J., told a reporter " that this case was misreported, but that having been acted upon it could not now be shaken." Bonzi v. Stewirt (1812), 4 MI. \& S. 307.

4 Pickering v. Busk, 15 East, 44.

${ }^{5}$ See Martini v. Coles (1813). 1 M. \& S. 145; Iforn v. Bater (1858), 11 Cal. 39:3; Strory on Agency (9th ed.), $124, \mathrm{n}$.
6 Gray v. Agnew (1880), 95 Ill. 320.

7 Newbold v. Wright (1833), 4 Rawle (Pa.), 213. And see Mechem on Agency, § 994 .

8 Lausatt v. Lippincott (1821), 6 Serg. \& R. (Pa.) 392. And see Kinder v. Shaw (1807). 2 Mass. 397; Rodriguez v.Hefferman(18:1),5 Johns. Ch.(N. Y.) 417; Newbold v. Wright (1833), 4 Rawle (Pa.), 211; Gray v. Agnew (1850), 9.; Ill. 319; Allen v. St. Louis (1886), 120 U. S. 3:.

9 Mechem on Agency, $\$ 994$. 
But this reason would of course answer as well for the "doctrine" that if I employ an agent to sell my horse he cannot sell my cow; and overlooks all questions of usage and estoppel, which often lead to a conclusion contrary to that arrived at by the simple statement that an agent cannot bind his principal if he has no authority to do so.

In Story on Agency it is suggested that the true point for consideration is

"whether a party ostensibly clothed with the ownership of property by the real owner, and thus aceguiring an apparent authority to dispose of the whole interest, may not dispose of an interest in such property less than the whole to another innocent party." l

But this raises one of our distinctions. No doubt if the case be one of ostensible ownership (case 2 or 3), a pledgee or a transferee of any interest ought to be protected. But that will not help us in the case of a factor who is known to be a factor - how can he pledge if he has no authority to do so?

The English courts then had made this one mistake and the American courts adopted it. But the custom for a factor to advance money on goods consigned to him and of keeping himself in funds by pledging the goods, although refused acknowledgment by the courts, was too firmly settled and too important to be indefinitely ignored, and thus it came about that the English Parliament commenced its series of Factors Acts. The statute (1523) recites that

"the law, as it now stands, relating to goods shipped in the names of persons who are not the actual proprietor's thereof and to the deposit or pledge of goods, affords great facility to fraul. produces frequent litigation, and proves in its elfects highly injurious to the interests of commerce in general." 2

Its provisions were ineffective, and the act was amended (1525) two years afterwards. ${ }^{3}$ These statutes were not limited to the matters to which they were intended specially to apply, but were of greneral charieter and related to "any person . . . intrusted with any goods . . . or the bill of lading for the delivery thereof." The unfortunate results were that the acts were taken to be a legislative leclaration of the whole scope of the law relating to all such cases, and that thenceforward the general prineiples which had heen propounded were very largely left out of view, discussion centering upon such ques- 
tions as, Who was a "person?" When could he be said to be "intrusted?" " For what could be pledge? etc.

With the humiliating acknowledgment that " much litigation has arisen on the construction of the said recited act;" and while one of the extraordinary decisions upon its language was on its way to the House of Lords, ${ }^{4}$ Parliament again (18+2) intervened, ${ }^{5}$ reciting that which the courts bad declined to acknowledge, namely, that

"advances on the security of goods and merchandise have become an usual and ordinary course of business."

Again in 1877, and while another erroneous decision was being considered in appeal, ${ }^{6}$ further legislation was passed; ${ }^{7}$ and still more recently (1S89) all the previous acts were amended and consolidated. ${ }^{8}$

Let us consider the main provisions of this last statute, observing their unprofitableness:

1. "Where a mercantile agent is, with the consent of the owner, in possession of goods, or of the documents of title to goods, any sale, pledge or other disposition of the goods made by him when acting in the ordinary course of business of a mercantile agent shall, subject to the provisions of this act, be as valid as if he were expressly authorized by the owner of the goods to make the same." 9

Admittedly there was no necessity for this provision so far as it related to sales. The reason was that by the custom of trade a mercantile agent intrusted with possession of goods usually bad power to sell; wherefore altbough in a particular ease there was no authority to sell, yet there was (owing to the usage) an appearance of such power; and the owner was estopped by the ostensible autbority. No statute was necessary for this result, for already the law had declared that:

"If the owner of gools had so acted as to clothe the seller or pledger with apparent authority to sell or pledge, he was, at common law, precluded as

1 Monk r. Whittenbury (1831), $2 \mathrm{~B}$. $\&$ Ad. 484. It is "difficult to say precisely what is meant." Janberry r. Britten (1838), 5 Sc. 655; Wood v. Rowcliffe (1845), 6 Ha. 191; Lamb v. Attenborough (1862), 1 B. \& S. 831; 31 L. J. Q. B. 41; Baines v. Swainson (186:3), 4 B. \& S. $2 \pi 0 ; 31$ L. J. Q. B. 281; Heyman v. Flewker (1863), $13 \mathrm{C}$. B. ․ S. 519: 52 L. J. C. P. 132.

2 Phillips v. Huth (1810), 6 M. \& W. 572: 9 L. J. Ex. 323; Hatfield v. PhilIips (1842), 9 M. \& W. 646; 12 Cl. \& F. $343 ; 11$ L. J. Ex. 425; Bonzi v. Stew- $\operatorname{art}(1842), 4$ M. \& G. 295; 11 I. J. C. P. 228.

3 Taylor v. Truman (1830), 1 Moody \& Mal. 453; Taylor v. Kymer (1832), 3 B. \& Ad. 320; 1 L. J. K. B. 114.

${ }^{4}$ Hatfield v. Phillips (1842), 9 M. \& W. $646 ; 12$ Cl. \& F. 343 .

$55 \& 6$ Vic. (Imp.), ch. 39.

6 Johnson v. Credit Foncier (187\%), 3 C. P. D. $41 ; 47$ L. J. C. P. 241.

$340 \& 41$ Vic. (Imp.), ch. 39.

852 \& 53 Vic. (Imp.), cl. 45.

${ }^{9}$ The Factors Act, 52 \& 53 Vic. (Imp.), ch. 45, § 2(1). And see Rev. St. Ont., cl. 150, 5 . 
against those who were induced bona fide to act on the faith of that appiarent authority from denying that he had given such authority, and the result as to them was the simme as if he had really given it." 1

And the contingent "if" (at the beginning of the sentence) is satisfied by declaring that

"the ordinary course of business is for factors to sell in their own name. - . That heing so, the very fact of intrusting your goods to a man as a factor, with right to sell them, is prima facie authority from you to him to sell them in his own name."

The case is the simplest example of estoppel by ostensible agrency. As early as 1612 Lord Ellenborough had said:

"Strangers can look at the acts of the parties and to the external indicia of property, and not to the first communication which may pass between a party and his broker: and if a person authorize another to a-sume the apparent right of disposing of property in the ortinary course of trade, it must he presumed that the apparent authority is the real authority.

"If the principal send his commolity to a place where it is the ordinary business of the person to whom it is consigned to sell, it must be intended that the commodity is sent thither for the purpose of sale. . . . When the rommorlity is sent in such a way and to such a place as to exhibit an apparent purpose of sale, the principal will be bound and the purchaser sale."

And this language has been widely approved and acted upon ever sinee, ${ }^{3}$ except where the distracting effect of the Factors Acts has interposed.

As bas been said, however, the courts held that " a factor cannot pledge;" and the fact that if usually a factor had authority to pledge there was the appearance of power and estoppel did not occur to them. The legislatures, therefore, had to intervene with a clause of which the above is the lineal descendant.

And there would be little objection to the clause if, by proriding that "a mereantile agent" can give a good title under the eircumstances detailed, it did not seem to indicate that nobody else could do so. For it is quite elear that the case of "a mercantile agent" is not a whit different in this respect from that of anybody else. Suppose that a trader (not a factor) is intrusted with possession of goods or the documents of title to goods, he may sell or pledge and give a grood title - not this time, however, because of ostensible agency, but because of

1 Cole v. North Western (15ij), IL R. 10 C. P. $363 ; 44$ L. J. C. P. 233. See also per Gould, J., in Cartwright v. Wilmerding (156:), 24 N. Y. 5:6.

2 Pickering v. Busk (18129, 15 East, 63. See cases cited with this one in ch. XXI.

'Lilusatt v. Lippincott (1821), 6
Serg. \& R. (Pa.) 392; Taylor v. Pope (1865). 45 Cold. (Tenn.) 416; Atlantic v. Hunt (1897), 100 Tenn. 89; 42 S. W. R. 483; Lewenberg $\checkmark$. Hayes (1897), 91 Me. 104; 39 Atl. R. 469: Heath v. Stoddard (1898), 91 Me. 499; 40 Atl. R. 517 . 
ostensible ownership. Nor is the case different in principle if the person who has possession is neither a factor nor a trader, and is known (by the purchaser) to be an agent of ordinary sort. For the principle is always the same. Is this agent (whoever he may be) a person who usually bas power to sell and pledge? If so, then be may sell and pledge. If he is not, he cannot. And it is merely because "a mercantile agent" is in the first of these categories, and not because of his name, that be can sell; for even he must, as the statute provides, be "acting in the ordinary course of business."

Estoppel has a further criticism of the clause, in that it makes no exception from its general provision for a case in which the purchaser is aware that the agent is violating bis instructions. Possibly it may be said that he was not then "acting in the ordinary course of business." But the reply goes too far. It would apply to a case in which the purchaser was not aware of the violation of bis instructions; for the factor would not then (either) be "acting in the ordinary course of business," but in quite extraordinary fashion. Yet such case is clearly one in which the purchaser ought to be protected.

The clause then (1) is useless; (2) is objectionable as suggestive of untrue distinctions; (3) is defective for the reason just mentioned.

2. "Where a mercuntile agent has, with the consent of the owner, been in possession of goods or of the documents of title to goods, any sale, pledge or other disposition which would have been valid if the consent had continued shall be valid notwithstanding the determination of the consent; provided that the person taking under the disposition has not at the time thereof notice that the consent has been deternined." 1

Construing one of the earlier acts the courts had said that if possession of the goods or documents had, with the consent of the owner, been given to a factor, yet if the consent to hold them had been withdrawn the act did not apply, even though the owner had permitted the possession to remain as before, and the purchaser knew nothing of the withdrawal." The merest glance outside the statute would have obviated this error. The authorities were, as we bave seen, amply sufficient for the case. For the only question was whether the factor had still ostensible authority to sell; and this admitted of but one

1 The Factors Act, $52 \& 53$ Vic. (Imp.), ch. 45, \&2 (2).

C. P. 282: 4 id. $93 ; 37$ L J. C. P. 137;

2 Fuentes v. Montis (1868), I R. 3 
answer. The debate, howerer, did not touch this point, but was directed to an interpretation of the statute - to ascertaining whether the factor could still be said to be "intrustel" with the possession. Hence the above clause. So great a judge as Willes, J., acknowledged himself to be absolutely help. less:

"I might desire that it was in the power of the judge to amend the law from time to time witl reference to nercantile convenience. . . . But were I to do this, I should be doing an unconstitutional atet. I am at atl times anxious to grive full chect to the intention of the legislature as expressed in the lingurige they have used. But I do not feel myself at liberty from any notions of rexpediency which 1 may entertain to go beyond that which I find written." l

It is impossible to imagine what the result would have been had Lord Mansfield been troubled with views of unconstitutionality when he was, somewhat radically, amending "the law from time to time with reference to mereantile convenience;" and had he thrown upon Parliament, as to bills and notes, the task which it was compelled to assume with reference to factors. ${ }^{2}$

3. "Where a mercantile agent has obtained possession of any documents of title to goods by reason of his being or laving been, with the consent of the owner, in possession of the goods represented thereby or of any other documents of title to the gools. his possession of the first mentioned documents shall, for the purpose of this act, be deemed to be with the consent of the owner:" 3

The courts had held, in construing the statutes, that if an agent had been intrusted with one document, and of his own motion got it changed for another document, he was not in possession of number two "with the consent of the owner," and therefore that the act did not apply. For example, a factor, being intrusted with a bill of lidding, and the goods at the termination of the royage having gone to a warehouse, the factor gare up the bill of latling and got a dock warrant. Upon general prineiple the case is simple enough; but looking minutely at the statute the courts sild that the factor was not in possession of the doek warrant "with the consent of the

1 Fuentes r. Montis (1869), L. R. 3 C. P. 283.

2 The language of Willes, J., is a remarkable illustration of the truth of Mr. Markby's remark (Elements of Law. 4tl ed., \$93): “ Well estisb. lished as the practice of the julges making the law has now become in
Englind, it is not easy to reconcile ourselves to the notion when the practice is brought under our observation."

3 The Factors Act, $52 \& 53$ Vic. (Im).), cls. 45. $\$ 2$ (3). And see Rer. St. Ont., ch. $150, \unlhd 4$ 
owner."1 Thile one of such decisions was on its way to the House of Lords, Parliament interposed with the above clause. ${ }^{2}$

The courts had also held that if a factor had deposited certain warrants as sccurity for an advance, and had afterwarls substituted other warrants as security for the same advance, the case was not within the statutes, because no alvance had been made upon the second set of warrants. ${ }^{3}$ The above clause, in conjunction with another, corrected that anomaly. Attention to the principles of estoppel would have led to contrary decisions in these cases and rendered appeal to Parliament unnecessary.

4. "Where the owner of goods has given possession of the gonds to another person for the purpose of consignment or sale, or has shipped the goods in the naine of another person, and the consignee of the goods has not bad notice that such person is not the owner of the goods, the consignee shall, in respect of advances made to or for the use of such person, have the same lien on the groods as if such person wert the owner of the goods, and may transfer any such lien to another person." 4

The statute is not now dealing with groods intrusted to "a mercantile agent," but with all cases of agency. The clause is bally drawn. It provides that if possession of goods be given to another person with instructions to sell, then "the consignee" shall have a lien for advances. That is to say, if I give possession of $\mathrm{my}$ horse to an agrent to sell, and he mortgatged the horse, I would not be bound; but if my agent were to consign him to somebody and get advances on him, I would be bound. Estoppel would have nothing to say to either case, for it is one simply of no authority to pleclge and no appearance of such authority. Estoppel would agree to the provisions (1) that if possession be given "for the purpose of consignment" (in the name of the person intrusted), or (2) if the owner "has shipped the goods in the name of another person," then the assignce shall have a lien for advances; for in such cases there is, with the assent of the owner, ostensible ownership in the person intrusted. But estoppel would of course draw no distinction between the case of the "consignee," and any other person being misled by the appearance of ownership; nor would

1 Close v. Holmes (1837), 2 Moody \& R. 22; Phillips v. Huth (1840), 6 M. \& W. 572; 9 L. J. Ex. 323: Hatfield v. Phillips (1842), 9 M. \& W. 646; 12 Cl. \& F. 313; 11 I. J. Ex. 425.

$25 \& 6$ Vic., ch. 39 , §4.
${ }^{3}$ Bonzi v. Stewart (1842), 4 M. \& G. $295 ; 11$ L. J. C. P. 228.

4 The Factors Act. 52 \& 53 Vic. (Imp), ch. 45, \$7. And see Rev. St. Ont., ch. 150, §il, 
it say that the consignce should be protected "in respect of adrinces" and should not be protected did he buy the groods. The ease being one of ostensible ownership, it is immaterial who the person is that acquires an interest in them or what the nature of that interest may ba

5. "Where a person having sold goods continues or is in possession of the goods, or of the documents of title to the goods, the delivery or transfer by that person, or by a mercintile arent acting for him. of the gools or documents of title. under any sile, pledge or other disposition thereof, or muler any agreement for sale, pledge or other disposition thereof, to any person recejving the same in good fath and without nolice of the previons sale, shall have the same effect as if the person making the divivery or transfer were expressly authorized by the owner of the goods to miake the same." 1

The courts had held that if a vendor sold goods but retained the documents of title to them, a subsequent sale by the same vendor to another purchaser passed nothing; ${ }^{2}$ and before the case could be heard in appeal Parliament declared otherwise by the adoption of the above clause. ${ }^{3}$

But the enactment went beyond the case, and raised further difficulty. It applies not only to a case in which a vendor retains the documents of title and so misleads a subsequent purchaser, but to one in which the vendor retains "possession of the goods."

Now distinguish: (1) A merchant sells goods but retains possession of them in his warehouse and resells them; the first purchaser ought to lose, for possession under such circumstances indicates either ownership or authority to sell.. (2) I buy from a farmer a horse, pay him and take a bill of sale of him, and the farmer agrees to send him to my house, but instead of doing so resells him. Apart from any local registry acts I am not estopped, because mere possession under such circumstances is not ostensible ownership. ${ }^{5}$ (3) But suppose that the second purchaser is some one who has previously known that the farmer was the owner of the horse, and relied upon such knowledge and possession as indicative of the continuation of the title?

In the United sitates it has been broadly asserted that "when the same thing is sold to two different parties, by contracts equally

1 The Factors Act, 52 \& $5: 3$ Vic. (Imp.), ch. 4.j, $\$$ S: Sille of Gools A(t, $56 \& 5 \pi$ Vic. (Imp.), ch. 21 , s : 25 (1); 59 Vic. (Man.), el. 2j, $\$ 24(1)$.
2 Johnson v. Credit (18ii), 2 C. P. D. 224: 3 ill. $3: 3: 4 \pi$ L. J. C. P. 224.

340 \& 41 Vic. (Imp.), ch. 39 , 3.

4 Ante. p. 299.

s. Aute, v. :99\%. 
ralid, and the second vendee is without notice of the first sale, he who first obtains possession is entitled to the property." 1

"It is the doctrine of Shaw v. Levy, $17 \mathrm{~S}$. \& $\mathrm{R}$. 99, which remains unshaken in this state, that if a vendee allow a vendor to remain in possession, or after a formal delivery immediately restore the possession to him, and he afterwards sell and deliver the goods to a bona fide purchaser for value without notice of the prior sale, such purchaser is entitled to the goods as against the first vendee and all claiming under him." 2

The general principle is recognized that

"allowing a person, therefore. to have actual possession of chattels, unless there is somle other fact connected with it, is not an act which holds him out to the public as owner, or as authorized to sell it as his own. The doctrine of caveat emptor, as to any title the purchaser may acquire, applies. Brown v. Wilmerding, 5 Duer, 225. But when the possession remains in the original owner, or after a formal delivery it is restored without any notorious break in the continuity of it under a secret understanding or agreement with him as servant, agent or bailee, this is an elenent which makes a very inmportant difference in the case. 'ihat inquiry which the party dealing with the possessor is bound to mike, and which the law presumes him to make, leads him back to the original title, and thus his diligence will only avail to confirm the deception. The vendee having acquired possession under his purchase must litve enjoyed it as long and in such a manner as to show that the delivery to him was not merely formal or colorable. before he can safely transfer it back to the vendor. Breckenridge v. Anderson, 3 J. J. Marshall, 614 ; Jarvis v. Divis, 14 B. Monroe, 5:9: Stevens v. Irwin, 15 Cal. 50:3."

The law thus stated would lose something of its arbitrary appearance if it were stated in terms of estoppel. The first quoted rule, that, as between two purchasers, he who first gets possession has the better title, appears at first riew to be as simply dogmatic as the rule which gives to the legal estate the determining faculty; and the objection to the last quotation is that its reasons apply as well to a case in which the second purchaser was misled by the ostensible title of the common vendor as to one in which he was not.

A priori one would say that as between two purchasers he has the title who alone acquired it - that is to say, the first of them; and that if any one else obtained possession (whether he be called a second purchaser or not is immaterial) be cannot have the title, but the possession merely. To this let us arld that where the first purchaser "has lent himself to accredit the title" of his vendor so "as to mislead" the second purchaser "into the belief that the person dealing with the property had authority to do so," the first purchaser will be estopped from setting up the facts.

I Winslow v. Leonard (18,54), 2:5 Pa.

St. 18. And see Lanfear v. Summer (1821), 17 Mass. 113; B̈̈own v. Pjerco (18iji), 97 Mass. 46; People's Bank v. Cayley (1880), 92 Pa. St. 527; Cum-

mings v. Gilman (1897), 90 Me. 524; 38 Atl. R. 538.

2 Davis v. Bigler (1869), $62 \mathrm{~Pa}$. St. 247. And see Webster v. Peck (186:3) 31 Conn. 495. And see a note in the Harvard Law Rev.. vol. 11. p. 418. 
The only question then is whether the first purchaser, by leaving his vendor in possession, has aceredited the title of the rendor, and so misled the second purchaser.

In discussing this point it may be said, on the one hand, that possession is not evidence of the vendor's title; that he may be a thief, or a borrower, or a bailee of any deseription; that for this reason no faith ought to be placed upon possession as evidence of title, and that the second purchaser, therefore, caunot say that he was deceived by it.

Upon the other hand there is much in the suggestion that possession, if no evidence of title, is at all events a starting point for inquiry as to title; that orlinarily a venclor is asked as to his predecessors in title; that in this way investigation may begin; and that if the vendor bas been left in possession by the first purchaser, and has thus been enabled to vouch his original title and not that through his vendee, any chance of discovering the first purchaser's interest is taken away.

Such doctrine is applicable, however, only in cases in which inquiry as to title has, in fact, been undertaken and has been ritiated by the continued possession; and not in cases in which it might have been ritiated had such inquiry been made by the second purchaser as "the law presumes him to make." Estoppel applies only in cases in which the estoppel-asserter has been injuriously affected by the act complained of, not to those in which be would have been injured if something else had occurred than that which really happened.

The clause in the Factors Act appears to ignore all such conditions as those surgested. It scems to apply to every case of a vendor being left in possession, whether the fact had any bearing upon the second purchaser's action or not. It is hardly too much to say, however, that the decisions bave amended the statute.

"There is no inflexible rule of law that because a man who was once the owner of goods and has sold them remains in possession of them, he must therefore be held to be the reputed owner. The statute does not say that. If he remains in possession with the reputation of oucnership. and unler those circumstances which create a remesentation of ouncrship, then the property will pass to his assignees; but it is always a question of fact whether or not the circumstances are such as to create that representiation." 1

1 Per Lord Selborne in Ex parte Bk. 51. See Re Gaetz v. Jones (1898), Watlins (18i3), L. R.8 Ch. 528; 42 L. J. 1 Q. B. isi; 6i L. J. Q. B. 5i氵. 
The amendment consists in adding after "continues or is in possession of the goods," the worls "with the reputation of ownership and under those cireumstances which create a representation of ownership." " This robs the statute of much of its purely arbitrary and mechanical character. One further amendment and it would be reduced to the reasonableness of the law of estoppel, namely, that the seeond purchaser should have been misled by the "misrepresentation of ownership."

Possibly this is implied in Lord Selborne's language. If so, then the statute merely reflects a single instance of the law of estoppel, and is misleading because by indicating that if $a$ vendor be allowed by a vendee to mislead people by ostensible ownership, then the vendee ought to lose; whereas the law is general and applies to everybody - being a vendee does not increase or decrease a person's duty of "an appropriate measure of prudence" for the welfare of others. ${ }^{2}$

6. "Where a person having bought or agreed to buy goods obtains with the consent of the seller possession of the goods, or of the documents of title to the goods, the delivery or transfer by that person, or by a mercan. tile agent accing for him, of the goods or documents of title, under any sale, pledge or other disposition thereof, or under any agreement for sale, pledge or other disposition thereof, . . . shall have the same efrect as if the person making the delivery or transfer were a mercantile agent in possession of the goods or documents of title with the consent of the owner." 3

This case is to some extent the converse of the last. If a purchaser may be estopped by leaving the documents of title in the hands of his vendor, so also may a vendor be estopped by handing them over prematurely to the purchaser. Again, the clause was passed to overcome a decision which the mercantile community could not understand. An owner of goods shipped them in two quantities but under one bill of lading. The owner's agent sold the goods to two different persons; gave one of them (A.) the bill of lading; and got that purchaser to give to the other (B.) a delivery order for his part of the goods. B. resold his goods to $X$. on time, and hancled him the delivery order; $X$. plediged the goods, and passed on the order.

1 The phrase "reputation of ownership" was borrowed no doubt from the reputed ownership clauses of the hankruptey acts. See ch. XXI.

2 See a note in Harvard Law Rev., vol. $11, \mathrm{p} .418$.
3 The Factors Act, $52 \& 53$ Vic. (Imp.), ch. 45, \$9; The Sale of Goods Act, $56 \& 57$ Vic. (Imp.), ch. $71, \S 25$ (2); 59 Vic. (Man.), ch. $25, \S 24$ (2). 
The pledgee would now seem to be safe; but it was held that B. could stop in transitu because the goods were being dealt with under a delivery order only, and not under a bill of lading.' Estoppel would of course not recognize the distinction.

The baneful effect of the legislation has recently been very forcibly illustrated. But for it a case of this kind would be free from all difficulty: $A$ vendor sent to his purchaser a bill of lading, and also for acceptance a bill of exchange for the price of the goods; the purchaser ought to have returned the bill of lading, unless he accepted and returned the draft; he did neither, but wrongfully transferred the bill of lading to an innocent purchaser. From the standpoint of estoppel the case is perfectly clear, for the vendor has aceredited the title of the purchaser. Arguing, however, from legislation, a contrary result was at tirst arrived at, the case not being thought to be one "where a person having bought or agreed to buy goods obtains with the consent of the seller possession of the documents of title." Upon appeal a different view of the statute was taken. ${ }^{2}$

The clause moreover goes far beyond that which was intended, and is open to the criticisms abore applied to the preceding paragraph of the statute. The principal of its unexpeeted resul ts has been its effect upon hire and sale agreements those contracts which contemplate an eventual sale, but for security for payment provide that meanwhile the property in the groods is to remain in the vendor. In such cases a bona fide purchaser from the purchaser (if in possession) will be secured. ${ }^{3}$ If, howerer, the effect of the agreement is, not that the purchaser shall be bound to buy, but merely that he shall have an option to purchase, the act does not apply."

7. "Where a document of title to goods has been lawfully transferred to a person as a buyer or owner of goods, and that person transfers the document to a person who tikes the doeument in grol faith and for valuable consideration, the last mentioned transfer shall have the sime effect

1 Jenkyns จ. Usborne (1844), 8 Sc. 62 L. J. Q. B. 591. The law would be N. S. $50 \overline{5}$ : 13 L. J. C. P. 196 . Spear r. Travers (1815), 4 Camp. 251, was not referred to. otherwise were there no statute. See ante, p. 27\%. s.

4 Helly v. Mathers (1894), 2 Q. B.

- Cahn v. Pocketts (1898), 2 Q. B. 222; (1895) A. C. 471:63 L. J. Q. I3. 61; 67 L. J. Q. B. 625; (1899) 1 Q. B. 5\%; 64 id. 46.5. And see Pyne v. Wil. $643 ; 68$ L. J. Q. B. 515.

son (1895), 1 Q. 13. 653; (1595) 2 Q. B.

${ }^{3}$ Lee v. Butler (1893), 2 Q. B. 318; 53i; 64 L. J. Q. B. 328. 
for defeating any rendor's lien or right of stoppage in transitu as the transfer of a bill of lading has for defeating the right of stoppage in transitul." 1

This clause was passed because of the distinction above alluded to between a bill of lading and a clelivery orler. It was said that a vendor retained his lien although he had handed over a document of title (other than a bill of lading), and bacl thus apparently transferred the complete title. His right, it was said, remained until possession of the goods had been taken by the innocent purchaser. ${ }^{2}$ The idea was that the indorsement of a bill of lading passed the title to the goods, but that the transfer of other documents of title did not, and therefore the necessity for possession in order to vest the right to stop in transitu. As has alrealy been seen, however, ${ }^{3}$ property in goods passes by contract, and indorsements of bills of lading and other documents have no effect upon it. Estoppel, too, as has been said, makes no distinction among those documents of title which in the mercantile world are taken as indicative of title.

Summary.-Reviewing all the sections above quoted, we find that the general principle of estoppel by ostensible ownership and ostensible agency is cut down to seven very sharply detined cases selected from infinity, because by merest chance they had bappened to present themselves in more than usually conspicuous form - that is, in notable law-suits:

1. The case of a "mercantile agent" being in possession of goods or the documents of title to goods, with the consent of the owner.

2. Or without that consent, if it at one time existed and its cessation was unknown.

3. Or if there had been consent to the possession of previous documents, by means of which the later ones were obtained.

4. The case of goods giren to "another person" (not necessarily a mercantile agent) for consignment or sale; and the case of goods shipped in the name of another person. In such cases a "consignee's" advances are protected.

5. The case of a vendor remaining in possession of the goods or of the documents of title.

1 The Factors Act, 52 \& 53 Vic. (Imp.), ch. 45 , $\$ 10$.

2 Jenkyns v. Usborne (1814), 8 Sc. N. S. 50.; 13 I J. C. P. 196.

3 Ante, p. 3:2. 
6. The case of a purchaser obtaining possession of the goods or the dlocuments prematurely.

7. The case of a document of title lawfully transferred to a person as a buyer or owner of the goods, who transfers to another. In such case the right to stop in transitu is gone.

Next notice that the first three of these cases are instanees of ostensible agrency, and the last four of ostensible ownership, although the draftsman did not so observe; for in numbers 5 and 6 it is provided that the transaction is to have the same effect as if the ostensible owner were in reality an arrent, instead of in reality the owner.

Lastly, note that the result of the provisions is not in all cases the same. While in numbers $1,2,3,5$ and 6 an innocent person who acquires any interest, whether by "sale, pledge or other disposition," is protected, yet in the fourth ense the protection afforded is only "in respect of advances;" and in the seventh the interests excluded are only "any vendor's lien or right of stoppage in transitu."

The partial and ineongruous character of the legislation is rery apparent. A vendor of goods may be estopped, although another person who hald misled in precisely similar fashion would not be; a purchaser may be estopped if he permit his vendor to bave the documents of title, but will not be estopped if he give them to anyboly else; an owner will be estopped if he ship the goods in the name of another person, as against the consignee and "in respect of advances," but he will not be estopped as to other persons, or if the consignee have purchaserl the goods; where a document of title has been transferred "to a person as a buyer or owner of the goods;" the transferror will be estopped as against an innocent purchaser in respect of his vendor's lien or right to stop in transitu, but not in respect of other claims to the goods.

But the principal objection to the acts is that in so far as they aceord with the prineiples of estoppel they are not only unnecessary but injurious (for they divert attention from those principles and fix it upon interpretation of the language of statutes); and so far as they conflict with the law of estoppel they are vicious, for they are then unsupported by principle and unamenable to reason. 


\section{American Legislation.}

The early English legislation, with certain alterations, passed into the statute books of several of the states of the Union.' But the confusion wrought in England was largely obviated by (among other methods) a most fortunate, or most courageous, misinterpretation of the acts.

The New York statute of 1830 provided that

"every factor or other agent intrusted with the possession . . . shall be deemed to be the true owner thereof, so far as to give validity to any contract made by such agent with any other person for the sale or disposition of the whole or any part of such merchandise, for any money advanced, or negotiable instiument, or other obligation in writing, given by such other person on the faith thereof."

And the words "on the faith thereof" were held to mean on the faith of the agent being the true owner, and not on the faith of the possession of the goods or document of title. ${ }^{2}$ This construction was adopted by the Ohio courts. ${ }^{3}$

The effect of these decisions was to bring the statutes into complete harmoiny with the law of estoppel. For thus construed, they really enact that when factors and other agents are permitted by the true owner to hold themselves out as owners of the groods, purchasers and others may claim the benefit of estoppel.

The other legislatures which passed Factors Acts do not seem to bave encountered the opposition from the courts which was presented by the judges in England; and upon the whole it may be said that the derelopment of the American law has been but very slightly affected by statutory provisions. The cases touching those enactments, therefore, do not require to be separated from those relating to the general law, and are for that reason not specially noted in this chapter.

An exception perhaps should be made from this statement with reference to the "doctrine" that a factor cannot pledge, the cases upon which have been referred to in the foregoing

1 See Kentucky, 1880, May 5; Maine, Rev. St. 188:3, ch. 31 ; Maryland, Rev. Code, 1870, ch. 34; Massachusetts, Pub. St. 1882, ch. 71; New York, 1830, ch. 179; Ohio, 1880, Rev. St., \$3214, ff; Pennsylvania, Factors, 2; Rhode Island, Pub. St. 188:, ch. 136; Wiscon- sin, Rev. St. 1878, § 3345 . See Stimson's Am. St. Law (2d ed.), \$§ 43804388.

2 Stevens v. Wilson (1844), 6 Hill, 512; 3 Denio, 472.

${ }^{3}$ Cleveland v. Shoeman (1883), 40 Ohio St. 176. 
pages. The courts, however, even where unaided by statute exhibited an inclination to orerturn the "doctrine."

"Numerous cases may be found where it has been held that a factor who holds a bill of lading for sale cannot pledge; but in such cases either it appeared that there were grounds for cliarging the pledgee with knowledge of the factorship. or the decisions were male before the modern development of the doctrine of estopel, or witlout giving it full consideration." 1

The Californian judges showed not a little dexterity - perhaps timely temerity - in abolishing the "doctrine" by a qualification which limited its application to impossible cases, or something very near that. ${ }^{2}$

1 Pollard v. Rearion (189j), 13 C. C. App. 174; 65 Fed. R. 851. 61.

2 Wright $\nabla$. Solomon (1861), $19 \mathrm{CaL}$

24 


\section{CHAPTER XXIV.}

OSTENSIBLE OWNERSHIP AND AGENCY - CHOSES IN ACTION AMBULATORY AND NON-AMBULATORY.

In the application of estoppel to negotiable instruments difficulty emanates principally from three suurces:

1. The phrase "law merchant," like many another, is uncritically employed in handy explication of seeming anomalies. As objections to the Mosaic cosmogony, presented by the existence of fossils, were allayed by convenient reference to omnipotence, so perplexing questions relating to negotiable instruments are waived by unthinking allusion to the "law merchant." Omnipotence and law merchant work their arbitrary will, and are irreducible and distracting.

2. Uncertainty as to the meaning of the term "negotiable."

3. Misconception of the principles of the law of estoppel.

Such questions as these present themselves: Why is it that if a bill or note be stolen or found, the thief or finder can pass a good title to it; and that the law is otherwise as to chattel property? Why is it that if a bill be misapplied by an agent for custody of it, a good title will pass; and that the law is otherwise as to other property? Why is it that if a man write his name upon stamped paper, and a note be written over it, he is liable; although if a lease had been so written he would not be bound?

The Law Merchant.-To these and to other such questions the time-sanctioned reply is negotiability and the law merchant working in antagonism to the ordinary rules of law. All application of the principles of the law of estoppel, which, as the writer believes, would explain "how the fossils got there," and barmonize the law merchant with the general law, is expressly denied. The following are examples of current treatment of the subject:

M[r. Justice Byles, in Swan v. N. B. A., ${ }^{1}$ said:

"The object of the law merchant as to bills and notes, made or become payable to bearer, is to secure their circulation; therefore honest acquisi-

1(1863) 2 H. \& C. 184 . And see 32 L. J. Ex. 277. 
tion confers title. To this despotic but necessary principle the ordinary rules of the common law are nade to bend. The misapplication of a genu. ine signature, written across a slip of stamped paper (which transaction being a forgery would, in ordinary ('ases, convey no title), may give a good title to any sum fraudulently inscribed within the limits of the stanp - . negligence in the malier of an instrument payable to bearer makes no difference in his liahlity to an honest holder for value; the instrument maly be lost by the maker without his negligence, or stolen from hiu, still he must pay." l

\section{Lord Manstield's words are frequently quoted:}

"The indorsement of a blank note is a letter of credit for an indefinite sum. The defendant sijd: 'Trust Galley to any amount and I will be his security.' It does not lie in his mouth to say the indorsement was not regular.":

The fact may be, and usually is, that the defendant said, and intended to say, nothing of the kind. The law merchant, however, declares that he did say it; and the defendant must submit. This comes out very clearly in the following language of Baron Pollock; and estoppel is exclucled from operation:

"In such a case the acceptor is liable to a bona fide holder . . . and the reason for this is not because the aeceptor gave authority for this or that sum to be inserted,- for in truth he gave no such authority.- but because in favor of commerce it is essential to ipheld the negotiability of bills of cxchange. That this is so may be further illustrated by a case in which a fraud is practiced upon the aceptor of a bill drawn in blank with reference to the amount. . . Here is a clear absence of authority, and a fraud against $A$. (by inserting $\mathbb{E}^{-i}$ instead of $\$ 50$ ); yet he is liable, for the reason we have given. . . . In the present case . . the ordinary rule as to authority cannot be adhered to, and something like a fiction must be resorted to, in favor of a bona ficle inclorsee for value: or, as we would prefer to say, the law merchant in snch a case holds that, although the ac. ceptor did not authorize the drilwer"s name to be used, he enabled the person to whom he gare the bill to use it, and so to give the bill currency, and this as against the acceptor is sufticient to render him liable.

Estoppels are orlious. . . He should prefer not to use the word 'estoppel,' which seems to imply that a person by his conduct is excluded from showing what are the true facts; but rather to say that the question is whether, when all the facts are admit ted, the accept or is not liable upon the well known principle that where one of two imnocent persons must suffrr from the fraud of a third, the loss should be borne by him who enabled the third person to commit the frated." 3

To the same effect is the sugrrestive language of Baron Wille:

"The law merchant validates in the interest of conmerce a transaction which the common law would declare void for wint of title or authority;

1 This passage having been cited to Mr. Justice Byles in a subsequent case (Foster v. McKinnon (186!), L. R. 4 C. P. 709, and see 38 L. J. C. P. 313), he said: "If that be right. it can only be with reference to the case of a complete instrument: it can hardly be applicable to a case where a man's signature has been obtained by a fraudulent representation to a document which he never intended to sign."
${ }^{2}$ Russell v. Langstaffe (17 80$)$. Doug. 516. See Merchants' Bank v. Good (1590), 6 Man. R. 346.

${ }^{3}$ Lonclon v. Wentworth (18s0), 5 Ex. D. 104; 49 I, J. Ex. 661. See in the same sense. Marston v. Allen (1841), 8 M. \& W. 504; Foster v. McKinnon (1869). L. R. 4 C. P. $712 ; 38$ L. J. C. P. 316; Bechuanaland v. Lon. don (1898), 2 Q. B. 679; 67 L. J. Q. B. 959. 
and transactions within its operation are as absolutely valid and effectual as if made witl title and authority. But how difjerent is the principle of cstoppel. It validates no transaction whatever. It all along implies a transiction itself invalid, and a person who is forbldden for equitable reasons to set up that invalidity. It operates in a different way, founded upon principles of equity and fairness, between man and min. It rests on a wider basis thin the principle which supports title in negotiable instruments; and as it is not confined to commercial intercourse or the exigencies of trade, so it is not confined to instruments which have become negotiable by the demands of commerce." I

Williams, J., put the matter in this way:

"The reason is that such negotiable instruments have by the law merchant become part of the mercantile currency of the country; and in order that this may not be impeded, it is requisite that innocent holders for value should have a right to enforce payment of them against those who by making them have caused them to be a part of such currency." 2

In the opinion of Lord Herschell,

"the general rule of law is that where a person has obtained the property of another from one who is dealing with it, without the authority of the true owner, no title is ac:puired as against the owner, even though full value be given, and the property be taken in the belief that an unquestionable title thereto is being obtained; unless the person taking it can show that the true owner has so acted as to mislead him into the belief that the person dealing with the property had authority to do so. If this can be shown a good title is acquired by personal estoppel against the true owner. There is an exception to the general rule, however, in the case of negotiable instruments." 3

Finally, Mr. Bigelow, in his recent work on Bills and Notes, referring to transferees of them free from equities, says:

"It is here that the law merchant appears in its strongest colors and in its most striking contrast to the common law. It is negotiability that affords the coloring and the contrast."

And Sir Frederick Pollock speaks of the doctrine as "a positive exception to the ordinary principles of legal ownership." 5

Antagonism.-These quotations (1) bring the law merchant and the common law into sharp antagonism. "The law merchant validates - . a transaction which the common law would declare void;" (2) show that reconciliation has been attempted in some cases by the adoption of "something like a fiction," namely, imagined but non-existent principal-and-agent authority; (3) declare that the law of estoppel has nothing to do with any such cases; and (4) support the application of "the well-known principle that when one of two innocent persons must suffer from the fraud of a thirl, the loss should be borne by him who enabled the third person to commit the fraud."

${ }^{1}$ Swan v. N. B. A. (1862), 7 H. \& N. 603 ; 31 L. J. Ex. 436.

2 Ingham v. Primrose (1859), 7 C. B. N. S. $85 ; 2$ L. J. C. P. 295.
3 Simmons v. London (1892), A. C. $215 ; 61$ L. J. Cl. 729.

4 P. 206. And see p. 8.

5 Pollock on Contracts (6th ed.), 427. And see p. 216. 
It is of somewhat curious interest, too, that when it came to be held that

"the actual holder of an indorsed bill of lading may undoubtedly by in. dorsement convey a greater title than he himself has,"

all that could again be said for so holding was that

"it is at variance with the general principle of the law that a man should be allowed to transfer to another a right which he has not; hut the exception is founded on the nature of the instrument in question, which buing, like a bill of exchange, a negotiable iustrument, for the general conven. ience of commerce has been allowed to have an elfect at variance wilh the ordinary principles of law." 1

\section{The Law Merchant.}

What then is this law merchant which opposes itsclf to the common law and dominates it? and whence does it come? As a matter of fact, and not merely of phrase, may we not even ask whether there is a law of merchants, in any other sense than there is a law of financiers or a law of tailors? Frequent use of the word bas almost produced the impression that as there was a civil law and a canon law, so also there was somewhere a "law merchant," of very peculiar authority and sanctity; about which, however, it is now quite futile to inquire and presumptuous to argue. ${ }^{2}$

If the custom of merchants as to bills of exchange was recognized by the courts, so also has the custom of financiers as to the "negotiability" of bonds and scrips been recognized; but no one would think of referring to the "law financier" in speaking of that "negotiability." The custom of financiers, as of social clubs or other organizations or coteries, is observed and enforeed by the law; not because the financiers or clubs enacted or had power to enact liws, but because it is with reference to those customs that the parties have acted or con-

1 Per Tindall, C. J., in Jenkyus v. Usborne (1844), 7 M. \& (i. 699: $13 \mathrm{I}$. J. C. P. 196. See also Williams v. Colonial Bank (1883), 39 Ch. D. 383 : 57 L. J. Ch. 826; Bank of Bittivial v. New York (158\%), 106 N. Y. 145; 12 N. E. R. 433. As to the allegerd antagonism in cases of bills of latlin: see ch. XXIV.

2 In Blackburn on Sales (2d el.). $31 \%$, it is said that "there is no part of history of English law more obscure than that connected with the common maxim that the law merchant is part of the law of the land. In the carlier times it was not a part of the common law as it is now, but a concurrent and co-existent law exforced by the power of the realm, but alministered by its own courts in the staple or else in the Star Chamber:" It is not suggested.however. that it is from precelents in these courts that the modern law is derived. 
tracted; and it is with reference to them, therefore, that rights and liabilities ought to be adjusted. When these or any other customs obtain general acceptance by the community they then pass into and for the first time become laws. MLodus et con. ventio vincunt leges.

The rules respecting bills and notes are not traceable to any foreign or extraneous body of laws, but have been derivel from the usages and customs of the people; ${ }^{2}$ from whence also are derivel the main part of the whole body of the law. And it would therefore be very extraordinary were we to find some portion of our law in antagonism to other parts of it; for we sbould then have to sayy either that one part of our usage was out of harmony with the rest, or else that, in process of crystallization into law, it bad become so. The present writer begs to subscribe to the following extracts rather than to those which allege antagronism:

"This chronolorical list of authorities tends to elucidate the manner in which the custom of merchiats ganed an establishment, in the courts of law as part of the common or general law of the land, and shows that it ought not to be considered as a system contrary to the common law, but as an essential constituent part of it, and that it always was of co-equal authority, so far as subjects existed for it to act upon." 3

"The 'lex mercatoria,' or custom of merchants, like the lex et consuetudo parliamenti, describes only a great division of the law of England. The law relative to bills of exchange, insurance, and all mercantile contracts, are as much the general laws of the land as the laws relating to marriage or murder." 4

Describing the law merchant, thus, as part of the general law makes the assertion of antagonism much more difficult than if it be thought of as some imported and despotic corle to which "the ordinary rules of the common law are made to bend." We fcel that reconciling principles between a part and the

1"Usage adopted by the courts, laving been thus the whole of the so-called law merchant," per Cock. burn, C. J., in Goodwin v. Robarts (1875), L. R. 10 Ex. 352; 44 L. J. Ex. 16.j. Negotiability of bills is but an example of that which Mr. Herbert Spencer speaks when he says (Man $v$. The State, 298): "One of the most familiar political truths is that, in the course of social evolutions, usage precedes law; and that when usare has been well establisher it becones law by receiving authoritative indorsement and defined form."
2 See Goodwin v. Robarts (1875), L. R. 10 Ex. 346; 44 C. J. Ex. 16?. In Woodworth v. Bank (1821), 19 Johns. (N. Y.) 416, there is the following: "The law merchant, says Malynes in the time of King James, is a customary law approved by the authority of all kingdoms and commonwealths, and not a law established by the sovereignty of any one prince."

${ }^{3}$ Dunlop v. Silver (1801), 5 U. S. $\Lambda$ pp. 374, a most valuable exposition of the early law.

¿ Christian's note to $1 \mathrm{Bl}$. Corn. $\mathbf{7 5 .}$ 
whole must exist, unless indeed our jurisprudence is, so far, an absurdity. Let us return to antagonism, at all events, only if harmonizing efforts shall fail.

What Custom of Merchants?- And let this mean while be answered: What custom of merchants was recognized by the courts? A custom that the transferee could sue in his own name? No; custom could not possibly affect that question, or determine that in equity he could, and at law he could not. Well, then, a custom that the transfer cut out the equities, and that a thief could pass a good title? No; there is no more reason for so saying that than for asserting that we are indebted to farmers for the law which declares that the purchaser of land, taking the legal title, is not atfected by equities, or to horsemen for the provision that the thief of a chattel can give a good title by a sale in market overt. Then it must have been a custom that the transferee acquired the legal title, and not the equitable only? Once more, no; the merchants were not sulficiently skilled in such abstruse matters as to draw a finely dividing line among them. No custom then? Yes; this and nothing but this: The law finally and with much apprehension reeognized the fact that ambulatory promises - promises redeemable to third person - had by custom become an essential requisite of commerce; and the courts thereupon set themselves to derelop law applicable to instruments of that kind, naming them "negotiable" instruments. The simplicity of the law ball declared that there could not be a contract redeemable to persons other than the immediate contractor; the merchants said that they constantly used such contracts, could not indeed get along without them; and the usage finally received "authoritative indorsement and defined form."

To the writer it has always seemed to be somewhat absurd to suggest that such works as those of Mr. Justice Byles, Mr. Daniel and others were the result of investigations into the law merchant. Judge-made law (not merehant-made), with Lord Manslield as chief builder, is what we have here.

\section{"Nggotiability."}

After being informed that "it is negotiability that affords the coloring and the contrast" 1 between the law merchant aud 
the common law, it is somewhat depressing to find that there is very little agreement as to what "negotiability" really is. Probably many would agree with the widely-quoted language of Blackburn, J. It will furnish at any rate a sufficient basis for discussion:

"Bills of exchange and promissory notes, whether payable to order or to the bearer, are by the law merchant negotiable in both senses of the word. The person who, by a genuine indorsement, or where it is payable to bearer by a delivery. becomes holder, may sue in his own name on the contract, and if he is a bona ficle holder for value he has a good title notwithstandins any defect of title in the party (whether indurser or deliverer) from whom he took it." l

I. Transferee Suing in His Own Name.-The first of these distinguishing characteristics of bills and notes - that a transferee can sue upon them in his own name ${ }^{2}$ - is very easily displaced, and that in four different ways:

(1) Assignees of covenants " running with the land" can sue upon them in their own name. ${ }^{3}$ This is not because of any law merchant or law farmer, but because the covenant was made with the person who, for the time being, might have the land. That is to say, the covenant was ambulatory.

(2) It was for the same reason, and not because the law merchant so declared (an absurd idea), that the transferee of a note could sue upon it in his own name.

"The note is an original pronise by the maker to pay any person who shall become the bearer; it is therefore payable to any person who successively holds the note bona fide. not by virtue of any assignment of the promise, but by an original and direct promise moving from the maker to the bearer." 4

"Bearer is descriptio persono, and a person may take by that description as well as any other. In the nature of the contract there is no im.

1 Crouch v. Credit Foncier (1873), L. R. 8 Q. B. $374 ; 42$ L. J. Q. B. 183. Quoted approvingly in Pollock on Contracts (6th ed.), 219; Chalmers on Bills (5th ed.), 10:3; McLitren on Bills, 197, 445; Addison on Contracts (9th ed.), 1096; Cababé on Estoppel, 130. And see Bouvier's Law Dic. (Rawle), title "Negotiate." To same effect per Bowen, L. J., in Simmons $r$. London (1891), 2 Ch. 294; 60 L. J. Ch. 324.

${ }^{2}$ In a noteworthy judgment in Shaw v. Railroad Co. (1879), 101 U.S. 557, Strong, J., contends that "the capability of being thus trinsferred, su as to give to the indorse a right to sue on the contract in his own name, is what constitutes negotjability." The acquisition of a better title than that of the transferror he treats as a consequence of this capability.

3 On ward v. Snithson(1893), 1 Ch.6; 62 L. J. Ch. 138; Spencer's Case and notes, $1 \mathrm{Sm}$. L. C. (10th ed.) 52, ff; Mitchell v. Warner (1825), 5 Conn. 498; Tapscott v. Williams (1841), 10 Ohio. 443.

+ Per Story, J., in Bullard v. Bell (1s17), Mason, 243. And see Reed v. Ingham (1799), 3 Dall. (Pa.) 505, and Thompson v. Perrine (1832), 106 U.S. 593. And see post, p. 38s. 
propriety in doing so. It is a contract 'to pay the hearer, or the person to whom he may deliver it' (whether it be a note or a bill of exchance), and it is repugnant to the contract that the drawer should object that the bearer has no riglit to demand payment from him." I

"For the words, 'or to his order, give authority to the plaintıf to assinn it by indorsement: and 'tis an agreement by the first drawer that he would answer it to the assignee." 2

"The person seems sufficiently described at the time that 'tis made a deed, which is at its delivery: and suppose a bond were now male to the Lord Mayor of London, and the party seals it, and after this man's mayoraity is out he clelivers the bond to the subsequent mayor, this is good. et traditio facet chartam lorqui. And by the delivery he expounls the person before meant: as when a merchant promises to pay to bearer of the note, uny one who brings the note shall be paid." 3

(3) All choses in action may be sued upon in equity in the name of the transferees of them. The characteristic in hand, therefore, is that of the courts of law rather than that of certain choses in action; and that which has been spoken of as a distinguishing characteristic of bills and notes is really but a point of practice, upon which different courts took opposite views."

1 Grant v. Vaughan (1;64), 2 Burr. 1527. See also Carter $v$. Palmer (1700), 12 Mod. 380 ; Peacock v. Rhodes (1is1), Doug. 636; Re Agra (1867), L. R. 2 Ch. 391; 36 L. J. Ch. 222; per Bowen, L. J., in Easton v. London (1886), 34 Ch. D. 112: 57 L. J. Ch. 332; and per Lord Watson in Simmons $v$. London (1892), A. C. 20: 61 L. J. Ch. 313. But see Re Blakely (186\%), L. R. 3 Ch. 158; 36 L. J. Ch. 655, and Dixon v. Bovill (1850), 3 Macq. 13, 14.

2 Hill v. Lewis (1794), 1 Salk. 132.

3 Sheldon r. Hurtley (1690), 2 Show. 161. Upon general principles it is much easier to understand why bills and notes should be sued upon in the name of the transferee thim why they should not. In other words, if we look at some of the documents themselves (e. g., "I promise to pily to the bearer hereof," or to "Ship) Fortune or bearer"), it is hard to imagine how it came about that there was any other course than that the action must be brought in the name of the bearer; for the promise is made to hin. The best that can be said for the other view is that the maker of a note promises the person to whom he gives it that he will pay it to the bearer; and that he makes no contract at all with the bearer: "I promise you that I will pay to the bearer." This is, however, not only to alter the form but the substance of the note-probally to take it out of the category of notes (as usually understood) altogether. If I were to advertise that I would pay $\$ 5$ to "the finder" of my dos. there could be no doubt that any one who answered that description could sue me for the noney. My contract was not with the newspaper. Williams s. Carwardine (18:33), 4 B. \& Ad. 6:1; Denton v. Great Northern (18i6), 5 E. \& B. 860; 25 L. J. Q. B. 129; Warlow r. Harrison (1858), 1 E. \& E. 295, 309; Scott . Pilkington (1862), 2 B. \& S. 11; 31 L. J. Q. B. 81.

* That the point was one of practice lecomes very clear when it is remembered that although an assignee of a chose in action was not permitted to sue at law in his own name. yet his real presence was aclinowledged when suing in the name of his assignor. To a defense, valid 
(4) Whaterer may be thonght of these three points, it will not be doubted that in many jurisdictions modern statutes have abolished all distinctions between "negrotiable" instruments and other choses in action (arising out of contract), with reference to the right of assignees to sue upon them in their own names. All transferees may now so sue.

As to this first characteristic then we may say either that it never existed or that if it dicl it has been abolished.

II. Ilonest Acquisition Confers Title. - It is very extraordinary that it shonld ever have been said that a distinguishing characteristic of "negotiable" instruments was that honest acquisition of them confers title. Consider these points:

(1) A "negotiable" instrument is a "negotiable" instrument whether it is due or overdue; and yet honest acquisition of it at one stage of its career will (generally) confer title, but when it is past due an honest transferee takes what is given him and no more. The language of Strong, J., seems to be correct:

"A bill or note past due is negotiable . . . but its indorsement or delivery does not cut off the defenses of the maker or acceptor against it - and it does not give to the purchaser of lost or stolen bills the right of the real owner." I

The codes, too, tell us that

"where an orerdu-bill is negotiated it can be negotiated only subject to any defect of title affecting it at its maturity." 2

What can be made of such a sentence with present ideas of "negotiability?"

(2) Again, it is not true, even of current instruments, that honest acquisition will always confer title, for it will be no assistance if the signatures to them have been obtained by certain frauds, ${ }^{3}$ or if the amount payable has been fraudulently increased, ${ }^{4}$ or if the signature to a blank piece of paper has been

as against his assignor, it was sometimes a good replication that the plaintiff (the assignor) was suing as a trustee for the assignee, who was therefore the real plaintiff. In other words, courts of law allowed trans. ferees to assert their rights through their trustees, whereas equity permitted the same thing to be done directly. See Master v. Miller (1791), 4 T. R. 310, judgment of Buller, J., pussim. See post, p. 388.
1 Shaw v. Railroad Co. (1879), 101 U. S. 557.

$245 \& 46$ Vic. (Imp.), ch. 61, \$36 (2); 53 Vic. (Can.). ch. 38 , \$ $36(2)$.

${ }^{3}$ Foster v. McKinnon (1869), L. R. 4 C. P. 704 ; 38 L. J. C. P. 310 ; Second Nat. Bank v. Hewitt (1896), 59 N. J. L. 57; 34 Atl. R. 988 .

4 Schofield v. Londesborough (1894), 2 Q. B. 660 ; 63 L. J. Q. B. 649 ; (1895) 1 Q. B. $536 ; 64$ L. J. Q. B. 293 ; (1896) A. C. $514 ; 65$ L. J. Q. B. 593. 
stolen and conrerted into a bill, ${ }^{1}$ or if eren a completel but unissued bill be stolen, ${ }^{2}$ or if a material alteration has been made in a bill, ${ }^{3}$ or in many other cases. ${ }^{4}$

(3) Nor can it be said that the "honest acquisition" doctrine is confined to "negotiable" instruments, for there is the everwidening class of cases provided for by that most important rule:

"Generally speaking, a chose in action assignable only in equity must be assigned subject to the equities existing between the original parties to the contract: but this is a rule which must yield when it appears from the nature or terms of the contract that it must have been intended to be assignable free from and unatfected by such equities." 5

(4) The cases are legion, moreover, in which acquisition of such "non-negotiable" articles as goods and lands will confer a better title than that beld by the transferror:

(a) A mortgargee allows the mortgagor to bave the deeds and they are fraudulently deposited as security for a loan. The depositee gets a better title than the depositor had. ${ }^{6}$

(b) Goods intrusted to a mercantile agent may be sold and a good title passed, althongh he had no interest in the goods and no right to sell them. ${ }^{7}$

1 Byles on Bills (15th ed.), 255; Dan. iel on Negotiable Instruments, $\$ 814$; Parsons on N. \& B., vol. 1, 114.

2 Baxendale v. Bennett (18;8), 3 Q. B. D. 525 ; 47 L. J. C. P. 624 ; Bigelow on Bills and Notes, 177, 178, and cases there cited. But see per Williams, J., in Inglanm v. Primrose (1859), 7 C. B. N. S. 82: 28 L. J. C. P. 294.

${ }^{3}$ Calvert v. Baker (1838), 4 MI. \& W. 417; Desbrow v. Wetherly (1834), 1 Moo. \& R. 438; Crotty v. IIorlges (1842), 5 Sc. N. R. 2:1; 4 II. \& G. 561 ; 11 L. J. C. P. 289: Burchfield v. Moore (18.54), 23 L. J. Q. B. 261. See the codes. 45 \& 46 Vic. (Imp.), ch. 61, \$ 64; 53 Vic. (Can.), ch. 33, \$ 63; Midaugh v. Elliott. 1 Mo. App. 46:; King. ston Sav. Jank v. Bosserman (1893), 52 Mo. A pp. 269; Mount Morris r. Lawson (1894), 58 N. Y. St. R. 35; 7 Misc. R. 22S; 27 N. Y. Supp. 272; 63 N. Y. St. R. 432; 10 Misc. IR. 359; 31 N. Y. Supp. 18; Newman v. King (1806), 54 Ohio St. 273; 43 N. E. R. $6 \$ 3$.

4 Master v. Hill (1763), 4 T. R. 320;
5 T. R. 367 ; 2 H. Bl. 140; Mason v. Bradley (1843), 11 M. \& W. 593; 12 L. J. Ex. 425; Harrison v. Cotgreave (1S47), 4 C. B. $562 ; 16$ L. J. C. P. 198; Warrington v. Early (1853), 2 E. \& $B$. 763: 23 L. J. Q. B. 47; Gardner v. Waalsh (1855), 5 E. \& B. 91 ; 24 L. J. Q. B. 285; Hirschlield v. Smith (1866). L. R. 1 C. P. 310; 35 L. J. C. P. 1\% : Hirschman v. Buld (18i3), L. R. 8 Ex. 171; 42 L. J. Ex. 113; Vance v. Lowther (18;6), 1 Ex. D. 176; $45 \mathrm{~L}$. J. Q. B. 200; Columbia v. Cornell (1888), 130 U. S. 6.58; Hosler v. Beard (1896). 5t Ohio St. 395; 43 N. E. R. 1040: Swinney v. Edwards (1898), 5.) Pac. R. (Wyo.) :06.

${ }^{5}$ Re Agra \& Masterman's Bank (186r), L. R. 2 Ch. 39 i: 36 L. J. Ch. 22:3.

${ }^{6}$ Perry-IIerrick v. Attwool (185i), 2 De G. \& J. 21; 2r L. J. Ch. 121: Brocklesby v. Temperance (1895), A. C. $173 ; 64$ L. J. Ch. 433 .

TThe Factors Act, 52 \& 53 Vic. (Imp.), ch. 45, :\$: $2,7,8,9,10$. 
(c) Any one held out as the owner of goods may transfer a better title than he has - at least the owner will be estopped from asserting to the contrary. ${ }^{1}$

(d) A purchaser in market overt may obtain a better title than that of his rendor.

These examples, and others that will readily occur to any one, amply warrant the statement that there is no antagonism between the law relating to bills and notes and the rest of the law in the respect referred to. On the contrary, we see that the phrase "Honest acquisition confers title" applies in many branches of the law other than that relating to bills and notes. And we shall see that it applies in all departments for the same reason.

It may be urged that, at all events, there is a distinction between bills and notes on the one hand and chattel property on the other, where title is acquired from a thief or finder. But once more, it is not always true that a good title to a bill or note is obtained from a thief or finder. The authorities seem to be agreed that if a signed blank bill be stolen and filled up, the transferee gets no title; ${ }^{2}$ and it has been heid that if a bill complete, sare by delirery (and therefore an unissued bill), be stolen, no title to it can be acquired from a thief. ${ }^{3}$

And it is not always true that a thief or finder of chattels cannot give a better title than he himself has. Sale in market overt is a sufficient contraliction of the statement. And the fact that the law governing such siles is part of the general body of the law is some indication that sufficient sanction for a similar result in the case of bills and notes may also be found without going outside of it. The transferee of stolen bonds takes a good title. ${ }^{4}$

III. Negotiability and Transferability.-Abandoning then these two customary significations of "negotiability," let us

1 See chs. XXI, XXII, XXIII.

2 Byles on Bills (15th ed.), 255; Parsons on N. \& B., vol. 1, 114; Daniel on Negotiable Insts. (4th ed.), $\$ 814$, 840. See the subject discussed in ch. XXV.

3 Baxendale v. Bennett (1879), 3 Q. B. D. 525; 47 L. J. C. P. 624. And see Bigelow on B. \& N. 176, ff; Daniel on Negotiable Insts. (4th ed.), vol. 1,
\$839. It is doubtful whether the Bills of Exchange Act has affected this and the previous point. Probably it has. See $\$ \$ 21,29$.

4 Venables v. Baring (1892), $3 \mathrm{Ch}$. 52г; 61 L. J. Ch. 609; Bechuanaland v. London (1898), 2 Q. B. 658; 67 L. J. Q. B. 986; Whiteside v. First Nat. Bank (1898), 47 S. W. R. 1109 (Tenn.). 
try the dictionary meaning, namely, "transferability." This has been adopted by some writers, but only very summarily to be departed from. For example, in "Daniel on Negotiablo Instruments" we find it stated that

"an instrument is called negotiable when the legal title to the instrument itself, and and to the whole amomit of money expressed upon its face, mily be transferred from one to another by indorsement and delivery by the holder, or by delivery only." 1

But the learned author approves of such language as the following:

"Written contracts are not necessarily negotiable, simply because by their terms they inure to the benetit of the bearer. Doubtless the certificates were assignable, and they would have been so if the word 'bearer' had been omitted, but they were not negotiable instruments in the sense supposed by the appellants. Holders might transfer them, but the assignees tools them subject to every equity in the hands of the original owners." 2

Here then are documents which are transferable but not negotiable. In another paragraph, referring to bills of lading, the same writer says:

"Bills of lading are generally classed among negotiable instruments and are frequently spoken of as negotiable like bills of exchange by textwriters and by jurists of high reputation and authority. ${ }^{3}$ But while they are assignable and possess certain capacities of negotiation which assimi. late them quite closely in some respects to negotiable instruments. they are not negotiable in the same sense as bills of exchange or negotiable promissory notes. And it is more correct to speak of them as quasi-negotiable instimments, since they are rather like, than of, them." 5

It would of course be quite out of the question to substitute for "quasi-negotiable" the phrase "quasi-transferable." That would be to alter Mr. Daniel's meaning, which was that although bills of lading were capable of complete transfer, yet that they lacked some of "the peculiarities which attach to negotiable paper" - in other words, they are completely trans. ferable, but only quasi-negotiable.

Not much help is to be obtained from the codes. We find it stated in the English and Canadian compilations that

"a bill is negotiated when it is transferred from one person to another in in such a manner as to constitute the transferee the holder of the bill." ${ }_{b}$

1 Sec. 1. See also Snith's I. C. (10th ed.), 456; and Addison on Contracts (9th ed.), 1096.

2 Railroad Co. v. Howard (1868), 7 Wall. 415. Quoted by Mr. Daniel, 1456.

${ }^{3}$ Lickbarrow r. Mason (1isi), 2 T. R. 63, in which the jury found "that by the custom of merchants bills of lading . . . to order or assigns have been and are .. . ne- gotiable and transferable." Berkling v. Watling (183r), 7 Ad. \& E. 29; Bell r. Moss, 5 Whart. 189.

4 Gurney v. Behrend (1854), 3 E \& B. $622 ; 23$ L. J. Q. B. 265; Barnard v. Camplell (18;4), 55 N. Y. 46:; 1 Smith's Learl. Cas. (10th ed.), 693.

5 Schouler's Personal Property, 410. 605; Davenport v. Homeyer (1\$69), 45 Mo. 145.

$645 \& 46$ Vic. (Imp.), cl. 61, §31; 
But if we were to say that a blacksmith's account "is negotiated when it is transferred from one person to another in such a manner as to constitute the transferee the holder of the" account, the assertion would be quite as valid and just as fruitless. For the gist of both statements is merely that bills and accounts may both alike be transferred - a remark that, of course, docs not help one to appreciate any distinction between them.

The last hope of intelligibility (upon the view that negotiability means simply transferability) seems to be removed with Mrr. Chitty's perfectly accurate remark that

" it is now well established that it is not essential to the validity of a bill that it should be transferable from one person to another." 1

If now we say that bills are negrotiable instruments; that negotiable means transferable; and that bills are very often not transferable, we have some notion of the confusion to which current phraseology has reduced us.

The great uncertainty concerning the meaning of this word "negotiable" becomes so conspicuously noteworthy when, standing by itself, it has to be construed, that one cannot but be surprised that it should continue to be used as though it had some

53 Vic. (Can.), ch. $33, \S 31$. The codes also provide that a bill containing "words prohibiting transfer . . is not negotiable" (\$ 8$)$. But the codes, of course, do not mean that such a bill cannot be transferred. For as Chalmers says (on Bills, p. 129): "A bill may be transferred by assignment or sale, subject to the same conditions as would be requisite in the case of an ordinary chose in action. Thus $\mathrm{C}$. is the holder of a note payable to his order. He may transfer his title to D. by a separate writing assigning the note to D. (Re Barrington (1801), 2 Sch. \& Lef. 112); or by a voluntary deed constituting a declaration of trust in favor of D. (Richardson v. Richardson (1867), L. R. 3 Eq. 685); or by a written contract of sale (Shelion v. Parker (1875), 3 Hun (N. Y.), 498). A bill is a chattel, therefore it may be sold as a chattel.
A bill is a chose in action, therefore it may be assigned as a chose in action."

1 Chitty on Bills (11th ed.), 115. For example, days of grace are allowed on a note payable to A. without adding "or to his order or bearer." Smith v. Kendall (1794), 6 T. R. 123. Of a similar note it was said that "it is not necessary that such a note should be in itself negotiable, it is sufficient that it should be a note for the certain payment of a sum of money, whether negotiable or not" (per Le Blanc, J., in King v. Box (1815), 6 Taunt. 328); and a conviction for forgery of such a document was sustained. And sce Whyte r. Heyman (1859), 34 Pa. St. 143 . Now by the codes - altering the law, $45 \&$ 46 Vic. (Imp). ch. 61, $\$ 8(4)$; 53 Vic. (Can.), ch. 33, $\S 8(4)-$ such a note is "negotiable." 
clear definition. For example, an American statute provided that bills of lading

"shall be negotiable, and may be transferred by indorsement and delivery;"

and another act declared that they

"shall be negotiable by written inlorsement thereon and delivery in the same manner as bills of exchange;"

whereupon arose for clecision the question whether transferees took a better title than that held by the transferrors; and an answer quite contrary to generally accepted notions was given by the United States Supreme Court:

"The capability of being thus transferred so as to give to the inilorses a right to sue on the conlract in his own name is what constitutes nogotiability. . . In regard to bills and notes certain other conseguences gen. erally, though not always, follow. . . . But none of these conseguences are necessary attendants or constituents to negotiability or negotiation. They niay exist without them."1

The bills of lading were negotiable, but honest acquisition of them did not confer title.

So in an English case evidence had been given that certain bonds were negotiable, and the judges could not agree what that meant. Bowen, I. J., declared that although the bonds passed by delivery, yet it did not follow

"that delivery by a person who has no title confers nevertheless a title on a bona fide holder."

But in the House of Lords, Lord Watson thought that "it necessarily follows from the negotiable character of the documents that Delmar, who was lawfully in possession of them for a special purpose, was nevertheless in a position to give a valid title to any person acquiring the bonds from him in good faith.'

IV. What then is Negotialility? - The difficulties commence to dissolve as soon as it is observed that the word "negotiable" is used in two senses. The primary meaning unquestionably is transferable; but consider the following sentence:

"A non-negotiable promissory note is a mere chose in action; as such it is assignalule, and the assignee there of may maintain an action thereon in his own name." 3

The language is in perfect larmony with our ideas; but of course it does not mean that a non-assignable note is assignable. In like manner, and in langriage that is customary, Mr. Daniel, treating of "the trunsfer of certificates of deposit," expresses doubts as to whether they are negotiable. ${ }^{5}$ Stock

l Shaw v. Railroad Co. (18\%9), 101 U. S. $55 \%$.

2 Simmons v. London (1891), $1 \mathrm{Cl}$. 294: 60 L. J. Ch. 224: (1592) A. C. 213; 61 L. J. Cl. 727.
3 Barry v. Wachosky (1S99), ir $\mathrm{N}$. W. R. 1080 (Neb.).

4 On Negotiable Instruments, $\S 1,02$.

5 Id. § 1703. 
certificates are undoubtedly transferable, but Mr. Daniel says that they

" are not regarled as strictly negotiable, although they inure to the benefit of the bearer, and may be classed amongst iustruments quasi-negotiable." 1

The truth is that "negotiable" has an original and an acquired signification. Originally it meant transferable; but afterwards it was used to indicate the supposed effects of transfer, namely, that the transferee (1) took free from equities, and (2) could sue in his own name. And thus we say that certain choses are transferable, although not negotiablemeaning that they are transferable, but that certain effects do not accompany their transfer. ${ }^{2}$

According to primary meaning, then, a "negotiable" instrument is a transferable instrument; and in that sense the word truly inclicated, at one time, a real distinction among choses in action. The secondary meaning, however - that in which it is taken as indicating the existence of peculiar effects of transfer - was always inaccurate and unscientific; for as to the transferee bringing an action in his own name, that is the normal result or effect of all transferability; and as to honest acquisition conferring title, this secondary meaning arrogates to the transfer of bills and notes alone, an effect (1) which existed sometimes in the case of other property, and (2) which sometimes was absent from bills themselves. In other words, "negotiable" was used (in the secondary sense) to mark off bills and notes from other choses in action, by a peculiarity of which they not only had no exclusive possession, but which frequently was altogether absent. However dubious to some lawyers this assertion may appear to be, there is at least no doubt (1) that at the present day all choses in action arising out of contract are trausferable; and (2) that any rule as to transferees of choses in action taking free from equities is by no means confined to bills and notes, but is, as we have seen,

"a rule which must yield when it appears, from the nature or terms of the contract, that it must have been intended to be assignable free from and unaffected by such equities." 3

${ }^{1} \mathrm{Id}, \$ 1$ 1\%08. Consider also the sentence from Chalmers on Bills (5th ed. 115): "The character and incidents of negotiability depend upon the time of nerotialility."

2 Ashhurst, J., as early as 1787 had said: "The custom of merchants only establishes that such an instrument may be indorsed, but the eff'ct of the indorsement is a matter of law." Lickbarrow v. Mason, 2 T. R. 71. 
We must get away, then, from the terms " negotiable" and "non-negrotiable." For (1) their primary and only true meaning has been lost to them; (2) that meaning would now be useful only to distinguish between choses which arise out of contract from those which do not (for the former are by statute assignable - i. e., negotiable, while the others are not), and the word "transferable" (having no false connotations attached to it) is better for that purpose; (3) the acquired meaning of the terms was never scientific - at all events at the present time they are inaceurate and misleading.

\section{Ambulatory and Now-nimetatory.}

Nevertheless, as the quotation just made sufficiently shows, there is a real distinction among choses in action (arising out of contract), namely, between those "intended to be assignable" free from equities and those not so intended-or, as the present writer ventures to suggest, between ambulatory and non-ambulatory contracts. All contracts are now transferable (negotiable); but some are intended to be redeemable to persons other than the immediate promisee; are intended to be passed on from hand to band; are intended, that is, to be ambulatory.

Of such contracts there were in early times none (the simple preceded the complex), and the courts declined to acknowledge their validity long after they came into existence, and the customary rules concerning them were well known to ererybody. Foreign bills of exchange formed the thin edge of the wedge; the statute of Anne ${ }^{1}$ overruled Cuief Justice IIolt in his refusal to sanction the admission of promissory notes; in $175 \mathrm{~S}$ a banknote was held to be negrotiable; ${ }^{2}$ in $176+$ a draft or check on a bank; ${ }^{3}$ in 1571 a note indorsed in blank; ${ }^{4}$ exchequer bills in $1820 ;{ }^{5}$ and bonds of the King of Prussia, payable to the holder, in $1824 .^{6}$

All these instruments have a common characteristic (they are intencled to be ambulatory), but one that is by no means necessarily confined to them, as we shall see later on. Some members of a class must necessarily be known before the class

$13 \& 4$ Anne, ch. 9.

2 Miller $r$ Race, 1 Burr. 452.

3 Grant v. Vaughan, 3 Burr. 1516.
4 Peacock v. Rhodes, Doug. 636.

5 Wookey r. Pole, 4 3. \& All. 1.

6 Gorgier v. Mieville, 3 B. \& C. 4 I 
itself can be accurately described; and non-recognition of a true distinguishing characteristic bas of ten led to unnecessary difficulty. Thus it happened that it remained for Lord Cairns (1S62), in perhaps the most noteworthy single sentence of modern law, to indicate the clear and simple ground upon which rested the asserted peculiarities of "negotiable" instruments. It is worth repeating:

"Generally speaking, a chose in action assigignable only in equity must be assigned subject to the equities existing between the original parties to the contract; but this is a rule which must yield when it a ppears from the nature or terms of the contract that it must latve been intended to be assignable free from and unaffected by such equities." 1

In other words, when it is intended that an obligor is not to set up equities, he is not to be permitted to do it. Strange that there should ever have been any difficulty about that proposition - particularly in getting it stated.

Observe how this sentence and the statutes cut into our notions of "negotiability." A "negotiable" chose in action is one transferable at law, upon which the transferee may sue in his own name. Is it? Then all contracts arising out of contract are now "negotiable." A "negotiable" instrument is one that passes to a transferee free from equities. Is it? Then all contracts "intencled to be assignable free from and unaffected by such equities" are "negotiable;" and overdue bills and notes are not.

\section{Tine Crocle.}

Observe the cycle through which we have come: (1) Certain instruments (bills, and afterwards notes) were intencled to be ambulatory - to be performed to transferees, and therefore to be assignable free from equities. (2) The law, with certain misgrivings, sanctioned the intention and enforced the contracts. (3) Customs expanded; contracts other than bills and notes arose which were intended to be ambulatory. (4) But the law remained crystallized - bills and notes, and at the utmost, checks, exchequer bills, and finally foreign government bonds - all eo nomine and not as examples of a class, are alone "negotiable;" transferees of all other choses in action (although in reality also members of the class) must take subject to equities. (5) Then Lord Cairns, with his exception to the general rule as to assignees of choses in action taking subject to equities, namely,

1 Ante, p. 379. 
that such is not the case where the choses were intended to be ambulatory; a dictum which placed all instruments belonging to the same class upon the same footing.

So we started and ended very reasonably - documents intended to be redeemable to third persons shall be so redeemed; although for many intermediate years we refused to admit the generality of the proposition, stumbling foolishly over law merchant and negotiability.

Choses in action, then, intended to be ambulatory are ambulatory, even although an equitable title to them merely may jass by transfer. But if this be too difficult a proposition for minds addicted to legal estate priorities, they may be comforted by the statute which provides that to all choses in action arising out of contract the legal title shall pass where the transfer is by writing. This may still leave open the annoying anomaly that the transferee of an instrument payable to order (bis assignment being in writing) would be more favored than the transferee of a document redeemable to bearer (his assignment having been by delivery only). But the anomaly would be too absurd and worrying to live long. It would be unanimously clubbed upon its first appearance. By logic or club we must retain the faith, now that we have again got it; that ambulatory contracts are ambulatory.

Decay of the Old System. - Some idea of the old system and the inroads upon it - the evolution out of it - may be obtained by the perusal of two quotations. The first is taken from a judgment of the United States Supreme Court, in which may be found a most elaborate and exhaustivo elucidation of the old law. In it there is the following:"

"To this it may be answered that the antiquated doctrine that a chose in action 8 not assignab'e was introlucesl in early times before negotiable instruments were in use, when trade was carried on in its simplest form. and when the principal if not the only purpose intended to be answered by the rule was to prevent maintenance in controversies respecting titles to land. It was to prevent the poor man from being oppressed by a powerful antagonist, to whom his competitor might assign his title, and who by his wealth. his influence or his power might prevent justice. At what time or by what means it was first applied to personal rights is nut ascertained; but it seems clear that 11 its original adoption it was never intended to apply to those instruments uhich by their nuture and the originat contract of the parties were made neyotiable. Every man has a natural right to make such contricts as he pleases. provided they are not rejurnant to any positive law nor injuriums to others: and all contracts entered into witlout fraud or force are legilly and morally obligatory, according

1 Dunlop v. Silver (1863), ij U. S. A PP. $36 \%$. 
to their spirit and intent. The reason of the rule was to prevent maintenance. Co. Lit. 214. But no man could be oppressed by maintenance who had expressly agreed to pay his debt to such a person as his creditor might appoint."

\section{With the above should be real a very able judgment of} Buller, J. ${ }^{1}$ In it he said:

"It is laid down in our old books that for a voiding maintenance a chose in action cirnnot be assigned, or granted over to another. Co. Lit. 214a, 266a; 2 Roli. 45, 1, 40.2 The good sense of that rule seens to me to be very ques. tionable; and in early as well as in modern times it has been so explained away that it remains at most only an objection to the form of the action in any case. . . . Courts of equity from the earliest times thought the doctrine too absurd for them to adopt, and therefore they always acted in direct contradiction to it; and we shall soon see that the courts of law also altered their language on the subject very much. . . ."

"After these cases we may venture to say that the maxim was a bad one, and that it proceeded on a foundation that fails. Bnt still it must be admitted that though the courts of law have gone the length of taking notice of assignments of choses in action, and of acting upon them, yet in many cases they have adlered to the formal objection that the action shall be brought in the name of the assignor and not in the name of the assignee. I see no use or convenience in preserving that shadow when the substance is gone; and that it is merely a shadow is auparent from the later cases in which the courts have taken care that it shall not work injustice. . . ."

"There is no reason for confining the power of assignment to the two instruments which I have mentioned; and I will show you other cases in which the courts liave allowed it. First, in Fenner v. Mears, where the defendant, a captain of an East-Indiaman, borrowed $£ 1,000$ of Cox, and gave two respondentia bonds, and signed an indorsement on the back of them, acknowledging that in case Cox chose to assign the bonds he held himself bound to pav them to the assignees. Cox assigned them to the plaintiff, who was allowed to recover the amount of them in an action for money had and recejved. De Grey, Ch. J., in disposing of the motion for a new trial, said: 'Respondentia bonds have been found essentially necessary for carrying on the India trade; but it would clog these securities and be productive of great inconvenience if they were obliged to remain in the hands of the first obligee. This contract is therefore devised to operate upon subsequent assignments. and amounts to a declaration that, upon such an assignment, the money which I have borrowed shall no longer be the money of $A$., but of B., his substitute. The plaintiff is certainly entitled to the money in conscience; and therefore also I think at law; for the defendant has promised to pay any person who is entitled to the money."

lMasters v. Miller (1791), 4 T. R. 340 ; and also the exposition of Cock. burn, C. J., in Goodwin v. Robarts (18i5), L. R. 10 Ex. 346: 44 I. J. Ex. $15 \%$, which did much to bring the law into harmony with modern finance.

${ }^{2}$ Sir Frederick Pollock would as sign a different reason. He says (On Contracts, 6th ed., p. 206): "The origin of the rule was attributable by Coke to the 'wisdom and policy of the founders of our law' in discouraging maintenance and litigation; but it is better explained as a loyical consequence of the archaic view of a contract as creating a strictly personal obligation between the creditor and the debtor." In truth the founders of our law were too much given to inalienability, for which probably the necessarily personal relation of the feudal system is largely responsible. Lands were inalienable and non-devisable, until the equity lawyers invented their system of uses. And even after Quia Emptores and the Statute of Wills, rights of entry remained inalien. able-upon the ground mentioned in the text. 
“And in Winch v. Keeley, K. B. Hil. 27 Geo. 3, where the obligee assigned over a bond, and afterwarils became a bankrupt, the court holds that be minht notwitbstanding maintain the action. Mr. J. Ashburst said: 'It is true that formerly courts of law did not take notice of an equity or trust: but of late years, as it has been found productive of great expense to send the parties to the other side of the hall, wherever this court has seen that t'it justice of the case has been clearly with the plaintiff, they have not turned him round upon this objection. Then, if this court will take notice of a trust, why shoulil they not of an equity? It is certainly true that a chose in action cannot strictly be assigned, but this court will take notice of a trust, and see who is beneficially interested."

We see here the old law - contracts must be sued upon in the name of the original parties to them - law formulated for certain kinds of contracts, fading by usual process before the introduction of other sorts of contracts to which it is inapplicable. It is clear that these early judges were not conscious of excursions outside the general law. They were quite aware that they were dealing with a new kind of contract; but they were applying to it their general law, with such expansions to surt novel conditions as they could devise.

\section{SUMMARY.}

Let us sum up the conclusions arrived at:

1. As to the alleged distinction between "negotiable" and "non-negotiable" instruments upon the ground that "the person who becomes holder may sue in his own name on the contract," we may say:

(a) Originally and correctly the distinction was attributed to the difference between the contracts themselves, and not between the general law and the law merchant. That is to say, a contract with $A$. could not be sued upon by B.; but a contract with the bearer of a document could be sued upon by the person so described.

(b) The distinction therefore is one between ambulatory and non-ambulatory promises; and not one between bills and notes on the one hand, and - covenants for title (for example) upon the other.

(c) In any event the right to sue in the name of the transferee was a mere point of practice in the courts.

(d) And has now by statutes been abolished.

2. As to the other alleged distinction - that a transferee "has a good title notwithstanding any defect of title in the party from whom he took it" — we may say:

(a) Transferees of "negotiable" instruments sometimes take 
subject to equities, and transferees of other choses in action sonetimes talio free from them.

(b) Purchasers of such "non-negotiable" commorlities as groods and lands often acquire better titles than those of their rendors.

(c) And, as we shall see, for precisely the same reason as do transferees of "negotiable" instruments.

3. If by "negotiability" we mean merely transferability, we better say so; for "negotiability" has now too many meanings - or none at all.

4. There are two very distinct classes of choses in action, which not being describable by any known terms may (until better is suggested) be called ambulatory and non-ambulatory.

Retrospect.-Looking back over the many legal battle-fields we can now see that this classification contains the principle which was struggling towards the light; and we can rightly gauge the forces opposed to it. The "wisdom of the common law" declared against the recognition of trusts. Thus arose the war of legal and equitable estates, not to be completely terminated even by the annibilation of the contestants. ${ }^{1}$ The same wisdom forbade the sale of rights of entry until overruled by statute. And the same wisdom declared that "for avoiding maintenance a chose in action cannot be assigned or granted orer to another." To this is due all the trouble about negotiability. To evade it all sorts of subterfuges and fictions have been resorted to. Probably we have not altogether done with them yet; and "negotiability by estoppel" has recently been added to our perplexities. ${ }^{2}$

\section{FreedoM from EQuíties.}

There are generally supposed to be two points at which "negotiability" affects the rights of the holders of bills and notes. The first has regard to equities affecting liability upon them; and the second relates to the equities of the real owner of the paper against some holder of it who claims title through a finder, a thief, or a fraudulent trustee. These two cases must

1 Recent legislation in many juris. dictions has merged courts of equity and law into one court. Nevertheless we still speak of equitable es- tates, by which we mean those that are recognized by the one court and tabooed by the other.

2 See infra. 
be treated separately in order to ascertain accurately the true foundation of the law which governs them. The law we know fairly well; what is the rationale of that law?

I. Equities of the Obligors. - There is a choice of explanations in the case of the first of these problems (Why cannot the maker of a note set up his equities as against a bona fide transferee of it?); and neither of them is indebted for its rationality to the law merchant:

(a) One of them has already been indicated: the maker of a note is liable upon it to a holder in lue course, although be may have equities, beeause

"the note is an origmal promise by the maker to pay any person who shall become the bearer; it is therefore payable to any person who successively holds the note bona fide, not by virtue of any assignment of the promise, but by an original and direct promise, moving from the maker to the bearer." 1

Observe carefully what is here meant. It is not that the transferee does not acquire title to a note "by virtue of any assignment" of it; but that, having so acquired it, the promise that he sues upon is one directly with himself. That is to say, be does not allege that the maker promised the payee that he would pay a thied person; but that the promise wats to the transferee, although at the time of the promise be was an unascertained person. In this view the case would be analogons to promises frequently made by advertisement to pay to the finder of a lost article, in which the promise is not with the newspaper (as we have noted), but with the person who answers the description contained in the promise. The promise is "an original and direct promise moving from the" advertiser to the finder.

(b) Perhaps, however, the better view is that of Page Wood, L. J., who, in holling a company liable upon its bonds notwithing equities between it and the origrinal holder, said:

"Where there is a distinct promise hell out by the company informing all the world that they will paly to the order of the person named. it is not competent for that company afterwarls to set up equities of their own."?

In other words, although there may be equities, yet the company is estopped from setting them up. It issued bonds r:deemable to bearer; it was aware that the bonds, being ambulatory, would probably be transferred to third parties; it might 
have placed upon the face of the bonds notice of the equities; it enabled the original holder to deceive innocent purchasers, and it is consequently estopped from setting up its equities. Here we are upon firm ground. No support is required from the law merchant, nor from "negotiability." We are not in antagonism to the general law. We are appealing to it.

II. Equities of the True Owner. - When a thief, a finder or a fraululent trustee of a "negotiable" instrument transfers it to a holder in due course, it is said that the transferee takes it free from the equities, meaning thereby that a good title passes to the purchaser. But the phrase is wrong. The transfer does not affect any equity of the true owner of the document. It disturbs his legal title. This premised, let us ascertain the rationale of the law.

The usual suggestion is "law merchant" and "negotiability" in hopeless antagonism to the general law:

"The law merchant validates in the interest of commerce a transaction whell the common law would declare void for want of title or authority." 1

And thus, when the question of title to lost, stolen or misappropriated bonds came to be decided, and the courts felt that transferees in dne course ought to be protected, the Canadian" and American ${ }^{3}$ judges declared that the bonds were "negotiable." That was thought to be a sufficiently satisfactory solution of the problem.

In England a different and a most peculiar course was adopted. Most of the judges were quite unwilling to hold that bonds were "negotiable," and yet they were unable to see any other ground upon which they could decicle in favor of the transferee. They therefore determined that although bonds were not "negotiable," yet that the persons dealing with them were estopped by their form (payable to bearer) from so saying. We shall return to this point.

"Negotiability," then, whether real or by estoppel, is the reason assigned for holding that the transferror's title may be improved by his assignment; but this explanation is altogether unsatisfactory, for "negotiability," as we have seen, itself stands very much in need of explanation.

1 Ante, p. 371.

${ }^{3}$ Daniel on Negotiable Instru-

2 McKenzie v. Montreal (1878), 29 ments, $\$ 1500$. And see infra.

U. C. C. P. 371. 


\section{Estoppel by Ostexshim Owineship axd Age:cy.}

Although without much direct support, the present writer rentures to suggest that the true foundation for the decision of such cases is to be found not in "estoppel by negrotiability", nor in "negotiability" of any kind, but in estoplyel by ostensible ownership or ostensible agency.

Let us commence with $N$ cmo dat quod non labet. That proposition looks as though it ought to be universally true. But it is said that it fails in the case of "negotiable" instruments, and that a man can give that which he has not got, provided he is dealing with a "negotiable" document. Is the principle a true one? And, if so, are "negotiable" documents exceptions, and the only exceptions to it?

Let us remember" that if a thief sells a horse in marliet orert he gives a title that he has not got. And if a mortgagror, having been foolishly intrusted by the mortgagee with the titledeeds, conveys to an innoeent purchaser, he grives that which he has not got.' In short, the cases are legion in which ostensible owners of property give bona fide purchisers that which they have not got.

But we are going much too fast, and, although with plenty of precelent for it, are using language in much too loose a fashion. Is it true that an ostensible owner of property can convey to a purchaser a better title than he has? Should the true owner of a horse stand by while a pretending owner sold the animal to an innocent purchaser, it would be quite inaccurate to say that the vendor gave a better title than he bad. He conld not do so. And the language really imports nothing but this: that although the purchaser has acquired no title at all, yet that the true owner is estopped from so saying.

Nemo dat quod non habet is then true - universally true; but its truth in no way prevents an owner of property from being estopped by his conduct from setting up his good title as against a transferee who bas none. ${ }^{2}$

That is the point. And it applies as well to "negotiable" instruments as to all other sorts of property. When so applied

1 Perry-Herrick v. Attwood (18.5\%), 2 De G. \& J. 21; 27 L. J. Ch. 121; Brockleshy v. Temperance (1895), A.

C. 1 i3; 64 L. J. Ch. 433 .
2 See a good discussion of the maxim in McMation $x$. Sloan (1849), 12 Pa. St. 229. 
it solves all the difficulties which, being thought to be insolvable, have been referred to the inscrutable play of the lawmerchant operating in antagonism to the common law.

Remembering, then, that ostensible ownership may often estop a true owner (of all sorts of property) from setting up his title as against an innocent purchaser, attention must be directed to the fact that the appearance of ownership takes its color sometimes from the character of the property in question, sometimes from the nature of the usual employment of the ostensible owner, and sometimes from the customs of the locality in which the transaction takes place. ${ }^{\prime}$ Observe next the rlistinction between the appearance of ownership (1) of goods and (2) of ambulatory instruments. Possession of goods is (usually) no indication of ownership of them, and therefore no one is misled by possession; but -

"Every holder of the bill takes the property, and his title is stamper on the bills themselves. The property anil possession are inseparable. This was necessary to render them negotiable; and in this respect they differ essentially from goods of which the property and possession may be in different persons." 2

A holder of a bill then appears to be the owner of it, while there is usually no such appearance in the case of goods. Now the law of estoppel by ostensible ownership of goods is well known, and may shortly be stated to be, that if an owner permit another to appear to be the owner he will be estopped as against persons dealing with that other. And the rule includes of course ambulatory instruments; the only distinction between them and goods being as to the circumstances which constitute

1 See ch. XXVI.

${ }^{2}$ Collins v. Martin (1879), 1 Bos. \& P. 651. And see per Lord Mansfield in Peacock v. Rhodes (1781), Doug. 636 ; Siltus v. Everett (1838), 20 Wend. (N. Y.) 276; Murray v. Lardner (1864), 2 Wall. 110; Craig v. Vicksburg (1856), 31 Miss. 216; Commissioners v. Clark (1876), 94 U. S. 278, 285; Martin v. Martin (1898), 174 Ill. 371; 51 N. E. R. 691; Cent. Dig. vii, 2551, 2, 8 . The language quoted in the text is inaccurate. Property and possession of bills, as of aught else, are separable; otherwise I could never bring trover for bills against my book-keeper. What is meant is that possession and appearance of property are inseparable. Even that is not universally but only conmonly true. Circumstances may sometimes indicate agency, and not titie. It is very instructive in this connection to note the reason why assignment of a bill or note by a separate paper, and not by inclorsement, is said to pass the equitable title only: "For such mode of transfer separates the evilence of ownership from the paper itself." See Daniel on Negotiable Instruments, $\$ 748$. 
appearance of ownership. In the case of ambulatory documents mere possession of them is enough;' while as to groods there must be something more. But in both cases alike the true owner must aroid the appearance of ownership in another person. And therefore the owner of an ambulatory instrument must, if he wish to be safe, keep it in his own possession.

Lstoppel by Ostensible Agenry.- Sometimes the validity of a transferee's title must be attributed to ostensible angency rather than to ostensiblo ownership. In the case of groods, for example, the owner may be estopped by a person alleging his agency to sell, although none in fact existed - if the owner has permitted the appearance of agrency. The usual ease of a sale by a factor in defiance of his instructions is a sufficient illustration of the point. In the same way a bill-broker having bills in his possession may be understood to be an agent merely; and a transferee of the bills would therefore be unable to plead that the broker was the ostensible owner of them. Ostensible agency to deal with the bills would answer the same purpose.

Lost or Stolen.- It may be suggested that this explanation is insullieient in the ease of lost or stolen doeuments. No doubt it may be said if an owner of bills or of goods permit the appearance of ownership or agency in another person ho ought to be estopped as against an innocent purchaser; but how can that apply to cases in which the true owner gives no such permission, to cases in which, indeed, he may be actively endeavoring to neutralize false appearances?

Much analogy to the law of estoppel is to be found in the department of torts which declares for liability as well where injury is due to carelessness as where it is the result of premeditation. And so also in the law of estoppel if, through the carelessness of the true owner of property, another person is enabled to pose as its owner, he may be estopped to the same extent as if the deception were designed.

An owner of ambulatory instruments is aware that possession of them is evidence of their ownership. It behooves him, therefore, to exercise "consummate caution" with regard to them, and if they escape him, he and not an innocent purchaser 
ought to suffer. This law is not more drastic than that which provides that

" more than ordinary care, nay 'consummate caution,' 1 is required of per. sons dealing with dangerous weapons;" 2

and is supported by the dictum of Lord Coleridge:

"A man may be more careless with regard to the custody of a thing thiat can be maile available only by means of forgery than if by mere larceny;" 3

more carcless, for example, of a wardrobe, than of money or company bonds.

Owners of ambulatory instruments have two courses open to them. They may, by appropriate indorsement, restrict the transferability of their documents; or they may leave them payable to bearer. If they adopt the former alternative they are safe from loss and theft. But if, for their own purposes, they prefer that the instruments should remain payable to bearer, they must provide sufficiently against their escape, in order that innocent purchasers may not be swindled. This doctrine found acceptance as early as 1764:

"Though both the claimants are innocent. yet as Bicknell lost the note and Grant took it in the course of trade bona fide and upon a valuable consideration, Grant has the better equity. But if their equity were only equal, it is a known and good rule that melior est conditio possidentis, and that would be sufficient to turn the scale; if there was negtigence on one side and none on the other, that also would tum the scale; and if there be any on either side in this case it should seem to have been rather imputable to the person who lost it than to him who thus took it in the course of trade." 4

And in 1820 Mr. Justice Best, in dealing with misappropri. ated exchequer bills, which the owner had kept in blank instead of rendering them useless to others by filling in his own name, saill:

"It is the plaintiff's own negligence in not filling up the blank that has rendered it impossible for the defendants to ascertain that he had any right to it: and it would therefore be inconsistent with the law of justices that under such circumstances he should be allowed to call on them to make good the loss that had arisen from the fraud of his agent." 6

${ }^{1}$ Per Earle, C. J., in Potter v. Cowdry v. Vanderberg (18\%9), 101 U. Faulkner (1861). 1 B. \& S. 805. And S. 572; to bills of lading in Lickbarsee Dixon v. Bell (1816), 5 M. \& S. row v. Mason (1787), 2 T. R. 71; to 198.

2 Pollock on Torts (5th ed.), 46, 455.

${ }^{3}$ Arnold v. Cheque Bank (1876), 1 C. P. D. $581 ; 45$ L。 J. C. P. 562 ; Hat tchett v. Gibson (1818), 13 Ala. 587.

" Per Wilmot, J., in Grant v. Vaughian, 3 Burr. 1526. See the same reasoning applied to vouchers in stock certificates, with blank but signed transfers and powers of at. torney, in National v. Gray (1898), 12 A pp. D. C. 276. Contra, Scollans v. Rollins (1899), 53 N. E. R. 863 (MIass.). 5 More specifically estoppel. 6 Wookey v. Pole (1820), 4 B. \& Ald. 1. 
Bills and notes if stolen or found may be passed with a good title; bonds may now be said to be in the same category $;^{1}$ they are so placed because they are of ambulatory character; and the same considerations that warrant such law as to these instruments will justify the application of its fundamental prineiple to all other ambulatory documents. Let their owners observe "an appropriate measure of prudence to aroid causing barm" to others."

\section{Estopipe axd Amulatory Instruments.}

Aided by the prineiples of estoppel let us for a moment con. sider an ambulatory instrument apart from all legal notions of negotiability and law merchant and fictions. The case is the simplest. Take the usual points:

1. I promise to pay to $\mathrm{A}$. or bearer; or a company issues a debenture payable to $A$. or bearer; or a bank issues a deposit receipt redeemable to bearer; or a man gives me a voucher payable to my order; there are equities between the original parties to the document; but these equities cannot be set up between the obligor and the transferee. Why? Because the obligor intended the document to be ambulatory; he enabled the holder to pass that which appeared to be an unconditional obligation; and he is estopped by the assistance which he has rendered to the misrepresentation of no equities.

2. I give to "Galley" an acceptance, blank as to amount, authorizing him to fill it up for $£ 100$; he inserts $£ 200$; and I am liable to a holder in lue course for the larger amount. Why? Not because Galley had authority; nor because he must (despite the evidence, and by fiction) be held to have authority; but beeause he had ostensible authority to fill up the blank for any amount the stamp would cover; ${ }^{3}$ and I am estopped because I equipped him with such appearance of authority. ${ }^{*}$

I Venables v. Baring (1892), $3 \mathrm{Ch}$. 527; 61 L. J. Ch. 609; Bechuanaland จ. I.ondon (1898), 2 Q. B. 658; 67 L. J. Q. B. 986; Trust \& Loan Co. v. Hamilton (185i). 7 U. C. C. P. 98; Whiteside v. First Nat. Bank (1898), 47 S. W. R. 1108 (Tenn.).

2 Ante, p. 30 . The law has not, however, as yet gone that far. Ex parte Swan (1859), 7 C. B. N. S. 400 ;
30 L. J. C. P. 113: Swan r. North B. A. (1862), 7 H. \& N. 603: 31 L. J. Ex. 425; 2 H. \& C. 165; 32 L. J. Ex. 2i3; Bangor v. Robinson (1892), 52 Fed. R. 520.

3 Or for any amount whatever, in jurisdictions where there are no stamp laws.

t See chs. XXV, XXVL. 
3. Suppose that the bolder of an ambulatory instrument intrusted it to some agent, who fraudulently transferred it to an innocent purchaser; the holder must sustain the loss. Why? Because the agent appeared to be the owner of the instrument; the true owner enabled bim so to represent; and the true owner is therefore estopped by the assistance rendered to the misrepresentation of ownership. Possession of a chattel is not usually ostensible ownership of it, but

"every holder of the bills takes the property, and his title is stamped on the bills themselres. The property and possession are inseparable." 1

The holder of a bill or note is therefore the ostensible owner of it.

4. Suppose that the holder of such an instrument loses it, or that it is stolen from him; a transferee of a finder or thief will take a good title. Why? Because of the ostensible ownership of the finder or thief. But how has the true owner assisted in any misrepresentation of ownership? By lack of vigilance in its custody; or, at all events, by the fact that he chose, knowing the risk, to keep the instrument in easily transferable form. He might have restricted its negotiability by a word. He cannot, for his personal convenience, throw risks upon other people.

Illustrations.- A few words in illustration: If I send my horse to boarding-stables, no one has the right to presume that the horse is there for sale. But if I should send him to salestables - that is, to a place which is devoted solely to the custody of horses on sale,- I would certainly be estopped by ostensible agency from asserting my title as against a purchaser in due course. ${ }^{2}$ No special law decrees this difference. The general law of estoppel is ample. In the first case the circumstances do not amount to a representation of agency; in the second they do; and ostensible agency may result in estoppel. Precisely the same law applies to bills and notes. Blanks in them indicate agency to fill up, and ostensible power will estop.

In France the rule as to movables is "Possession vaut titre." Chattels "are there on the same footing as these bonds, trans. ferable by delivery, are with us." ${ }_{3}$ But it is impossible to say

1 Ante, p. 394.

2 See ch. XIX. ${ }^{3}$ Per Ritchie, C. J., in Young v. Bank v. Barrow (1880), 5 A pp. Cas. 6is.
MacNider (1895), 25 S. C. Can. 2r8. But see per Blaclsburn, J., in City 
that in France it is the law merchant that declares in the interest of commerce, as to all morables, that "honest acquisition confers title." It confers title because "possession vaut titre;" and that is the reason also with us in the case of bills and notes.

Suppose that a mortgagce intrusts the deeds to the mortgagor, who fraudulently deposits them as security for a loan; the mortgagee is estopped. Why? Because he has enabled the mortgagor to appear as the unincumbered owner.' That is an application of the familiar rule of estoppel. Now suppose that the owner of a bill intrusts it to another, who fraud. ulently transfers it for his own benefit; the owner again loses. But this is said to be by virtue of the law merchant, which "validates in the interest of commerce a transaction which the common law would declare void." 2 The results are identical, but are said to be arrived at by antagonistic principles.

The holder of a note and a land mortgage as collateral security placed them in the hands of another under such circumstances as enabled the latter to represent himself as their owner; he did so, and assigned them to an innocent purchaser. ${ }^{3}$ And are we to say that the law which declared in faror of the transferee as to the mortgage was the common law; that the law which declared in his favor as to the notes was the law merchant; and must we add, in the latter case, that "to this despotic but necessary principle the ordinary rules of the common law are male to bend?"

If "negotiability" and legal estate principles are to continue to influence decisions, the effect of the statutes authorizing the assignability of "non-negotiable" choses in action will raise some perplexing questions. In this way: Bills and notes were assignable at law; a purchaser of them for that reason (shall we say?) took them free from equities; now by statute other choses are transferable at law; purchasers of them therefore ought also to take free from equities; but the same statute provides that they are to be held subject to equities.

and Saltus r. Everett (1838), 20 Wend. (N. Y.) 2\%6. The new German Code (1896) proceeds upon the French prin. ciple: See $\$ \$ 931-935$.

1 Perry-Herrick v. Attwood (18j8),
4 Jur. N. S. 101; 27 L. J. Ch: 121; Brocklesby v. Temperance (1\$95), $\Lambda$. C. $173 ; 64$ L. J. Ch. 433 .

${ }^{2}$ See ante, 1. 371.

3See ante, pp. 19, 20, note. 
The difficulty is emphasized when attention is directed to a "negotiable" and a "non-negotiable" note. A note may be made payable to "A. and no other person." Prior to the statutes such an instrument could not be transferred at law, although it was assignable in equity. It may now be completely transferred, and the legal property will pass to the purchaser. Why then does the statute provide that the usual effect of an assignment of a legal interest shall not ensue? Why will the purchaser not take free from unknown equity?

The answer is to be found only by disregarding old ideas of "negotiability" and legal estate, and by attending to the distinction between contracts which are intended by the parties to be ambulatory, and those which are intended to be fulfilled as between the parties only. For although now both classes of contracts are assignable at law, and therefore the principles regulating the rights of transferees of them must be identical, that is far from saying that all distinction which exists in the contracts themselves must be abolished. It will at once be seen that if I promise to pay to "A. or bearer," a transferee of the contract may well assume the absence of equities between me and A.; whereas, if I promise to pay to "A. and no one else," the opposite assumption should be drawn. If I made a note to "A. or bearer" and underwrote a warning as to equities between A. and me, a transferee would take subject to such equities. Restricting the negotiability of a note by drawing it to "A. and no one else" has the same effect.

If then we ask, Why is it that transferees of bills and notes take free from equities, and the assignee of some other instruments do not? the answer is as follows: Bills and notes are usually intended to be ambulatory - intended to be releemed to third parties; and these other instruments, although assignable at law, are usually intended to be redeemed as between the original parties to them; to both cases must be applied the principles of purchasers for value without notice and estoppel $;^{1}$ certain instruments indicate by their form the absence of equities, while certain other instruments carry with them (expressly or by convention) a warning or notice of equities; a purchaser

1 In the light of chapter XI the out notice and" might be omitted words "purchasers for value with-

from this sentence. 
for value may take free from equities of which he has no notice, but not from those of which he hatd warning.

There seems, then, to be at very plain path through all this, when the law merchant obstructions are removed. The principle employed is not only not antagonistic to the general law, but is a part of it. And that principle is at the present time in very actwe operation, and is being applied, although not always consciously, to the decision of many cases.

\section{Negotiamitity ax Estoppent}

Althongl the reader may now see his way through the various difficulties with which we have been dealing (withont the aid of law merchant or "negotiability"), he cannot afford to be ignorant of the doctrine of "negotiability by estoppel" which has been put forward as the solution of all such questions, and a few pages must therefore be devoted to it.

Pressed by the apparent impossibility of applying the word "negotiable" to bonds - documents under seal with various contractual complications - it was at length ingeniously suggested that the parties might be estopped from saying that such instruments were not negotiable. In other words, that althongh the courts themselres would have to declare as a matter of law that certain documents had a certain character and none other, yet that a litigant could not only contend to the contrary, but might even preclude himself from asserting the law to be that which it indubitably is.

Observe the wide difference between this sort of estoppel and that above snggested, namely, that a man may be estopped from denying the ostensible ownership or agency of another person. Estoppel from denying negotiability means, or implies, this: If these documents were by law negotiable, the transferee would have a good title to them, free from equities; the owner is estopped from saying that they are not negrotiable; therefore the transferee has a good title. The other view is entirely different. It is this: If the transferror had been the owner of these documents, or had he had the owner's authority to sell them, the transferee would have a good title; the owner is es-

${ }^{1}$ The phrase belongs to Bowen, L J.: Easton $\nabla$. Lonuon (1SS6), 31 Cl.. D. $113 ; 56$ I. J. Ch. 569 . 
topped from saying that the transferror was not the owner or his duly authorized agent; therefore the transferee has a good title. In the former case the estoppel is as to the legal character of a document. In the latter as to ownership or agency with respect to it. With the latter class of cases - estoppel by ostensible ownership or agency - we are perfectly familiar. Estoppel as to the legal character of a document is novel.

Negotiability by estoppel was put in this way by Lord Cairns:

"The scrip itself would be a representation to any one taking it - a representation which the appellant must be taken to have made or to have been a party to - that if the s(.rip were taken in good faith and for value the person taking it would stand to all intents and purposes in the place of the previous holder. Let it be assumed for a moment that the instrument was not negotiable; that no right of action was transferred by the delivery: and that no legal claim could be made by the taker in his own name inainst the foreign government; still the appeilant is in the position of a person who has made a representation on the face of his scrip, that it would pass with a good title to any one on his tilking it in good faith and for value; and who has put in the p.wer of his agent to hand over the scrip with this representation to those who are induced to alter their position on the faith of the representation. My lords, I am of opinion that on doctrines well established, of which Pickard v. Sears must be taken to be an example, the appellant cannot be allowed to defeat the title which the respondents have thus acquired." 1

This is the riew that the estoppel is as to the legal character of the document. The representation "made on the face of his scrip" is "that it would pass with a good title."

In the same case Lord Hatherly presented the other view, namely, that the broker was the ostensible owner or agent for the sale of the scrip; that the true owner had enabled the broker so to appear, and that the owner was therefore estopped. But, strangely enough, he indicates that this riew is the same as that propounded by Lord Cairns. Lord Hatherly said:

"The appellant, therefore, gives the broker scrip which is and for the last tifty years has been disposed of every day in the market, and has for all those vears been so disposed of upon the sole representation by the liolder, the seller or pledger to the person to whom he wishes to sell or pledge it, and that without any suspiteion being aroused to suggest the necessity or even the propriety of asking a single other question. Can a person who in that manner acquired the instrument, who knows that as Iong as he has it safe in his pocket, in his box, or in lis desk. he can rely on that instrument; but that as soon as he parts with it the new holder will, as he did, become in a position to claim those bonds which he himself might have clitimed if he had retained possession of the scrip - cam he, by placing it in the hands of a broker, with no instructions whitever, except to dispose of it as he may direct - can he according to the principle of the cases uhich were referred to in the course of the argument, with regard to limited agency, hold any person to be bouml by that limited agency. when, on the face of it, that which constitutes. you may say, the authority of the agent, namely, the possession of tle document, appears to be sufficient

1 Goodwin v. Robarts (15;G), 1 A. C. $490 ; 45$ L. J. Q. B. 748. 
alone for oitaining the bonds in question? I agree with my noble and learned friend on the woolsack in thinking that this ease might be dispossed of on that ground alone."

In a later case' the court of appeal judges adopted Lord Cairns' view, holding that the owner must lose because he was aware that, although the bonds were

"not strictly negotiable securities, they were to be treated as such between the parties."

Bowen, L. J., referred to both views of estoppel, and indicated that, practically, they ran into one another. He said:

"This second way of looking at the matter may be dealt with from two points of view, but practically they run iuto one another. You may say that Lord Sheffield - having placed in the hands of his agents these honds with the intention that they should be transferred beyond these agents, and held his agents out to the world as clothed with authority to transfer them as negotiable, cannot afterwards, by any unknown dealing or any limitation of authority which he has conferred on his agents, prejudice those who took the bonds which have been so floated. Or you miny sily that as regards Lord Sheffield and the bank, these bonds have become negotiable by estoppel, and, therefore, hord sheffield is precluded from saying that the legal title to these bonis is not in the bank."

In London v. Simmons ${ }^{2}$ Lord Watson recurs to Lord Cairns' view of " negotiability by estoppel." He said:

"Each bond, according to its tenor, appears to me to represent that the document will pass from land to haud, and that a bona fide holder will be entitled to claim fulfilment of its terms."

But he seems also to approve of the other view, for he added:

"I think the appellants were entitled to assume, in the absence of anything to indicate the contrary, that whether the bonds belonged to Delmar or to a customer, he had full authority to deal with them."

'The present writer has found it impossible to accept Lord Cairns' view of estoppel, although so substantially indorsed. Reduced to simple terms the proposition is this: A non-negotiable instrument payable to bearer is in itself a representation that it is a negotiable instrument, and such representation will estop some one from denying that such is its legal effect. But surely a non-negotiable instrument or any other document cannot in itself be a representation that it is anything but what it is. If, connected with the instrument, there was some misrepresentation of its character, that would be another matter. A man may allege that he is a woman, but he can hardly, himself, be such a representation.

Observe further that the point is that the document is a representation "that it would pass, with a good title, to any one

1 Easton r.London, etc. Bink(1896), Bank (1898), 13 A. C. 393; 57 L. J. 3: Ch. D. 95; 56 L. J. Ch. 569; S. C. Ch. 956.

sub nom. Sheffield v. London, ete. 2(1592) A. C. 213;61 L. J. Ch. 723. 
on his taling it in good faith and for value." But the only feature that can be referred to in support of this is that the instrument was payable to "bearer," and that surely cannot amount to a representation that according to law the title of a new bearer would be any better than that of an old one.

Another essential ingrealient, too, of estoppel is entirely absent from the eases, namely, evidence that the purchaser of the bonds was misled by the misrepresentation, and upon the faith of it changed his position. The probabilities are that he had exactly the same opinion as the true owner of the documents had, and that he acted exclusively upon his own idleas of negotiability.

\section{Considerations in Support.}

Market Overt.- It is noteworthy that the application of the la $w$ of estoppel suggested by the present writer, or sometling very nearly akin to it, was the foundation for bolding that a purchaser from a thief in market overt was to be protected from the true owner. Cockburn, C. J., in Crane v. London said:

"Look to the origin of the law as to such sales. It arose at the time when there was much greater simplicity of practice between buyer and seller. The practice then was to buy in markets at fairs. Shops were very few in London, and persons whose goods were taken feloniously woild know to what place to resort in order to find them. I can therefore quite understand that the law in question was established for the protection of buyers. that if a man did not pursue his goods to market where such goods were openly sold, he ought not to interfere with the right of the lonest and bona fide purchaser." 2

Observe the close analogy here presented to estoppel as applied to bills and notes. As we have seen, "title is stamped on the bills themselves;" the holder may, therefore, properly be presumed to be the owner; the real owner might have lept them "in his poeket;" but if he permitted others to have them, the representation of ownership which they carried with them would estop him from asserting his title. So it is in the case of sales of goods in market overt. There possession indicates ownership, and if a man does not "pursue his goods to market," but allows the representation of ownership in others to be made, "he ought not to interfere"- be is estopped.

1 See the judgment of the same learned judge in Re Natal (1868). L. R. 3 Ch. $360 ; 37$ L. J. Ch. 362. Also
Williams v. Colonial Bank (1888), 36 Ch. D. 659; 57 L. J. Ch. 826. .2(1864) 5 B. \& S. 318. 
Loss of Seal.- Further support for the views advanced may be gathered from the olden times, when every man of property hal his own distinctive seal, with which, rather than with his signature, he executed his obligations. In those days a fincler, a thief, or a fradudulent custodian of the seal might bind the owner in faror of innocent persons, upon the ground that "he (the owner) should have taken better care of it." Sufficient of the learning upon this subject for present purposes is contained in the following extract from a julgment of Wills, J.:

"In Glanvil, book 10 , ch. 12 , it is said that the man who intrusts his steward with his seal will be hound by it if the steward seals a deed with it. for he shomld hare taken better care of it. Bracton (edition published by the Record Commissioners, and edited by Sir Travers Twiss, vol. vi, p. 126) says that a man may get rid of his deeds by showing various matters, such as duress, mistilie. or the like, but adds the qualificition that there must be nothing in the way of negligence on his own part - as in intrusting his seal to his seneschal or his wife. Britton says that a man may plead that the writing ought not to affect him, for when it was made he harl lost his seal and cansed it to be cried and published at the churches and markets: so that if anything was made under that seal after a certain day on which it was lost it ouglat not to affect him (book 1. ch. 29. pl. 17). A curions accour is given in Mr. Nicholl's note (vol. $1, \mathrm{p} .164$ of his edition) of a plea of this description. relating to the seal of Arnold de Thorley, which was met and defeated br production of a record of acknowledgment at the Hertford Assizes $39 \mathrm{H}$ 'n. III. of the seal in question by the sail Arnold: and two advertisements of the loss of a seal, warning the public that an instrument sealed with it after a certain day would be forgery, are given in Blount's Law Dictionary, title "Seal" and "Siqillum." The passage from Bracton is reproduced in Fleta, whn wrote towarks the end of the thirteenth century, but without any additional remarks." 1

Neglect as to the custody of your property then, be it horses, seals or transferable documents, may, where other persons are misled by ostensible title in possessors of them, estop the owner from following his property. This is general law and was not borrowed from the law merchant. ${ }^{2}$

Further Consideration in Support.-Acknowledging that there is not much direct and specific support for the proposition contended for in this chapter, it is nevertheless of interest to note the trend in that direction (culminating in something little short of formulation of the principles enounced), and to put in contrast the older view and the reasons for it.

I (1887) 21 Q. B. D. 166.

${ }^{2}$ In Pollock on Contracts (6th ed.), 135, referring to the loss of seals, it is said: "That the practice of publishing formal notice in case of loss really existed is shown by the exam. ple given in Blount's Iaw Dictionary, s. v. Sigillum, dated 18 Ric. IL In modern law such questions, when they occur, come under the head of estoppcl." 
Commencing with money, jt is usually said that the reason that a thicf can pass a good title is because

"of the currency of it; it cannot be recovered after it has passed in currency;" 1

that is to say, a good title to money passes because it is money! And if we ask for something more satisfactory than this, we may find it in Lord Shand's remark (one hundred and thirtyfive years afterwards) with reference to some cash which had been intrusted to an agent, and by him wrongfully diverted to his own purposes:

"He has thus the opportunity, and may take advantage of this, to misapply and to appropriate to his own use the money intrusted to him." 2

This reason must, however, find foundation in some specific law, and its proper reference is clearly apparent. The true owner enabled bis agent to pose as owner, and is therefore estopped by the assistance rendered to his misrepresentation of ownership.

If the reason in the case of money was because it was money, the rule was applied to bills and notes because they are "like so much money," and are "negotiable:"

"If a bill be payable to A., or bearer, it is like so much money paid to whomsoever the note is given; that let whatever accounts or conditions soever be between the party who gives the note, and A. to whom it is given, yet it shall never affect the bearer." 3

"Bills of exchange and promissory notes are representatives of money circulating in the commercial world as such." 4

"The reason is that such negotiable instruments have, by the law merchant become part of the mercantile currency of the country.":5

"A negotiable instrument for the general convenience of commerce has been allowed to have an effect at variance with the ordinary princlples of law." 6

Money passes with a good title because it is money; and notes because they are like money; and then a foreign bond because it is like a note. It is

"in its nature precisely analogous to a bank note payable to bearer, or to a

'Per Lord Mansfield, in Miller v. Freem. 257. And see per Channell, Race (1758), Burr., p. 457. And so B., in Moss v. Hancock (1899), 2 Q. B. where a 55 gold piece, which, al- 119; 68 L. J. Q. B. 6577; Byles on Bills though current coin, was something of a curiosity, had been stolen and sold to a dealer in curiosities, the title revested in the owner upon conriction of the thief. Moss $v$. Hancock (1899), 2 Q. B. 111; 68 L. J. Q. B. 657.

${ }^{2}$ Thomson v. Clydesdale (1893), A. C. $291 ; 62$ L. J. P. C. 91. (15th ed.), 186: Foster v. Green (1862), 31 L. J. Ex. 158.

${ }^{4}$ Friedlander v. Texas (1889), 130 U. S. 416.

${ }^{3}$ Per Williams, J., in Ingham v. Primrose (1859), 7 C. B. N. S. 82.

${ }^{6}$ Per Tindal, J., in Jenkyns v. Usborne (1844), 7 M. \& G. 699; 13 L. J. C. P. 196 . 
bill of exchange indorsad in hinls. Being an instrument, therefore of the silur description, it must be subject to the same rule of law, that whorver is the holder of it has power to give title to any person honestly acyuiring it." 1

The transition starge from mere empiricism to rationality may be represented by language of Lord Cairus with reference to certain misappropriated scrip for bonds:

"The appellant might have kept his scrip in his own possession. and if he had done so no question like the present conld have arisen. He pre. forred. howerer. to place it in the possession and ander the control of his broker or atent; and althomgh it is stated that it remained in the agent's hamds for clisposial. or to be exchanged for the bonds when issued as the appellant should direct, those into whose hands the scrip would come condd know nothing of the title of the appellant or of any private inslructions he might have given to his agent."

In other words, the broker had ostensible authority to sell; ostensible authority cunnot be displaced by "private instruction;" therefore, although there was no anthority to sell, yet the true owner is estopped from so asserting. That is the ordinary law of estoppel.

To the same effect, but much more nearly approaching scientific statement, is the language of Mrr. Justice Tascherau in a case in the Canadlian Supreme Court with reference to bonds:

"In constituting his agent the apparent absolute owner of these secu. rities and conferring upon him all the indicia of ownership. he precludes himself from disputing the title of any subsequent bona fide transferee." 3

There is much in the United States authorities which may be cited in support of some of the views here adrocated. For example, in Colebrook on Collateral Securities it is said:

"The principle of estoppel by conduct, that when the owner of property in any form clothes another with the alparent title and power of dis. position, third partios who are thereby induced to ieal with him are protected, is applied to choses in action non-nerotiable in character."

"The rules of estoppel in pais are enforced anainst an owner of a non. negotiable chose in action who has, with mistaken confidence, intrusted the indicia of title and the apparent absulnte ownership by indorsement and delivery to a third porson, so that he is able to deceive bona fide pledgees advancing value upon the faith aul credit of such documents of title and apparent absolnte ownership withont notice that the act of the pledgee is a fraudulent misappropriation and an unathorized act." 5

1 Gorgier v. Mieville (1824), 3 B. \& C. 45 .

2 Goodwin v. Robarts (18i6), 1 App. Cas. $476 ; 45$ L. J. Q. B. 748.

3 Young $v$. MacNider (1595), 2.5 S. C. Can. 272, 279.

4 P. 590; citing Cowlry r. Vanderburgh (1879), 101 U. S. 5i2: McNeil v. Tenth Nat. Bank (18i1), 46 N. Y. 32.5. See to same elfect, per Boyd, C., in Re Central Bark (1s99), 1i Ont. js6.
${ }^{5}$ P. 487 : citing Coombes $v$. Clim dler (18ii), 33 Ohio St. 178: Moore v. liank (15i3), 5.5 N. Y. 41; McNeil v. Tenth Nat. Bank (1851). 46 id. 325; Cowdry v. Vanderburgh (15i9), 101 U. S. 5i: Davis v. Brekstein (15\%), $69 \mathrm{~N}$. Y. 442; Werrieh s. Mlihonmg Co. Bank (1565). 16 Ohin St. :96; Dillaye s. Commercial Bank (1573), 51 N. Y.:34.; Clark v. Roberts (Issi), 25 Hun, s6. 


\section{So also in Bigelow on Estoppel: ${ }^{1}$}

"It should be observed that while the rule in Pickard $v$. Sears finds most frequent expression in transfers of property, it is not confined to such cases: it includes all cases of false representation and fraudulent silence, whatever the nature of the transfer. . . So again. if a man purchase bona firle and for vilue an unnegotiable chose in action from one whom the owner has, by assionment or otherwise, conferred the apparent absoInte ownership, he obtains a valid title against the real owner, supposing the act of purchase to have been indnced by such act of the owner."

And in England in a case ${ }^{3}$ in which a transfer of shares, blank as to the purchaser's name, was given to a broker who misapplied it, Lord Hersebell said:

"If the owner of a chose in action clothes a third party with the apparent ownership and right of disposition of it, he is estopped from asserting his title as against a person to whom such third party has disposed of it and who received it in gool faith and for value. And this doctrine has been held by the court of appeals of the state of New York to be applicable to the case of certificates of shares with the blank transfer and power of attorney signed by the registered owner, handed by him to a broker who frauclulently or in excess of his a uthority sells or pledges them. The bank or other persons, taking them for value without notice, have been entitled to hold them as agiunst the owner. As at present allvised, I do not see any difference between the law of the state of New York and the law of England in this respect." 4

It will be observed that these supporting quotations all deal with "non-negotiable" choses in action. They sufficiently establish the principle that ostensible ownership or ageney of such doenments may estop the true owner from setting up his title to them. But it has not hitherto been observed that the same doctrine applies to "negotiable" instruments also (why should it not?); and that there is no necessity, in their case either, for an appeal to the law merchant and its "antagonism" to the ordinary law.

15 th ed.. p. 562; citing Moore v. Metropolitan Bank (1873), 55 N. Y. 41; Henty v. Miller (1883), 94 N. Y. 64; Coombes v. Chandler, 33 Ohio St. 178.

2 Mr. Bigelow did not observe the general application of this language in his later work (on Bills and Notes) when he wrote (p. 3): "Purchase of land or goods for value and without notice cuts off equities; that is a carlinal rule of law and always has been in courts of equity. But it has never been applied to undertakings to pay in the case of common-law contracts; applied to undertakings to pay, as purchase for value without notice of ten is, the principle has reference to bills, notes and checks only."

${ }^{3}$ Colonial Bank v. Cady (1890), 15 App. Cas. 257; 60 L. J. Ch. 131.

${ }^{4}$ For the New York law see McNeil v. Tenth Nat. Bank (1871). 46 N. Y. 325. See also in Ontario, Smith v. Rogers (1899), 30 Ont. 256; and in Ireland, Horne v. Boyle (1890), $27 \mathrm{~L}$. R. Ir. 137: Waterhouse v. Bank of Ireland (1892), 29 L. R. Ir. 384. 


\section{Summare.}

It is advisable to sum up what has been said:

1. A chose in action is ambulatory or non-ambulatory. It may also be sometimes the one and sometimes the other. A promissory note, for example, may be ambulatory (redeemable to third persons) or non-ambulatory (redeemable to a certain person only). It is alwaly "negotiable" in the sense that, being a chose in action arising out of contract, it may be transferred. It is sometimes not "negotiable," in the sense that a transferee of it will take subject to equities.

2. Contractors in ambulatory agreements are estopped as against innocent transferees from setting up equities which may exist between them and their immediate contractees.

3. The true owners of ambulatory contracts may be estopped from asserting their title to them by permitting the appearance of ownership in other persons.

4. These results are in no way due to the law merchant; they are not in antigronism to the general law; they are parts of it.

5. The word "negotiability" with its double entente is not only unnecessary, it is disturbing and distracting.

6. There is no such thing as "negotiability by estoppel."

Having thus opened up a new category (ambulatory instruments) let us take a short survey of the documents to be placed in it.

\section{Bonds.}

If the views here advanced are correct, there would seem to be no reason why company bonds should not always have been as "negotiable" as promissory notes;' and why a holder of them in clue course should not have always been free of equities. Nevertheless it has only been within the last year in England" that their absolute "negotiability" has been recognized, and only with the assistance of the invention of a new doctrine was that result arrired at. $A$ short resumé will be instructive.

1 Reference is intended to bonds intended to be ambulatory. Those of other character are not of course assignable free from equities, for they are not so intended. Coles $v$.
Jones (1715), 2 Vern. 692; Cator $\mathbf{}$ Burke (179.j). 1 Jro. C. C. 43.4; Gould v. Close (18it), 91 Gr. 27:3.

2 Bechuanaland s. Lomdon (1898), ? Q. B. 658; 6i L. J. Q. B. 956 . 
The question of the "negotiability" of bonds arose in Gorgier $v$. Mieville, ${ }^{1}$ in 1524 . Bonds of the King of Prussia payable to the "holder" had been misappropriated by an agent. There was evidence that "bonds of this description were negotiated like exchequer bills." Abbott, C. J., sairl:

"It is therefore in its nature preciselv analogous to a bank note payable to bearer or to a bill of exchange in blank. Being an instrument therefore of the same description it must be subject to the same rue of law, that whoever is the holder of it has power to give title to any person honestly acquiring it."

In 1867, in Re Blakely, ${ }^{2}$ it was held with reference to a company bond payable to bearer, that a transferee could not sue upon it in his own name, but had an equitable title only; that althongh an assignee of a chose in action takes subject to equities, yet that the obligor can contract to pay free from equities; that a bond payable to bearer is not necessarily such a contract; but that there being in fact at the time of the issue of the bonds an intention of the company that they should be transferred, such intention debarred the company from setting up the equities. In other words, a transferee of company bond payable to bearer was not safe unless be could show that the company had contemplated a transfer of it; and that such intent did not sufficiently appear by the bond being payable to bearer.

With some hesitation this difficulty was surmounted, and it is now said that " the negotiable character of the bond depends on the bond itself;" 3 and that the use of the word "bearer" exhibits an ambulatory intent, independently of evidence of extraneous intention. ${ }^{4}$

Escaping this point (that bonds are negotiable or not according to extrinsic evidence of ambulatory intent), it was said that they could only be negotiable if (as in the case of bills and notes) they were for a certain amount, and payable unconditionally, and at a certain time, and so on. Judges felt themselves much pressed with this objection. Was there a condition for payment by successive dlawings; ${ }^{5}$ or was there

1(1824) :3 B. \& C. 45; 2 L. J. K. B. 206. Glyn v. Baker (1811), 13 East, 509 , had decided the point adversely (subject to the possibility of evidence otherwise) as to East India bonds; as to which see 51 Geo. III., ch. 64.

2 (1867) L. R. 3 Ch. 154; 36 L. J. Ch.
${ }^{3}$ Venables v. Baring (159:), $3 \mathrm{Ch}$. 527; 61 L. J. Ch. 609.

${ }^{4}$ See infra, sub-title "Intended to be assigned."

${ }^{5}$ Crouch v. Credit Foncier (1873), L. R. 8 Q. B. $374 ; 42$ L. J. Q. B. 183 . 665 . 
a mortgage as security, with provisions limiting the powers of the bondholder; ${ }^{1}$ then there was a contractual relation outside of the promise to pay and associated with it which precluded the idea of "negotiability." No authoritative decision has yet declared that such considerations may be disregarded." We are, however, rapidly reaching an intellectual climate which is very fatal to them; in fact the question will necessarily arise whether such objections can properly be lield to affect the "negotiability" of even bills and notes. Though some of the asserted essentials of a note may be absent, yet if the instrument was intended to be transferred, does not a transferee, upon the principles enunciated, take free from equities? ${ }^{3}$

Returning to bonds unalfected by these special provisions, it maty be observed that notwithstanding the partial recognition of their "negotiability" the judges were loath to admit it "in the full sense of the word." The term had for so long been confined to bills and notes, and its derivation was so thoroughly understood to be from the law merchant, that it seemed to be impossible to apply it to documents of more modern nse. Accordingly in 1873 we find Blackburn, J., saying:

"but as the instruments themselves are only of recent introduction it can be no part of the law merchant." 4

Bowen, L. J., too, in one case hesitated to say that they were negrotiable, suggesting the presence of a seal as being a dilficulty in the way. ${ }^{5}$ And in another case in the face of evidence and admission that they "are dealt with as negotiable securities," the same learned judge objected that there was no evidence

"that delivery by a person who has no title confers nevertheless a title on a bonc fide holder for value without notice." 6

1 Easton v. London (1886), $34 \mathrm{Ch}$. D. 95 ; 56 L. J. Ch. $569 ;$ S. C. $s u b$ nom. Slieftield v. London (1858), 13 App. Cas. 333; 57 L. J. Ch. 986.

2 Gooklwin v. Robarts (18\%5), L. R. 10 Ex. $76,35 \tau ; 1$ App. Cas. $476 ; 45$ L. J. Q. B. 748, dealt them a very severe blow.

${ }^{3}$ See practically to that effect. Bank of Hamilton v. Harvey (1555), 9 Ont. 65s: $16 \mathrm{~S}$. C. Can. 714.

+Crouch r. Credit Foncier (1873), L. R. 8 Q. B. 3it; 42 L. J. Q. B. 183.
5 Easton v. London (1886), $34 \mathrm{Ch}$. D. $113 ; 56$ L. J. C'h. $569 ;$ S. C. $s u b$ nom. Sheftield v. London, $13 \mathrm{App}$. Cas. 333; 57 L. J. Ch. 986. No difliculty was felt upon this ground in Canadia (Bank of Toronto v. Cobourg (1584), i Ont. 1); nor in the United States: Daniel on Neg. Inst., ș 14sr, 1500.

${ }^{6}$ Simmons $v$ London (1891), $1 \mathrm{Ch}$. $294 ; 60$ L. J. Ch. 313; (189:) A. C. 201; 61 L. J. Ch. 723 
A further point raised a distinction between foreign and domestic bonds - raised much difference of opinion upon that question, ${ }^{1}$ which it may be hoped has been settled in favor of no distinction, by a recent judgment of Mr. Justice Kennedy.

American Law. - The United States courts do not appear to have been much troubled with such points. Pennsylvania in 1860 , indeed, heroically declared that

"we will not treat bonds like these as negotiable securities. On this ground we stind alone. All the courts, American and English, are against us. Be it so." 3

But in $19 s+$ Mercer, C. J., of the same State said:

"The clear intent of the maker was that they should pass as negotiable paper. With the language of negotiability on its face, did the seal inpressed thereon destroy the negotiability of this bond?"

No. And with this larger view (what was "the clear intent" of the maker?) the other courts agree. ${ }^{5}$

Canadian Law. - The Canadian eourts too solved, or at least avoided, all difficulty as to bonds by declaring them to be "negotiable." 6

\section{Other Ambulatory Contraots.}

Scrip for Bonds. - It has been said that various objections were made to the recognition of debentures as negotiable instruments upon the ground of lack of some supposed essential

1 Lang v. Smytl (1831), 7 Bing. 29:; Sinith v. Wegnellin (1869), L. R. 8 Eq. 198; 38 L. J. Ch. 465; Crouch v. Credit Foncier (18\%3), L. R. 8 Q. B. 384; 42 L. J. Q. B. 183 ; Goodwin v. Robarts (1875), L. R. 10 Ex. 76, 345: 1 App. Cas. 476; 45 L. J. Q. B. 748; Picker v. London (1887), 18 Q. B. D. 515 ; 56 L. J. Q. B. 299; Williams v. Colonial Bank (1887), $36 \mathrm{Ch}$. D. $403 ; 57$ L. J. Ch. 826 ; 38 Ch. D. $388 ; 58$ L. J. Ch. 826; S. C. sub nom. Colonial Bank v. Cady, 15 A pp. Cas. 267; 60 L. J. Ch. 131; Venables v. Baring (1892), 3 Ch. 539; 61 L. J. Ch. 609.

2 Bechuanaland v. London (1898), 2 Q. B. $658 ; 67$ L. J. Q. B. 986.

${ }^{3}$ Diamond $\nabla$. Lawrence (1860), 37 Pi.. St. 358.

4 Mason v. Frick (1881), 105 Pa. St. 162. And see Carr v. Le Fevre (1856), $2 \tau$ Pa. St. 418.
5 Delafield v. Illinois (1811), 2 Hill (N. Y.), 177; Chaplin v. Vermont (1857), 74 Mass. 575; White v. Vermont (1858), 62 U. S. 575; Mercer v. Hackett (1863), 68 U.S. 83 (overruling the Pennsylvania case of 1860 ); Morgan v. United States (1885), $113 \mathrm{U}$. S. 476; Provident v. Mercer(1898), 170 U. S. 18 ; S. C. R. 788; American Nat. Bank v.American Wood Co.(1895), 19 R. I. 149; 32 Atl. R. 305; Strauss v. United Tel. Co. (1895), 164 Mass. 130; 41 N. E. R. 59: Whiteside v. First Nat. Bank (1898), 47 S. W. R. 1108 (Tenn.); Daniel on Neg. Inst., secs. 1487, 1491a, 1500; Colebrooke on Coll. Sec. 8; Massachusetts Pub. St., ch. 77, $\S 4$.

6 McKenzie v. Montreal (1878), 29 U. C. C. P. 833; Bank of Toronto v. Cobourg (1884), 7 Ont. 1; St. Cesaire v. McFarlane (1887), 14 S. C. Can. 73. 
of form. These variations from old time rigidity were to somo extent overlooked, but a point of dissimilarity arose in Goodwin $v$. Robarts, 'which could not be altogether blinked:

"Thist thase instrmments be payable in money has always been essential, and the custom of merchants to that elfect has received the sanction of statute.":

And here is a case ${ }^{3}$ of a document not for money at all, but for the delivery of bonds, and redeemable at very uncertain time. It was as follows:

"Received the sum of twenty pounds, being the first instalment of wenty per cent. upon one lumbled pounds stock, and on payment of the remaining instalments at the perioul specified the bearer will be entitled to receive a definite bond or bonds for one hundred pounds after receipt thereof from the Imperial Government."

Scrip in this form (which was admitted "to pass . . . by mere delivery as a negotiable instrument transferable by delivery") was left with a broker to be dealt with as the owner might direct; and the broker fraudulently pledged it for his own benefit. Ancient law merchant will eridently not help the pledgee. Bills and notes are undertakings to pay money. This document is one declaring that upon payment of money certain bonds will be delivered "after receipt thereof from tho Imperial Government." It appears to be an ordinary contractual obligation; and legal-title theories are of no avail. According to all our notions it is "non-negotiable," and the purchaser must take subject to all equities.

The case is at the parting of the ways, or rather, perhaps, at their final rupture, though certain tendencies may remain for a little. Baron Bramwell's great good sense is of inestimable value. A Prussian bond redeemable in money, he says, has been held to be negotiable; and to distinguish between a bond and

"something preparatory to a bond being given . would be draw. ing a distinction which would be utterly unintelligible to the commercial world at large" -

subversion of the legal intellect luckily overlooked. And it was fortunate that Cockburn, C. J., sat in appeal. Ancient law merchant, without which it has been said there can be no negotiability, he thus dealt with:

"Usage adopted by the courts having been thus the origin of the whole of the so-called law merchant as to negotiable securities, what is there to

$1(1875)$ L. R. 10 Ex. 76, 345; 1 App. Cas. 476: 45 L. J. Q. B. 748 .

2 Bigelow on Bills and Notes, 14. ${ }^{3}$ Goodwin v. Robarts (18i5), 1. R. L. R. 8 Q. B. 390 ; 42 L. J. Q. B. 183.
10 Ex. 76,$345 ; 1$ App. Cas. $476 ; 45$ I. J. Q. B. its.

* Crouch r. Credit Foncic (1s:3), 
prevent our acting upon the principle acted upon by nur predecessors, and followed in the precedents they have left us? Why is it to be said that a new usige which has sprung up under altered circumstances is to be less admissible than the usage of past times? Why is the door to be now shut to the almission and adoption of usage in a matter altogether of cognate character, as though the law had been finally stereotyped and settled by some possible and peremptory enactment? it is true that this scrip purports on the fice of it to be a security not for money, but for the delivery of a bond: nevertheless we think that substantially and in effect it is a security for money, which. till the bond shall be delivered, stands in the place of that dociment, which, when delivered, will be beyond doubt the representative of the sum it is intended to secure." 1

The Ilouse of Lords, however, hesitated.' Unprepared to declare for negotiability, their Lorlships find relief in estoppel, Lord Cairns promulgating the doctrine of negotiability by estoppel, while Lord Hatherly more correctly, as the present writer thinks, applies the well-known principles of estoppel by ostensible agency. Estoppel of some sort at all events we have arrived at; negotiability by estoppel we have already dealt with.

Scrip for Shares.- The case was almost immediately followed by Rumball $v$. Netropolitan. ${ }^{3}$ This time scrip for shares (admitted to be customarily passed "by mere delivery as a negotiable instrument transferable by delivery"), deposited with and misappropriated by a broker, is the subject of controversy. IIeld, that the document was "negotiable," and passed free from equities to a holder in due course; but if not, it was at the least "negotiable by estoppel." The commercial world is evidently having its way - the particular language employed being a matter of indifference to it.

Mortgage-debentures. - The influence of Cockburn, C. J., was of value in a case preceding those just referred to. ${ }^{4}$ Bonds might be negotiable, but what was the position of mortgagedebentures, or rather documents which, containing no promise at all, ${ }^{5}$ merely mortgaged a proportionate part of the rates of a municipality? By statute these mortgages were assignable,

${ }^{1}$ L. R. 10 Ex. 352, and see 355, 356; 44 L. J. Ex. 157 ff. See, to same effect, Mercer v. Hackett (1863), 68 U. S. $8:$, where it is said that " this malleability to suit the necessities and usages of the mercantile and commercial world is one of the most valuable characteristics of the common law:"

2It is very extraordinary that so little attention was paid in the case to the Lord Cairns dictum. See ante, p. 386.

${ }^{3}(18 ; 6) 2$ Q. B. D. $194 ; 46$ L. J. Q. B. 346.

${ }^{4}$ Webb v. Herne Bay (1870), L. R. 5 Q. B. $642 ; 39$ L. J. Q. B. 221.

${ }^{5}$ Alisence of a promisee is no objection in the United States. Daniel on Neg. Inst., $\$ 1494$. 
and the assignec was to have the benefit of the security transferrel. Cockburn, C. J., said:

"The defendants issued the debentures with the knowledge that they were capable of being transferred and would very liliely be transferred to a holder for value; how can it lie in their mouths to sily that the transac. tion in respect of which they gave these debentures was illegal?"

And Lush, J., groing still further, said:

"Now the effect of these sections I think is to make these mortgages negotiable securities, and to attach to them the incidents of negotiable securities: one of which is that an innocent holder for value . . * acpuires a title of his own. unatfected by any infirnity to which the title of his assignor would have been subject." !

Morlyuges. - It is interesting to note the application of the principles in hand to the case of a mortgage. Here we have a debt - a chose in action ${ }^{2}$ - and real-estate security for its payment. By its terms and by usage the document is intended to be ambulatory; but the transfer of it is a mitter requiring time for its accomplishment, and it is therefore unsuitable for the rapid timancial operations of the moment; moreover its payments are usually long deferred, and thus changes in the relations of the parties to it are more customary than in the case of shorter dated commercial paper.

The law of estoppel has adapted itself to these peculiarities. It is customary for a purchaser of a mortgrage to make inquiries of the morteragor as to the state of the account between him and the mortgagee; and it is not doubted that by his answers the mortgitgor would be estopped. No such inguiry is made in the case of bills and notes, and transferees of them are not affected by premature payments. The reason is to be found in custom, and the custom is founded upon the considerations above sugrgested. Estoppel proceeds upon misrepresentation. In the case of a mortgage premature payment will not mislead because of the eustom to inquire, which the mortgagor may depend upon being pursued. There is no such custom in the ease of bills and notes; premature parment will mislead, and the payer may have to pay acrain.

But observe that if a mortgage be offered in sale to me, although I ought to inquire as to alterations of relations between the parties, I have no reason for doubting that the document is a real instrument, and that it truthfully sets forth the transaction as it originally existed. For example, if $\$ 200$ appears

1 But see Jones v. Dulick (1898), 5.j Pac. R. 522 (Katu.).

Q. B. 20.5. See however, Ilopkins r. Hemsworth (1895i): C Ch. 3ti; 6 i L. J.

2 Martin v. Bearman (18s0), 45 U. C. Ch. 526 . 
to be secured by it (and more especially if a receipt for that amount aplears upon it), I am not bound to imagine that only $\stackrel{f t 0}{ }$ was really advanced. The mortgagor linew when executing the document that it was of ambulatory character; he knew that people would rely upon its appearance; and he is therefore estopped. ${ }^{1}$

"But they were inexact and careless. and placed in the hands of Bates or Astley the means of deceiving other persons, and these are in the court of equity demerits." 2

This law is of speeial importance in the United States, where usually a mortgage debt is also represented by a promissory note. It was there said that the mortgagor was estopped upon principles

"which forbid a man who, as security for negotiable notes, had executed a mortgaye . . . to impair its binding force and effect by pleading secret equities created by lis own fault. negligence or imprudence, and of which the subsequent holder of the notes had no notice and no means of information." 3

Vouchers. - Sometimes vouchers or certificates, indicating that persons named in them are entitled to certain sums of money, are intended to be ambulatory; and transferees of them will therefore, upon principles of estoppel, take free from equities. In one case ${ }^{4}$ a contractor obtained a certificate from the auditor of a board of works that be was entitled to $\$ 8,451.88$; the contractor indorsed the certificate in blank, and deposited it as security for a loan of $\$ 3,160$; and the pledgee fraudulently disposed of it to an innocent purchaser; it was held that

"the complainants could have expressed in their indorsement the purpose of the deposit . . - - that it was as security for a specified sum of money - and thus imparted notice to all subsequent purchasers or assignees that the pledgee had only a qualified interest in the claim. But having indorsed their name in blank, they virtually authorized the holder to transfer or lispose of the certificate by writing an absolute assignnent over their signature."

In a case of somewhat sinilar circumstances the judgment (frequently eited) is summed in the head-note as follows:

"A bona firle purchaser for value of a non-negotiable chose in action from one upon whom the owner has by assignment conferred the apparent absolute ownership, where the purchase is made upon the faith of such apparent ownership, obtains a valid title as against the real owner, who is estopued from asserting a title in hostility thereto." 5

1 Bickerton r. Walker (1885), $31 \mathrm{Ch}$. D. 151; 55 L. J. Cl. 22\%. And see cases cited with this one in ch. IV.

2 Per Fry, I. J.

${ }^{3}$ State Bank v. Flathers (1892), 45 La. Inn. 78; 12 S. R. 244. See note, ante, pp. 19, 20.
${ }^{4}$ Cowdry v. Vandenburgh (1879), 101 U. S. 572. But see Crawford v. Board (1899), 58 Pac. R. 616; Hammond v. Evans (1899), 55 N. E. R. 784 (Ind.).

5 Moore v. Metropolitan (1873), 55 N. Y. 41. See also Armour v. Michi- 


\section{In the juldgment it is sail:}

"Where one known to be the owner of shares or chattels delivers to another the scrip or possession of the chattels, tongether with an absolute written transfer of all his title thereto. he thereby enables him to holl himself out as owner, and as such obtain crelit upon, aml make sale of, the property: and if, after he has so done, the owner was permilted to come in and assert his title against those lealing upon the faith of these appearances, the dishonest might combine and practice the grossest frauds."

Bank Dncuments. - Letters of credit are peculiarly of ambulatory character. ${ }^{1}$ So, usually, are deposit receipts ${ }^{2}$ and certifiel ehecks. ${ }^{3}$

Life Policies. - Drawing still further away from the former narrow list of "negotiable" securities, we come to a document of debatable character. The owner of a life-insurance policy transferred it apparently absolutely, but really as seeurity only for money lent; the assignee, being thus the ostensible owner, fraudulently assigned the policy to an inuocent purchaser, who, It was held, took it free from equities. ${ }^{4}$ It may be said that a policy is a "non-negotiable" chose in action, and that it therefore carries with it all equities of prior hollers. ${ }^{5}$ A fair reply

gan Ry. (1875), 65 N. Y. 123; Cudahy Co. v. Sioux (1896), 21 C. C. A. 428; 75 Fed. R. 473.

1 Pillans v. Mierop (1765), Burr. 1663; Pierson v. Dunlop (17\%7), Cowp. 5\%1; Re Agra (1867), L. R. 2 Ch. 391; 30 L. J. Ch. 22:? Bank of Montreal v. Thomas (1588), 16 Ont. 503; Russell v. Wiggins (1842). 2 Story, 213; Coolidere v. Payson (1817), 15 U.S. 66; Boyce v. Edwards (1830), 29 U. S. 111; Carnegie $v$. Morrison (1841), 2 Met. (Mass.) 381; Franklin v. Lynch (1898). 52 Ma. 2:0: Johannessen v. Munroe (1899), 185 N. Y. $641 ; 53$ N. E. R. 535.

2See 3 \& 4 Anne, ch. 9: Nicholson v. Sectgwick (1690), 1 Ld. Ray. !80; 3 Salk. 6i: Partridge v. Bank of England (1846), 9 Q. B. 396; Re Commercial Bank (184ĩ), 11 Min. 494; Re Central Bank (1889), 17 Ont. ir4; First Nat. Bank v. Security (1892), 34 Neb. 71: 51 N. W. R. 305: Kirliwood v. First Nat. Bank (1894), 40 Neb. $484 ; 58$ N. W. R. 1016; Sauce $v$ Exchange (1894), 40 Neb. 497; $58 \mathrm{~N}$.
W. R. 1135; Hager v. Buffalo (1894), 31 N. Y. 448; Antem v. Crahan (1899), 81 Ill. App. 502. But see Mander $v$. Roval (1869), 20 U. C. C. P. 125; Lee v. Bank (1879), 30 U. C. C. P. 25\%; Richer v. Voyer $(18 i 4)$, L. R. 5 P. C. 461.

${ }^{3}$ American v. Crowes (1899), 8: Ill. App. 5i3i.

4 Quebec Bank v. Taggart (1896), 27 Ont. 16:. And see Bridge v. Con. necticut (1890), 152 Mass. 343; 2J N. E. R. 612.

$3 \mathrm{And}$ it was very recently so held. Brown v. Equitable (1898). $78 \mathrm{~N}$. W. R. 103 (Minn.). "The defendant has done nothing upon which to base an equitable estoppel except the bare fact that plaintiff delivered possession of the policy to H., accompaniel by an absolute assignment without any expressed conditions or limititions, and thereby clothed him with the indicia of absolute ownership." Usmally the bare fact of enabling another person to mislead third persons by appearing to be the owner 
js that 'ands, too, are somewhat " non-negotiable," but that if an owner of real estate executes an absolnte conveyance to his mortgagee instead of a mortgage, he is estopped from setting up his equities as against an innocent purchaser from the grantee. In other words, a life policy is an article of property, and the principles of estoppel by ostensible ownership apply equally to all sorts of property which is usually intended to be passed on from one person to another.

Transfers of Shares. - Securities of this character are more particularly treated of in a previous chajter. ${ }^{1}$ At this place it must suftice to notice some very satisfactory dicta in Williams v. Colonial Bank, ${ }^{2}$ in which blank transfers of shares were intrusted to a broker and by him misapplied. It was proved that

"merchants . . . do regard documents of this character as passing from hand to hand, or what $I$ think is the better expression as equivalent to securities to bearer."

The ease is unfortunately complicated by the fact that the true owner of the shares was an executor; but it is nevertheless valuable for its statement of the law where that feature is absent. Lord Watson said:

"When the registered shareholder executes the transferindorsed on his certificate, he can have only one intelligible purpose in view. that of passing on his right to a transferee. It is not so in the case of an executor."

And Lord IIerschell added:

"If, in the present case, the transfer bad been signed by the registered owner and delirered by him to the brokers. I should have come to the conclusion that the banks had obtained a good title as against him, and that he was estopped by his act from asserting any right to them."

Charter-parties.- The importance of the distinction-between documents which are intended to be transferred free from equities, and those which are not, may be seen by reference to the case of Mangles $v$. Dixon. ${ }^{3}$ A ship-owner executed a charterparty to $A$. at a certain freight; in reality the ship-owner and charterer were partners in the venture; the ship-owner assigned the charter-party, and requested A. (in writing) to pay to the assignee "what is due;" the assignee was misled by the char-

of your property is thought to be an ainply sufficient ground of estoppel. See the dissenting judgment in the same case, and the result after reargument, 79 N. WV. R. 938.

Isee ch. XXII.

2 (1837) 36 Ch. D. 659 ; 38 Ch. D. 395 ;
57 L. J. Ch. 826; 15 App. Cas. 267; 60 L. J. Ch. 131. See also Robinson $\nabla$. Montgomeryshire (1896), 2 Ch. 841; 6.) L. J. Cl. 915.

3 (1848) 1 McN. \& G. 437; 3 H. L. C. 702. 
ter-party; he knew nothing of the partnership arrangement, and naturally thought that the ostensible charterer was liable to the ship-owner for the whole of the freight. Iord Cottenham held that the ostensible chinterer was liable to the assignee for the freight, accolding to the terms of the charter-party;

"for not only was the secret equity suppressed, but the party claiming it armed the apparent owner with proof, resting upon their own declinttion that none existed, and therefore camot afterwards dispute an act founded upon such applarent right as against a party claiming under it."

In the Honse of Lords, however, this decision was reversed; but unfortunately the principle which supported it (above quoted) was entirely overlooked. Lord St. Leonards said:

"The only ground on which I understand the decision was rested was this: that where it man having an interest in property stands by and sees auother man dealing with that property as owner with another person who is ignorant of the want of title in the person with whom he is dealing. equity will bind the man who stands by. . . I I annot find any facts to hring this a ase within that rule. There was no standing by on the part of Messirs. Mangles when they saw Messrs. Boyd dealing with diessis. Dixon, the bankers; the dealing was behind their backs, five or six months before; they did not even know that the transaction had taken place."

Lord Cottenham was therefore overuled; but it cannot be said that his view of estoppel by having "armed the apparent owner with proof," etc., was dissented from; for it was not considered.

But there is a further point in the case (as the foregoing liscussion has made apparent), namely, whether a charter-party is such a document as is intended by the charterer to be transferred by the ship-owner free from the equities between them. If yea, then it is submitted that Lord Cottenham's judgnent ought to stand. But if nay, then the rule put forward in the House of Lords that an assignee of such a cliose in action talies it subject, etc., is that which should grovern the ease.

Generally. - We have now arrived at this: Bonds, mortgage debentures, scrip for bonds, scrip) for shares, mortgages (its explained), vouchers, letters of credit, deposit receipts, blank transfers of shares, life policies, and many other such doeuments are "negotiable" instrments. At all events it is yuite immaterial whether they are or not, for either through necrotiability by estoppel, or estoppel by ostensible ownership or areney, a good title free from equities will pass to a holder in due cunrse. We are a long way from law merehant with its certain dilys, and times, and amounts, aud antagonisms to the general law. There is still, howerer, much reluctunce completely to aldopt 
the ineritable change of view. Expressions are, and for some. time no doubt will be met with, such as

"documents which, though not negotiable in the strict sense of the word, were . . . equivilent to securities to bearer." 1

When, however, the current connotations of the word "negotiable" are displaced and the term "ambulatory" adopted, such language will cease, for the uncertain and mysterious significance of "negotiability" will have passed away. This is well illustrated by the decisions referred to in the next succeeding paragraph.

Promises to Pay Money. - It is a most curious fact, and one which well illustrates the frequently baneful effect of corlifications, that while the law is (as we bave just been observing) rapidly expanding upon the lines above indicated, so that we are now fairly well able to say that choses in action pass to a transferce free from equities where that was the intention of the parties (the wit of man has at length come that far), certain promises to pay money to order or bearer, on the other hand, by reason of certain recent decisions in England and Canada bid fair to become an exception to the rule.

A promissory note is by the codes closely defined. This is within the prescribed limits, and this is not. Any addition to the given form takes the document out of the category of notes. And if it is not a note, then it is thought that all its equities must assuredly accompany it upon transfer. ${ }^{2}$ The result then is that a document which is very nearly a promissory note or bill of exchange carries its equities with it - even if it be one intended to be redeemable to third persons - because of the codes; while documents having no relation to bills or notes (and very much less like them), but which are also intencled to be ambulatory, do not. The fault of the decisions is that they are still using the old classification of "negotiable" and "non-negotiable" instruments." The language of Malins,

1 Williams v. Colonial Bank (188\%), 36 Ch. D. 6r1; Carr v. Le Fevre (1856), 27 Pa. St. 418. And see quotations ante, p. 381 ff.

2 Kirkwood v. Smith (1896), 1 Q. B. 582 ; Bank of Hamilton $\nabla$. Gillies (1899), 12 Man. 495.

${ }^{3}$ The cases in the United States vary very much as to the effect of unusual clauses in notes. The most, recent of them are Citizens v. Booze (1898), 75 Mo. App. 189; Louisville v. Gray (1899), 26 S. R. 205 (Ala.): Third Nat. Bank v. Spring (1899), 59 N. Y. Supp. 794; Sclauch v. O'Hare (1899), 22 Pa. Co. Ct. 384. 
V. C., of thirty years ago ought to be recognized as something more than a notion of a somewhat radical judge:

"Are they then promissory notes or debentures? or does it make any difference which they are in the result? My opinion is that whichever they are the result is the same, because they in any case nake a contract by which the company have bound themselves to pay, not to any pauticular person, but to any person who may be the bearer, the sum appearing to be due upon their face." 1

\section{INTENDED to be Assigned.}

The rule that the assignee of a chose in action will not take subject to the equitios between the original parties,

"when it appears from the nature, or terms, of the contract that it must have been intended to be assigned free from, and unaffected by, such equities," 2

opens wide and somewhat difficult questions, namely: (1) What is it, in "the nature" of documents, that indicates the intention referred to; and (2) What terms in a document will, and what will not, indicate sucb intention.

Custom must always supply the answer to the first of these questions. The difliculty in this connection is one largely of fact.

For complete answer to the second question we shall have to await some further development in the cases. The points so far raised involve the significance of such words as "his transferces," ol " his assigns," or "the holder," or "the bearer." In Re Natal Investment Co., where a company's bonds were payable to " $\mathrm{C}$., or to his executors, administrators or transferees, or to the bolder for the time being of this debenture bond," Lord Cairns said:

"The word 'transferees' would obvionsly simply be equiralent to 'assigns;' and 'assigns' Woull mean. al'cording to the ordinary construction of such an instrument, an assign by deed - an assign in a way in which an assignee of a bond or other chose in action of the same hind is created. .. We then find added these words: . . 'or to the holder for the time being of this debenture.' As I understand those words, they do noth. ing more than this: In orler to save trouble and expense of assignments by deed, they provide that the company will recognize any person who holds the debenture to be in as good a position as if he had become the assign of it by deed, and will not insist upon his proving his title by produc. ing a formal assignment; but there is nothing whatever in these words which, as it seems to me, is intended to put the holder, for the time being, in a better position than an issign by deed.' . . . There is nothing therefore. . . in the construction of the debenture itself to forego or

1 Re Imperial, etc. (18\%0), L. R. 11 362. And see Dickson v. Swansea Eq. $488 ; 39$ L. J. Ch. 331.

2 Ante. p. $3 \% 9$. (1868), L. R. 4 Q. B. 44: 38 L. J. Q. B.

${ }^{3}$ (1S68) L. R. 3 Ch. 355 ; 37 L. J. Ch. 85; 52 L. J. Ch. 729. 
to renounce the ordinary rule that the assignee of a chose in action must take subjtet to the equities between the original parties."

In a case of about the same date, however, in which debentures were payable in a similar way, Rolt, L. J., said: ${ }^{1}$

"They are payable to bearer, and the object and intention of the parties in making them so payable was, no doutit, to give to any person taking them the right of resorting for payment directly to the obligors without reararl to any equities that miglit exist between them as the original obligees."

Lord Cairns, subsequently in the House of Lords, seems to have adopted L. J. Rolt's view rather than his own, for he said: ${ }^{2}$

"The use of the word 'bearer' in the scrip itself made it negotiable; it made the Russian government liable to deliver a bond and pay money to any one who was the actual holder of the scrip. . . And the actual bearer was in no way bound by any legal liability or by any equities that might be set up as to any of the previous holders of the scrip."

$\Lambda$ nd it may now be said (as already indicated) that " the negotiable character of the bond depends on the bond itself ;" 3 and that the use of the word "bearer" renders a document negotiable, independently of extraneous intention. ${ }^{4}$

A distinction may possibly be made between obligations entered into with the obligee and "his assigns," and those in which other more general terms are used, such as "the bearer" or "the holder." But probably the line is not to be drawn altogether with a view to the use of one particular word rather than another, but keeping in mind also the nature of the document. In that case we shall judge of the intention to make the instrument transferable free from the equities, not only from "the nature or terms of the contract," but by inference drawn from both of these sources.

Conclusion.- Enough bas been said to indicate the safe line of further development.

Lands are intended to be transferred; so are goods; so are some choses in action.

The law as to all classes of property is the same. Ostensible

1 Re Blakely (1867), L. R. 3 Ch. 159 ; 37 L. J. Ch. 420. And see to similar effect, Re General Estates Co. (1868), L. R. 3 Ch. 759; 38 L. J. Ch. 233.

2 Goodwin v. Robarts (18\%(5), 1 App. Cas. 485; 45 L. J. Ch. 750. And see JicKenzie v. Montreal (1878), 29 U. C. C. P. 338.

${ }^{3}$ Per Kekewich, J., in Venables v.
Baring (1892), 3 Ch. 527; 61 L. J. Ch. 609. And see Higgs v. Northern Assam Co. (1869), L. R. 4 Ex. 387; 38 L. J. Ex. 233; Re Imperial Land Co. (1871), L. R. 11 Eq. 478; 40 L. J. Cl. 79 ; Webb v. Herne Bay (1870), L. R. 5 Q. B. 651 ; 39 L. J. Q. B. 221.

${ }^{4}$ Goodwin v. Robarts (1876), 1 App. Cas. $476 ; 45$ L. J. Q. B. 748. 
ownership or agency may estop the true owner from setting up his title as against an innocent purchaser.

The primary question then as to any particular chose in action is whether it was intented to be redeemed to the immediate contractee or to third persons also. It is not suflicient to ask whether or not it is a note or bill, for even so it may be ambulatory or non-ambulatory, and must be classified accordingly.

When the character of the document has been ascertained, either by its form or by usage with relerence to the class of instruments to which it belongs, or by both of these considerations, the law of estoppel and not the law merchant - the ordinary' law and not antagonism to it will sulfice for the settlement of all questions relating to the rights of innocent transferees.

\section{Orende Paper.}

The principles adrocated in this chapter necessitate some modification of current views as to overdue paper. Apart from any asserted ipse dixit of the law merchant, the only reason for declaring that the holder of an overclue bill or note takes it subject to equities is that he has notice that payment bas been refused; this refusal may have been because of the existence of equities; the purchaser should bare inquired; if he had he would have discovered equities; he therefore takes with notice actual or constructive of them, and for that reason ought to hold subject to them.

"After a bill or note is due it comes discraced to the indorsee, and it is his duty to make inquiries concerning it." 1

But we must remember a listinction. The equities of which a transferee is relieved are (1) the equities of the obligors, and (2) the equities of the true owner of the document - or rather the legal title of this true owner. Now the reason for cutting out equities applies very forcibly to the former of these cilses; but it has no relation to the latter.

'Test it: The holder of an orerdue note payble to bearer offers it for sale; the intending transferee inquires of all persons liable upon the note as to equities or claims, and is told that there are none; he then buys the note; afterwarls some stranger demands it from him, saying that the transferror wais his agent of the note for custody merely; that it was overlue

1 Per Lord Ellenborough, in Tinson v. Francis (180\%), 1 Camp. 19. 
when it was transferred; and therefore that the transferee took it subject to all defects. It is at once apparent that the principle of notice, actual or constructire, will not aid this claimant. Nothing but ipse dixit and law merchant will fit his case.

Clearly our theory of ostensible ownership condemns him. The holler of a bill to bearer appeal's to be the owner of it"the property and the possession are inseparable." " Due or not due does not affect or modify this appearance. The true owner is as much estopped by ostensible ownership of a dead horse (overdue as we may say) as of one still able to trot.

Nevertheless law merchant has had its way both in cases ${ }^{2}$ and codes; ${ }^{3}$ and the distinction has not sulliciently been drawn between equities in favor of persons liable upon a bill or note, and assertions of title to the instruments themselres. ${ }^{4}$ It is to be remarked, however, that as soon as the same question arises as to bonds (when the close association between bills and law merchant ceases to dominate the mind) we easily slip into rationality and estoppel:

"I am of opinion that the appellants, having placed their bonds transferable by delivery in Welch's hands, and having thus enabled him to deal with them as his own, are now, when lie has committed a fraud which must result in a loss either to themselves or to the respondents, precluded from asserting their title in such a way as to throw the loss upon the respondents. In applying thas principle of estoppel it appears that the circumstunces of the bonds being overdue is of no importance." 5

The United States Supreme Court did not slip so easily. It has maintained that the same rule applies to bonds as to bills and notes. ${ }^{6}$ But in declaring that although default has been made in payment of interest, yet that the holder of the instrument may be free from equities in respect of the principal sum, it has removed the only ground upon which the rule can be supported.

1 Ante, p. 394.

2 Lee v. Zagury (1817), 8 Taunt. 114; 1 Moo. 556; West v. MacInnes (1864), 23 U. C. 357; Re European Bank (18;0), L. R. 5 Ch. 358; 39 L. J. Ch. $59 s^{\circ}$; Byles on Bills (15th ed.), p. 40, note. But see Moore v. Metropolitan (1873). 55 N. Y. 41; Pomeroy on Equity, \$ $107 \mathrm{ff}$.

345 \& 46 Vic. (Imp.), ch. 61, \$36 (2); 53 Vic. (Can.), ch. $33, \$ 36$ (2).

4 The remark that " the indorsee of an overdue bill takes it subject to the equities of the bill, not the equities of the parties" (Re Overend
(1868), L. R. 6 Eq. 359; McArthur v. MacDowell (1893), 23 S. C. Can. 595), involves the distinction referred to in the text, and may yet serve to establish it, if ostensible ownersbip fails.

${ }^{5}$ Per Strong, C. J., in Young $\nabla$. MacNider (1896), 25 S. C. Can. 277; and see p. 281. See also McKenzie v. Montreal (18is), 29 U. C. C. P. 333.

${ }^{6}$ Cromwell v. Sac (1877), 96 U. S. 51. And see Morgan v. United States (1884), 113 U. S. 476; and Dillon on Mun. Corp., Sิs 4\$6, 513. 
For the reason, as we have seen, why equities attach to an overdue instrument is that "it comes disgraced to the indorsee, and it is his duty to make inquiries concerning it:" and it is lisgracel as much by refusal to make one payment as by declining to neet the other instalments.

The principle advocated is also incolved in the holding that the purchaser of a "non-nergotiable" chose in action will talie it subject to ey!nities between the original parties to the instrument (about which he can inquire), but is not affecterl by equities between sucessive holders about which he can linow or find out nothing.

This distinction received the sanction of the IIouse of Lords in an early case, ${ }^{1}$ and it was accepted by Chancellor Kent:

"It is a generil and well-settled principle that the assignee of a chose in action takes it subject to the same equities it was subject to in the hands of the assignee. 2 Vern. 691-705: 1 P. Wms. 497; 1 Ves. 122: 4 Ves. 11s. But this rule is generally understool to mean the equities residing in the original obligor or debtor, and not an equity residing in some third person against the assignor. . . The assignee can always go to the debtor and ascertain what claims he may have against the bond or other chose in action which he is ahout purchasing from the obligee, but he may not he able, with the utmost diligence, to ascertain the latent equities of some third person against the obligee." 2

The principle upon which the assignee of a non-negrotiable chose in action takes it free from equities between prior holders of it must, however, be relegated to some more elearly delined principle than can be found in such general language - namely, to the law of estoppel. 50.

1 Redfern v. Ferrier (1813), 1 Dow, 2 Murray v. Lylburn (1817), 2 Johns. Ch. (N. Y.) 441. See also Mott v. Clark (1848), 9 Pa. St. 399; Williams r. Donnelly (1898), $5+$ Neb. $193 ; 7+\mathrm{N}$. w. R. 601. The latest New York (ase is not in harmony with the Chancellor's view. David Stevenson r. Iba (1898), 155 N. Y. 294: 49 N. E. R. 6i氵. The United States Supreme Court, while regarding it favorably in $18 \pi 3$ (National v. Texas. 8 r U. S. 72 ). has in later cases departed from it. Cromwell v. Sac (1sit), 96 U. S. 51; Morman v. United States (1884), 113 U. S. 476. In Illinois a distinction has been drawn between equities and the lenal title. If a trustere held overilue securities and had the legal

title to them, a purchaser from him would take free from the equities of the beneficiary: but if overdue securities were stolcn, the thief not having title to them could not by transfer affect the title of the true owner. Rockford v. Young II. C. $A$. (1s95), 78 1ll. App. 180; affirmed, 54 N. E. R. 297; and see Henderson $v$. Cilse (1879). 31 La. Ann. 215. According to this view if a trustee held notes for custorly only and had not therefore the legal title to them, a fraudulent transfer would not affect the true owner. But we have seen much reason for the opinion that in sucn case ho ought to be estopped by the ostensible ownership of the trustea. 


\section{CHAPTER XXV.}

\section{OSTENSIBLE OWNERSHIP AND AGENCY - EXECUTION OF DOC- UMENTS.}

There are two elasses of eases to which attention is now asked:

I. Cases in which the execution of documents has been fraudulently obtained; and

II. Cases in which executed documents bave been fraudulently completed.

And the questions for discussion are: (1) Under what cireumstances are signatories bound by the documents with re. gard to third persons who have changed their position upon the faith of the documents? and (2) Upon what ground does such liability rest?

Estoppel the Ground of Decision.-It may be as well at the outset to suggest that the rules for such cases are those of estoppel as applied to cases of assisted misrepresentation. Instances arise in this way: The signature, whether fraurlulently obtained or fraudulently applied, is by the defrauder represented to some innocent party as being of obligatory character, while, as a matter of fact owing to the fraud, it is not. Now the law of estoppel provides that a misrepresentation will estop not only him who makes it, but him who, in disregard of some duty, did that which provided the opportunity or occasion for the misrepresentation, and so made the misrepresentation eredible. Applied to the case in hand, then, estoppel would say that if there be a duty of carefulness in the execution of a document towards persons who afterwards and upon the faith of it may change their positions; and if that duty be disregarded; and if upon the faith of the document the position of some third party is changed, then the executing party will be estopped. One further (qualification ought to be expressed, namely, that the document must be one of ambulatory character; that is to say, one that not merely operates between the original parties

'See ch. IV. The presence of other necessary conditions is assumed. 
to it, but one that is usually passed on to other persons or acted upon in some way by them.

A priori there does not seem to be much difficulty in asserting a duty of carefulness with regard to the execution of ambulatory documents; indeed, the duty seems to be of the most apparent and obligatory character. Some one asks me to sign two documents, telling me that they are a petition in duplicate for a sewer; after I have signed them, they turn out to be a mortgage upon $\mathrm{my}$ lands and an order for the payment of the money to the defrauder; the mortgragee acts upon these documents, and, exercising every usual precaution, aceepts the mortgage and pays my order. I ought to lose. And observe the reason. If the law imposes no duty of carefulness upon me, I have been no more negligent than the mortgagee, for without duty there can be no negligence.' If I have neglected no duty, I have acted quite properly. If I have acted properly, I cannot be blamed for the mortgagee's loss. And if I am not responsible for the loss, I ought not to pay it. Positing the existence of a duty of carefulness, however, we may say that, although the documents were not binding upon me when I signed them, yet by reason of my neglect of duty they became obligatory when the mortgagee changed his position upon the faith of them; or rather that I then became estopped from denying their obligatory character.

\section{Execution Fraddulently Obtained.}

A study of the authorities of this class reveals the greatest confusion; principally, it is thought, because of the almost entire absence from them of conscious reference to the principles of the law of estoppel. Various other principles and various distinctions have been attempted, but without satisfactory result, or with this result only, that they may when elosely examined be found to be, in one way or another, unconseious illustrations or adaptations of the principles of estoppel.

Laymen and Lettered; Void and Voidable.-For eximple, distinctions are drawn between the case of a lupe who is "a layman and not a lettered" individual, and a dupe of greater

1 Per Bramwell, L. J., in Dickson v. Reuters, etc. (18ri), 3 C. P. D. $5 ; 47$ L. J. C. P. 1. And see ante, ch. V. 
pretension; between occasions in "which no extraordinary caution was necessary" and those in which it was; between cases in which the dupe was deceived as to the actual contents of the document, and in others as to its legal effect; between cases in which the deception was as to the land affected by the document, and in others as to the disposition made of the land; and above all between cases in which the document was void, and in others in which it was voidable.

To the writer all these distinctions may be supplanted by the law of estoppel; and the various circumstances referred to will. have their due effect in helping us to determine whether or not in each particular ease the dupe ought to be estopped.

The Authorities. - A short review of some of the authorities is necessary to malie this clear.

(15s2) In Thoroughgood's Case ${ }^{1}$ Lord Coke held that if a deed be read or explained

"to the party who delivereth it . . . in other words than in truth it is, . . it shill not bind.. . so as he who maketh it be a layman and being not lettered be (without covin in himself) deceived; and that is proved by the usual form of pleading in such cases, that is to say, that lie was a layman and not learned, and that the deed was read to him in other words."

Lord Coke said nothing as to lettered but lazy people who complacently assume the truth of that which is told them and are deceived; but it is not hard to see what he would have said to them.

In Touchstone (56) we find the following:

"So if the party that is to seal the deed can read himself and doth not, or being an illiterate or a blind man doth not require to hear the deed read or the contents thereof declared, in these cases, albeit the deed be contrar'y to his mind, yet it is good and unavoidable."

These two authorities are old, but their doctrine is wholesome.

\section{(1S31) In Edwards v. Brown ${ }^{2}$ it is said:}

"I agree with my brother Russell that whatever shows that the bond never was the deed of the defendant may be given in evidence under non est fuctum. But if the party actually executes it, and was competent at the time to execute it, and was not deceived as to the actual contents of the bond, though lie might be misled as to the legal effect, and though he might have been entitled to avoid the bond by stating that he was so misled, it nevertheless became by the execution the deed of the defendant, and he is not at liberty upon the plea of non est factum to say it was not."

(1852) Hioms $v$. Holton. ${ }^{3}$ The execution of a deed was "frandulently obtained" (particulars not given), upon the faith of which money was advaneed by a third person; and Sir
12 Pep. $9 a$.
21 Cr. \& J. 311: 9 L. J. Ex. 984.
316 Beav. 259. 
John Romilly held the dupe bound, although " he did not understand what he was doing." He was probably a lettered individual.

(1557) Vorley v. Coolie. ${ }^{1}$ A solicitor laid before his client a mortgage reciting that costs $(£ 780)$ were owing to the solicitor, and that it had been agreed to give a mortgage for the amount. The solicitor told the client that the instrument was a covenant to produce title-deeds, similar to other instruments which be had theretofore executed. The elient took the solicitor's word for it, and executed the mortgage, which, of course, was shortly afterwarls transferred to an innocent holder for value. Kindersley, V. C., decided in favor of the dupe, saying:

"If the solemnities of signing, sealing and delivering are tainted with imposture and deceit. these solemnities cease to have a binding effect. and the instrument to which they have been fradulently applied cannot be the act and deel of him who had no mind or intention to execute such an instrument. and who applied tliese solemnities on a false representation of the nature of the deed. and with the mind and intention to execute a deed of a different hind and for a different purpose from that which. by deceit. and friud, was substituted. Therefore it is that evidence of the imposture, falsehood and fraud of such a description can be given at law unler the plea non est factum, for the instrument is no more a genuine deed than if the signature had been forged."

No distinction bere between lettered and lay people.

(1860) Ogilvie v. Jeaffreson, ${ }^{2}$ three years later and by the same judge, was to the same effect, but with this important suggested qualifieation:

"When the plaintiff was imposed upon, the occasion was one on which no extraordinary caution was necessary."

(1869) Foster $v$. McKinnon. ${ }^{3}$ The indorsement of a bill was obtained by fraudulently alleging that it was a guaranty, similar to one previously given. The bill was "in the ordinary shape of a bill of exchinge, and bore a stamp, the impress of which was risible through the paper." The dupe placed his signature on the back of the bill, immediately after that of another indorser. In an action upon the bill by a bona fide holder a verdict went for the dupe upon the following charge:

"If the indorsement was not the defendant"s signature. or if, being his signature, it was obtained upon a fraduluent representation that it was at guarantee. and the defendant signed it without knowing that it was a bill and under the belief that it was a guarantee, and if the defenclant wess not guilty of any negligence in so signing the proper, the defendant wis entitled to the verdict."

In term this charge was held to be right; but the court was evidently not very well satisfied that there was no nergligence,

11 Giff. $230 ; 27$ L. J. Ch. 185.

22 Giff. $353 ; 28$ L. J. Ch. 905.

${ }^{3}$ L. R. 4 C. P. $701 ; 38$ L. J. C. P. 310. 


\section{for a new trial was ordered so that there might be "further} investigation."

\section{(1s71) In IIunter $v$. Walters ${ }^{1}$ Lord Hatherley said:}

"I apprehend that if a man executes a solemn instrument by which he convers an interest. and if he signs on the bick a recelpt for money - a dicunient which, ats the vice-chancellor observes, could not be mistaken,he camnot affect not to know uhat he is doing, and it is not enough for him afterwards to say that he thought it was only a matter of form."

Mellish, L. J., said :

"Now in my opinion it is still a doubtful question at law, on which I do not wish to give any decisire opinion, whether. if there be a false representation respecting the contents of a deed, a person who is an educated per:son, and who might by a very simple means have satisfied himself as to what the contents of the deed really were, may not, by exceuting it negligently, be estopped as between himself and a person who innocently acts upon the fanth of the deed being valid and who accepts an estate under it."

And James, L. J., said:

"I am of opinion that the rule of equity is the rule of common sense, that the principal must suffer for the fraud of his agent. and not the stranger who is dealing with the agent; that the man who has made the representations (i.e., the man who although decerved has executed the doc. ument), under uhatever circumstances, must bear the comsequences of those representations, and not the man who has trusted to the representations so mide."

\section{(1SS6) National v. Jackson..$^{2}$ One Jackson induced his two} sisters to execute conveyances of property to him by telling them that they

"were two deeds respecting the mortgage of £700. which it was necessary that they shouk sign, as he was going to clear off King's mortginge and send the deeds to King."

Cotton, L. J., said :

"The defendants trusted Jackson, both as their brother and solicitor, and cannot be said to have heen guilty of negrect in so doing. . . Now the rule of law is, that if the person who seals and delivers a deed is misled by the misstatement or misrepresentation of the persons procuring the execution of the deeds, so that he does not know what is the instrument to which he puts his latnd. the deed is not his deed at all: because he was neither mincled nor intended to sign a document of that character or class, as, for instance, a release while intending to execute a lease. Such a deed is void. . . . On the exidence it is clear that nothing was said to mislead them as to the nature of the instrument they were executing. It is doubtful how fir they understood the nature of the deeds, but it is in my opinion clear upon the evilence that they knew that the deeds dealt in some uay with their housss. This contention therefore fails."

Lindley, L. J., said :

"It is impossible, consistently with legal principles, to hold the conveyance executed by their sisters absolutely void. They knew that they related to their houses although they did not understand their effect. They trusted their brother and were cheated by him. On the authority of Thoroughigool's ease and other cases these deeds cannot be considered void, though they may be set asjde as voidable, except as against a purchaser for value without notice." 
Lopes, I. J., said :

"Were their conveyances void in law? That depends on the evilence, from which it apprears that they knew they were procuting dects of some kiud or other. "They clearly diel not know the efrect of them-but as to this they relied on their brother."

(1Ss7) Herchmer $v$. Elliott.' A female mortgagree left her mortgage with her solicitor. Subsequently she executed an assignment of it upon a representation male by the solicitor that it was a document to extend the time for payment. Boyd, C., said :

"The plaintiff executed the assignment upon a misrepresentation male as to its nature, character and coutents. She was told, and believerl. that it was to provide an extension of the term of payment of lise mortcrage held by her, and that only. Her signature in this view was obtained ly a piece of deception which involved a fundamental mistake on har part, and the assignment, according to authorities by which I an bound, would be void even in the hands of an innocent holler."

(1593) Onward v. Smithson. ${ }^{2}$ A deed was executed upon the faith of a misrepresentation as to the land which it affeeted-probably the most important part of a deed,-and it was held not to be roid.

"For they intemled to execute a deed containing what this deed did contain, though they were imluced to execute it by a framblulent concealment of the fact that it related to land which they had already conveyed."

Void and Voriluble.-One cannot peruse these various opinions and retain any elear view of the distinction between void and voidable deeds." (1) If we take the distinction to be between deception "as to the actual contents" on the one hand, and "as to the legal effect" on the other (Elluards v. Brou", ante), we find ourselves confronted with National $v$. Suclison (ante), and find it impossible to say whether the cireumstances of that case brought it within the one or the other elass. There the dupes "dealt in some way with their houses," and they

114 Ont. 714. But see Dominion Bank v. Blair (1980), 30 U. C. C. P. 591.

'(1893) 1 Ch. 14; 62 L. J. Ch. 138.

${ }^{3}$ In Kerr on Fraud (2d ed.. p. 9) the matter is put thus (the italies are by the present writer): " $A$ distinction must be taken between cases where a man executes an instrument with the mind and intention to execute it, though his assent may have been obtained by framd, and cases where a man is by fraudulent contrivances induced to put his hami and seal to an instrument which he never intended and had no mind to execute." If by this is meant that there is a distinction between cases in which a man intends to deticer a deed and those in which be does not, the proposition can be rearlily assented to, but in that case it has no relation to the problem of void and roidalile deseds. If there he some other meaning in the sentence, its illusive quality well illustrates the prevalent confusion. 
knew nothing as to the effect of the deeds because they knew little or notling of their contents. We have also to explain Onucurd $x$ Smithson (ante). (2) If we take the distinction to be between cases in which a document is executed "with the mind and intention to execute a deed of a different kind and for a different purpose from that which by deceit and fraud was substituted" (Vorley $v$. Coole, arte), we are met with the quotation from Touchstone (ante) that in some such eases, "albeit the deed be contrary to his mind, yet it is good and unavoidable;" by the statement in Kennedy $v$. Green" that "a man is not to avoid the consequenees of a want of due diligence by stating that he has neglected those means which would have been required if he had used reasonable caution," and by the statement in IIunter $v$. Walters (ante) that sometimes a man "cannot affect not to know what he was doing."

The strong impression left by the cases is that the terms "void" and "voidable" are used teleologically, so to speak, rather than in a seientific classification. That is to say, we bave no specification of the essential elements of the two classes of documents; but the words represent vaguely the quantity of moral shock which the various cases produce - a very abominable fraud, and we say "void;" one not so disturbing, and we say "voidable."

The justness of this criticism will become very apparent to any one who endeavors to follow the words into the numerous cases relating to the transactions of infants and lunatics. Perhaps the best that can be said with reference to the contracts of infants is contained in the old dictum of Eyre, C. J.:

"When the court can pronounce the contract to be to the infant's prejudice, it is roid: and when to his benefit, as for necessaries, it is good; and when the contract is of an uncertain nature as to bellefit or prejudice, it is voidable only at the election of the infant." 2

In an able judgment Hemphill, C. J., suggested

"that if the semblance of benefit be regarled as a criterion, the more rational and consistent rule wonld be that the act should not be deemed void unless it was one of those which, as a general principle, it would be better for the infant that they should be deemed roid than voidable." 3

But the learned Chief Justice is constrained to avow that "notwithstanding the many attempts of the bench, the profession, and jurists to elucidate the subject, yet the questions as to what acts of minors

1(1834) 3 Ny. \& K. 713.

${ }^{2}$ Keane v. Boycott (1795), 2 H. Bl.
${ }^{3}$ Cummings v. Powell (1852), 8 Tex. 90. And see the cases there cited. 51. 
shall be regarded as void and what roidahle, and what the criterions by which the precise eharacter of their acts shall be determined, remain involved in duubt and ditliculty." 1

The law in the United States with reference to the contriets of lunatics is still less satisfactory, for in such cases much is said to depend (in addition to considerations of benefit or disadvantage) upon whether "the incompetent has been placed under guardianship." 2

The sime uncertainty attends deeds mado under duress, and there is the same attempt to divide them into roid and voidable. $^{3}$

The justness of the criticism (that the words are customarily used in loose and indetinite fashion) may also be argued from the ambiguous way in which they are employed in statutes the word "void" being frequently used when "voillible" is intended $;{ }^{4}$ and also from the fact that sometimes judicial language indicates that although a leed may be "null and roid, yet, as between $S$. and a purcbaser for value on the faith that they were valid, they may be valid." 5

To the writer it appears that the current phraseology was employed faute de mieux; or ratber, perbaps, in default of a clear apprehension of the principles involved. T!e two classes of cases were clearly seen to exist - those in which the signer ought and those in which he ought not to be bound; and the reason also was (for the most part) seen, namely, carelessness. What was not understood was, upon what prineiple a leed could be not binding when executed, as between the parties to it; and yet afterwards, without any further act on the part of

1 Id. 86.

2Devlin on Deeds, rol. 1, $73,7 t$; Allis v. Billings (184:), 6 Met. (Mass.) 417; Cockrill r. Cockrill (1899), $34 \mathrm{C}$. C. App. 254; 92 Fed. K. 811.

3 Anson on Contracts (2d Am. ed.), 177; Clark on Contracts, 363; Chand on Consent, 62; Bush v. Brown (15i5), 49 Ind. 57 7 ; Oregon v. Forrest (1891), 128 N. Y. 83 ; 28 N. E. R. 137: Sorn. borger v. Sanford (1892), 34 Neb. 498; 52 N. W. R. 368; Miller v. Minor (1893), 98 Mich. 163: 57 N. W. R. 101.

tSee Ewell r. Dilggs (18S2), 108 28
U. S. 143; Bennett v. Mattingly (1\&86), 110 Inı. $20 ?$; 11 N. E. R. $79 ?$.

5 Per Erle, C. J., in Swan v. North B. A. (1859), r C. B. N. S. 4:30: 30 L. J. C. P. 113 . With reference to juilg. ments, too, we are very truly told that "the distinctions between void and roidable judgments are very nice, and they may fall under the one class or the other as they are re. garded for different purposes." Ex parte Lange (1Si3), 1s Wall. (U. S.) $175,176$. 
the signer, become binding upon him as against other persons. Thus it was said that there is no case

"that shows that an instrument which, when executed, is incapable of having any operation and is no deed, can afterwarls become a deed by being completed and delivered by a stranger in the absence of the party who executed, and unauthorized by instrument under seal." 1

Distinctions were therefore attempted between degrees of fraud practiced on the dupe rather than between degrees of carelessness exhibited by him. And it was said that if the fraud of the knave was of certain (not very certain) character, the deel was roid against stmngers; instead of saying that if the carelessness of the dupe was the cause of his deception, he was estopped as against those strangers from asserting that it was voil.

Solution.- Rightly viewed, no document obtained by misrepresentation (whether the vilest, the most complex, the most simple, or the most innocent) is binding upon the dupe; and its character remains constant (it cannot change), accompanying it into whatsoever remotest hands it may come. ${ }^{2}$ As against persons, however, who upon the faith of it being a valid document have changed their positions, the dupe, if the fault be chargeable to bis carelessness, is estopped, for he has assisted the misrepresentation and provided the opportunity for it. That is the rationale of the matter.

It may be suggested that admitting this solution to be theoretically sufficient, yet that it is of no practical utility, for we are still left to the uncertainty of the word "carelessness." That is perfectly true; but it is sometbing at all events to know that it is carelessness that we have to deal with; for we shall then, for the first time, be in a position to develop rules for future guidance. That carelessness must be defined and ascertained is little reason for eliminating it from our jurispridence; and the advance obtained by regarding the matter from an estoppel standpoint may readily be appreciated by observing the reason at present given for regarding a document as roid:

"It is invalid not merely on the ground of fraud where fraud exists, but on the ground that the nind of the signer did not accompany the

1 Hibblewhite v. McMorine (19:0), 6 II. \& W. $: 00$. By curious coinci. dence the very deed to which the larned judge referred was afterwards an example of that which he tl.ought to be without jrecelent.
See Sheffield r. Woodcock (i841), 7 II. \& W. 574; 10 L. J. Ex. 49?.

¿Somes v. Brewer (18:4), 19 Mass. 1S3; Williams v. Given (1849), 6 Grat. (Va.) 268; Onward r. Smithson (1893), 1 Ch. 14; 62 L. J. Ch. 138. 
signature: in other words, that he neser intended to sign and therefore in contemplation of the law never did sign the contract to which his nane is appended." I

It is something to be able to relieve the courts from such contradiction as this, and to substitute the remark that although the signer did in contemplation of everyboly sign the contract, yet that because of the fraud he is not bound by it; and that he is or is not estoppel from so saying according as his conduct may or may not exbibit "an appropriate measure of prudence to aroid causing harm" to others. ${ }^{2}$

It is not asserted that there is no true distinction between void and roidable deels. Beyond question there is a very clear line between them, determinable by the well-known consideration that some of them are capable of confimation and others are not. ${ }^{3}$ According to this classification, certain deeds (such as those in violation of public policy) are void; and leeds obtained by misrepresentation (whatever the character of it) are roidable; that is to say, are capable of confirmation. ${ }^{4}$ It would be clearly unscientific and confusing were we, by different definitions and fresh considerations, to subdivide these voidable deeds again into void and voidable.

The matter, therefore, may be put in this form: (1) The dupe, having been misled, is not bound by the document, and as between him and the knave there is no estoppel; but (2) as between him and innocent parties he will be estopped, if he have been careless, "albeit the deed be contrary to his mind." He will be estopped although be was tricked into executing a document of a nature wholly different from that which he in fact believed it to be -

"by executing it negligently be estopped as between hinself and a person

1 Foster v. MacKinnon (1s69), L. R. set aside by the action of some per4 C. P. $711 ; 38$ L. J. C. P. 310.

2 Ante, p. 30.

${ }^{3}$ Cummings v. Powell (1S.i2), \& Tex. 85. The continental division into (1) absolutely voill (e.g., a will of an infant), (2) relatively roid (e. gr. a bishop's lease " "xceeding the period prescribed by law; which is gool as against the bishop, but not as a gainst his successor"), and (3) roidilile, namely, "those which produce their legal result; but this result can be son concerned" (Markby's Elements of Lilw, sec. 273 ), is scientific. It re. mained for English-spealing lawyers to sublivide this voudable class into roid and roilable. See it referred to in Pearsoll v. Chapin (186?) $44 \mathrm{~Pa}$ St. 1): Seglar v. Carson (1Si1), 69 Pah. St. $\& 1$.

4 It camnot be contended that in any of the instances ahove given the document conk not have been confirmet by the dupe. 
who innocently acts upon the fuith of the deed being valid and who ac cepts an estinte under it." 1

Or, as put in Coote on Mortgages: ${ }^{2}$

"Where two innocent persons are affected by the fraud of the solicitor, the one who, by simmer ilocomments. although in ignorince, enables the solicitor to commit the frand, suffers."

In this view the distinctions between lettered and unlettered individuals, between occusions calling for "extraordinary caution," and other occasions, etc., are distinctions not in the law but in the facts. The question must always be whether the dupe has acted with reasonable diligence or whether he has been careless, and the circumstances (including those just referred to) of each case must be taken into account in judging his conduct.

United States Law. - The law in the United States seems to be fairly established upon this basis. Chief Justice Gibson thus states it:

"If a party who can read will not read a deed put before him for execution; or if, being unable to read, will not demand to have it read and explained to him, he is guilty of supine negligence, which I take it is not the subject of protection either in equity or law." 3

So in Green v. Willie it is said that

"a party who is ignorant of the contents of a written instrument from in. ability to raul, who signs it without intent to do so. and is chargeable with no negligence in not ascertaining its character, is not bound by it in the hands of a bona fide purchaser." 4

1 Per Mellish, L. J., in Hunter v. Walters (18i1), L. R. 7 Ch. S2; 41 L. J. Ch. 175 .

24 th ed. 856. So also, if a creditor be fraudulently induced to give up some of his securities, he, and not the surety, must suffer. Mejchants' Bank v. McKay (1890), 12 Ont. 498.

3 Re Greenfield (1850), 14 Pa. St. 496.

${ }^{4}$ (1896) 98 Iowa, $74 ; 66$ N. W. R. 1046. Signer must read if he can. Rouch v. Karr (1877), 18 Kan. 529; Etna v. Franlss (1880), 53 Iowa, 618; 6 N. W. R. 9; Cowgill v. Pettifish (1ธ92), 51 Mo. App. 264; Kalamazoo ๙. Clark (1892), 52 MIo. App. 593; Elmendorf $v$. Tejada (1893), $23 \mathrm{~S}$. W. R. 935 (Tex.); Metcalfe v.Metcalfe (1893), 8.j Me. 473; 27 Atl. R. 457; Blaisdell r. Leach (1894), 35 Pac. R. 1019; Eldridge v. Railroad Co. (1895), 88 Me. 191; 33 Atl. R. 9r4: Lill v. Yarbrough (1996), 62 Ark. 326; 3j S. W. R. 433; Engstad $\nabla$. Syverson (1898), 72 Minn.
188; 75 N. W. R. 125; Olson r. Royern (1899), 77 N. W. R. 818 (Minn.). If signer cannot read he must require the document to be read to him. Metcalfe v. Metcalfe, 8.) Me. 473. There must be no carelessness. Webb v. Corbin (1881), 78 Ind. 403; Green v. Willie (1896), 98 Iowa, 74; $66 \mathrm{~N}$. W. R. 1046. For example, if the document be improperly read by a stranger, and neighbors are present who might have been appealed to, the signer is bound. Swamell v. Watson (1874), 61 Ill. 456. Distinction is sometimes taken where the document is altogether different from that intended. Webb v. Corbin, ante; and Green v. Wilkie, ante. But the general argument (as above) leaves no room for such a consideration. The question is not whether the dupe has been deluded as to the whole document, or as to part or parts of it only; but whether he has 
In some cases even the excuse of reasonable diligence seems to be excluded; and it is certainly more in accordance with principle that the person selecting the rascal should sulfer, rather than he who is misled by him.

"Upon this same principle it is almost universally held that whenerer an instrument is proculed from one person by the fraud or villainy of another, even if such frawd or villainy should amount to a criminal offense, If all the rights which the instrument ajparently gives should at that time or afterwards be transferrel to another who shomld be in innocent and lme fide holder for vilue, the innocent and bona fide holder could enforce the instrument against the maker, although the maker might also be an innocent person. In such a case the maker woul! be estopped from claiming that the instrument was void as against the innocent bona fide holder." 1

Analogy. - Useful analogy may be found in one of the points consiclered in a previous chapter. ${ }^{2}$ We there saw that if an owner of goods were swindled into parting with possession of them, a purchaser from the swindler would be protected if the title had passed from the owner to the swindler; but if it had not passed - if there had been in reality no contract at all between them - then of course the swindler's vendee could talie nothing. We also saw, however, that although there might be no contract, yet if the owner had equipped the swindler with indicia of ownership of the goods, the owner would be estopped from denying that the title had passed.

These principles are applicable to the subject under discussion. For where a transler of property is executed, the title passes to the grantee eren though he be a swindler (for the act is separable from the motive which induced it, and is an act, although revocable for fraud); and the swindler, passing on the title, gives to the innocent purchaser that which be can be deprived of by superior equity only.

But waiving this point, the intervention of estoppel, as in the analogous case above referred to, ends the dispute. For even if it be admitted that the transfer from the owner to the swindler is roid, yet the owner is estopped from so saying as against an innocent purchaser who has relied upon the document. The question then becomes, not one "of aflirming or disafirming any contract"- not a question of void and voidable - " but a question whether the owner of the groods has by his con-

too easily fallen a prey to the swindle - whatever its character.

1 State v. Mattlews (1890), 44 Kan. 596; 25 Pac. R. 36. And see Atchison v. Brassfield (1833), 51 Kau. 167; 32 Pac. R. 814. It would hardly be contended, however, that a lunatic would be bound by a note which he signed under misrepresentation. If the rule of "reasonable diligence" be sufficiently drastically construed and applied, it may meet the requirements of all cases.

2 Ch. XXI. 
duct allowed the person who has either cheated him, or to whom he has intrusted the goods, to holl himself out as the owner so as to give a good title to a bona fide purchaser for value." 1

\section{Execution Fraddulently Completed.}

The conclusion arrived at in the preceding paragraphs that there is a duty of carefulness with reference to the execution of documents upon the faith of which other persons may change their position - a duty that one shall inform himself as to the contents of that which be signs - does not involve, but is not disparate from that which is now to follow, namely, that there is a duty of carefulness not only as to the contents but as to the form and custody of such documents.

Once admitted that towards one's fellow-men there is some duty of carefulness that one is not too readily made an instrument for their undoing, and it would seem difficult to say that opportunity for fraul ought not to be given by carelessly signing a document the contents of which were misrepresented; but that such opportunity might with impunity be given by signing an incomplete document which was afterwards fraudulently filled up, or by intrusting a completed instrument to the custody of one who made fraudulent use of it. That in one case the frand is prior, and in the others subsequent, to the execution of the instrument, is not sufficient ground for distinction; and there is the same carelessness and betrayed trustfulness in all such cases.

Division of the Subject. - For the sake of clearness it will be well to divide the subject into:

I. Documents conficled to another person.

II. Documents stolen or found.

Cross-divisions will be made as follows:

(1) A. Documents in complete form.

B. Documents in incomplete form.

(a) Blanks purposely left.

(b) Spaces carelessly left.

(c) Signed, but otherwise blank slips of paper.

(aa) Blanks or spaces known to the transferee.

(bb) Blanks or spaces unknown to the transferee.

(2) A. "Negotiable" instruments.

B. Other documents.

${ }^{1}$ Henderson $\vee$. Williams (1895), 1 subject more fully discussed, ante, Q. B. 527; 64 L. J. Q. B. 308 . See the

p. 303. 


\section{Documents Confided to Axotien Person.}

\section{A. "Negotiatie" instruments.}

Premising that the worl "negotiable" is being used in its common acceptation, ${ }^{1}$ observe that rarious cases may arise:

(1) $\Lambda$ signed document, in complete form, may be left with some one for custody merely, or for delivery upon the happening of sone contingency.

(2) The document so left may be in blank - blank spaces or entirely blank.

(1) Completed Negotiulle Documents. $-\Lambda$ s to these cases the present writer adopts the language of Mitchell, J.:

"They themselves have created the agency or trust by means of which the fraul. if any, has been committed. It is the duty of the maker of ne. gotiable paper to guard not only himself but also the public against frauds of this kind." 2

In a very recent case in the Supreme Court of the United States Mrr. Justice Brewer said:

"It is said that the bonds were placed in escrow, and that when an instrument is so placed there can be no valid delivery until the condition of the escrow has been performed, and if without performance the instra. ment passes out of the hamls of the one holding the instrument in escrow it is not enforceable against the maker, amil that in a suit on the instrument the inquiry is always open whether the condition of the escrow has been performed. Whatever may be the rule in case the instrument so placed in escrow be a deel or non-negotialule contract, we are of opinion that a different rule obtains when the instrument is a negotiable obligation." 3

Mr. Daniel in his valuable book on Negutiable Instruments takes a different view:

"In these cases, it will be observed, the person with whon such instrument is left is its mere custodian. and not an agent having any absolute power to dispose of it. He is not as to the instrument an agent with fimited powers, but the arency itself is conditioned upon the happening of the event upon which he is to becone the agent to deliver it."

1 Its meaning is discussed in ch. XXIV.

2 First Nat. Bank v. Compo (1895), $61 \mathrm{Minn} .274 ; 63 \mathrm{~N}$. W. R. 731. And see Fearing v. Clark (1860), 82 Mass. 74; Morris v. Preston (1879), 93 Ill. 215; Chase Nat. Bank v. Faurot (1s!6), 149 N. Y. 532; 44 N. E. R. 164; Galvin v. Srfers (IS9s), 5: N. E. R. (Ind.) 96; Cross v. Currie (18s0), 5 Ont. App. 31 ; Merchants' Bank v. Good (1S90), 6 Man. 339; Bills of Exchange Act, 45 \& 46 Vic. (Imp.), ch. 61, \$21; 53 Vic. (Can.), ch. 33, §21.
3 Provident $\checkmark$. Mercer (1S98), 170 U. S. 593; 18 S. C. R. 788. And see Vallett r. Parker (1831), 6 Wend. (N. Y.) 620; Graff x. Logue (1S:3), 61 Iowa, 707; 17 N. W. K. 171; Long Island $v$. Columbus (1s95), 6j Ferl. R. 4.5. But see Burson v. Iuntington (18\%0), 21 Mich. 415.

+Sec. 8.it. And see Ontario Bank r. Gibson (18s6), 3 Man. 406; 4 Man. 440. Mr. Diniel cites awde v. Dixon (18.i1, 6 kx. $869 ; 20$ L.J. Ex. 29ii) as farorable to bis views; but that case is complicated with the cireum. 
This reasoning would be appropriate were the question one of agency. But it is not; it is one of estoppel by ostensible ornership. It is within the language of Lord Herschell when he saicl:

"If the owner of a chose in action clothes a third party with the appar. ent ownership and right of disposition of it, he is estopped from asserting his title as against a person to whom such third party has disposed of it, and who received it in good faith and for value." 1

A distinction is sometimes taken between cases in which the depositee was to remain a mere custodian, and those in which he was to become active upon the happening of a contingency.

"Whether the acceptor of a blank bill is liable upon it depends upon his having issued the acceptance intending it to be used." 2

But it will be observed that Lord Herschell's language applies to the one case as well as to the other.

The ground of estoppel in such cases is clearly ostensible ownership (or in some special eases ostensible ageney). As we have already seen, ${ }^{3}$ the possession of a nerotiable instrument carries with it the appearance of ownership; the person intrusted therefore is the ostensible although not the real owner of the document; the obligor is in some measure responsible for this appearance of ownership - he bas assisted the misrepresentation of ownership by banding over the evidence of it; and for that reason ought to be estopped.

Blanks in Negotiable Instruments.-The instrument which is conficled to another person may be in blank form. Let us deal more at length with such documents, for if when they are fraculuently filled up and transferred obligors are liable upon them, any question as to liability were the instruments in completed form when parted with will be set at rest.

A form of note is indorsed and given to another person, with authority to fill it up for $£ 100$; in fraud of the maker, this person fills it up for $£ 500^{4}$ and transfers it for value; is the

stance that the bill was incomplete in form when taken by the transferee; and the language of the judgment leaves it uncertain whether that fact was not the ground of decision.

1 Colonial Bank v. Cady (1890). 15 App. Cats. 267; 60 L. J. Ch. 131. See also per Lord Cairns in Goodwin $v$ Robarts (1876), 1 App. Cas. 476; $45 \mathrm{~L}$. J. Q. B. 748 .
${ }^{2}$ Per Brett, L. J., in Baxendale v. Bennett (18i8), 3 Q. B. D. 525; 47 L. J. Q. B. 624; Whitney v. Snyder (1870), 2 Lans. (N. Y.) 477; Ledwick v. McKine (1873), 53 N. Y. 307; Schuylkill v. Copley (1871), 67 Pil. St. 386; Kagel v. Totten (185?), 59 Mu. 447: Randolph on Commercial Paper, $§ 181$.

3 Ante, p. 394.

4 In this and other supposititious 
maker liable? and if so, why? Lord Mansficld would have answered both questions in this way:

"The indorsement of a blank note is a letter of credit for an indefinite sum. The defendant said, "Trust Galley to any amount, and I will be his security.", 1

This view has been very widely approved in English, Canadian and United States courts. ${ }^{2}$ Indeed, in a recent ease, it is said that it "has never been disputed." 3 And Mr. Bigelow in his latest work (1S93) has the following:

"The rule of law upon this point may be thus stated: One who writes his name as malier, acceptor. drawer, or indorser, and intrusts the paper to

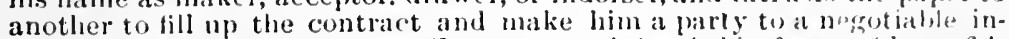
strument, thereby confers upon the person so inlrusted in favor of boun fisle holders for vilue the right to complete the contract at pleasire, so fiar as consistent with the instrument as written or printed, at the time it is de. livered to the person intrusted with it." 4

Criticism. - But this language is inexact. Either the power was conferrel or it was not. The case is impossible that it was not conferred and yet that it was, even if we add to that statement, "in favor of bona fide holders." If it was conferred, then calit quastio. If it was not conferred, then it is impossible that the signer ean be liable on the ground of authority.

Observe further that there are two elasses of cases, and that the explanation, "Trust Galley to any amount," can have no reference at all to one of them. If the transferee knows that the doenment was delivered in blank, then it may be that its appearance indieates to him the existence of authority to fill up. But if Galley fills up the blanks before going to the transferee, and the transferee knows nothing of there having been blanks - believes that the instrument was complete when it was signed, - then no message about Galley's authority can have come to him. "Trust Galley" has nothing to do with such a transaction.

cases we shall assume that, in jurisdictions in which there are stamp laws, the amount filled in does not exceel the amount warrinted by the stamp affixed.

1 Russell v. Langstaffe (17S0). Doug. 514. And see Schultz v. Astley (1836), 2 Bing. N. C. 54t: 5 L. J. C. P. 130; 2 Sc. S15; Stoessing v. South Eastern (1Si5), 3 E. \& 13. 万infi: 3:3 L. J. Q. 13. 293; Robarts v. Tueker (1ะ51), 16 Q. B. 560; 20 L. J. Q. B. 270.
2Schofield v. Londesborough (1895), 1 Q. B. $555 ; 64$ L. J. Q. 13. 293; II Innes v. Milton $(1570) .30$ U. C. Q. B. 489: Van Duzer $\vee$ Howe (1860), 21 N. Y. 53.i; First Nitt. Bank v. Jolınston (18.9)), yi Ala. 65.j; 11 S. R. 690; Market $\checkmark$. Sargent (1593). $85 \mathrm{Me} .349$; $2 \tau$ Atl. R. 19:.

${ }^{3}$ Per Killam. J., in Merchants' Bank v. Good (1 $\$ 90)$. 6 Mian. 346.

4 On Bills and Nutes, 227. 
Little notice, howerer, has heretofore been taken of this distinction, Lord Mansfield's dictum being supposed to be applicable to all cases. Of it Mr. Daniel says:

"This admirable statement of the law is almost universally quoted with approval and followed as a precedent, applying equally to maker, acceptor and "lrawer as to the indorser." I

"By some authorities it is held that if he knew that the paper had been signed as a blank and filled $u_{p}$ by force of authority by the holder, he should inquire as to the extent of such authority, and if he fails to do so he takes the paper at his peril. But this qualification of Lord Mansfielil's doctrine that the blank signature is 'a letter of credit for an indefinite sum' does not impress us as an improvement upon it. The paper being limitless in its terms is prima facie limitless as to the authority it confers. The holder is invested with a general authority as to that paper; and the graphic phrase of Lord Mansfield describes it to perfection. High authorities. jncluding Story and Parsons, concur in these views, which seem to us clearly the most philosophical.",

The language most frequently met with in the cases is this:

"Where a party to a negotiable instrument intrusts it to the custody of another with blanks not tilled up, . . . such negotiable instrunent carries on its face an implied authority to fill up the blanks and perfect the instrument." 3

Blanks in Negotiable Instruments Rnown to the Transferee. Taking this class first, observe that the case we have to deal with is one in which Galley (the custodian of the instrument) has either no authority at all to fill the blanks or else has authority limited to a certain amount; and that Galley exceeds his authority and passes the document to a person who knows of the blanks. It is resorting to mere fiction in such a case to allege that the obligor said: "Trust Galley to any amount." The blanks may indeed have given to Galley the appearance of widest authority, and such ostensible agency may estop tho obligee from denying the existence of such authority, but that is another matter.

Instances of estoppel in analogous cases are very familiar in the law of principal and agent. An agent may in many cases exceed his anthority, but yet, the circumstances surronnding the agrency having been such as to indicate the existence of the assumed power, the principal is estopped from denying its existence. When I am dealing with one whom I know to be

i On Negotiable Instruments (4th ed.), $\$ 142$.

2Sec. 147. And see First National Bank v. Compo (189.5), $61 \mathrm{Minn}$. 274; 63 N. W. R. 731.

3 Goodman v. Simonds (18.57), 61 U.S. 361; Pank of Pittshurghl v. Neal (18.59), 63 U. S. 107; Whitmore v. Nickerson (1878), 125 Mass. 496; Ellis v. Wait (1893), 4 S. Dak. $454 ; 57$ N. W. R. 231; Market v. Sargent (1893), 85 Me. 351; 27 Atl. R. 19:. And see Am. Cent. Dig. (ed. VII), pl. 134-147, and the innumerable cases there cited.

4 See the subject fully treated of in cl. XXVI. 
acting as an agent, the general rule is that I must, at my peril, inform myself as to the scope of his agency. I may, however, be misled by some act or omission of the principal; and it is upon this ground that the principal is sometimes estopped.

For example, a broker is employed to buy and sell shares in the market. In dealing with him I may be aware that he is acting as an agent; but, in consilering his authority, $I$ am entitled to assume that he has those powers which a broker, so acting, usually has.' Employment of a man in the line of his business is usually accompanied by delegation to him of the powers which he customarily exereises; and the principal is estopped by the appearance of usual authority from asserting the existence of any unusual instructions which he may have given but of which I have no notice.

Somewhat in the same way, custom may have attached to the possession of a blank note a presumption that the holder has power to fill it up for any amount he chooses. If so, tho signer would be estopped from asserting the existence of any unknown limitation of that power. We cannot indeed say that signing a blank note "thereby confers upon the person so intrusted, in fivor of bona fide holders for value, the right to complete the contract at pleasure" (for the real fact may bo quite otherwise); we say merely that the signer is estopped, by the appearance of power, from denying that it was con. ferred.

Customary Effect of Blanks.-The cases are not quite unanimous as to the existence of such a custom." They are, however, overwhelmingly in favor of it; and the law, whatever one may think of ${ }^{2}{ }^{3}$ firmly establishes the inference of au-

1 Sutton v. Tatham (1839), 10 A. \& E. 30; 8 L. J. Q. B. 210; Pickering v. Busk (1812), 15 East, 45.

2 See a strong judgment of Kin. dersley, V. C., in Hatch v. Searls (18.54), 2 Sm. \& G. 147; 23 L. J. Ch. 46\%. See also Awde v. Dixon (1851), 6 Ex. 869; 20 L. J. Ex. 295; Hogarth v. Latham (1878), 47 L. J. Q. B. 339. 3 Presumption proceeds upon probability. We presume that an event happened because experience has indicated its probability. We can hardly say that we are entitled to presume the existence of a fact when we are reasonably sure that it never occurred. In the present ciase it is said that one ouglit to assume, from the mere possession of a blank note, that the holder of it has authority to fill it up for "any amount" however magnificent, or, as Mr. Bigelow puts it, "it pleasure." In ('allita, at all events, where fortumes are somewhat limited, such unhounded authority is of the very 
thority to fill up blanks. "We have been speaking so far of blinks for amounts merely. The same rule applies to other blankis (for date, place of payment, and so on); and with better reason, for presumption proceeds upon probability, and it is much more likely that absolute discretion was conferred as to such features of the document than as to the amount of it. ${ }^{2}$

Estoppel the True Ground for Decision.-Procecding by elimination it is quite clear that liability in such cases does not proceed from the fact that the signer himself made the instrument, or from the fact that any one having authority to do so

rarest occurrence. And in other countries, apart from unusual faniliarity with the pleasures of unneasured wealth, it is certain that in the very large majority of cases one ought rather to anticipate that some maximum amount had been agreed upon than that it had not. In business affairs every one knows that there is almost always some limit fixed.

No doubt the law, for ulterior purposes, may arbitrarily detach probability and presumption, and may declare that a certain act shall be taken as conclusive evidence of some intention which is not commonly associated with it. But unreasonable rules are bad ones. $\Lambda$ nd it is unfortunate if we are compelled to say that although as a matter of fact the maker of a blank note seldom confers power upon the holder of it to fill it up for "any amount," yet, as a matter of law, he always does so. Fictions have no place in fully-developed jurisprudence.

The cases, too, show the impossibility of getting it into everyborly"s bead that when one really says to Galley, "I authorize you to fill up this blank for $\$ 5$," he technically says to the world: "Trust Galley to any amount and $I$ will be his security." And the frequent reappearance in the courts of Galley's surprised principals, amazed at the marnificence of their intrusted con- fidences, almost leads one to wish that legal presumptions had sometimes closer relations with the undisputed facts.

One can easily see how the presumption arose, and was in its inception reasonable. If upon a blank note the maker should write "to be filled up witl any amount not exceeding $\$ 1,000$," it could fairly enough be held that he had given authority up to that amount. And if under the provisions of some stamp act he should affix duty sufficient for a $\$ 1,000$ note, the same meaning might very well be taken out of his action. And the law so commenced. But it is irrational from that to argue that if there be no limitation upon the note the authority is unlimited. For that is to make a reasonable inference responsible for one known to be unreasonable and non-existent.

1 The codes are however very puzzling. $45 \& 46$ Vic. (Imp.), ch. 61 , $\S 20: 53$ Vic. (Can.), ch. 33, $\$ 20$.

2 Cason v. Grant (1895), $97 \mathrm{Ky} .487$; $31 \mathrm{~S}$. W. R. 40. But there would be no presumption of authority to fill in "with interest at six per cent." Gettysburg Bank v. Chisholm (1895), 169 Pa. St. 564; 32 Atl. R. 730; Farmers' Bank v. Norrich (1896), 89 Tex. 381 ; 34 S. W. R. 914; First State Sav. Bank v. Webster (1899), 79 N. W. R. 1068 (Mich.). 
male it for him. Esc hypothesi these are not the facts. How then can he be liable? In one way only as the writer sees it and that is by estoppel - by estopping him from denying that the contract is his. As against this, however, there is much authority. There is the opinion of Baron Pollock: ${ }^{1}$

"In such a case the acceptor is biable to a tona firle bolder, . . . and the reason for this is not becaluse the the acceptor gave anthority for this or that name to be inserted, - for in truth he gave no such anthority-but lecause, in favor of commerce, it is essential to uphold the negotialial. ity of bills of exchange. That this is so may he further illustrated by a case in which a fraud is practiced upon the acceptor of a bill drawn in blank with reference to the amount. - . Here is a clear absence of authority and a fralu against $A$. (by inserting $£$ is instead of 500 ), yet he is liable for the reason we have given. . . In the present case. the ordinary rule as to authority camnot be adhered to, and something like a fiction mist be resorted to in favor of a bona fide indorsee for value, or, as we should prefer to say, the law morchiant in such a case holits that although the acceptor di:l not authorize the drawer's name to be used he enabled the person to whom he gave the bill to use it. and so to give the bill currency, and this as agianst the acceptor is sufficient to reniter lim liable. . Estoplels are odious. . . We should prefer not to use the wor? estoppel, which seems to imply that a person by his conduct is ex. cluded from showing what are the true facts. but rather to say that the question is whether, when all the facts are admitted, the acceptor is not liable upon the well-known principle that where one of two innocent persons must suffer from the frind of a thirl, the loss should be borne by him who enabled the thind person to commit the fraud."?

With great respect for so learned a judge it must be said that while he was condemning estoppels as odious he was really deciding the case upon principles peculiar to that branch of the law. The learned judge said: "IIe enabled the per'son to whom he gave the bill to use it and so to give the bill currency"- that is to say, the signer had, by his conduct, induced, or assisted in inducing, the holder to believe that the bill was a genuine obligation, and the holder had acted upon that belief. In other words, although the instrument was not a real obligation the first holder of it had represented to the tramsferee that it was; the signer had assisted in this misrepresentation - had given opportunity for it and made it credible; and

1 London v. Wentworth (1S80), 5 Ex. D. 104; 49 L. J. Ex. 65\%.

2 Sre in the same sense Marston $r$. Allen (1841), 8 M. \& W. 504; 11 L. J. Ex. 12:; Foster v. McKinnon (1 469$)$, L. R. 4 C. P. 712 ; 38 I. J. C. P. 310 ; Swin v. N. B. A. Co. (1863), 2 H. \& C. 185: 32 L. J. Ex. 273. It was probably to this principle that Lord Esher referred when he said (Baxendale $r$. Bennett (1875), 3 Q. B. D. 525): "When a man has signed a blank acceptance and has issued it and author. izel the bolder to fill it up, he is lial. ble on the bill whatever the amount may be, though he has girou secret instructions to the holler as to the anount for which he sliall filt it up: he has enabled his agent to dcceive an innocent party and he is liable." But the language is also referable to estuppel. 
was therefore estopped from denying the truth of the representation.' To estoppel the learned judge prefers, as he says, "the well-known principle that where one of two innocent persons," etc. But, with respect, that principle is either estoppel or it is notbing, as will appear by reference to the chapter of this work devoted to it. ${ }^{2}$

There is, also, against us the opinion of Mr. Bigelow: ${ }^{3}$

"The rule that one who has left with another his signature to an incomplote mereantile instrument or other contract - tlat is, with a blank to be filled in - is bound by the act of that person in completing the instrument has been called an estoppel. Estoppel by conduet broadly this cannot be, for the principal's conduct in trusting the agent is not, or nay not be, in the other shange of position, or in immediate connection with it, as it must be for an estoppel.4 Nor is there any false representation - the only other kind of estoppel the case could fall under. On the contrary there is a true representation, to wit. agency; and the only question is liow far the agency ought to extend. That is not estoppel, but agency pure and simple; the agent has only exceeded his instructions."

But there may be misrepresentation as to the extent of agency as well as to its existence. ${ }^{3}$ If a man represents that he has anthority to fill up a blank with $£ 500$, and his authority extends to $£ 100$ only, surely it is an undue stretch of charity to say that "there is a true representation," and that the only justifiable criticism is that "the agent has exceeded his instructions." Again, Mr. Bigelow takes it that the only representation made is as to agency. But if the transferee knew nothing of blanks, there is no representation of agency or appearance of agency. The tacit and real representation is that the note was a completed instrument when signed. This is false, and it is because the maker has assisted in that misrepresentation that he is estopped by it and is liable to those who have acted on the faith of it.

As against these authorities may be set the following from Jervis, C. J.: ${ }^{6}$

"The rules applicable to the question of authority on this bill of exchange do not differ from those which ought to govern the question if it arose in the case between printipal and agent. In the case of a blank acceptance prims fucie the person giving it gives the person to whom it is given authority to fill it up for the amount and for the time limited by the stamp laws. As between these two there may be secret stipulations binding upon them, but not binding as between the public and the person

1 For a discussion of the principle here involved, see ante, ch. IV.

2 Ante, ch. XlV.

3 On Estopuel (5th ed.), 4.5\%.

4 This position is believed to be unsound. It is dealt with in ch. XVI. s See ch. XXVI.

"Montagu v. Perkins (1853), 22 L. J. C. P. 187. See also Brocklesby v. Temperance (189i), A. C. 173; 64 L. J. Cls. 433; Merehants' Bank v. Good (1820), 6 Man. 337, 347. 
giving the acceptance. . . How does this difer from the ordinamy case of an agent held out to the public at large us competent to contract for and to bind his principal? The agent mity have secret instructions, but notwithstanding he deviates from them the prinejpal is bound by his atcls."

And the following from Bowen, L. J.:

"I arrive at the conclusion that a man who gives his acceptance in blank holds out the person to whom it is intrusted as clother with ostensi. ble authority to fill in the bill as he pleases within the limits of the stamp." 1

That estoppel is the only ground upon which it can be held that a principal is liable in "the ordinary case of an agent held out to the public at large as competent to contract for and bind his principal" is urged in a later chapter. ${ }^{2}$

Some direct support for the views here advocated is to be obtained too from a cautious note in Byles on Bills: ${ }^{3}$

"Perlaps the obligation created by blank makings, acceptances and in. dorsements of bills, checks or notes depends on the principles of estoppel, and not on any peculiarity of negotiable paper. On this ground it is put by Lord Manstiefl, in Russell v. Langstaffe. Doug. 5]4. and by Lord Chief Justice Tundal, jn Shultz v. Astley, 2 Bing. N. C. 544. But see the ohservittions of Williams, J., in Ex parte Swan, 7 C. B. 4ti: and Martın, B., and Channel. B., in Swan v. N. B. A. Co., 31 L. J. Ex. 43.),"

In all fairness, howerer, it must be admitted that no very explicit reference to estoppel is to be found in the langragre of either of the learned judges who are here cited in support of the application of its doctrines.

Blanks in Negotiable Instruments Unknown to the Transferee.- If Galley fills up the blanks before offering the instrument in transfer, then, as has been said, Lord Mansfield's dictum ("Trust Galley," etc.) has no application; for the transferee cannot allege that he believed that Galley had authority to fill up the blanks. IIis position in such case is that he believed that the instrument was completed at the time of its execution; that the signer is responsible for that belief (haring supplied Galley with a document which can easily be turned to a fraudulent purpose); and that he is therefore estopped from denying that it was so completed. Estoppel can have no competitor in this case as the ground of decision.

Spaces as Distinguished from Blanks.- Let distinction be made between blanks purposely left in documents (such as for amount, date, etc.) and spaces carelessly unfilled with pen scrateh, which are afterwards fraudulently filled up); for example, a space left after the words "three hundred," to which

1 Garrard v. Lewis (1882), 10 Q. B. D. $3 \overline{5}$.
${ }^{2}$ Ch. XxVI.

${ }^{3} 15$ th ed. 25.5 
is added "and fifty." These latter cases are dealt with in chapter V.

Signed but Otherwise Blank Slips of Paper.- The distinction above drawn between cases in which instruments containing blanks are (1) known, and (2) not known, by a transferee to have been executed in incomplete form, becomes of greater practical importance when the paper signed is otherwise altogether blank.

Imperfection Known to Transferce.-If a person in possession of such a paper were to offer it in negotiation alleging authority to fill it up as he pleased, the transferee would undoubtedly have to take the chance of the assertion being well founded. There is no authority, so far as the present writer is aware, which would afford him any comfort. If the signer had affixed a revenue stamp the result would be otherwise, ${ }^{1}$ for the signer has then indicated the existence of agency.

Imperfection Unknown.-More difficulty arises where the slip has been completely filled before it is offered in negotiation - wbere it has the appearance to the transferee of having been issued in perfect form. Upon this point the cases are far from satisfactory; due probably to oversight of the law of estoppel. For the question is not, Was there sulficient authority to fill up the slip? nor yet, Was it the signer's intention that a note should be made of it; but Did the signer assist the fraud in such manner as to estop him from alleging defect upon either of these grounds? - has be exercised "an appropriate measure of prudence to avoid causing harm" to others. ${ }^{2}$ Some of the cases are cited in the notes. ${ }^{3}$ They are not reducible to any principle.

To the present writer there is little difference between the ease of a paper partially blank and one altogether blank, where the authority to fill up has been violated; for in both there are fraud and forgery, assisted by a signature intrusted to a rascal. In both the person who has selected the swindler and not the person cheated by him should lose. ${ }^{4}$

14 i) \& 4f Vic. (Imp.), ch. 61, $\$ 20$.

2 Ante. p. 30.

3 McDonald $v$. Muscatine (1869), 27 Iowa, 319; Abbott v. Rose (187:3), 62 Me. 194; Breckenridge v. Lewis (1892),
84 Me. $349 ; 24$ Atl. R. 864 . See a valuable juilgment of Denio, J., in Van Duzer v. Howe (1860), 21 N. Y. 531.

${ }^{4}$ See remarks, post, p. 463 ff. 


\section{SUMM.ATI.}

As to negotiable instruments we may then say:

1. If when in complete form they are intrusted to other persons, either for custody merely or to be delivered upon the happening of a contingeney, the obligors will be liable upon them to bolders in due course, although the authority of the person intrusted is exceeded.

2. Obligors will also be liable in like cases, eren if the instruments have in them certain blanks, whether the existence of such blanks were or were not known to the transferees.

3. If the papers were altogether blank, save for the signature, the obligors will be liable if the transferees were not aware of the imperfection at the time of negotiation, but not liable if the transferees knew of the defeets.

4. Estoppel is the true ground for decision in all such eases.

\section{B. NON-NEGOTIABLE INSTRLMENTS.}

Deeds. - Before considering, as a class, documents which are usually termed "non-negotiable," we must ascertain whether or not deeds, because of their sealed character, ean be properly combined with others of the class when treating of estoppel. It has been said that

"a deed delivered without the knowledge, consent or acquiescence of the grantor is no more effectual to pass title to the grantee than if it were a totil forgery." 1

And it is therefore sometimes held that if a deed be deposited in escrow with instruetions to delicer it upon a certain contingency, and it be otherwise delivered, and the grantee convey to an innocent purchaser, that the deed is altogether inoperative. ${ }^{2}$

Putting a stronger case: Suppose that the deed is not onlyincomplete as to delivery, but that it has some blanks in it which unknown to the grantee are filled up without authority before it is handed to him. Can estoppel avail? In such a case Martin, B., saicl there was no authority which shows that

"where a deed is not the deed of the party, he may he estopped, br negli. gence or carelessness on his part, from being permitted to aver that it is not." 3

1 Henry v. Carson (1884), 96 Ind. 4:2. And see Everts v. Agnes (185i), 4 Wis. $356 ; 6$ Wis. 445 ; Chipman s. Tucker (15i5), 38 Wis. 43; Harkraeder v. Clayton (187i), 56 Miss. 383; Allen

r. Ayer (1595), 26 Oreg. 589; 39 l'ac. Ro 1 .

"See cases in preceding note.

${ }^{3} \mathrm{Sw}$ in v. North B. A. (1:6?), 7 H. \& N. 649; 31 L. J. Ex. 425. 
$A$ like riew was taken in the same case by Ryles, $J_{.} ;^{1}$ and in another ease by Willes, J.; ${ }^{2}$ and although the point appears not to hare been pressed upon the appeal from the former of these eases, ${ }^{3}$ yet it finds acceptance in a modilied form in the judgment given by Coekburn, C. J.4

In Everest and Strode on Estoppel, too, it is said that "the doctrine of estoppel by executing instruments in blank is confined to negotiable instruments; and does not apply to deels." 5

At first sight the point seems to be somewhat formidable. The deel is incomplete; the signer does notbing further; no one has authority to perfect it (and of this there can be no question, for authority to complete a deed, it is said, ${ }^{6}$ must itself be by (leerl); how then can the document become operative?

Upon reflection, however, the difficulty disappears. For the problem as to deeds is not different from that involved in other eases. In both it is admitted that the instrument was incomplete when signed, and that it was eompleted without sufficient authority. In both then, according to the facts, there is no binding document. But it is of the essence of the principles of estoppel that under various eircumstances people may be precluded from setting up the facts; and a man may as well be estopped from saying that a deed is not bis deed as from saying that a note is not his note. In a vigorous passage Wilde, B., protests against the limitation of estoppel to negotiable instruments:

"It is, therefore, independent of negotiability; it operates in a different way, founded upon principles of equity and fairmess between man and man; it rests on a wider basis than the principle which supports title in negotiable instruments: and as it has no relation to comnercial intercourse with the exigencies of trade, so it is not confined to instruments which have become negotiable by the demands of commerce." 7

Mellor, J., was of the same opinion and put it thus tersely: Estoppel operates

"not by valiclating a void deed, as was supposed in the argument, but by holding that parties shall not be permitted to aver, against equity and good

${ }^{1}$ Id.: 2 H. \& C. 184; 32 L. J. Ex. 273. Baker (1862). 9 Gr. 97, 298; Martin r.

${ }^{2}$ Re Swan (1859), 7 C. B. N. S. 400; Hanning (186(i), 26 U. C. Q. B. 80. 30 L. J. C. P. 113.

${ }^{3}$ Swan v. North B. A. (1863), 2 H. \& C. 175; 32 L. J. Ex. 273.

${ }^{4} \mathrm{Id}$.

5 Page 358.

${ }^{6}$ This old doctrine is losing some of its authority. Leonard v. Merritt A more recent case proceeds upon estoppel. Bank of Toronto v. Colourg (1884), 7 Ont. 1. And see the American cases as to bonds infra; and Washburn on Real Prop. (5th ed.), vol. 3, p. 256 , note.

iSwan v. North B. A. (1862), 7 H. (1830), Dra. 281; Bank of Montreal s. . \& N. 634; 31 L. J. Ex. 425. 
faith, the invalidity of a deed which, either by words or conduct, they have asserted to be valid and "pon which the others have acted." 1

It would be extraordinary if deeds were to be placed outside the rach of the principles of estopyel. If a deed or any other doeument has in reality not been executed by a party to it, but if he represents that it has, and it appears so to have been, why should he not be estopped? If, for example, a man signs and seals a document, and procures it to bo attested in tho usual form, and if afterwards some blanks which the has left in it are filled up, and upon the faith of the doeument in its completed form some one changes his position, the signer ought to be estopped.

At all events, the only point that we have in hand at present is that the presence of a seal does not oust the application of estoppel. Lord Mansfield was not much troubled because of a seal, in Texira v. Evans; ${ }^{3}$ and although ho was orerruled upon the ground that authority to complete a deed must be by deed, ${ }^{4}$ yet we have now estoppel wherewith to reply that lack of authority is granted but is quite immaterial.

$A$ very recent (1899) writer in the United States ${ }^{5}$ adheres to the old rule, saying that it is still the law where the distinction between sealed and unsealed documents continues. And no doubt there are many cases which so say; but they all overlook the estoppel point, which nevertheless is by no means without exposition and application in that country. ${ }^{6}$ And there can be little doubt that the American cases overwhelmingly hold that if a bond be executed by a surety, and handed to the principal debtor with a condition that it is not to be delivered unless executed by another surety; and if the bond be delivered without fulfilment of the condition, and without further intervention of the surety, he is liable.' The language of Turner, L. J., is to the same effect:

"If a party will leare a deed executed by him in the hands of another

1 Id.; 2 H. \& C. 177; 32 L. J. Ex. \$1 1St. See a betteropinion in Wash274. See also per Erle, C. J.

2 An attestation clause is evidence of delivery. Evans v. Grey (1832), 9 L. R. Ir. 539.

3 Cited 1 Anst. 228.

4 Hibblewhite v. McMorin (1540), 6 M. \& W. 200; Squire v. Whitton (1818), 1 H. L. C. 333 .

5 Ritudolph on Commercial Paper, burn on R. P. (5th ed.), vol. 3, p. 256, note.

ts se State r. Pepper (IS69), 31 Ind. 76: Sumth s. Peoria (15i1).5! 111. 412 Bartlett v. Board, id. $36 \%$ The case of State $r$. Dean (1860), 40 Mo, 464 , probibly goes too far, for there was no smomal of estoppel in it.

iStilte v. Peck (1865), 53 Me. 284; 
person, and that deed so left in his hands is made by him a security to a third party, who acts hourstly and fairly in the transaction, I am by no means satisfied that it is competent for the person who has left the deed in his hands to set up against the third party. who has honestly taken it as security, the fact, if fiact it be, of fraud having been committel upon the persoll having it." 1

Perhaps enough has now been said to warrant the inclusion of deeds with other "non-negotiable" instruments in the remarks which have to be made concerning them.

Completer Non-negotiable Instruments.- No distinetion upon principle can be made between negrotiable and non-negotiable instruments which have been intrusted to some person either for custody merely, or to be delivered upon the happening of some contingency, when the decision of such cases is based upon estoppel. No doubt if we were to admit considerations of law merchant and negotiability (as to which see chapter XXIV); or if we referred the point to the law of agency merely; or if we ran wreck upon the theory that authority to complete a deerl must itself be by deed, we might have to say that although the makers of the deeds "themselves have created the agency or trust by means of which the fraud . . . has been committed," yet they are saved by the presence of a seal. But the law of estoppel disregards all such points. It fixes attention upon the fact that the purchaser has changed his position upon the faith of some misrepresentation of ownership; that the person who "created the agency or trust" assistel the misrepresentation and made it credible; and declares that by reason of such assisted misrepresentation he ought to be estopped seal or no seal very immaterial.

Smith r. Peoria (1871), 59 Ill. 412; McCormick v. Bay City (1874), 23 Mich. 4.ĩ; Nash v. Frigate (1874), 24 Grat. (Va.) 20?; Hunt v. States (1876). 5). Ind. 321 ; State v. Potter (1876), 63 IIo. 212; Brown v. Probate (1880), 42 Mich. i01; 4 N. W. R. 195; Lyttle r. Cozard (1882), 21 W. Va. 183; Palacios v. Brasher (1893), 18 Colo. 593; 34 Pac. R. 251; Rose v. Douglas (1893), 52 Kan. 451; 34 Pac. R. 1046; Dolbeer v. Livingston (1893), 100 Cal. 617; 35 Pac. R. 328; Crystal Lake v. Ifill (1896), 100 Mich. 246; 67 N. W. R. 121; Stoner v. Keith (1896), 48 Neb. $279 ; 67$ N. W. R. 311; Hart v. Mead (1897), 53 Neb. 153; 73 N. W. R.
458; and the Canadian case, Reg. v. Chesley (1889), 16 S. C. Can. 306. See as to a mortgage, Garland v. Wells (1983), 15 Neb. 298; 18 N. W. R. 132; Hollis v. Harris (1892), 96 Ala. 288; 11 S. R. 377; Lloyds v. Bullock (1896), 2 Ch. 192; 65 L. J. Ch. 580 . A case of forced delivery, Gould v. Wise (1893), 108 Cal. 365; 32 Pac. R. $5 \% 6$; 41 Pac. R. 408.

1 Greenfield v. Edwards (1865), 2 De G., J. \& S. 596. And see per Wilde, B. in Swan v. North B. $\Lambda$. (1862), 7 H. \& N. 631; 31 L. J. Ex. 425; Benterick v. Londlon (1893), 2 Ch. $141 ; 62$ L. J. Ch. 3is. 
But of course we will not apply this principle unless the assistance referred to has been of effective quality. If a deed from $A$. to $B$. has been delivered in escrow and been improperly handed over, and B. afterwards sells the property to C., $A$. ought to be estopped because of the ostensible ownership of B. But B. could not claim the same estoppel; for he did not act upon any representation of ownership - he did not think that the custodian of the deed was the owner of the property. Ile knew that he was an agent merely; and as to the extent of autholity, inquiry ought to lave been made - as in other cases.

Blanks in Non-negotiable Instruments. - Let it be remem. bered that with reference to bills and notes we found two principles of estoppel in operation:

1. Where an agent exceels his authority the principal may be estopped from denying the existence of the assumed authority, if he has enabled the agent to mislead the person with whom he dealt. That principle was applied in this way: Intrusting a person with a blank note is evidence of such person's authority to fill it up as he pleases; therefore the signer of a blank note is estopped from denying the existence of such authority as against any one who dealt upon the faith of the appearance of anthority.

2. If the blanks have been filled up prior to delivery of the document then also the signer is estopped, not because of ostensible agency (for nothing in this case is known of agency), but becalse of the appearance of an originally completed document, for which appearance the signer is, by his assistance rendered to the fraud, responsible.

Now observe that there is nothing in these two principles which suggests their limitation to cases of bills and notes; and that there can be no reason why persons who bave been misled by other documents in similar ways should not have the like benefit of the law of estoppel. ${ }^{1}$

Blanks Known to the Tiansferee.- For example, it has been quite customary to execute transfers of shares leaving the name of the transferee blank; and the hiatus is filled up only when some one of the successive owners desires to register the transfer. Of such instruments Lord Mansfield would no doubt have

1 Angle v. N. W. Mutual (1875), 92 Brown (1894), 59 Mo. Ap!. 461 ; Jewel U. S. 339; New England, etc. v. v. Rock River (1581), 101 IIL. 57. 
said that their plain import was "Galley or any subsequent holder may fill up as he pleases," and some of the more modern judges would hare agreed with him. In one case Chitty, J., said:

"Having regard to the practice prored, and the condition in which these documents are when they pass from hand to hand, the right principle to adopt with reference to tisem is to hold that where.. . the transfers are duly signed by the registered holders of the shares, each prior holder confers upon the bona fide holder for value of the certificates for the time being an authority to fill in the name of the transferee, and is estopped from denying such authority; and to this extent and in this manner. but not further, is estopped from denying the title of such holder for the time being." 1

It will be observed that everything depends upon custom. No one would suggest, with reference to a conveyance of land, that the existence of blanks in it indicated authority to till them up. ${ }^{2}$ Custom has, however, attached that interpretation to a blank for the name of the transferee in share transfers; ${ }^{3}$ such blanks, therefore, constitute a representation by the signer of them that the holder has autbority to fill up, and by such representation the signer is estopped as against a purchaser for value without notice.

Lord Herschell recently said: ${ }^{4}$

"And this doctrine has been held, by the court of appeals of the state of New York, ${ }^{5}$ to be applicable in the case of certificates of shares with the blank transfer and power of attorney signed by the registered owner. handed by him to a broker who fraudulently or in excess of his authority sells or pledges them. The banks or other persons taking them for value without notice have been entitled to holl them as against the owner. As at present advised, I do not see anv difference between the state of $\mathrm{New}$ Fork and the law of England in this respect."

No assumption of unlimited antbority to fill up would probably arise in case of blanks left for the description of the shares

1 Colonial Bank v. Hepworth (1897), 36 Ch. D. 53 ; 56 L. J. Ch. 1099 . There is some confusion here. If by handing over blank transfers "each prior holder confers . . . an a uthority to fill in the name of the transferee," there is no place or ground for estoppel. It is because such authority is not always so conferred, but because it appears to have been con. ferred, that estoppel arises.

${ }^{2}$ Ellis v. Wait (1893), 4 S. D. 4i54; $5 \%$ N. W. R. 229.

${ }^{3}$ In Taylor v. Great Indian, etc. Co. $(1859,4$ De G. \& J. 571; 28 L. J. Cl. (00), Turner, L. J., said: "It appears that it is a common, perhaps a universal, practice on the Stock Exchange, between the brokers and jobbers or dealers in shares, for the broker or dealer who sells, to deliver the deed of transfer of the shares to the dealer who purchases in blank as to the name of the transferee, leaving the name to be filled in when the dealer who purchases may hinself find a purchaser for the shares." "Colonial Bank v. Cady (1890), 15 App. Cas. 285: 60 L. J. Ch. 131.

${ }^{5}$ As to the New York law, see McNeil v. Tenth National Bank (1871), 46 N. Y. 325. See also the cases cited with this one in $\mathrm{ch}$. XXII. 
to be transferred. A purchaser from a holiler of such a transfer would not be justified by custom in believing that the signer had griven authority to fill up any class and any amount of shares. In such case the purchaser would be in the usual position of one dealing with a person known to be acting as an agent; he would have to inquire as to his authority, and no answer to such incuiry would be found in the form of the doeument, as in the case by custom where the transferee's name merely is omitted.

If, however, transfers blank as to the description of the shares were filled up before negotiation, and the transferee had no reason to suspect that the document was incomplete when executed, then the signer ought to be estopped from denying the validity of the document, upon the principle laid down by Kindersley, V. C., in Ihutch v. Searles. ${ }^{1}$

General Applicability of Estoppel.- It will now be seen that there is thus fitr no difference in principle between bills and notes and other documents with reference to blanks in them when signel. The question always is, What, according to custom, do such blanks import? If they indicate the existence of authority to fill up, then there is estoppel. If they do not so indicate, there is none. Custom established the law as to bills and notes. It can do the same for other documents:

"Usage, arlopted by the courts, having been thus tile whole of the socalled law merchant as to negrotiable securities, what is there to prevent our acting upon the principle acted upon by our predecessors. and fol. lowed in the precedents they have lelt to us? Why is it to be sail that a new usige which has sprung up under altered circumstances is to be less admissible thin the usige of past times? Why is the door to be now shut to the admission and atoption of usage in a matter of altogether cosnate character, as though the law hat been linally stereotyped and settled by some positive and peremptory enactment?":

Not merely transfers of shares, then, but bills of larling, warehouse and cotton-press receipts, and other like symbols of property, are all subject to the same prineiple. ${ }^{3}$ The question as to all documents is the same.

Blanks Unkmown to the Trunsferee. - As has already been pointed out, ${ }^{4}$ where the existence of blanks is unknown to the transferee, the ground of estoppel is not, and eannot be, the

1 (18.j4) 2 Sm. \& G. 14r; 23 L. J. Cl. 467. Anil see Reg. v. Chesley (18s9), 16 S. C. Can. 306.

. 2 Per Cockliurn, C. J., in Goodwin v. Robarts (18:5), L. R. 10 Ex. $351 ; 44$ L. J. Ex. 15\%.
'3Colebrooke on Collateral Securities, 34. And see the cases there citell.

4 See cases ante, p. 451, note 7. . 
presumption of authority to fill up the blanks, but the justifiable assumption that the document was complete when executed. It is obvious that the reason for estoppel in such cases applies equally to negotiable and non-negotiable instruments; although, no doubt, it is more frequently involied in the former than in the latter class of documents. Blanks in a bond, therefore, left by the sureties and filled up without authority will not constitute a defense as against an obligee who has had no notice of them.

And where a deed, blank as to consideration and name of grantee, but signed and sealed and indorsed by the proper officer, with a certificate of execution, was delivered to an agent for use in case he found a purchaser; and the agent filled in his own name and a pretended consideration, and sold the land as his own to an innocent purchaser, it was held that the grantor was estopped.'

\section{Documents Stolen or Found.}

\section{A. NEGotiable instruments.}

Present Uncertainty.-It is curious that there should be doubt as to the liability of the maker of a note who loses it, or from whom it is stolen. $A$ well-known writer, in a recent work as to stolen instruments, says:

"Thus it is laid down that where a negotiable instrument is stolen or fraudulently taken from the acceptor or maker. such party cannot be requirel to pay it to any holder whatever; and that, too, though the acceptor or maker may have nade the theft or fraud easy loy putting the paper in an unlocked drawer in a desk to which clerks and servants and others bad access.". 2

In the case of a lost note, on the other hand, there might, in view of the same writer, be liability:

"If this be sound doctrine, it will follow that where the instrument got into circulation by being dropped. picked up and passed, there has been no delivery, unless the dropping was negligent: possibly to drop a negotiable instrument transferable by delivery would be presumptive negligence." "3

The learned author deprecates the introduction of the principles of estoppel into the discussion of the case of a stolen note, because "theft is not the natural consequence of negligence" in the method of its custody. May it not, however, similarly be said in the case of a found note that the fraudulent passing

1 Pence v. Arbuckle (1876), 22 Minn. 417. And see cases as to mortgages, ante, p. 452, note.
2 Bigelow on Bills and Notes, 177. 3 Id. 
of it is not the natural consequence of the maker losing it? Yet in such case the author thinks that there may be liability and estoppel. If in both cases there is the criminal appropriation of another person's property, and in both an innocent purehaser for value, ought not the result in both to bo the same?

Braxendale 2 . Bennett.- In the well-known case of Braxendre $v$. Bennett, ${ }^{1}$ a blank acceptance was returned before issued to the acceptor, who put it in a drawer from which it wits stolen. It was held that the acceptor was not liable. Bramwell, L. J., saill:

"Is it not a rule that every one has a right to suppose that a crime will not be committed and to act on that belief? . . . If suppose there was no stamp law. and a man simply wrote his name, and the pitper was stolen from him, and somebody put a form of check or bill to the signature, would the signer be liable?"

Referring to Young v. Grote and Ingham v. Primrose, he said that they

"go a long wiy to justify the julgment; but in all those cases, and in all the others when the alleged maker or acceptor has been held liable, he has voluntarily parted with the instrument: it has not been got from him l,y the commission of a crime. This undoubtedly is a distinction, and a real distinction."

Brett, L. J., put the case upon this ground:

"Whether the acceptor of a blank bill is liable on it depends upon his having issued the acceptance intending it to be used." 2

A Crucial Question.- Lord Justice Bramwell's question is a crueial one; and if, as he assumes, there is but one possible answer to it, much difficulty will arise in drawing an intelligible line between cases in which there is iability and those in which there is none.

The point is simply this: A man has a habit of writing his name upon blank folms of promissory notes, and leaving them carelessly within reach of every one; somehody fills in the blanks in one of the papers, and passes it to a bona fide holder for value; is the signer liable? Or (to bring the case more clearly within the Lord Justice's language), suppose that the note was put "in an unlocked drawer in a desk to which clerks

${ }^{1}(19 ; 8) 3$ Q. B. D. 525; 47 L. J. Q. B. 624.

2 This distinction has found favor in New York. Ledwiek v. McKim (1873), ji3 N. Y. 30i; Davis v. Best (108i). $10 j \mathrm{~N}$. Y. fii. It had been otherwise hell in Gould 8 . Legee (18.56), 5 Duer. 250; dilfering from the earlier case of Hall $v$. Wilson (15.73), 16 Barb. 5.5. See also Schuylkill $\therefore$ Copley (1871), 67 Pa. St. 386; Kagel v. Totten (158:), $59 \mathrm{MJ} .447$. 
and servants and others had access," from whence it was stolen and made into a note; would the signer be liable?

Complete and Incomplete Instruments.-To these fundamental questions the answer of the authorities is in the negative. ${ }^{1}$ But as soon as one gets away from the simplest form of the question the cases commence to vary, and the lack of principle of decision becomes apparent. For example, Mr. Daniel distinguishes between complete and incomplete instruments. As to the former he says:

"Where the maker has perfected the instrument and left it undeliverul in a safe, desk, or other receptacle, it should then be at his hazard. Such pilpers are made for use and not for preservation. The maker creates the rist of their being eloigned by keeping them on hand, and places them on the same base as negotiable papers which have been put upon the market. When once issued the purchaser is protected and the owner loses, even though he had guarded his property with boit and bar; and if bankers and others who must necessarily be in jossession of negotiable securities in the course of trade are not protected, we can liscover no principle which can be invoked to protect one who holds his own paper contrary to the ordinary wants and usages of trade."'2

As to incomplete instruments, on the other hand, the same author says:

"The second class of cases arises when an incomplete instrument has $\mathrm{b}$ en signed and stolen, without any delivery to an agent in trust or other. wise intervening. In such cases no trust fur any purpose has been created. No instrument has been perfected. No appeirance of validity has been given it. No negligence can be imputed. Therefore if the blank be filled it is sheer forgery, in which the maker is in no wise involvel, and he is not therefore bound, even to a bona fide holder without notice." 3

Lord Justice Bramwell, as we have seen, would not have admitted the validity of Mr. Diniel's distinction between the theft of a complete and an incomplete instrument. His principle:

"Is it not a rule that every one has a right to suppose that a crime will not be committed, and to act on that belief?"

applies to both cases alike. Lord Justice Brett would also repudiate the distinction, basing bis opinion, however, not upon the ground of crime, but because liability depends upon issuing

1 To the cases already cited add First Nat. Bink v. Zeims (1894), 93 Iowa, $140 ; 61$ N. W. R. 483; Byles on Bills (15th ed.), 2\%. See, however, Cooke v. United States (1875), $91 \mathrm{U}$. S. : 89 . Treasury notes were fraudulently printed from the genuine plates and the treasury was held to be liable upon them. No signature was necessary. Distinguish Colum- bia v. Cornell (1888), 130 U. S. 655, where the word "canceled," written in ink upon negotiable certificates, was erased, and the certificates passed.

2 On Negotiable Instruments (4th ed.). vol. 1, p. 85\%.

${ }^{3} \mathrm{Id}$. 8.5\%. The same distinction is made.in Parsons on Bills and Notes, vol. $1,114$. 
an instrument "intending it to be used," and in neither ease was there any issue, or any such intention.

Williams, J., on tho other hand, would agreo with Mrr. Daniel's contention as to a complete instrument:

"It is we think settled law that if the defendant had drawn a check, and before he had issued it he hall lost it. or if it had been stolen from him, and it had afterwards found its way into the hands of a holer for value without notice who had sued the defendant upon it, he would have had no answer to the action. So if he had indorsed in blank a bill payahle to his order, and it had been lost or stolen before he delivered it to any one as indorsee. The reason is, that such negotiable instruments have by the law merchant become part of the mercantile currency of the country; and, in order that this may not be impeded, it is requisite that innocent holilers for value should have a right to enforce payment of them against those who by making then have caused them to be a part of such currency." 1

And Cockburn, C. J., may bo taken to have thought that there would be liability even when the instrument had not been completed prior to its being feloniously applied, for in Watson v. Russell ${ }^{2}$ he said:

"I consider the law to be now quite settled, that if a person puts his name to a paper which either is. or by being filled up or indorsed may be, converted into a negotiable security, and allows such paper to get into the hands of another person, who transiers the same to a holder for consideration and without notice, such party is liable to such bona fide holder, however fradulent or felonious as against him the transfer of the security may have been."

Criticism of Present Rules. - It is bard to get a footing here. Lord Justice Brumwell's rule that every one may safely act upon the supposition that a crime will not be committed finds ample contradiction not only as to one's own interests (as an overwhelming matter of fact), but with regard to the interests of others in various departments of the law. In the-realm of torts many examples are met with; and the law of estoppel by misrepresentation is largely founded upon the contrary view. Not, however, to leave the suivect of bills and notes, the following may be taken to be undisputed law :

"The misapplication of a genuine signature, written across a slip of stamped paper (which transaction being a forgery would in ordinary cases convey no title), may give a good title to any sum fradudently inscribed, within the limits of the stimp." 3

And it can hardly be argued that if the signer of a slip of paper may be made liable by forgery, it is beyond the bounds

1 Ingham r. Primrose (1859), $7 \mathrm{C}$. B. N. S. s2: 28 L. J. C. P. 294.

2 (1stiv) 31 L. J. 304. And see McInnis v. Milton (18\%0), 30 U. C. Q. B. 493.
${ }^{3}$ I'er Byles, J., in Swan v. North British (1863), 2 H. \& C. 185. (See the report in $3:$ L. J. Ex. 2i\%.) 
of reason to hold that the signer of a completed note may be mate liable by larceny.

The distinetion of Lord Justice Brett:

"Whether the acceptor of a blank bill is liable on it depends upon his having issued the acceptance intending it to be used,"

must, of course, be subject to this: that the acceptor may be estopped from denying the issue of the bill, and his intentions with regard to it, by appearances for which he is responsible. And the argument comes back once more to the question of "the duty of fellow-citizens to observe in varying circumstances an appropriate measure of prudence to a void causing harm to others"l-

the duty, in this case, of preventing the appearance of a note issued and intended to be used. May it not be said that

"It is the duty of the maker of the note to guard not only himself, but the public, against fraud and alteration by refusing to sign negotiable paper made in such form as to admit of fraudulent practice upon them with ease and without ready detection." 2

Eigoistic and Altruistic Vieus. - As bas already been said, ${ }^{3}$ there are two views which may be taken with reference to the conduct of affairs - the egoistic and the altruistic. According to the former, as applied to the subject in hand, I may sign my name to as many pieces of paper as I wish, scattering them broadcast among my neighbors, leaving other people to take the risk of forgery; I may amuse myself by signing dozens of completed notes and carelessly permit "clerks and servants and others" to remove them if they please, aware that not I, but other people, must suffer for my alleged faith in universal honesty; I may, with easy indifference, leave spaces of the most tempting character in notes which I sign and issue, and if they be improperly filled and my seeming liability increased, I may say that I acted upon the assumption that there was no one in the world that would do such a thing, and that there are places to which, with certain difficulties of procedure, such an one may be sent.

Accorling to the altruistic view, I shall have some care for the interests of my fellow-citizens. Being perfectly aware that the world is full of rascals, and that my pretense of other belief is absurd, I shall not furnish them, if I can avoid it, with tempting opportunities for defrauding others. As I would not

${ }^{1}$ Pollock on Torts, 22. See ante, (1875), 79 Pa. St. 370. See cases rech. V, passim.

ferred to with these in ch. $V$.

2Zimmerman v. Rote (1874), $75 \mathrm{~Pa}$.

St. 191. And see Brown v. Reed

3 See ch. V. 
indulge myself in signing slips of paper were the risk of notes being written on them my own, so, also, shall I exercise proper circumspection where there is danger to others. And as notes are made for use and not for storage, I shall refrain from signing them until they are needed, or at least so draw them that they may not be immediately negotiable. I would do that were the risk my own.

Ostensible Ownership. - Liability in all such cases must rest upon the principles of estoppel by ostensible ownership. A thief appears to be the owner of the instrument which he proposes to negotiate. Possession of a watch does not indicate ownership; ${ }^{2}$ but the property and possession of bills and notes are inseparable.

"Every holder of the bills takes the property, and his title is stamped in the bills themselves." 3

Possession of a bill is ostensible ownership of it. If the real owner assists in the misrepresentation of property by an ostensible owner, such real owner ought to be estopped from setting up bis own title. And it is hard to see how such assistance can more effectually be afforded than by bringing into existence that which from its very nature carries with it a representation of ownership. Did I write upon my goods, "The bearer is the owner of these," I would certainly be estopped from setting up my title to them, even though some one tempted by the writing had stolen them from me and passed them on. I would have assisted in his misrepresentation. And if I create a document which carries with it to everybody a similar assertion, I ought likewise to be estopped. ${ }^{4}$

Incomplete Instruments. - These remarks have primary reference to cases of completed instruments which have been stolen

1 This precaution would insure safety, for it would be unreasonable to hold that a thief could effect a transfer by forging $m y$ signature. First Nat. Bank v. Bremer (1593), $\tau$ Incl. App. 685; 34 N. E. R. 1017. See, lowever, Wegner v. Second Ward (1890), 44 N. W. R. 1096; Tobin v. Manhattan (1893), 57 N. Y. St. R. 856 ; 6 IIsc. R. 110 ; 26 N. Y. Supp. 14; 27 i.l. 11:4. And see Leather v. Morgan (185i), 11; U. S. 96; Walters v. Tielkmeyer (1s97), 70 Mo. App. 371.
2 Gabarron v. Kreeft (18ij), L. I. 10 Ex. 281; 44 L. J. Ex. 238. See cl. XXI.

${ }^{3}$ Collins v. Martin (179r), 1 Bos. \& P. 651.

4 Some athorities are, however, otherwise. Ledwick v. McKim (18;3). 5: N. Y. $30 \%$; Hinckley r. Bank (1 $8 \& 1)$, 131 Mass. 147: Bangor v. Robinson (1892), 52 Fed. R. 5:0; Young v. Brewster (189.j), 6: Mo. App. 6:8. 
or found and subsequently passed on. Let us now look at Mr. Daniel's reasons for a contrary conclusion in the case of incomplete instruments - those in which blanks have been left. He mentions five:

1. "No trust for any purpose has been created." But there was no trust either in the case of the completed instrument.

2. "No instrument has been perfected." Nor in the other case either; for delivery is necessary to a perfected note. ${ }^{1}$

3. "No appearance of validity has been given it.". As the authorities stand, the holder of a blank note has the appearance of authority to fill it up. A blank note is then just as a vailable in the hands of a thief as is a completed one. There is therefore in both cases the same appearance of valiclity.

4. "No negligence can be imputed." But there is exactly the same negligence in the one case as in the other.

5. "If the blank be filled it is sheer forgery, in which the maker is in no wise involverl." And in the case of the completed note there is sheer lareeny, "in which the maker is in no wise inrolved;" and also the wrongful emission of the document which may well be argued to be a further criminal act.

It is difficult then to see any ground for distinction between a complete and an incomplete note. They are equally negotiable, and over both the maker ought to exercise the same vigilance and control.

Among the authorities relating to instruments fraudulently appropriated the much-discussed case of Ingham v. Primrose ${ }^{2}$ may be noticed. A drawer of a bill returned it to the accommodation acceptor unused. The acceptor, intending to cancel it, tore it into two pieces and threw them on the ground. The drawer pieked them up, pasted them together, and passed the bill. The appearance would not have suggested anything but a severance for more secure transmission. The acceptor was held to be liable

"because the defendant. by abstaining from an effectual cancellation or destruction of the bill, has led to the plaintiffs becoming the holder of it for value."

In other words, he has provided an opportunity or occasion for fraud - has by his negligence made credible the misrepre-

1 See the Codes, $45 \& 46$ Vic. (Imp.), ch. 61, §21;53 Vic. (Ciın.), ch. उs, $2(1859) 7$ C. B. N. S. 82 ; 28 L. J. C. $\S 21$. 
sentation of the drawer that the paper was a real obligation. He is therefore estopped from denying that it is such.

Although the case has been seriously questioned in Baxendale $v$. Bennett, ${ }^{1}$ the writer ventures the opinion that it is well founded, and ample justilication for it ean be found in the principles of the law of estoppel. There seems to be littlo reason for holding an acceptor liable upon a really uncanceled bill confided to inother person who fraudulently negotiates it, if he is not to be liable upon one which is in appearance at least uncanceled, and which he throws down in the presence of the person to whom a moment before it had been confided. There is a difference in the acceptor's intention, no loubt; but none in the facility afforded for fraud, and none in the position of the transferee.

Signed Slips. - If distinction between a completed and a blank note may be denied (upon the ground that the latter carries with it ostensible.authority to fill it up), the same argument will not apply when comparing the case of a completed note with that of a mere slip of paper bearing a signature, for there is not in that case any appearance of authority to subscribe a note. If, indeed, a stamp required by the local law Lad been affixed by the signer, the case would be different and 'within the statutory law as to blank notes. ${ }^{2}$ But if the slip be entirely blank it cannot be said that there is ostensible authority to write on it a bill or note; and if there be no osten. sible authority there can be no estoppel by appearance of agency.

This remark, however, is necessarily limited to cases in which the transferee knew that the superscription had been added by some one other than the signer. ${ }^{3}$ If the instrument be in complete' form when offered in negotiation, then its appearance indicates that the body of it was written prior to the signature; and the case is not at all one of ostensible authority to fill up blanks. In such a case, if the signer is to be liable, it is upon the ground already indicated, namely,

"the duty of fellow-citizens to observe, in varying circumstances, an ap. propriate measure of prudence to avoid causing hitrm to others."

1 (1878) 3 Q. B. D. 532; 4 L. J. Q. B. 624 .

2 Post, pp. 464. 465. And see the Codes, 45 \& 4 ii Vic. (Imp.), ch. 61, $\$ 20$; 53 Vic. (Cin.), cl. $33, \$ 20$.
3 See the same distinction noticed, ante, p. 455.

1 See ante, p. 30. 
Can it be saicl that there is an appropriate, or indeed any, measure of prudence in spreading broadcast your autograph upon slips of paper suggestive of promissory notes, and in blindly trusting to the impeccability of the world?

Distinction is made between completed or blank instruments on the one hand, and mere autographs on the other, by Beck, J., ${ }^{1}$ as follows:

"The reason is obvious. The maker ought to suffer on account of the fraudulent act of one to whom he intrusts his paper, or who is made agent in respect of it, rither than an inuocent party. The law esteems him in fault in thus putting it in the power of another to perpetrate the fraud, and requiresim to bear the loss consequent upon this negligence. In the case under consileration, no fault can be imputed to the defendant. He did not intrust his signature to the possession of the forger for the purpose of binding himself by a contract. He conferred no power upon the party who rommitted the crime to use it for any such purpose. He was not guilty of negligence in thus giving it, for it is not unusual, in order to identify signatures and for other purposes, for men thus to make their autographs."

But do not the same remarks apply to both cases? May it not be said in both cases that "he did not intrust his signature . . . for the purpose of binding himself by a contract;" that "he conferred no power upon the party who committed the crime to use it for any such purpose;" and that "he was not guilty of negligence, . . . for it is not unusual . . . for men thus" either to intrust their bills for custody or to give their signatures for identification. And may it not be added, too, that "the maker (signer) ought to suffer on account of the fraudulent act of one to whom he intrusts his paper... rather than an innocent party," etc.,-for there is not much clifference between "intrusting" your clerk with papers partially blank which you tell him to put in the safe and which he misappropriates, and "trusting" that he will not appropriate and use other papers wholly blank (with the exception of your accommodating signature) which you put in his way. In both cases trust is betrayed; in both crime is committed; in both an innocent purchaser has paid out his money; and in both you have supplied the opportunity for the fraud. Should you not be more careful for the interests of others? What is "an appropriate measure of prudence?"

The English Code provides: ${ }^{2}$

"When a simple signature on a blank stamped paper is delivered by the

${ }^{1}$ Citulkins r. Whisler, $2 \tau$ Iowa, 49.5. Jacques Cartier (1886), 13 Que. L. R. Quoted by IIr. Daniel (on Negotiable Instruments), 495. And see Ford v. Auger (18i4), 18 L. C. J. 296; Banque 39.

245 \& 46 Vic. (Imp.). ch. 61, $\$ 20$; 53 Vic. (Can.), ch. 61, 今ั20. 
signer in order that it may be converted into a bill, it operates as a prima facie authority to fill it up as a complete bill for any amount the stamp
will cover."

The Canadian Corle is similar, but omits all reference to stamps; and its effect, therefore, is to declare that a mere signature delivered "in order that it may be converted into a bill operates as prima facie authority," etc. The transferee must, therefore, inquire whether it was delivered for the purpose of being converted; but he need not inquire as to the particulars of the authority, or as to any conditions attached to its exercise. Yon may not assume that there was any authority at all. But if there was, you may assume that it was absolutely un. limited and untrammeled!

Current I'ructice.- In considering the cases upon the subject in band one cannot help attributing their rarity to the universal existence of a very strong sense of the danger of either storing blank notes or distributing signatures, and also of the absolute necessity for care with regard to them. Were a well-known merchant to amuse himself by learing his auto graph on blank slips of paper in hotel reading-rooms, and were some rascal to superscribe a note upon one of them, it would seem to the writer to be a mere travesty of justice to say that he should not be liable (1) because he did not intrust the paper to any one, (2) because he conferred no power upon any one, and (3) because he was not guilty of any negligence. Mr. Daniel is, however, of a different opinion. He says: ${ }^{1}$

"It could hardly be said that the party was guilty of any negligence ir. exercising his right to do so simple a thing as the mere writing of his name when he at tiched no words to it to give it any significance."

But cannot it fairly be argued that the negligence consists in attaching "no words to it." When it is considered that there are so many simple methods of protecting an autograph from misapplication (e.g., placing it at the top of the page, instead of at the bottom; superseribing the words "Yours very truly;" filling the blank above with a pen-scratch) - methods which are adopted by probably every reasonable business man (despite the authorities which indicate that there is no negligence in doing otherwise), is it too much to say that if such simple, every-day precautions are neglected there is sulficient carelessuess to estop? Is there not in this region also a "duty of fellow-citizens to observe $\dot{p}_{\text {prudence to a void causing harm to others? } 2 \text { an appropriate measure of }}$

1 On Negotiable Instruments, 85s. 2 Ante, p. 30. 
For example, payment of a bill before due date is a satisfaction of it. But suppose that afterwards it be fraudulently reissued to an innocent holder, the parties to it are liable. They should have destroyed or canceled it - they owed a duty to their fellow-eitizens to do so.

"It is the duty of bankers to make some memo. on bills and notes which have been paid; but if they do not, the holders of such securities cannot be affected by any payment made before they are due." 1

It may indeed be that liability should not arise ont of some new product of "ingenious wickedness;" 2 but it is quite another thing to declare that the strongest temptation to the simplest fraud may be held out to all the rascals in the world, and that the temptor should not be the one to bear the loss.

Unissued Bills Under the Code.-Section 21 of the Code ${ }^{3}$ provides that

"every contract on a lill, whether it is the drawer's, the acceptor's or an indorser's, is incomplete and revocable until delivery of the instrmment in order to give effect thereto."

“2. As between immediate parties, and as regards a remote party other than a holder in due course, the delivery:

"(a) In oriler to be effectual, must be made either by or under the authority of the party drawing, accepting or indorsing. as the case may be.

"(b) May be shown to have been conditional, or for a special purpose only. and not for the purpose of transferring the property in the bill.

"But if the bill is in the hands of a holder in due course, a valid deliv. ery of the bill by all parties prior to him so as to make them liable to him is conchusively presumed.

" 3 . Where a bill is no longer in the possession of a party who has signed it as drawer, acceptor or indorser, a valid and unconditional delivery by him is presumed until the contrary is proved."

This legislation terminates controversy in jurisdictions in which it is in force as to liability upon a completed bill or note which is stolen or found and passed on to a holder in clue course. The signers of such instruments can no longer "suppose that a crime will not be committed, and act on that belief." They can no longer urge that liability depends upon having issued the instrument "intending it to be used." Larceny may make him liable.

But it is doubtful whether the statute applies to incomplete bills, and still more questionable whether it was intended to provide for the case of a mere signature. The language is,

"Every contract on a bill . . . is incomplete and revocable until delivery;"

and where the instrument is in blank, and still more where

${ }^{1}$ Per Lord Ellenborough in Burbridge v. Manners (1812), 3 Camp). 193, 195. And see Wheeler s. Guild (1838), 37 Mass. 545.
2 Co'unbia v. Cornell (1888), 130

U. S. 65.

$345 \& 46$ Vic. (Imp.), cl. 61 ; 53 Vic. (Cau.), cl. 33, รั 21 . 
there is nothing but a signature, can it be said that there is a "contract." 1 Possibly it may be argued that the clituses qunted (assisted by section 20) do apply to the case of blank notes, but that the legrislation does not tonch the question of papers carrying nothing but signatures.

The statute does, howerer, take us away from the principles of Lords Justices Bramwell and Brett above dealt with, viz: (1) 'That no liability can arise out of a crime; and (2) that the question of liability depends upon "his having issued the acceptance intending it to be used." And it gives some effect to the principle of appropriate prudence where the interests of others are in rolved.

The question in cases not provided for by the statute ought to be whether requisite prudence has been exercised. Some observations upon this subject are to be found in a preceding cbapter. ${ }^{2}$

B. NON-NEgotIABLE INSTRLMENTS, S'TOLEN OR FOUND.

The term "negotiable" is being used in this chapter in its customary acceptation. But the term is inaccurate and misleading, and in considering the difference between "negotiable" and "non-negotiable" instruments when misapplied, stolen or found, perusal of a previous chapter is recommended. ${ }^{3}$ Reference is also requested, for the purposes of the present section, to the discussion in a previous part of this chapter of the misapplication of non-negotiable instruments by persons to whose custody they had been confided.'

In considering the question of liability upon non-negotiable instruments when stolen or found, as indeed all other questions relating to estoppel by misrepresentation,

"the duty of fellow-citizens to observe in virying circumstances an appro. priate measure of prudence to avoid citusing harm to others" 5

cannot be too strongly insisted upon. Opinion will vary as to the degree of prudence reguired; but once we gret away from the idea that one eannot throw the burden of sugrgested dishonesty on other people's shoulder's, and adopt in place of it the view that "an appropriate measure of prudence" means that although "parties cannot prevent forgery bemor committed, they must use reasonable care not to afford opportunity for it," 6

1 See section 3 of the Code as to the requisites of a contract.

2 Ch. XXIV. ante, p. 295.

s Ch. XXIV.

4 Ante. p. 30.
${ }^{5}$ lollock on Torts, 22. And see ch. $\mathrm{V}$, pussim.

6Societé v. Metropohtan (1873), 27 L. T. $\$ 49$. 
and that "too much opportunity" 1 must not be given for the commission of fraud, there will be less divergence of opinion. Meanwhile let it be noted that some progress has already been made.

For example, stolen company bonds may be passed with a good title. ${ }^{2}$

And if a certificate of shares should be taken in the name of a non-owner, and he sbould steal it and sell the shares, the purchaser would be safe, ${ }^{3}$ although it is thought that it would be otherwise were the thief an entire stranger to the shares."

It has been held, too, that although the thief of a bill of lading cannot give a good title to the goods represented by it, ${ }^{5}$ yet if the theft be due to the negligence of the owner of the bill the result would be otherwise. ${ }^{6}$

But if a mortgagor should steal, or eren upon fraudulent excuse obtain the title-deeds from the mortgagee, and make use of them adversely to the mortgagee, the purchaser wonld take the equity of redemption only.

To the writer the only distinction between different classes of documents (for the purposes in hand) rests upon the facility with which they lend themselves to fraud. A eompleted note can be passed with somewhat greater diffienlty than money; but, given a person willing to purehase it, its possession evidences the title of the holder. ${ }^{8}$ If, therefore, its owner allow it to escape, he, and not an innocent purebaser of it, ought to lose.

Transfers of shares under present methods are as easily translerred as notes. ${ }^{9} \quad$ If, then, an owner of shares will execute

1 Per Best, C. J., in Young v. Grote (18:7), 12 Moore, 484; 4 Hing. 253; 5 L. J. C. P. 16.5.

2 Venables v. Baring (1892), $3 \mathrm{Ch}$. 527 ; 61 L. J. Ch. 609 . And see cases cited with this one, ante, p. 380.

3 Winter v. Belmont, 53 Cal. 428. Cf. Ex parte Swan (1859), 7 C. B. N.S. 400; 30 L. J. C. P. 113; Swan v. North British (186?). 7 H. \& N. 603; 31 L. J. Ex. 425; (1863) थ H. \& C. 175; 32 L. J. Ex. 273.

${ }^{4}$ Bangor v. Robinson (1872), $52 \mathrm{Fed}$. R. 520. And see Young v. Brewster, 1 Mo. App. R. 577; 62 Mo. App. 628.
5 Gurney v. Behrend (18.54), 3 El. \& B. $622 ; 25$ L. J. Q. B. 265: Shaw v. The Railroad (1879), 101 U. S. 565.

'Lowe v. Raleigh (1897), $101 \mathrm{Ga}$. 320 ; 28 S. E. R. 867.

7 Northern Counties v. Whipp(1884), 26 Ch. D. 482 ; 53 L. J. Ch. 629 . And see cases referred to with this one in ch. XIX.

8 Ante, p. 394.

${ }^{9}$ McNeil v. Tenth Nat. Bank (1871), 46 N. Y. 325. And see cases cited with this one in ch. XXII. 
blank transfers of them prior to their being required, and allow them to escape, he, and not an innocent purchaser of them, ought to lose.

The same reasoning would reverse the decisions above referred to, in which it is held that a purchaser of land from a mortgagor ought to suffer and not the mortgagee, when the mortgagee hands over to the mortgagor (upon reasonable but fraudulent excuse) possession of the title-deeds; and it would impose consummately careful' circumspection on the part of the holders of bills of lading whose whim it was to keep them on hand in negotiable form.

\section{"Nfgotiable."}

'The reader should be now reminded of what has been said in tha preceding chapters as to the use of the word "negotiable," and the suggestion that it shonld be superseded by the term "ambulatory." Thus far in the present discussion the old word has for convenience sake been used, for we have been enga, red in the inquiry whether there is a distinction between instruments heretofore styled "negotiable" and other instrumınts, with reference to the applicability of the principles of estoppel to them. We have found that there is no distinction. And it should now be pointed out that there could be none, for (1) there is no distinction between "negotiable" and "nonnegotiable" instruments; (2) the proper division is into "ambulatory" and "non-ambulatory" documents; and (3) the ambulatory list embraces some "non-negotiable" as well as all "negotiable" instruments.

Is there then some distinction between ambulatory and nonambulatory documents? - that is to say, between documents in tended to be operative between the original parties to them only and those intended to be passed on? Yes, there is the very clear and important distinction that third persons do not aequire interests under non-ambulatory documents. There is therefore no estoppel in connection with them; for there is no estoppel between the original parties to the instrument (when it has been obtained or completed by the fraud of the estoppelasserter); and no estoppel as against third persons, for there are none such in the case. 
The estoppel, then, of which we have been treating occurs in cases of ambulatory instruments, and as against persons who have cbanged their position upon the faith of their being validly executed. And any distinctions to be met witb among such documents are to be attributed not to the inapplicability to any of them of the unvarying principles of estoppel, but to the difference in usage with reference to them. For all cases alike the law imposes

"the duty of fellow-citizens to observe, in varying circurnstances, an appropriate measure of prudence to avoid causing harm to others." 1

\section{Summary of the Chapter.}

I. EXECUTION FRAUDULENTLY OBTAINED.

1. The true distinction between void and voidable transactions is determined by the consideration whether or not they are capable of ratification.

2. Documents impeachable because of fraud are voidable, and not roid, for they may always be ratified.

3. As between a swindler and his dupe, transactions may be rescinded.

4. But if there have been carelessness on the part of the dupe, he will be estopped as against innocent third parties who have changed their position upon the faith of an executed document.

5. Distinctions between lettered and unlettered people, with reference to occasions calling for "extraordinary caution," etc., are merely factors in determining whether the dupe bas obserred that rule of conduct by which every one is required to exercise "an appropriate measure of prudence to avoid causing harm to one another."

6. Analogy from fraudulent purchase of goods. If the owner of goods, although induced thereto by fraud, has transferred the property in them to another, an innocent sub-purchaser will be protected. If the property has not passed - if there has in fact been no contract between the swindler and the dupea sub-purchaser takes nothing. Nevertheless, if the rlupe has equipped the swindler with indicia of title to the goods, he may be estopped from denying the existence of a contract under which the property passed. 
II. EXECUTION FIALDLLENTLY COMPLTLD.

A. Negrotiable instruments:

(a) Completed instruments intrusted to other persons will earry their obligation to pay with them, al. though the authority of the persons intrusted is exceeded.

(b) Blank instruments are in the same eategory.

(c) Signed slips will carry liability if the transferee had no notice of their original imperfection; otherwise there is no liability.

P. Non-negotiable instruments:

(a) Completed instruments intrusted to other persons will estop the signers of them in favor of those who ehange their position upon the faith of them.

(b) Blank instruments are subject to the same prineiple; but observe that where the existence of the blanks is lnown to the estoppel-asserter, he will be safe only in eases in which custom authorizes him to infer authority to fill up the blanks.

C. Doenments stolen or found:

(a) Negotiable instruments:

(1) There is no difference between complete and incomplete instruments.

(2) Nor between those intended, and those not intended, to be issued.

(3) There is no rule that every one has a right to suppose that a crime will not be committed, and to act on that belief.

(4) Estoppel declares for liability in all such cases.

(5) Signed slips are distinguishable, but here too the rule ought to exact "an appropriate measure of prudence to avoil eausing harm to others."

(b) Non-negotiable instruments:

(1) The rule just quoted ought to apply to all sorts of instruments.

(2) Stolen or found company bonds pass with a good title.

(3) The law is approaching the same conclusion as to eompany shares.

(4) And also as to bills of lading. 
(5) But a mortgagee is thus far safe as against damage through abstraction from him of the titledeeds.

(6) The true distinction among all classes of documents ought to be made with reference to the facility with which they lend themselves to fraud - failure to exercise "an appropriate measure of prudence" should be the test of estoppel.

D. The classification in to "negotiable" and "non-negotiable" instruments is unscientific and misleading. 


\section{CHAPTER XXVI.}

\section{OSTENSIBLE AGENCY - PRINCIPAL AND AGENT.}

The principal difliculties in the way of scientific treatment of the law of principal and agent are four: (I) the rogne of serious misconceptions relative to the classification of agents into general and special; (II) lack of elear appreciation of the application to the subject of the principles of the law of estoppel; (III) misunderstanding as to the effect upon an unauthorized act of its having been done "for the master's benefit;" and (IV) confusion arising out of the phrase "within the scope of his apparent authority." An attempt will be made to clear away these difliculties. Their discussion will form the four chief divisions of the present chapter.

\section{Some Propositions.}

It will be well, however, to interpose and tentatively suggest a few simple propositions:

1. A man cannot be bound by the act of another unless he authorized it. ${ }^{1}$

2. Nevertheless, if he personally represents that he has authorized it, and on the faith of that representation some third party has changed his position, he ought to be estopped from denying the existence of authority. In such case the act was, and remains, unauthorized; but there is estoppel against so saying.

3. Assisted misrepresentation also will estop: ${ }^{2}$ If the ostensible agent is the one who makes the representation of authority, and the supposed principal has merely assisted that representation - done that which has male it credible - he will be as much estopped as if he had himself made the representation. For example, if I should employ a broker to sell some shares, he would appear to have all the anthority usually possessed by a broker. ${ }^{3}$ Now suppose that I had in fact limited that au-

1 Ratification as a ground of liabil. ity is not within the scope of the chapter.
2 see ante, ch. 1V.

3 Pickering v. Busk (1812), 15 East,

38. And see infra. 
thority, and the broker nevertheless acted as though it were unlimited, I would be estopped from denying his possession of customary power; because I had, by my employment of that particular sort of a person, given the appearance of usual authority.

4. Representation of the existence of authority may arise in two classes of cases:

(a) There may be a representation that the person acting was an agent, when in fact he was not.

(b) There may be a representation that the person acting had larger powers than he in fact had.

In other words, there may be representation (1) as to the existence of ageney; or (2) as to the extent of it. This distinetion (altbough probably not scientific) will be of much service.

\section{Generat and Specral Agency.}

It will observed that in the above short but comprehensive view of the principles of estoppel as applied to the law of principal and agent, nothing is said as to the much-used distinction between general and special agents. Indeed there appears to be not only no necessity but no place for it. Nevertheless there is bardly any distinction more generally affirmed and more frequently appealed to. We must see what there is in it.

The most usually adopted statements of the distinetion are construetions of the language of Lord Ellenborough which is quoted everywhere:

"When that question is discussed it may be material to consider the distinction between a particular and a general authority; the latter of which does not import an unqualified authority, but that which is derived from a multitule of instances, whereas the former is confined to an individual instance." 1

A general authority is that "which is derived from a multitude of instances;" and a particuiar authority "is confined to an individual instance." Does this mean that if partieular authority be griven in a multitude of instances, then at some point in the sequence, or at the end of it, the authority will become general? If so, and there be some real distinction between the power of a general and special agrent, it is extremely

1 Whitehead v. Tuckett (1812), 15 Butler v.Maples (1869), 9 Wall. (U.S.) East 409. A mong the scores of cases 766 . and text books see a discussion in 
important that wo should be able to say exactly how many instances make up the magic number? Unless indeed we are to be told that the multitude of instances spoken of are not instances of particular authority at all (changing mechanically into general authority), but instances, all of them, of general authority. In which event, however, a new difficulty confronts us, for the first of the series is then, ex hypothesi, a case of general authority; while according to our definition it can only be a case of particular autbority, for it is "confined to an indivilual instance."

It is hard to see how the extent or nature of an agrent's authority can, in any way, depend upon the frequency or infrequency of the employment. Powers of all and every sort, unlimited as well as the most restricted, may be bestowed upon the agent at his first employment; and may be so continued throughout his life-time. And his exercise for decades of the powers which are given him cannot alter, or affect, or enlarge their extent.

For another and altogether different purpose, no doubt former acts of agency are frequently of great importance: You want to prove that A. is B.'s agent, with certain powers; and you know that on previous occasions A. so acted with B.'s consent. But observe that these prerious instances (even though there be a multitude of them) do not in any way enlarge or affect the character of the agency. ${ }^{1}$ They are merely evidence of an express grant of that sort of authority which the agent has theretofore exercised. For example, a servant has been accustomed to pledge his master's credit for wine; the master refuses to pay the last of a long series of bills; and evidence is given of the previous dealings to prove that the master had in fact authorized the pledge of his credit - not to show that the servant was a general agent or any other sort of all agent, but to prove actual grant of authority. That is the full extent of the doctrine of "a multitude of instances." It prores ageney. ${ }^{2}$ It does not alter it. A long course of deal-

1 Note particularly the reasoning in Sponer r. Browning $\left(1 \varsigma^{5}\right), 1 \mathrm{Q}$. B. .333; 6i L. J. Q. B. 339.

2 "A single instance repudiated, not enomrh." Stewart v. Rounds (1882): 7 Ont. Aop. 515. As to several instances, see Sponner r. Browning (1898), 1 Q. B. 528: 67 L. J. Q. B. 333: Sproner v. Cummings $(1 \leq 90), 151$ Mass. $313 ; 23$ N. E. R. 539: Marsh v. French (1899), 82 Ill. App. 76. 
ing "raises a presumption that the agent had actual authority to do what is done by him;" 1 not to do something else. ${ }^{2}$

Mr. Justice Story, in his work on Agency, ${ }^{3}$ refers to Lord Ellenborough's dictum as containing "the true distinction;" but himself frames one which is quite different from it: 4

"A special agency properly exists when there is a delegation of authority to do a single act; a general agency properly exists when there is a delegation to do all acts connected with a particular trade, business or employment." 5

This distinction is defective because (if for no other reason) its classifications are not sufficiently discriminative or exhaustive. For example, suppose that I employ a broker to purchase all the stock of company $A$. that he can from time to time obtain; but insist upon his acting in some unusual method. Here I employ him to do more than "a single act;" and yet there is no "delegation to do all acts connected" with his business. In which category is such a case?

Mrr. Campbell, in his recent work on "Sale of Goods and Commercial Agency," refers to Lord Ellenborough's dictum as "pregnant language, truly indicating a distinction." 6 If so, one would expect to find a factor, and a broker, in the same category - in an individual instance of employment both of them would always be particular agents; and the line would be drawn between "an individual instance" and "a multitude of instances;" and not between persons of such closely allied occupations. Nevertheless Mr. Campbell says:

"A factor is the term used in English law as a general agent laving authority to sell." 7

" Nor is there by the mere fact of employment as a broker any presumption of general authority. Prima facie he is a special agent; but a general authority of limited extent may easily be inferred from a course of dealing." 8

Of the authority of partners, Mr. Campbell says ${ }^{9}$ that "every member of an ordinary partnership is its general agent." But

1 Wheeler r. Benton (1897), 67 Minn. 293; 69 N. W. R. 927; Graves v. Horton (1887), 38 Minn. 66; $35 \mathrm{~N}$. W. R. 568; Lythe v. Bank (1899), 26 S. R. 6 (Ala.); Marsh v. French (1899), 82 Ill. A pp. 76.

2 For example, the receipt of rent on many occasions through an agent will not extend the authority so as to cover payment to the agent in kind, or in repairs. Paisley v. Lannatyne (188\%), 4 Jan. 25j.
3 Sec. 19.

4 Sec. 17.

5 Paley on Agency, p. 2; and Stephen's Com. (9th ed.), II, 65, are to the sime effect. And see Montgomery v. Hardaway (1893), 104 Ala. 115; 16 S. R. 33.

6 Page 526.

7 Page 539. And see p. 540.

8 Page 558.

9 Page 622. 
not eridently because of "a multitude of instances;" for prior to a single instance there is the same authority as after twenty years of action.

In the oft-quoted case of Fenn v. Marrison, ${ }^{1}$ Buller, J., said:

"I agree with my brother $A$ shhurst that there is a wide distinction between general and particular iggents. If a person be appointed a geveral agent. as in the case of a factor for a merchant resicling abroad, the principal is bound by his acts. But an agent constituted so for a particular purpose and under a limited and circumscribed power cannot bind the principal by any act in which he exceeds his anthority; for that would be to say that one man may bind another agiainst his consent."

Is there any such distinction? IJere is the erux of the whole situation, and a complete understanding of it will banish much difficulty: "The principal is bound by the acts of a general agent; but a particular agent cannot bind the principal by any act in which he exceeds his authority." If this were really the law the cases would be replete with examinations of the exact nature of the distinction between general and special agents. That point once well settled, the prescribed result in each ease would invariably follow. But there are no such examinations, nothing but general statements of the nature of those already referred to, and no analysis of them.

Mr. Broom's statement of the law may form the basis of exposition: ${ }^{2}$

"An important difference is to be noted between a 'general' and a 'particular'agency; for, if a particular agent exceeds his authority, his principal is not bound by what he does; whereas if a general agent exceeds his authority, his principal is bound, provided what he does is in the ordinary and usual scope of the business which he is deputed to transact."

Observe the proviso - the principal is bound by the acts of a general agent, not in all cases, but only (a rery necessary qualification) where "what he (the agent) does is within the ordinary and usual scope of the business which he is deputed to transact." What is meant is this: I employ a general agent in a certain business; such agents usually have certain powers bestowed upon them by their principals; my agent does something within those usual powers, but something which I have probibited him from doing; and I an bound by his act. The agent exceeds his powers; nevertheless I am bound. ${ }^{3}$

1 (1790) 3 T. R. 762.

2 Common Law (8th ed.), 5r5. See also East India r. Ifensley (1794), 1 Esp. 182; Banks v. Ererst (i896), 35 Kan. 6sĩ 12 Pac. R 141; Catholic
Bishop r. Troup (1895), $6 \mathrm{l}$ Ill. App. 611; Phonix v. Gray (1899), 32 S. E. R. (Ga.) 948.

3 Or rather I am estopped from denying the existence of authority. 
But that is not because the agent was a general agent; for precisely the same result will attend the case of any agrent. In other words, it may as well be said of a particular agent as of a gencral, that the principal will be bound although the agent exceeds his autbority, "provided what he does is within the ordinary and usual scope of the business which he is deputed to transact." Many examples of this will be given later on. One at present: I employ a broker (a special agent, according to M[r. Camplell ${ }^{1}$ ) in "a single instance," prohibiting him, however, from doing something which is usual in the stock marliets; he acts for me and disregards my prohibition; and I am bound. $^{2}$

And the reason is the same as in all other cases of agency. It has nothing to do with any distinction between diffecent sorts of agency. It depends upon the fact that my agent has ostensibly certain powers; I have enabled him so to appear; and I am therefore estopped from denying that he has those powers. If I stood by and allowed another person to pose as the owner of my horse, I would be estopped from setting up my title to him as against a purchaser in good faith. Ostensible ownership would there estop me. Ostensible agency, for which I am responsible, will also estop, and for precisely the same reason.

The current rule as stated in Smith's Mercantile Law is as follows:

"The authority of an agent to perform all things usual in the line of business in which he is employed cannot be limited ${ }^{3}$ by any private order or direction not known to the party dealing with him. The rule is directly the reverse concerning a particular agent, that is, an agent employed in one single transaction; for it is the duty of the party dealing with such an one to ascertinin the scope of his authority; and if he do not, he must abide the consequences." 4

The first part of this rule is open to the observation that it is a patent truism; for it is plainly impossible to give authority to an agent "to perform all things usual," and yet to withhold

1 Ante. p. 4\%6.

2 Pickering v. Busk (1812), 15 East. 45: Sutton v. Tintham (1839), 10 A. \& E. 31: 8 L. J. Q. B. 210: Robinson v. Montgomery (1s96), 2 Ch. 841; 65 L. J. Ch. 915.

${ }^{3}$ The expression "cannot be limited," although often made use of (Towle v. Leavitt (1851), 23 N. H.
$358)$, is inaccurate. A principal can, of course, impose such limitations as he pleases upon his own agent. What is meant is that he may be estopped from alleging the existence of limitations.

4 10th ed., 140. See also Bryant v. Moore (1846), :6 Me. 84 . 
from him the power to do some of these things. Waiving this point, what is meant, no doubt, is that "it is the duty of the party dealing with" a particular agent "to ascertain the scope of his authority," whereas there is no such cluty in the case of a general agent; and a particular agent is one "employed in a single transaction," while a general agent is one employed " to perform all things usual in a line of business."

Now, suppose that I employ a broker to purchase on the stock market twenty shares of certain stock for me, what are his powers? and what sort of an agent is he? If we answer that he is a particular agent because he is "employed in one single transaction," then every one dealing with him must inquire into the exact limit of his authority - a result which will not be asserted.' And if we reply that he is a general agent, as being employel "to perform all things usual in the line of business" of a broker, then we shall probably be asked as to the value of "one single transaction" as a tesi of particular agency. In fact, the case suggested is within both of the alternatives, and would therefore have, by it, to be decided both ways.

Mr. Dicey properly criticises the statements of law above quoted, but does not quite ricl himself of the current ideas:

"But the distinction thus laid down is not. it is submitted, maintain. able, since if even a particular agent (though the term itself is not a very happy one ${ }^{2}$ ) is helil out to other persons as having an authority beyond that which his principal intends him to possess, the principal will be bound up to the extent of the agent's apparent authority. ${ }^{3}$ The true rule seems to he that an apparent authority can never be restrined by private orders from the principal which are unknown to the thad party; but that a particular agent as being employed in one instance only can rarely have any apparent authority whatever, and third persons, therefore, must als a generial rule trust to his real or actual authority." 4

Mr. Dicey elearly sees that the same law must be applied to all sorts of agencies, but retains the "one instance only," becanse in such cases he says the agent "can rarely have any apparent authority whatever." But the cases are far from lare. On the contrary they are multitudinous. Every day there are thonsands of brokers plying their vocition. If I send one of them into the market he has "an apparent authority," namely, that authority which a broker usually exercises in that line of business; and not any the less is this the case that he is " $\mathrm{cm}$ -

1 See ante, p. 4is.

2 Byles on Bills (8th ed.), 29.
${ }^{3}$ Story on Agency, sce. $12 \%$.

+Dicey on Parties, 243, n. 
ployed in one instance only." It would be better to leave by itself Mr. Dicey's statement

"that an apparent authority can never he restrained by private orders from the principal which are unknown to the third party."

But this, too, cannot be strictly accurate; for Mr. Dicey himself says: ${ }^{1}$

"The principal is always bound by the acts of the agent up to the extent of the agent's authority; and is never bound beyond the extent of that authority."

If this be true, and it indisputably is, the extent of the real authority must be everything, and the extent of the "apparent" authority must be wholly immaterial. And so it would be but for the law of estoppel, the application of which the text writers almost unanimously overlook. The principal cannot be bound by an unauthorized act; but if the principal has enabled the agrent (any sort of agent) to appear to have greater authority than he really has, the principal is estopped from asserting that such authority does not exist. This, and not distinctions between single and multitudinous instances, explains all the difficulties. ${ }^{2}$

Altbough Mr. Justice Story, at one part of his work (sec. 21), says that the distinction between general and special agents is very important, "as the doctrine applicable to the one sometimes wholly fails in regard to the other,"

at another (sec. 133) he contends that,

"properly considered, the same principle pervades and governs each of the cases:" 3

and again (sec. 70) he says:

"Principles very similar may be traced back to the Roman law; for in that law, where the authority was express or special, the agent was bound to act within it; and where it was of a more general nature. still the agent could not bind the principal beyond the manifest scope of the objects to be accomplished hy it."

See also scctions $71,73,83$; and the longer note to section 127 , in which he says:

"It has been already suggested (ante, sec. 73) that the same general prin-

1 On Parties, 240.

2 The distinction is very important. The court does not say, "the agent has no authority, nevertheless the principal is bound:" which would be absurd. But it does say: "Upon the facts proved, the agent apparently had authority; the principal permitted such appearance; this is good evidence against the principal that there was, in fact, such authority; the principal will not be allowed to assert anything inconsistent with that on the faith of which the contract was made; the evidence therefore proves the existence of the authority."

"See Beem v. Lockhart (1891). 1 Ind. App. 202; 27 N. E. R. 239. 
ciple provdes all cases of ageney, whether the party he a general or a spe. cial arent. But nevertheless the distmetion betwen gromeral and special atgents is not mutonuted or useless It is suffickent to sorve many cinces."

So far as the present writer can see, however, the very able author malies no such use of it; and if it be true that " the same general principle pervales all eases of agency," it is dillicult to see what can be obtiuned from a division of them into an cmployment on one occasion and an employment on more than one.

Mr. Justice Stury then may be said to agree that in considering the contractual relation between the princijal and the third party the same gencral principles are applicable, whether the agency be greneral or special. Those principles, in the langraagre of estoplel, are: (1) That an agrent camnot bind his principal unless he has authority to do so; but (2) that novertheless the principal may by his conduct be estopped from asserting the lack of authority. Not observing the estoppel feature of the case, and substituting therefor (as the writer thinks) an erroneous principle, Mrr. Justice Story (sec. 127, n.) put the matter in this way:

"The principle which pervades all cases of agency, whether it be a general or a special agency, is this: The principal is bound hy all acts of lis agent within the scope of the anthority which he holds himself out to the world to possess; althomgh he ma have griven him more limited private instructions unknown to the persons dealing with him. And this is fonnded on the doetrine thit where one of two persons must suffer by the act of a thirl person, he who has held that person out as worthy of trust and confidence, and having anthority in that matter, shall be hound by it. It will at once he perceived that this doctrine is equally applicable to all cases of agency, whether it be the case of a general or special agency."

If this paragraph be turned (as it easily may) into the language of estoppel, it would declare the law in accordance with the present writer's contention; and if it would then be correct there can be no reason for continuing the old dirision in to single and multitudinous instances.

Mr. Mechem, while giving the usual distinction between general and special agents, points ont that "as ordinarily drawn" it is "artificial and unsatisfactory, if not positively misleading," 2 and suggests the following:

"One is in its nature limited and implies limitatiuns of power. Of these limititions third persons nust inform theliselves, unless the principal has by his worts or conduct liehl ont the agent as one mpon whose anthority sich limitations are not imposed. The olher is in its nature generisl and unrestricted by other limitations than those which conline the andbority within the bombls of whit is usmil. proper am necessing under like circumstances. If there are other limititions the principal must disclose them." 3

1 On Agency, $\S 6$.

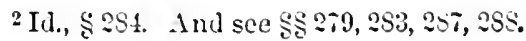


To test the validity of this distinction let us recur to the case of a broker employed in a single transaction, and let us ask again whether it is a case of special or general agency? It is "in its nature limited," and so special; but the limitations are confined to "what is usual, proper and necessary under like circumstances," and so the agency is general. In fact it seems to be a case (if we are to use the customary terms) within the dillicult definition of Shepley, J.: ${ }^{1}$

"A special agent is one employed for a particular purpose only. $\mathrm{He}$ also may have general authority to accomplish that purpose."

And probably if our present phraseology gives us special agents with general powers, and (for the samo reason) general agents with special powers, something of a case is made out for the revision which Mr. Mechem attempts.

But all must agree that the powers of both general and special agents are limited, and that no arent of any kind can bind his principal by an ultra vires act - general and special agents are alike so circumscribel. And Mr. Mechem would also agree that there is no distinction between general and special agency with reference to the estoppel of a principal by holding out an agent as having larger powers than he really possesses. His language upon this point is well worth quotation:

"It may therefore be stated as a general rule that whenever a person has held out another as his agent authorized to act for him in a given capacity, or has knowingly and without dissent permitted such other to act as his agent in such capacity; or where his habits and course of dealing have been such as to reasonably warrant the presumption that such other was his agent authorized to act in the capacity, whether it be in a single transaction or in a series of transactions, his authority to such other to act for him in that capacity will be conclusively presumed so far as it may be necessiry to protect the rights of third parties who have relied thereon in gool fitith and in the exercise of reasonable pruilence, and he will not be permitted to deny that such other was his agent authorized to do the act that lie assumed to do, provided that such act is within the real or apparent scope of the presumed authority." 3

Summary.-We may then say:

1. No advantage is derivable from the usual division of agents into general and special.

I Bryant . Moore (1846), 26 Me. 87.

2 Chicarro v. Troup (1895), 6 Ill. App. 641, may perhaps be in the same category. New Albany v. Meyers (1890), 43 Mo. App. 121. was the case of a general agent "in a particular lne." The master of a shij on a par- ticular voyage, too, is sometimes called a general agent. Arthur v. Barton (1810), 6 M. \& W. 143; 9 L. J. Ex. $18 \pi$.

${ }^{3}$ On Agency, § 84. Approved in Johnson v. Hurley (1893), 115 MLo. 513; 22 S. W. R. 49:. 
2. For in all cases of agency

"the principal is always bound by the acts of the agent up to the extent of the agent's authority, and is never bound beyond the extent of that authority."

3. Nevertheless, if the principal should untruly represent that bis agent (any sort of agent) had authority to do the act in question, the principal would be estopped from denying the authority.

4. And if he assisted the agent's misrepresentation of authority — did that which made it credible - then also he would be estopped.

5. "The same general prineiple pervades all cases of agency whether the party be a general or a special agent."

\section{EsTOppel.}

Having now some clear idea of the significance of individual and multitudinous instances, let attention be more particularly directed to the relation of estoppel to the law of principal and agent.

It has been said that although an act be unauthorized, yet if the person on whose behalf it was assumed to be done was responsible for the appearance of real authority he ought to be estopped from denying its existence. For the purposes of discussion let the subject be divicled into:

I. Cases in which the appearance of power relates to the existence of agency.

2. Cases in which it relates to the extent of the agency. But for the purposes of discussion and clearness only; for if the extent of the agency do not inclurle the act (No. 2), then as to that act ageney does not exist at all (No. 1). And contrariwise, if agency exists as to a certain act (No. 1), the extent of the agrency (No. 2), ex hypothesi, includes the act.

(1) Estoppel as to Existence of Ageney.-Although it is universal knowledge that a principal may be bound by the unatuthorized act of his argent (if the act be within the agent's ostensible authority), it is rot only sonewhat unfamiliar, but is sometimes denied that there may be estoppel where there was in fact no agency at all, but only the appearance of agency.

Yet the merest reference to the multitudinous cases which arise in the law of partnership ought to dispel all donbt upon the point. Those cases are so uumerous that a special chapter 
of this work is deroted to their consideration. They are of this sort: A man appearing to be a member of a partnership, but in reality not so, is sued upon the firm's obligation, and the question is as to bis liability. Observe that there is no controversy whatever as to the extent of the agency of one member of a firm to bind his partners. The point is, was the defendant a partner at all? was there any agency? The question is as to existence of agency; and this is to be settled by appearance of agency - that is, by estoppel. ${ }^{1}$

Many calses overlook this point. Biggs $v$. Eyans ${ }^{2}$ is one of the most notable of them. The owner of a table-top sent it to a dealer in such things, accompanied by the following letter:

"I will intrust you with the sale of my opal table upon the following conditions: That the table shall not be sold to any person, nor at any price, withont my authorization is first obtained that such sale shall be effected. That the check handed to you in piayment for the table sliall be handed over to nie intact," etc.

The dealer, disregarding the limitations imposer, sold the table-top; and it was held that the owner was not bound by the sale. Wills, J., said:

"It is suid that the plaintiff enabled G. to sell the table-top as his own, and that his doing so was within the scope of his authority as it would be understool by persons who dealt with him; and that as he had pat it in the power of G. to commit the frand. he must bear the loss. I think, however, that a fallacy underlies the expression that he enabled $G$. to commit the fraul. In one sense, and one only, did he do so. He gave lim the corporal possession of the table-top, and it was that power that enabled G. to sell it as his own. or by way of a transaction within the scope of his apparent anthority, as a person carrying on a business in which sales are liabitually ellected. Bnt it is quite clear that it requires more to found the argument in question. In one sense every prison who intrusts an article to any person who deals in second-hand articles of that description enables him, if so disposed, to commit a fraud by selling it as his own. A man who lends a book to a second-hamd bookseller puts it into his power, in the same sense, to sell it as his own. A man who intrusts grvocis for sitfe custody to a wharfinger who also deals in his own goods, or in other people's goods intrusted to him for sale, in such a sense enables him to eommit a fraud by selling them to a customer. But such a transa'tion clearly cond not give a title to a purchaser as agamst the owner. The true test is, I take it, whether the anthority given in fact is of such a nature as to cover a right to deal with the artiele at all. If it does, and thes

1The Catlifornia Crvil Code provides for estoppel as to existence of agency: "An agency is ostensible when the principal, intentionally or by want of ordinary care, causes a third person to believe another to be his agent who is not really employed by him." Sec. 2300 . And see Iteald v. Henely (1891). 89 Cal. 6:32; 27 Pac. R. 67. Persons dealing with an agent, whether "general or special, are bound at their peril to ascertain not only the fact of the agency, but the extent of the authority, and in ease either is controverted the burden of proof is upon them to establish it." Lester v. Snyder (1898), 12 Colo. App. 351; 55 Pac. $R$ 61j.

${ }^{2}(1894) 1$ Q. B. 88. 
dealing effected is of the same nuture as the dealings contemplated by the anthority, and the arent carries on a business in which he ordinarily -Ife-ts fur other people such dispositions as he does effect, what he has done is within the general anthorily conferred: and any limitations ims. posed as to the terms on which, or manner in which, he is to sell are mat. ters which may give a right of action by the principal, but cannot atrect the person who contracts with the atrent. The foundution. hourerer. of the uhote thing is that the agent should be anthorized to euter into some transaetion. Now, in the present calse, the letter taken as a whole sliuws that the table-top never was intrusted to $G$. to sell. He was forbidien in exfrrs terms to sell without further authority."1

This julgment would limit the application of estoppel to cases in which there has been some minor departure from an anthorized course. There must be (1) authority to do something; (2) something done "of the same nature as the dealings contemplated by the authority;" and (3) a departure merely as to terms or manner. In other words, there must as a "foundation of the whole thing" be some agency. The authority of the agent may be exceeded, but agency itself eannot be constituted by estoppel.

Simplify the case: Suppose that a man is in reality not my agent, but I tell some person that he is, or stand by while he professes to act as my agent, would I not be estopped as atrainst any one misled by my conduet? ${ }^{2}$ If I stood by while another person pretended to own my goods, and sold them as owner to an innocent purehaser, I certainly would be estopped becaluse of the ostensible ownership. The case cannot be different if the vendor pretended to be my agent. It is only changed to an instance of ostensible agrency.

This, however, is not the only answer to the remarks of $\mathrm{M} x$. Justice Wills. There is this further: that the case was probably not one of ostensible agency at all, but one of ostensible ownership; ${ }^{3}$ and the principles of the two classes of cases are confounded together in the judgment. Note that the learned julge observes that the contention was "that the plaintiff enabled G. to sell the table-top as his own;" and that his answer to this is that (changing orer to ostensible argency)

"the true test is, I take it, whether the authority given in fact is of such a nature as to cover a right to deal with the article at all."

But the question is not one of authority or ageney at all. Admittelly there was no argeney; and as there was no appear-

I (1891) 1 Q. B. 8?.

2 Cf. Re Consort Deep Lerel Gold Mines Co. (185\%), 1 Ch. 5\%5; 66 L. J. Ch. 12:2, in which the quention wats whether Stark was estopped by his conduct from denying that Ackerman's authority to act for him had arisen.

${ }^{3}$ See this distinction treated of, ante, ch. XVII. 
ance of agency there could be no estoppel by ostensible anthority. There was, however, an appearance of ownersbip, for which the plaintiff was responsible, and, with deference, be should have been estopped npon that ground.

Observe the distinction between ostensible ownership and agrency. Were I to allow my wateh to appear amongst the stock in a jewelry shop, the proprietor of the establishment would be the ostensible owner of my watch, and I would certainly be estopped by its sale. But if I were to send my goods to an auction-room, the auctioneer would be the ostensible agent for the purpose of selling them in the usual way, and ostensible agency would be the ground of estoppel. Lord Ellenborough's language applies to the latter case:

"If the principal send his commodity to a place where it is the ordinary business of the person to whom it is consigned to sell, it must be intended that the commodity was sent thither for the purpose of sale. If the owner of a liorse send it to a repository of sale, can it be implied that he has sent it thither for any other yurpose than that of sale? Or if one send good; to an auction-room, can it busposed that he sent them thither merely for safe custody? When the commodity is sent in such a way, and to such a place, as to exhibit an apparent purpose of sale, the principal will be bound and the purchaser safe." 1

Distinguish carefully this statement of the law from that of Blacliburn, J., in Cole v. North Western Bank. ${ }^{2}$ If a furnished house be rented to an auctioneer, and he surreptitiously remove the furniture to his auction-rooms and sell it there, the owner would not be estopped. But the case would be very different if the owner bimself sent his furniture to the auction-rooms (if only for the purpose of enabling the auctioneer to present the appearance of doing large business), and with the strictest instructions not to sell.

Two noteworthy cases are cited below in which there was beld not to have been ostensible agency, although upon cursory glance it might have been thought otherwise. ${ }^{3}$

(2) Estoppel as to Extent of Agency.-This second class includes all those cases in which, admittedly, there is some agency, and the question is as to the extent of it. The agent not having had authority to do this particular thing, is the principal nerertheless, by permitted appearance of authority, estopped

1 Pickering v. Busk (1812), 15 East, 43. See authorities cited with this one, ante, p. 299.

2 (1874) L. R. 9 C. P. $470 ; 10$ id. 354 ;

${ }^{3}$ Re Consort Deep Level Gold Mines (1897), 1 Ch. 575; 66 L. J. Ch. 122, 297; Timpson v. Allen $(1596)_{h} 149$ N. Y. $513 ; 44$ N. E. R. 111. 43 L. J. C. P. 194; 44 id. 233. 
from denying its existence. This question, too, can be answered without reference to single or multitudinous instances.

Mr. Bigelow is of opinion, however, that estoppel has nothing to do with such a question. He says: ${ }^{1}$

"The question is simply one of the right to dispute not the agency altogether, but the extent of the agency - that is. whether the act lone was within the admitted agency. There lies the line between agency and estoppel."

But it may well be asked why a man may not by misrepresentation be estopped to dispute extent of agency as well as existence of it? - indeerl, as already pointed out, are not these in reality but two phases of the same question? If agency exists as to a certain act, the extent of the agency must ew necessitate rei cover the act. In any case, it cannot be according to the law of principal and agent that I am bound if I permit my agent to appear to have larger powers than be really has and he takes adrantage of bis situation to exceed his authority, for by that law

"the mincipal is bound hy the acts of the agent up to the extent of the agent's authorsty; and is never bound beyond the extent oi that author. ity." "

In other woris, I am not bound for the reason that the person who did the act was not for that purpose my agent. Nevertheless, by estoppel, I am precluded from saying that his power was not sufficiently extensive. Lord Cranworth's view was that, in order to aflix liability to a principal, you

"must show that the agency did exist. anil that the agent had the author. ity he assumed to exercise, or, otherwise, that the prineipal is estopped from disputing it." 3

In other words, you must prove agency and extent of agency, or else estoppel - agrency or estoppel; fact or preclusion to deny fact.

(3) Estoppel, in What Cases? - In general terms we shall now endeavor to indicate the circumstances under which a principal will be estopped when his agent has exceeded his authority. Where the principal himself has personally and directly misled the third party, there is of course no difficulty. But troublesome questions arise where, from the character of the employment of the agent or other circumstances, certain deductions

1 On Estoppel (5th ed.), 565, 566. And see pages 457 and $503, \mathrm{n}$.

2 Anle, p. 480. 162.

3 Pole v, Leask (1\$63), 33 L. J. Ch. 
or assumptions are drawn by the third party, and we have to inquire whether such inferences were sufliciently well foundel to bare justified action upon them by the estoppel-asserter and consequent estoppel of the principal.

General Proposition.- At the outset this general proposition is worth noting: that in cases in which the law assumes (from the nature of the duty to be performed, from the relation of the parties, or from aught else) the existence of certain powers, the public will be justified in making a similar assumption.

Medium Powers. - Authority will be implied by the law, and may be assumed by the public, in the following cases:

A. When an agent is employed to perform a certain duty, be has the power to do those things usmally incidental to the discharge of such duty.

B. When an agent is employed to act in a certain capacity, he bas the power which persons acting in that capacity usually have.

C. When an agent is employed to act in the line of a certain business, he has the power usually exercised in that business. .

D. When an agent is employed to act in a certain place, he has the power which persons doing such things, at such place, usually have.

E. When an agent is employed to act under certain circumstances, he has the power which persons acting under such circumstances usually have.

F. When agency arises as incidental to some other legal relationship, the agent has the power which persons in such relationship usually bave.

It is not pretended that these rules are framed according to scientific illeal. Indeed, by such standard, they are open to the criticism that class E. includes all the others, or might easily be made to do so. For practical purposes, however, and at all events in exposition of the subject, they will prove useful; for it will be found that the vast majority of the cases range themselves into classes represented by these rules. A few of the authorities to support them are as follows:

Iiule $A$.

"An authority of this nature (to fray debts. etc.) necessarily includes medium powers which are not expressed. By medium powers I mean all 
the mrans necessary to be usal in order to attin the accomplishment of the olnect of the principal power.",

\section{liules B. and C.}

"A person who employs a broker must be supposed to give him anthority to acet as other broker's do. It does not matter whether or not he hinseif is accluainted with the rules by which brokers are governed.":

\section{liule $D .^{3}$}

"If the principal sends his commodity to a place where it is the ordi. nary business of the person to whom it is consigned to sell, it must he intended that the commolity was sent thither for the purpose of sile."

"A person who deals in a particular market munt be taken to deal according to the custom of that market: and he who directs another womatio a contract at a particular places must he talsen as intembling that the coutract maly be made according to the usige of that place."

A principal gave power to insurance brokers at Liverpool to write policies "not exceeding $£ 100$ for any one ressel." The brokers mulerwrote a policy for $₫ 150$. Liability now depends upon whether, at Liverpool, brokers grenerally have or have not unlimited authority as to amount. If they have then there was appearance of authority to underwrite the $\& 150$ policy, and the principal is estopped. From the evidence it appeared that at Liverpool "in almost all cases, if not in all, a limit is put on the amount for which a broker can sign his principal's name." In Liverpool, therefore, there could be nothing to in-

1 Howard r. Baillie (1796). 2 H. Bl. 618. And see Dingle v. Hare (1859), 7 C. B. N. S. 1.74 : 29 L. J. C. P. 143 ; Wheeler v. MeGuire (1\&88), 86 Mlia. 398; Montgomery v. Hardaway (1894), 104 Ala. 100; 16 S. R. 29; Van Dusen v. Jungrleblut (1s99), $\approx i$ N. W. R. (Minn.) 970 .

2 Suttun r. Latham (1839), $10 \mathrm{Ad}$. \& E. $30 ; 8$ โ. J. Q. B. 210. And see Titylor s. Stray (1S5i), 2 C. B. N. S. 193;: 26 L. J. C. P. 185; Mollett v. Rohinson (18\%0), L. R. 5 C. P. (itti: I. R. 7 C. P. 84: L. R. 7 Il. L. 802 ; 39 L. J. C. P. $290 ; 41$ id. 6.5: IIarrison 8. Kansis, 50) Mo. Ajp. 3:j2: IIeath v. Stculditral (1s98). 91 Me. $499 ; 40$ Atl. R. 54 .

${ }^{3}$ Pickering v. Busk (1812), 15 Filst, 38. And see among its many contir. mations: Meggy v. Imperial (18is), 3 Q. B. D. 717; $4 \tau$ L. J. Q. B. 119: $4 \mathrm{~S}$ L. J. Q. B. 5t: lausatt v. Lippuncott (18:1), 6 Serr. \& I. (Pia.) 39\%; l'uwle v. Leavitt (1851), 23 N. H. 3.58; Taylor v. Pope (1868), 45 Coll. ('Tenn.) 416; Lewenberg v. Hayes (189i), 91 Me. 104; 39 Atl. R. 469; Atlantia v. Ilmut (1897), 100 Tenn. 94; 42 S. W. R. 483; Heath v. Stodiard (1898/. 91 Me. 499; 40 Atl. R. j4i; Van Dusen r. Jungleblut (1899), 77 N. W. Ru (Minn.) 970.

4 Bayliffe v. Butterworth (184i), 1 Ex. 429); Bailey r. Bensley (18ri). 8 i III. 556. The usare must of course lie reasonable. Mollett $v$ Robinson (1870). L. R. 5 C. P. 646; r i.l. 81: L. R. $千$ H. [.. $802: 39$ L. J. C. P. 290; 41 id. 65. And see Iruland v. Livingstone (1N(ii). L. R. 2 Q. B. 10i: : :6 L. J. Q. B. 50: Picliert v. Marston, 68 Wis. 46.5; 4.? N. W. R. 550; Western v. Page (1496i, 9. Wis. 251; $68 \mathrm{~N}$. W. R. 1003: Herring v. Skaggs (1878), 62 Ahr. 186: lierso r. Ibales (1597), $94 \mathrm{~V}$ it. 321; 20 S. E. L. $ะ 60$. 
dicate that the agency was other than what it really was, and the principal could not be estopped. ${ }^{1}$

The fact that the agent is employed to operate at a place distant from the principal has often much bearing upon the appearance of the extent of his authority.?

Rule E.

"This is the common and usual manner in which the business is done, and the agent must be taken to be vested with power to transict the business with which he is intrusted in the common and usual manner."3

livele F.

"One partner, by virtue of that relation, is constituted a general agent for anotler as to all matters within the scope of the partnership dealings, and has communciated to him, by virtue of that relition, all authorities necessary for carrying on the partnership business, and all such as are usually exercised by partners in that business in which they are engiged."

Medium Poivers Withheld - Estoppel. - As has already been pointed out, the law assumes the grant of medium or usual powers in the rarions cases just treated of. But this assumption is, of course, only made in the absence of special arrangement between the principal and agent to the contrary. Whatever the arrangement is, by that they must be bound. The public, too, is entitled to assume the grant of similar powers; the agent is acting as though he had such powers; and the public assumes that he has them. If he has not? In such case the law of agency declares that the principal cannot be hound; for, as Mr. Dicey told us:

"The principal is always bound by the acts of the agent, up to the extent of the agent's authority, and is never bound beyond the extent of that authority."

But it is precisely at this point that the law of estoppel intervenes - the law which probibits the principal asserting the fact that the power of the agent is other than that which he has allowed it to appear to be.

The following are some of the statements of the rules which apply to such cases. It will be observed that they are not

1 Baines v. Ewing (1866), L. R. 14 Ch. D. 133; 46 L. J. Bk. 20; Atty. Ex. 320; 4 H. \& C. 511 ; 35 L. J. Ex. Gen. v. Great Eastern (1\$\$0), 5 App. 194.

2 Rathburn v. Snow (1890), $123 \mathrm{~N}$. Y. $343 ; 25$ N. E. R. 379.

3 Alexander v. Gibson, 2 Camp. 555. And ste also Smith v. Hull (1849), 8 C. B. 6f5; 19 L. J. C. P. 123 ; Taunton v. lioyal (1864), 2 H. \& 11. 13.5: :3:? L. J. CH. 406; Ex parte Dixon (1ธ76), Cas. 473 ; 49 L. J. Ch. 545; McMullen v. Willians (1880), 5 Ont. App. 518; Hayner v. Churchill (1588), 29 Mo. App. 676: Cawthorn v. Lusk (1892), 97 Ala. 674; 11 S. R. 731.

4 Hawken v. Bourne (1841), 8 M. \& W. 710 ; 10 L. J. Ex. 361. 
couched in the language of the law of estoppel, but it is a simple matter to make the necessary translation:

"Wlien a person is deceived ly another into believing he may safuly deal with property, he bears the loss, unless he can show that he was misled by the act of the true owner."!

He may show that he was misled by the appearance of the character of the authority. The rule as to this is expressed in various ways. Pickering $v$. Busk ${ }^{2}$ is the leading case. In it Lord Ellenborough said:

"Strangers can only look at the acts of the parties, and to the extromal indicia of property, and not to the first communications which nuy pass between a principal and his broker: and if a person anthorize another to nssume the appintent right of disposing of property in the ordinary conrse of trade. it must be presumed that the apparent authority is the real authority."

In more modern cases it is said:

"Where the true owner has clothed any one with apparent authority to act as his agent, he is bound to those who deal with the apparent agerit on the assumption that he really is an agent with that authurity." 3

"Where an agent is clotbed with ostensible autliority, no private instructions prevent his acts within the scope of that authority from bind. ing his principal."

And the American law is to the same effect:

"Where a principal has, by his voluntary act, placed an agent in such a situation that a person of ordinary prudence, conversant with business usiges and the nature of the particular business, is justified in presuming that such arent has authority to perform a particular act, and therefore deals with the agent, the principal is estopped as against such third person from denying the agent's authority."s

"Ostensible authority to act as agent ma be conferred if the party to be charged as principil affirmatively or intentionally, or by lack of ordinary care, caluses or allows third persons to trust and act upon such ap. parent agency." 6

It will be observed that in none of these rules is there any reference to the distinction between general and special ageney. And there is no suggestion that they would not apply equally in an individual as in multitudinous instances.

\section{Apricications.}

Having now a sufficiently clear idea of the principles and methods to be employed in determining questions of liability of principals for ultra vires acts of other persons, let us apply

1 Cole v. Northwestern (1875), L. R. 10 C. P. $372 ; 44$ L. J. C. P. 233.

2 (1812) 15 East, 43.

${ }^{3}$ Cole v. Nortliwestern (187.5), L. R. 10 C. P. :364; 44 L. J. C. P. '33:3.

4 National v. Wilson (1880), 5 App. Cas. 209.
3 Johnson v. Investment Co. (189\%), 46 Neb. $485 ; 64$ N. W. R. 1100. And see Holt v. Schneider (1899), it N. W. IR. 1086 (Nels.).

'T'hompson v. Shelton (1896), 49 Neb. $644 ; 65$ N. W. R. 1055. 
them to some of the cases usually placed in the category of special ageney - that is, cases of a single employment. If the rules in present rogue as to the difference between general and special agents are eorrect, the principal will of course never be liable, for (as we have seen), according to Broom's Common Law,

"if a particuliar agent exceed his authority, his principal is not bound by what he does." I

And according to Smith's Mercantile Law,

"the rule is direcily the reverse concerning a particular agent; i. e., an agent employed in one single transaction; for it is the duty of the party dealing with such an one to ascertain the extent of his authority; and if he do not lie must abide the consequences." 2

A Horse Case. - The results to be arrived at, however, are fitr otherwise. "Take the case of a horse," which the owner intrusts (on a single occasion) to an agent for sale, prohibiting all warranty, and let the eircumstances vary as follows: 1 . The agent is told to sell the horse at a fair. 2. The owner of the horse is a hol'se-dealer. 3. The agent is a horse-dealer. 4. Neither the owner, nor the agent, is a horse-dealer, and no particular place of sale is prescribed.

Now, if the rule be that "it is the duty of the party dealing with" an agent, employed in one single transaction, "to ascertain the extent of his authority," then the owner is not bound in any of these cases by the warranty. But the solution is not so simple, and the varying answers will be found to be in no way affected by the singleness or frequency of the transaction. They are as follows:

1. Instructions to sell at a fair indicates a place at which the authority is to be exereised; if at that place (as has been held ${ }^{3}$ ) it is customary in selling horses to give a warranty, then the agent appears to have authority to warrant, and the owner being responsible for that appearance is estopped from denying the actual existence of the power. If it is not usual at that place to sell with a warranty, then there is no appearance of power and therefore no estoppel. ${ }^{4}$

18 th ed., 575 .

210 th ed., 140.

${ }^{3}$ In England. It is held otherwise in the United States.

4 Alexander v. Gilson (1811), 2 Camp. 5i5; Moran v. Pitt (1873). 42 L. J. Q. B. 47; Brooks v. Hassal (1853),
49 L. T. N. S. $569 . \quad$ As to sale of horses at fairs see the English Statutes, 2 \& 3 P. \& M., ch. 7: 31 Eliz., ch. 12, which are not interfered with by The Sale of Goods Act, 56 \& 57 Vic. (Imp.), ch. $71, \S 22$. 
2. If a horse-dealer (as has been held) usually sells with a warranty, then an agent of a horse-dealer appears to have authority to warrant, aud the horse-dealer will be estopped from assepting the contrary. If it were not usual for a horse-dealer to sell with a warranty, then there would be no appearance of power and no estoppel. ${ }^{1}$

3. So, also, if (as has been held) a horse-dealer in selling for others usually gives a warranty, then, inasmuch as in the given case he appears to have authority, the owner will be estropled from denying the authority. And if not usual, there is no estoppel. ${ }^{2}$

4. If there are no circumstances indicating existence of alltbority (such as place of operation, usual employment of the parties, etc.), then, as there is no false appearance, there is no reason why the owner should be estopped from asserting the facts. $^{3}$

The Text Boolis. - Simple and necessary as all this seems to be, the present writer cannot but be aware that in so stating the law he is out of hamony with most of the text-writers. The views of some of them are as follows:

Evans on Principal and Agent, referring to Alewenter $v$. Gibson (in which it was held that when a horse was sent to a fair and the usual mode of selling there was by giving a warranty, the principal was bound by a warranty), indicates his dissent from its conclusions, leclaring that it

"was afterwarls overruled by the Court of Common Pleas: Brady v. Todd, 9 C. 3. N. S. 39 ..." 5

And the learned author might cite the language of Martin, B., in Chell v. Atherton ${ }^{6}$ in support of the statement. Both, howerer, orerlooked the fact that Alerander $v$. Camplyill was the case of an agent sent to a fair, and that Brady $v$. Tould, so far from dissenting from that case, has these worls:

"When the facts raise the quetion, it will be time enough to decile the liability created by such servant as. . a person intrusted with the sale of a horse in it fair or other public mart."

1 Fenn v. Harrison $(1 ; 90), 3$ T. R. 760 .

" lloward v. Sheward (1866), L. li. 2 C. P. 151 ; :36 L. J. C. P. 42; Baldry s. bittes (158.)), 52 L. T. N. S. 630: McMullon r. Williams (1880), j Ont. A Plי 518: Taylor v. Gardiner (1892), \& Man. 310.
${ }^{3}$ Brally s. Told (1S6!), 9 C. B. N. S. 59 ?; 30 L. J. C. P. $\stackrel{2}{2} 3$.

\section{Supra.}

${ }^{3} \mathrm{P} .46 \pi$.

${ }^{6}(1861)$ i H. \& N. 1\%9; 30 L. J. Ex. $33 \%$. 


\section{Story on Agency has the following:}

"But if the owner of a horse should send the horse to a fair by a stranger, with express directions not to warant him, and the latter sliould on the sale, contrary to his orders, warrant him, the owner would not be bound by the warrinty." 1

Everything depends, surely, upon what is usual at that particular fair.

Paley on Principal and Agent says:

"So a servant intrusted to sell a horse may warrant, unless forbidden. And it is not necessary for the party insisting on the warranty to show that he harl special anthority for that purpose." 2

This, with deference, is very clearly wrong.

Smith's Mercantile Law ${ }^{3}$ says :

"And it is said a warranty given by an agent intrusted to sell, prima facie binds the principal."

Under certain circumstances, no doubt, yes; but under others, no.

\section{Addison on Contracts says:}

"It has been held that a buyer who takes a warranty from a known agent professedly selling on behalf of his principal takes the warranty at the risk of being ahle to prove that the arent had the principal's authority for giving the warranty, and that the litw clothes a known servant intrusted to sell with no implied authority to warrant, unless such servant is the general agent of a tradesman employed in the business of buying and selling." 4

\section{Later on the author adds:}

"The servant of a horse-dealer. with express directions not to warrant, does warrant; the master is bound, because the servant, having a general authority to sell, is in a conlition to warrant, and the master had not notified to the world that the general authority is circumscribed."

The reason is not that the servant had "a general authority to sell," for it was of "circumscribed" character, as the language of the author indicates. The reason is that although the servant had only special authority, the horse-dealer, for reasons already giren, was estopped from so saying.

Still later (at p. 560) the law is better stated:

"The general presumption is that where a principal intrusts property to an agent to sell, he aluthorizes him to make all such warranties as are usual in the ordinary course of that particular business of selling, and that if it is usual to sell with a warranty he has an implied authority to warrant."

But the true point is missed. The effect of the presumption is not that ihere is "an implied authority to warrant," but that

19 th ed., sec. 132.

$2 \mathrm{P}$. 197. To the same effect is Schuchardt v. Allens (1863), 1 Wall. (U. S.) 36\%. "Autliority without restriction to an agent to sell carries with it authority to warrant." This was very recently approved in Belmont v. Talbot (1899), 51 S. W. R. 588 (Ky.). And see Bryant v. Moore (1846). 26 Me. 84.

3 lotlı ed., 142.

49 th ed., 314. 
the principal is estopped from denying that there was express authority.

"The case of a horse" has been used for illustration. But it must not be understood that the law with reference to horses differ's from the law as to groods of any other character.' For variety consider for a moment the law under other circum. stances.

Originally factors were those to whom groods were sent for sale. An owner, therefore, was bound by any sale made, whether anthorized or not ${ }^{2}$ - or rather he was estopped from denying the plenary character of the power which the factor appeared from his employment to have. It was beld nevertheless that the owner was not bound by a pledge made by the factor in breach of instructions, ${ }^{3}$ for it was thought that fictors usually sold merely and did not pledge. Afterwards the Factors Acts recognized that it had

"becone a usuinl and accustomed course for factors intrusted with goods for sile to make atluances to their principals, either in money or by the acceptanc of hills irainst their con-imments, and to keep themselves in funds by repledging the documents of title with brokers or other money dealers:"

and therefore enacted that the owner should be bound by pledges. Everything depends upon custom. The statutes proceed upon that.

And if it be asked whether a factor may bind his principal by a warranty given in defiance of instructions, the answer to that, too, is that everything depends upon custom and circumstance. If from the custom or from any other circumstance (for which the owner is responsible) an agent appears to have certain authority, the owner is estopped from denying its actual existence. All cases ought to proceed upon the same principle.

1 Mechem on Agency, sino, says: "But no satisfactory reason is perceived why the question of the warranty of a horse should stand mpon any different basis than the warranty of any other chattel." For its application to pianos see Mc.Mullen v. Williams (1880), 5 Ont. App. 518.

"See statute \& Geo. IV., ch. 83.

a Paterson v. Tash (1742), 2 Str. 1178; Fletcher v. Heath (18:5), $7 \mathrm{~B}$. \& C. 517; Cole r. N. W. Bank (1875), L. R. 10 C. P. 367 ; 44 L. J. C. P. 233 ; Johnson $v$. Credit (18ii), 2 C. P. D.
294; 3 id. 32; 47 L. J. C. P. 241; Warner s. Martin (1850), 11 How. (U. S.) 6is: Berry v. W. D. Allan \& Co. (1894), 50 ill. A IIP. 149.

45 \& 6 Vic. $([\mathrm{m}$ \%), ch. 39. See Fuentes r. Montis (1868), L. R. 3 C. P. 2i7; 38 L. J. C. P. 93; London r. Simmons (1893). A. C. 217; 61 L. J. Ch. 730. And see Cartwright 5 . Willuerding (1862), 24 N. Y. 521; Soltau s. Gerdau (1890), 119 X. Y. 380: 23 N. E. R. 864: Fourth Nat. Bank v. American (1590), 13\% U. S. 234. 


\section{III. "For tחe Master's Benefit."}

The thirl of the "difficulties" referred to in the opening sentence of the present chapter is the current misunderstanding as to the elfect upon an unauthorized act of its having been done "for the master's benefit." This dilliculty can be removed by a little careful analysis.

Let us commence with the case of MLutual $v$. Charnwood: 1 A secretary of a company represented that certain debenture stock of the company existed; the representation was false, for the stock had been fraudulently issued by the secretary for his own purposes and in excess of the powers of the company; and the representation was therefore made not for the benefit of the company, but to shield the secretary; held, that the company was not liable in deceit. Lord Esher decided the case upon the following ground:

"The secretary was held out by the defendants as a person to answer such questions as those put to hin. . . . and if he had answered them falsely on behalf of the defendants, he being then authorizerl by them to give answer for them, it may be that they would be liable. But,although what the secretary sail related to the matters about which be was authorized to give answer, he did not make the statements for the defendants, but for limself."

Compare this with the decision in Shrew v. Port Phillip: ${ }^{2}$ The secretary of a company, not being intrusted with the seal,

1 (1887) 18 Q. B. D. 714; 56 L. J. Q. B. 449. See Barwick r. English J. S. Pank (1867), L. R. 2 Ex. 259; 36 L. J. Ex. 147; Thorne v. Heard (1891), 1 Ch. 611: 63 I. J. Ch. 362; Erb v. G. W. Ry., 3 Ont. App. 4r9, 480; Molson's Bank v. Brockville (1880), 31 U. C. C. P. 1it; Gibbons v. Wilson (1859), 17 Ont. 290: Richards v. Bank of Nora Scotia (1896), s6 S. C. Can. 381; and the decision of the Privy Cunncil in McKay v. Comm reial Bank (18;4), L. R. 5 P. C. 394; 43 L. J. P. C. 31 , where is expressly reserved the question whether the absence of benefit retld have varied the result.

2 (1884) 13 Q. B. D. 108; and see 53 L. J. Q. B. 372. Distinguish the contemporaneous case of Northern Counties v. Whipp (1884), 26 Ch. D. 457 ; 53 L. J. Ch. 6;5, where the com pany was not estopped by the act of its manager, because he had no authority to do the class of acts of which the instance in question was one. See also Re Overend (1869), L. R. 4 Ch. 475 ; 39 L. J. Ch. 27; Bryant v. La Banque (1892), A. C. $1 \% 0 ; 63 \mathrm{~L}$. J. P. C. 68: Re Building, etc. (1896), 1 Ch. $100 ; 65$ L. J. Ch. 104: Biggerstaff v. Rowatts (1896), 2 Ch. 93; 6.j L. J. Ch. 586; Re Concessions (1836), 2 Ch. 75\%; 65 L. J. Ch. 909: Robinson v. Montgomery (1896), 2 (h. $841 ; 65$ L. J. Ch. 915; Smith v. Walkerville (1896), 23 Ont. Ap]) 102.

The American cases agree with Shaw v. Port Phillip: Fifth Avenue Bank v. Forty Second (1892). 6:3 Hun, 629; 17 N. Y. Supp. 826; 137 N. Y. 231; 33 N. E. R. :38: Allen v. South Boston (1889), 150 Mass. 200; 2: N. E. R. 917; Union Loan v. Southern California (159:), 51 Fed. R. 840. 
grot possession of it and aflixed it to a certificate of shares, and forged also the signature of one of the directors. He was acting entirely for his own benelit. The platintiff acted upon the faith of the certificate, and the company was held to be estopped.

"The company made it the duty of the secretary to procure the preparation, execution, and signature of eertificates with the preseribed formalities. and thereupon to issue them to the persons entitled to receive them. They thereby gave the secretary the opportunity of doing what he has done in this case. A person cain informhinself whether the certifieate cones from the seeretiry, because he gets it from the secretary's oflice; but I to not see how, accorling to any practicable course of business. he can go behind the certiticate, and aseertain for himself such matters as whether the signature of the director is genuine. It appears to me, therifore, that the company have anthorized the secretary, and malde it his oificial duty, to act in such at way thit his alets amount to a warranty by them of the genuineness of the certificate issued by him."

Both cases seem to have some foundation. With the first we go this far: An agrent has authority to do a certain act for his principal; but that gives him no power to bind his principal if he does the same thing on his own behalf; therefore, whether the principal ought to be liable must depend upon whether the agent was acting for the principal's benefit or for his own. But the second case takes us further, and suggests that where an agent appears to be acting in pursuance of his authority and not for himself, it would be unjust to affect the person dealing with him by that which was purposely kept concealed, and as to which he could obtain no information. Now when we obserre that in the first case the secretary "was held out by the defendants as a person to answer such questions as those put to him;" and in answering them he appeared to be exercising the authority with which he had been intrusted, we feel that the two decisions are inconsistent; unless indeed one can be upheld upon the ground that it was an action in deceit, and the other because it proceeded upon estoppel. Is there a distinction here, or is one of the cases wrong?

Deceit and Estoppel.-Observe the difference between estoppel and tort as to the reason for bolding a principal liable for the unauthorized act of an agent. In estoppel you say that the agent appeared to hare authority; that the principal was re-

Distinction must of course be made where the officer who issues the certilicate is not the one intrusted with that luty: Hill v. Jewett (1891), $15 t$
Mass. 172: or where the purchaser had notice: Moores v. Citizens (1583), 111 U. S. 156 ; 15 Fed. R. 141 ; 4 S. C. R. 345 . 
sponsible for that appearance; that upon the faith of that appearance you changed your position; and that therefore the principal ought to be estopped. Nothing of that sort can be said in tort. An omnibus driver, in defiance of instructions, overturns a rival omnibus, ${ }^{1}$ or runs over a pedestrian, and the master is liable; but not because the party injured changed his position upon the faith of any appearance of authority. In estoppel you say that you were misled; that you acted upon the misrepresentation, and so were injured. In tort you say merely that you were injured. In estoppel you acted voluntarily; and seek notwithstanding that to put the responsibility elsewhere. In tort you were acted upon.

The cases then are very different, and we must expect to find some difference between them as to the ground of liability of the employer. In tort, inasmuch as nothing can turn upon appearance of authority, every thing must depend upon whether the agent was really acting for his master's benefit or for his own - in other words, whether be was acting in the course of his employment or outside of it. But in estoppel the contrary is the case. There appearance of authority is the sine qua non and the reality is unimportant, for the fact is excluded by the estoppel.

In tort, then, we may say with Willes, J.: ${ }^{2}$

"A person who puts another in his place to do a class of acts in his absence necessarily lea res hin to determine, according to the circumstances that arise, when an act of that class is to be done, and trusts him for the manner in which it is done; and consequently he is held answerable for the wrong of the person so intrusted, either in the manner of doing such an act or in doing such an act under circumstances in which it ought not to have been done; provided that what was lone was done not from any caprice of the servant, but in the course of his employment."

In estoppel, on the other hand, it is immaterial that the agent was really acting for himself and in fraud of his principal, if the agent had or appeared to have the autbority; or appeared to be or was acting within the authority which be had. Estoppel provicles that

"Whenever the very act of the agent is authorized by the terms of the power. . . such act is binding on the constituent as to all persons dealing in good faith with the agent; such persons are not bound to inquire into facts aliunde." 3

1 Limpus v. London (1852), 1 H. \& B^ll (1879), 3 Ex. D. 245; 47 L. J. Ex. C. 526 ; 32 L. J. Ex. 35 .

705; Barwick v. English (1867), L. R.

2 Bayley v. Manchester (1872). L. R. 2 Ex. 259; 36 L. J. Ex. 147.

7 C. P. 420; and see $4:$ L. J. C. P. 78.

See pər Bramwell, L. J., in Weir v.

3 Infra. 
Consider the partnership cases - the firm is liable upon an. acceptance given by an inclivilual member in the name of the firm but for his own purposes. Could it be said (as in the British Mutual v. Charmwood ease) that there was no liability, because although the accepting partner was authorized to atecept for the firm and appeared to be doing so, yet that he did not do it "for the defendants, but for himself?"

This is a clear case of principals being liable, although the agent was not only not acting for their benefit, but in fraud of them and to their cletriment. And he was not acting in the course of his employment in any other sense than was the secretary in the British Mrutual v. Charnwood case.

It seems, then, that a principal may be liable in estoppel although the agent was acting for himself, and not for his master's benefit, but that it is otherwise in tort. The Shaw w. Port Phillip case therefore is unimpeachable. How stands British Mutual v. Charnwood?

It was an action in deceit. It was therefore (as usually classified) in tort; ${ }^{1}$ and we have said that in tort the complaint is not that you were misled; that you consequently changed your position; and so were injured; but merely that you were injured. But have we not generalized too widely? Is it true that in deceit the ease is merely that you were injured? Not at all. Upon the contrary, the necessary factors in deceit are precisely those which we found to be necessary in estoppel: (1) a misrepresentation, (2) change of position, and (3) consequent damage? In this respect, then, deceit seems to be distinguished from other kinds of torts; and to be closely allied to estoppel. ${ }^{2}$

And it approaches contract also in this: that there is in the necessary change of position something very much akin to a consideration. I represent to a merehant that $A$. is a man of substance; upon the faith of that representation the merchant gives A. eredit and suffer's dimage; and eonsideration may as well be detriment to the promisee as benefit to the promisor the merchant has therefore given some sort of consideration for my representation. If, in consideration of the merchant

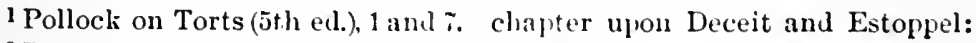

2 Peruse in this cunnection the cli. XVI. 
giving crellit to A., I had guarantied his solvency there would have been a clear contract. It is not very far from that to this: I represent to you that $A$. is solvent; and if, upon the faith of that statement, you trust him and lose, the law will compel me to pay your loss - remember, I do not guarantee to pay, it is the law that will make me pay. There is an express promise in the one case; while in the other the law compels payment just as thongh there were an express promise. This is often called an implied promise. Note also that in deceit there is (as in contract) the element of voluntary action, the responsibility for which, however, you desire to place elsewhere; and that in this respect also it differs from other torts.

The action in contract is: In consideration of the plaintiff doing so-and-so, the defendant promised so-and-so. In deceit it is: The defendant, by falsely representing so-and-so, induced the plaintiff to do so-and-so. The essentials are somewhat the same, namely: (1) an inducement by the defendant to action on the part of the plaintiff; and (2) some change of position on the part of the plaintiff.

On the other hand, claims in other actions of tort run in these forms: "That the defendant wrongfully converted," ete. ; that the defendant disregarding his duty," etc.; "that the defendant so negligently carried that," etc. The action, in other words, arises ex parte, as it were, and not from mutual interaction, as in contract and deceit.

Admitting then the general rule that in tort the prineipal is not liable for the unauthorized act of his agent unless it is clone, not for himself, but for his master; but observing that in estoppel appearance of acting for the master is sufficient to mako him liable, what is to be sail with reference to actions of deceit? Are they for this purpose to be classed with actions of tort or to be placel with their closer affiliations? To the present writer's mind (somewhat filled, as at present it is, with the principle of estoppel) the answer cannot be doubtful. In the British Mlutual v. Clearnwood case

" the secretary was held out by the defendants as a person to answer such questions as those put to him;"

he did answer them, and answered falsely; and it is said that the defendants are not liable in deceit, because "be did not make the statement for the defenclants, but for himself." But 
the secretary had anthority to do the class of acts; and his aet appeared to be within that class; ${ }^{1}$ and the defendants ought to have been estopped from denying that the act was theirs. ${ }^{2}$

\section{IV. "Wirhis me Seope of IIs Aplarext Althomity."}

Elueidation must now be directed to another phrase constantly met with in the law of principal and agent: namely, that an agent's unathorized aets will bind his principal where such acts are "within the scope of his apparent authority." This is difliculty number four.

Let us drop the word "scope," for it is useless and misleading. It is suflicient to say that the agent aeted within or beyond his authority. Inserting the word "seope" adds nothing to the expression, for an aet cannot be beyond authority and yet within the seope or extent of it. Omitting the word, we have the statement that if an agent act within his apparent anthority (within the authority which he appears to have within his ostensible authority) the prineipal will be bound. This is true; but it is also true (although it is not usually so formulated) that if an agent appears to be acting within bis authority, the principal will be bound. Let these alternatives be put in the following form, and denominated (A.) and (B.); and let us test their value:

(A.) If an agent acts within what appears to be his authority, the principal is bound.

(B.) If an agent appears to be aeting within his authority, the principal is bound. ${ }^{3}$

Application of (A.).- I employ a broker to sell my shares in the market, giving him special instructions which limit his usual powers; he sells in disregard of my instructions; and I am bound.4 Observe that the reason is beeause he was aeting within what appeared to be his authority (A.). And it cannot be said that he appeared to be acting within his real authority (B.), for his real authority was unknown.

1 See this point elaborated in the next succeeding paragraphs of the present chapter.

2 Barwick v. English (186i), L. Ii. 2 Ex. 266: 36 L. J. Ex. 147, bears out the conclusion.
${ }^{3}$ It would be more correct of course to say in these cases that the principal is estopped from denying that he is bound.

+ Ante, p. 459. 
Application of $(B$.).-I take a check to a bank for acceptance; the ledger-keeper has no authority to aceept unless there are funds; nevertheless, in the absence of funds he does accept; and the bank is bound. The reason is that the ledgerkeeper appeared to be aeting within bis anthority (B.). It cannot be said that be was acting within what appeared to be his authority (A.); for I did not imagine that be had authority to accept if there was notling at the check-d rawer's credit. There was no appearance of authority that did not corrrespond to the fact (A.). But so far as I could see, the ledger-keeper was acting within his authority (B.).

In other words, in the (A.) ease the question is whether the act is really within the ostensible autbority; and in the (B.) case whether it appears to be within the real anthority. There may be appearance as to the extent of the real authority (A.); and appearance as to the act being within the real authority (B.) - appearance in relation to the authority (A.); and appearance in relation to the act (B.).

"Class of Acts."- This distinction is of peculiar assistance in dealing with those very various cases in which an agent is intrusted with authority to perform a certain "class of acts," and in which he does an act which appears to be within the class as, for example, the case of the bank ledger-keeper just referred to. Had it been appreciated, it is probable that the cases affected by it would present more uniformity than can be predieated of thein.

In some departments of the law the operation of the distinction, if not the distinction itself, is very apparent. Observe first the law of partnership. Each partner is usually intrusted with the performance of a class of acts; amongst other things, to accept bills for the purposes of the firm. Now, suppose that a partner accepts a bill in the firm's name, but for his own purposes; is the firm liable? May it not be said that he had no power to bind the firm by such an aceeptance? He had authority to accept for firm purposes; everybody knew that bis authority was thus limited; should not everybody interested have inquired whether this particular instanee of the class to which it belonged was within his authority? The true answer and its reason have just been statel. The act appeared to be within the accepting partner's authority (B.), and his copartners are therefore estopped. 
A root example of the same ductrine is presented by the case of Sevire v. Fremeis.' $\quad$ un algent in change of his principal's business had power to daw bills upon P. CE S. for advances in respect of purchatses male on account of that firm. The aregent drew upon ls. W S. for an amomnt which had noi been, but which he asserted to them hat been, alsanced for purchases on their accomt, and received the moncy. The principal was helat to be bound to repray the amount to $\mathrm{B}$. \& $\mathrm{S}$. The act appeared to he within the anthurity (B.).

Montrignes $v$. Shith" was somewhat similar. It related to powers of borrowing to be exercised under certitin circumstances. In griving jumlegment Lord IIerschell satil:

"If the occision might latwe arisen on which his borrowing powers would hive heen properly inlerpereted as comprining the recourse fosuch means as these, then their lomblaing to not think it was incumbent upon the lender to inguire whether in the particular cabe the comergency had arisen or not."

In an American case ${ }^{3}$ it was contended without much success that the authority of an agent to sell goods wis limited to sales to persons who were "responsible and in tirst-class eredit," and that contracts, therefore, with persons of other character were not binding upon the principal. In another case ${ }^{4}$ an agent's purchase of unripe cabbages was repudiated (but unsucecstully) because his anthority was to purciase those only which were quite mature.

The law applicable to such cases cannot be better put than in the following extract from a judgment by Finch, J. It suggests some better phraseology than that associated with a "cliass of acts:"

"It is a settled doctrine of the law of ngency in this state, that where a

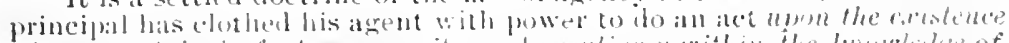

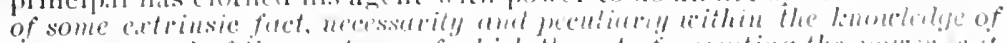

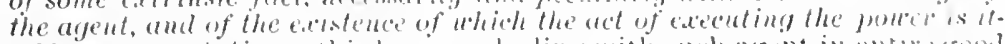
self a represcutation, at thirl person dealing with such a fent in entere good faith. pursuant to the alparent power. maly rely mpon the representillon, and the principhl is cotelpeed from denying its iruth to his prejullee." 5

This language is very applicable to the case already referred to) of a bank ledger-keeper "matring" a check. It mity be

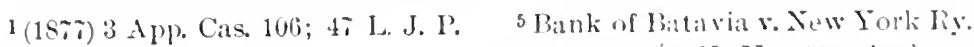
C. 18 .

$2(1890) 15$ App. Cis. 362. Co. (15:3), 10; X. Y. 19\%. Anl see Bank of New lork s. American, ete.

3 Merrinac v. Illinols (18se), $30 \mathrm{Ill}$. Co. (1s94), $143 \mathrm{~N}$. L. 563 ; is $\mathrm{S}$. E. R App. : :ts: 21 N. E. R. isi. 713.

4 Jaker s. Jiarnett (1S9\%), 113 Mich. $533 ; 71$ N. IV. L. s66. 
said that that officer's authority extends only to cases in which there are funds of the drawer on hand. But this is an "extrinsic fact, necessarily and peculiarly within the knowledge" of the ledger-lieeper. In a very instructive judgment concerning such a case Selden, J., saicl:

"The bank selects its teller, and places him in a position of great responsibility. Persons having no voice in his selection are obliged to deal with the bink through him. If, therefore, while acting in the business of the bank and within the scope of his employment, as far as is known or can be seen by the party dealing with him, he is gulty of a misrejresentation, on wht not the bank to be held responsible?"1

"It is. I think, a sound rule that where the party dealing with an agent has ascertained that the act of the agent corresponds in every particular, in regard to which such party has or is presumed to have any knowledge, with the terms of the power, he mal take the representation of the agent as to any extrinsic fact which rests peculiarly within the knowledge of the arrent, and cannot be ascertained by a comparison of the power with the act done under it." 2

Maling reference to Attwood v. Munnings ${ }^{3}$ and Alexander v. MeKenzie, ${ }^{4}$ the learned judge added:

"The general princip!e laid down in such cases is in perfect accordance with the views here expressed. It is simply that where an agent accepts a bill in a form which imports that he acts by virtue of a special power, any person taking the bill is bound to inquire into, and is chargeable with knowledge of, the terms of the power. This is not denied. But the question is whether, after inquiring in to the terms of the power, and ascertainine as far as can be done by comparison that the act of the agent is within the power, he is chargeable without proof with a knowledge of extrinsic facts which show the act to be unauthorized?"

Applying that rule to the case in hand the learned judge said:

"It is conceded that every one taking the checks in question would be presumed to know that the teller had no authority to certify without funds. But this knowledge alone would not apprise him that the certificate was defective. To discover that he must not only have notice of the limitition upon the powers of the telles, but of the extrinsic fact that the bank had no funds: and as to this extrinsic fact, which be cannot justly be presumed to know, he may act upon the representations of the agent. There is a plain distinction between the terms of a power, and facts entirely extraneous upon which the right to exercise the authority confered nay depend. One who deals with an agent has no right to confide in the representations of the agent as to the extent of his powers. - . But in regard to the extrinsic fact, whether the bank had funds or not, the case is different. This is a fact which a stranger who takes a rheck certified by the teller cannot be supposed to have any means of knowing." 5

1 Farmer's' \& M. Bank v. The Butcher's' \& D. Bink (18.57), 16 N. Y. 133. The passage has been quoted with approval in the United States Supreme Court. Merchants' Bank v. State Bank (18;0), 10 Wall. 646.

2 Id., p. 135 .

3 (1827) 7 B. \& C. 278; 1 Man. \& Ry. $66 ; 6$ L. J. K. B. O. S. 9.
${ }^{4}(1848) 6$ C. B. $766 ; 18$ L. J. C. P. 94. ${ }^{5}$ See also Exchange Bank v. People's Bank (1887), 23 Can. J. J. 391 (S. C. Can.); North River Bank v. Aymar (1842), 2 Hill, 262: New York v. National (1872), 50 N. Y. 575 . But see Murray v. Eigle Bank (1845), 50 Mass. 306. 
The view of the law here presented was carried from the United States to the Province of Quebec; and, upon appeal from the court there, was adopted by the Judicial Committee of the Privy Council, ${ }^{1}$ where it was said:

"The law appears to their lordships to be very well stated in the court of appeal of the state of New York in President : Cornen, ${ }^{2}$ citel hy Andrews. J.. in his judgment in another case brought by the Quebec: T3ank against the company. The passage referred to is a follows: Wherever the very act of the agent is authorized by the terms of the power, that is whenever by comparing the net done by the agent with the words of the power the act in itself is wirranted by the terms used. such act is binding on the constituent as to all peroons dealing in good fisith with the agent; such persons are not bound to inquire into facts aliunde. The apparent autlority is the real authority." "3

Jarmain $v$. Hopper is in another department of the law, and although not so professing, in reality proceods upon the principle in hand. Plaintiff's attorney directed a sheriff to seize goods, which turned out not to be the goods of the defendant. The plaintiff repuliated the act of the attorney, asserting that he had no authority to direct the seizure of anybody's goods but those of the debtor. Tinclal, C. J., said:

"And when it is argued that he (the attorney) cannot be his agent in giving false information, the answer is that if his agent do the particular act the client must stind the consequence if he act inalvertently or ignorantly, as in Parsons v. Lloyil, 3 Wils. 341 , where trespass was held mintainable against the client for causing the plaintiff to be arrested under a writ which was afterwards set asule for irregularity. It was argued in that case that suing out of the wit was the immediate act of tine attorney: that he had not heen retained to sue out a void or an irregular wit: and that it was therefore not within the scope of his authorty. But it was answered by De Grey, C. J., that "the act of the attorney is the act of his client,' and hy Goukl, J., that 'the pliantitf should have euployed a more skilful and diligent atturney: for the act of the attorney in point of law is the act of the pirty lis client." "

The attorney did not act within his apparent anthority ( 1 .), for his apparent authority did not differ from his real authority. He did, however, appear to be acting within his authority (B.), and the elient was liable.

So also where a manager of a bank made a representation (false to his knowletge) as to the crelit of R., and upon the faith of the representition the plaintiff advanced money, the batuk was held to be liable. For although it was not within

1 Bryant v. La Panqur du Peuple (1893), A. C. $180: 6 \%$ L. J. P. C. 73.

2(186i) 3\% N. Y. $3: 2$.

${ }^{3}$ This last sentence is incorrect; sulstitutiner as it does our (A.) for our (B.) case. The apparent antiority (in the cases alluded to) is as a mit- ter of fact always the real authority, ani requires no assumption or principies of law to make it so. That the act is apparinty within that authority (13.) is the point iutented. 4(1s13) 6 M. di (i. 850; 13 L. J. C. P. 66. 
the manager's authority to make false representations as to credit, yet to a person not aware of the falsity he appeared to be acting within his authority (B.). Upon appeal the decision was reversed, but upon other grounds. ${ }^{1}$

In a somewhat similar case ${ }^{2}$ a bank manager by misrepresentation induced the plaintifis to accept bills of exchange in which the bank was interested. IIeld, that the bank was liable in deceit, and the language of a prior judgment ${ }^{3}$ is quoted with approval:

"In all these cases it may be said, as it was sair here, that the master had not anthorized the act. It is true he has not authorized the particular act, but he has put the agent in his place to do that class of acts, and he must be answerable for the manner in which the agent has conducted himself in doing the business which was the act of the master to place him in."

This langnage, howerer, is not satisfactory; for may it not be said that the question is begged when it is asserted that the agent had authority to perform the class of acts in question?the fact being that he had no power to do the particular act. In truth are not the statements contradictory? If the particular act belongs to a class, and if there was authority to perform all the acts in that cliss, there was, of course, necessarily power to do the particular act - but ex hypothesi there was not. ${ }^{4}$ This difficulty is avoidel by using the better phraseology employed by Finch, J., already quoted. ${ }^{5}$

The foregoing review shows very clearly the widely extended operation of the (B.) principle; and seems to demonstrate that it merely requires to be formulated in order to be accepted. For lack of earlier formulation and the consequent grouping together under a recognized principle of the seemingly very diverse cases to which it is applicable, one set of them (shortly to be mentioned) has somewhat rigidly (in England and Canadia) established itself in opposition to the general trend. These cases may, however, be searched in vain for any attempt at

1 Swift $\nabla$. Winterhotham (1873), L. R. 8 Q. B. 244 ; L. R. 9 Q. B. $301 ; 42$ L. J. Q. B. $111 ; 43$ id. 56. See, however, British v. Charnwood (1887), 18 Q. B. D. 717 ; 56 L. J. Q. B. 449 , per Bowen, L. J.

2.rekay v. Commercial Bank (15it), L. R. 5 P. C. 410 ; 43 L. J. P. C. 36 .
${ }^{3}$ Barwick v. English (1867), L. R. 2 Ex. 266; 36 L. J. Ex. 147.

4 This reminds one very much of the obvious criticism of the syllogism as a form of reasuning, namely, that when the conclusion arrived at is correct, it is always already contained in the premises.

5 Ante, p. 50.3. 
a general synthesis of the law applicable to them, and the textwriters unfortunately do not suggrest their close relation to those with which we have been dealing.

Before passing to them let it be remarked that not the least advantage to be derived from a clear perception of the recognition of the dnal character of the subject (hitherto theoretically referred to one phrase - "within the scope of his apparent authority") is the fact that we are now better able to test liability of prineipals in disputed cases. Hitherto it has sometimes been impossible to declare anganst liability, even if the case did not fall within the customary phrase; for we wero conscious that there were very many cases to which it did not apply but yet in which there ought to be liability; and for these we had no rule. The present writer ventures to hope that it is now otherwise.

Will not the distinction assist in giving us a clear view of this case: A company wanted to borrow $₫ ?, 000$ upon the security of some of its stock; its broker fraululently applied to a banker for $£ 6,(100)$, who arreed to make the loan upon receiving $£ S, 000$ of the stock; the company issued that amount, and the broker received $£ 6,000$ from the banker and paid orer $\{3,000$ to the company; the banker knew that the broker was an agent. Who is to lose - the company or the banker? For answer we say that the real authority was to borrow $\$ 3,000$; that the transaction had no appearance of being within that real authority (B.), and there was no appearance of any other authority than that actually conferred (A.). We must then saly that the company cannot be bound by the manthorized act; nor can it be estopped from saying that it was unathorized.

A recent case, nevertheless, contralicts this conclusion:

"It seems to me that the one fact which was present to his (the banker's) mind was the fact that the company deliberately put Power into at position to represent them."

But that is what everyboly does who employs an agent; and estoppel arises only when the prineipal puts an agent into a position to misrepresent bim - enbbles him either to present the appearance of having greater power than he really has (A.), or to malie the act appear to be within his real aluthority (B.).

If this conclusion is wrong the present writer will at least

1 Robiuson v. Montgomeryshire (1891), 2 Ch. $841 ; 65$ L. J. Ch. 915. 
hare the satisfaction of knowing that the case brings destruction to those also who insist that in the case of

"an agent employed in one single transaction . . . it is the duty of the party dealing with such an one to ascertain the scope of his authority; and if lie do not, he must abide the consequences." 1

Bills of Lading. - We are now ready to approach the law with reference to unauthorized bills of lading; but we are hardly prepared for the very exceptional results which have been arrived at in that department of the law. The problem is this: The master of a ship, or the freight agent of a railway company, signs and issues a bill of lading for goods which hare not been shipped; it was part of his duty to sign bills of lading for goods shipped, but he bad no power to sign if the goods were not shipped; the bill is transferred to a holder in due course; are the ship-owners liable upon the bill?

Acceptance of the conclusions already arrived at would seem to leare little room for hesitation as to the answer to be given. It is but another example of the (B.) cases, namely, those in which the agent appears to be acting within bis authority - a case in which

"a principal has clothed his agent with power to do an act upon the existence of some extrinsic fact necessarily and peculiarly within the knowleuge of the agent;" 2

and it

"was not incumbent . . to inquire whether in the particular case the emergency had arisen or not." 3

The anthorities nevertheless are to the contrary effect, and determine that the carriers are not liable. No general survey of the law is, however, attempted; and the reasons advanced are out of harmony with the cases above quoted, and appear to the writer to be fallacious. A short review and discussion of them will aid in the understanding of the general application of the principles of estoppel; and may perhaps be not without some benefit in clearing the particular subject of some of its difriculties. Let us look at the two principal decisions:

(1851) Grant v. Norway." This is the learling case on the subject. The master of a ship gave a bill of lading for goods not

1 Ante, p. 492.

2 Ante, p. 503.

3 Ante, p. 503 .

410 C. 13. 688; 20 L. J. C. P. 98 . See also the earlier case of Howard $\mathbf{v}$. Tuclier (1831), 1 B. \& Ad. 712; 9 L. J.
K. B. O. S. 103; and the later ones, Hubbersty v. Ward (1853), 8 Ex. 330; 22 L. J. Ex. 113; Mc:Lean v. Fleming (1871), L. R. 2 H. L. Sc. 128 ; Brown v. Powell (1875), L. R. 10 C. P. 562; 44 L. J. C. P. 289; Cox v. Bruce (1886), 
shipped; the bill was assigned to the plaintiff; the jury found that, "by the custom of merchants, bills of lading are commonly pledged and deposited by the holders with others as security for the payment of money; " and that by the bill the holders of it "were enabled to plerlge and deposit the said bill . . . as security for the payment of money." It was held that the shipowners were not liable:

"It is not contended that the captain harl any real authority to sign bills of lading unless the goods haul been shipped: nor can we discover any grounds upon which a party taking a hill of lating by indorsement would be justilied in assmming that he hald atuthority to sign such bills, whether the goods were on board or not. If then from the usage of trade and the general practice of shipmasters it is generally known that the master cle. rives no authority from his position as mister, the case may be consilered as if the party taling the bill of latling hall notice of an express limitation of the authority; and in that case undoubtedly he could not claim tobind the owner by a bill of lading signed when the goods therein mentioned were never shipped."

The master (lid not act within his apparent authority (A.). That he apparently acted with in his authority (B.) was not present to the minds of the judges.

(1Ss1) Erd v. Great Western Ry. Co. ${ }^{1}$ is to the same effectthe authority of the agent

"was in limited authority: lis power and the authority to sign a bill of lading dependel on the actuil receipt and shipping of the goods. If the fact on which the power depended did not exist the authority could not exist.". 2

The data of the problem aro that the master had no authority to sign a bill of lading unless the goods were shipped $;^{3}$ and that be did sign although the goods were not shipped. There can be no doubt, therefore, that the owners cannot be bound unless they are in some way estopped from showing the facts. If now the question be whether the master was held out as having authority to sign when no goods were delivered - whether this signing was within his apparent anthority $(A$.$) ? the answer$

18 Q. B. D. 44ז; 56 L. J. Q. B. 121 ; Thorman v. Burt (1880), j4 l. T. N.S. 319; Porter on Bills of Lauling. $\$ \$ 16 \%$. 180, 428; Travis on Sales, vol. II, pp. 8-29. The point seems to have been overlooked in Coventry r. C. E. Ry. Co. (1883), 11 Q. B. D. $7 \% 6 ;$ 5) I. J. Q. B. 694. The statute (18 \& $19 \mathrm{Vic}$ (linp.), ch. 111, s 3 ) rendering bills of lating conclusive evidence of shipment "agaiust the master or other person signing the same" does not affect the question under discussion. Jessel r. Bath (1867), L. R. $2 \mathrm{Ex}:: 67$; 36 L. J. Ex. 149; Brown v. Powell (1505), L. R. 10 C. P. 562; 44 L. J. C. P. 289.

1 (1ST) 42 U. C. Q. B. 90; 30 Ont. App. 446; 5 S. C. Cinn. 179. See also Oliver v. G. W. R. Co. (15ii), 28 U. C. C. P. 143 .

$25 \mathrm{~S}$. C. Can. 159.

If he had cullit questio. See 18 \& 19 Vic. (Imp). ch. 111, s่ 3 . 
must still be in the negative, and there can be no estoppel. A sentence from the case ${ }^{1}$ is indisputable:

"Be this as it may, it cannot be doubted that every person in business who deals with a railway company knows that in the ordinary and usual course of business no such receipts and bills of lading are erer given or josucd nuless the goods have been actually roreived to be shipped; and no. boly so dealing but must know that if a freight agent, discharging the ordinary duties of a freicrlat agent, did give or issue such receipts and hills of lacling without the gools having been dolivered, he would be acting in direct opposition to his duty and in fraud of his principals."

Undoubtedly so. But every person "knows that in the ordinary and usual course of business" a partner who uses the firm name for his own purposes "would be acting in direct opposition to his duty, aud in frand of his principals;" nevertheless the firm is liable.

Every one linows, too, that a bank ledger-keeper is "acting in direct opposition to his duty" if he mark a check for which there are no funds; but yet the bank is liable.

There must be some general principle which will apply to cases in which a partner binds the firm although acting for his own benefit; in which an attorney binds his client although he makes grievous blunders quite unwarranted by his instructions; in which an agent, haring power to borrow money for his firm under certain circumstances, borrows in their absence; in which an agent, having authority to give receipts, issues one without observing certain specilied prerequisites; and many other analogous cases. For such cases may we not say that it is

"a sound rule that, where the party dealing with an agent has ascertained that the act of the agent corresponds in every particular, in regard to which such party las or is presumed to have any knowledge, with the terms of the power, he may take the representation of the agent as to any extrinsic fact which rests peculiarly within the knowledge of the agent and which cannot lie ascertained by a comparison of the power with the act done under it." 2

"For, seeing somelody must be a loser by this deceit, it is more reasonable that he that employs in! puts a trust and confidence in the deceiver should be a loser, than a strang+r." 3

Or, in other words: "If an agent appears to be acting within his authority (B.), the principal is bound." If this rule be valid, then the decisions which declare that carriers are not liable to transferees of bills of lading for goods not put on board cannot be maintained.

An American writer aggrees that such a holding is, at all

15 S. C. Can. 192.

2 Ante, p. 504.

3 Per Hn't, C. J.. in Hern v. Nichols (1712), 1 Salk. 289. 
erents, "most consonant with reason and justice;" but although many of the authorities in his country have ranged themselves upon that side of the question, ${ }^{2}$ yet there are many others which hold the other view. ${ }^{3}$

Aprearance of $A$ uthority.-An interesting point connected with the appearance of authority was raised in Cole $v$. North Western Bank:4 Suppose that the owner of goods sends them to a person who carries on two businesses, that of a factor and that of a warehouseman - sends the goods to be warehoused and not sold; and suppose that the groods are nevertheless sold; is the owner bound by the sale? that is, is he estopped by appearance of authority to sell? IIad he sent them to a factor (who usually has power to sell) he woukl undoubtedly be estopperl. ${ }^{5}$ Had be sent them to a warehouseman (who usually has no power to sell) he wonld not. ${ }^{6}$ Suppose he sends them to a man who carries on both businesses? The decision was in fiavor of the owner. Blackburn, J., sitil:

"For example, if a furnisheal house be let to one who carries on the business of an anctionere he is intrusted, as tenant. with the furniture, leing in fact an anctioneer: but it never was the common law. anll could not he intended to be enacted, that if he carried the furniture to his auction room and there sold it. he colld confer any hetter title on the purclaser than if he, as anctioneer, acted for some other tenant who committed a similar larceny as a fraudulent bailee; nor. to come nearer to the fresent case, that a warelouseman or whintinger who as such is intrusted with the custoly of gools, if lie happens also to purste the trable of a factor. can give a bethe title hy sile of the roouls than he could if they hati been intrusted to some other warehouseman who employed him to selt."?

1.Mechem on Agency,

2 Wichitil v. Atchison (1578), 20

Kan. 519; Sioux v. First Nat. Bank (1880), 10 Nob. 5is6; T N. W. R. 311: Brooke v. New York (185i). 108 Pa. St. 5:9; Bank of Batavial v. New York (188\%), 106 N. Y. 19.; 12 N. E. R. 433; Smith v. Mlissouri (1895). it Mo. App. 48; $A$ mericau, etc. v. Manldock (1S99), 36 C. C. All). 4\%: 93 Fed. R. 4 ! 90.

${ }^{3}$ The Freeman v. Buckingham (155.)), 18 How. (U. S.) 152: Dean v. King (18i1), :2 Olıin St. 118: Louisiana v. Lilveille (1873). 5: Mo. $8: 0$; Baltimore v. Wilkins (15iil, 44 lod. 11: Hunt v. Mississippi (1SiT). 29 Lal. Ann. 146; Witzler $\therefore$ Collins (15i9), 70 Me. :90; Pollard v. Vinton (18s1), 105 U.S. $\tau$; Willians v. Wilmington
(1985), 93 พ. C. 42: National v. Chi-

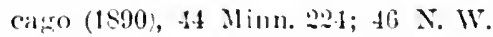
R. 342,560 . See Porter on Bills of Lading, ch. 31 .

4 (1sit) L. R. 9 C. P. 470: 10 icl. 354; 43 L. J. C. P. $191 ;$; 4 L. J. C. P. 233. See also Johnson v. Credit (15iT), L. R. 2 C. P. 22: 3 i I. 3:; 47 L. J. C. P. 241.

5 Ante, p. 489.

6 Wilkinsour. King (IS03), 2 Camp. 33.): as explained in Pickering s. lusk (181:3), 15 Ealst, 42; Cole v. $\mathrm{x}$. W. Bank (18it). 1. R. 9 C. 1'. tio: 10 i.l. 354; 44 L. J. C. L. 2:33; Fuentes s. Montis (186s), L. R. 3 C. P. 2ir: 3 i L. J. C. P. $13 \%$.

${ }^{7}$ L. R. 10 C. P. 369 ; 44 L. J. C. P. 283. 
As to the relative negligence of the parties the learned judge added:

"But if the plaintiffs knew that the warehouseman whom they trusted was also a wool broker, the defendants were aware that the wool broker whom they trusted was a warehouseman; and there seems no reason why, without inguiring, they should think he was intrusted in one capacity rather than the other."

The decision was approved in the House of Lords in City Bank v. Barrlow.'

1 (18s0) 5 App. Cas. 677. See also 313; (1892) A. C. 201; 61 L. J. Ch. 723; Sheffield v. London (1886), 13 App. Towle v. Leavitt (1851), 23 N. H. 360; Cas. 333; 57 L. J. Ch. 986; Cooke v. Tripp v. Martin (1891), 45 Kan. 765: Eshelly (188\%), 12 App. Cas. 271; 56 26 Pac. R. 424; Hamlin v. Abell L. J. Q. B. 505; Baker v. Nottingham (1893), 120 Mo. 188; 25 S. W. R. 516; (1891), 60 L. J. Q. B. 542; Simmons v. Baxter v. Sherman (1898), 73 Minn. London (1891), 1 Ch. 2\%0; 60 L. J. Ch. $434 ; 76$ N. W. R. 211. 


\section{CIIA PTER XXVII.}

\section{OSTENSIBLE AGENCY - PARTNERSIIP.}

Although headed "Partnership," this chapter is deroted to cases in which there is no partnership. If partnership exists, liability for partnership acts is clear; and it is not within the purposes of this work to determine the eircumstances under which partnership exists. The law of estoppel commences where the law of partnership ends. It treats of cases in which, admittelly, there was no partnership; and declares that, under such-andsuch circumstances, the defendant ${ }^{1}$ is estopped from saying that he was not a partner - that he is liable as though he were. For like reasons we have nothing to do with the law of agency. ${ }^{2}$ lielation of Estoppel to Partnership and Agency. - The cases with reference to the liability of promoters of companies illustrate rery clearly the relation of estoppel to partnership and agency. In such cases liability may arise in several ways: (A) Promoters may be engaged in making preliminary arrangements, e.g., obtaining the charter, advertising, etc. In such cases there is usually no partnership. The question for decision is either one of agency or of estoppel - agency if real authority is allegred; and estoppel where the defendant is not

1 For conrenience, "the defend. ant," in this chapter, will represent the person allecred to be a partiner.

2It is usual, no duubt, to speak of a partner as an agent of the firm (53 \& 54 Vic. (Imp)), ch. 39, \$5: 60 Vic. (Man.), ch. 24. 55 ; Burber v. Van Horn (1891), 54 Kan. 33; 30 Pac. R. $10 \% 0$ ); but that is not quite correct, althongh the methol of expression lats its ablvintiges, and is marle use of in the present work. When an inlividual acts as such, his action is of course his own. When lie acts as a member of a firm, the ate is not his, but that of the firm. He is not in such case an agent of the firmfor he cannot be agent for himseif.
Nor can it be said that he is acting for himself as principal and for the others as agent, for the firm is an entity. As was said by Jessel, M. R.: "If you cannot grasp the notion of a separate entity for the firm, then you are reduced to this: that inas. much as he acts partly for himself and partly for the others, to the extent that he acts for the others he must be an agent, and in that wily you get him to be an agent for the other partners, but only in that way. lecause you must insist upon ignoring the existence of the firm as at separate entity" Pooley r. Driver (1Si6), L. R. 5 Ch. D. $4.6 ; 40$ L. J. Ch. 469. 
a promoter, but, having held himself out as such, is estopped from saying that he was not one. Lake $v$. Argyll' was a case of this latter lind; but the judgment does not draw a clear line. (B) The promoters maly be carrying on business to which it is intended the company shall succeed. Liability, in such cases, is frequently based upon partnership. Estoppel arises where the person sought to be charged is not a promoter or partner, but has been beld out to be such. ${ }^{2}$

The following case ${ }^{3}$ shows the necessity for carefully distinginishing between agency and estoppel: $A$ man for a consideration gave to two other persons "leave, license and liberty to use his name in their firm, and for all and every the business purposes of said firm," stipulating, however, that he was not to be a partner. A creclitor, who had known nothing of the man $o r$ the arrangement, sned him as a member of the firm, and succeeded upon a rule which had been suggested in Parsons on Partuership: ${ }^{4}$

"Where one is held forth to the world as a partner the first question is, was he so held out by his own authority, assent or connivance, or by his nerligence. If by his authority, consent or connivince, the presumption is alsolute that he was so held out to every creditor or customer. If so held out by his own negligence only, he should be held only to a creditor who had been actually misled thereby."

Mr. Parsons has wisely omitted this rule from a later edition of the book, although it had been thus judicially indorsed, and declares that the decision which was founded upon it is erroneous. ${ }^{5}$ It is submitted, howerer, that the case may ${ }^{6}$ be upheld upon another ground, namely, that of actual agency. For the defendant having given authority to make contracts in his name, he was by that law liable upon them. It is not a sufficient reply that the contract was made in the name of the firm, and that the defendant was not a member of the firm; for the name was intended to include the defendant as well as the partners. People may contract under any name they please to adopt. The case is very like Brown $v$. Leonard, in which the defendant told the plaintiff " that be had ceased to be a part-

1 (1841) 6 Q. B. 477. The later case of Maddick v. Marshall (1864), $16 \mathrm{C}$. B. N. S. $38 \pi ; 1 \tau$ id. 829 , is more satisfactory.

2 See Wood v. Argyll (1841). 6 Man. \& G. 928: 13 L. J. C. P. !)(i: Co!!ingwood v. Blakley (1833), 15 C. B. N. S. 14is.

${ }^{3}$ Poillon v. Secor (1875), 61 N. Y. 456.
$43 d$ ed., 130.

3 th ed., 104, n. 2.

"It depen.]s upon the interpretation of the document. And see post, p. 519 ff.

${ }^{7}$ (1816) 2 Chitty, 120 . Compare Miles v. Furber (1873), L. R. 8 Q. B. $7 \tau$; 42 L. J. Q. B. 41. 
ner . . but that bis name was to continue for a certain time," and Bayley, J., said:

"Brown, notwithstanding the knowledge of the dissolution of the partnership, knew that Bush's name was to be continued and that he wats therefore responsible."

\section{Division of the SubJect.}

There are two classes of cases in which the law of estoppel in relation to partnership is most frequently appealed to:

1. Cases in which the defendant never was a member of the firm with which the plaintiff dealt; but he is alleged to be estopped from denying nembership. ${ }^{1}$

2. Cases in which the defendant had been prior to, but was not at the time of, the transaction in question a member of the firm; and it is alleged that he is estopped from setting up his retirement from the firm. This latter case may be divided into $\mathrm{t}$ wo orders of which each has two species:

1. With reference to dealings with the firm prior to the dissolution:

(a) Persons who had such dealings.

(b) Persons who had no such dealings.

2. With reference to knowledge of the constitution of the firm prior to the dissolution:

(a) Persons who had such knowledge.

(b) Persons who had no such knowledge.

The requisites of estoppel most frequently involved in these cases are as follows:

1. There must have been a representation of partnership.

2. The defendant must have either made the representation or assisted it - done that which made it credible.

3. It must have been made to the plaintiff.

4. Upon the faith of the representation credit must have been given, which implies, of course, that the plaintiff must have been aware of the representation.

\section{A Representation.}

Premising that a representation may as well be made by conduct as by direct assertion, ${ }^{2}$ let distinction be made between

1 Upon the general principle mily be cited Jacobs v. Shorey (1868), ts N. H. 100; Moore v. Harper (1896), 19 W. Va. $59 ; 24$ S. E. R. 633 .
2Dickinson v. Valpy (18:9), $10 \mathrm{~B}$. \& C. 141; Re Fraser (1893), 2 Q. B. 63i: McLean v. Clark (1893), 20 Ont. Alp. 6i1. Representation being a 
(1) the case of a defenclant who, as a matter of fact, never was a member of the firm, and (2) the case of a retired partner.

(1) Defendant Never IVas a Partner.-In this class of cases the representation is usually of some active character. The defendant has asserted directly that he was a member, or some one else with his authority or connivance bas so asserted, or his conduct has been such as to produce that impression. There is seldom much dilliculty in these cases - they usually involve questions of fact only. ${ }^{1}$ The law is clearly stated in some of the codifications:

"Every one who by words spoken or written, or by conduct, represents himself, or who knowingly suffers himself to be represented, as a partner in a particular firm, is liable as a partner to any one who has, on the faith of such representation, given credit to the firm, whether the representation has or lias not been made or communicated to the person so giving credit by or with the linowledge of the apparent partner making the representation or suffering it to be made." 2

It may be noted, however, that a representation of an intention to become a member of a firm is no estoppel. ${ }^{3}$

(2) A Retired Partner.- Upon what ground may we say that although a member of a firm retires from it, nevertbeless he may be liable upon its subsequent contracts. Clearly nothing but estoppel will suffice. For observe that the defendant is not, as a matter of fact, a party to the contracts; yet he is sued upon them, and when he pleads and proves non assumpsit he must succeed but for estoppel.

But why shonld he be estopped? What has he done? Usually he has done nothing, and is estopped because he ought to have been active. He was aware that third persons might assume that he was still a partner and might give credit upon that assumption; he was under obligation as a member of society "to observe in varying circumstances an appropriate meastre of prudence to avoid causing harm" to others; ${ }^{4}$ it was his "duty to be active;" it was his "duty" to give such

question of fact, different juries may come to different conclusions upon the same facts. Wood v. Argyll (1814), 6 Man. \& G. 928; 13 L. J. C. P. 95: Lalie v. Argyll (1814),6 Q. B. $4 \%$.

1 Sherrod v. Langdon (1866), 21 lowa, 518.

259 \& 54 Vic. (Imp.), ch. 39, §14(1); (0) Vic. (Man.), ch. 21 , 14 (1).
3 Bourne v. Freeth (1829), 9 B. \& C. 6:2; 7 L. J. K. B. O. S. 292; Reynell v. Lewis (1846), 15 M. \& W. $517 ; 16$ L. J. Ex. 65.

${ }^{4}$ Pollock on Torts (5th ed.), 22.

${ }^{5}$ Compare Ramsden v.Dyson (1866). L. R. 1 H. L. 141. 
notice of his retirement as would protect third persons from injury bzcause of that fact.'

The reason for the classification above sugrgested will now be apparent; for evidently the retiring partner's duty will not be the same to all persons, but must vary according to the position in which they respectively stood with reference to the tirm at the time of the dissolution.

For example, if after the partner's withdrawal goods wero sold to the firm, and the vendor sued the retired member, alleging that the usual notices had not been given, it wonld obviously be a sufficient reply that the vendor knew nothing of the constitution of the firm, and had no dealings with it, prerious to the dissolution; and was not therefore misled by it. But observe that (1) if the rendor bad known of the constitution of the firm, or (2) if he bad had dealings with it (before (lissolution of course), the retired member would be liable - if he had not given the customary notice.

Distinguish between these two grounds. Observe that either of them will suffice for liability; and that the only difference between them is as to the sort of notice each is entitled to receive-as we shall see. In the meantime notice how little regard some of the codifications of the law of partnership pay to the existence of such points. The Imperial and Manitoba statutes provide that:

"Where a person deals with a firm after a change in its constitution, he is entitled to treat all apparent members of the oid firm as still being members of the tirm until he has notice of the change." 2

What description of "a person" is here intended? If one who had prior knowledge of the constitution of the firm, the statute (if we may so say) is right. But if "a person" inclucles "any person," it is wrong. Again, if persons who have had previous dealings with the firm are intended, the statute is intelligible; but if all persons are included, it is not.

It might be suggested that there is sullicient ambiguity about the word "apparent" to permit of any elasticity which might be necessary in the application of the clause. For it might be said to a plaintilf who desired "to treat all apparent

I Scarf v. Jardine (1882), 7 A pp. Cas. 357: 51 L. J. Q. B. 612; Stinson v. Whitney (1881), 130 Mass 591: Strecker v. Conn (1853), 90 Ind. 469.
253 \& 54 Vic. (Imp.), ch. 39, §36; 60 Vic. (Man.), ch. $24, \S 36$. 
members of the old firm as still being members," that they must bave been thus apparent to him. But to give this relative meaning to the word would be to alter the law in a way probably not intended with reference to persons who bad previonsly dealt with the firm. For in such cases, although the person dealing knew nothing of the constitution of the firm, yet he is entitled to assume that there has been no change in its membership.

"The principle of law . . . is incontrovertible . . . that when an ostensible partner retires, or when a partnership between several known parties is dissolved, those who dealt with the firm before a change took place are entitled to assume, until they have notice to the contrary, that no ehange has occurred." 1

As to prior dealers, therefore, we cannot say that they are entitled to treat as members those persons only who were apparently so to them.

Apart from the statute and observing the distinction suggested, there is not much difficulty. Let us make three classes of cases:

1. As to those who have had dealings with the firm prior to dissolution, they "are entitled to assume, until they have notice to the contrary, that no change has occurred." In other words, persons who were members of the firm at the time of the prior dealings, whether then known to be members or not, may still be held liable as partners. This general statement must not be understood as applying to a person who two years before the transaction in question had made a single cash sale to the firm; 2 but rather to persons who bad been in the habit of dealing with the firm.

2. As to persons (1) who have had no previous dealings with the firm, but (2) who were aware of its constitution, we may say that

"in case a known member of a firm retires from it, and credit is afterwards given to the firm by a person who has had no previous dealings with it, but has become aware as one of the public that it existed, and has not

1 Per Lord Selborne, in Scarf v. Jardine (1892), 7 A pp. Cas. 349; 51 L. J. Q. B. 615. And see Miles v. Furber (18r3), L. R. 8 Q. B. 77 ; 42 L. J. Q. B. 41; McLenmore r. Rankin (1891), 68 Miss. $196: 8$ S. R. 845; Frankel v. Wathen (1899), 58 Hun, 543 ; 12 N. Y. Supp. 591 (firm changed to company); Norquist v. Dalton (1891), 32 N. Y. 240; 11 N. Y.
Supp. 351; Gage v. Rogers (1892), 51 Mo. App. 428; Robinson v. Floyd (1894), 159 Pa. St. 165; 28 Atl. R. 258; Brown v. Foster (1894), 41 S. C. 118; 10 S. E. R. 299; Arnold v. Hart (1898), 176 Ill. $445 ; 52$ N. E. R. 937.

2 Merritt v. Williams (1876), 17 Kan. $28 \%$ 
become aware of his retirement, the retiring member is liable for the amount. unless he shows that he has given reasonable public notice of his retirement." 1

3. And as to persons (1) who had no previous dealings; and (2) who bad no information as to the prior constitution of the tirm, we may ardopt the language of an American judge: ${ }^{2}$

. When a firm which remains after the dissolution as the successor of the partnership dissolved, whether carying on business under the same or a different name, has business relations with a stranger who has had no dealings with the former partnership, and who hats had no knowledere of such pirtnership, notice of any kind is unnecessiry in order to enable the retiring members of the old company to escible liability for such subserpuent contracts: but it would be otherwise held where the stranger had linowledge of the formes partnership, but had no notice, actual or con. structive, of its dissolution."

The persons then to whom it is the duty of the retiring partner to give notice are: (1) persons who had previously dealt with the firm; and (2) persons who had become aware of the constitution of the firm, although they might not have dealt with it; and the notices to be given are those prescribed by the rule requiring "an appropriate measure of prudence," namely, specific notices to the prior dealers (for they are known and can be personally reached), and general notice by public advertisement to all others. ${ }^{3}$

Name of Firm.--In connection witb the points just suggested, the continuation of the name used by the old firm is frequently of importance. For example, in the case of persons who have bad no dealings with the firm prior to the dissolution, the name, if indicative of the persons carrying on the business, may sometimes be talien as a representation that such persons are members of the firm; and such a representation would of course create an estoppel in filvor of people acting upon it. For the

${ }^{1}$ Reid v. Coleman (1590), 19 Ont. 102. See Wigle v. Williams (1595), 24 S. C. Can. 713 ; Dreher v. Connolly (1890), 30 N. Y. 6it; 9 N. Y. Supp. 635; Hahn v. Kenefich (1892), 45 Mo. Apl. 518; Alexander v. Harkins (1597), 120 N. C. $452 ; 27$ S. E. R. $1: 0$. The words, "as une of the public:" might, for the purposes of at general rule, well be omittel; for if the sime information had been obtained as an indivilual the result would no doubt be the sime.

2 Collins, J., in Swigert r. Aspden
(1893), 52 Minn. 565; 54 N. W. R. 739. See also Carter v. Whaller (15:0), 1 B. \& Al. 11: Heath v. Sansom (1832), 4 B. \& Ai. 1i:?

353 \& j. Vic. (Imp.), ch. 39, s :36 (2); 60 Vic. (Man.), ch. 24, $\$ 36$ (2). In Canada and the United States it would be very advisable to grive notice to the mercautile agencies Reid v. Coleman (IS!)0), 19 Ont. 102; Gage v. Rogers (1S!): 51 Mo. App. 4:S; Bank of Monougathelat v. Weston (1599), 150 N. Y. 801 ; jt N. E. R. 40. 
use of a firm name may estop as well those persons who were at one time partners of the firm as those who never were members of it.

"If I go to a shop and find the name 'Thompson \& Jones' on the door, and I go in and find Thompson and Jones selling goods, am I not warranted in believing that they are partners?"1

The general principle may be said to be that the permitted use of a name is

"a holling out of himself as a partner in that firm to any one who knew, or liat reaison to believe. that this represented the name of the defendant, and not that of some other person." 2

Employment upon the premises in such way as might indicate either partnership or managership, without more, is said not to be sufficient to estop. ${ }^{3}$

Ilistoric and Indicative Names. - Turning to the cases in which a prior name has remained unchanged notwithstanding the withdrawal of one of its members, a distinction must be made. Firm names are sometimes indicative and sometimes merely historic; and may easily pass from the one to the other. Where they indicate who the members of the firm are, great care bas to be taken by a retiring member, for the firm name is a constant assertion that he is still there.

The often-cited case of Nerssome $v$. Coles ${ }^{4}$ was a case in which the name had become historic. Thos. Coles \& Sons, by that name, had carried on business, and when the father died the name was continued. It then, of course, ceased to be indicative. Afterwards two of the sons retirel, leaving the third the sole proprietor of the business, who still maintiined the old name. He became indebted to a creditor who tried to hold the other sons liable because of the continuation of the sign. But the clear answer was (although not put exactly in that way) that the name was historic, and owing to the death of Thos. Coles harl ceased to have the appearance of being indicative.

This reasoning would not apply, of course, to a case in which "Archer" retired from the firm of "Keats, Archer \& Co." For there, although the name has in reality become historic, it still

1 Ex parte Hayman (1878), 8 Ch. D. 17; 14 L. J. Bk. 54. And see McLean v. Clark (1893), 20 Ont. App. 665; Bartlett v. Raymond (1885), 139 Mass. 275; 30 N. E. R. 91.
2 Per Osler, J., in McLean v. Clark (1893), 20 Ont. App. 668.

${ }^{3}$ Edmunson v. Thompson (1861), 2 Fos. \& F. 564.

4 (1811) 2 Camp. 617. 
retains the appearance of being indicatice. In that case Archer was liable because

- He hal imprudently suffered notice to ragiven of the continuance of the parturership, by permitting his name to remain on the door." 1

The distinction between historic and indicative names was altogether overlooked in Re Fraser." From the firm of "W. Wt $J$. Friser" the J. retired; the old name was continuel; afterwards certain bankers discounted a bill accepted by "W. \& J. Fraser," and sued the J. member upon it. They were beaten, Kay, L. J., saying that Newsome v. Coles showed that carrying on the business in the old name did not

"insount to a representition by lijen to the bank that he, John Fraser, was a jartner in the firm."

Lorl Esher said that there was no evilence of any holding out by John Fraser to the petitioning creditors:

"If they had dealt with the old firm. and had no notice of the dissolution of paitnership, the case would be entirely different."

But it is immaterial, as we have seen, whether the case is one of a new or an old dealer, if the creditor had had knowlelge of the constitution of the firm. And so the case would be reduced to one of fact, in which respect it is defectively reported. It suggests this question, however: whether if an indieative name be continued and people be misled, it is a sufficient answer to say that notice of the dissolution was advertised in the Gazette - whether an oflicial and never-read notice of a dissolution will outweigh the constant and obtrusive assertion that there was none?

\section{Misrerresentation by the Defendaxt.}

Discussion in a previous chapter ${ }^{3}$ of one of the prime requisites of estoppel,

"the misrepresentation must be made either (1) hy the estoppel-denier (Personil Misrepresentittion), or (2) by some person whuse misrepresentation the estoppel-denier his made credible (Assisted Misrepresentation),"

renders it unnecessary to say much here upon a point that a primi secms to be sulficiently clear, namely, that a misrepresentation which will estop must be one for which the defendant is responsible. It may be pointed out, however, that the

1 Williams r. Keats (181\%). 2 Stark. 290; Dolman v. Orchard (1525), 2 C. 2(1892) 2 Q. B. 633 .

\& P 184: Evans \&. Harlfield (1896), ${ }^{3} \mathrm{Ch}$. III. 93 Wis. $605 ; 68$ N. W. R. 468. 
assertion that a man cannot be estopped from denying membership in a firm merely because some other person chooses to represent him as such, includes the case of the misrepresentation being made by the real members of the firm, who are as little eapable as other people of binding the defendant by their falsehoods. ${ }^{1}$ According to the language of the Imperial Statute $^{2}$ it is

"every one who by words spoken or written, or by conduct, represents himself. or who knowingly suffers himself to be represented, as a partner in a particular firm,"

that is liable. The neeessity for bringing the representation home to the defendant is illustrated in the holding that he cannot be estopped by what takes place after his death. Suppose that a partner dies; that the continuing partners give no notice of dissolution; and that the old firm name (possibly the name of the deceased) is flamingly continued; nevertheless the decedent's estate is not liable. ${ }^{3}$

\section{Mispepresentation to the Plaintiff.}

One of the essential conditions of estoppel is that

" the estoppel-asserter must be a person to whom immediately or mediately the misrepresentation was made." 4

It need not, however, surprise us to find that prior to the derelopment of the law of estoppel this point was not always insisted upon.

"Formerly it was considered sufficient if the party was held out to the world as a nember of the firm or company; now, however, it is necessary that there should be direct evidence that the holding out had come to the knowledge of the plaintiff; lie need not hear or see the defendant's concuct; it is enough if the fact has come to his knowledge." 5

Indirect Misrepresentation.- In one case ${ }^{6}$ too much stress was laid upon the necessity for distinct authority from the

1 Even if advertised. First Nat. Bank v. Cody (1894), 93 Ga. 127; 19 S. E. R. 831. See also Fox v. Clifton (18:30), 8 L. J. C. P. 261; Marschall $\nabla$. Aikin (1897), 170 Mass. 3; 48 N. E. R. 84.).

$25.3 \& 54$ Vic. (Imp.), ch. 39. §14(1); 60 Vic. (Man.), ch. 24, §14 (1).

3 Welster v. Wobster (1791), $3 \mathrm{Sw}$. 490 ; Vulliamy v. Noble (1817), 3 Mer. 614. And see the Imp. St., $53 \& 54$ Vic., ch. 39, 514 (2), 36 (3); 60 Vic. (Man.), ch. 24, same sections.

${ }^{4}$ Ante, ch. X.
5 Martyn v. Gray (1863), 14 C. B. N. S. 839. And see Shott v. Streatfield (1830), 1 M. \& Rob. 8; MeLean v. Clark (189:3), 20 Ont. App. 671: Holman v. Herscher (1891), 16 S. W. R. 984 (Tex.); Burrows v. Grover (1897), $41 \mathrm{~S}$. W. R. 822 (Tex.); Marschall v. Aikin (189i), 70 Mass. 3; 48 N. E. R. 84i): Norfinger v. Goldman (1898), 122 Cal. 609; 54 Pac. R. 425; Thornton v. McDonald (1899), 33 S. E. R. 680 (Ga.).

${ }^{6}$ Edmonson v. Thompson (1862), 2 Fos. \& F. 564; 31 L. J. Ex. 20\%. And 
plaintiff in order that he miglit be bound by a representation made by another person. The defendant had represented himself to be a partner to various persons; but neither he nor such persons had made any representation to the plaintiff - thus far no estoppel. A real member of the firm, however, had made representations to the plaintiff; but did so without authority from the defendant - and again it was said that there was no estoppel.

But the cases do not usually proceed upon the law of principal and agent, and the neessity for authority to transinit information; but upon this, rather, that the defendant has originated an impression which has in some way reachel the plaintiff. And it might very well have been held in the case just referred to that if a man was accustomed to represent himself is a partner, such action would be sulficient evidence that he "knowingly suffered" the real members of the firm to do likewise. He could hardly expect them to contradict him. His own representation would of course be strong evidence agrainst him of the fact of partnership; ${ }^{1}$ but that is a remark not pertinent to estoppel. The law may be taken to be that

"if the defendint informs $\mathrm{A}$. B. that he is a partner in a commercial establishment, and $A$. B. anforms the plaintiff: and the plaintilf, believing the defendant to be a nember of the firm, supplies goods to them, the defendant is lighle." ?

The ease mentions but leares undecided the question whether if the estoppel-denier, instead of informing $\mathrm{A}$. B. that he is a partner, does acts from which $A$. B. fairly draws that inference; and A. B. either communicates his information to the estoppel-isserter or informs him that the estoppel-denier is a partner-whether, in such case, there is a sufficient holding out. It is submitted that there is, and that the dictum of Erle, C. J., in the same case is correct:

"He meed not hear or see the defendant's conduct; it is enongh if the fact his come to his knowledge."

The Imperial Statute declares for liability

"whether the representation has or has not been male or communicated to the person so giving credit, by or with the knowledge of the apparent partner making the representation or suffering it to be made." 3

see Armstrong v. Potter (1894), 103 Mi.'H. 40!9: 61 N. W. R. 6.5\%.

III(Neilan's Estate (18!4), $16 \mathrm{~Pa}$. Co. Ct. R. 46. Aftirmed in $16 \%$ P'ir. St. 473: 31 Atl. R. $7: 2$. 2.Martyu s. Gray (1863), 14 C. B. N. And see 60 Vic. (Man.), ch. 24, $514(1)$.
S. 841. And see Shott r. Streatfield (1S;0). 1 M. \& Rub.s: Quirk v. Thomas (1sis), 6 .lich. 76, 119; Rimel r. Hayes

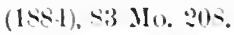

3,33 d it Vic (Imp.). ch. 39. $514(1)$. 
The expression beld out " to the world," although now usually repucliated, ${ }^{1}$ still retains something of its influence, and necessitates some careful distinguishings. For example, in a quotation upon a previous page ${ }^{2}$ it is said

"that there should be direct evidence that the holding out had come to the knowledge of the plaintiff."

But sometimes it is thought that if the holding out were sufficiently public, direct eridence would be unnecessary; and this seems to be coming back to the statement that if a man be beld out "to the world" as a partner he is liable. But it is not so. The law remains that there must be proof that "the holding out had come to the knowledge of the plaintiff;" and all that is asserted is that

"there may be cases in which the holding out has been so public and so long continued that the jury may infer that one dealing with the partnership knew it and relied upon it, without direct testimony to that effect. - . The nature and amount of evidence requisite to satisfy the jury may vary according to circumstances. But the rule of law is always the sime, that one who had no knowledge or belief that the defendant was held out as a partner, and did nothing on the faith of such a knowledge or belief, cannot charge him with liability as a partner, if he was not a partner in fact." 3

It is sometimes loosely asserted, too, that if a retiring partner allows his name to continue to appear - in this way to hold himself out to the world - be will be liable for the subsequent debts of the firm. The law is more accurately stated as follows:

"A partner withdrawing from a firm must see to it that his name is renoved from the business signs in front of the establishment, or persons relying upon such signs as evidence of the firm's continuation and lnouing nothing to the contrary are entitled to recover for all goods parted with on the faith of the partnership relation." 4

It has been pointed out that one who has previously dealt with a firm is entitled to treat all active ${ }^{5}$ partners " as still being members of the firm until he has notice of the cluange," whether such partners had or had not been "apparent members" to himthat is, whether he did or did not know of their membership. That statement, however, in no way conflicts with the rule that misrepresentation as to partnership must be made to the plaintiff; for the misrepresentation to him in such a case is that there has been no change in the constitution of the firm.

$1 \mathrm{Mr}$. Parsons would continue it: On Partnership (4th ed.), 104.

2 Ante, p. 522.

${ }^{3}$ Thompson v. First Nat. Bank (185:2), 111 U. S. 537. And see Dickenson v. Valpy (1829), 10 B. \& C. 140 ; Davis v. Allen (1849), 3 N. Y. 168;
HIefner v. Palmer (1873), 67 Hll. 163; Rizey v. James (1881), 26 Kan. 221; Braithwaite v. Power (1891), 1 N. D. 496: 48 N. W. R. 359.

4 Norquist v. Dalton (1890), $32 \mathrm{~N}$. Y. 240; 11 N. Y. Supp. 351.

${ }^{5} \Lambda$ s to dormant partmers, see infra. 
iV. Credit U fon Fatti of Reriegsentation.

Thnovledge of the Representation.-In order that a plaintiff may be able to say that he gave eredit upon the faith of a representation it is clearly necessary that he should have known of it prior to his action $;^{1}$ and believed it to be true ${ }^{2}$ which of course includes that he did not know it to be untrue. ${ }^{3}$

It is beeause a representation cannot estop unless it be known, that a dormant partner camnot be estopped from denying partnership after his retirement from the lirm.4 But the term "dormant partner" must be construed strietly, as

"one who takes no part in the business and whose connection with the business is unknown. Both secrecy and inactivity are implied by the word." 3

For if he chooses to throw off his character he may leave himself open to the estoppel which befalls other partners. ${ }^{6} \quad$ And of course the retirement of a dormant partner will not relieve him from eontracts already made, even if part of the consideration for the firm's promise be furnished after the dissolution. ${ }^{7}$

Nature of the Representation.-Observe that what the plaintiff relies upon is the presence of the defendant in the firm, and, as a consequence, his being a party to the contract. It is not at all essential that the plaintiff should be able to establish that the defendant was a man of "financial ability," and so an $\mathrm{im}$ portant factor in the contract. ${ }^{8}$ Nor indeed that he should be able to swear that if the defendiunt had not been a partner ho (the plaintiff) would not have sold the goods. ${ }^{9}$ All that is

1 Baird r. Planque (1856), 1 Fos. \& F. 34.1; Rives v. Michaels (1896), 16 Misc. R. 5i; 37 N. Y. Supp. 644; Stewart v. Brown (1898), 10: Ga. 836 ; 30 S. E. R. 264.

2 Pott v. Eyton (1S16), 3 C. B. 32; 15 I. J. C. P. 257: Wright $\checkmark$. Fonda (1891), 44 Mo. App. 634.

3.Mclean r. Clark (1893), 20 Ont. App. 660: Alderson v. Pope (Is09), 1 Catmp. 404, n.; Kraus v. Lutly (1894), 50 Ill. App. 506.

453 \& 54 Vic. (Imp.), ch. 39, \$ 36 (3); 60 Vic. (Man.), ch. 60, $\$ 36$ (3); Farrar v. Deflinne (1844), 1 Car. \& K. 5\$0; MeFarlane v. McHugh (1891), 12 Ohio Cir. Ct. 455 ; 1 Ohio C. D. 546; Pitkin r. Benfer (1892), 50 Kan. 100; 31 Pac. R. 69j; Milmo Nat. Bank v. Carter (1592), 1 Tex. Civ. App. 151; $20 \mathrm{~S}$. W. R. 836: Gorman v. Iaris (1896), 118 N. C. 370; 24 S. E. R. $7 \% 0$.

${ }^{3}$ National v. Thomas (1871), 4i N. Y. 19.

6 Elmira v. Harris (1891), $124 \mathrm{X}$. Y. 280; 26 N. E. R. 541; Brown v. Foster (1894). 41 S. C. $118 ; 19$ S. E. R. 299.

7Court v. Berlin (18:T), 2 Q. B. 306; 66 L. J. Q. B. 714. See 14 Law Quar. terly Review, 5. And see ante, p. 247. ${ }^{8}$ Strecker $v$. Conn (1883), 90 Ind. 469.

${ }^{9}$ Libel v. Cribldock (18s8), $87 \mathrm{~K}$. 525. 
necessary is that, believing the defendant to be a partner, the plaintifl entered into a contract with the firm. And if he be asked whether he would have made it harl he known that the defendant was not a partner, be may reply that that question was not raised and is therefore immaterial. Upon the faith of this, he did that; he has changer his position - that is the requisite of estoppel.

\section{Election and Estoppel.}

The have seen that, by estoppel, a retired partner may continne to be liable for the engagements of the firm. For example, if Smith \& Co. be composed of two partuers and one of them withdraws without notice to an old customer, both will remain liable. Now suppose that as one man drops out another groes in; will all three be liable? In other words, will the old as well as the new partner be liable - the new partner because of the contract to which he is a party, and the old partner because he is estopped from denying that he is also a party to it.

In Scarf v. Jardine (in the Houso of Lords ${ }^{1}$ ) it was held that, in such case, the creditor must elect between the old firm and the new - that he cannot hold both the retired and the added member. Lord Selborne said:

"Put it as I can, I am unable to understand how there could have been a joint liability of the three. The two principles are not capable of being brought into play together: You cannot, at once, rely upon estoppel and set up the facts; and if the estoppel mikes A. \& B. liable, neither the estoppel, nor the facts, nor any combination of the two, can possibly make A., B. \& C. all liable jointly."

With deference, however, it is a mistake to make two situations out of one; and to say that "the estoppel makes $A$. and B. liable; and the facts make B. and C. liable;" for estoppel cannot operate apart from facts. ${ }^{2}$ Nor are there two sets of facts. The only duality is that B. and C. would be liable upon one principle of law (contract) and A. upon another (estoppel), and that seems luardly to be a sufficient reason for saying that either A. or C. cannot be sued at all.

Take the ordinary case of a partner retiring from his firm, and tho continuing partner making a contract. It is not

1 (1882) 7 App. Cas. 319; 51 L. J. facts." Rector v. Board of ImproveQ. B. 615 . ment (1887), 50 Ark. 128.

2 " Estoppels in pais depend upon 
doubted that both may be liable. But how? One is liable upon the facts, and the other by estoppel again - if we chuose to say so. But perhaps it would be better to declare that the continuing partner is liable upon one principle of law (contract), and the other member upon another prineiple (estopyel). We have it, then, that if $A$. and $B$. are in partnershipl, and $A$. goes out, both may be liable $-A$. by estoppel and B. by contract. And what diffieulty is added if J3. has talken a new partner, C., and that B. and C. are the parties liable upon the contract?

Suppose that the eustomer was not aware that $\Lambda$. had left the firm, but was aware that $C$. had joined it; ought not both A. and C. to be liable to him? C. is, in reality, a party to the contract - perhaps the signature to it is in his own bandwriting. In no case can he escape. ${ }^{1}$ And $A$. too ought to be liable, for the contract was made upon the faith of his membership, and he is therefore estopped from denying his liability.

It is said that this conclusion cannot be correct, for were the new firm sued they could not plead in abatement the nonjoinder of the oll member - the old member is therefore, it is said, not a proper party to the suit. But observe that the reason that they conld not so plead is that they could not say that the retired partner was a party to the contract. The creclitor may, if he wishes, sue the old meinber; but he is not bound to do so. ITe may, if he chooses, sue on the contract as it is in fict, and the real contrictors cannot defend themselves by asserting the plaintiff's right to add to their number by estoppel. Rut it is quite another thing to say that he himself cannot claim the right which estoppel gives him. The objection moreover goes much too far. For if it be valid, then if $\mathrm{A}$. and $B$. are in partnership, and after $A$. retires $B$. makes a contract, these two can never be jointly liable-B. if sued alone would, in this case too, be unable to pleal in abatement the absence of $A$.

It is also argued that if $A .$, B. and $C$. were all sued together there must be a nonsuit, for the plaintiff could not prove a joint contract. That may be technically true. But if $\mathrm{A}$. and 13. were sued alone, they could plead the non-joinder of C.'

ISchmilt r. Ittman (1S94), $40 \mathrm{La}$ 2See Cameron v. Cameron (1886), Ann. 885; 15 S. R. 310 . 3 Man. 30s. 
Thus the difficulties may be set off the one against the other. An argument derived from obsolete forms of plearling, moreover, is not always the most convincing. ${ }^{1}$ It night, incled, be employed to show that $A$. could not be liable at all. Take it that the contract was made with $\mathrm{B}$. and $\mathrm{C}$. It is impossible now for the plaintiff to sue B. without C.: For the same reason he cannot sue A. without joining B. But, according to Scarf $v$. Jurdine, A. (the retired partner) and C. (the new one) cannot be sued together. Therefore $A$. cannot be sued at all $;^{3}$ and there is no election!

If the case be one of election it is of this peculiar character: that a creditor having two persons liable to him in respect of the same contract must abandon one of them if he desires to sue the other. That the liability of one of these depends upon his being undoubtedly a party to the contract, and the liability of the other upon his inability to deny that he too is a party to it, does not seem to be a sufficient ground for requiring a release of either one or the other. Estoppel may add a man as a party to a contract, but it is difficult to see how it can subtract one, or how the aldition of one can entail the discharge of another. ${ }^{4}$

1 For example, Lord Eldon, in Ex parte Hodglinson (1815), 19 Ves. 294, when dealing with an analogous difficulty, said: "It has leen constantly taken as clear law that a creditor dealing with A., and knowing nothing of a dormant partner, may consider himself a separate creditor: yet it las been determined very lately that the defemiant in an action may plead in abatement that there is a dormant partner. I, however, will not listurb the decisions which have taken place here for thirty years . . declaring that those decisions . . will not in. duce me to alter my course in bankruptey."

"Summers v. Heard (1899), 50 S. W. R. Tis (Ark.); Parsons v. Krurer (1899), 57 ‥ Y. Supp. 416; Hyde v. CaseyGrimsluawe (1599), 82 Ill. App. 83.

${ }^{3}$ In the case supposed the creditor knew of the accession to the firm, of C. That is, however, immaterial. It merely serves to make clear the justice of the creditor's claim to holl both him with whom he contructed and the retired member with whom he believed he was contracting liable for the debt. The real point is that the contract was made with the new member, and that it is the contract that is the basis of the action.

4 It miglit be that if a contract was made with A., B. and C. under the belief that the parties were A., B. and D., there would be no contract at all (Boulton v. Jones (18ir), 2 H. \& N. 564; 27 L. J. Ex. 111\%); but if the contract is, as a matter of fact, or as an allegration which cannot be disputed, with A., B. and C., how can estoppel ever eliminate C.? 


\section{Liability in Tort.}

When, as formerly, liability proceeded upon a holding out to "the world" (instead of to the plaintiff), it might well be that persons so held out as partners would be liable for the negligence of the servants of the firm, although they were not, in fact, members of it. And so, in Stables v. Eley, ${ }^{1}$ such a person was held liable for a collision eaused by the firm's driver.

But the modern doctrine requires that if a man is to be liable as a partner in a firm of which he is not a member, it must be because the plaintiff has dealt with the firm in the belief that the defendant was a member of it - has changed his position upon the faith of the misrepresentation. It would be hard to contend, in the case of a man injured in a collision, that he had sustained his hurts because of representations that had previously been made to him as to the ownersbip of the guilty wagon.

1(1825) 1 C. \& P. 614. And see the later case of Burk v. Clark (1888), 5 Man. 150. 



\section{INDEX.}

The figures sometimes Indicato the pare at which the subjoct commences meraly.

\section{ACTIVITY -}

obligation to be active, $40,42,48,105,136$.

as against crime or fraud, 50 .

see Passive Misrepresentation.

ACTUAL AND CONTRACTUAL ESTATE, 269.

ADMISSION -

estoppel not an, 4.

agent (see Ostensible Agexcy; Principal and Agent),

ALTRUISM (see EGOISM).

AMBIGUity OF MISREPRESENTATION, 14, 142

factor also a trader, 511.

AMBULATORY AND NON-AMBULATORY INSTRUMENTS-

classification suggested, 385 .

Lord Cairns' dictum, 386.

transferee takes free from equities of the obligors, 391. even although parties themselves defrauded, 96.

transferee takes free from legal title of the owners, 392

possession of ambulatory instruments is appearance of ownership, 394 or of agency to transfer, 395 .

duty of owners of ambulatory instruments, 395 .

estoppel applied to ambulatory instruments, 397.

considerations in support of suggested views, 404 .

market overt, 404 .

lost seal, 405 .

further considerations, 405 .

contrast with old view, 400 .

ambulatory instruments -

bonds, 409.

scrip for bonds, 412

shares, 414.

tortgage debentures, 414

mortgages, 415 .

vouchers, 416.

bank documents, 417 .

life policies, 41i.

share transfers, 418 .

charter-parties, 418.

bills and notes, 420 . 
AMBULATORY AND NON-AMBULATORY INSTRUMENTS (con.)intended to be assigned, 421 .

conclusions, 422 .

overdue paper, 423.

blanks and spaces in, see Custody of Documents.

stolen or found instruments, see Custody of Docuniests.

ANTICIPATION OF CHANGE-

estoppel-denier must have reasonable ground for, 155.

personal misrepresentation, 156.

impertinent questions, 156.

assisted misrepresentation, 160 .

summary, 161.

APPROPRIATE MEASURE OF PRUDENCE-

a rule in torts, 30 .

what is, 30,31 .

application to estoppel, $31,37,67$.

already made, 34 .

but other reasons given, 35 .

duty to be active, 40,42, 48, 105, 136 .

as against crime and fraud, 50 .

see also specific heads.

ASSIGNMENTS OF CHOSES (see AMBULATORY).

ASSISTED MISREPRESENTATION, 18.

requisites for estoppel, 20.

examples, 21.

no fraud necessary, 94.

carelessness sometimes essential, see CarELESSNESS.

B.

BANK DOCUMENTS -

ambulatory character of, 417.

BANK OFFICERS -

exceeding authority, 504 .

BANK PASS-BOOKS-

duty to check over, $105,136$.

BILlS AND NOTES (see Ambulatory aNd Non-AMbulatory; Forgeries; Negotiable Instruments; Custody of Documents; OverDUE).

BILLS OF LADING-

for goods not delivered; carelessness, $106,508$.

see Documents of Title; Indicia of Tithe.

BLANKS (see Execution of Documents).

BONDS (see Ambulatory INstruments; Overdue Instruments).

BROKER -

as a special agent, $476,478,479,482$. 


\section{C.}

\section{CARELESSNESS SOMETIMES ESSENTIAL, 99.}

only important where there is misrepresentation, 100.

personal misrepresentation; carelessness not essential, 101.

assisted misrepresentation; carelessness sometimes essential, 102

execution of documents, 103.

mortgagee intrusting deels to mortgagor, 104.

ostensible agency, 105.

checking over bank pass-books, 105, 136.

standing-by, $26,106$.

bill of lading for goods not delirered, 106, 503.

bills and notes, spaces in, 107. See Custody of Docoments.

rules supplied by the cases, 109 .

Mr. Bigelow's criticism, 109.

Mr. Cababé's criticism, 111.

I. There must be neglect of some duty, 112 .

II. The neglect must be in the transaction itself, 112

this inpossible, 113.

authorities reviewed, 115.

result and its explanation, 116.

"in the transaction," 117.

analogy from law of torts. 119.

III. The neglect must be the proximate cause, etc., 119.

this impossible, 119.

proximate and real cause, 120.

summary of chapter, 121.

CAUSE OF ACTION -

estoppel as a, 187.

CERTAINTY (see IMplied Misrepresentation).

CHANGE OF POSITION ESSENTIAL, 131.

misrepresentation not acted upon, 131.

change prior to misrepresentation, 132.

misrepresentation unknown, 132.

inactivity may be a change of position, see LuLLivg Into Securitr.

means of knowledge of incorrectness of misrepresentation immaterial,

137.

what is a change of position, 139.

change of style of living, 139.

change by bringing an action, 139.

a possible change, 140 .

on the faith of the misrepresentation, 140.

where truth known, 140.

where nisrepresentation withlrawn. 140.

where misrepresentation not believel, 140.

where representation ambiguous, $1+1$.

certificate of shares not relied on, 141 .

seeming exceptions where classes of estoppel-asserters, 141. 
CHANGE OF POSITION ESSENTIAL (continued)on the faith of the misrepresentation (continued) reputed-ownership clauses, 142 .

two sets of bankruptcy creditors, 143. what was the actuating motive, 144. onus of proof, 145 .

several reasons for change, 146.

prejudice, 146.

damage, real or assumed, 147.

amount of damage. 191.

lulling to rest, 147.

purchaser for value, see Purchaser. anticipation of change, see ANTICIPation. change must be reasonably consequent, see CONSEQUENT. change other than that intended, see CoNSEquENT.

CHECKS (see Negotiable Instruments; AMbUlatory Instroments; Execution of Documents; Custody of Docunents).

\section{CLASSES OF PERSONS CLAIM ESTOPPEL -}

although not act upon faith of misrepresentation, 142.

\section{COMIERCIAL AGENCIES -}

information to, intended for members, 128.

notice to, upon dissolution of partnership, 519 .

CONDITIONS OF ESTOPPEL, 10.

\section{CONSEQUENCES -}

does estoppel proceed upon duty, or has it consequences merely, 232.

\section{CONSEQUENT -}

change of position must be reasonably consequent, 163.

Barry v. Croskey and Carr v. London rules compared, 163.

change other than that intended, 163.

direct and indirect misrepresentation, 163.

honest and fraudulent misrepresentation, 163.

application to the cases, 171.

what are consequent changes, 174 .

summary, 175.

\section{CREDITORS -}

estoppel in favor of, as to ostensible property of debtor, 25.

creditors in class, claim estoppel although not act upon faith of mis-

representation, 142 .

effect of estoppel of debtor upon his creditors, 208.

bearing of privity considerations, 209 .

true position, 212.

joint and separate creditors of partners, 213.

effect of estoppel of company to deny validity of some debentures

upon other debenture holders, 217.

same question as to some shareholders, 219.

CRIIE -

see Reputed OWNERSHip.

duty to guard against, 48 . 


\section{CUSTODY OF DOCUMENTS-}

stolen or found negotiable instruments, 456.

when forgery necessary to complete, $22,51,458,466$.

signed slips, 463.

when in complete form, $61,461,460$

stolen or found dociments of title, 345 .

stolen or found non.negotiable instruments, 467.

CUSTODY OF SEALS -

duty as to, $63,108,237,405$.

CUSTODY OF RUBBER ST $\triangle M P S$, 65.

D.

DAMAGES -

amount of, 191.

necessary to estoppel, 146.

see Chaxge of Position.

DEBENTURE HOLDERS -

effect of estoppel of company to deny validity of some debentures upon other debenture holders, 217.

\section{DECEIT -}

compared with misrepresentation, 83.

compared with estoppel, 227 .

fraud necessary in deceit, 224 .

fraud unnecessary in estoppel. 226.

application of respective remedies, 226 .

anomalous result, 227 .

illustrations, 228 .

present situation, 231 .

company's secretary giving erroneous information, 237.

acts done by agent not "for master's benefit," 497 .

DEEDS -

estoppel applies to, 345, 449.

possession of, see Passession of Title Deeds.

DEFAOLT -

taking advantage of one's own, 185

DELIVERY ORDERS (see Docuyents of Title; Indicia of TItLE),

DIRECT AND INDIRECT -

misrepresentation may be direct or indirect, 123 .

Barry v. Croskey criticised, 163.

DOCUMENTS -

custoly of, see Custody of Documents

execution of, see Execution of Doculants.

DOCUMENTS OF TITLE-

three classes of documents, 305

1. Certificates of title, 305 .

2. Transfers of title, 305 .

3. Records of transfers, 302 . 
DOCUMENTS OF TITLE (continued)estoppel by transfers of title, 305 .

lands and goods, 306. conveyances are intended as representations and will estop, 307 . bills of lading -

not operative merely between the parties, 308 .

intended as representation and will estop, 3:8. dock warrants, etc., also so intended, 309. share certificates and transfers also so intended, 300. resemblances ainong all documents of title, 310 . estoppel the true ground of decision, 311. purposes of documents of title to goods, 313 .

intended to be passed on, 125 .

signers of them estopped, $313,314,316$.

carelessness material in cases of bills of lading, 106, 316. carelessness not material in other cases, $39,316$.

no estoppel as to certain points, 318 .

when issued improperly by agents, see Principal and Agent. transferrers estopped, $313,319$.

bills of lading -

estoppel of transferrer only as to stoppage in transitu, 319.

1. Passing property by transfers, 320 .

2. Negotiability, 322, 328 .

3. Symbolism, 324.

these three compared, 325.

the true view - estoppel, 327.

tendency in that direction, 330 .

dock warrants, etc.-

early law enunciated valuable principles, 335 .

submergence, 336 .

parliament versus the courts, 336 .

compared with bills of lading, 338 .

right to stop in transitu not affected by, 338.

until statute, 339 .

other documents unaffected by statute, 339 .

shares in companies -

company estopped by certificates, 340 .

compared with land, 340 .

transferrer estopped, 341.

seals, 345 .

stolen or found, see Custody of Documents; Indicla of TItLE.

DOWRESS -

standing-by, 27.

\section{DUTY -}

as a requisite of estoppel, 29.

estoppel proceeds upon duty, 232 .

as to appearance of ownership, see OSTEXSIBLE OWNERSHIP. 


\section{DUTY (continuel) -}

as to appearance of agency, see Priscipal AND Agext.

as to execution of documents, see ExEcution of Documests.

as to custody of documents, see Custody of DocunEsts.

as to guarding against crime, see CRIME.

of activity, see Passive Misirepresentation; Lullina to Rest.

in partnership cases, see Partariship.

egoism and altruism, see EGolsis.

appropriate measure of prudence, see APPropriate.

E.

EFFECT OF ESTOPPEL (see Nature and EFfect).

EGOISIS AND ALTRUISH, 37, 291, 460.

ELECTION -

in partnership cases, 526 .

EQUITABLE RIGHT AND ESTATE-

estoppel is an equitable right, 199.

parallel between equity under contract for sale and estoppel, 202 .

solution applied, 202 .

does an estate pass by estoppel, 206 .

effect under Factors Act, 208.

see Legal Estate.

\section{EQUITIES-}

the phrase equivalent to "merits," $251,291$.

estoppel concealed under the phrase, 200.

"no defenses," 128.

see Ambulatory.

\section{ESTOPPEL -}

subdivisions, 1,2 .

classification, 3 .

definition, 3.

justification, 5 .

history, 7.

conditions, 10.

\section{EVIDENCE -}

estoppel as a rule of, 188.

\section{EXECUTION OF DOCUMENTS -}

carelessness in execution may estop, 103, $\mathbf{4 2 5}$.

I. Execution fraudulently obtained-

the authorities, 428.

void and voidable, 427 .

solution, 434.

analogy, 437 . 
EXECUTION OF DOCUMENTS (continued) -

IL Execution fraudulently completed, 438.

division of subject, 438 .

negotiable instrument confided to another person, 439.

(1) completed instruments, 439 . grounds of liability, 243.

(2) blank instruments, 440. current phraseology, 441. criticism, 441.

blanks known to transferee, 442. customary effect of blanks, 443. estoppel, 444.

blanks unknown to transferee, 447.

(3) spaces in instruments, 42. carelessness as to, 107 .

(4) signed slips of paper, 448 . imperfection known, 448.

summary, 449. unknown, 448.

non-negotiable instruments confided to another person, 449. deed, estoppel applies to, 345, 449. completed instruments, 452 .

blank instruments, 453 .

blanks known, 453. unknown, 455 .

documents stolen or found negotiable instruments, 456 . carelessness, 457. complete and incomplete instruments, $\mathbf{4 5 8 .}$ criticism of present rules, 459. egoism and altruism, 460 . signed slips of paper, 463 . current practice, 465 .

the codes, 466. non-negotiable instruments, 467 . summary of chapter, 470.

EXPECTED CHANGE (see ANticipated Change).

F.

\section{FACT AND INTENTION -} misrepresentation of, 68 .

FACT AND LAW misrepresentation of, $7 \%$ FACT AND OPINIONmisrepresentation of, 72 .

\section{FACTORS -}

conflict between courts and parliament, 350 . confusion in Factors Acts, 240. 
FACTORS (continued) -

general principles sufficient for factors, 350 .

legal-estate considerations ignored in Factors Acts, 274.

goods intrusted to one who is a factor, 351.

specially accredited factor, 351.

merchant, 35?.

and factor, $332,511$.

review of legislation, 353.

"factors cannot pledge," 353, 368.

corrected by statute, 355 .

criticism of the statute, 356 .

documents of title with factor "with the consent of the owner," 358 . possession of goods for consignment or sale, 360 .

vendor retaining possession or indicia, 361 .

purchaser prematurely getting possession or indicion, 364 .

vendor's lien and stoppage in transitu affected by all documents of title, 365 .

summary. 366.

American legislation, 368 .

FAIRS -

power of agents when dealing at, 492

FALSÂVERT, III, 142 .

FORGERIES-

duty to guard against, 22,48 .

not advising of, 135.

see Lulling Into Security; Bane Pass-books; Crime

\section{FRAUD -}

what is, 259.

as affecting priorities, 259, 285 .

used by court of equity as against legal estate, $25 \%$.

not essential to estoppel, 83.

sometimes an ingredient in misrepresentation, 89.

diverse views, 86 .

reconciliation by classification, 87 .

possession of goods obtained by, 302

possession of inlicia of title obtained by, 303 .

no difference between land and goods with regard to fraud, 97. Ste

Crime.

as affecting character of change of position, 164 .

duty to guard against fraud as compared with crime, 48.

G.

GOODS (see Possession of Goods; Sale of Goods; Ostexsible OWNerSuip; Ostexsible AGency).

II.

HALIFAX $\tau$. WHEELWRIGHT RULE, 185.

either inaccurate or estoppel insufficiently stated, 18j. 
HISTORY OF ESTOPPEL, 7.

HONEST (see FraUd).

HORSES -

power of agent to warrant upon sale, 492.

I.

\section{IMPLIED MISREPRESENTATION -}

certainty, 14,141 .

general statements as to, 14 .

examples, 15 .

distinction where fraud, 17.

INDICIA OF TITLE-

possession of by third party will estop true owner, 311, 313, 315, 319, $325,338,350-369,407$.

even if possession obtained by fraud, 303, 304, 312.

as applied to ambulatory instruments, 407 .

when stolen or found, see Custody of Documents

INDIRECT MISREPRESENTATION (see DiRECT).

INFANTS -

estopped by misrepresentation of agent, although innocently made, 96 .

INNOCENT (see FraUd).

iNNOCENT PERSONS SUFFERING (see LickBarRow u Mason).

INSURANCE BROKER -

extent of authority, 489.

INTENDED TO BE PASSED ON -

delivery orders, 125.

warehouse receipts, 126.

letters of credit, 126.

bills of lading, 126 .

certificates of shares, 126.

company's reports and prospectuses, 127.

commercial agencies, 128.

stock exchange, 128.

title deeds, 128 .

no defenses, 128.

persons who will probably be questioned, 129 .

negotiable instruments, 129.

subscription lists, 130 .

see Ambulatory Instruments.

INTENTION -

misrepresentation of, will not estop, 68 .

\section{J.}


by-stander must be aware of his own rights, 90 .

estoppel-asserter must be unaware of by-stander's rights, 90 .

of incorrectness of misrepresentation, means of, 137.

I.

LaND (see Legal Estate; Possession of Title Deeds; Qdi Prior Est TEMPORE).

\section{LANDLORD -}

giving undertaking to grant lease which he had already given, 228.

$\mathrm{LAW}-$

misrepresentation of, 72 .

LAW IIERCHANT -

usual solution of certain questions, $3 \% 0$.

antagonism to general law, 372 .

what is it, 373 .

LEGAL AND EQUITABLE ESTOPPELS-

distinction, 6 .

LEGAL ESTATE - PRIORITY BY -

the scramble, 252 .

ubi pig, ibi priority, 254 .

contrasted with estoppel, 254, 263.

originated in defective administration, 255.

equity checked by it, 256 .

equity introduces questions of fraud, 257.

union of courts and opportunity for reform, 258.

"fraud or evidence of fraud" as ground to postpone legal estate, 259. apologies for old rule, 268 .

actual and contractual estates, 269.

support for new methods, 271 .

not apply to estoppel of owner of shares, 344 .

not applicable to Factors Acts, 27.

LICKBARROW $v$. MASON RULE-

an anticipation of estoppel by assisted misrepresentation, $7,178$.

not disparate from estoppel, 178.

priorities, 179.

bills of exchange, 179.

principal and agent, 180.

sales of goods, 181.

Mr. Pomeroy's concurrence, 181.

ubiquity of rule, 184.

the case itself, $18 \mathrm{t}$.

not incapable of support, 183.

LOST (see Custody or Documests). 
LULLING INTO SECURITY, 40.

inactivity may be a change of position, 133.

vendor handing receipt for purchase-money to agent who keeps the money and delivers receipt to purchaser, 134 .

not advising of forgery, 135 .

not objecting to accounts, 105, 136.

must be damage to estoppel-asserter, 147.

see Chavge of Position.

M.

MARGINAL WRITINGS (see Ambulatory Instruments).

MARKET OVERT, 404.

master AND SERVANT (see Principal and Agent).

MATERIALITY OF MISREPRESENTATION AND ASSISTANCE, 80. several misrepresentations, 81.

MEDIUM POWERS -

assumed to exist, 488.

when withheld, 490.

see Principal and Agent.

MISREPRESENT ATION -

definition, 12.

necessity for, 12 .

classification, 13.

personal and assisted, 18. See Assisted Misrepresentation.

direct and indirect, see DIRECT AND INDIRECT.

active and passive, see Passive Misrepresentation; Lolling Into

SECURITY.

expressed and implied, 14. See IMPLIEd MisRepresentation.

MORTGAGE DEBENTURES (see Ambulatory).

MORTGAGEE -

estoppel by conduct with reference to deeds, $23,243,279$.

carelessness essential, 105.

estoppel by misstatements, 229 .

MORTGAGOR -

estoppel as to amount stated to be secured by mortgage, $23,415$.

even although himself deceived, $\mathbf{9 5 .}$

MOTIVE -

what was the, 144 .

N.

NATURE AND EFFECT OF ESTOPPEL, 187.

as a cause of action, 187.

as a rule of evidence, 188.

relief granted, character of, 190.

goods not ordered to be delivered where title rests on estoppel, 190. 
NATURE AND EFFECT OF ESTOPPEL (continued)-

amount of damages recoverable, 191.

parties and privies, see Partifs and Privies.

does estoppel bind purchasers from estoppel-denier, $19 a$

creditors of the estoppel-denier, 208. And see CredITORS.

NEGLIGENCEin favor of assignee of estoppel-asserter, 220 .

double application of word, 98.

carelessness substituted, 02.

see Carelessnfas.

\section{NEGOTIABLE INSTRUMENTS -}

definition, $3 \pi 6$.

transferee suing in his own name, 370.

honest acquisition confers title, 378 .

negotiability and transferability, $2 s 0$.

negotiability explained, 383, 399.

application of estoppel to, 179.

ambulatory and non-anibulatory, 385. See AuBdLatory.

cycle througlı which law passed, 386.

summary, 389.

see Execution of Documents; Custody of Documents

NEGOTIABILITY BY ESTOPPEL -

reason for statements of doctrine, 401.

difficulty of accepting doctrine, 403.

NEJO DAT QUOD NON HABET, 296, 311, 335, 350, 393.

OMNIBUS DRIVER -

O.

acting contrary to instructions, 497.

ONUS OF PROOF -

as tc the actuating motive, 145 .

OPINION -

misrepresentation of, 72

OSTENSIBLE AGENCY -

contrasted with ostensible ownership, 238, 480.

confusion between, 239 .

benefit of distinction, 242 .

agent to borrow upon deeds exceeding his authority, 244

agent to sell goods exceeding his authority, 246.

estoppel as to existence of agency, $238,246$.

extent of agency, 246.

carelessness essential, 40, 105.

see Principal and Agext; Specific heads.

OSTENSIBLE OWNERSHIP -

contrasted with ostensible agency, 238,486 .

confusion between, 239 .

benefit of distinction, 242 
OSTENSIBLE OWNERSHIP (continued) -

accrediting title, 238 .

where ostensible owner is a real agent, 242.

will not support an act of agency, 247 .

application of estoppel, $2 \pm, 39,248$.

in trustees, 254, 293, 311.

involuntary trustees, 295.

name of purchaser painted on goods, 304 .

owner defrauded, 96.

see Possession of Goods; Indicla of Title.

OVERDUE DOCUMENTS-

equities of obligors, 423 .

title of true owners, 423.

P.

PARTIES AND PRIVIES-

purchasers from the estoppel-denier, 196.

who are privies, 196.

rule as to privies not intended for estoppel by misrepresentation, 198.

suggested solution, 199.

relation of to rule respecting creditors of estoppel-denier, 209.

PARTNERSHIP -

relation to agency, 513.

estoppel, 513

use of non-partner's name, 514.

estoppel although estoppel-denier himself defrauded, $\mathbf{9 6}$.

representation of partnership, 22,515 .

where defendant never a partner, 516.

defendant is a retired partner, 511.

duty to give notice, 41,511 .

three classes:

1. Those who had prior dealings with firm, 518.

2. Those who had none, but who were aware of its membership, 518.

3. Those who had neither prior dealings, nor such knowledge, 519 . firm's name, 519, 524 .

historic and indicative names, 520 .

conflict between joint and several creditors, 213.

dormant partner, when liable, 247.

Passed ON (see Intended to be Passed on; Ambdlatory).

PASSIVE MISREPRESENTATION -

duty of activity, 40, 42, 48-57, 105, 134, 135, 136.

as to recorded transactions, 138 .

no duty to anticipate ignorance, 66 .

of insurance company to advise as to premiums, 66 .

to warn against self-deception, 66 .

of surety to warn creditor not to release debtor, 66 .

of purchaser to advise vendor of non-arrival of goods, 67 .

see Standing-by. 


\section{PATENTEE -}

duty to advise intending purchasers, 91.

POLICIES -

assignee's rights regarding prior equities, 417.

\section{POSSESSION OF GOODS -}

mere possession not appearance of ownership, 297.

by factor or auctioneer constitutes appearance of agency, 246 .

when constitutes appearance of ownership or agency, $296,484$.

character of the goods, 298.

$$
\text { place, } 298 \text {. }
$$

usual employment of the person, 299.

reputed-ownership statute, 300 .

contrast with estoppel, 300 .

vendors and vendees, 301 .

name of vendee painted on goods, 304 .

other circumstances, 301 .

obtained by fraud, 302 .

by merchant, when appearance of ownership, 312.

by person who is both merchant and factor, 511 .

for consignment or sale; 360 .

POSSESSION OF TITLE DEEDS, PRIORITY BY, 276.

current phraseology, 276 .

suggestion of estoppel, 276 .

possession a circumistance merely, 278 .

tables of cases, 279 .

analysis of them, 283.

estoppel the true doctrine, 287.

PREJUdice (see Chasge of Position).

\section{PRINCIPAL, AND AGENT-}

propositions respecting estoppel, $4 \pi 3$.

general and special agency discussed, $4 \pi 4$.

single and multitudinous instances of employment, 474 .

application of estoppel, 180, 483 .

estoppel as to existence of agency. 483.

extent of arency, $246,453,436$.

application of distinction, $4 \$ 4$.

estoppel in what cases, 487 .

medium powers, 488.

agent employed to perform certain duty, 488 .

in certain capacity, 485.

to act in line of particular business, 489 .

to act under certain circumstances, 488 .

when employment arises out of legal relation, 485 .

horses. sales of, power of agent to warrant, 492.

"for the master's benefit," 496.

distinction between tort, deceit and estoppel, 237.

secretary of company acting for hmself, 490.

deceit and estoppel compared, 49\%.

partner acting for his own benetit. 499 . 
PRINCIPAL AND AGENT (continued)-

"within the scope of his autlority," 501.

A. Acting within ostensible authority, 501.

B. Appearing to act within real authority, 501 .

"classes of acts," 502 .

partnership cases, 502.

borrowing powers, 503 .

extrinsic facts, 503.

bank ofticers exceeding authority, 504 .

attorney exceeding authority, 505.

agent of company exceeding authority, 507.

bills of lading and warehouse receipts, 505 .

appearance of authority, 511.

factor who is also trader, 511.

agent also an owner, 141.

by possession of receipt for money to be paid, 133 . see Ostensible Agency.

PRIVIES (see Parties and Privies).

PROXINATE CAUSE (see CARELESSNESS).

PRUdence (see Appropriate Measure of Prudence).

PURCHASER FOR VALUE WITHOUT NOTICE -

auxiliary jurisdiction, 150 .

concurrent jurisdiction, 150.

supersession by estoppel, 151, 154.

legal estate, 158 .

PURCHASERS FROM ESTOPPEL-ASSERTER (see Parties and Privies). PURCHASERS FROII ESTOPPEL.DENIER (see Parties and Privies).

Q.

QUI PRIOI EST TEMPORE, ETC.-

relation to other priority rules, 240 .

resemblance to estoppel, 291 .

divergence from estoppel over word "merits," 291.

egoism and altruism, 291.

illustration of divergent conclusions, 293 .

R.

REASONABLE GROUND FOR ANTICIPATING CHANGE (see ANTICPATION).

REASONABLY CONSEQUENT (see CONSEQUENT)

REOISTRY OFFICES -

silence as to recorded transactions, 138.

RELIANCE UPON MISREPRLSLNTATION (see ChaNGE of POSITION). REPUTED-OWNERSIIIP CLA USES, 25, 142, 214, 300. See CREDITORS. 


\section{RESCISSION -}

compared with misrepresentation, 85.

RESTITUTION -

its relation to estoppel, 222.

is fraud necessary, 22.5.

\section{RUBBER STAMPS-}

custody of, 65.

\section{S.}

SALE OF GOODS-

confusion in statute between ostensible ownership and ostensible agency, 241 .

estoppel of owner by wrongful sale, 246 .

where owner tricked, 181.

power of agent to give warranty, 492 .

property passes by estoppel under statute, $20 \mathrm{~S}$.

appearance of authority to sell, 484.

see Ostexsible Ownelshilp; Ostexsible Agexcy.

SCRIP (see Ambulatory).

SEAL (see Custody of Seal).

SHARES, CERTIFICATES OF -

estoppel of company, $23,40,230,234,309,313,340$.

although itself deceived, 95 .

SHARE-TRANSFERS (see AmbUlatory Ixistrumexts; Docemexts of Title).

\section{SHAREHOLDERS -}

effect of estoppel of company to deny valiality of some shares upon other shareliolders, 219.

in class may claim estoppel although not act upon faith of misrepresentation, 142.

SIGNATURES MISAPPROPRIATED (see ExECUTION OF DOCUMENTs)

SPACES IN INSTRUMENTS (see ExrcuTION of Documexts).

\section{STANDING-BY -}

duty when mistake is observed, 89.

mast be a ware of my own right. 90.

other party must be unaware of my right, 90 .

must have reasonable ground for assuming other party's ignorance, $90,106$.

at tax sale, 26 .

building on another's land, 106.

see Passive Miskeplesentation.

mformation to, intended for nembers, 12 s.

STOLEX AND FOUND IXSTRUMEXTS (see CUSTODY OF INSTRIMANS). 
STOPPAGE IN TRANSITU -

affected by transfer of bill of lading, 319 .

estoppel the true reason, $32 \pi$.

statute as to other documents of title, 339, 365.

SYMBOLISM, 32t. See Doccmexts of Titi.

T.

TAX SALE -

standing-by at, 20.

title deeds (see Possession of Titla Deeds)。

TORT -

liability of partners, 529 .

compared with estoppel, 498.

TRUSTEE -

giving incorrect answer to inquiries by intending purchaser of the fund, 228.

ostensible ownership, estoppel by, 254, 264, 340 .

\section{V.}

Vendors and vendees of goods (see Possession of Gonds). VOID AND VOIDABLE (see Execution of Doccments). VOUCHERS (see AMBULatory).

$$
\text { W. }
$$

WAREHOUSE RECEIPTS (see Documents of Tithe).

WAREHOUSEMAN -

issuing erroneous receipt, $229,235$.

WARRANTY -

power of agent to give, 492 . 



$B$ G. B. BODOA 
